\title{
Något betydelsefullt
}

Leonid Dobyčins möten bortom orden i den sovjetiska samtiden

\section{Hans Andersson}

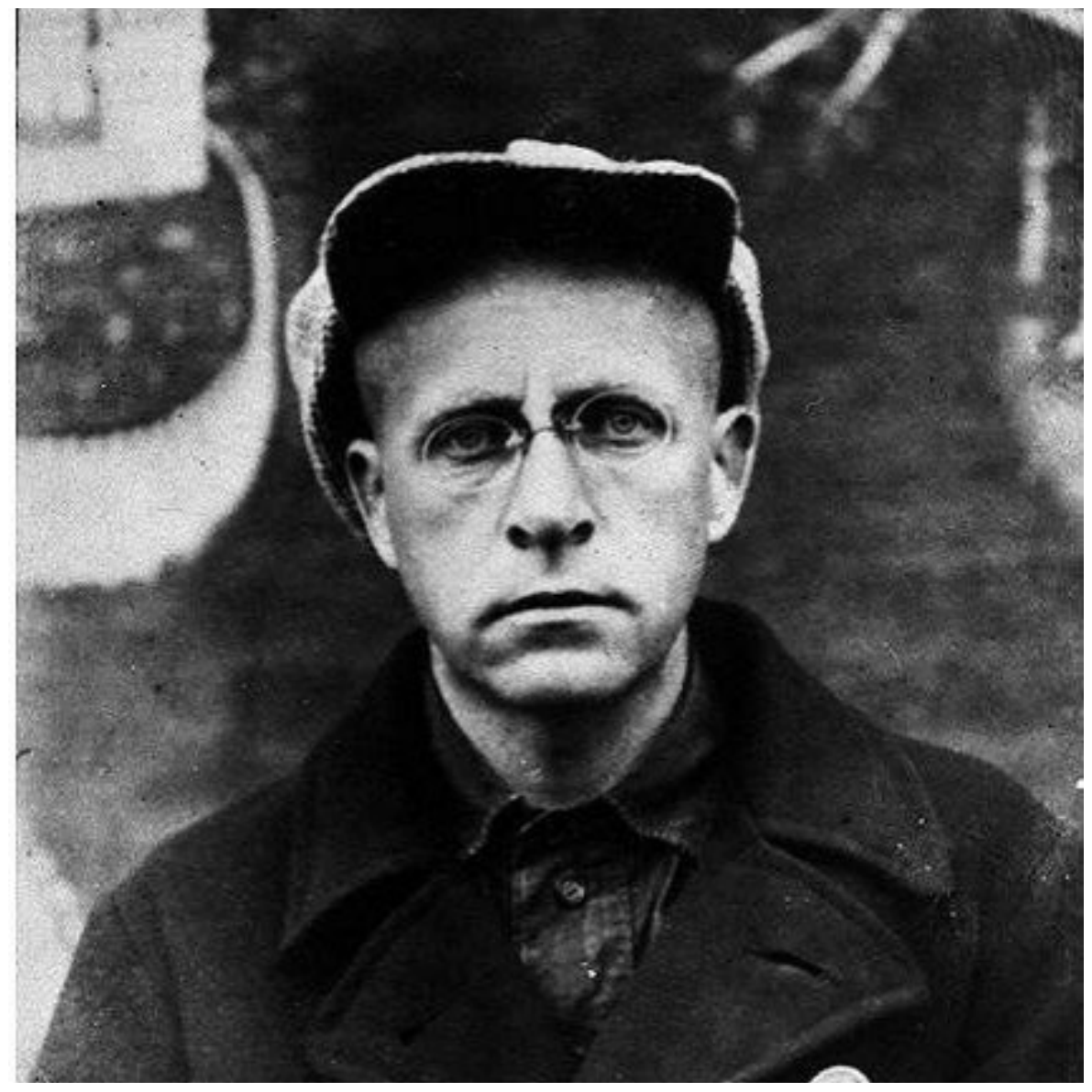




\title{
Något betydelsefullt Leonid Dobyčins möten bortom orden i den sovjetiska samtiden
}

\section{Hans Andersson}

Akademisk avhandling för avläggande av filosofie doktorsexamen i slaviska språk vid Stockholms universitet som offentligen kommer att försvaras fredagen den 20 september 2019 kl. 10.00 i hörsal 9, hus D, Universitetsvägen 10 D.

\author{
Abstract \\ Something Important. Leonid Dobychin's Encounters Beyond Words in Soviet Times
}

This thesis studies the 1931 short story collection Portret [The Portrait] by the Russian author Leonid Ivanovich Dobychin (1894-1936?). My main argument is that the principal theme in Dobychin's writings arises out of the complexities of human encounters.

My approach is based on affirmative interpretations that I call "encountering" readings. They draw on critical practices developed by Boris Gasparov, who argues in his 2013 study of Pasternak Boris Pasternak: Po tu storonu poètiki (Filosofiia. Muzyka. Byt) that the key to Pasternak's work lies not in the dominant feature of their linguistic texture, but in the momentary states of everyday life that the author captures, and Henri Meschonnic's Critique du rythme: Anthropologie historique du langage (1982). Meschonnic focuses on rhythm as an intrinsic aspect of the text that requires the reader to participate actively in appreciating the text as a work of art by following the interplay between rhythm, the active subject and what is expressed. Both scholars reflect a turn away from the linguistically informed theoretical approaches that dominated the academic study of literature in the twentieth century.

Similarly, I approach Dobychin's characters on the level of their personal conflicts and everyday lives by simulating an interpersonal encounter in an anti-theoretical search for meaning that is congenial to both the central theme of the stories and the way in which they reveal human encounters "beyond words," as it were, both within the works and with the reader, through suggestive associations and not yet categorized, "precategorial" experiences in everyday life.

The "unoutspokenness" (nedogovorënnost') - i.e. reticence, a deliberate avoidance of explicitness that Dobychin's contemporary critics ascribed to his writings and often disparaged as "incomprehensibility" - serves as a starting point for a critical discussion of both earlier research on Dobychin and theoretical approaches to literature more generally. In searching for a dominant formal feature, a 'key' or 'code', in Dobychin's writings, earlier scholars have tended to describe it in terms of an anti-aesthetic. The alleged lack of plot, inner coherence and meaning is explained as deliberate, intended to performatively mirror the absurdness and inadequacies, the disorientation and loss of meaning in Soviet reality itself. In this thesis, I argue instead that there is no such lack or incoherence in Dobychin's works. The "nedogovorënnost"” of his short stories is instead understood as an exact and purposeful way of conveying meaning through what is experienced and shared beyond words in a time that was overburdened with idealistic ideological discourses. At the heart of Dobychin's stories are moments of fragile human interaction that underlie trivial dialogues and actions in banal everyday existence. The stories let the reader experience the sudden and unexpected human connections that the characters encounter in their everyday impressions. The contrasts and plurality of human perspectives thus perceived evoke a potential interaction beyond societal roles. These brief encounters are presented as something precarious in a Soviet society striving towards a single true ideology. Such a reading suggests that Dobychin is not so much a deliberately enigmatic author as a writer who aspires to express in words that which is profoundly wordless: the encounters between people outside of the ideological categories and discourses of their language.

Keywords: Leonid Dobychin, L. Dobyčin, Russian Literature, Soviet Literature, Soviet Culture, 1920s, 1930s, Prose, Short Stories, Modernism, Formalism, Realism, Encounter, Meeting, Detail, Rhythm, Epiphany, Everyday Life, Bryansk, Leningrad, Petrograd, Saint Petersburg.

Stockholm 2019

http://urn.kb.se/resolve?urn=urn:nbn:se:su:diva-171254

\section{Institutionen för slaviska och baltiska språk, finska, Stockholms nederländska och tyska universitet}

Stockholms universitet, 10691 Stockholm 

NÅGOT BETYDELSEFULLT

Hans Andersson 



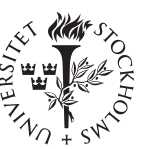

Stockholms universitet

\section{Något betydelsefullt}

Leonid Dobyčins möten bortom orden i den sovjetiska samtiden Hans Andersson 
(CHans Andersson, Stockholms universitet 2019

ISBN tryckt 978-91-7797-773-5

ISBN PDF 978-91-7797-774-2

ISSN 0347-7002

Tryckeri: Universitetsservice US-AB, Stockholm 2019 
Till Julia och Leonid 



\section{Tack}

Ordet "spasibo" förekommer inte en enda gång i Leonid Dobyčins noveller. Jag ska inte följa hans exempel. Jag har fått så mycket hjälp, stöttning, stöd, uppmuntran, värdefull granskning och ekonomiskt bistånd i mitt arbete om honom. Jag har inte varit ensam. Det är många jag vill tacka.

Tack professor Per-Arne Bodin, först och främst, min huvudhandledare för din enorma hjälpsamhet och din lätthet, ditt aldrig hybrisskapande sätt att berömma och din försiktiga men kärnfulla kritik. Tack för ditt tålamod och att du alltid funnits där. Tack professor Irina Sandomirskaja, min handledare, för alla idéer och ifrågasättande av idéer. Tack för att du sett mig. Tack professor Peter Alberg Jensen för din vänskap, ditt hjärtliga lynne, din godartat dialogiska ironi och ditt allvar. Tack för alla möten. Tack docent Susanna Witt för din fantastiskt noggranna grönläsning och för givande nya uppslag, och tack Charles Rougle för din omsorgsfulla språkgranskning av de engelska texterna. Jag vill också tacka professor Anna Ljunggren, min första huvudhandledare, för all hjälp och utvecklande kritik i avhandlingsarbetets första skede, samt professor Boris Gasparov som då var min handledare - tack för ett givande samtal. Ett stort tack vill jag också rikta till professor Georg Witte som med stor vänlighet och entusiasm handledde mig under en utbytestermin vid Freie Universität i Berlin. Tack också docent Ljudmila Pavlovna Grigor'eva som först gjorde mig bekant med Dobyčins författarskap och orienterade mig i den tidigare forskning om honom under mina tidigare studier vid Sankt Petersburgs statliga universitet.

Jag vill tacka alla de kollegor - ingen nämnd, ingen glömd - vid Slaviska institutionen (som det hette) som hjälpt och glatt mig under dessa år, och också de nya kollegorna vid den nuvarande större institutionen, samt andra vid Stockholms universitet som på olika sätt har bistått mig under åren. Jag vill också nämna sammanhanget på CBEES och Södertörns högskola som Irina Sandomirskaja introducerade mig i, bland annat genom sina seminarier i rysk teori vid vilka jag också fick presentera mitt arbete. Tack till alla där som vid sidan av Irina har inspirerat mig - Lars Kleberg, Marcia Sá Cavalcante Schuback, Tora Lane, Aleksei Semenenko med flera. Jag vill även rikta ett tack till alla de engagerade studenter, doktorander och lärare vid Freie Universität och Humboldt-Universität zu Berlin som förgyllde min 
vistelse där och utvecklade mig som forskare. Tack också till Kungliga biblioteket för alla timmar i forskarsalen och för vänlig assistans, tack ni andra som satt där för gemenskapen.

Jag är tacksam för den hjälp jag fick av medarbetare på Puškinskij dom IRLI i Sankt Petersburg där jag studerade Dobyčins manuskript. Jag vill också tacka de Dobyčinforskare jag lärde känna vid konferensen Slavjanskie čtenija XI i hans hemstad Dvinsk, Lettland. Jag är tacksam för att biblioteket BULAC under mina forskningsvistelser i Paris frikostigt lät mig använda deras rika samlingar, och för flott boende på Svenska institutet. Jag vill även tacka för insiktsfulla kommentarer från kollegor och ett givande sammanhang vid nionde ICCEES-kongressen i Makuhari, Japan - och tack Anna Ljunggren för ditt panelinitiativ som tog mig dit. Tack också för det Bachtinsymposium vid Vitterhetsakademien där jag fick medverka, och för gemenskap och värdefulla kommentarer från kollegor vid de nordiska slavistmötena i Bergen och Stockholm.

Jag är ett stort tack skyldig de finansiärer som möjliggjort mina forskningsvistelser och konferensresor: Deutscher Akademischer Austauschdienst, Helge Ax:on Johnsons stiftelse, Stiftelsen Lydia och Emil Kinanders fond, Svenska institutet, Stiftelsen Wallenbergsstiftelsens fond, Stiftelsen Birger Callemans fond. Ett särskilt tack vill jag rikta till de två stiftelser som finansierade det sista avgörande halvåret $\mathrm{i}$ avhandlingsarbetet: Johan och Jakob Söderbergs stiftelse och Helge Ax:on Johnsons stiftelse. Sist och inte minst vill jag tacka Stockholms universitet och ytterst svenska staten för min anställning och forskarutbildning, tack.

Och så finns det dem som ordet tack känns alltför litet för, men vad ska man göra. Tack vänner. Tack kära föräldrar för hjälp med barnpassning och korrekturläsning. Tack Julia mitt allt för all kärlek, för dina idéer och allt du hjälpt mig med. Tack min son Leonid för att du lär mig att leva. 


\section{Innehåll}

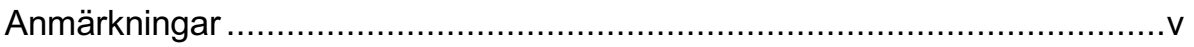

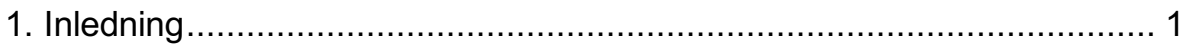

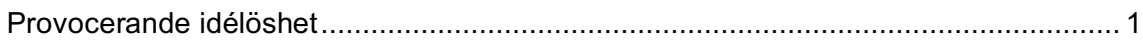

Igenkänningar av tillvaron (teoretisk hopplöshet) .................................................... 20

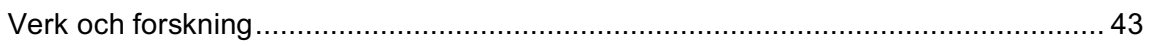

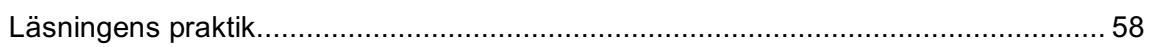

2. Avskedet och samtiden ......................................................63

Konstens avsked från huvudstaden, en ramberättelse .......................................... 63

"Kozlova" - i väntan på ett brev från monsieur..................................................... 78

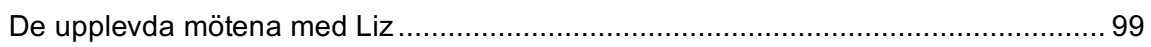

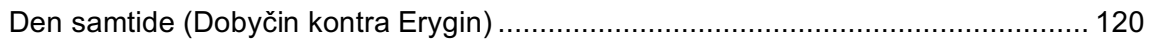

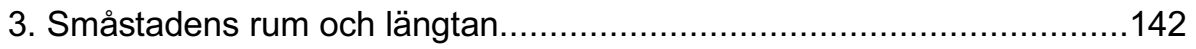

Kvinnor som drömmer om möten..................................................................... 142

Flugan och björnen, pojken och matrosen ......................................................... 166

"Konopatčikova" - om en konst bortom orden ................................................... 184

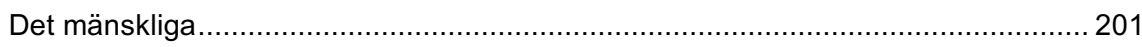

4. En dag, en stund och något slags möte - samtidens sista berättelser ..204 Vardagens stunder som något betydelsefullt .................................................... 206

Samtidens mörknande trädgård, en ostädad sång ............................................ 236

"Porträttet" - ett avsked till samtiden ........................................................... 248

5. Slutet på samtidsberättandet, slutdiskussion ...............................286

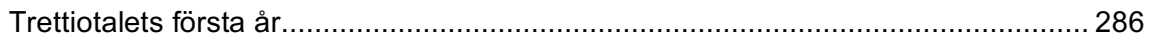

"Jag kan inte tiga" - författarskapets fortsättning …........................................ 297

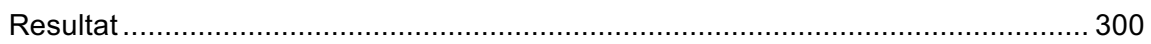

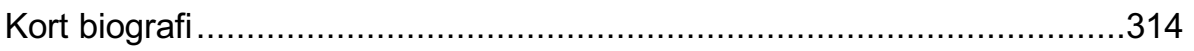

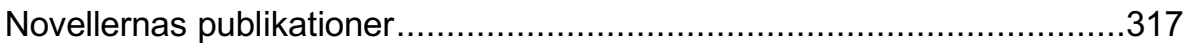

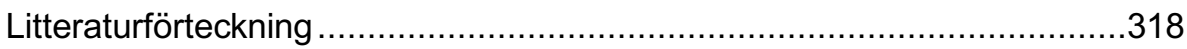

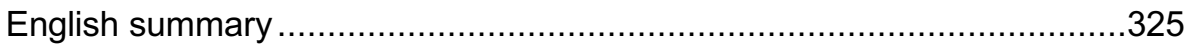





\section{Anmärkningar}

Översättningarna i avhandlingen är mina om inte annat anges. I översättningarna av Dobyčins verk har jag använt gängse svensk transskribering för skönlitterära översättningar från ryska. I avhandlingen i övrigt används internationell akademisk transskription i den svenska texten och förenklad engelsk transskription i abstract och den engelska sammanfattningen. 



\section{Inledning}

\section{Provocerande idélöshet}

\section{Ämne och syfte}

Leonid Dobyčin (1894-1936?) är på samma gång en mycket svår och en mycket enkel författare. Det beror på hur man ser det. Han passar inte riktigt in någonstans. Det är i sig en möjlig förklaring till varför han fortfarande är så föga känd trots alla ansträngningar som gjorts de senaste trettio åren för att lyfta fram hans bortglömda författarskap som ett av de främsta från det ryska nittonhundratalet.

Det som den här avhandlingen tillför är att demonstrera att Leonid Dobyčins författarskap visserligen är gåtfullt men att det öppnar sig när man slutar att leta efter nyckeln. Placerar man honom i en modernistisk kontext så kan man visserligen finna prov på en sammanhangslöshet och brist på framträdande handling som kan förklaras som medvetna grepp för att blottlägga tillvarons brist på mening. Men så betraktade förefaller också hans berättelser som tämligen meningslösa att läsa. Om man inte söker efter en särpräglande kod eller teknik utan istället efter mening i dem så finner man betydelse i det liv som gestaltas, men inte i vanliga utvecklade dialoger mellan människor eller i stora händelser och avgörande handlingar. Det är ingen traditionell realism. Det Dobyčin lyckas fånga är ett mänskligt samspel liksom bortom orden på ytan - men förstås språkligt uttryckt. Dessa möten blir ett sätt att söka en existentiell mening och gemensam mänsklig grund bortom de särskiljande ideologiska diskurser vi är instängda i. För det förhållningssätt och tillvägagångssätt som krävs för att uppleva detta och förverkliga Dobyčins berättelser kan man låna ett recept från en av hans noveller: "- Titta på den där tallen, sade gumman, och tänk inte."

\footnotetext{
I "- Смотрите на ту сосенку, - сказала бабка, - и не думайте." Ur novellen "Požalujsta" ("För all del") som behandlas i kapitel 3. L. Dobyčin, Polnoe sobranie sočinenij i pisem, Sankt Petersburg 2013, 90.
} 
I fokus för avhandlingen står Leonid Ivanovič Dobyčins samling av arton samtidsskildrande noveller från I920-talet. Sexton av dessa utgavs i samtiden som en novellsamling under titeln Portret (Porträttet) 1931. Samlingen läses som ett porträtt av vanliga människor och deras sovjetiska samtid ur vilket en genomgående mötesproblematik framträder. Den nya sovjetiska samhällets ideologiska förklaringar och ordnande av verkligheten, vilket $\mathrm{i}$ ökande grad under tjugotalet medförde ett inskränkande av friheten för olika sätt att vara, för personliga uttryck och öppna meningsutbyten, gör drivkraften bakom att fånga subtila upplevelser av en mänsklig interaktion bortom de stora orden och handlingarna, att fånga människor bortom sina samhällsroller och ett genomideologiserat språk, särskilt förståelig. I all sin synbara banalitet - för det är i det banala och vardagliga som det framträder - framstår detta Dobyčins sökande efter något betydelsefullt alltmer som en frihetskamp och omsorg om livet i denna tillvaro. Det kan ytterst ses som författarens egen kamp för att bevara det mest dyrbara i sitt liv: sig själv som människa och sitt personliga uttryck.

Utgångspunkten för avhandlingen är att fördjupa förståelsen av Leonid Dobyčins författarskap utifrån vad dessa noveller gestaltar och uttrycker. Det mer specifika syftet är att visa att en meningssökande, affirmativ och kreativ, mötande läsning av novellerna och den vardagliga tillvaro de gestaltar framkallar det jag kallar möten bortom orden med denna samtida tillvaros människor och mänskliga uttryck. I de konflikter som novellerna på så sätt upplevs avtäcka i det nya sovjetiska samhället visar jag vidare på en genomgående existentiell problematik som kretsar kring det mänskliga mötet. Jag argumenterar slutligen för att en uppmärksamhet inför detta centrala mötestema hos Dobyčin fördjupar förståelsen av novellerna som en del av författarens meningssökande i relation till den samtid och samhällsutveckling de växer fram under och gestaltar.

Beskrivningen av mötestemat och dess utveckling i Dobyčins samtidsskildrande noveller, som avhandlingen begränsar sig till, syftar indirekt också till att fördjupa förståelsen av författarskapets helhet och Dobyčins övergång vid trettiotalets början till att istället skildra historisk tid och andra miljöer i två längre verk. Att Dobyčin avlägsnar sig från samtiden i sitt berättande men fortsatt upptas av mötestemat föreslås kunna förstås dels som ett sätt att utveckla mötesproblematiken genom andra kontexter och dels som att den sovjetiska samtiden gav allt mindre utrymme för och uppslag till det slags möten bortom orden som han försökte fånga. 


\section{Ett inledande exempel}

"[Č]to-to značitel'noe", "något betydelsefullt", ärvad det skrivs ut att huvudpersonen i Dobyčins allra första berättelse "Timofeev" upplever. Det är den centrala händelsen i den korta novellen. Timofeev kommer hem och sover efter att ha misslyckats med en examensskrivning. Hans tärande studentliv framställs genom beskrivningen av rummet och hans sovande kropp. När han vaknar går han ut efter hyresvärdinnan för att få sig en kopp te. Han finner henne ute på trappen njutande av stillheten och slår sig också ner, ett trappsteg ovanför. De delar denna stund tyst blickande mot den rödaktiga himlen i väster, med dess dammfärgade strimmor ("som skräp som sopats till tröskeln och lämnats") och en tung, röd måne hängande över bakgårdarna. ${ }^{2}$ Ett ånglok visslar så i fjärran vilket får värdinnan att suckande viska: "Fil'janka." Timofeev förstår inte, "fil'janka"? Och värdinnan upprepar med det fullständiga namnet för järnvägslinjen till Finland, som hon tycks gissa att loket hörs ifrån (men fortsatt feluttalat vilket nog var den egentliga anledningen till att Timofeev inte förstod): "Fil'janskaja železnaja doroga". ${ }^{3}$ Sedan sluter de sig och sitter tysta igen till dess en annan hyresgäst öppnar fönstret och kallar på värdinnan med samma ärende som det Timofeev ursprungligen haft. När han efteråt sväljer sitt te och tuggar på en bit siktbröd (vetebröd) tänker han tillbaka på stunden på trappen och att han då, när han såg på den regnförebådande himlen, upplevde något betydelsefullt. ${ }^{4}$

Läsaren har genom novellens uppbyggnad av stunden förmedlats samma känsla. Något ödesmättat, känslofyllt. Men vad? En kort stund i ett tyst möte tycktes de dela upplevelsen av något som inte behövde ord för att utsägas. Redan den specifika beskrivningen av himlen innehåller på samma gång lyriskt stämningsgivande och realistiskt verklighetsförankrande och berättande detaljer. Den triviala felsägningen skingrar visserligen upplevelsen av samförstånd och samhörighet i deras försjunkenhet inför kvällshimlen. Samtidigt förankrar konkretionen dialogiskt dessa två olika individer i en levande verklighet och ger ett begrepp om både värdinnan och Timofeev som personer. Med sitt innehåll, det tåg som avlägsnar sig från staden, talar

\footnotetext{
2 "Красная луна, тяжеловесная, без блеска, как мармеладный полумесяц, висела над задворками. На красноватом западе тускнелись пыльного цвета полосы, точно сор, сметенный к порогу и так оставленный.” L. Dobyčin, Polnoe sobranie sočinenij i pisem, Sankt Petersburg 2013, 329.

${ }^{3}$ Dvs. ungefär "Filjändskan" och "Filjändska järnvägen" (det riktiga hade varit "Finljanka" och "Finljanskaja").

4 "Глотал он чай и жевал ситный задумчиво: что-то значительное, казалось ему, было в тех минутах, когда он сидел на крыльце и смотрел на мутноватое, сулящее на завтра дождь, небо." (Min kursiv.) L. Dobyčin, Polnoe sobranie sočinenij i pisem, Sankt Petersburg 2013, 330 .
} 
det som felsägs både för värdinnans längtan och för vad huvudpersonen genom denna stund möjligen kommer till insikt om som ett avgörande livsval.

I läsningen förmedlas vi detta genom att vi dras in både i att uppleva själva känslan i stunden med dess blandning av lättnad och existentiell insikt, och i att genom dess konkreta detaljer utveckla ett slags intuitiv förståelse av hela livssituationen för de människor som skildras, deras tankar och känslor och det som stunden så kan betyda för huvudpersonen som i slutet ännu bara konstaterar sin upplevelse av något betydelsefullt. Det framstår som en avgörande händelse som han själv försöker förstå innebörden av. Denna mötesliknande delaktighet som läsaren blir indragen i gör att de vardagliga och tidsbundna detaljerna bringas i en konstens tidlösa rörelse. Så formas ett uttryck för något i denna ordlöshet som vi erfarit vilket inte låter sig formuleras annorlunda. Vi har upplevt kvällsstundens impressionistiska tillstånd men det som gör novellen drabbande som en händelse är det djupgående möte mellan och med just dessa människor i deras verklighet som därigenom gestaltats. Det är med det mötets insikt och inlevelse i deras liv och vardagliga tillvaro som novellen också blir förståelig som in i varje beståndsdel betydelsefull.

\section{De första läsarna}

Något betydelsefullt. Men vad? Vad vill då författaren egentligen säga? Detta Dobyčins berättande nästan utan förklarande och förmedlande berättarinslag, hans istället sinnliga gestaltande av en levande vardaglig tillvaro som genom associativt samspelande detaljer formar sig till konstnärliga helheter, till berättelser som fångar något betydelsefullt - en sådan "outsagdhet" ("nedogovorënnost"'s), som det kom att betecknas i en av de första recensionerna, betraktades med misstänksamhet i den sovjetiska samtiden. Vad dolde sig egentligen för världssyn bakom detta, vilken ideologisk ståndpunkt gav författaren uttryck för genom alla dessa detaljer och brottstycken? Vad var syftet med att göra det så svårförståeligt?

Dobyčins svårbegriplighet var föga förvånande ett problem i sig för den nya sovjetiska litteraturkritik som såg som sitt uppdrag att i det som inte tydligt byggde på den rätta ideologin spåra en borgerlig och reaktionär världssyn - för att skarpt tillrättavisa (under tjugotalet) och sedan fördöma som skadligt och fientligt (under trettiotalet). Men att förstå hans verk tycks också ha varit en utmaning för dem som var vänligt inställda, de läsare som

\footnotetext{
${ }^{5}$ Nikolaj Stepanovs recension av den första novellsamlingen Vstreči s Liz (Mötena med Liz) i Zvezda, II, I927, I70.
} 
drogs till det han skrev och upplevde honom som en fascinerande författare. Frågan är om det verkligen var ett problem för dem i själva läsningen, kanske uppstod svårigheten först när de skulle försöka förmedla läsupplevelsen.

Så här återger Dobyčin själv mötet med en av sina läsare och vad denna hade att säga efter publiceringen av sin första novell "Vstreči s Liz" ("Mötena med Liz") i fjärde numret av tidskriften Russkij sovremennik I924:

«Я очарована. Когда читаешь в первый раз, кажется - так себе. Потом я как-то начала читать еще раз и тут поняла: «Моды де-Ноткиной»!» - и тут она принялась перебирать одно украшение этой истории за другим. ${ }^{6}$

"Jag är förtrollad. När man läser första gången verkar det inte vara något särskilt. Sedan började jag liksom läsa en andra gång och med ens förstod jag: 'De-Notkinas moden'!' - och med ens började hon att gå igenom utsmyckning efter utsmyckning i denna historia.

Å ena sidan är hon förtrollad av något hon upplevt som vid första läsningen inte framstod som något särskilt. ̊̊ andra sidan tycks det enda sätt hon kan uttrycka denna förtrollning på vara att räkna upp alla de detaljer - "utsmyckningar" - i texten som berört henne. Det framgår redan här att Dobyčin önskar sig något mer och att den äldre kvinnan enligt hans uppfattning trots uppskattningen inte har förstått berättelsen i dess helhet. Vad problemet är blir tydligt när Dobyčin återkommer till henne efter att hon har läst hans andra publicerade novell ("Kozlova"). Nu är hon som förbytt och ovillig att ens tala om den. Den anledning som Dobyčin ser till hennes kyliga inställning är ett helgons profana roll i berättelsen och beskrivningen av en biskop som tömmer sin slaskhink. Den tidigare förtjusningen förklaras så indirekt endast ha avspeglat hennes (mot kritikerna motsatta) ideologiska ståndpunkt - kyrkans och den förrevolutionära kulturens - som hon i de fina detaljerna då fann uttryck för.7

Dobyčin återger också provocerade reaktioner på den första novellen. Upprördheten kommer sig av att dessa läsare inte ser någon skönhet i de enskilda beståndsdelarna i sig och inte heller har förstått sig på hur de hänger ihop:

\footnotetext{
${ }^{6}$ Till Kornej Čukovskij 3 mars I925, brev I2 i L. Dobyčin, Polnoe sobranie sočinenij i pisem, Sankt Petersburg 2013, 252.

7 "Желая вновь подвергнуться похвалам старухи [...] я дал ей прочитать Козлову. Сегодня утром я ее встретил на улице: - Как вы нашли? - она прищурилась. - Понравилось. Какая мерзкая погода. - Каково благовещение, такого и пасха, - сказал я. - Есть и еще примета, - обрадовалась она: - Осеняя: Дмитриев день в снегу - и пасха в снегу. - Правда, правда. Причина ее холодности - святой Кукша и епископ с помоями." Till Kornej Čukovskij 7 april I925 (brev I8), L. Dobyčin, Polnoe sobranie sočinenij i pisem, Sankt Petersburg 2013, 255.
} 
Хулы же были вот какие: «я удивляюсь, как цензура это пропускает: лето, и вдруг - лед!» А другая: «Вот, например: Пыльный луч пролезал между ставнями. Ели кисель и, потные, отмахиваясь, ругали мух. - Что тут красивого? И потом - кто это? где?.. И не написано, что они сидели». ${ }^{8}$

Klandren har varit av följande slag: "jag är förvånad, hur kan censuren släppa igenom det här: det är sommar och plötsligt - is!" Och en annan: "Hör här till exempel: En dammig stråle trängde in mellan fönsterluckorna. De åt kräm och viftade svettiga ifrån sig och svor åt flugorna. Vad finns det för vackert i det? Och sedan - vilka är de? var?.. Och det står inte att de satt ner."

Antingen är det bara Dobyčins ironiska lättsamma sätt att beklaga sig eller så blir han faktiskt inte beklämd av reaktionerna, inte bekymrad över att hans skrivande inte tycks nå fram till läsarna, inte oroad över att det faktiskt skulle vara för svårt. Han tycks trygg i att det är dessa läsare som är bristfälliga, liksom en del av samma provinsiella enfald som han skildrar i sina berättelser.

De reaktioner Dobyčin återger är nämligen från läsare i Brjansk, den småstad nära gränserna till Ukraina och Belarus (med cirka 30 ooo invånare I9I7 som på tio år kom att fördubblas) dit han såg sig nödgad att flytta sommaren I9I8 för att bo med sin mor och syskon och försörja sig som statistiker efter sina, likt huvudpersonen i den första berättelsen "Timofeev", aldrig fullbordade studier i Sankt Petersburg, sedermera Petrograd. Det är per post från Brjansk till vad som 1924 blivit Leningrad som Dobyčin får sina första verk utgivna och upprättar kontakter med några av stadens författare och litteratörer. De två som blir särskilt avgörande för Dobyčins karriär är den främst som barnboksförfattare, översättare och litteraturkritiker kände Kornej Čukovskij, som antog och lät publicera Dobyčins första novell i fjärde och sista numret av tidskriften Russkij sovremennik I924, och författaren Michail Slonimskij - en av grundarna av den litterära grupperingen Serapionsbröderna som Čukovskij också ingick i - till vilken Čukovskij överlät omsorgen om Dobyčins fortsatta utgivning. Deras omdömen bryr Dobyčin sig om, dem anpassar han i någon mån sitt skrivande efter. I ett av sina brev kallar han dem sina enda läsare. ${ }^{9}$

\footnotetext{
8 Till Čukovskij 3 mars 1925 (brev I2), L. Dobyčin, Polnoe sobranie sočinenij i pisem, Sankt Petersburg 2013, 252.

9 De enda två som beskurits honom, som han uttrycker det: "Мне суждены всего два читателя: І) Вы, 2) Корней Иванович." Till Michail Slonimskij 20 april 1927 (brev 9I), L. Dobyčin, Polnoe sobranie sočinenij i pisem, Sankt Petersburg 2013, 292.
} 


\section{Den samtida kritiken}

I de första recensionerna Dobyčin får, av tre noveller publicerade i fjärde numret av Serapionsbrödernas tidskriftsantologi ("almanach") Kovš 1926, talas det i ena fallet bara om "frånvaron av en tydlig ideologisk linje" hos samtliga nya prosaister i samlingen (vilket inte är mer än kännetecknande för Serapionsbröderna som en litterär gruppering av just mycket olikartade författare förenade i den överordnade föresatsen att skapa litteratur av hög kvalitet). I den andra recensionen, som visserligen generellt beskriver de nya prosaisterna som ointressanta, lyfts Dobyčin fram som den främste bland dessa. Dobyčins berättelser hade, som det står, "inte varit så tokiga om författaren bara inte haft så mycket manér för sig och inte varit så utstuderat fragmentarisk och lakonisk, vilket ibland gör hans berättelser föga begripliga"..

På utgivningen av hans första novellsamling Vstreči s Liz (Mötena med Liz) I927 följer bara en recension av den formalistiskt skolade litteraturvetaren Nikolaj Stepanov. Berättelserna behandlas framförallt i relation till vad recensenten anför som en aktuell problematik för litteraturen, nämligen att skildra den samtida historiska tillvaron ("bytopisanie"). Förklaringen till det lyckade med samlingen i detta avseende, att den varken blir för dokumentär eller litterär, ser han i berättelsernas originella "stilistiska manér" som gör dem till "fragment till en krönika där slumpmässiga och tillsynes onödiga detaljer (övertygande i sin vardagligt dokumentära 'fotografiskhet') ger nästan handlingslösa 'tavlor' av det provinsiella livet". Det utmärkande för Dobyčins prosa, vilket bidrar till "illusionen av en 'tillfälliga anteckningars' objektivitet", ser Stepanov i dess "outsagdhet" ("nedogovorënnost") samt i en den "lugna tonens ironi" - "utan patos och till och med utan humor" som kommer sig av ett jämställande av "händelser, människor och föremål". Den ibland "svårgissade" historien i novellerna beskriver Stepanov som en endast genom få antydningar framskymtande eller "'utprickad' historia" ("'punktir' fabuly"). Historiens nästan omärkliga utveckling bakom kulisserna ligger samtidigt till grund för en subtil och vass psykologisk karaktäristik av den huvudperson den kretsar kring." Detta återkommer Stepanov till i en studie av författaren Isaak Babel' från samma tid där han på en sida i förbifarten också tar upp Dobyčins detaljanvändning och betecknar den som lik Tolstojs i hur den skapar en "zakulisnaja fabula", "en

\footnotetext{
Io M. Majzel' i Zvezda, 1926, 4, 236, resp. A. Ležnev i Pečat' i revoljucija, 1926, 5, 212, citerad i L. Dobyčin, Polnoe sobranie sočinenij i pisem, Sankt Petersburg 2013, 463.

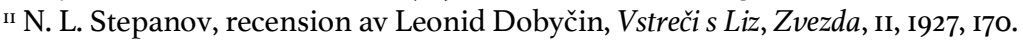


historia bakom kulisserna". ${ }^{12}$ Varken här eller i recensionen utvecklas dock vad den historien eller hela novellerna som handlingslösa tavlor i sin tur, som konst, uttrycker. Slutsatsen i recensionen är att det viktiga för Dobyčin inte är "linjer och färger" utan berättelsens "faktur", dess "legering av 'banala' detaljer vilka tillsynes tillfälligt tränger fram med den bakomliggande historien och huvudpersonens 'psykologi'". Stepanov begränsar sig till hur det är gjort. Det är därför förståeligt att han har en slutlig invändning mot att författaren blir något enahanda i sin metod och sitt val av material.

De sista två tidskriftspubliceringarna av Dobyčins noveller i början av år 1930 förses med en form av varningstexter för författarens ideologi. I tidskriften Leningrad publiceras tre noveller av Dobyčin "som typexempel på verk av en småborgerlig författare som helt saknar förbindelse med vår samtid". ${ }^{13}$ Publiceringen av novellen "Portret" i Strojka motiveras med att författarens "ovanliga arbetsmetod" sägs ha "framkallat och framkallar livliga diskussioner" och därför "är av visst intresse även för den breda läsaren som vill följa litteraturens utveckling och det konstnärliga sökandet hos dess enskilda utövare" samtidigt som det varnas för att författarens "'[a]nalytiska' varseblivande av världen som löser upp den i separata 'föremålsliga' detaljer som ännu inte på något organiskt sätt har förenats med varandra [...] i sig innebär en fara för ett typiskt borgerligt förfall i världsåskådningen." ${ }^{14}$

I recensionerna av Dobyčins andra novellsamling Portret (Porträttet) som trots det hårdnade kulturklimatet utkommer i slutet av samma år (med följande år, I93I, som angivet utgivningsår) övergår kritiken till att utpeka boken, och på samma gång författaren, som direkt skadlig, som en fiende, som förlaget gjort fel i att ge ut och som alla hädanefter måste stänga sina dörrar för.

I Portret hade Dobyčin till ett helhetligt verk sammanställt en så gott som fullständig samling av sina samtidsskildrande noveller. Bland de totalt sexton novellerna ingick samtliga nio noveller från första samlingen. Vad som saknades var två korta noveller från hösten 1930 som han inte hann eller kunde få medtagna. (Dessa två, med den ena av dem som ny titelnovell, tillfogade han såsom avsett 1933, efter att också lätt ha reviderat övriga noveller, till en komplett men då outgivbar samling med titeln Materjal (Materialet).) Den likt en ramberättelse inledande novellen "Proščanie" ("Avskedet") som

\footnotetext{
${ }^{12}$ N. L. Stepanov, "Novella Babelja", B. V. Kazanskij \& Ju N. Tynjanov (red.), Babel': Stat'i i meterialy, Leningrad 1928, 37 .

${ }^{13}$ Leningrad, 3, 1930, 469, citerad i L. Dobyčin, Polnoe sobranie sočinenij i pisem, Sankt Petersburg $2013,469$.

${ }^{14}$ Strojka, 3I mars, 4, I930, 7-8, citerad i L. Dobyčin, Polnoe sobranie sočinenij i pisem, Sankt Petersburg $2013,470-47 \mathrm{I}$.
} 
skildrar Petrograd strax efter revolutionen - och utgör en utarbetad version av "Timofeev" (den aldrig publicerade första novellskissen om "något betydelsefullt") - är den enda novellen som inte utspelar sig i den sovjetiska samtiden och i en provinsiell småstad. Som uppenbar men inte namngiven förlaga för den provinsiella tillvaro som skildras tjänar verklighetens Brjansk där Dobyčin förblev bosatt och fortsatte att arbeta som statistiker vid Brjanskguvernementets statistikbyrå, som företrädare för statistikavdelningen vid guvernementets fackföreningsråd och de sista åren vid en artillerifabrik - fram till 1934 .

Recensionerna av Portret liknar varandra i det att själva svårförståeligheten ligger till grund för stämplandet av författaren som en klassfiende. Den i och med den första femårsplanen allmänna mobiliseringen för "byggandet av socialismen" och den nytända klasskampen innebar på litteraturens område vid övergången till trettiotalet att proletärförfattarna (RAPP i sina olika varianter) och proletära kritiker tilläts härja fritt mot alla på något sätt icke-proletära författare utifrån vad som ur en arbetares perspektiv ansågs ideologiskt skadligt och fientligt. "Pozornaja kniga" ("En skamlig bok") löd rubriken på den första recensionen, av Osip Reznik i Literaturnaja gazeta. ${ }^{5}$ I den andra, av Lev Levin i Krasnaja gazeta, har detta förstärkts till "Avtoportret vraga" ("En fiendes självporträtt") och såväl den "nyborgerliga" författaren som förlaget (det av bland annat Slonimskij grundade kooperativa icke-statliga Izdatel'stvo pisatelej v Leningrade (Leningrads författarförlag)) utpekas som fiender till själva det socialistiska uppbyggnadsarbetet. ${ }^{16}$

Argumentation för dessa slutsatser är likartad. I den första recensionen förklaras de sexton novellerna vara "innehållslöst prat". I den andra heter

\footnotetext{
I5 O. S. Reznik, "Pozornaja kniga", Literaturnaja gazeta, I9 februari, I0, I93I, 3. I avdelningen för "Icke rekommenderad litteratur" i Bibliografiska institutets bulletin Kniga - stroiteljam socializma [En bok för dem som bygger socialismen] (9, mars, I93I, 74-75) som samme Reznik var redaktör för hade en tidigare version av recensionen dessutom utgjort den starkaste sortens avrådan till biblioteken från inköp av boken. (Återgiven i sin helhet i L. Dobyčin, Polnoe sobranie sočinenij i pisem, Sankt Petersburg 2013, 456-457.)

16 "Факты революционной современности перерабатываются мировоззрением писателя, реакционным и до конца враждебным не только пролетарской, но всей советской литературе. [...] Появление книги Добычина еще раз подчеркивает активизацию классового врага, всеми силами сопротивляющегося социалистическому строительству.” ("Den revolutionära samtidens fakta omarbetas av den reaktionära och inte bara till den proletära men hela den sovjetiska litteraturen fullkomligt fientliga världssynen hos författaren. [...] Tillkomsten av Dobyčins bok understryker återigen hur klassfienden aktiverar sig och med all kraft motverkar det socialistiska byggandet.") L. I. Levin, "Avtoportret vraga", Krasnaja gazeta: večernyj vypusk, 20 mars, 67, I93I, 3, citerat ur en fullständig återgivning av artikeln i A. F. Belousov, "Vokrug 'Portreta', Dobyčinskij sbornik -7, Daugavpils 20II, 20-3I, 24-26.
} 
det att novellerna är "meningslösa" och att "[i]dén i Dobyčins bok är själva avsaknaden av en idé, avfärdandet av ett idédrivet skapande". ${ }^{17}$ Det ligger sedan till grund för att hävda att revolutionens slagord och namnen på dess hjältar förfulas bara genom att ingå i novellernas kontext, att boken hånfullt driver med den revolutionära samtiden och att författaren så (trots idélösheten) för fram "synnerligen bestämda, i omisskännliga klasstoner färgade idéer". Utgivningen av sådan litteratur är därmed skadlig och måste upphöra och Dobyčins bok är inte bara förkastlig utan "organiskt fientlig mot vår samtid".

Det är lätt att bara vilja avfärda dessa ideologiska recensioner som angiveri - med texterna som bevismaterial - snarare än litteraturkritik, helt i stil med den huvud- och ryggradslösa röda karriärism som i själva verket många av novellerna innehåller nidporträtt av. Men i sak, att novellerna på ett djupgående sätt, "organiskt", faktiskt var fientligt inställda (i betydelsen på ett grundläggande sätt kritiska) till den sovjetiska samtiden kan man ändå inte ge recensenterna direkt fel i. Den fråga som inställer sig i efterhand, men som var irrelevant för samtidens kritiker, är dock om denna novellernas samhällskritik verkligen utgjorde ett samhällsskadligt hot eller tvärtom gav uttryck för en mänsklig möjlighet även i det sovjetiska samhället. Denna sorts existentiella realism hade samtidens kritiker uppenbart svårt att hantera. Författaren sägs å ena sidan bara vara en "gatufotograf", vilket gör att berättelserna inte handlar om något, är "idélösa". Å andra sidan sägs författarens påstått "reaktionärt borgerliga" världsbild (eftersom detaljerna ironiserar över den sovjetiska samtiden) grunda sig i en idealistisk och inte realistisk metod. Till sist påstås - motsägelsefullt - att (den alltså enbart dokumentärt fotografiske) författaren inte ser utan "kisar i skräck inför verkligheten". ${ }^{18}$

\section{Slut på samtidsberättandet - men inte på kritiken}

Dobyčin skriver inte mer om samtiden efter 1930. Korrespondensen med Michail Slonimskij, som hade fått till stånd utgivningen av Portret, upphör helt i två år. Slonimskij förklarar det med ett förkommet brev när Dobyčin tar kontakt igen. Under tiden har vad som då tycks vara den värsta stormen lagt sig i litteraturpolitiken i och med att proletärförfattarnas organisation

\footnotetext{
${ }_{17}$ "Det idédrivna" eller "det (rätt) ideologiskt grundade" ("idejnost") återkommer som en av grundpelarna för den socialistiska realism som lanserades som allenarådande konstnärlig metod (och inte stil) 1932 och proklamerades vid det enade Sovjetiska författarförbundets första kongress 1934 .

${ }^{18}$ Denna motsägelsefullhet i Rezniks kritik påpekas också av Aleksandr Belousov i "Vokrug 'Portreta', Dobyčinskij sbornik - 7, Daugavpils 20II, 20-3I, 24.
} 
RAPP liksom alla andra litterära grupperingar upplösts I932. Av breven i den återupptagna korrespondensen framkommer det att Dobyčin felaktigt trott att hans bok aldrig släpptes för försäljning (det är bland annat av den anledningen han sammanställt den tredje novellsamlingen Materjal). Han har därmed sannolikt inte heller tagit del av kritiken av Portret. Det nya skrivande som upptagit Dobyčin, även om det går väldigt långsamt, är istället en historisk, delvis självbiografisk roman förlagd till uppväxtens Dvinsk från strax efter sekelskiftet till åren före första världskriget.

Våren I934, samma år som ett för alla författare gemensamt sovjetiskt författarförbund grundades och socialistisk realism stadfästes som allenarådande litterär metod, upplevde Dobyčin en vändning i sin karriär. Återigen med hjälp av Slonimskij blev Dobyčin av författarförbundet i Leningrad tilldelad ett rum i en kollektivlägenhet och en smärre författarpenning, trots att det gått flera år sedan hans senaste publicering, vilket möjliggjorde både en länge efterlängtad flytt dit där han hade sitt litterära liv och ett skrivande på heltid. Samma vår fick Dobyčin dessutom början av sin roman publicerad i den kanske mest prestigefyllda Moskvabaserade litterära tidskriften Krasnaja nov' (dock följde ingen fortsättning i tidskriften som först avsett).19 Var gränserna för socialistisk realism gick var inte självskrivet. I Leningrad färdigställde Dobyčin snart sin roman med titeln Gorod Ėn (Staden En) och Slonimskij lyckades få den utgiven på det nybildade Moskvaförlaget Sovetskij pisatel' i slutet av 1935.

Recensionerna av romanen som kom i början av 1936 skulle emellertid följa samma mönster som kritiken av novellerna och vara starkt negativa. Det trots att romanen skildrade det förrevolutionära samhället. Romanen präglas också av ett sökande efter mening och en längtan efter en mer äkta vänskap, en mer fri och levande mänsklig samvaro. Ur en närsynt pojkes perspektiv avtäcks på så sätt inskränktheten och de mänskliga lågheterna och samtidigt möjligheten till något annat - i det borgerliga samhälle som nu skildrades. En del av förklaringen till de skoningslösa angreppen låg $\mathrm{i}$ att kritiken kunde passas in i den statuerande kampanj mot vad som ansågs bryta mot den socialistiska realismen inom alla konstformer, "kampen mot formalism och naturalism" ("bor'ba s formalizmom i naturalizmom"), som just tagit sin början med en artikel i Pravda (28 januari) om Dmitrij Sjostakovičs opera Lady Macbeth från Mtsensk som redan i rubriken stämplades som "Oreda istället för musik" ("Sumbur vmesto muzyki"). Även i Dobyčins roman kunna man finna prov på "oreda" och svårförståelighet, en så kallad formalism som i sig sågs som borgerlig, och även ytliga naturalistiska impressioner istället för den socialistiska realismens djupgående ideologiska

19 "Načalo romana", Krasnaja nov', 5, 1934, 98-II3. 
förklaringar av verklighet. En sådan kritik hade redan recensionerna av hans noveller lagt grunden för. Recensionerna av romanen kom så att utvecklas till något av ett drev mot Dobyčin som kulminerade under en rättegångsliknande konferens. Det kom att innebära slutet för honom både som författare och som människa.

Vid konferensens första sammanträde 25 mars 1936 - en konferens som anordnats av författarförbundet i Leningrad på temat "Om kampen mot formalism och naturalism", tillsynes för att allmänt diskutera konsekvenserna av kampanjen för litteraturens vidkommande - kom oväntat all uppmärksamhet och en lång rad talares anklagelser att riktas mot just Dobyčin som formalist och fiende. Efter att avslutningsvis ha kallats fram till scenen för att svara på anklagelserna - och där yttrat "några förvirrade ord" om att han inte kunde hålla med om det som sagts, att det gjorde honom bedrövad att romanen ansågs idémässigt fientlig - lämnade Dobyčin salen och närvarade inte vid konferensens följande sammanträden där kritiken fortsatte..$^{20}$

Redan recensionerna, med rubriker som "En misslyckad herremansson" ("Neudavšijsja barčuk"), "Historisk impressionism" och omnämnanden av romanen som formalistisk, hade påbjudits att vara skarpt negativa. Det blev Dobyčin upplyst om av Nikolaj Stepanov (samme formalistiskt skolade kritiker som mestadels positivt recenserat den första novellsamlingen 1927). Stepanov hade meddelat att han tvingats stryka alla försiktigt berömmande ord i sin recension av romanen. ${ }^{21}$ Möjligen såg han sig också tvingad till de negativa formuleringar i recensionen som ligger i linje med ett socialistiskt

20 Dobyčins framträdande återges så, sammanvägt, av Venjamin Kaverin ("IX: Leonid Dobyčin", Épilog: Memuary, Moskva 1989, 19I-205, 198-199), i rapporten från diskussionerna i Literaturnaja Leningrad 27 mars (citerad i Kaverin, a.a., 499) samt av Marina Čukovskaja i "Odinočestvo", V. S. Bachtin (red.), Pisatel' Leonid Dobyčin: Vospominanija, stat'i, pis'ma, Sankt Petersburg 1995, 7-15, I4). Enligt Marina Čukovskaja (Kornej Čukovskijs fru) vilket inte styrks av andra källor, sade Dobyčin även att han "inte förstod på vilket sätt han förtjänat sådana anklagelser, att han aldrig haft en tanke på någon formalism utan alltid bara hade skrivit så som han kunde". Kaverin beskriver det som att de verkliga formalisterna, dvs. tidigare anhängare av OPOJAZ (Sällskapet för studiet av det poetiska språket) och den formella skolan som upplösts och nu fanns på framskjutna positioner på alla håll i kulturlivet, fruktade att kampanjen skulle drabba dem, och att Dobyčin utvalts som syndabock.

${ }^{21}$ Dobyčin skriver att "det finns ett dekret från kritikersektionens styrelse om att denna bok endast ska skällas ut" ("имеется постановление бюро секции критиков эту книжку только ругать") när han redogör för telefonsamtalet med Stepanov i sitt sista brev till Slonimskij 9 februari 1936 (brev I46, L. Dobyčin, Polnoe sobranie sočinenij i pisem, Sankt Petersburg I999, 319). Den enda positiva recensionen av romanen, av Georgij Adamovič, publiceras i Paris och först efter Dobyčin försvinnande. "Literaturnye zametki: Mich. Zoščenko. 'Golubaja kniga'. Moskva, 1935; L. Dobyčin. 'Gorod Ėn'. Moskva, 1935", Poslednie novosti, 23 april, 5509, 1936, även i V. S. Bachtin (red.), Pisatel' Leonid Dobyčin: Vospominanija, stat'i, pis'ma, Sankt Petersburg 1995, I85-I86. 
realistiskt perspektiv. Stepanov beskriver det nämligen som att närsyntheten hos den unga huvudpersonen som vi upplever världen genom också präglar författaren vilket får till följd att "hans ironi och hans iakttagelseförmåga lider brist på det allmänna och en äkta social satir". I behandlingen av författarskapet märks Stepanovs formalistiska skolning (sökandet efter författarens grepp) samtidigt som han avslutningsvis klandrar romanen just för dess effektsökande formalism:

\begin{abstract}
Для [Добычина] нет „ценностей“, все одинаково бессмысленно и ничтожно. [...] Близорукость героя возводится в творческий прием. Однако, она мешает автору показать действительное соотношение предметов, найти подлинную историческую перспективу [...] [В] «экспериментальности» Добычина слишком много - от формалистических ухищрений и объективизма. ${ }^{22}$
\end{abstract}

För [Dobyčin] finns inga "värden", allt är lika meningslöst och obetydligt. [...] Huvudpersonens närsynthet upphöjs till ett konstnärligt grepp. Emellertid hindrar det författaren att visa föremålens verkliga samband och hitta ett riktigt historiskt perspektiv [...] [I] Dobyčins experimentalitet finns alltför mycket - av formalistiska knep och objektivism.

Drevet mot Dobyčin utvecklades framförallt i tidskriften Literaturnyj Leningrad där romanen i recensionen i samma anda förklaras utgöra "en samling av litterära trick" ("sbornik literaturnych trjukov") som står "i öppen motsats till den socialistiska realismens metod". ${ }^{23}$ Den tidigare RAPP-medlemmen Efim Dobin som var redaktör för tidskriften var den som gick vidare med att göra Dobyčin till måltavla för "kampen mot formalism och naturalism". I sitt inledningsanförande på författarkonferensen i Leningrad lyfter Dobin fram just Gorod Én som exempel på de formalistiska tendenserna i samtidslitteraturen. Dobyčin förklaras (i negativ bemärkelse) helt och hållet följa i James Joyces fotspår. ${ }^{24}$ Från anklagelsen om formalism tar han snabbt steget vidare, likt recensenterna av novellsamlingen Portret fem år tidigare, till en nu helt oförtäckt politisk anklagelse då han hävdar att det romanen ger uttryck för är en ren nostalgi för det förflutna, dessutom "det förflutna hos en som härstammar från de mest reaktionära kretsarna i den ryska bourgeoisien":

\footnotetext{
${ }^{22}$ N. L. Stepanov, recension av L. Dobyčin, Gorod Ėn, Literaturnyj sovremennik, 2, I936, 215-216. ${ }^{23}$ Z. Štejnman, "Istoričeskij impressionizm", Literaturnyj Leningrad, 20 feb, 9, 1936, 3, citerad i V. A. Kaverin, Épilog: Memuary, Moskva 1989, 497. Tidskriften redogör senare (I4 mars) för ett sammanträde med författarförbundet i Moskva där förlaget Sovetskij pisatel' kritiserades för att ha blivit liberala och ge ut böcker som inte behövdes, vilket Dobyčins Gorod Ėn sades utgöra det främsta exemplet på. Ibid., 498.

24 Joyce var en aktuell referens då utdrag ur Ulysses hade publicerats i tidskriften Internacional'naja literatura 1935 (därefter utkom inte Joyce i Sovjetunionen förrän på 1970-talet).
} 
Любование прошлым и горечь от того, что оно потеряно, - квинтэссенция этого произведения, которое можно смело назвать произведением глубоко враждебным нам. 25

Ett kärleksfullt tillbakablickande och en sorg över att det gamla gått förlorat, - det är kvintessensen av detta verk som man rakt ut kan benämna ett för oss djupt fientligt verk.

En av Dobyčins författarvänner, Venjamin Kaverin, menar i sina memoarer att anklagelserna stod helt i motsats till vad Dobyčins verk egentligen uttrycker. Han beskriver det som absurt hur kritikerna (bland annat Stepanov) tog närsyntheten hos romanens unga huvudperson till intäkt för att anklaga den då fyrtioåriga ekonomen och författaren för politisk närsynthet. Det romanen ytterst handlar om, menar Kaverin som stöd för författarens politiska klarsyn, är "inte försvunna föremål utan försvunna relationer". ${ }^{26}$ I förordet till den första utgåvan av Dobyčins samlade verk (I999) tar Vladimir Bachtin på liknande sätt Dobyčins roman i försvar och hävdar att den snarast "hällde vatten på den officiella sovjetiska propagandans kvarn" med sin illusionslösa skildring av den förrevolutionära världen. Bachtin placerar vidare Gorod Én i en tradition av rysk demokratisk litteratur, "den som sten för sten bröt ner de monarkistiska idealen, den som väntade på, krävde en djupgående förändring av det politiska systemet”. Han tillägger att grunden till Dobyčins "ensamhet, osalighet, tragedi" låg i att han med samma illusionslöshet, eller "hopplösa pessimism", hade framställt det sovjetiska samhället i novellerna vilket gjorde att han inte vann sympatisörer i något läger. ${ }^{27}$

Hur man än vänder på det, även med den medelväg som Kaverin och Bachtin stakar ut, tillskrivs det outsagda och svårgreppbara, det om man så

\footnotetext{
25 Dobins anförande på konferensen publicerades i Literaturnyj Leningrad (27 mars, 15, 1936) under rubriken "Formalizm i naturalizm - vragi sovetskoj literatury". En rapport i tidskriften från diskussionerna slår fast att Gorod Ėn hade bevisats vara formalistisk till själva sitt väsen. Efim Dobin hade först satt Dobyčin i samband med kampen mot naturalism och formalism just utifrån de påstådda influenserna från Joyce i sin ledare till numret med recensionen (20 februari). Att Dobin tagit ett nytt steg i anklagelserna på konferensen underströks i Štejnmans redogörelse "Pervyj den' diskussii" i Večernjaja Krasnaja gazeta (26 mars, 70, 2, 1936); medan övriga kritiker, skriver Štejnman, endast hade sett ett fientligt konstnärligt system hade Dobin gett en träffande politisk karaktäristik av boken som "en idealisering av ett borgerligt förflutet". V. S. Bachtin, "Pod igom dobrych načal'nikov", L. Dobyčin, Polnoe sobranie sočinenij i pisem, Sankt Petersburg 1999, 7-44, 13-I4, och V. A. Kaverin, Épilog: Memuary, Moskva 1989, 497-499. Det kan tilläggas att denne Dobin, som så många under de stora utrensningarna inom kulturen, snart själv kom att hamna i onåd och bli utesluten ur både författarförbundet och partiet. Därefter kom Dobin, som Vladimir Bachtin beskriver det, till insikt och blev" "en respektabel litteratör och människa". V. S. Bachtin, a.a., I2.

${ }^{26}$ V. A. Kaverin, ”IX: Leonid Dobyčin", Ėpilog: Memuary, Moskva 1989, I9I-205, 203.

${ }^{27}$ V. S. Bachtin, a.a., I4, I9.
} 
vill "idélösa" i Dobyčins gestaltande ett politiskt eller etiskt uppsåt som kanske överhuvudtaget inte var drivkraften för hans skrivande. ${ }^{28}$ För kan man inte återigen, även om man genom konsekvenserna av anklagelserna får impulsen att invända mot dem, faktiskt ge kritikerna rätt i att romanen visst rymmer något av ett kärleksfullt tillbakablickande mot den förrevolutionära världen, men då i all dess inskränkthet och låghet, på samma sätt som novellerna med en kärleksfull ironi, samtidigt som de avslöjar, visar på något betydelsefullt och mänskligt levande i den sovjetiska samtiden?

Även Dobyčin invände som sagt kort mot anklagelserna innan han lämnade konferensen den 25 mars. Troligen var han djupt omtumlad av de med ens ödesdigra angivelser som riktats mot honom genom att han utpekats som en klassfiende och överhuvudtaget antisovjetisk, vilket avvikandet från den socialistiska realismen nu i sig innebar. Nästa dag talade Venjamin Kaverin med honom på telefon och frågade först varför Dobyčin inte hade yttrat något mer än att han inte kunde hålla med om det som sagts om honom. Med en för honom typisk ambivalens mellan mångtydig ironi och bara ett trivialt konstaterande förklarade Dobyčin det med en praktisk omständighet: "för att jag är kortväxt och fick ljuset rakt i ögonen" ("- Потому что я маленького роста, и свет ударил мне прямо в глаза"). De blev tysta. Kaverin hörde en nervös andning och kände Dobyčins anspänning, hur han som han brukade liksom "av alla krafter höll tillbaka en framsprängande rättframhet". När så Kaverin upprört började tala om Dobin och de andra kritikerna avbröt Dobyčin honom med ett hest skratt: "De hade alldeles rätt." ("- Они были совершенно правы.") $)^{29}$

\section{Dobyčins sista verk och försvinnande}

Vad menade Dobyčin? Var han bara förkrossad som människa? Var det bara ett uttryck för en total uppgivenhet om att någonsin bli förstådd? För

\footnotetext{
${ }^{28}$ Det Bachtin vill framhålla är att Dobyčin med sin illusionslöshet visar att "dumheten, lågheten, inskränktheten är lika i alla tider". För att visa på detta anför Bachtin några övertygande exempel som han funnit i dagstidningen Dvinskij listok på att Dobyčin har använt anekdoter från sin uppväxts förrevolutionära Dvinsk i novellerna som skildrar den sovjetiska samtiden. Dessa exempel kan dock lika gärna tas till intäkt för att den primära drivkraften för Dobyčin inte är det samhällskritiska, utan den mänsklighet som dessa anekdoter rymmer som något betydelsefullt i sig. V. S. Bachtin, a.a., 19.

${ }^{29}$ V. A. Kaverin, a.a., 199-200. Varken Kaverin eller Marina Čukovskaja som ringde Dobyčin på kvällen efter konferensen beskriver sig ha anat oråd i Dobyčins sätt. Även Čukovskaja nämner för övrigt hans gälla (örnskrikslika) skratt, efter att Dobyčin lovat komma förbi nästa dag, som hon tidigare beskrivit som karakteristiskt för honom ("znakomyj klëkot-smech"): "Odinočestvo", V. S. Bachtin (red.), Pisatel' Leonid Dobyčin: Vospominanija, stat'i, pis'ma, Sankt Petersburg I995, 7-I5, I4.
} 
en djup ensamhet, för ett misslyckande med att nå fram till någon - som ett slags spegling av den djupa mötesproblematik som jag menar utgör det genomgående temat och den centrala konflikten i hans berättelser? Hade han misslyckats som författare?

Sin förtvivlan och ensamhet i denna situation, och sin rädsla, det han håller tillbaka i samtalen med Kaverin eller Marina Čukovskaja, ger han uttryck för i ett odaterat brev, troligen från före konferensen, till poeten Mar’ja Škapskaja där han bara ber henne, att om hon får tid, skriva något litet till honom: "Мне как-то очень неспокойно, хочется немножко жаловаться, а народу мало." ("Jag har det liksom väldigt oroligt, får lust att beklaga mig lite, men det finns nästan ingen människa att tala med.")30

Om bemötandet av romanen och det skenande drevet mot honom våren I 936 får Dobyčin att ge upp som människa, vilket vi inte vet säkert, så präglas i vilket fall inte slutet av hans författarskap av vare sig misslyckande eller uppgivenhet. Tvärtom. Han hade fortsatt skriva efter romanen. Manuskriptet till sitt sista verk går han efter konferensens första dag med till en av sina nya bekantskaper, den unge litteraturvetaren Aleksej Grigor'ev. Ett andra verk som tillkommit efter romanen hade han redan lämnat i Slonimskijs förvar. I dessa två efterlämnade verk finner man något av en ny öppning, en rörelse mot en större enkelhet i författarskapet.

Om än fortsatt konsistent i sitt pregnanta sinnliga gestaltande och i en mötesproblematik som grund för konflikten är framställningen i dessa verk - som präglas av huvudpersonernas enklare, folkligare och mer handlingskraftiga sinnelag - mer oförvägen och rättfram än tidigare. Det som skildras är också en annan tillvaro än tidigare, nämligen en avlägsen by någonstans i trakterna av staden Samara.

Materialet - en tillvaro som Dobyčin själv inte upplevt som i de tidigare verken - och troligtvis även sinnelaget stod en viss Aleksandr Drozdov för. Redan romanen Gorod Én hade tillägnats honom och till de två efterlämnade verken anges han rentav som medförfattare. Denne unge arbetare,

\footnotetext{
30 Brev I5I (odaterat), L. Dobyčin, Polnoe sobranie sočinenij i pisem, Sankt Petersburg 2013, 323. Att denna Škapskaja, till vilken bara detta brev finns publicerat och som Dobyčin annars aldrig nämner, var av särskild betydelse för honom (kanske den enda han kände att han kunde vända sig till med sin oro) antyds också av ett brev till henne från en annan kvinnlig poet, Elizaveta Polonskaja, som efter konferensens första dag ber Škapskaja att, om hon inte är alltför upptagen, skriva "несколько человеческих слов Добычину. С ним, по-моему, неблагополучно. На дискуссии, после вполне корректного доклада Добина он вышел на трибуну и лепетал что-то бессвязное." ("några mänskliga ord till Dobyčin. Han har det riktigt illa tror jag. På diskussionerna, efter Dobins fullkomligt korrekta föredrag, gick han upp på scenen och mumlade något osammanhängande.") [Min kursiv.] V. S. Bachtin, "Pod igom dobrych načal'nikov", L. Dobyčin, Polnoe sobranie sočinenij i pisem, Sankt Petersburg 1999, 7-44, I6.
} 
som "inte på något sätt var intressant" och som Dobyčin ofta talade som förälskad om, så som det beskrivs av Dobyčins litterära vänner, var en granne i den kollektivlägenhet där Dobyčin tilldelats ett rum av författarförbundet.31 Troligen är det denne grannes mustiga familjeberättelse såväl som hans folkliga berättarstil som Dobyčin försökt återge i förstapersonsberättelsen "Dikie" ("Vilda"). Berättaren "ska berätta lite om sina släktingar", en berättelse som börjar när han är fjorton år och blickar tillbaka mot tiden efter revolutionen som en tid då "bylivets idiotism ännu inte utrotats av kollektiviseringen" när folk ännu "var väldigt vilda".32

I det längre efterlämnade verket, Šurkina rodnja (Šurkas släkt; en povest', kortroman), har Dobyčin återgått till ett gestaltande i tredje person liksom i novellerna men med en historia som mindre uppbrutet, med mer utbyggda scener och ett givet sammanhang, stadigt rör sig framåt i tiden. Šurka (smeknamn till Aleksandr) är den nu mycket unga huvudpersonen, fyrafem år gammal i början, vars uppväxt vi får följa. Genom honom, som ett av tre barn till en ensamstående mor som flyttat tillbaka till sin uppväxtby sedan hennes man blivit inkallad, får vi uppleva denna bytillvaro som de först avlägsna världshistoriska händelserna - första världskriget, revolutionen och inbördeskriget - alltmer sätter sin prägel på. Den faderlösa uppväxten innebär att Šurka tidigt måste ta ansvar och hjälpa sin mor med försörjningen men ger också utrymme och frihet. Den unge Šurka utstrålar en levnadsglad hängivenhet inför tillvaron. Baksidan av hans otämjdhet och oförvägna handlingskraft är en moralisk ostadighet. Han skrattar åt sådant han inte förstår, är ofta okänslig inför andras olycka och lockas av allt laglösare lekar.

Den enkla direkthet som verket präglas av genom huvudpersonens hängivna livsnärvaro bidrar till att öppna en liknande förståelse för vad de tidigare verken - de "svårförståeliga" samtidsnoveller som är i fokus för denna

${ }^{31}$ Marina Čukovskaja, "Odinočestvo", V. S. Bachtin (red.), Pisatel' Leonid Dobyčin: Vospominanija, stat'i, pis'ma, Sankt Petersburg 1995, 7-I5, IO-I2.

32 "Еще недавно люди были очень дикие. Я расскажу немного про своих родных. Когда эта история, которую я здесь описываю, началась, мне было лет четырнадцать. Всё это было уже после революции, но тогда, когда идиотизм деревенской жизни еще не был уничтожен коллективизацией, которая тогда еще имела малое распространение." L. Dobyčin, Polnoe sobranie sočinenij i pisem, Sankt Petersburg 2013, I85. "Dikie" bevarades av Slonimskij och publicerades för första gången 1989 (Zvezda, 9, I9I-I95). Denna novell inbjöd Dobyčin också till en uppläsning av i sitt rum i kollektivlägenheten. Grigor'ev som var en av de cirka tio närvarande berättar att Dobyčin kom fram till honom efteråt för att han sett att Grigor'ev lett och förklarade att avsikten just var att det skulle vara roligt: "- Вы улыбались. Я и хотел, чтобы было очень смешно." V. S. Bachtin, "Pod igom dobrych načal'nikov", L. Dobyčin, Polnoe sobranie sočinenij i pisem, Sankt Petersburg 1999, 7-44, 36. 
avhandling - fångar som det betydelsefulla i tillvaron: den levande vardagliga tillvaron och det mänskliga i sig som en gränslös möjlighet.

Berättelsen om Šurkas släkt innehåller också en i all sin banalitet möjlig formulering av vad man snarast måste kalla frånvaron av en politisk hållning, det vill säga den ideologiska otydlighet eller "idélöshet" som Dobyčin beskylldes för. Denna idélöshet eller relativism kan nämligen också betraktas som en förbehållslös strävan efter det mänskliga och levande i ett slags tillvarons egna uttryck för något betydelsefullt bortom instängande, civiliserande ideologier - något som i sig förstås innebar en politisk provokation i den samtida sovjetiska kontexten:

\footnotetext{
- Эта книга, - сказал дед вознице, - очень умная. Заметил, как в ней все показывается и так и этак, и еще по-третьему? И это очень правильно. О всяком деле можно рассуждать и так и этак.33
}

- Den här boken, sade farfar till kusken, är väldigt klok. Lade du märke till att allting i den visar sig vara både si och så, och dessutom på något tredje sätt? Och det är mycket riktigt. Om varje sak kan man resonera både si och så.

Dobyčins kritiker kan med detta synsätt ha både fel och alldeles rätt i sina ideologiska slutsatser, liksom hans försvarare. Det är inte det som är det viktiga.

Berättelsen slutar med att faderns länge emotsedda återkomst endast leder till en kortvarig glädje. Šurka kan lämna det arbete han tvingats ta och återvända till skolan. Där hamnar han dock ständigt i bråk och börjar istället tillsammans med en ny äldre vän att stjäla saker och åka allt längre iväg med tågen för att sälja stöldgodset. Detta rövarliv, som han redan tidigare ägnat sig åt, försöker nu fadern sätta stopp för. Men Šurka låter sig inte kuvas. Efter en uppläxning lämnar han hemmet och då hans vän avböjer att följa med tar han sig ensam upp i en godsvagn och väntar på att tåget ska avgå till den hägrande storstaden Samara. På vännens fråga vad han ska dit att göra har han svarat: "Известно, зачем: жить, разбойничать." ("Det är väl givet varför: leva, röva.")

Den "vän" som vad man vet är den siste som ser Dobyčin i livet, när han lämnar sin lägenhet morgonen den 28 mars I936, arbetar som agent för säkerhetstjänsten, NKVD. Enligt dennes uppgifter till NKVD, under agentnamnet "MORSKOJ", hade Dobyčin dagen före till honom sagts sig vilja överlämna sitt rum i kollektivlägenheten, medlemskortet i Författarförbundet och sitt pass - som han inte ansåg sig behöva. Han hade uppsåt att lämna

33 L. Dobyčin, Polnoe sobranie sočinenij i pisem, Sankt Petersburg 2013, 214. 
Leningrad utan att vilja uppge vart han ämnade resa. Anledningen som Dobyčin skulle ha angivit var att Dobins utpekande av honom som klassfiende lett honom i händerna på NKVD. 34

I denne "MORSKOJS" rapportering klargörs samtidigt att NKVD redan deltagit i att utmåla Dobyčin som antisovjetisk. ${ }^{35}$ Det framgår också att de är fullt medvetna om att Dobyčin bara hade kopplingar till "en grupp formalister, särskilt KAVERIN och ĖJCHENBAUM" och att uppmärksamheten på konferensen hade riktats mot Dobyčin som en sekundär figur istället för mot "formalismens ledare" vilka fastslås ha undvikit att delta i diskussionerna..$^{36}$

I NKVD:s arkiv har också information återfunnits om att Dobyčin året innan ska ha hjälpt författare som dömts för kontrarevolutionär aktivitet (Ostrov, Uksusov med flera). Där citeras även några politiska ståndpunkter som han ska ha yttrat, bland annat följande som har en viss koppling till mötestemat i hans författarskap:

„Сейчас налицо расслоение общества. Каждый живет сам по себе. Все слои общества отделены друг от друга плотными перегородками. Вот почему трудно писать, трудно жить и понимать современных людей.“"зт

"Nu är samhällets skiktning tydlig. Alla lever var för sig. Alla lager i samhället är skilda från varandra med kraftiga barriärer. Det är därför det är svårt att skriva, svårt att leva och att förstå samtida människor."

Samme "vän" som Dobyčin på detta för honom ovanliga sätt ska ha öppnat sig för (den 3 mars) rapporterar efter konferensen att Dobyčin, efter antydningar om att vilja begå självmord, till sist, innan han lämnade lägenheten den 28 mars, ska ha sagt "att han inte har någon revolver utan ska försöka ta livet av sig på något mer primitivt sätt". Att så faktiskt skedde finns emellertid inga uppgifter om ens i NKVD:s arkiv. Där rapporteras bara vidare att pratet om Dobyčins självmord snart ersätts av ett rykte om att han

\footnotetext{
34 "Poslednie dni Leonida Dobyčina" (publ. A. V. Bljum), V. S. Bachtin (red.), Pisatel' Leonid Dobyčin: Vospominanija, stat'i, pis'ma, Sankt Petersburg 1995, 25-32, 29-30. (Alla personnamn skrivs med versaler i NKVD-rapporterna.)

35 ”ДОБЫЧИН прорабатывался нами как антисоветски настроенный автор [...]" Ibid.

36 Ibid.

37 "Iskusstvo idet vperedi, konvoj idet szadi: diskussija o formalizme 1936 g. glazami i ušami stukačej (Po sekretnym donesenijam agentov gosbezopasnosti)" (publ. A. Bljum), Zvezda, 8, 1996, 218-227, citerad i V. S. Bachtin, "Pod igom dobrych načal'nikov", L. Dobyčin, Polnoe sobranie sočinenij i pisem, Sankt Petersburg 1999, 7-44, 27-28.
} 
hade gett sig av till småstaden Luga och där gått under jorden. NKVD:s dokument om Dobyčin slutar med att de försökt fastställa Dobyčins adress i Luga utan resultat men att sökandet fortsätter. $3^{8}$

En antydan om antingen självmord eller avresa finns också i slutet av ett sista brev som Dobyčin efter konferensen avsänder till Nikolaj Čukovskij (son till Kornej Čukovskij som tolv år tidigare hade antagit Dobyčins första novell). Dobyčin ber honom där bara att reglera hans skulder med ett innestående honorar, och avslutar: "Och sök mig inte - jag ger mig av till fjärran trakter." ("А меня не ищите - я отправлюсь в далекие края.")39

\section{Igenkänningar av tillvaron (teoretisk hopplöshet)}

\section{En metodologisk parallell}

Det förhållningssätt till Dobyčins författarskap som jag nått fram till bär flera likheter med det språk-, musik- och litteraturvetaren Boris Gasparov utvecklar i en bok om Pasternak från 2013 med den för teorin och metoden talande titeln Boris Pasternak: Po tu storonu poètiki (Boris Pasternak: På andra sidan poetiken).

Gasparov beskriver där inledningsvis en situation som i flera avseenden liknar Dobyčins. Boris Pasternak hade på tjugotalet förvånats och förfasats över hur hans läsare som han upplevde det "sammansvurit sig" om hans dikters "totala oförståelighet". ${ }^{\circ}$ En uppfattning att man inte behövde förstå

\footnotetext{
38 "Poslednie dni Leonida Dobyčina" (publ. A. V. Bljum), V. S. Bachtin (red.), Pisatel' Leonid Dobyčin: Vospominanija, stat'i, pis'ma, Sankt Petersburg 1995, 25-32, 30-3I. Valerij Meškov hävdar att Vol'f Ėrlich är den som döljer sig bakom agentnamnet "MORSKOJ" i NKVD:s rapporter om Dobyčin. Meškov argumenterar för att dennes rapport om Dobyčins självmordstankar i själva verket kan tydas som att han på eget bevåg avrättade Dobyčin. Om det är Vol'f Ėrlich som är "MORSKOJ" överenstämmer det i så fall med att Bachtin i sitt förord till Dobyčins samlade verk, där han av risk för att ha fel inte vill namnge den han tror döljer sig bakom agentnamnet, nämner att denne vän till Dobyčin snart själv skulle bli avrättad, vilket Ėrlich blev 1937 (enligt Meškov just för att han tog flera egna initiativ av denna art). V. A. Meškov, Pisatel'-zagadka Leonid Dobyčin: krymskie stranicy, Simferopol 2015, 19-2I; V. S. Bachtin, "Pod igom dobrych načal'nikov", L. Dobyčin, Polnoe sobranie sočinenij i pisem, Sankt Petersburg 1999, 7-44, 17.

39 V. A. Kaverin, "IX: Leonid Dobyčin", Épilog: Memuary, Moskva 1989, 19I-205, 200. En kort biografi över Dobyčin återfinns i slutet av avhandlingen.

$4^{\circ}$ Pasternak omvärderar visserligen detta senare och förhåller sig då själv mycket kritisk till komplexiteten i sin tidiga diktning.
} 
hans dikter, att det inte var därför han skrev, spred sig även bland hans beundrare. ${ }^{4 \mathrm{l}}$ Svårförståeligheten låg även i Pasternaks fall till grund för ett officiellt avfärdande av hans författarskap på trettiotalet. Vid Sovjetiska författarförbundets högtidlighållande av hundraårsdagen av Aleksandr Pusjkins död 1937 läser en av talarna upp några rader ur Pasternaks dikt "Mefistofel" från I919 för att konstatera att dessa dikter "betraktade utifrån Pusjkins klarhet och enkelhet, betraktade utifrån sunt förnuft, inte är något annat än ett äkta sortens sinnessjuka, kliniska yranden".42

Den för denna avhandling intressanta parallellen till Dobyčins fall är hur Gasparov karaktäriserar den instinktiva reaktionen från dagens horisont på detta slags kritik: "Att skratta åt denna officiella indignation är lätt och behagligt; skrattet bara ökar det estetiska nöje som den sprudlande energin i Pasternaks vers bereder oss. Men har verkligen vår hänförelse avlägsnat sig så långt från den enfaldiga kritiska domen?” Denna retoriska fråga ger en ingång till Gasparovs nyvunna insikt om Pasternaks tidiga så kallat svåra dikter. Han tillstår att han själv tidigt hänfördes av dessa dikter och kunde dem utantill långt innan han ens började fundera över vad deras "beståndsdelar som bars av denna bildliga virvelvind" egentligen betydde. ${ }^{43}$

Det Gasparov vill visa i sin bok (vilket innebär en indirekt kritik mot vad som dominerat i tidigare forskning) är att dessa dikter öppnar sig och blir förståeliga, som en del av Pasternaks genomgående sökande efter att fånga den vardagliga tillvarons uttryck, först när man rör sig bortom denna estetiska fascination inför själva komplexiteten i dikternas språkliga faktur. Gasparov beskriver detta som att förhålla sig som en läsare och inte en kritiker till dikterna. Dikterna låter sig inte lösas som komplicerade språkliga rebusar utan kräver en hängivelse av läsaren i att försöka känna igen de förbiflimrande tillstånd och situationer, de stycken av en levande tillvaro som de vardagliga beståndsdelarna i dikterna, likt kvantpartiklar som Gasparov uttrycker det, framkallar i tillfälliga blixtar. ${ }^{44}$

Det är denna vardagligt förståelseinriktade läsning - men mot bakgrund av Pasternaks filosofiska studier, musikaliska karriär och den samtida sov-

\footnotetext{
${ }^{4 I}$ Dobyčins nämns ofta på tillsynes motsvarande sätt ha väckt livfulla diskussioner om just den säregna stilen men inte om vad hans berättelser uttryckte.

${ }^{42}$ Boris Gasparov, Boris Pasternak: Po tu storonu poetiki (Filosofija. Muzyka. Byt), Moskva 2013, I7-I9. Recensenten Reznik betecknade på ett jämförbart sätt Dobyčins noveller som "isteriki" ("hysterier") och "razgovori ni o čëm" ("samtal om ingenting"). O. S. Reznik, "Pozornaja kniga", Literaturnaja gazeta, I9 februari, IO, I93I, 3.

43 Boris Gasparov, a.a., 19.

${ }^{44}$ Ibid., I3, 2I, 23.
} 
jetiska tillvaron - som Gasparov betecknar som att behandla Pasternak bortom författarskapets poetik i gängse mening. ${ }^{45}$ Anledningen till att detta förhållningssätt är särskilt relevant för Pasternaks författarskap föklarar Gasparov med att Pasternaks strategi för att råda bot på automatiseringen av verkligheten, det vaneseende som gör omgivande föremålen och själva livet liksom osynligt för oss, i själva verket var rakt motsatt den som avantgardets konstfilosofi föreskrev utifrån Viktor Šklovskijs tongivande artikel "Konsten som grepp" ("Iskusstvo kak priem") från 1917. Istället för att skapa en distans som bryter vårt vanemässiga igenkännade och får oss att se vår vardagliga tillvaro, så som Šklovskij beskriver konstens generella funktion med främmandegöring som främsta medel, framställer Gasparov det som att Pasternak, om än med ett liknande resultat, gör precis tvärtom. Pasternak följer efter de ständigt undanglidande föremålen i en outtröttlig strävan att så förbehållslöst som möjligt igenkänna den vardagliga tillvarons föremål bortom de konventionella ramarna. 46

Även min väg till en förståelse av Dobyčins författarskap har gått via en delvis förblindande fascination inför hans prosas ytliga sinnlighet och laddning som fick mig att söka formella nycklar till författarskapet - dels i användningen av tillsynes betydelselösa detaljer, dels i språkets ofta metriskt avkodbara rytm - innan jag ens på allvar försökt förstå vad berättelserna handlade om. Den förståelse som jag istället har kommit att söka, och som är det som jag utvecklar i denna avhandling, har samtidigt lett till att de formella aspekterna av prosans särdrag blivit naturligt motiverade och oskiljbara från vad Dobyčin uttrycker.

\footnotetext{
45 I Pasternaks fall är det Roman Jakobson som satt djupast spår för den poetologiska kategoriseringen av författarskapet. Jakobson blandar i sin inflytelserika artikel från $1935 \mathrm{om}$ det metonymiska hos Pasternak anmärkningar om Pasternaks stil med en större systematisering av författarskap och litterära strömningars evolution utifrån metaforisk eller metonymisk dominans. Roman Jakobson, "Zametki o proze poèta Pasternaka", Raboty po poètike, Moskva 1987, 324-338. Det Gasparov har att invända, är att de intressanta iakttagelserna där hamnar i skymundan för en jakt, som fortsatt i senare forskning, på metonymier som kännetecknande för Pasternaks poetik. Men kärnan för förståelsen av författarskapet, skriver Gasparov med hänvisning till en artikel av Peter Alberg Jensen ("Po tu storonu 'svoego' i 'čužogo'. Zametki ob èstetike Pasternaka", Studia russica Helsingensia et Tartuensia, 4. 'Svoe' i 'čužoe' $v$ kul'ture, Tartu 1995, 273-283; vilken också tycks ha inspirerat till titeln på Gasparov bok), "ligger inte i något särskilt överflöd av metonymier, utan i en 'horisontell' strategi i gestaltningen av verkligheten" vilket metonymierna är en följd av. Det Jakobsons koncept ignorerar, genom att $\mathrm{i}$ enlighet med futurismens estetik och litteraturteori bestämma Pasternak utifrån texternas faktur, är den bakomliggande motivationen, "den energi som ger liv åt denna 'faktur", skriver Gasparov. "Pasternaks metonymiska stil är inte en retorisk artefakt konstruerad för att ge en viss 'konstnärlig' effekt", som Jakobson implicerar, utan har sin grund i den subjektiva drivkraften och uttrycket. Boris Gasparov, a.a., I3.

${ }^{46}$ Boris Gasparov, a.a., 2I.
} 
Den strategi som Gasparov i sin bok betecknar som sin igenkänning (uznavanie) av de vardagliga beståndsdelar och de momentana tillstånd som Pasternak i sitt skapande har igenkänt i tillvaron, motsvarar i flera avseenden, trots att författarskapen kraftigt skiljer sig åt, vad jag i Dobyčins fall valt att tala om som en mötande läsning som framkallar Dobyčins möten bortom orden i den vardagliga tillvaro som han gestaltar. Novellernas stundliga upplevelser av andra människors perspektiv, och en potentiell mänsklig interaktion bortom samtidens genomideologiserade språk, är som jag ser det centrala för en mötesproblematik som genomgående präglar Dobyčins författarskap. Det svåra med Dobyčin liknar det svåra med Pasternak så som Gasparov beskriver det, det vill säga att känna igen det betydelsefulla i den banala mänskliga enkelhet som Dobyčin - men med en lakonisk subtilitet istället för Pasternaks passionerade iver - i det vardagliga kaoset har fångat.

\section{Det förkategoriella}

Pasternak beskriver vägen till den konkreta kontakt med verkligheten han eftersträvar som att genom tillfälligheten i infångandet av föremål komma bort, gå vilse, från de logiska vägarna. I det slags utomrationella tillstånd som på så sätt plötsligt kan upplevas tycks varje föremål och intryck utbytbart mot ett annat men samtidigt vart och ett värdefullt som vittne för just detta tillstånd. I sådana tillstånd som fångar verkligheten i sin pågående förändring skriver Pasternak att "detaljerna vinner i klarhet när de förlorar sin självständiga betydelse". Alla delar av verkligheten framstår som likgiltiga inför varandra, de följer inte någon associativ princip eller likhetslag, de förhåller sig inte till någon konceptuell kärna, det som återstår är vad Pasternak kallar ett "innehållets associativa oro". ${ }^{47}$

Detta slags tillstånd betecknar Gasparov som "förkategoriella".48 På ett snarlikt sätt har det förhållande till verkligheten kännetecknats som Dobyčin i romanen Gorod Én fångar genom den unga huvudpersonens osorterat associerande medvetande. 49 Ett barns perspektiv, som också två av

\footnotetext{
47 Boris Pasternak, "Ochrannaja gramota", Sobranie sočinenij v pjati tomach, 4, Moskva I99I, 7; Lazar Fleishman, Hans-Bernd Harder, Sergei Doraweiler (red.), Boris Pasternaks Lehrjahre: Neopublikovannye filosofskie konspekty i zametki Borisa Pasternaka, I-II, Stanford 1996, I:228, II:I35, citerad i Boris Gasparov, a.a., 46-47.

${ }^{48}$ Boris Gasparov, a.a., 46.

49 Jurij Ščeglov beskriver det som att detta "icke-officiella associativa tänkande" har sin grund i ett hos Dobyčin generellt utpräglat citerande ("citatnost") - både bokstavligt, med citationstecken, och till sin karaktär - vilket i romanen leder till att huvudpersonen bär med sig andras ord liksom i orört, ickeassimilerat skick, och därigenom utstakar och undviker färdiga kategorier, hierarkier och åsikter. "Zametki o proze Leonida Dobyčina ('Gorod Ėn')", Proza.
} 
novellerna präglas av, kan ses som en naturlig motivering till att uppmärksamma något betydelsefullt i det banalt vardagliga och så få mänskliga möten att framträda liksom vid sidan av, bortom eller hitom samhällets påträngande ideologier och konventioner. Även de vuxna huvudpersonerna i novellerna upplever dock dessa mötesframkallande tillstånd. De skildras både latent under händelserna på ytan och som utblommande i det slags stunder av ännu oklar betydelse som jag inledningsvis visade prov på i novellen "Timofeev". Det jag där också försökte ge en första demonstration av är att vi som läsare när vi ger oss hän och lever oss in i berättelsens värld också tar del i att utveckla dessa inre men potentiellt ömsesidigt upplevda möten.

Den förbehållslösa kontakt med den levande vardagliga tillvaron som jag menar är central även för Dobyčins strävan som författare - och därmed för förståelsen av hans berättelser - tycks handla om att i denna vardagens tinglighet fånga det mänskliga och personliga, det i den tillvaro som skildras annars instängda, vilket i sig kan upplevas som en potential till en rikare och friare samvaro. Det jag vill understryka, vilket ett fokus på formen lätt skymmer, är att det är just denna mänsklighet, de olika i den pågående verkligheten levande människorna som möter oss i de triviala detaljernas och händelsernas samspel, som gör novellerna drabbande, inte de sinnliga detaljerna i sig. För att de mänskliga mötena bortom orden ska uppstå, liksom genom dem en naturlig förståelse för den formella komplexitet som skapandet av detta innebär, behövs en läsning som söker betydelse i den vardagliga värld som gestaltas. En sådan läsning uppnår vi först när vi ser bortom de formella särdragen i språket och utformningen, när vi lämnar det strukturella avkodandet av en poetik eller estetik därhän, när vi slutar att leta efter nycklar.

Gasparovs metod kan alltså beskrivas som att försöka utveckla de igenkännelser han i läsningen upplever av det som författaren känt igen som förkategoriella uttryck i den vardagliga tillvaron. Denna förkategoriella igenkänning (uznavanie) som ett mål för skapandet framstår så förvirrande nog närmast liktydig med det seende (vídenie) som Šklovskij, i "Iskusstvo kak priem", menar att konsten ska väcka oss till ur uznavanie, med vilket Šklovskij då avser vårt vanemässiga, liksom automatiska igenkännande av tillvaron. Men medan medlet, konstens huvudsakliga grepp, för att åstadkomma detta är främmandegöring (ostranenie) enligt Šklovskij, så är medlet

Poėzija. Poètika: Izbrannye raboty, Moskva 2012, 333-357. Caroline Schramm har i sin doktorsavhandling betecknat detta som ett restspråk ("Restsprache") och som ett tredje fält mellan polyfoni och monologicitet i Bachtins mening. Minimalismus: Die Prosa Leonid Dobyčins im Kontext der totalitären Ästhetik, Frankfurt am Main 1999, 50, 67, 188. 
för Pasternak, som Gasparov beskriver det, detsamma som målet. Det är alltså skillnad på vanans blinda igenkänning och en uppenbarande igenkänning i det vardagliga.

Det jag med hjälp av Gasparov vill belysa är att även om målet för Dobyčin liksom för Pasternak ytterst kan sägas vara detsamma som det Šklovskij generellt föreskriver för konsten, så är insikten om deras omvända strategi för att uppnå detta avgörande för förståelsen. Dobyčin liknar Pasternak i det att han inte heller tycks eftersträva att med medvetna konstnärliga grepp främmandegöra den vardagliga tillvaron. Det Dobyčin också snarast tycks vara ute efter är istället att försöka fånga något betydelsefullt, mänskliga och levande uttryck just i det trivialt vardagliga liksom bortom givna kategorier och ideologiska diskurser. Att förkategoriellt igenkänna blir så ett seende som potentiellt öppnar oss för mänskliga möten.

Ett annat sätt att reda ut begreppen är att det finns en tvetydighet redan i Šklovskijs begrepp främmandegöring, åtminstone såsom han presenterar det i artikeln. Idéhistorikerna Carlo Ginzburg ger en möjlig förklaringen till detta genom att visa på en möjlig kombination av två helt olika inflytanden hos Šklovskij. Med sina exempel på främmandegöring från Tolstoj, menar Ginzburg att Šklovskij i själva verket beskriver ett retoriskt verktyg med långa anor. Tolstojs fysiskt konkretiserande reflekterande ser Ginzburg som influerat såväl direkt av Marcus Aurelius självbekännelser som av den franska upplysningslitteraturens vidareutveckling av denna tradition. Šklovskijs teoretiska utveckling av begreppet visar däremot, enligt Ginzburg, på en påverkan från den varseblivningsinriktade samtida kontexten vilken särskilt Marcel Proust var tongivande för. Det jaget i Prousts romansvit i sin konstnärliga utveckling inspireras till är att framställa saker precis så som vi varseblir dem istället för att förklara dem genom deras orsak. Medan Tolstojs främmandegöring, som ett retoriskt verktyg för en djupare förståelse av verkligheten, kan sägas söka just den kausala principen bakom våra föreställningar, vill Proust bevara de första intryckens friskhet mot inkräktande idéer, liksom oskadade av kausala förklaringar. Detta att vilja framhäva den levande erfarenheten framför intellektets och vetandets stelnade former ser Ginzburg som impulsen till modernismens konstnärliga experiment. Ginzburgs poäng är att det avautomatiserade seende som Šklovskij beskriver som målet för konstens främmandegöring inte i något av fallen, varken hos Tolstoj eller Proust, bara är en estetisk effekt. Prousts form av ett seendets främmandegöring genom en gestaltning av något som sett som för första gången - vilket förefaller närmast identiskt med det Gasparov beskriver som ett förkategoriellt igenkännande av tillvaron hos Pas- 
ternak - ansluter nämligen till Tolstojs retoriska och intellektuella främmandegöring i det att det potentiellt utvecklar en kunskap grundad i den levande erfarenheten..$^{\circ}$

Detta Ginzburgs avslutande resonemang belyser indirekt också Pasternaks väg, såsom Gasparov beskriver den, när han överger sina avancerade filosofistudier i Tyskland i en sträng nykantiansk tradition för att istället $\mathrm{i}$ sin poesi förverkliga den kontakt med verkligheten såsom oformad av vår "apperception" (vår av tidigare kunskaper präglade medvetenhet) som enligt denna filosofiska riktning är en omöjlighet. Det Pasternak strävar bort ifrån, och som Gasparov vill understryka med att beteckna det som en jakt efter igenkänning av den vardagliga tillvarons beståndsdelar, är själva den rationella avsikten som ett formalistiskt perspektiv lätt implicerar. Det Pasternak som konstnär strävar efter är heller inte, möjligen till skillnad från Proust, att gestalta sina subjektiva impressioner, utan att tvärtom öppna sig, göra sig så mottaglig som möjligt för verklighetens egna uttryck. En följd av detta, menar Gasparov, blir att inte heller språket hos Pasternak intar en självständig position i förhållande till den verklighet som beskrivs. Istället får det en liknande föremålslig egenskap och präglas av samma oavsiktlighet och tillfällighet som den verklighet det gestaltar. Det Gasparov så vill understryka är att även det virtuosa språket hos Pasternak inte bör förstås som manipulerande konst utan som en strävan efter verklighetens förspråkliga tillstånd i vilket världen liksom språket som en del av den uppträder i sina fria egenskaper. ${ }^{5}$

Som vi ska se rymmer Dobyčins gestaltningar av den vardagliga tillvaron i sina ömsom allmänt konstaterande ömsom insisterande precisa (eller obestämda respektive bestämda) detaljer också hur den varseblivs. Samtidigt finns ofta en tvetydighet i vem så väl varseblivningen som det språk den uttrycks genom ska tillskrivas. Å ena sidan kan intrycken bidra till vår förståelse av karaktären hos den person som vi följer och som motiverar gestaltningen (som så sett narratologiskt, enligt Gérard Genette, kan betecknas som fokalisator), å andra sidan kan de framstå som fristående från den närvarande varseblivaren och tyckas fånga, "känna igen" något i den vardagliga verkligheten som ett tillsynes neutralt, liksom själva den reella verklighetens, korrektiv till de närvarande personernas tankar och handlingar.

I forskningen om Dobyčin har Boris Maslov teoretiskt (genom metapragmatik) tyckt sig kunna lokalisera det särskilda med Dobyčins berättande (det som betecknats som ett associativt och citerande drag av Ščeglov och

\footnotetext{
${ }^{50}$ Carlo Ginzburg, "Making Things Strange: The Prehistory of a Literary Device", Representations, 56, 1996, 8-28.

${ }^{51}$ Boris Gasparov, a.a., 47-50, 64.
} 
ett "restspråk" mellan polyfoni och monologicitet av Schramm) i Dobyčins dominerande användning av direkt tal framför såväl indirekt som fritt indirekt tal (erlebte Rede). Det, menar Maslov, för med sig att den språkliga interferens (dialog, polyfoni) som särskilt fritt indirekt tal vid återgivandet av andras ord bidrar till, som annars är något av det mest utmärkande för den modernistiska prosans utveckling, helt saknas hos Dobyčin. I Dobyčins användning av direkt tal, okommenterat eller med kontrasterande anföringar, ser Maslov samtidigt en vidgad tillämpning av dess berättande funktioner. Inte bara repliker utan också tankar och politiska slagord framställs i direkt tal och framstår ofta som tillfälliga och liksom ryckta ur sitt sammanhang. ${ }^{22}$ Genom att Dobyčin, som Maslov ser det, på så sätt skriver som om författaren inte är närvarande ens som diskursiv mellanhand för de olika citerade rösterna lämnas det i mycket åt läsaren att kalibrera dem, gissa hur det direkta talet skall intoneras, vilket mått av ironi eller empati som ska läsas in. ${ }^{53}$

Samtidigt är Maslov mindre övertygande när han inte heller i övrigt i gestaltningen vill se att de personer som skildras tar del i berättandet. Han tillstår att berättelsernas beskrivningar ibland kan avgränsas till personernas ideologiska förväntningar, fokaliseras genom dem, så att deras omdömen och ordval "projiceras på den beskrivna verkligheten". ${ }^{4}$ Han vill dock inte i detta se grunden för vad man möjligen skulle kunna beteckna som att en interferens mellan medvetanden hos Dobyčin, istället för i talet, uppstår i varseblivandet, just genom tvetydigheten i vem man faktiskt ska tillskriva intrycken och upplevelserna, liksom orden som beskriver dem. Så skulle möjligen med detta formella perspektiv den samtidighet av och dialog mellan olika mänskliga intentioner som ändå upplevs i själva läsningen kunna beskrivas. Med ögonen öppna för dessa möten bortom orden framstår dock

\footnotetext{
${ }^{52}$ Dobyčins berättande har också beskrivits som en filmisk montageteknik med det direkta talet inskjutet som textskyltarna i stumfilmer. Fedor Fedorov, "Dobyčin i kinematograf", V. S. Bachtin (red.), Pisatel' Leonid Dobyčin: Vospominanija, stat'i, pis'ma, Sankt Petersburg 1995 , 69-76.

53 Boris Maslov, "Oratio recta kak modernističeskij priem (Poètika povestvovanija L. Dobyčina s pozicii metapragmatiki)", Dobyčinskij sbornik-4, Daugavpils 2004, IOI-I25. Med fokuset begränsat till talet, i och med det tydliga avgränsande av andras ord som direkt anföring för med sig, blir beteckningar av Dobyčins prosa som rentav antidialogisk förståeliga. Se bland annat Viola Ėjdinova, "Slovo Leonida Dobyčina (Antidialogičeskaja tendencija v proze 20ch godov)", V. S. Bachtin (red.), Pisatel' Leonid Dobyčin: Vospominanija, stat'i, pis'ma, Sankt Petersburg 1995, II7-I29, II9-I2O.

54 När Maslov inte behandlar talet lämnar han också metapragmatiken för en berättarcentrerad narratologi (Genette) som därför är svårtillämpad på Dobyčin. Med exempelvis Käte Hamburgers berättarlösa narratologiska modell skulle det troligen, vid en narratologisk analys, vara lättare att få grepp om beskrivningarna som en del av gestaltningen av tillvarons olika medvetanden och deras interaktion. Käte Hamburger, Die Logik der Dichtung, Stuttgart I957.
} 
inte heller det direkta talet som så avgränsande, lösryckt och okalibrerat. I de talande tystnaderna kan vi i varseblivandet uppfatta såväl författarens kommentarer och ironiska eller empatiska reflektioner som den skildrade personens självreflekterande, självberättande tankar - eller möjligen något tredje som såväl författaren som personen möter och upplever som ett kontrasterande, ifrågasättande uttryck i den vardagliga tillvaron, något som låter ana ytterligare andra människors perspektiv, och medvetanden.

Den återhållna, neutrala tonen till trots framstår Dobyčins språk som en del av den vardagliga tillvaro som fångas, som format efter den i sin syntax, brukande dess diskurser, rytmiskt efterföljande stämningsskiftningar och kontraster, liksom precist avlyssnande den akustiskt med även felsägningar bevarade. Diktion och prosodi från denna tillvaro präglar så även sådant som inte är uttryckt som direkt tal. På samma gång kan detta språkliga avlyssnande eller igenkännande ses som en del av att framhäva en musikalisk, konstnärlig rörelse i det trivialt vardagliga och tidsbundna.

Dobyčins samordnande av i direkt tal uttryckta ord, tankar, paroller, titlar och skylt- eller affischtexter av olika slag med beskrivningar och intryck mer eller mindre färgade av den gestaltade världens människor till ett berättande samspel lämnar förvisso mycket av utläsningen av berättelserna till läsaren. Denna indragning av läsaren i förverkligandet av berättelserna gör deras idémässiga ståndpunkter svårbestämbara. Dessa möten, dessa tillstånd av ett förkategoriellt igenkännande av den vardagliga tillvaron som olika mänskliga medvetanden och intentioner framträder genom, blir samtidigt ett sätt att just gestalta berättelserna bortom en given ideologi. Svårbegripligheten - eller tvetydigheten - i vems upplevelsen är öppnar en samtidighet av olika människor perspektiv och livsberättelser. Så sett är den inte ett problem utan grundläggande för detta berättande, grundläggande för att förnimma de mänskliga mötena i denna tillvaro som något betydelsefullt.

\section{Människorna i detaljerna}

Problemet med ett strikt formalistiskt förhållningssätt, åtminstone till författarskap av Pasternaks och Dobyčins slag, kan belysas med teoretikern och författaren Jurij Tynjanovs artikel "Literaturnoe segodnja" ("Litteraturen av idag") vilken publicerades i första numret av samma tidskrift som Dobyčin debuterade i, Russkij sovremennik, 1924. Tynjanov söker där så gott som förgäves efter vad han kallar nya "litterära ting" hos de samtida ryska prosaförfattarna. Han upplever det mesta som lika konstlat som (de även $\mathrm{i}$ Sovjetunionen omåttligt populära böckerna och filmerna om) Tarzan, även 
när författarna skriver bloddrypande om inbördeskriget. Det enda undantaget, den enda prosa som Tynjanov finner något nytt och därför berörande i är Pasternaks povest' (kortroman) Detstvo Ljuvers (Ljuvers barndom). Men när kritikern Tynjanov så med sin teori ska förklara varför detta verk inte känns konstlat som de övriga visar han samtidigt teorins tillkortakommande. Det berörande - som Tynjanov som läsare upplever - i Pasternaks tingliga detaljer har, förstår man med Gasparovs ingång, att göra med vad vi i dem igenkänner av den konkreta vardagliga tillvaron och framförallt, enligt mitt synsätt, den mänskliga interaktion som de gestaltar. När Tynjanov som formalistiskt inriktad kritiker däremot vill specificera hur Pasternak gjort för att få dem drabbande blir det föga övertygande. Som jag ser det handlar det om att Tynjanov i sitt fokus på hur tingen främmandegjorts bortser från de mänskliga medvetanden och den levande interaktion som detaljerna subtilt fångar i den vardagliga tillvaron. Det enkla blir hos Tynjanov istället svårförståeligt komplext och det formellt komplexa antyds ha ett egenvärde:

Все дано под микроскопом переходного возраста, искажающим, утончающим вещи, разбивающим их на тысячи абстрактных осколков, делающим вещи живыми абстракциями. [...] Вещь быта должна была раздробиться на тысячи осколков и снова склеиться, чтобы стать новой вещью в литературе. 55

Allt skildras ur ett uppväxtålderns mikroskop som förvränger och förfinar tingen, slår sönder dem i tusen abstrakta skärvor, gör tingen till levande abstraktioner. [...] Den vardagliga tillvarons ting var tvunget att delas upp i tusentals skärvor och åter limmas ihop för att bli till ett nytt ting i litteraturen.

Tynjanov tar naturligt nog inte upp Dobyčin eftersom dennes debutnovell ingick först $i$ ett senare nummer av tidskriften, men Tynjanov blev senare bekant med Dobyčin och tog del i redaktörsarbetet med novellsamlingen Portret. På trettiotalet, sedan Tynjanov lämnat sitt litteraturteoretiska värv för att själv framförallt vara författare, skisserade han en kort parodi på Dobyčins berättande (tillsynes utifrån Gorod Ėn) som finns bevarad. Den tar på motsvarande sätt som texten om Pasternak fasta på yttre formella aspekter (vilket också är kännetecknande för en parodi) och fångar därigenom heller inte mycket av det väsentliga. Det hela ter sig då nonsensartat och därmed, skulle man kunna säga, just så eftersökt konstlat, så "formalistiskt", som trettiotalskritiken med sitt bruk av ordet framhöll det.

${ }^{55}$ Jurij Tynjanov, "Literaturnoe segodnja", Russkij sovremennik, I, I924, 292-306, 302. 
Мерзавец поклонился. В руках у него был сверток с конфетами Би-БаБо. Все кругом радостно закричали:

- А, мерзавец, мерзавец!

Папа вынул запонки из манжет. Одна запонка изображала Золя, другая Дрейфуса. У Дрейфуса были усы. Папа сказал задумчиво:

- Исправник, наверное, умер.

Он съел конфету Би-Ба-Бо. Мадам Лунд сказала:

- Рыба у бр. Клуге - того-с.56

Uslingen bugade. I händerna höll han en strut med konfekten Bi-Ba-Bo. Alla omkring började glatt ropa:

- Ah, usling, usling!

Pappa tog ut knapparna ur manchetten. På den ena manchettknappen var Zola avbildad, på den andra Dreyfus. Dreyfus hade mustasch. Pappa sade tankfullt:

- Poliskommisarien har troligen dött.

Han åt en konfektbit Bi-Ba-Bo. Madame Lund sade:

- Fisken hos br. Kluge är liksom vad heter det.

Som en formalist (eller strukturalist) som kommer till insikt om att det inte är utformningen i sig utan det liv som fångas som ytterst avgör om konstnärliga detaljer är drabbande kan man läsa Roland Barthes bok om fotografiet, La chambre claire: Note sur la photographie (Paris 198I). Det formella försök som Barthes överger, som en konsekvens av att ha kommit till djupare insikt, är att förklara det drabbande i vissa fotografier enbart utifrån en uppdelning mellan det han benämner punctum respektive studium. Det är, enligt denna uppdelning, det tillsynes tillfälligt fångade som framkallar ett genomträngande punctum i vissa fotografier. Det drabbande har att göra med den kausalkedja som denna detalj bär på som plötsligt öppnar sig i betraktandet. Det ställer Barthes mot fotografier med ett enbart lätt intresseväckande studium där vi intellektuellt förstår detaljerna och vad fotografen vill uttrycka med hjälp av våra kunskaper. Men detta, inser så Barthes, duger inte som förklaring. Vad som gör vissa fotografier drabbande beror nämligen ytterst inte på de tillfälliga objekten eller detaljerna i sig, utan på det levande som de fångar som varje gång man ser fotografiet lever upp, är där, som han beskriver det, samtidigt som man vet att det inte längre finns. Han specificerar detta först som ett "tidens punctum" men har inte längre någon systematisk ambition med beteckningen. Vilka fotografier som har denna egenskap går nämligen inte, som Barthes tillstår, att formellt bestämma då upplevelsen också har att göra med vad de fångar i den konkreta verkligheten, om det för en själv som människa är något berörande i mötet.

${ }^{56}$ Citerad i Venjamin Kaverin, "Dobyčin", V. S. Bachtin (red.), Pisatel' Leonid Dobyčin: Vospominanija, stat'i, pis'ma, Sankt Petersburg 1995, I6-20, I6-I7. 
Det blir på ett sätt hopplöst subjektivt. Barthes kan slutligen inte bevisa något objektivt utan bara i ett slags indirekt självbiografi med ord beskriva de fotografier som berör honom och vad i dem som drabbar honom. Utan en teori för fotografiet kan han inte heller ge generella exempel.

Denna insikt gällande fotografiet kan tolkas som att Barthes också överger sin tidigare teori om obetydliga detaljers rena verklighetseffekt $\mathrm{i}$ litterärt berättande. ${ }^{57}$ Det bör dock understrykas att Barthes redan där, liksom med den provisoriska distinktionen mellan punctum och studium, bara säger sig vilja pröva hypotesen om att obetydliga detaljer i litterärt berättande tjänar en rent verklighetsframkallande funktion - att de närmare bestämt betecknar "det verkliga" som kategori - för att på så vis kunna inordnas i en heltäckande strukturalism eller semiotik. Redan i detta fall tillstår Barthes att det i själva verket är svårt att ge ett övertygande exempel på en sådan detalj.

Det relateras ofta till Barthes artikel som att han slår fast en sådan renodlad verklighetseffekt i den barometer i en berättelse av Flaubert som han i själva verket bara tar som utgångspunkt för sitt resonemang..$^{58}$ Utifrån en läsning av Flauberts berättelse är det lätt att ifrågasätta att den barometer som nämns hänga på väggen i beskrivningen av ett rum bara skulle ha funktionen att indikera att detta är verkligt och inte ha någon betydelse för det mänskliga sammanhang som berättelsen gestaltar.

Litteraturkritiken James Wood inriktar sig också just på detta exempel i sin invändning mot Barthes i How Fiction Works (2008). Wood menar att barometerns specifika betydelse för berättelsen visserligen kan vara svår att peka ut men att den ändå, som en faktiskt väldigt träffande detalj, karaktäriserar denna småborgerliga miljö och dess människor. Det Wood vill framhålla mot Barthes slutsats om verklighetseffekten är att den sinnliga påtaglighet och närvarokänsla som tillsynes irrelevanta detaljer ger (något Wood valt att kalla "thisness") visserligen är en effekt, men att denna verklighetskänsla inte bara framkallas genom att "det verkliga" betecknas som en abstrakt kategori. Wood ser det istället som att tillsynes irrelevanta detaljer

\footnotetext{
57 "L'Effet du réel", Communications, II, I968, 84-89.

${ }^{58}$ Det är i samma berättelse ("Un cœur simple" i Trois contes från I877), som Sara Danius i sin bok om den franska realismen tar en blå tvål som exempel på realismens nya riktning mot det i sin rena sinnlighet estetiskt drabbande (mot ett rent seende, vídenie, för att tala med Šklovskij). Men för att tala med Gasparov skulle man kunna invända att man genom att tillskriva den detaljen (på samma sätt som barometern) en från berättelsen fristående funktion skymmer igenkännandet av den vardagliga tillvaro och det mänskliga sammanhang som denna tvål är en del i gestaltandet av; i berättelsen ingår tvålen, förutom i ett kännetecknande och konkretiserande av just denna tillvaro, i ett samspel med andra blå och färgade detaljer, vilket Danius inte analyserar. Sara Danius, Den blå tvålen: Romanen och konsten att göra saker och ting synliga, Stockholm 2013, II-36, 363-37I.
} 
(utöver att de ändå vagt kan sägas karaktärisera ett visst mänskligt sammanhang) upplöser kategorier och abstraktioner genom att visa på tillsynes irrelevanta aspekter av livet självt. Utifrån ett exempel från Čechov menar Wood också att sådana detaljer ibland har en temporal funktion: "to evoke a lifelike passing of 'real time". .59

Det relevanta för Čechov - som Dobyčin också utpekar som en förebild för sitt skrivande - är på samma sätt som för Flaubert inte detaljernas allmänna verklighetseffekt. ${ }^{60} \mathrm{Om}$ än fångandet av vissa detaljer i skapandet kan upplevas som präglat av en tillfällighetsprincip ${ }^{61}$ så är de i det skapade verket inte längre tillfälliga utan fångar något mänskligt i det tillsynes tillfälliga. Därigenom kommer de också att ingå i det system av vågor och stämningsnyanser som berättelserna baserar sig på, såsom Nabokov karaktäriserat det i Čechovs fall. ${ }^{2}$

Nabokovs insikt om grunden för detta slags berättande är något som delvis saknas i den amerikanska slavisten Cathy Popkins annars mycket belysande studie som berör denna problematik i rysk litteratur: The Pragmatics of Insignificance: Chekhov, Zoshchenko, Gogol. Det berättande om det obetydliga som Popkin behandlar utifrån dessa författare är ett litterärt sammanhang som Dobyčins författarskap mycket väl kan skrivas in i.63 Som "pragmatics" betecknar Popkin sitt fokus på själva produktionen och konsumtionen av berättelser som, enligt henne, kan sägas handla om obetydligheter eller som är präglade av tillsynes ovidkommande eller betydelselösa detaljer. ${ }^{64}$ Att hon bortser från den konstnärliga drivkraften i skapandet, och istället uppehåller sig vid frågan om vad som är möjligt att berätta

\footnotetext{
59 James Wood, How Fiction Works, New York 2008, 47-50.

${ }^{60}$ Den självbiografiske huvudpersonen i romanen Gorod $\dot{E} n$ upplever förvånat när han läser Čechovs "Step"' ("Stäppen") att det är som "att jag skrivit det själv": "Когда я читал ее, то мне казалось, что это я сам написал." (Kapitel 32). Polnoe sobranie sočinenij i pisem, Sankt Petersburg 2013, I75.

6r Så karaktäriserar Aleksandr Čudakov Čechovs skapande i Poètika Čechova, Moskva 197I, I38-I87.

62 "The story ["Dama s sobačkoj" ("Damen med hunden")] is based on a system of waves, on the shades of this or that mood. If in Gorki's world the molecules forming it are the matter, here, in Chekhov, we get a world of waves instead of particles of matter, which, incidentally, is a nearer approach to the modern scientific understanding of the universe." Vladimir Nabokov, "Anton Chekhov", Lectures on Russian Literature, New York 198I, 245-295, 262.

63 Även Čechovs tidiga noveller anklagades av sin samtida kritik för att vara innehållslösa och idélösa, vilket Popkin (på ett liknande sätt som Gasparov om Pasternak) menar att vi idag har lätt att bara skratta avfärdande åt eftersom vi utgår från att Čechov är en stor författare. The Pragmatics of Insignificance: Chekhov, Zoshchenko, Gogol, Stanford 1993, 20-2I.

${ }^{64}$ Popkin distanserar sig i inledning till sin studie från Gary Saul Morsons koncept "prosaics" med vilket han beskriver Tolstojs inriktning på triviala, tillfälliga händelser för att det är på dessa som allting väsentligen kommer an. Prosaics innebär så - i likhet med den strategi som
} 
med förutsättningen att läsarens intresse ska väckas och hållas vid liv, gör att hennes slutsatser kommer att begränsas till något av en narrativt inriktad bedömning av berättelsernas underhållningsvärde. Čechov och Zoščenko läses med nöje eftersom deras berättelser handlar om det obetydliga på ett sätt som roande utmanar våra förutfattade meningar och krav på betydelse, menar Popkin, medan hon finner läsningen av Gogol' närmast plågsam eftersom själva berättandet där ständigt uppehåller sig vid obetydligheter och underminerar berättandet som sådant. ${ }^{65}$

Nabokov, som även i sina läsningar av Gogol' söker det grundläggande för det konstnärliga uttrycket, ser inte dessa "irrelevanser", som Popkin uttrycker det, som något som försvårar tillgodogörandet av Gogol's berättelser. Det väsentliga hos Gogol' finner man, enligt Nabokov, helt enkelt inte genom att söka den underliggande historien, utan istället just i de tillsynes ovidkommande detaljerna och passagerna där levande människor plötsligt fångas. Det är detaljerna i Gogol's konst som får de döda själarna att skymta fram och leva upp i läsningen, och därmed åtminstone för ett kort tag åter-

Gasparov ser hos Pasternak - att det är i det vanliga och osensationella som det betydelsefulla måste sökas, att de verkligt betydelsefulla händelserna är dolda i det normala och därför omärkliga; Hidden in plain view är huvudtiteln på Morsons bok om Tolstoj (Stanford 1987). Det Popkin tar avstånd från är den etiska implikationen i Morsons prosaics. Hon är inte intresserad av det "insignifikanta" hos de författare hon studerar som en del av ett sanningssökande utan av den narrativa problematiken eller "pragmatiken", av "tellability and interest value" som hon uttrycker det. Min invändning mot Popkins pragmatik är densamma som mot de narratologiskt eller på något sätt till det förutsatt rent estetiska avgränsade studierna av Dobyčin i forskningen, nämligen att varken pragmatiska eller estetiska aspekter låter sig avgränsas från det etiska - från betydelsen och från författarens konstnärliga drivkraft och sanningssökande - utan att bestämningen av dem riskerar att bli ofullständig eller rentav missvisande. Cathy Popkin, The Pragmatics of Insignificance: Chekhov, Zoshchenko, Gogol, Stanford $1993,7-8$.

${ }_{55}$ Cathy Popkin, a.a., 213-217. Det är möjligen Popkins huvudfokus på den med Dobyčin samtide Michail Zoščenko som ligger bakom hennes pragmatiska inriktning. Kanske kan man beskriva skillnaden mellan Dobyčin och Zoščenko som att Zoščenko, med sina berättelser om obetydliga händelser som parodiskt betydelsefulla - som en medveten provokation i den monumental samtiden, som Popkin beskriver det (a.a., II) -, kan ses som en arvtagare till den komiske, anekdotiske Čechov, medan Dobyčin snarare är influerade av den allvarligt meningssökande Čechov. Dobyčin tar inte som Zoščenko aktivt del i den ideologiska diskursen genom sin upptagenhet vid det lilla i 1920-talets kontext, utan söker däri med subtil ironi en betydelse bortom det ideologiska. Dobyčin är inte upptagen av det ovanliga eller oväntade som avviker från det normala utan mer tolstojsk, mer prosaisk eller realistisk - i den franska realismens, särskilt Flauberts mening - i sin inriktning på att avtäcka eller igenkänna det normala. Snarare än att berätta om triviala händelser så att de blir betydelsefulla söker han något betydelsefullt i den triviala vardagen. Gennadij Gor har i samma anda beskrivit Dobyčins humor som besläktad med Flauberts medan han menar att Zoščenkos går tillbaka på Cervantes. G. S. Gor, "Na kanale Griboedova, 9", Pjat' uglov: Povesti, èsse, Leningrad 1983, 248-250, 256. 
upplivas, så som Nabokov formulerar det. Så, skulle man kunna säga, uppstår ett slags möten bortom orden också hos Gogol' som är en för Dobyčin central influens. Det "insignifikanta" är därmed inte bara en ironisk drift med berättandet och ett lekfullt utmanande av läsaren. ${ }^{66}$

Det James Wood förtjänstfullt tagit fasta på i sin bok om skönlitterärt berättande är att dess olika aspekter - såsom exempelvis detaljanvändningen - inte kan isoleras utan måste förstås som ömsesidigt beroende av varandra (han låter därför sin behandling av varje aspekt mynna ut i en ny).67 Det är vad Nabokov också har en utvecklad känsla för i sin förståelse av Čechovs och Gogol's detaljer. Detta samspel är vad som framträder först i en analys som utgår från en hängivet förverkligande läsning av de enskilda verken och inte från att studera ett visst estetiskt fenomen eller att tillämpa vissa analytiska verktyg. Som jag kommer att demonstrera i denna avhandling är en sådan förverkligande läsning av särskild vikt för Dobyčins författarskap. Med fokuset begränsat till de föremålsliga detaljerna eller den ytliga handlingen framstår hans berättelser annars lätt som just så innehållslösa som de kritiserades för att vara. Ett sådant perspektiv har i den tidigare forskningen om Dobyčin ibland tillsynes berättigats av att särskilt hans noveller har lästs som ett slags performativt framvisande av meningslösheten i den provinsiella tillvaro som skildras. Läser man Dobyčins berättelser så, som enbart ett nedlåtande ironiserande över dessa människor och deras tillvaro, så blir berättelserna mycket riktigt meningslösa. De kan då antingen kritiseras för detta, så som i den samtida kritiken, eller positivt förklaras som en medvetet och provokativt meningslös absurd konst som skildring och kritik av en tom och meningslös tillvaro. ${ }^{68}$

\footnotetext{
${ }^{66}$ Vladimir Nabokov, Nikolai Gogol, Norfolk, Connecticut, I944, 98-I03. Talande för Gogol's inflytande på Dobyčin är att den icke namngivna stad (staden N.N.) som Mërtvye duši (Döda själar) utspelas kring rentav fått ge namn åt Dobyčins roman Gorod Ėn utifrån den unge huvudpersonens längtan till den som en tillvaro präglad av äkta vänskap (hans närsynt oironiska - men därmed också betydelsefullt förverkligande - läsning av Gogol' antyds också av att han använder anonymiseringen av staden som om det var dess verkliga namn, "Én"). Även den andra novellsamlingens titel Portret kan (bland annat) tänkas anspela på Gogol's novell med samma namn.

${ }^{67}$ James Wood, How Fiction Works, New York 2008, xvii-xviii.

${ }^{68}$ Som medvetet sammanhangslösa och otillräckliga betraktar exempelvis Caroline Schramm Dobyčins noveller utifrån teorier om den litterära grupperingen OBĖRIUs absurda estetik i "'Čto za istorija!' - poètika nedostatočnosti Leonida Dobyčina ('Staruchi v mestečke')", Dobyčinskij sbornik-2, Daugavpils 2000, I08-I33.
} 


\section{Rytmen}

En väg till att teoretiskt förklara det man upplever i en affirmativ, meningssökande läsning, nämligen hur de många sinnliga och föremålsliga detaljerna i Dobyčins noveller i själva verket tar del i gestaltandet av människor och en mänsklig interaktion bortom sociala roller och ideologiska diskurser - och i dessa möten faktiskt fångar något betydelsefullt i tillvaron - skulle faktiskt kunna vara att studera rytmen. Även om han inte uttrycker det så skulle man kunna se det som att det är den specifika rytmen som Nabokov beaktar när han ser hur Čechovs detaljer ingår i stämningsvågor eller hur Gogol' i just sina ovidkommande detaljer framkallar levande människor. Verkets eller författarens specifika rytm som detaljernas betydelse sammanhänger med kan i sin tur emellertid inte beskrivas isolerat från det mänskliga sammanhanget och vad som faktiskt uttrycks.

Denna teoretiska hopplöshet, återigen, eller kritiska insikt - då det är resultatet av en närmare förståelse - är vad den franske lingvisten och översättaren Henri Meschonnic's stora arbete om språklig rytm kan sägas mynna ut i: Critique du rythme: Anthropologie historique du langage (Kritik av rytmen: Språkbrukets historiska antropologi) från 1982. Meschonnic menar att det ligger i den litterära rytmens natur att den inte kan omfattas av en enhetlig teori. En djupare vetenskaplig förståelse av den faktiska företeelsen kan bara nås indirekt, genom en utvecklad kritik av befintliga teorier. ${ }^{69} \mathrm{Me}-$ schonnic vetenskapliga tillvägagångssätt liknar på så sätt Gasparovs försök att närma sig Pasternak bortom poetiken. Såväl denna alternativa metod som Meschonnics fördjupande av förståelsen för den faktiska rytmen som upplevs i läsningen har varit betydande för mitt sätt att närma mig Dobyčins författarskap där rytmen i prosan är en central aspekt.

Meschonnics kritik av teorier om rytm går ut på att en teori i sig kräver upprättandet av ett system. Teorier om språkliga fenomen kan därför endast förhålla sig till språket sett som ett system - till la langue - och inte till det levande, historiska och osystematiserbara språkbruket - le langage..$^{\circ}$ För

\footnotetext{
${ }^{69}$ Henri Meschonnic, Critique du rythme: Anthropologie historique du langage, Lagrasse 1982, 155 I.

${ }^{70}$ Enligt Ferdinand de Saussures uppdelning i sin av andra nedtecknade Cours de linguistique générale där han behandlar det förstnämnda, synkrona perspektivet. Med stöd i andra arbeten av Saussure som berör det diakrona, historiska språkbruket, menar Meschonnic visserligen att man kan se att Saussure även med språkets system i själva verket avsåg språkbrukets historiska tillstånd som inte innebar en uppdelning mellan lingvistik och filologi. Det som fått Saussures syn på språket som ett system att göra ett lika produktivt som förödande avtryck på 1900-talets språk- och litteraturteori är enligt Meschonnic först nedtecknarnas och sedan strukturalismens formalisering av det synkrona systemet som en ahistorisk struktur. Ibid., 29, 37-38.
} 
den litterära rytmens vidkommande innebär detta att det som kan teoretiseras endast är metern, det vill säga den abstraherande avkodningen av verkens faktiska rytm. ${ }^{11}$

I forskningen om Dobyčin har hans prosas metriska drag ägnats en hel del uppmärksamhet. ${ }^{72}$ Min kritik mot dessa teoretiskt grundade försök att bestämma rytmen i hans texter är just att de inte når mycket längre än till att konstatera och belägga själva förekomsten av vad som kan avkodas som en upprätthållen meter. Detta utgör förvisso en säregenhet i Dobyčins prosa, men att enbart påvisa en tvåstavighet i framförallt de senare novellerna och såväl en två- som trestavighet i de två längre verken från trettiotalet säger inte mycket om den faktiska rytmens karaktär i novellerna, och överhuvudtaget inget om hur rytmen tar del i berättandet. Som Meschonnic beskriver det ingår rytmen i gestaltningen - oavsett om det är prosa eller poesi - i en oskiljaktig treenighet med det aktiva subjektet och det som uttrycks. ${ }^{73}$ För att bestämma den faktiska rytmen, och inte bara vad som metriskt kan avkodas, återstår därför enligt Meschonnics kritik i princip bara att steg för steg försöka beskriva den. (Meschonnic utvecklar visserligen försöksvis ett noteringssätt för rytmen som beaktar andra akustiska fenomen än betoningen men blir samtidigt tvungen att komplettera det med kommentarer om hur det som uttrycks och det aktiva subjektets karaktär påverkar rytmen i de litterära texter han analyserar.)74 För att fånga den verkliga

\footnotetext{
${ }^{71}$ En alternativ formulering till la langue kontra le language som Meschonnic använder, är den mellan språket, som metriska studier endast förhåller sig till, och diskursen, som studier av den faktiska rytmen måste förhålla sig till (a.a., I05-II5). Gasparovs insikt om nödvändigheten i att gå bortom en systembaserad teoretisk poetik för att istället försöka igenkänna de tillstånd i den vardagliga tillvaro som Pasternak fångar, kan också ses som att förhålla sig till Pasternaks verk och språk som en del av denna verklighet, en del av det levande språkbruket, le langage. Detta förhållningssätt kan dessutom ses mot bakgrund av att Gasparov också skrivit ett fördjupande arbete om Saussure. Liksom Meschonnic framhåller han där försummelsen av den mest som utkast existerande diakrona delen av Saussures språklära som en grund till den moderna systemorienterade lingvistiska teorins brister. Boris Gasparov, Beyond Pure Reason: Ferdinand de Saussure's Philosophy of Language and Its Early Romantic Antecedents, New York 2012.

${ }^{72}$ S. I. Kormilov, "Metrizovannaja proza L. Dobyčina na fone tradicii russkoj metrizovannoj prozy pervoj treti XX veka", Bachtin, V. S. (red.), Pisatel' Leonid Dobyčin: Vospominanija, stat'i, pis'ma, Sankt Petersburg 1995, I42-I54; Ju. B. Orlickij, "Metr v proze Leonida Dobyčina", Bachtin, V. S. (red.), Pisatel' Leonid Dobyčin: Vospominanija, stat'i, pis'ma, Sankt Petersburg 1995, I55I6o; I. V. Fomenko, "Ritm i smysl: Opyt interpretacii romana 'Gorod Ėn'", Dobyčinskij sbornik - 6, Daugavpils 2008, II6-I27; Ju. B. Orlickij, "Osobennosti sillabotoničeskoj metrizacii rasskazov Dobyčina", Slavjanskie čtenija XI, Daugavpils 2016, 213-220. Aleksandr Belousov tar på ett belysande sätt för den faktiska rytmen in musikinslagen och menar att en ljudande läsning påkallas men utvecklar inte samspelet mellan rytmen och vad som uttrycks. A. F. Belousov, "Ozvučenie teksta v proze L. Dobyčina", Russian Literature, 46, I, I999, 19-22. 73 "Rythme, sens, sujet" ("rytm, betydelse, subjekt"). Henri Meschonnic, a.a., 69-73.

${ }^{74}$ Han ger även exempel på hur noteringssättet kan användas för prosa. Ibid., 515-5I8.
} 
rytmen, den språkliga kroppen och rörelsen som upplevs i läsning såsom Meschonnic utifrån Benveniste förstår begreppet, kan en analys av rytmen helt enkelt inte särskiljas från förståelsen av texten. ${ }^{75}$

Vill man beskriva rytmen blir det så ofrånkomligen en del av själva läsningen och tolkningen, av det möte som förverkligar texten som verk. Det är också anledningen till att jag övergett att försöka behandla såväl Dobyčins rytm som hans detaljanvändning som från de enskilda verken fristående fenomen.

\section{Det mänskliga mötet}

Belysande ord och tankar om än ingen vetenskaplig teori för de mötesframkallande förkategoriella tillstånden hos Dobyčin, för den mötesproblematik i novellerna som denna avhandling istället har i fokus, har jag också funnit i Martin Bubers med Dobyčin samtida traktat om mötet, Ich und Du, från I923.

Buber gör där en grundläggande, vetenskapligt svårdefinierad uppdelning mellan möten med ett Det - där vi (så att säga inomkategoriellt) objektiverar och placerar in de människor och ting vi möter i relation till andra och till tidigare kunskap - och de sanna, omedelbara, uppfyllande möten med ett Du genom vilka vi blir till som människor och får kontakt med själva skapelsen. Den eftersträvade Du-relationen beskriver Buber som något vi föds till och som präglar det ännu inte fördärvade barnets förhållningssätt till såväl människor som föremål (vilket barnperspektivet hos Dobyčin skulle kunna sägas visa prov på). Senare i livet blir det en del av ödets tragik, skriver Buber, att varje uppfyllande möte med ett Du är flyktigt och genast förvandlas till ett Det som en del av vår erfarenhet. Även konsten beskriver Buber som att den blir till genom ett uppfyllande möte med ett $\mathrm{Du}$, men ett Du i form av en uppenbarad gestalt. När denna gestalt materiellt eller språkligt gestaltas blir den ofrånkomligen en del av tingens ordnade Det-värld, men äger samtidigt potentialen att varje gång i upplevelsen

\footnotetext{
75 Meschonnic utgår i sin definition av rytm från Émile Benvenistes artikel "La notion de 'rythme' dans son expression linguistique", Problèmes de linguistique générale, I, Paris 1966, 327335. Där menar Benveniste att det är efter Platon, som för att beskriva dans först använder ordet rytm (för hur själva rörelsen ter sig ut) tillsammans med meter (mått och antal), som rytm i sig felaktigt började förstås som en regelbunden upprepning av något likartat, medan det grekiska ordet, från ett verb med betydelsen "flyta", överhuvudtaget brukades för något rörligt som tagit form och avsåg dess sätt att flyta, rörelsens organisation, dess disposition och konfiguration. "Le rythme est organisation du sens dans le discours" ("Rytm är organisering av betydelse i diskursen"), uttrycker Meschonnic som mest kortfattat sin definition (a.a., 70).
} 
av konsten åter förverkligas till ett närvarande Du. Trots en hotande utbredning av Det-världen, som Buber ser i det moderna samhället (motsvarande den automatisering av livet som Šklovskij beskriver som att bara känna igen utan att faktiskt se), menar Buber att inte bara barnet och konstnären utan alla människor upplever ögonblick av ett dolt sammanhang i vilket något av världsordningen i sin helhet kan upplevas som närvaro av ett Du. $7^{6}$

Bubers beskrivning av dessa ögonblick påminner i sin tur om det som Gasparov benämner igenkänning hos Pasternak:

Där förnims i flykten den ton, vilkens otydbara notbild är den ordnade världen. Dessa ögonblick är odödliga och samtidigt de förgängligaste: intet innehåll kan bevaras av dem, men deras kraft går in i skapelsen och i människornas kunskap, strålar av deras kraft tränger in i den ordnade världen och smälter ner den gång på gång. ${ }^{77}$

Dessa ögonblickliga upplevelser av något betydelsefullt mitt i den vardagliga tillvaron, den materiella och Det-relationspräglade ordnade världen, följer samma mönster som konstupplevelser i det att de uppenbarar något $\mathrm{i}$ en omedelbar levande närvaro, det Buber ser som en relation, ett möte med ett Du. Bubers ögonblick liknar så också Barthes beskrivning av ett "tidens punctum", där något flyktigt lever upp och har liv, är där, som faktiskt fångat ljus i fotografiet samtidigt som vi vet att det inte längre finns.

Dessa olika beskrivningar av tillsynes liknande upplevelser av något betydelsefullt i tillvaron har bidragit till min förståelse av de stundliga möten bortom orden som Dobyčins noveller uppenbarar i den Det-präglade, ideologiskt inordnande nya sovjetiska tillvaron.

Den i grunden teologiska termen epifani som betecknar en plötslig gudomlig uppenbarelse är i den litterära modernismens sammanhang annars det ord som vanligen brukar användas för denna typ av flyktiga ögonblick av en möteslik igenkänning av något i en vardaglig tillvaro. Sin litterära tilllämpning har ordet framförallt fătt genom James Joyce - som Efim Dobin som den förste, inte helt missvisande, jämförde Dobyčin med som en anklagelse. Att fånga och försöka frambringa den typ av plötsliga upplevelser av något betydelsefullt $\mathrm{i}$ helt triviala fraser, gester eller rörelser i sinnet, som Joyce benämnde epifanier, såg han som sitt centrala uppdrag som författare..$^{7}$ Morris Beja lyfter i Epiphany in the Modern Novel fram användningen

\footnotetext{
${ }^{76}$ Martin Buber, Jag och Du, Ludvika 2006, 7-72.

77 Översatt av Margit och Curt Norell. Ibid., 43-44.

78 "By an epiphany", skriver Joyce om sin självbiografiska huvudperson i Stephen Hero, en förlaga till A Portrait of the Artist as a Young Man, "he meant a sudden spiritual manifestation, whether in the vulgarity of speech or of gesture or in a memorable phase of the mind itself. He believed that it was for the man of letters to record these epiphanies with extreme care,
} 
av epifanier som central för berättandet i modernistisk prosa. Han understryker där det intuitiva och icke-rationella i epifanin och att den i berättandet ofta fungerar retrospektivt; något faller plötsligt på plats, genom att på något sätt återkallas, och får skärpa, en känsla av ett mönster uppenbarar sig med väsentlig men oklar betydelse.79

Begreppet epifani har också använts i relation till just Dobyčins noveller av hans engelska översättare Richard C. Borden som menar att de är uppbyggda kring Joyces typ av sekulära epifanier, kring en "tillsynes trivial händelse, handling, eller enskild detalj" som skiljer sig från de andra i berättelsen i det att "den belyser, samordnar och ger dem betydelse"..$^{80}$ Denna i huvudsak formella tillämpning av begreppet som Borden också ger prov på visar dock på problemet med att avgränsa epifani från dramatiska grundbegrepp för att beteckna en berättelses sammanhangsskapande moment som exempelvis Aristoteles igenkänning, anagnorisis. Särskilt när denna igenkänning sammanfaller med peripetin, vilket Aristoteles menar är föredömligt, kan anagnorisis beskrivas ha en liknande funktion och effekt som epifanin. ${ }^{81}$ Det en forminriktad tillämpning av epifani lätt skymmer (på samma sätt som Tynjanovs formalistiska förklaring av Pasternaks ting) är också att det ytterst är det mänskliga som uppenbaras eller igenkänns, om än i det trivialt tingsliga, som en del av berättelsens skildrade samspel, som är det som den upplevda och potentiellt drabbande betydelsen grundar sig i. Den plötsliga och avgörande igenkänning av en människa utifrån något attribut som Aristoteles begrepp brukar användas för är något som handlingen i Dobyčins noveller ofta är uppbyggd kring. Det de annars präglas av

seeing that they themselves are the most delicate and evanescent of moments." James Joyce, Stephen Hero, New York 1963, 211.

79 Morris Beja, Epiphany in the Modern Novel, London 1971, 13-23, 45-70.

${ }^{80}$ Richard C. Borden, "Introduction", Leonid Dobychin, Encounters with Lise and Other Stories, Evanston, Illinois, 2005, vii-xxvii, xv-xvi. (Borden citerar Irene Hendrys definition i "Joyce's Epiphanies", Seon Givens (ed.), James Joyce: Two Decades of Criticism, New York 1963, 30.) Jag återkommer till detta i samband med novellen "Erygin" som är en av de två noveller Borden ger exempel ur på det han menar kan betecknas som epifanier hos Dobyčin.

${ }^{81}$ Aristoteles, Om diktkonsten, Göteborg 1994, 40. Morris Beja skiljer på anagnorisis och epifani utifrån två kriterier: anagnorisis är rationell medan epifanin är "själslig" ("spiritual", utifrån Joyce), och epifanin framkallas av något obetydligt, tillfälligt och trivialt. När Beja i detta sammanhang ger Erich Auerbach rätt i att den upptagenhet vid "små, oansenliga, på måfå framlyfta händelser" som Auerbach noterar hos Virginia Woolf är något av det mest utmärkande för 1900-talets litteratur, undergrävs dock delvis distinktionen; epifani kan så helt enkelt ses som den moderna litteraturens form av anagnorisis. Beja, a.a., 15-17. Erich Auerbach, "Den bruna strumpan", Mimesis: Verklighetsframställningen i den västerländska litteraturen, översättning Ulrika Wallenström, Stockholm I999, 552-582, 576. 
är inte så mycket en enskild avgörande trivial händelse, handling eller detalj, som ett samspel av sådana till i en vidare mening "epifanilika" tillstånd. ${ }^{82}$

Även hos Joyce bottnar epifanierna i en möteslik igenkänning av något mänskligt, en mänsklig berättelse, som visar eller avslöjar sig i det triviala. Joyce samlade tidigt det han benämnde epifanier nedtecknade från livet vilka postumt givits ut separat. I ett förord till sin svenska översättning av dessa menar Jonas Ellerström att även novellerna i Joyces Dubliners i sig, i sina helheter, kan betraktas som epifanier i sin karaktär av utsnitt utan bakgrund om de agerande vilka samtidigt får läsaren att ana en helhet i det stycke liv som beskrivs. Att på detta sätt "närma sig sin upplevda verklighet", och "epifanera" den, i betydelsen att fånga dess i det triviala uppenbarade "genomlysta ögonblick", menar Ellerström samtidigt blir ett sätt att "avslöja det av religion och politiskt käbbel lamslagna irländska samhället".83

Att fånga något betydelsefullt mänskligt bortom det ideologiska skulle man också kunna säga är vad Dobyčin gör i sin sovjetiska samtid. Även hans noveller kan på detta sätt sägas både innehålla och i sin helhet utgöra epifanier, eller, som jag valt att kalla det för att understryka denna vidare innebörd: möten bortom orden.

\section{Liv utan svar}

Det som är besläktat med både Pasternak och Dobyčin i Joyces inriktning på att fånga de vardagliga epifanierna i sitt författarskap är att den banala vardagligheten inte bara utgör ett verklighetens skräp som konsten kan växa fram ur - såsom Anna Achmatova exempelvis beskrev sitt diktande. ${ }^{84}$ Den vardagliga verklighetens vanemässiga, låga och grova trivialitet är istället just det liv vars levande uttryck dessa författare tycks vilja fånga. Svårigheten i denna uppgift beskriver Gasparov som grunden till Pasternaks tidiga dikters komplexitet och svårförståelighet. Svårigheten handlar å ena sidan om det vanemässiga i vardagligheten, den förutsägbarhet som gör att den så lätt underordnar sig redan givna föreställningar och språkliga ut-

\footnotetext{
${ }^{82}$ När Morris Beja analyseras användningen av epifani i modernistisk prosa begränsar han förvisso inte epifani som enbart en avgörande enskildhet i en berättelse. Ett berättande utan framträdande berättarinstans, som Dobyčins, beskriver han som en teknik där istället epifanier görs till organiserande element i strukturen. Morris Beja, a.a., 22-23.

83 Jonas Ellerström, "Genomlysta ögonblick", James Joyce, Epifanier, Lund 20II, 5-I2.

${ }^{84}$ Så ser Boris Gasparov det (a.a., 20) utifrån en välkänd sentens ur Achmatovas dikt "Tvorčestvo" ("Skapandet") i sviten Tajny remesla (Hantverkets hemligheter): "Когда б вы знали, из какого сора / Растут стихи, не ведая стыда [...]" ("Om ni visste blott ur vilket skräp / som dikter växer, utan minsta skam [...]"). Stichotvorenija i poėmy, Leningrad I976, 202.
} 
tryck och å andra sidan om den svindlande hastighet med vilken dessa invanda bilder och idiomatiska språkliga avbildningar i vårt dagliga liv ständigt löses upp i den vilda strömmen av ögonblickliga intryck. Pasternaks senare enkelhet i författarskapet handlar inte om att han estetisk inordnar sig i kravet på enkelhet, enligt Gasparov, utan om att han finner ett annat sätt att komma åt dessa intryck av livet eller livets egna uttryck som han genom hela författarskapet försöker skildra..$^{85}$

Det väsentliga som läsning av skönlitteratur ger oss, menar filosofen Richard Rorty med utgångspunkt från Marcel Proust och Henry James som särskilt utpräglade exempel, är inte etiska sanningar om hur man ska leva ett gott liv. Det skönlitteratur gör är att genom upplevelserna av olika sätt att leva och olika perspektiv på tillvaron vidga oss, fortsätta förändra oss som människor, göra oss varse klichéer och hycklande högtidlighet, och därigenom förlösa oss något från vår självupptagenhet och självbelåtna uppfattningar om hur livet eller verkligheten är. ${ }^{86}$

Kallet att igenkänna eller uppenbara det levande och mänskliga i tillvaron kan så också förstås som ett sätt att indirekt avtäcka en mänsklig dramatik i den triviala vardagens brist på autenticitet och autonomi (med Rortys begrepp från Martin Heidegger respektive Harold Bloom). ${ }^{87}$ Upplevelserna av något betydelsefullt och ett slags möten bortom orden genom tillvarons sinnligt påträngande detaljer innebär inte att Dobyčin ger några svar på hur man ska leva. Novellernas upplevda inre möten kan ses som en ersättning för bristen på yttre autentiska möten men också omvänt, som något som hindrar förverkligandet av ett faktiskt mänskligt om än banalt möte. Som kommer att framgå problematiseras så också själva sökandet efter något betydelsefullt i tillvarons detaljer.

Å ena sidan tycks Dobyčin vara ute efter att gestalta en upplevelse av en betydelsefull helhet genom de sinnliga detaljerna - och han kräver därmed av sin läsare mer än att (som den äldre kvinna vars läsarreaktion på den första novellen han återger visar prov på) enbart njuta av enskilda utsmyckningar. För detta kan man finna möjliga metapoetiska uttryck i Dobyčins verk. I den i samtiden opublicerade längre novellen "Evdokija" från 1923 (från vilken såväl den förrevolutionära miljön som fler konkreta händelser återanvänts i romanen Gorod Én) beskriver en av de kvinnor som skildras

\footnotetext{
85 Boris Gasparov, Boris Pasternak: Po tu storonu poėtiki (Filosofija. Muzyka. Byt), Moskva 2013, 20-2I.

${ }^{86}$ Richard Rorty, "Redemption from Egotism: James and Proust as Spiritual Exercises", Telos (Venezuela), 3, 200I, 243-263.

${ }^{87}$ Richard Rorty, a.a., 245.
} 
hur hon i stjärnhimlen plötsligt igenkände blomman på en brosch som hennes avlidne make en gång gett henne. Detta igenkännande som de enstaka stjärnorna bildar för henne kallar hon broschens själ, och igenkännandet har genom den triviala berättelsen den väckt också öppnat vår förståelse för henne som människa:

Тогда я замечала там один цветок - как раз как моя брошка, эта маленькая ромашечка, которую мне Карльхен привез из Риги... И я была счастливая и думала, что это есть душа от моей брошки, стояла и смеялась. ${ }^{88}$

Då lade jag märke till en blomma där - precis som min brosch, den här lilla kamomillen, som Karlchen hade med sig från Riga till mig... Och jag var lycklig och tänkte att det där är min broschs själ och stod och skrattade.

I slutet av romanen Gorod Én när jaget upptäcker sin närsynthet och skaffar sig glasögonen står han avslutningsvis också under en stjärnhimmel som han tidigare inte kunnat se tydligt. Han noterar nu, vilket möjligen antyder de sammanhang som kan bildas, att stjärnorna har strålar. Detta motsvarar också hur han, åtminstone för en stund, tycks nå ut ur sig själv till en ny kontakt med verkligheten och se de människor som omger honom i deras nakna mänsklighet bortom hans romantiska, instängande föreställningar.

$\AA$ andra sidan skildras ofta ironiskt det fruktlösa i ett sökande efter en förståelse av tillvaron utifrån sinnliga tecken som i sig talande och förebådande (vilket flera noveller visar prov på men som får sitt mest centrala uttryck genom den av sin handspådomskonst självuppfyllda huvudpersonen i novellen "Chiromantija" ("Kiromanti")). De sinnliga intrycken är inte en säker väg till möten bortom orden. ${ }^{89}$

Med Rorty skulle man kunna uttrycka det som att vi visserligen inte får med oss några sanningar om det mänskliga mötet eller vad som är betydelsefullt från läsningen av Dobyčin, men väl ett problematiserande av detta i den vardagliga tillvaron vilket har potentialen att förlösande fortsätta utveckla oss som människor.

\footnotetext{
${ }^{88}$ L. Dobyčin, Polnoe sobranie sočinenij i pisem, Sankt Petersburg 2013, 349.

89 Utifrån de konflikter mellan ideal och verklighet som Dobyčin skildrar har hans författarskap karaktäriserats med Bachtins begrepp "romantisk grotesk" vilket förklaras som att Dobyčin gestaltar "the dissonance between idealistic aspirations and reality, between dreams and their effects". Som vi ska se har denna dissonans i Dobyčins noveller både att göra med den påbjudna ideologiska idealismen och med den personliga idealiserande längtan som de inre upplevelserna av möten bortom orden på samma gång, beroende på perspektiv, kan sägas framkallas av och ge upphov till. Andrew Kahn, M. N. Lipoveckij, Irina Reyfman \& Stephanie Sandler, "Grotesque modernism of the I920s and I930s", A history of Russian literature, Oxford 20I8, 66I-672, 66I-662.
} 


\section{Verk och forskning}

\section{Dobyčins samlade verk 90}

I. En samling om arton noveller. Novellsamlingen Portret (Porträttet), som utgavs av Izdatel'stvo pisatelej v Leningrade (Leningrads författarförlag) I93I, innehöll sexton noveller, skrivna mellan I923 och 1930, vilka Dobyčin sammanställt som en konstnärlig helhet. Nio av novellerna (några med andra titlar) hade utgjort en första novellsamling, Vstreči s Liz (Mötena med Liz), utgiven av förlaget Mysl' i Leningrad I927. Två nyskrivna noveller från hösten 1930 som var avsedda för Portret men inte medtogs publicerades inte under Dobyčins livsstid. Dessa, "Mater'jal" ("Materialet") och "Čaj" ("Teet"), tillfogade Dobyčin sedan till en tredje samling, nu med titeln $M a$ terjjal, som han 1933 förgäves försökte få utgiven. Där hade han även bearbetat de sexton novellerna från Portret. "Mater'jal" och "Čaj" publicerades för första gången i Leningradskaja pravda, 2I augusti, I988 respektive Zvezda, 9, 1989. Mater’jal återges i sin helhet i Dobyčins fullständiga samlade verk (Polnoe sobranie sočinenij i pisem, 1999 och 2013).

Det är dessa arton noveller som är i fokus för avhandlingen. Jag har som de flesta forskare och översättare valt att utgå från versionerna i Portret för de sexton noveller som redan ingick där (men beaktat ändringarna av dem när de varit av relevans för förståelsen). (För vissa av novellerna finns även tidigare versioner bevarade. Inledningsnovellen "Proščanie" ("Avskedet") finns i en betydligt avvikande version under titeln "Tetka" ("Mostern") som postumt har publicerats separat (först i Raskoldovannyj krug, 1990).)

I slutet av avhandlingen finns en lista över samtliga samtida publiceringar (även i tidskrifter) av de analyserade novellerna.

2. Gorod Én (Staden En), en roman, utgavs I935 av Sovetskij pisatel' i Moskva.

3. "Dikie" ("Vilda"), en längre novell eller skaz (folklig berättelse), tillkom efter Gorod Én och utgavs postumt (först i Zvezda, 9, 1989).

4. Šurkina rodnja (Sjurkas släkt), en povest' (kortroman), tillkom efter Gorod Ėn och utgavs postumt (först i Ežegodnik rukopisnogo otdela Puškinskogo Doma na 1990 god, Sankt Petersburg 1993).

\footnotetext{
90 Jag har i avhandlingen i huvudsak inte beaktat att Dobyčins ville att hans namn som författare skulle skrivas endast "L. Dobyčin" och inte "Leonid Dobyčin". Han understryker det i ett brev inför publiceringen av Portret där han kallar dem "som av okänd anledning" inte efterföljt detta (i några av tidskriftpubliceringarna och i den första novellsamlingen) för "uslingar": "Только «Л. Добычин», а не «Леонид», как некоторые мерзавцы неизвестно на каком основании практикуют." Till Michail Slonimskij 8 september 1930 (brev 130), L. Dobyčin, Polnoe sobranie sočinenij i pisem, Sankt Petersburg 2013,3I4.
} 
5. Večera i staruchi (Kvällar och gamla kvinnor), en samling om fem noveller som föregick debuten, troligen skrivna 1923. Samlingen utgavs som en helhet för första gången i Dobyčins fullständiga samlade verk 1999. Den sista novellen "Pis'mo" ("Brevet"), något omarbetad och under titeln "Kozlova", var den enda som publicerades under författarens livstid och medtogs i novellsamlingarna. Den ovan diskuterade första novellen "Timofeev" kan därutöver ses som en förlaga till inledningsnovellen i Portret, "Proščanie" ("Avskedet"). Den längsta novellen, "Evdokija", som upptar över hälften av samlingen med sina åtta kapitel, finns även i en förkortad version om fyra kapitel under titeln "Staruchi v mestečke" ("Gamla kvinnor i en köping"; först utgiven i emigranttidskriften Čast' reči: Al'manach literatury i iskusstva i New York 1984, nummer 4-5).

Förutom dessa litterära verk var Dobyčin i sin yrkesroll som statistiker medförfattare till en bok om industri och arbete i Brjanskguvernementet (Promyšlennost'Brjanskoj gubernii: Materialy po statistike promyšlennosti i truda, Brjansk 1929).

\section{Återkomsten}

Efter litteraturkonferensen och Dobyčins försvinnande 1936 dröjer det till sextiotalet innan hans namn överhuvudtaget nämns igen i något publicerat sammanhang. Det börjar med en kort notis i Kratkaja Literaturnaja Énciklopedija I964 som betecknar Dobyčins verk som "handlingslösa skisser" ("bessjužetnye zarisovki") av den ryska glesbygden, vilka visserligen tillstås vara egenartat och talangfullt skrivna men - som en mycket diskret sammanfattning av vad den samtida kritiken sägs ha pekat ut - präglade av "en viss överdriven svartmålning" ("nek-roe sguščenie krasok") av enfalden och den småborgerliga inskränktheten i den efterrevolutionära provinsiella tillvaron (trots att Gorod Én som räknas upp bland verken utspelar sig före revolutionen). Inget nämns om konferensen 1936. Författaren sägs ha tagit livet av sig.91

Snart därefter börjar några av Dobyčins forna bekanta i Leningrad ta upp honom i essäer och memoarer. Författaren Gennadij Gor är först ut i sina minnen från tjugotalet i tidskriften Zvezda 1968 där han ger en kort karaktärisering av Dobyčins prosa: han jämför den med impressionisten och

\footnotetext{
${ }_{91}$ A. Ju. Narkevič, "Dobyčin Leonid Ivanovič", Kratkaja Literaturnaja Énciklopedija, 2, Moskva 1964, 725. Främst Stepanovs recensioner tycks ha legat till grund; "bessjužetnye 'kartiny"” ("handlingslösa 'bilder'") är Stepanovs klassificering av novellerna i recensionen av Vstreči s Liz i Zvezda, II, 1927, I70.
} 
pointillisten Georges Seurats tavlor där storstadens poesi förenas med nästan karikatyrartat tecknade småborgerliga figurer, och menar att den framvisar "vardagshändelsers komplexitet och motsägelsefullhet". ${ }^{2}$

Venjamin Kaverin är annars den av Dobyčins författarkollegor som bidragit mest till återupptäckten av honom: I Zvezda, 9, I97I och sedan i sina memoarbok Sobesednik 1973 tar han upp Dobyčin och de två seminarier som ägnades honom då Kaverin var lärare vid Konsthistoriska institutet i Leningrad (Institut istorii iskusstv). ${ }^{33}$ Som en försiktig första återutgåva låter Kaverin en hel novell av Dobyčin ("Otec" ("Fadern")) ingå i avsnittet. I sina senare memoarer utökar han inte bara sina minnen om Dobyčin utan låter också en ny novell ("Požalujsta" ("För alla del")) ingå i sin helhet.94

Under åttiotalet följer också författaren Leonid Rachmanovs minnen $\mathrm{i}$ hans självbiografiska Ljudi - narod interesnyj 198I. Han skriver att Dobyčin knappt läste de författare han umgicks med, att de enda han respekterade var Tynjanov och, om än med ett komplicerat förhållande, Zoščenko, och att Flaubert var den enda klassiker han värdesatte. ${ }^{95}$ Kornej Čukovskijs fru Marina Čukovskaja skildrar i artikeln "Odinočestvo: Iz vospominanij o pisatele L. I. Dobyčina" (först publicerad i tidskriften Ogonëk, I2, 1987) personligt och kärleksfullt Dobyčins tid i Leningrad.96

En första och mycket insiktsfull ren forskningsartikel (om Gorod $\dot{E} n$ ) av den sedermera kända kroatiska författaren Dubravka Ugrešić publiceras i Jugoslavien I98I. ${ }^{97}$ Litteraturvetaren Il'ja Serman skriver i emigranttidskrifter i Paris och New York om Dobyčin 1983 och 1984, i det senare fallet i anslutning till den första publiceringen av Dobyčin utomlands (på ryska). $9^{8}$

${ }_{92}$ G. S. Gor, "Zamedlenie vremeni", Zvezda, 4, I968, I74-I9I, I78. I ett senare sammanhang utvecklar han som nämnt en jämförelse mellan Dobyčins och Zoščenkos humor där han ser Dobyčins som "genetiskt förbunden" med Flauberts. "Na kanale Griboedova, 9", Pjat' uglov: Povesti, èsse, Leningrad 1983, 248-250, 256.

93 V. A. Kaverin, "Gorod Ėn", Sobesednik, Moskva 1973, 19-23.

94 V. A. Kaverin, "Leonid Dobyčin", Večernyj den': Pis'ma. Vstreči. Portrety, Moskva 1980, 92-96; även i Epilog: Memuary, Moskva 1989, I9I-205. Kaverin sammanställer också en tidig publicering av fem noveller i tidskriften Literaturnoe obozrenie (3, 1988).

${ }^{95}$ L. N. Rachmanov, Ljudi-narod interesnyj, Leningrad I98I, 330-33I.

96 Även i V. S. Bachtin (red.), Pisatel' Leonid Dobyčin: Vospominanija, stat'i, pis'ma, Sankt Petersburg 1995, 7-15.

97 Dubravka Ugrešić, "O «Gradu N» Leonida Dobyčina", Dometi, 6, I98I, 9I-IOO; övers. till ryska, "O 'Gorode Ėn' Leonida Dobyčina", i Russian literature, 43, 2, 1985, I77-I86 (även i V. S. Bachtin (red.), Pisatel' Leonid Dobyčin: Vospominanija, stat'i, pis'ma, Sankt Petersburg, 1995, 280288).

${ }_{98}$ I. Z. Serman, "Propavšij bez vesti", Russkaja mysl', 3494, 8 dec., Paris 1983, I2; "Lišnij. O proze Leonida Dobyčina", Čast' reči: Al'manach literatury i iskusstva, 4-5, New York 1984, I45-150, även i V. S. Bachtin (red.), Pisatel' Leonid Dobyčin: Vospominanija, stat'i, pis'ma, Sankt Petersburg 1995, 33-37. De två noveller som publicerade i samma nummer av tidskriften (sidorna I25-I36) var "Staruchi v mestečke" ("Gamla kvinnor i en köping") och "Otec" ("Fadern"). 
Den tyska forskaren Elisabeth Markstein är också tidigt ute med en artikel om Dobyčins prosa 1986.99

I Sovjetunionen är det dock först I988-89, i samband med att man börjar återutge Dobyčin, som också forskningen på allvar inleds. En första publicering av romanen Gorod Ėn i tidskriften Rodnik i Riga 1988 (nummer 8-II) följs 1989 av en första bokutgåva i Moskva (Gorod Ėn: Roman; Rasskazy i serien Zabytaja kniga (En bortglömd bok)) vilken också innehåller de flesta av novellerna. Efter introduktioner och förord, korta omnämnanden och recensioner, blir forskningen i författarskapet snart mer vetenskaplig och organiserad.

I Dobyčins uppväxtstad Daugavpils hölls i slutet av 1990 de första Dobyčinläsningarna (Dobyčinskie čtenija) vars föredrag samlades i en artikelsamling i häftesform. ${ }^{\text {oo }}$ Att läsningarna ägde rum i det följande år självständiga Lettland bidrog sannolikt till det stora inslaget av lokalhistoria i forskningen (i artikelsamlingen från den andra läsningen har dessa artiklar särskilts i en separat del). ${ }^{\circ}$ Under titeln Pisatel' Leonid Dobyčin utgavs i Sankt Petersburg 1996 på tidskriften Zvezdas förlag en första forskningsantologi som introducerar författarskapet både med minnen från Dobyčins samtida och med så gott som samtliga vetenskapliga artiklar från de två första Dobyčinläsningarna. På samma förlag utgavs 1999 också den första upplagan av Dobyčins fullständiga samlade verk med ett fylligt förord och utförliga kommentarer till texterna av Vladimir Bachtin. Merparten av de vetenskapliga artiklarna om Dobyčin har även fortsättningsvis utgått från föredragen vid Dobyčinläsningarna och finns samlade i sju stycken Dobyčinantologier (Dobyčinskij sbornik, I998, till och med Dobyčinskij sbornik - 7, 20II) utgivna av Daugavpils universitets förlag Saule. 2013 utgavs en andra upplaga av Dobyčins fullständiga samlade verk med nytt förord av Andrej Ar'ev och Bachtins kommentarer korrigerade och utökade av Aleksandr Belousov. För referenser till de samlade verken respektive artiklarna i antologierna har jag fortsättningsvis använt följande förkortningar:

PSSP = L. Dobyčin, Polnoe sobranie sočinenij i pisem, Sankt Petersburg 2013. Vid referens till första utgåvan (Polnoe sobranie sočinenij i pisem, Sankt Petersburg 1999) anges årtal: PSSP, 1999.

\footnotetext{
99 Elisabeth Markstein, "Die Syntax des Absurden. Zur Prosa von Leonid Dobychin", Pontes Slavici: Festschrift fur Stanislaus Hafner zum 7o.Geburstag, Graz 1986, 237-248; översatt till ryska av Michail Lobanov i V. S. Bachtin (red.), Pisatel' Leonid Dobyčin: Vospominanija, stat'i, pis'ma, Sankt Petersburg 1995, I30-I4I.

roo Pervye Dobyčinskie čtenija, Daugavpils I99I.

Ior Artiklarna om Dobyčin återfinns i första delen: Vtorye Dobyčinskie čtenija: $V$ 2-ch častjach, čast' I, Daugavpils 1994.
} 
$P L D=$ V. S. Bachtin (red.), Pisatel' Leonid Dobyčin: Vospominanija, stat'i, pis'ma, Sankt Petersburg 1995.

DS, DS-2 ... DS-7 = Dobyčinskij sbornik, Dobyčinskij sbornik - 2 ... Dobyčinskij sbornik -7, Daugavpils I998, (2) 2000, (3) 200I, (4) 2004, (5) 2007, (6) 2008, (7) $20 I$.

En sista antologi utgående från Dobyčinläsningarna i Daugavpils publicerades som ett specialnummer av internettidskriften Kul'tura i tekst, I (I9), 2015. Från 20I4 har Dobyčinläsningarna i Daugavpils kommit att lösas upp till en sektion och snart bara enskilda föredrag i universitetets filologiska fakultets årliga vetenskapliga konferens (antologin Slavjanskie čtenija XI (Daugavpils 20I6) samlar några av de artiklar om Dobyčin som detta resulterat i). Traditionen med Dobyčinläsningar har istället nyligen återupptagits i Dobyčins andra huvudsakliga levnadsort, vid Brjansks tekniska universitet. 2018 ägde de första rum utifrån vilka en första Brjanskantologi om Dobyčin kunde sammanställas (Dobyčinskie čtenija v Brjanske 20I8, Brjansk 20I8). En tidig samling artiklar om Dobyčin (på ryska) från en internationell konferens i Moskva publicerades också i Italien 1995 som en del av antologin "Vtoraja proza": russkaja proza 20 -ch-30-ch godov XX veka ${ }^{102}$

Några som förutom nämnda Vladimir Bachtin spelat nyckelroller för återintroduktionen av och forskningen om Dobyčin är: Författaren och litteraturvetaren Viktor Erofeev, med sitt djuplodande förord till den av honom sammanställda första återutgåvan i Ryssland och ett flertal artiklar.103 Il'ja Serman, som efter de tidiga artiklarna om Dobyčin utomlands också skrev om Dobyčin i det franska upplagsverket Histoire de la Littérature Russe. ${ }^{104}$ Andrej Ar'ev, som både kommenterade och skrev förordet till en tidig utgåva av Dobyčin tillsammans med två andra försummade författare I990, författade artikeln om Dobyčin till uppslagsverket Russkie pisateli 20 veka: Biografičeskij slovar' samt står bakom förordet till den andra utgåvan av Dobyčins fullständiga samlade verk från 2013.105 Aleksandr Belousov, som, förutom att i denna andra utgåva av Dobyčins samlade verk agerat veten-

${ }^{102}$ Willem G Weststeijn, Daniela Rizzi \& Tat'jana Vladimirovna Civ'jan (red.), "Vtoraja proza": Russkaja proza 20-ch-30-ch godov XX veka, Trento 1995.

${ }_{103}$ V. V. Erofeev, "Nastojaščij pisatel”", L. Dobyčin, Gorod Ėn: Roman; Rasskazy, Moskva 1989, 5-I4; "Poėtika Dobyčina, ili Analiz zabytogo tvorčestva", V. V. Erofeev, V labirintach prokljatych voprosov, Moskva 1990, I39-I60; "O Kukine i mirovoj garmonii", Literaturnoe obozrenie, 3, I998, även i $P L D, 5 \mathrm{I}-56$.

${ }^{104}$ I. Z. Serman, "Léonide Dobytchine", Histoire de la Littérature Russe. Le XX Siècle. Gels et Dégels, 3, Paris 1990, 19I-196.

${ }^{105}$ A. Ju. Ar'ev, "Vozvraščenie k ljudjam", V. Andreev, N. Baršev, L. Dobyčin, Raskoldovannyj krug, Leningrad I990, 3-29; "Dobyčin Leonid Ivanovič", P. A. Nikolaev (red.), Russkie pisateli 20 veka: Biografičeskij slovar', Moskva 2000, 234-236; "Otplytie", PSSP, 7-42. 
skaplig redaktör och bearbetat och utökat kommentarerna, i en specialutgåva i Daugavpils av Gorod Én försett romanen med över hundra sidor djuplodande kommentarer och noter. Han är därtill en av dem som författat flest artiklar om Dobyčin, varav merparten är publicerade i antologierna. ${ }^{106}$ Litteraturprofessorn Fëdor Fëdorov har i Daugavpils spelat en viktig roll för Dobyčinläsningarna och -antologierna och själv skrivit en rad centrala artiklar, särskilt om Dobyčins montageteknik.107 I Brjansk har framförallt Ėl'vira Golubeva spritt kunskapen om den där också lokale författaren; med grunden i ett eget gediget historiskt arkivarbete (vid sidan av framförallt Belousovs i Lettland) har hon både givit ut en biografi om Dobyčin och skrivit ett flertal artiklar i antologierna som biografiskt och lokalhistoriskt belyser innehållet i Dobyčins noveller. ${ }^{108}$

Även Richard C. Borden och Peter Urban som översatt Dobyčin till engelska respektive tyska har med sina för- eller efterord och kommentarer haft betydelse för att inte bara sprida utan också fördjupa kunskapen om Dobyčins författarskap. ${ }^{109}$ Två litteraturhistorier med utförliga, insiktsfulla inslag om Dobyčin som i båda fallen Mark Lipovetsky varit inblandad i är också värda att framhålla, liksom den redan nämnda tidiga och inflytelserika artikeln från 1993 om det citerande draget i Dobyčins prosa av den kände litteraturvetaren Jurij Ščeglov."10

Förutom Belousovs specialutgåva av Gorod Én och Golubevas biografi finns ytterligare fyra utgivna monografier om Dobyčins författarskap: Caroline Schramms doktorsavhandling (försvarad vid Konstanz universitet 1998), Minimalismus: Die Prosa Leonid Dobyčins im Kontext der totalitären Ästhetik (Frankfurt am Main 1999), som klassificerar Dobyčins prosa som minimalism och teoretiserar kring själva denna estetiks verkan i den historiska

\footnotetext{
${ }^{106}$ A. F. Belousov (kommentarer och noter), L. Dobyčin, Gorod En, Daugavpils 2007.

${ }^{107}$ F. P. Fedorov, "Dobyčin i kinematograf", $P L D, 69-76$; "O kompozicionnom montaže v russskoj proze 1920-x godov (Ju. Tynjanov, L. Dobyčin, M. Zoščenko)", DS-7, I62-I75.

${ }_{108}$ Ė. S. Golubeva, Pisatel' Leonid Dobyčin i Brjansk, Brjansk 2005.

${ }^{109}$ Richard C. Borden (översättning tillsammans med Natalia Belova, förord och kommentarer): Leonid Dobychin, The Town of N, Evanston, Illinois, 1998; Leonid Dobychin, Encounters with Lise and other stories, Evanston, Illinois, 2005. Även följande artikel av Borden är ögonöppnande: "The Flogging Angel: Toward a Mapping of Leonid Dobychin's Gorod En", The Russian Review, 2, 200I, 259-274.

Peter Urban (översättning, efterord och kommentarer): Leonid Dobyčin, Im Gouvernement S.: Šurkas Verwandtschaft, Berlin 1996; Leonid Dobyčin, Evdokija, Berlin 2008; Leonid Dobyčin, Die Stadt N., Berlin 2009; Leonid Dobyčin, Die Erzählungen, Berlin 2013.

ıо "Glava 5: Formuly stilja Leonida Dobyčina", N. L. Lejderman, M. N. Lipoveckij, Russkaja literatura XX veka: 19I7 - I920-e gody, 2, Moskva 20II, 86-98. Andrew Kahn, M. N. Lipoveckij, Irina Reyfman \& Stephanie Sandler, A history of Russian literature, Oxford 20I8. Ju. K. Ščeglov, "Zametki o proze Leonida Dobyčina ('Gorod Ėn')", Proza. Poèzija. Poètika: Izbrannye raboty, Moskva 2012, 333-357 (först i Literaturnoe obozrenie, 7-8, 1993, 25-36).
} 
kontexten."I Tetjana Šechovcovas Proza L. Dobyčina: Marginalii russkogo modernizma (Charkov 2009), som ger en allmän orientering i författarskapet och placerar det litteraturhistoriskt. ${ }^{112}$ Valerij Meškovs vidareutveckling av sina tidigare artiklar till monografin Pisatel'zagadka Leonid Dobyčin: krymskie stranicy (Simferopol 2015), vilken är mer essäistiskt undersökande och reflekterande om både verken utifrån deras få kopplingar till Krim (i Gorod Ėn) och deras litterära och historiska bakgrund i övrigt, samt om Dobyčins öde (med den svårbevisbara tesen jag nämnde att Dobyčin blev avrättad av den NKVD-agent som rapporterade om honom före försvinnandet). Den enda av de totalt tre ryska (kandidat-)avhandlingarna om Dobyčin som utgivits är Sergej Korolevs Problema avtora $v$ proze L. Dobyčina (Saarbrücken 2013) som framförallt utreder det ovan diskuterade problemet med författarinstansen i Dobyčins berättande. ${ }^{113}$ En tidigare narratologiskt inriktad avhandling är Zoja Popovas Poètika prozy L. Dobyčina: Narratologičeskij aspekt vid Sankt Petersburgs statliga universitet som försvarades 2005. Även Evgenija Radiščevas avhandling vid Moskvas pedagogiska universitet Chudožestvennyj mir prozy L. I. Dobyčina (2004) är inriktad på berättandets formella aspekter. A. N. Neminuščij ägnar också nära femtio sidor åt Dobyčin i relation till Čechov utifrån sina tidigare artiklar i antologierna $\mathrm{i}$ boken $V$ prostranstve vremeni literatury: do Čechova - Čechov - posle Čechova (Daugavpils 2009).

Värt att nämna är till sist också den betydelse som Dobyčin omvittnat haft för vad man skulle kunna beteckna som en strömning inom den sensovjetiska och postsovjetiska ryska litteraturen av lakoniskt samtidsskildrande, ofta autofiktiv prosa utifrån en underground-position. Sergej Dovlatov är den första och mest kända av dessa författare som tillerkänt Dobyčin ett avgörande inflytande, åtminstone stilmässigt, på sitt författarskap; till grund för sin egen särpräglat korthuggna stil förklarar sig Dovlatov

III Utifrån minimalismen som teoretiskt ramverk utreder Schramm i första hand olika formella aspekter av Gorod Én, dieges ("en pluralistisk jag-berättelse"), perspektiv ("en närsynt roman"), men ser också en homosexuell tematik i romanen som en del av estetiken ("homosexualitetens outsägbarhet"). Novellerna tas främst upp för en teoretisk utveckling av innebörden av en minimalistisk estetik i trettiotalets (och inte tjugotalets) kontext.

II2 Utöver denna bok har Šechovcova skrivit ett flertal artiklar i Dobyčinantologierna. 2010 försvarade hon också vid Charkivs universitet (på vars förlag boken är utgiven) en doktorsavhandling om Dobyčin med ett liknande ämne: Tvorčestvo L. Dobyčina vdinamike estetičeskich poiskov russkogo modernizma: kontekst, ontologija, poètika.

${ }^{113}$ Avhandlingen med samma namn försvarades vid Tvers universitet 2008. Sergej Korolev står också förutom en mängd artiklar i antologierna bakom en bibliografi över Dobyčin som kontinuerligt uppdaterats i antologierna och på internet. Den mest omfattande och senast uppdaterande finner man här: "Leonid Dobyčin: Bibliografičeskij ukazatel", Wordpress, https://dobychin.wordpress.com/press-about-dobychin/, 2019-O2-II. 
ha tagit Dobyčins och endast "lätt förbättrat den"."14 Senare efterföljare är Anatolij Gavrilov och Dmitrij Danilov varav den senare inte bara inspirerats av utan också skrivit om Dobyčins liv och författarskap, främst i romanen Opisanie goroda (2012) som skildrar hans upprepade resor till dagens Brjansk för att vandra i Dobyčins fotspår."15

Att Dobyčin främst varit något av en författarnas författare ${ }^{116}$ - liksom redan under sin livstid då han som ofta nämns diskuterades mycket i den litterära världen men aldrig nådde någon bredare läsekrets - belystes på sätt och vis av Joseph Brodsky vid ett framträdande på Harvard i samband med nobelpriset 1987. När Brodsky där svarade Dobyčin på en fråga om vem han ansåg som den främsta ryska prosaförfattaren efter 1917 var det sannolikt ett för alla församlade helt okänt namn..$^{117}$ Trots återutgivningarna och all uppmärksamhet som forskare ägnat Dobyčin därefter har det i stort sett förblivit så att få ens har hört talas om honom.

Kanske kan man hoppas att Dobyčins tid kommer lagom till detta sekels tjugotal, åtminstone tycks vi också i behov av den omsorg om livet som de mänskliga möten och den förundran inför tillvaron som Dobyčin gestaltar äger en potential till att återuppväcka. I vilket fall fortsätter forskningen och även utgivningen. Så sent som i januari 2019 publicerades för första gången

\footnotetext{
${ }^{114}$ Citerat ur S. V. Lebedev, "Portret chudožnika v topose: Brjanskaja 'odisseja' L. Dobyčina glazami D. Danilova", Novyj mir, II, 20I4, I66-I76. Om behovet av Dobyčin under 60-80-talet och Dobyčin som en av de "virtuella grundarna av 'Leningrads prosaskola"” skrev Kirill Kobrin i en kort recension av Dobyčins samlade verk 1999 under sin stående rubrik "Polka Kirilla Kobrina" i Novyj mir, I, 2000.

${ }^{115}$ För en djupare undersökning av Dobyčins inflytande på Gavrilov och Danilov se Šechovcovas Proza L. Dobyčina: Marginalii russkogo modernizma, Charkov 2009, 264-286. En mer omedelbar form av vidarediktning står Oleg Jur'ev för i boken Neizvestnye Pis'ma, Sankt Petersburg 20I4. Ett långt fiktivt brev från Dobyčin till Kornej Čukovskij påbörjas på femtiotalet och förses med nya postscriptum fram till dess Dobyčin skulle ha uppnått en ålder av hundra år 1994.

${ }^{116}$ Gennadij Gor betecknar Dobyčin och Vaginov som just författare för författare, "alltför komplicerade och kammarmässiga" för studenter och unga arbetare. Gennadij Gor, "Zamedlenie vremeni", Zvezda, 4, I968, I74-191, I78. Nikolaj Stepanov ansåg också i sin recension av Gorod Én (Literaturnyj sovremennik, 2, 1936, 215-216) att romanen endast var ämnad för "en snäv krets 'entusiaster'".

${ }^{117}$ Det Brodsky förklarade som avgörande för detta var Dobyčins känsla för detaljer. V. A. Meškov, Pisatel'-zagadka Leonid Dobyčin: krymskie stranicy, Simferopol 2015, 33. I sina egna essäer hade Brodsky tidigare förvisso skrivit om Platonov som I90o-talets store mästare, större än Joyce, Musil och Kafka. Joseph Brodsky, "Catastrophies in the Air", Less Than One, New York 1986. Och i sina intervjuer med Solomon Volkov framhåller Brodsky Konstantin Vaginov framför Dobyčin (vilken han där överhuvudtaget inte lägger ut texten om). S. M. Volkov, Dialogi s Iosifom Brodskim, Moskva 2000, 289.
} 
Dobyčins brev från tjugotalet till en kvinnlig bekant i Leningrad, Lidija Varkovickaja, som visar nya sidor av Dobyčin och ger nya pusselbitar till förståelsen av hans konst..18

\section{Den tidigare forskningen}

Även om den litteraturvetenskapliga uppmärksamhet som ägnades Dobyčin redan under hans livstid inte resulterade i något enskilt arbete om honom, "'19 så framstår, utifrån hur Venjamin Kaverin återger det i sina memoarer 1971, de två seminarier som vigdes åt Dobyčin vid Konsthistoriska institutet (Institut istorii iskusstv) i Leningrad som symptomatiska också för en stor del av senare tids Dobyčinforskning. Kaverins insikt om vad han i efterhand betecknar som en blindhet i deras då ensidigt formalistiska förhållningssätt ger ännu en motivering till denna avhandlings inriktning. ${ }^{120}$

II8 "Pis'ma L. Dobyčina k L. M. Varkovickoj", Zvezda, I, 20I9, https://zvezdaspb.ru/index.php?page=8\&nput=3439, 2019-02-13.

19 De enda litteraturvetenskapliga arbeten värda namnet under Dobyčins livstid var Nikolaj Stepanovs redan nämnda formalistiskt präglade recensioner av Vstreči s Liz (Zvezda, II, I927, I70) och Gorod Én (Literaturnyj sovremennik, 2, 1936, 215-216) samt dennes omnämnade av Dobyčins detaljanvändning (om en historia bakom kulisserna) i sin bok om Babel'. Det är möjligen Stepanov som Dobyčin syftar på i ett brev till Varkovickaja när han uttrycker sin glädje över en ung man som hållit en föreläsning om honom och tänkt skriva en recension: "Для меня большой удар и большая неожиданность, что обо мне читалась лекция и что этот прелестный (поцелуйте его от меня) молодой человек вздумал написать рецензию." (Brev 5, 2 december 1927). "Pis'ma L. Dobyčina k L. M. Varkovickoj", Zvezda, I, 2019, https://zvezdaspb.ru/index.php?page=8\&nput=3439, 2019-02-13. Senare beklagar sig Dobyčin, apropå inbjudan till reaktioner på novellen "Portret" när den publiceras i Strojka, över att så många sagt sig vilja skriva något om honom utan att faktiskt göra det: "«Высказывания на страницах» я уже предвижу каковы должны быть, ибо все доброжелатели, сообщающие частным образом, что «я хотел писать о вас статью», ни на каких «Страницах» не «высказываются».” Till Slonimskij 27 augusti 1930 (Brev I28, PSSP, 312.)

${ }^{120}$ Kaverin hade som ung författare fått sitt arbete som lärare i samtida prosa vid institutet efter att ha studerat för Šklovskij, Tynjanov och Ėjchenbaum - de ledande figurerna inom OPOJAZ och den formella skolan, eller formalismen som det till en början främst nedsättande kom att kallas - vid Leningrads universitet. Att även Konsthistoriska institutet präglades av formalismen, där både Tynjanov och Ėjchenbaum också var verksamma, kan också ses mot bakgrund av att institutets fortsatta existens efter revolutionen (det hade grundats 1912 av greve Valentin Zubov) försvarades av självaste folkkommisarien för upplysning Lunačarskij just utifrån den stränga vetenskaplighet (som den formella skolan utvecklat grunden för) som han menade präglade konststudierna vid institutet och därför gjorde dem marxistiska och i linje med revolutionens intressen (vilket är intressant med tanke på den senare helomvändning i den officiella synen på formalismen). Att två av institutets seminarier om samtida litteratur ägnades helt åt Dobyčin trots att han bara givit ut några få noveller säger något om hans genomslag i dessa kretsar. "О нем много спорили", "Han diskuterades mycket", skriver Kaverin. V. Kaverin, Sobesednik, Moskva 1973, 9-23. Kaverin anger bara att seminarierna ägde rum "i mitten av tjugotalet". Möjligen skedde detta efter att första novellsamlingen getts ut och möjligen hölls den föreläsning (troligen av Stepanov som 
Slutsatserna som Kaverin återger att de kom fram till på seminarierna var att "principen om 'den frånvarande författaren' drivits till sin yttersta gräns i Dobyčins verk". Verken präglades därför av "antipsykologism" vilket fick författaren att framstå som enbart en "registrator av fakta". Resultatet blev att "livet börjar tala för sig självt" och författarinstansen (avtor) förvandlades till en osynlig människa. Dessa slutsatser som Kaverin återger från sina skolskrivhäften från seminariet nästan femtio år senare tar han nu som utgångspunkt för att förklara sin omvärdering av Dobyčins författarskap. Kaverin menar att de då "i sin iver att 'ta isär' Dobyčin egentligen aldrig läste honom". Det Kaverin nu tycker sig ha insett är att de i sitt närskådande med "ett ungt teoretiserandes lupp" för att "benämna och bestämma" inte förstod att den vanlighet och rentav obetydlighet som präglar Dobyčins huvudpersoner inte är en form av främmandegöring, förskjutning (smeščenie), rapportprincip eller sökande efter en historia (poiski fabuly) som de då såg det i linje med sin formalistiska grundval, utan "ett uttryck för en mänsklighet, för ett medmänskligt ansvar". Därtill är författaren i själva verket hela tiden närvarande - "förbittrad, ironiserande, lidande av lågheten hos några, av den omedvetna grymheten hos andra" - i en lidelsefull uppgörelse med alla former av småborgerlig inskränkthet. Det är en uppgörelse av samma art som den samtide Zoščenko, menar Kaverin, bara med helt andra medel: genom "återhållsamhet, understruken lakonism, det mosaikartade och en outsagdhet". Kaverin kan nu se drivkraften i Dobyčins skrivande som ett sökande efter inre knappt märkbara psykologiska skiftningar och att det novellerna fångar är en annars bara "förbiflygande och försvinnande själslig rörelse: tillgivenhet, medkänsla, godhet". ${ }^{21}$

Kaverins eftertanke om problemet med det formalistiska förhållningssättet till Dobyčin i hans samtid, som var det enda som tydligt kom till tals vid sidan av den ideologiska kritiken mot den upplevda svårförståeligheten och idélösheten, skulle ha kunnat ligga till grund för en senare forskning, åtminstone efter Sovjetunionens fall, som (på ett liknande sätt som Gasparov med Pasternak) inriktade sig på att igenkänna dessa själsliga rörelser som Kaverin ser fångade i den vardagliga tillvaron, en forskning som genom hängiven läsning av Dobyčins verk som konstnärliga helheter öppnade och diskuterade vad de uttrycker. Emellertid har påfallande mycket av forskningen om Dobyčin även i vår tid kommit att präglas av just poetologiska

ingick i samma formalistiska krets som Kaverin och vars recension också präglas av de slutsatser Kaverin återger) som Dobyčin nämner i slutet av 1927 (se förra noten) i samband med seminarierna.

${ }^{121}$ V. A. Kaverin, "Gorod Ėn", Sobesednik, Moskva 1973, 19-23. 
specificeringsförsök utifrån en lingvistikinspirerad, systembaserad strukturalistisk vetenskaplighet, $i$ en iver att teoretiskt klassificera författarskapet utifrån dess formella särdrag.

Flera av den senare forskningens bestämningar och etiketter är också snarlika de slutsatser från seminarierna som Kaverin insett var alltför närsynta. Ett flertal tycks stamma från Nikolaj Stepanovs forminriktade observationer i recensionerna. Novellerna i den första samlingen, Vstreči s Liz, karaktäriserade Stepanov som sagt som "handlingslösa 'bilder" ("bessjužetnye 'kartiny") eller "fragment av en krönika" ("obryvki chroniki"). Stilistiskt noterade han på samma gång "det fotografiska" ("fotografičnost") och "det nästan 'icke-föreställande/abstrakta"' ("počti 'bespredmetnost"'). Illusionen av en "'tillfälliga anteckningars' objektivitet" som jämställer "händelser, människor och föremål" menar han skapas genom en frånvaro av tydliga övergångar i berättelserna och en allmän "outsagdhet" ("nedogovorënnost"'). Historien utvecklar sig nästan omärkligt - endast antydd, "utprickad" ("punktir' fabuly") - bakom kulisserna. I sin recension av Gorod $\dot{E} n$ tar Stepanov också upp författarpositionen: författarens "icke-inblandning" ("nevmešatel'stvo") och karaktär av "betraktare och krönikör" ("nabljudatel', chroniker") och att stilen präglas av både "närsynthet" och "objektivism". Grunden för Dobyčins "konstnärliga manér" menar han ligger i detaljen, i hur Dobyčin skapar ett system av små, tillsynes sekundära kännetecken genom att" omsorgsfullt välja ut och visa upp enskilda detaljer för läsaren som genom ett mikroskop". ${ }^{122}$

Med ett liknande förhållningsätt har forskningen från åttiotalet och framåt föreslagit följande formella nycklar till Dobyčins poetik: "det absurdas syntax" "22, "ett neutralt skrivande" ("nejtral'noe pis'mo"); ${ }^{24}$ "ett 'objektivt' manér", "ickeverbal text"; ${ }^{125}$ filmiskt montage med skarpa övergångar mellan självständiga sekvenser, allt "i skärningen mellan bestämt och obestämt", "händelselös" ("bessobytien");:12 "en likhetens lag ... ett jämställandets lag" ("zakon toždestva ... zakon uravnivanija"), "ett antidialogiskt ord ...

\footnotetext{
${ }^{122}$ N. L. Stepanov, recension av Leonid Dobyčin, Vstreči s Liz, Zvezda, II, I927, I70; N. L. Stepanov, recension av L. Dobyčin, Gorod Ėn, Literaturnyj sovremennik, 2, 1936, 215-216. Ordet mikroskop använde som vi minns även Tynjanov i sin karaktärisering av Pasternaks prosa.

${ }^{123}$ Elisabeth Markstein, Markstein, Elisabeth, "Sintaksis absurda. O proze Leonida Dobyčina", PLD, I30-I4I.

${ }_{124}$ V. V. Erofeev, "Nastojaščij pisatel”, L. Dobyčin, Gorod Ėn: Roman; Rasskazy, Moskva 1989, 5-I4, II.

${ }^{125}$ A. N. Neminuščij, "O poėtike rasskaza L. Dobyčina 'Lekpom'", PLD, 275-I79, 279; "'Neverbal'nyj tekst' v maloj proze L. Dobyčina", DS-5, 59-64, 59.

${ }^{126}$ F. P. Fëdorov, "Dobyčin i kinematograf", $P L D, 69-76$, 73; "Gorodskoe prostranstvo v sbornike L. Dobyčina 'Vstreči s Liz", DS-3, 69-83, 74; "Flober i Dobyčin (k tipologii provincial'nogo soznanija", $D S-2$, I2-23, 19.
} 
ett utomdialogiskt ord", "schablonstil", "en likställande och seriell stil" ("stil' toždestvennosti i serijnosti"), en "det namnlösas poetik" eller"det namnlösa namngivandets poetik" ("poètika bezymjannosti", "poètika bezymjannoj imenovannosti"); ${ }^{127}$ en "det icke-officiella associativa tänkandets teknik" och "citerande" ("citatnost"); ;28 "det statiskas princip" ("princip statiki"), "ett fotografiskt precist konstaterande av realia" ("fotografičeski-točnaja konstatacija realij");129 "minimalism", "närsynthetens estetik", "otillräcklighetens poetik" ("poètika nedostatočnosti"), texten "praktiserar förstörd kommunikation"; ;30 "principen om en betydande frånvaro, 'minus-grepp"' ("princip značimogo otsutsvija, 'minus-priema"), "berättande pointillism" ("povestvovatel'nyj pointilizm"); ${ }^{131}$ "antihandling" ("antisjužetnost");:32 "minimering av talinterferens" ("minimacija rečevoj interferencii"), "tillsynes

${ }^{127}$ Viola Ėjdinova, "O stile Leonida Dobyčina", PLD, IOI-II6, IO2; "Slovo Leonida Dobyčina (Antidialogičeskaja tendencija v proze 20-ch godov)", PLD, II7-I29, II9-I2O; "O tajne Dobyčinskogo povestvovanija", DS-2, 88-I07, 90; "Poètika bezymjannosti: (Rasskazy L. Dobyčina I920-ch godov), $D S-3,44-5 \mathrm{I}, 45$, 50. Just Ėjdinovas hävdande att "likhetslagen" ("zakon toždestva") råder i Dobyčins texter har många senare forskare skrivit under på. Den annorlunda uppfattning om detta i själva läsningen, där intrycken och föremålen samtidigt frigörs från likheter och kategorier i de tillstånd som gestaltas, kan understrykas av min parallell till Pasternak som talar om just den "frihet från likhetslagen" ("svoboda ot zakona toždestva") som han försöker fånga. Lazar Fleishman, Hans-Bernd Harder, Sergei Doraweiler (red.), Boris Pasternaks Lehrjahre: Neopublikovannye filosofskie konspekty i zametki Borisa Pasternaka, II, Stanford 1996, I35, citerat i Boris Gasparov, a.a., 46.

${ }_{128}$ Ju. K. Ščeglov, "Zametki o proze Leonida Dobyčina ('Gorod Ėn')", Proza. Poėzija. Poètika: Izbrannye raboty, Moskva 2012, 333-357 (först i Literaturnoe obozrenie, 7-8, 1993, 25-36).

${ }^{129}$ Ė. B. Markov, "Chudožestvennoe prostranstvo v rasskaze L. Dobyčina 'Otec", DS-2, 47-56, 5I, 55 .

${ }^{130}$ Caroline Schramm, Minimalismus: Die Prosa Leonid Dobyčins im Kontext der totalitären Ästhetik, Frankfurt am Main 1999; "Die Ästhetik der Kurzsichtigkeit: Minimalismus in Leonid Dobyčins Roman 'Gorod Ėn'", Mirjam Goller, Georg Witte (red.), Minimalismus: zwischen Leere und Exzess: Tagungsbeiträge des internationalen wissenschaftlichen Symposiums am Institut für Slawistik der Humboldt-Universität zu Berlin vom II. bis I3. November 1999, Wien 200I, 249277; "'Čto za istorija!' - poètika nedostatočnosti Leonida Dobyčina ('Staruchi v mestečke')", DS-2, I08-133, II7.

${ }^{13 I}$ I. N. Suchich, "Dobyčin i Charms: dva absurda i metafizika prozy", DS-2, I33-137, I34; "Dobyčin i Čechov: dva 'sobytija' i metafizika prozy", DS-4, I40-I47, I46. (Som pointillistisk karaktäriserades som sagt Dobyčin redan av Gennadij Gor (som specifikt jämför honom med konstnären Georges Seurat) i "Zamedlenie vremeni" i Zvezda 1968.)

${ }^{132}$ G. V. Petrov, "Princip 'antisjužeta' v poètike rasskaza L. Dobyčina 'Vstreči s Liz"', DS-3, 8490,89 . 
historie(/fabel)lös, sammanhangslös" ("vidimaja besfabul'nost', bessvjaznost");:133 "antiestetisk";:134 "multiperspektivisk" ("mul'tiperspektivnost"). ${ }^{135}$

Att påfallande många av dessa etiketter betecknar frånvaron av någon central egenskap, som om bara negativa definitioner passade för Dobyčin, har konstaterats av Boris Rochlin. ${ }^{136}$ Det kan för att tala med Meschonnic förklaras med att de teorier som dessa avvikelser noteras i förhållande till just utgör generella system, estetiska teorier abstraherade från det faktiska, historiskt antropologiska sammanhang som verken med sitt språk och betydelse ingår i. Förvisso innehåller flera av dessa arbeten värdefulla iakttagelser som ligger till grund för de generella bestämningarna, men i sin strävan efter generalisering är även iakttagelserna ofta begränsade till enskilda motiv eller moment och utvecklar inte förståelsen av dem i relation till verken som konstnärliga helheter.

De som närmast har kommit att tala om mötet som ett genomgående tema och grundläggande problematik, om än narratologiskt forminriktad i sin analys av det, är Sergej Korolev som i en artikel med titeln "'Ja' i 'drugoj' v proze L. Dobyčina" ["'Jag' och 'den andre' i L. Dobyčins prosa"] beskriver sökandet efter den andre och att se med den andres ögon som utmärkande för författarskapet. ${ }^{137}$ Begränsat till romanen Gorod Ėn har Ar'ev i samma riktning betecknat ledmotivet som "behovet av vänskap och själsligt umgänge" ${ }_{138}$ och Kaverin framhöll till Dobyčins försvar mot anklagelserna om nostalgi i sina memoarer att romanen handlar om förlorade relationer (och inte om de förlorade förrevolutionära materiella tingen). ${ }^{339}$ Det Caroline Schramm i sin avhandling betecknar som en "homosexualitetens outsägbarhet" ("die Unaussprechlichkeit der Homosexualität") i Gorod Én utifrån författarens egen förmodade sexualitet kan ses som en bakgrund till den

\footnotetext{
${ }_{133}$ Boris Maslov, "Oratio recta kak moderničeskij priem (Poètika povestvovanija L. Dobyčina s pozicij metapragmatiki)", DS-4, IOI-I25, IO7; "O dvuch tipach pis'ma v rasskazach L. Dobyčina", DS-5, 5-23, I7. (Med detta "tillsynes" vill Maslov korrigera uppfattningar om Dobyčins prosa som faktiskt historielös ("besfabul'nyj") eller utan handling ("vnesjužetnyj"), samtidigt som han framhåller det som ett avsiktligt grepp för att skapa detta intryck, som en form av främmandegöring.)

${ }^{134}$ G. B. Markov, "Sposoby desakralizacii v sbornike L. Dobyčina 'Večera i staruchi'”, $D S-4$, I56-I64, I63.

135 E. S. Radiščeva, "Priem ostranenija v proze L. I. Dobyčina", Filologičeskie tradicii i sovremennoe literaturnoe obrazovanie, Moskva 2002, 57-59 (även i hennes kandidatavhandling, Chudožestvennyj mir prozy L. I. Dobyčina, Moskvas pedgogiska universitet, 2004, I8-23).

${ }^{136}$ Boris Rochlin, "Po ètu storonu Lety. (O proze L. Dobyčina)", DS-6, I03-II5, IO9.

${ }^{137}$ S. I. Korolev, "'Ja' i 'drugoj' v proze L. Dobyčina: postanovka problemy", DS-6, 83-I02, 98. ${ }^{138}$ A. Ju. Ar'ev, "Dobyčin Leonid Ivanovič", P. A. Nikolaev (red.), Russkie pisateli 20 veka: Biografičeskij slovar', Moskva 2000, 234-236, 236.

139 V. Kaverin, "Gorod Ėn", Sobesednik, Moskva 1973, 19-23, 22.
} 
gestaltade mötesproblematiken också i novellerna även om jag inte betraktar den som specifikt samkönad. ${ }^{140}$

En tendens till att förbise det konstnärliga uttrycket finns även inom den andra huvudinriktningen inom forskningen, den som upptagits av ett historiskt utforskande inte bara av Dobyčins liv utan också av den verklighet som gett materialet till Dobyčins berättelser, exempelvis av vilka verkliga personer och händelser som döljer sig bakom berättelserna. Aleksandr Belousov och Ėl'vira Golubeva är de som mest förtjänstfullt bidragit till denna forskning. Särskilt den senares forskning i Dobyčins Brjansk har ofta varit till hjälp för förståelsen av novellerna även om hennes egna läsningar präglas av att hon främst ser dem som skildringar av den historiska verkligheten.

Inom båda dessa huvudinriktningar i forskningen finns estetiska klassificeringar respektive historiska fakta som verkligen kan vara ögonöppnande för läsningen och fördjupa förståelsen av verken. Boris Maslov har i en artikel försökt visa på dessa två tendenser inom forskningen som komplementära och att olika verk av Dobyčin är i olika stort behov av det ena eller andra förhållningssättet för att förstås. De två tendenserna beskriver han i förhållande till verken som å ena sidan ett minimalistiskt "ärke-realistiskt" ("arche-realističeskij") perspektiv, att verken utgör krypterade realistiska skildringar av den sociala verkligheten, och å andra sidan ett modernistiskt och symboliskt perspektiv, med vilket man ser till textens estetiska egenskaper, som frånvaron av en samlande författarinstans och det överflöd av konnotationer som textens motiv genererar, vilket gör att handlingen framträder och skapar mening först på ett symboliskt eller allegoriskt plan.

När Maslov visar detta komplementära förhållningssätt i praktiken, i fyra noveller, blir dock läsningen begränsad av hans strukturalistiska narratologiska ramverk till antingen ett sökande efter den historia som berättas (fabula) som själva målet med läsningen i de berättelser där den är svårfångad - och i de fall det är en simpel historia till att söka symboler och undertexter (såsom anspelningar på verkliga personer och händelser). Maslov betecknar det i båda fallen som ett sätt att förstå handlingen (sujet) i vid mening, som föremålet för berättandet, och visar förtjänstfullt att berättelserna på intet sätt saknar historier eller är osammanhängande. Men vilka mänskliga uttryck som novellerna på så sätt fångar som föremålet för sitt berättande, utvecklar Maslov inte vidare. Artikeln leder till sist fram till den formalistiskt präglade slutsatsen att själva det svårfångade, tillsynes händelselösa, ut-

I40 Caroline Schramm, Minimalismus: Die Prosa Leonid Dobyčins im Kontext der totalitären Ästhetik, Frankfurt am Main I999, I45-I70. 
gör en främmandegöring av vardagen som är driven till den yttersta gränsen för vad läsaren förmår känna igen, vilket får läsaren att reflektera över orsaker, motiv och betydelse i de mest vardagliga händelser. ${ }^{141}$

Även andra arbeten med en narratologisk ingång, som de nämnda ryska avhandlingarna, tenderar att utifrån sin teoretiska grund på detta sätt trots de indirekta inblickarna i vad det betydelsefulla som uttrycks är fastna i att kategorisera hur det är berättat och vad själva detta sätt att berätta har för funktion.

Andra tendenser inom forskningen är att litteraturhistoriskt placera författarskapet, att jämföra Dobyčin med andra, att utveckla berättelsernas intertexter eller att lyfta fram vissa motiv som nycklar till förståelsen..$^{142}$

Mycket i den tidigare forskningen har haft betydelse för att utveckla min förståelse av Dobyčin men dess generella tendenser har samtidigt väckt övertygelsen om behovet av ett slags - i den mån det är möjligt - liksom idélös eller förbehållslös och hängivet mötande läsning, att inlevande försöka öppna de enskilda verken på ett sätt som svarar mot deras egenart och så söka närma sig deras uttryck, tema och grundläggande mänskliga problematik.

Jag vill understryka att detta inte ska förstås som ett avfärdande av den tidigare forskningen eller av litteraturforskning generellt, utan tvärtom som ett försök till utveckling av den bort från den sortens systemorienterade förmenta vetenskaplighet som kommit att så djupt prägla inte minst den ryska kontexten genom formalismens, strukturalismens och semiotikens stora genomslag under 1900-talet. Gasparovs bok om Pasternak visar i detta sammanhang på en väg tillbaka till författarskapen och en läsning av verken inriktad på det mänskliga uttrycket, något som av bland annat Galin Tihanov har beskrivits som en bredare rörelse efter vad han betecknar som den

\footnotetext{
${ }^{141}$ Boris Maslov, "O dvuch tipach pis'ma v rasskazach L. Dobyčina", DS-5, 5-23. I ett tillägg till artikeln visar Maslov också på en likhet med Tolstojs främmandegöring i användandet av tillsynes betydelselösa detaljer (det som Stepanov betecknade som berättandet av en historia i kulisserna i boken om Babel') genom att skriva om några kapitel av Krig och fred med Dobyčins som Maslov betecknar det konspektliknande stil. Ibid. 2I-23.

${ }^{142}$ Se exempelvis: Andrew Kahn, M. N. Lipoveckij, Irina Reyfman \& Stephanie Sandler, "Grotesque modernism of the I920s and I930s", A history of Russian literature, Oxford 2018, 66I-672, 66I-662; F. P. Fëdorov, "O kompozicionnom montaže v russkoj proze I920-x godov (Ju. Tynjanov, L. Dobyčin, M. Zoščenko)", DS-7, I62-I75; I. N. Suchich, ”Dobyčin i Charms: Dva absurda i metafizika prozy", DS-2, I33-138; "T. A. Šexovcova, "'Gorod Ėn' L. Dobyčina i 'Egipetskaja marka' O. Mandel'štama", DS-7, I76-I88; V.V. Ėjdinova, "L. Dobyčin - A. Platonov", DS-7, I89-200; A. F. Belousov, "Dostoevskij i ego geroi v 'Gorode Ėn'”, PLD, 205-207; V. A. Košelev, "Puškinskie motivy u Leonida Dobyčina ('Vstreči s Liz')", DS-2, 24-3I; N. N. Danilina, "Ideja zerkala v rasskaze 'Kozlova', DS-7, I5-19; F. P. Fëdorov, "Kosmos v Dobyčinskoj kartine mira", $D S$, 5-I2.
} 
allmänna litteraturteorins död. ${ }^{143}$ Åtminstone i det ryska sammanhanget har det också talats om en inriktning på människans meningsskapande aktivitet även inom litteraturstudier i termer av en antropologisk vändning inom humanvetenskaperna efter den för 1900-talet avgörande lingvistiska vändningen. ${ }^{144}$ Det är möjligen i denna nygamla utveckling inom litteraturforskningen, denna rörelse så att säga tillbaka till de litterära verken, som man skulle kunna placera mitt arbete. Enligt min mening är det förhållningssättet också det som bäst svarar mot Dobyčins i viss mån antropologiska undersökande av den meningsskapande aktiviteten och den därmed förbundna mötesproblematiken hos de människor han skildrar. Människor som särskilt i den nya sovjetiska tillvaron annars är språklösa.

\section{Läsningens praktik}

Till grund för mitt arbete ligger en förståelseinriktad läsning av verken som konstnärliga helheter. Vidare, som Gasparov visar i sitt arbete om Pasternak, kräver en sådan förståelse även i Dobyčins fall en så långt som det är möjligt oreflekterad, förutsättningslös hängivelse i läsningen, ett inlevande i den värld som gestaltas och ett igenkännande av de moment i den vardagliga tillvaron som detaljerna fångar, för att sammanhangen helt ska uppdagas. Läsningen kommer så delvis att likna ett deltagande och medskapande möte. ${ }^{45}$

${ }^{143}$ Tihanov har utvecklat detta bland annat i artikeln "Why Did Modern Literary Theory Originate in Central and Eastern Europe? (And Why Is It Now Dead?)", Common Knowledge, IO, I, 2004, 6I-8I. 2019 utkom han med en hel bok över ämnet: Galin Tihanov, The Birth and Death of Literary Theory: Regimes of Relevance in Russia and Beyond, Stanford 2019.

144 Tidskriften Novoe literaturnoe obozrenie ägnade 2012 ett helt nummer (II3) åt ämnet "antropologičeskij povorot" där också Boris Gasparov medverkar. Som en "språkbrukets historiska antropologi" beskrev som sagt redan Henri Meschonnics sitt angreppssätt för att utveckla en förståelse av språklig rytm (Critique du rythme: Anthropologie historique du langage, Lagrasse 1982).

${ }^{145}$ Mitt vetenskapliga förhållningssätt är också präglat både av det sammanhang där jag först kom i kontakt med Dobyčins författarskap - under ett utbytesår vid Petersburgs statliga universitet där litteraturundervisningen var inriktad på att förstå de enskilda författarskapen som helhetliga uttryck och vad de hade att säga om världen befriande fritt från sociologiska, historiska eller ideologiska förklaringsmodeller - och av miljön på Slaviska institutionen vid Stockholms universitet där jag därefter kom att skriva två uppsatser om Dobyčin. Den textnära, oftast som närläsning definierade grunden för litteraturstudierna där sågs som ett förvaltande av en tradition, av den "Stockholmsskola" inom särskilt ryska litteraturstudier som den tidigare professorn Nils Åke Nilsson med sina arbeten lyckats etablera som ett internationellt begrepp. Att det är förståelsen av verken som konstnärliga helheter som står i centrum för läsningen, och inte att utifrån enskilda moment inordna dem i ett större teoretiskt eller historiskt sammanhang, är det som Stockholmsskolans förhållningssätt tydligast lånat 
Avhandlingen syftar så egentligen inte till att avslöja något som döljer sig för en vanlig läsare. Det jag försöker göra är att medvetandegöra de vid en vanlig läsning lättflyktiga mänskliga mötena och interaktionen genom och bortom vad som händer och sägs på ytan i novellerna för att därigenom vidga förståelsen för deras uttryck.

De objekt som studeras utgörs således av novellerna så som de i läsningen förverkligas, som verk, och inte av deras yttre textuella faktur, det språkliga material som deras i alla beståndsdelar betydande konstnärliga form uppstår igenom..$^{146}$ Att studera vad verken gestaltar och uttrycker innebär så ofrånkomligen ett tolkande moment, ett hermeneutiskt möte redan $\mathrm{i}$ det att vi genom läsningen förverkligar dem som estetiska objekt.

Genom mina läsningar av novellerna har så succesivt det mänskliga mötet framträtt som en återkommande problematik och ett genomgående tema. Med detta mötestema avser jag det centrala ämnet för Dobyčin och inte författarskapets generella särpräglade karaktär. Med problematiken och temat syftar jag till vad Dobyčins verk handlar om och inte till hur de är gjorda. Jag utgår heller inte från sökandet efter ett genomgående särdrag utan från förståelseinriktade läsningar av vad verken faktiskt gestaltar och vad författaren kan vilja uttrycka därigenom.

På så sätt skiljer sig detta inte bara från att försöka definiera en författares poetik utan också från tematisk litteraturforskning, med vilket man oftast syftar på en grupp framförallt Genèvebaserade litteraturvetare. ${ }^{177}$ Dessa ser för det första generellt inte den fördjupande förståelse av de enskilda verken som vägen till att finna det de kallar ett tema, utan studier av all text av

från den amerikanska nykritikens close reading. Däremot följer Stockholmsskolan inte slaviskt den traditionella närläsningens skarpa avgränsning av verket från biografiska och kulturhistoriska förklaringar och har ofta, om än utifrån närstudier av verken som konstnärliga helheter, det vidare syftet att fånga det säregna i författarskapet i sin helhet.

${ }^{146}$ Detta enligt Michail Bachtins synsätt i "Problema formy, soderžanija i materiala v slovesnom chudožestvennom tvorčestve", Sobranie sočinenij, I, Moskva 2003, 266-325, 3II-324 ("Innehållets, materialets och formens problem i det litterära konstverket", Det dialogiska ordet, Gråbo, 1997, 198-25I). I denna tidiga artikel, som var avsedd för samma tidskrift, Russkij sovremennik, som Dobyčin debuterade i, men inte hann publiceras innan tidskriften lades ner, polemiserar Bachtin mot formalismen som han menade tog det språkliga materialet för det estetiska objektet i sina analyser. Bachtin beskriver det som att varje materiell beståndsdel i ett konstverk blir konstnärligt betydande genom att materialet avskiljs och avgränsas från det pågående varat när det formas genom konstnärens skapande aktivitet. (I Slovo v romane kom han att beskriva det som att författaren dialogiserar tillvarons olikspråklighet (raznoglasie): "Slovo v romane", Sobranie sočinenij, 3, Moskva 20I2, 9-179, 29-85.) Därför ser vi inte det estetiska objektet genom att studera materialets egenskaper i sig i relation till det pågående varat utan måste, genom vår skapande aktivitet när vi tillägnar oss verket, som läsare, realisera varje materiell beståndsdel som en del i den estetiska formen och därmed som en del av betydelsen.

${ }^{147}$ Georges Poulet, Jean-Pierre Richard och Jean Starobinski med flera. 
alla sorter som författaren producerat. Det de där försöka finna är återkommande särdrag, moment, motiv som slutligen utkristalliserar sig till ett genomsyrande tema för författarskapet. Detta liknar på många sätt formalismens sökande efter ett författarskaps dominant eller den franska strukturalismens sökande efter normavvikelser, ogrammatiskheter, utifrån vilket författarskapets särdrag kan avkodas samt även de i den ryska kontexten så vanliga språkvetenskapligt inspirerade och strukturalistiskt eller semiotiskt grundade poetikinriktade litteraturstudier som mycket av forskningen om Dobyčin kan beskrivas som. ${ }^{148}$

Att jag värjer mig för att formalisera min läsning som närläsning och mitt försök att förstå Dobyčins drivkraft, den problematik och det tema som upptar honom som ett sökande efter författarskapets poetik, estetik eller tema i den litterära Genèveskolans mening har att göra med den förståelse av Dobyčins författarskap som mitt arbete lett fram till - att hans verk visserligen är gåtfulla men öppnar sig för en bara man slutar att leta efter en formell nyckel till dem, när man istället i ett läsningens möte tar del i att förverkliga vad de gestaltar i den vardagliga tillvaron.

${ }_{448}$ Begreppet dominant härstammar enligt Aleksandr Čudakov från konstvetaren Broder Christiansens Philosophie der Kunst (Hanau 1909). Dennes "idé om dominanten" säger sig Čudakov vilja gå tillbaka på när han använder dominant för att beteckna ett genomgående, unikt och konstituerande särdrag som visar sig på olika nivåer i ett författarskap: A. P. Čudakov, Slovo - vešč - mir: Ot Puškina do Tolstogo: Očerki poètiki russkich klassikov, Moskva 1992, I05-IO7, 133-I34. Som ett exempel på en med Christiansen samtida variant av begreppet tar Čudakov upp Kornej Čukovskij, som antog Dobyčins första noveller, vilken beskrev det som att varje författare är sinnesjuk och att kritikens uppgift var att komma åt den särskilda punkten i denna sinnesjuka, "osobyj punkt pomešatelstva" (Ot Čechova do našich dnej, Sankt Petersburg och Moskva 1908, citerat i A. P. Čudakov, a.a., I33). Det Čudakov med detta vänder sig emot är den formalistiska och strukturalistiska genreinriktade litteraturforskningens senare "absolutiseringen" av begreppet som han menar leder till att dels de genreöverskridande särdragen i ett författarskap förbises, dels att genrens stilskapande roll överdrivs (ibid., I05-I07). Som begreppet strukturalistiskt, framförallt av Roman Jakobson, utvecklades, kom det att avse ett enskilt verks dominanta, konstituerande funktion som i sin tur låter sig beskrivas i relation till en genres, litterär riktnings eller epoks dominanter. Begreppet kan då tillämpas på ett liknande sätt som det Michael Riffaterre beskriver som ett sökande efter ogrammatiskheter ("ungrammaticalities"), på vilket sätt något i en litterär text, texten i sin helhet och ytterst ett författarskap avviker från normen (la parole i relation till la langue). Roman Jakobson, "The Dominant", Language in Literature, Cambridge, Massachusetts, 1987, 4I46; Michael Riffaterre, "The Referential Fallacy", Columbia Review, 57, 2, I978, 2I-35.

Den så kallade generativa poetik, generativnaja poètika, som Jurij Ščeglov (som beskrev det citerande draget som utmärkande för Dobyčin) tillsammans med Aleksandr Žolkovskij, båda med sin grund i lingvistiken, lanserade som vetenskaplig metod i slutet av sextiotalet är påfallande lik tematiska litteraturstudier i sitt fokus på det konstnärliga uttryckets egenhet. En konstnärlig texts generativa poetik ses som summan av det konstnärliga uttryckets teman och grepp genom vilka den blivit till. V. P. Rudnev, "Generativnaja poètika", Slovar' kul'tury WV veka, Moskva 1997, 67-68. 
Det är därigenom som det mänskliga samspelet bortom vad som händer och sägs på ytan har öppnat sig, de möten bortom orden som verken också som helheter kan sägas utgöra. I detta ligger också kärnan till förståelsen av vad författaren uttrycker (och indirekt av hur han uttrycker sig): att Dobyčin i det triviala och banalt mänskliga söker den mänskliga interaktion som de människor som skildras i den nya sovjetiska tillvaron annars har svårt att förverkliga i sina liv. Det har som vi ska se att göra med att både språket och samhällslivet genomsyras av ett ständigt ideologiskt kategoriserande och etiketterande präglat av en blandning av fortfarande kvarlevande förrevolutionära, borgerliga och kyrkliga ideal och den nya sovjetiska ideologin som, i ständiga manifestationer och påbud uppblandad i en ny melodramatisk och lättsam populärkultur, försöker att göra upp med och ersätta den gamla kulturen. Det ger inte utrymme för några riktiga samtal mellan människor.

Jag har försöksvis i olika sammanhang kallat denna inriktning på att uppleva den vardagliga tillvaro som gestaltas och vad som därigenom berättas för en realistisk läsning. Men som särskilt trettiotalskontexten som jag gett prov på ovan visat är ordet realism så gott som obrukbart i sammanhanget. De kritiker som med sin misstänksamma ideologiska läsning "avslöjade" Dobyčin skulle troligen kalla sin läsning just realistisk, men då i marxistisk mening (så som Georg Lukács bland annat definierat skillnaden mot en naturalism som bara ser till intrycken på ytan och därför inte förstår de djupare sambanden i samhället, under vårt falska medvetande, och både som litteratur och kritik därför inte bidrar till förändring av det rådande tillståndet). ${ }^{149}$

Att, som det ibland görs, istället för närläsning tala om "långsam läsning" tillför knappast något som metod betraktat. Det kan dock vara intressant att nämna att termen användes samtidigt som formalismen tog sin början av några litteraturkritiker - bland annat av Kornej Čukovskij som Dobyčin framhöll som en av sina totalt två läsare - för att beskriva en förståelseinriktad litteraturkritik som också låter sig påverkas i sitt framställningssätt av den författare man skriver om. Tongivande för denna långsamma läsning

\footnotetext{
${ }^{149}$ Georg Lukács, "Die weltanschaulichen Grundlagen des Avantgardismus", Wider den Mißverstandenen Realismus, Hamburg 1958, 13-48. Det jag avser med realism är närmast den franska realismen i sin strävan efter att förutsättningslöst fånga det verkliga medan den socialistiska realismen snarast liknar den idealism, det idealiserande av verkligheten, som den franska realismen var en reaktion emot. Flaubert som Dobyčin jämförts med och själv framhåller som förebild kan ju också beskrivas som idélös i sin berömda föresats att med Madame Bovary skriva "en bok om ingenting". Flaubert i ett brev till Louis Colet, I6 januari I852, citerat i Sara Danius, Den blå tvålen: Romanen och konsten att göra saker och ting synliga, Stockholm 2013, 25I, 4IO.
} 
("medlennoe čtenie") var Julij Ajchenval'd som i förordet till sina "siluetter" av ryska författare (först utgivna 1906) - för att siluetter är allt man kan ge, författarskap låter sig inte bestämmas - tar upp problemen med att försöka att göra vetenskap av litteraturstudier. ${ }^{150}$ Att formalismens vetenskapliga fokus på hur verk är gjorda var ifrågasatt redan i sin samtid framgår också av en dispyt inom Serapionsbröderna, den litterära gruppering Dobyčin stod närmast, mellan de som menade att nya former behövdes för den nya litteraturen och de som mot det invände att man som författare alltid måste utgå från vad man vill uttrycka för att därigenom finna hur man ska göra det.51

Den läsning jag eftersträvar, den som framkallar de möten i och med den tillvaro som verken gestaltar, är en affirmativ läsning. Den söker sammanhang och mening, försöker förstå vad som händer genom inlevelse i de vardagliga skeenden som skildras. Särskilt i Dobyčins fall kräver berättelserna ett moment av medskapande för att framträda. Läsningen är också upplevande. Den betraktar verken som konstnärliga helheter varigenom de tidsbundna levande intrycken, stämningarna och tillstånden och de människor som skildras därigenom, bringas i samspel och rörelse till ett betydelsefullt uttryck.

För att delvis ge den samtida kritiken rätt så kan man tala om detta i termer av att acceptera Dobyčins idélöshet och att på ett motsvarande sätt i läsningen idémässigt förutsättningslöst ge sig ner i den verklighet som skildras för att där, i detta gestaltade liv, liksom förkategoriellt, utan att spana efter någon bakomliggande idé, uppleva, känna igen, möta de vardagliga berättelser som växer fram och vad de uttrycker.

"- Titta på den där tallen, sade gumman, och tänk inte."

${ }^{150}$ Catherine Depretto-Genty, Le formalisme en Russie, Paris 2009, 4I-42. Julij Ajchenval'd, "Vstuplenie", Siluety russkich pisatelej, I, Haag, Paris I969[1929], I-49.

${ }^{151}$ Kaverin redogör för denna dispyt i sina memoarer. Det frågan handlade om för Serapionsbröderna liksom för många andra i början av tjugotalet var om den sovjetiska litteraturen behövde anamma nya former. När Lev Lunc ibland dem förespråkade att de borde ta till sig ett handlingsdrivet berättande efter västerländskt mönster invände Konstantin Fedin att de som författare alltid måste börja med att i djupet förstå vad de vill säga för att först därigenom finna hur det ska sägas. Den unge Kaverin som var inbjuden av sin lärare Šklovskij instämde i Fedins ståndpunkt även om han insåg att det gick stick i stäv med det formalistiska förhållningssätt han skolats i. V. Kaverin, Sobesednik, Moskva 1973, 40-44. Dobyčin hade troligen inte känt sig hemma i något av lägren - varken i anammandet av nya former eller i det tydligt idédrivna. 


\section{Avskedet och samtiden}

\section{Konstens avsked från huvudstaden, en ramberättelse}

Leonid Dobyčins andra novellsamling Portret (Porträttet) från I93I börjar med ett avsked - med novellen "Proščanie" ("Avskedet" eller "Ett farväl"). Novellen är å ena sidan en av de sju nya av samlingens sexton noveller (de övriga nio utgjorde tillsammans den första samlingen Vstreči s Liz (Mötena med Liz) från 1927). Å andra sidan kan den betraktas som en vidareutveckling av den tidiga korta novellen "Timofeev", med dess centrala upplevelse av något betydelsefullt, vilken som inledningsnovell i en första novellsvit rentav föregick de första publiceringarna. Man skulle därför kunna se det som att Dobyčin återgick till en ursprunglig struktur när han lät den andra utgivna samlingen på samma sätt inledas med en novell som utspelar sig i Petrograd våren efter revolutionen.

"Proščanie" skildrar liksom förlagan inte de revolutionära händelserna utan denna historiska tids vardag. Ur den minneskimrande tillvaron växer gradvis ett avsked fram från den då (sedan femte mars I9I8) redan forna huvudstaden. Det som finns kvar från "Timofeev" är kvällsstunden på trappen. Avresan dagen efter är nu uttalad och gestaltad i slutet. Kvällsstunden betecknas inte längre som något betydelsefullt men framställs så i den vardagliga tillvaron bortom tidens stora händelse. Innebörden av denna tillvaro och detta avsked koncentreras i känslan av en insikt som liknar en utgångspunkt och ett avstamp för ett författarskap drivet av att fånga detta slags stunder. Eftersom samtliga femton noveller som sedan följer i Portret (sjutton inräknat de två som inte medtogs vid publiceringen) utspelar sig $\mathrm{i}$ en provinsiell småstad efter inbördeskriget och fångar det nya sovjetsamhällets utveckling under tjugotalet kommer denna inledningsnovell också att framstå som ett slags ramberättelse och förhistoria.

Även utan vetskap om Dobyčins egen flytt från Petrograd till den lilla provinsstaden Brjansk vid samma tid, i slutet av våren eller början av sommaren 1918, kan huvudpersonen genom novellens drag av ramberättelse uppfattas som ett författarens alterego. Bidragande till det intrycket är också att denne nu inte längre heter Timofeev utan har fătt det i sammanhanget 
högst märkliga och för hans konstnärliga karaktär övertydligt talande namnet Kunst. Samtidigt upprätthålls en liknande distans till huvudpersonen som i de följande berättelserna. Liksom där är bakgrundsinformationen om honom knapp och vi får inte veta mycket om vad han tänker. Novellen är därför inte entydigt ett inledande porträtt av författaren (eller av en fiktiv författare i stil med Belkin i Puškins Povesti Belkina (Belkins berättelser)) som etableras som den som har upplevt och återger eller gestaltar de därpå följande berättelserna. Inte ens i denna inledningsnovell är det, trots självbiografiska överensstämmelser, i första hand ett självporträtt man får känslan av, utan snarare ett porträtt av en viss tids tillvaro med dess lyriska stunder och konflikter som Kunst helt i stil med senare självständiga huvudpersoner fungerar som ett upplevande och medskapande medvetande för.

Om än gestaltningen genomsyras av något av ett minnets vemod som inte präglar de följande novellerna så är det långt ifrån en idyllisk eller mer meningsfylld tillvaro som beskrivs. Även denna avgörande revolutionära tid och plats, den för den sovjetiska kulturen så centrala referenspunkten, gestaltas med en vardaglig konkrektion och omedelbarhet ur huvudpersonens eget närvarande perspektiv tillsynes opåverkat av senare mytologisering eller personlig nostalgi. Det som framträder är hur det faktiskt var just då i den pågående vardagliga tillvaron och i de stunderna, med de skiftena i naturen under den vårens framväxt, liksom i utkanten av den revolutionära dramatiken (detta speglas också av att huvudpersonen är bosatt i stadens faktiska utkanter). Dessa i den levande vardagen förankrade, unika intryck samspelar samtidigt i en minneslik sammanhållande rörelse, liksom exempel på denna tillvaro, på hur det brukade vara. Det tidsbundna bringas på så sätt, genom att ingå som en del av ett avslutat och inte längre pågående tillstånd, till en konstnärlig, tidlös betydelsefullhet. På samma gång bidrar detta i det förflutna förlagda avsked, denna "konstens avresa" till provinsen (även om huvudpersonen Kunst i novellerna som följer inte upplevs som en närvarande berättare eller betraktare), till att konstnärligt avgränsa gestaltningarna av den samtida sovjetiska tillvaron som därefter skildras. Avskedet bidrar till att forma provinstillvarons levande vardaglighet till något konstnärligt betydelsefullt, och till att göra läsningen lik ett möte med den.52

Det avsked som skildras blir tvetydigt. Huvudpersonens faktiska avresa framställs som i huvudsak framtvingat av den materiella nöden efter revolutionen, av en för honom ohållbar tillvaro. Ett brev från en moster eller faster ("tetka") i provinsen, med vilket han underrättas om att de har det

\footnotetext{
${ }^{152}$ Enligt Bachtins beskrivning, som jag nämnde i inledningen, av hur det språkliga materialet får betydelse då det i ett konstverk, genom att formas av konstnären, avskiljs och avgränsas från det pågående varat.
} 
bättre ställt än i staden, öppnar en möjlig utväg som han till slut väljer. Den postrevolutionära tillvaron i Petrograd gestaltas som ett i sig utdraget avsked av den kultur och det kulturella liv som staden utgjort centrum för. Det ger en problematiserande referenspunkt för den längtan efter ett rikare liv som staden när den dyker upp i de följande provinsiella novellerna ofta får ge uttryck för (då oftast under namnet Petersburg vilket i början av första världskriget, 1915, ändrades till den ryska motsvarigheten Petrograd, men även det sedan 1924 samtida Leningrad har en liknande aura när det nämns). Inledningsnovellen bidrar till att framställa det som en längtan efter något som inte längre finns.

Redan i "Proščanie" befinner vi oss i ett efteråt. Redan i denna novell gestaltas en vardag präglad av en längtan och ett sökande efter verkliga möten med andra människor, samtidigt som den mänskliga interaktionen framträder genom det banalt mänskliga. Denna längtan kan redan ses som en del av vad som driver huvudpersonen till sitt avsked. Att huvudpersonen inte känner sig hemma i huvudstaden antyds, liksom möjligen ett hopp om att, omvänt mot senare noveller, i provinsen "finna något annorlunda", såsom en utländsk kvinna, Mirra Osipovna, i novellen uttrycker sin anledning till att ha sökt sig till det Petrograd där hon nu sitter och fryser och längtar bort. Det är i sin triviala vardaglighet, på samma sätt som i de provinsiella noveller som följer, som denna tillvaro i sina mänskliga detaljer, bortom ideologiska eller idealiserade beskrivningar, låter ana möten och stunder av betydelse. Det är livet i denna tid som novellen ger ett samlat uttryck för som något i sin konkreta verklighet - liksom både avsymboliserat och avdramatiserat - trots allt betydelsefullt.

Medan förlagan "Timofeev" begränsade sig till den enskilda avgörande stunden, utvecklar "Proščanie" detta mänskliga sammanhangs mänskliga öden som leder fram till den faktiska avresan. Den stund där huvudpersonen sitter ner ett tag som seden bjuder i Ryssland inför en resa blir så en stund av samlande eftertanke, efter ett beslut som redan är fattat, om den tillvaro som huvudpersonen tar avsked av.

Avskedet komponeras rytmiskt och lyriskt på fler nivåer, med talande namn och musikinslag, som ett genomgående tema centrerat till huvudpersonen. Om det fanns något dokumentärt och fotografiliknande i det stundliga utsnittet från en verklighet i "Timofeev" har denna känsla av tillfällighet i "Proščanie" förankrats i en helhetlig berättelses värld och utveckling, i en social samvaro med ett dramatiskt förlopp, om än i förgrunden snarare framdrivet av naturens årstidsskiftningar än ett aktivt handlande i denna revolutionens efterdyning. 
"Proščanie" skildrar inte Kunst som student såsom Timofeev även om han fortfarande bär studentrock. Det är istället, vilket också överensstämmer med Dobyčins tillvaro i staden vid denna tid, någon form av kontorsarbete och dess sociala sammanhang som huvudpersonen beskrivs åka in till centrum för från sitt hyrda rum i utkanten av staden (varifrån tågen på de norrgående linjerna kan höras) där hans hyresvärdinna och grannar utgör ett slags ställföreträdande familj. De två sammanhangen är skilda från varandra. Redan i denna novell framställs en distans till stadens kulturella centrum.

\section{En vanlig dag}

Tiden sätts igång genom en konkret årstidsbeskrivning, att det blir ljust tidigare på morgnarna, vilket samtidigt tjänar som ingång till vad som tillsynes är en skildring av huvudpersonens vana, hur hans dagar brukade vara från det att han vaknade. Först i efterhand framgår det att just denna dag innebar något avgörande. Det är som vanligt men det vanliga framställs med en insisterande specificitet som gör denna dag kännbar som unik och stundligt närvarande. Detaljerna gestaltar i sin påträngande realitet på samma gång miljön som den inneboende konflikten i huvudpersonens situation:

Зима кончалась. В шесть часов уже светло было. Открыв глаза, Кунст видел трещины на потолке, из трещин получалась юбка и кривые ноги в башмаках с двумя ушками. За стеной сиделка уже шлепала своими туфлями без пяток и будила раненого. Стукнув в дверь, хозяйка приносила чайник. - Безобразие, - говорила она и показывала головой на стену. Замолчав, она прислушивалась и потом смеялась. Кунст краснел.153

Vintern led mot sitt slut. Vid klockan sex var det redan ljust. Kunst öppnade ögonen och såg sprickorna i taket, sprickorna blev till en kjol och svängande ben i kängor med två öglor. Bakom väggen smällde sköterskan redan med sina hällösa tofflor och väckte den sårade. Värdinnan knackade på dörren och kom in med tekannan. - Sanslöst, sa hon och visade med huvudet mot väggen. Hon blev tyst och lyssnade och skrattade sedan. Kunst rodnade.

Huvudpersonen (och Konsten) ser egentligen den materiella situation som sprickorna i taket (nu när det blivit ljusare) vittnar om, men formar genast (som en annan aspekt av den begynnande våren) en kjol och kvinnoben av det. Denna liksom sedda men inte insedda belägenhet följs av ännu en sexuell distraktion som samtidigt berättar om tillståndet, den krigstid som

${ }^{153}$ Novellen citeras ur PSSP, 45-48. 
råder. Hyresvärdinnan kommer med te och beklagar sig över vad som försiggår på andra sidan väggen som om hon med Kunst på något sätt stod över sådant, men bara för att därefter avväpnande skratta åt det. Det är en oförställdhet som Kunst inte tycks kunna dela. Han rodnar med en kroppslig rödhet som i takt med att närheten till de revolutionära händelserna klarnar ironiskt (han framstår inte som revolutionärt röd) talar för den lilla värld han är försjunken i.

I andra stycket ger han sig ut klädd i en "studentrock" och med "en bit bröd inlindad i tidningen Århundrandet": "В студенческом пальто, с кусочком хлеба, завернутым в газету «Век», он выходил из дома." 54 Bilder av denna samtid av mer dokumentär art följer, av brödköande gummor och kringstrykande vansinniga soldater från lasaretten. I ett möte med en bekant tvätterska ges också en kommentar till situationen: att ordentliga människor gett sig av, att hon inhyst en prostituerad som hon lättsamt kallar fe och gatufjäril (vilket passar in i den sexuellt och konstnärligt drömmande föreställningsvärld som slagits an hos huvudpersonen).

Sedan tar han spårvagnen. "Звенел трамвай. - Вперед пройдите, восклицал кондуктор." ("Spårvagnen ringde. - Fortsätt framåt, ropade konduktören.") Dess signal och konduktörens rop om att fortsätta framåt tycks liksom brödbiten i tidningen eller rodnaden i inledningen som potentiella ironiskt vardagliga tecken för den revolutionära rörelse som inte nämns. Bland vidare årstidsdetaljer sedda från spårvagnen utpekas de som står i gathörnen och säljer tidningar lakoniskt som "sabotörer" (enligt den nya ordningens förbud mot tidningar från andra partier än bolsjevikerna). De palats som Kunst sedan går längs med efter att ha stigit av spårvagnen står dystert blickande och med statyer i nischerna angivna som gamlingar, vilka samtidigt (liksom sprickorna $\mathrm{i}$ taket) får liv för någon - den nu som upplevande subjekt etablerade huvudpersonen. Huvudpersonen kan nu också omvänt ses som den som läser in det som pågår i tiden i dessa sinnliga och musikaliskt dynamiska detaljer:

[...] За Троицким мостом Кунст вылезал и шел по набережной. Темные дворцы смотрели мрачно. Каменные старики стояли в рыжих нишах, разводя руками и выделывая па.

\footnotetext{
154 Under namnet Vek (Århundrandet), som en av flera omdöpningar av det ursprungliga namnet Reč (Talet) som togs till för att trotsa utgivningsförbudet efter oktoberrevolutionen, utkom det liberala kadettpartiets (Konstitutionellt demokratiska partiets) tidning i endast två nummer i slutet av 1917. Men bland annat under det snarlika Naš vek (Vårt århundrade) fortsatte utgivning fram till augusti 19I8, vilket gör att den till skillnad från övriga tidningar som figurerar i novellen historiskt sett i princip kan överensstämma med den tid som skildras.
} 
[...] Efter Treenighetsbron klättrade Kunst av och gick längs kajen. De mörka palatsen tittade dystert fram. De gamla männen i sten stod i de brandgula nischerna, bredde ut armarna och utförde ett danssteg.

I tre stycken skildras sedan det sammanhang som Kunst begett sig in i staden för. Sammanhanget förklaras inte. Utan övergång befinner vi oss i en miljö där både ett flitigt skrivande och ett väntande sittande pågår. Snart tillkommer en föreståndare och en instruktör samt unga kvinnor. Det liknar en arbetsplats. Kunst nämns överhuvudtaget inte som interagerande med dessa personer, men hans resa in till staden har anslagit honom som närvarande, som den som uppfattar detta. Att han har någon form av anställning och dagligen uppehåller sig här är allt som framkommer. Omständigheterna tycks inte vara det väsentliga för berättelsen - utan vad dessa människor med sina namn, attiraljer, gester och korta yttranden tar del i att gestalta som ett mänskligt uttryck i denna tillvaro:

Иван Ильич уже писал, тщедушный, за большой конторкой с перламутровыми птицами, и Мирра Осиповна, поправляя волосы, уже сидела. В меховом воротнике, она поеживалась и подрагивала. - Слушайте, я замерзаю, - говорила она томно и драпировалась.

Ivan Iljitj skrev redan, spenslig vid den stora pulpeten med pärlemorsfåglar, och Mirra Osipovna satt redan och ordnade håret. Hon kurade i pälskragen och skakade lite. - Hör ni, jag fryser ihjäl, sade hon matt och draperade sig.

Här får vi möta en Ivan Il'ič (namne med den döende i Tolstojs berömda berättelse) som flitigt arbetar vid ett skrivbord med fåglar i pärlemor, och en kvinna vid hans sida med namnet Mirra Osipovna (det fullt normala förnamnet hon givits, med grekiskt ursprung, fick under en tid efter revolutionen ny popularitet förstått som en förkortning för "mirovaja revoljucija", "världsrevolution" - något som spelar ironiskt mot vad hon ger uttryck för med sin borgerliga uppsyn och passivitet). Att de redan skriver respektive sitter talar för Kunsts specifika - möjligen något försenade - ankomst (men tar också vid i vårens redan ljusare morgnar och grånade is som dock ännu inte tycks ha höjt temperaturen).

Föreståndaren heter Glan, namne med den i tiden så populära och tidstypiskt hedonistiska löjtnant Glahn i Knut Hamsuns Pan. Han vecklar upp den högst tidsbundna och politiskt utpekande tidningen Luč (Strålen) - en mot utgivningsförbudet trotsande omdöpning (men från slutet av I9I7 och inte våren I9I8) av den mensjevikiska tidningen Iskra (Gnistan) - och läser högt upp rubriken om den svält som hotar. Detta blandas med männens 
iakttagna lystna blickar på kvinnan som serverar te: "Девушка Маланья, колыхая мякотями, разносила чай. Мужчины на нее посматривали сбоку." ("Flickan Malanja bar gungande med mjukdelarna ut te. Männen tittade på henne från sidan.") En instruktör Baumštein kommer in och läser en rapport. Det beskrivs att den kortväxte Glan majestätiskt lyssnar till den och att de unga kvinnorna på kontoret förförs av instruktörens sätt, han gör honnör och blinkar åt dem. Vad rapporten handlar om sägs emellertid inget. Om Ivan Il'ič får vi på liknande sätt veta att han skriver på en avhandling, men det väsentliga är inte ämnet utan hur det får honom att för några timmar varje kväll glömma detta liv, vilket den sittande Mirra vid hans sida känner igen sig i:

[...] - Я пишу магистерскую диссертацию, - взглянув на окна, говорил тогда Иван Ильич, - и каждый вечер я на несколько часов позабываю эту жизнь. - Ах, я понимаю вас, - роняла набок голову и нежно улыбалась Мирра Осиповна.

[...] - Jag skriver en doktorsavhandling, sade Ivan Iljitj då och såg upp på fönstren, och varje kväll så glömmer jag det här livet för några timmar. - Åh, jag förstår er, föll Mirra Osipovna in med ett ömt leende och lutade huvudet åt sidan.

Därefter upplöses denna mänskligt profanerade professionella samvaro på föreståndarens initiativ: "- Время, - наконец, сорвавшись с места, складывал начальник Глан свой «Луч»." ("- Tiden, for till slut föreståndare Glan upp från sin plats och sade och vek samman Strålen.") Tillsammans med tidningsnamnet som nu blir tydligare gestaltande också för Glans och arbetsplatsen själva aktivitet, får också det vardagliga "vremja" ("tiden") i betydelse att det är dags eller hög tid, en underton av djupare innebörd. Det är något som vidare byggs ut - efter att de unga kvinnorna och Ivan Il'jič (som speglar sig i skrivpulpetens lack när han fräschar upp sin bena) ordnat sig för hemgången - genom att det korresponderar med ytterligare en tidning, "Novoe vremja" ("Ny tid"; en konservativ Petersburgstidning som förbjöds med ens efter oktoberkuppen I9I7) som i kontrast till namnet några (demobiliserade) generaler frysande står och säljer när de kommer ut. Som en del i skildringen av dagens gång ropar sabotörerna nu ut sina kvällstidningar. Deras fonetiskt återgivna, liksom akustiskt uppfångade rop, blir också en del i betydelseströmmen som igångsatts. Det skymmer för alternativa yttringar. Historiskt sett, som våren I9I8, är tidningarna redan nedlagda.

På detta sätt talas det om den nya tiden och om huvudpersonens tillvaro utan att han ens interagerar eller utväxlar några ord om den när han befinner sig i detta politiska centrum. Själva tingens och namnens samspel blir 
indirekt talande för huvudpersonens känsla av det ödesdigra i tiden likt en ersättning för ett verkligt samtal med någon av dessa om vad som händer och hur det ska förstås. Gestaltningen får genom undvikandet av detta "innehåll" samtidigt inriktning mot det mänskliga, ett slags gemensam botten bortom det politiskt historiska, ideologiskt förklarade och tidsbundna.

Generalernas triviala åkarbrasor och frusna stampande med "den nya tiden" leder, via en lyriskt stämningshöjande och platsförflyttande bild, över till en liknande vardaglig konkretisering av det nya "århundradet", vilket den unge huvudpersonen (som tidigare slagit in sitt bröd i det) nu försöker ta grepp om tillbaka i sängen på sitt rum:

[...] У выхода стояли саботажники с газетами. - Вичернии, - кричали они звонко и приплясывали. Хлопали себя руками по бокам и топали ногами низенькие генералы с «Новым Временем». Шпиль крепости блестел. Морские облака летели.

Сбросив обувь и взяв в руки «Век», Кунст осторожно, чтобы не измять штаны, укладывался на кровать. [...]

[...] Vid utgången stod sabotörerna med tidningar. - Kvällstiiningar, ropade de klangfullt och dansade till det. Små korta generaler stod med Nya Tiden och daskade sig med armarna mot sidorna och stampade med fötterna. Fästningens spira glänste. Havsmolnen flög.

Efter att ha sparkat av sig skorna och tagit Århundradet i handen lade sig Kunst försiktigt för att inte skrynkla byxorna tillrätta på sängen. [...]

Tidningens möjliga politiska utpekande av huvudpersonen som anhängare av det liberala Konstitutionellt demokratiska partiet utvecklas inte. ${ }^{55}$ Och när värdinnan nu kommer in som i inledningen, men med kvällsteet som en avrundning av denna dag, så frågar hon visserligen vad som står i tidningen, men bara för att genast börja prata om det närliggande och som tidigare med romantiska antydningar. Hon talar om Frida, en av hyresgästerna, som sjunger och som hon kallar poetisk och tycks vilja väcka Kunsts intresse för. $\mathrm{Nu}$ kommer hon också - pillemariskt leende i tron om att detta också hör till den romantiska sfären - med ett brev till Kunst.

Brevet visar sig så vara från en tetka (en moster eller faster) som läst kanske just i någon av de återstående icke-bolsjevikiska tidningarna - om den redan rådande materiella nöden i staden till skillnad från där hon befinner sig: "«Приезжай, - звала она. - Мы сыты. А у вас такие ужасы: недавно я читала, что от голода распух один профессор и упала замертво

155 Inte heller ger Dobyčin själv i sina brev uttryck för några sådana tidigare politiska sympatier (han placerar sig överhuvudtaget aldrig tydligt politiskt). 
писательница»." ("'Kom hit', manade hon. 'Vi är mätta. Och hos er sker sådana hemskheter: jag läste nyligen att en professor svällde upp av svält och att en författarinna föll död ner."”)

Den lätt humoristiska plumphet som de makabra uppgifterna återges med speglar möjligen en provinsiell tants föreställningsvärld. Brevet tränger i vilket fall inte in som något avgörande i detta skede men introducerar ändå en utväg ur situationens existentiella utsatthet och spänning.

Det som målas fram denna första dag är en stämning, en ännu rådande ovisshet, med först i efterhand fullt ut läsbara (eller intolkningsbara) tecken för det avgörande och ödesdigra i denna revolutionära tids vardag.

\section{En händelse?}

Ett händelseförlopp slås an med en nu avgörande, med perfektiv aspekt återgiven, årstidsförändring: "Стаял снег. Подсохло. Лед прошел - с дорогами и со следами лыж. На улицах уселись бабы с вербами." ("Snön smälte. Det torkade upp. Isen lossade - med vägarna och skidspåren. Gummor satte sig med videkvistar på gatorna.") Det är dock långt från revolutionsdiktningens och den senare sovjetlitteraturens vanligt förekommande användning av väder- och årstidsskiftningar för att skildra den revolutionära samhällsförändringen som en obönhörlig naturkraft. Frånsett några nya inslag fortskrider vardagen enligt gamla mönster. Det som följer med årstidsförändringen är, liksom det alltid har varit, att gummor på palmsöndagen sätter sig och säljer videkvistar.

Det nya sker i det kanslilika sammanhanget i centrum. Här utropas ett löfte om förändring i den materiella situationen som tycks spegla den i naturen (en öppning som fler fysiska detaljer och rörelser tar del i att förmedla känslan av - fingret, kragen, broschen):

[...] - Нам будет выдача, - обдернув пиджачок и потирая руки, объявил Иван Ильич. - Мед с пчелами, - вскочила Мирра Осиповна и, считая, отогнула палец. Распахнулся воротник, брошь «пляшущая женщина» открылась. - Красная икра и грушевый компот в жестянках! - [...]

[...] - Vi ska få ransoner, meddelade Ivan Iljitj och gnuggade händerna efter att ha dragit lite i den lilla kavajen. - Honung med bin i, for Mirra Osipovna upp och vek ut ett finger när hon räknade. Kragen öppnades, broschen "Dansande kvinna" syntes. - Röd kaviar och burkar med päronkompott! [...]

Vid slutet av arbetsdagen ombeds de vänta medan en ung dådkraftig kvinna åker iväg - beväpnad och med två beväpnade män - för att hämta ransonerna. Istället för att leda fram till ett triumferande resultat (i nästa 
stycke framgår att Kunst faktiskt fått sin ranson) avrundas episoden bara med deras väntan, med att elektriciteten (denna symbol för sovjetmakten) inte fungerar och att den Malan'ja vars mjuka kropp tidigare distraherat männen kommer med en lykta och liknar det vid att gå med vatten till korna (möjligen antydande både denna lantliga torftighet i staden och deras väntan som dumma kor på att bli utfodrade): "Ждали долго. Электричество не действовало. Девушка Маланья принесла фонарь и посмеялась: - Как коров поить, - сравнила она. Тени появились." ("De väntade länge. Elektriciteten fungerade inte. Flickan Malanja kom med en lykta och skrattade. Som att vattna korna, jämförde hon det. Skuggorna kom fram.") Tillståndet mynnar ut i att sabotörerna utanför sjungande hörs ropa ut sina kvällstidningar liksom dagen före. Nu först träder Kunst fram som mer än en betraktare i detta sammanhang. Han börjar sjunga på en romans - den romans, visar det sig, som tidningsförsäljarna använder sig av melodin till. Romansen tycks av brottstycket att döma - om man nu inte genast igenkänner den - handla om ett sorgligt avsked (vilket så det triviala skanderandet av oppositionella kvällstidningar stämmer väl in i). När Ivan Il'ič blygt ansluter uppstår en kort stunds samspel mellan dem i sången som med sin text samtidigt antyder att denna samvaro måste upphöra. Kanske är det för att de upplever en själslig närhet med varandra i sången eller bara på grund av att de blir varse det aparta och möjligen politiskt olämpliga i detta känslosamma avskedssjungande mitt i den bolsjevikiska revolutionens första vår: deras sång slutar i vilket fall i en plötslig förlägenhet:

[...] За окном газетчики кричали нараспев: - Ви-чер-нии. Кунст, опершись на подоконник, тихо подтянул им, и Иван Ильич, стесняясь, присоединился:

- слезы лились

из вокзала

- шепотом пропели они вместе и сконфузились.

[...] Utanför fönstret ropade tidningsförsäljarna mässande: - Kvälls-tiiningar. Kunst lutade sig mot fönsterbrädet och stämde stillsamt in med dem, och Ivan Iljitj anslöt blygt:

- tårar rann
från stationen

- sjöng de viskande tillsammans och blev förlägna. 


\section{Vardag med nya vanor}

Det blir påsk. I kontrast till revolutionsbesjungande poeters användning av uppståndelsemotivet för den samhälleliga omvälvningen leder påsken här bara till en sysslolös ledighet: "Настала пасха. Делать было нечего. Кунст спал, смотрелся в зеркало, ел выдачу." ("Påsken kom. Inget fanns att göra. Kunst sov, tittade sig i spegeln, åt ransonen.")

Han har fått sin ranson och att döma av värdinnans reaktion tycks den inte vara något att klaga på: "- Аx, чтó вы получили, - разглядела она и прижала к сердцу руки." ("- $\mathrm{h} h$, se vad ni fått, sade hon när hon fick syn på det och tryckte händerna mot hjärtat.") Efter en fördjupning av denna hemliknande sfär - med sköterskan i rummet intill som nu festar med sina kollegor på ransonerna, den sjungande Frida och tvätterskan Kubaricha med sin "fe" som Kunst äter påskkaka tillsammans med - tar årstiden ytterligare ett steg genom små företeelser i naturen, liksom iakttagna över en längre tid och summerade: "Раздвигая прошлогодний лист, полезли из земли травинки. Птичка завелась на Черной речке и по вечерам посвистывала." ("Grässtrån sköt ett fjolårslöv åt sidan och kröp upp ur jorden. En fågel dök upp vid Tjornajaån och visslade på kvällarna.") Det symbolikantydande i gräsets uppträngande och fågeln och dess återkommande sjungande leder dynamiskt över till en bild av den prostituerades nya aktivitet och Kunsts sätt att hantera sina vårkänslor: "Фея принялась ходить под окнами. Конфузясь, Кунст задергивался занавеской." ("Fen lade sig till med att gå omkring under fönstren. Kunst blev förlägen och drog för gardinen.")

En annan ny vana här i stadens nordliga utkanter som drar in de större historiska händelserna i denna sfär tecknas med flyktingar från Riga som kommer ut från staden på söndagarna. De betraktas av värdinnan vars bakgrund och karaktär härigenom utvecklas. Hon kan i sin tur läsas som varsebliven av huvudpersonen och ge uttryck även för hans provinsiella hemhörighet (även om det inte utsägs vara just denna, den som också ligger författarens ursprung nära). Avskedstemat kommer här in genom den omvända riktningen. Flyktingarna är troligen ryssar från det nu, I9I8, självständighetssträvande Lettland eller tidigare flyktingar från frontlinjen mot tyskarna i kriget (vilken Dobyčins mor flyttade till Brjansk från I9I7).

Dessa nya vanor tar del i skildrandet av årets gång samtidigt som de skildrar en förändring och liksom i ett medvetande associativt träs på varandra tills de till slut ger betydelse, tills allting sammantaget leder till det beslut som Kunst fattar. Här har vi sett honom i brist på handling eller andra självuttryck störas av fen och fördriva tiden med värdinnan. Därefter är det kontorsmiljön som skildras med sina inslag av nytt liv vilket samtidigt, inom 
Kunst som en betraktare av detta, tycks utveckla ett möjligt alternativ till en avresa:

Мирра Осиповна перестала мерзнуть и сняла свой воротник. Она носила с собой ветки с маленькими листиками и, потребовав у девушки Маланьи кружку, ставила их в воду. Забегал инструктор Баумштейн и, нагнувшись, нюхал их. - Аx, - заводя глаза, вздыхал он. - Утро года, - говорил Иван Ильич, обдергиваясь. Перламутр на его конторке блестел. За окнами синелось небо, Кунст засматривался, и письмо от тетки вспоминалось ему.

Mirra Osipovna slutade frysa och tog av sin krage. Hon bar med sig kvistar med små löv, bad flickan Malanja om ett krus och satte dem i vatten. Instruktör Baumstein sprang förbi och böjde sig och luktade på dem. - Åh, suckade han med himlande ögon. - Årets morgon, sade Ivan Iljitj och rättade till sig. Pärlemorn på hans pulpet glänste. Utanför fönstren lyste himlen mörkblå, Kunst betraktade den länge, och han mindes brevet från mostern.

Den krage som tidigare öppnats tar Mirra Osipovna nu helt av och tycks vakna upp ur sin tidigare depressiva passivitet. Ivan Il'ič talar klichéartat och med sina vanliga nervösa gester om denna vår som en ny början. Kanske väcker detta minnet av hur de sjöng en romans om en avresa, kanske är det de glänsande pärlemorsinläggen som nämnts föreställa fåglar, kanske är det den djupnande himlen - minnet av brevet återkallas i vilket fall för Kunst av denna stämning.

Avresan anslås så som ett annat slags början på något nytt än vad våren inom denna tillvaros ramar här ger hopp om. Mot bakgrund av den allmänna rörelsen i vardagen framstår Kunst inte entydigt som tvingad utan också med en dragning till avresan som en utväg från alla de problem - de svårhanterliga lustarna, känslan av att inte höra hemma i staden och djupast från själva sin existentiella längtan - som skildringen av våren här antytt.

\section{Handlingen}

Övergången från minnet av brevet till beslutet om avresan utvecklas genom en episod liknande den med livsmedelsransonerna. Det rör sig nu om ett löfte om utbetalning av reda pengar (det vill säga överhuvudtaget av lön för arbetet). Det är den dådkraftiga flickan som åter kommer med budet varefter ett replikskifte utspelar sig mellan Mirra Osipovna och Ivan Il'ič som indirekt belyser Kunsts velande om sin framtid.

Först reagerar Mirra med misstro på beskedet:"- Неужели? - поднялась и томно сомневалась Мирра Осиповна." ("- Verkligen? sade Mirra Osipovna matt och tvivlande och reste sig.") När de så faktiskt får kvittera ut pengar kommenterar Ivan Il'ič detta med udden riktad mot Mirra 
Osipovnas tvivel över det nya: "- Урок для скептиков, - сказал Иван Ильич и посмотрел на Мирру Осиповну." ("- En läxa för skeptiker, sade Ivan Iljitj och tittade på Mirra Osipovna.") Tillvaron upplevs som möjlig igen: "Приятно было." ("Det var trevligt.")

När denna materiella lättnad sedan bryskt återtas ger det upphov till ett avslutande meningsutbyte mellan Ivan Il'ič och Mirra Osipovna som framställer två positioner i denna tillvaro:

[...] Через день пришел мужчина и созвал собрание: союз не допускает наградных. Постановили, что их нужно вычесть, и вернулись на места уныло. - Я не ожидала, - говорила Мирра Осиповна мрачно. Вытащив из кружки свою ветку с листьями, она ломала ее. - Вы читали Макса Штирнера? - согнувшись и повеся нос, бродил Иван Ильич. Кунст думал, положив на ру́ки голову.

[...] Efter en dag kom en man och kallade till samling: fackföreningen tillåter inte premier. Det hade fastslagits att de måste avräknas och de återvände nedslagna till sina platser. - Det väntade jag mig inte, sade Mirra Osipovna dystert. Hon tog upp sin kvist med blad ur kruset och bröt av den. - Har ni läst Max Stirner? frågade Ivan Iljitj betryckt och gick hängande med huvudet omkring. Kunst hade lagt huvudet på händerna och tänkte.

Med en bitter ironi riktad mot Ivan Il'ič - hon väntade ju just detta, det var han som fick henne att hoppas - avbryter hon sina försök till gemyt i denna tillvaro medan Ivan Il'ič söker filosofiskt stöd för att dra sig tillbaka till sin tidigare position och möjligen åtminstone i sina kvällsstunder med avhandlingen fortsatt uppleva en personlig frihet.

Den tyske skeptiske filosofen Max Stirner var känd för sin så kallade etiska egoism som han utlade i sitt verk Der Einzige und sein Eigentum (I844). Det han med detta ville föreskriva var en frigörelse från alla slags underminerande falska föreställningar till förmån för individens personliga frihet och egendomsrätt, ett egoistiskt istället för socialt förhållande för att undgå att bli kuvad. Det han betonade var just autonomi och inte snävt egenintresse (vilket också kan bli förslavande). ${ }^{15}$ Att inte låta sig styras av andra, som nämnandet av Stirner i förbigående så kan vara ett uttryck för, kan ses som en filosofisk utgångspunkt för denna avresa och för det som novellsamlingen vidare problematiserar. Med denna enda kommentar om det skedda,

\footnotetext{
${ }^{156}$ Stirner intog en självständig position gentemot vänsterhegelianer i sin samtid. Det grundläggande felet hos dessa, som exempelvis Feuerbach, fann Stirner i att de gjorde den mänskliga naturen till en essens att sträva efter för individen. Men den mänskliga naturen är inte universell eller föreskriven och man kan därför inte utifrån den göra anspråk på hur vi ska leva. Detta är bara en ny fiktion som ersättning för religionens. "Max Stirner", Stanford Encyclopedia of Philosophy, https://plato.stanford.edu/entries/max-stirner/, 2019-03-II. Max Stirner, Der Einzige und sein Eigentum, Stuttgart 1986.
} 
troligen riktad till Kunst, tycks Ivan Il'ič också söka ett tyst samförstånd i sin protest. Och det är på nämnandet av Stirner som Kunsts eftertanke följer som en övergång till hans avslutande handling, hans personliga utväg från hela denna tillvaros problematik.

Att Kunsts följande avresa på något sätt är i linje med Max Stirner som ett sätt att bevara sin personliga frihet, en avresa Ivan Il'ič så indirekt rentav kan ses råda honom till, antyder tillsammans med den liberala tidning han läser en tämligen tydlig ideologisk position i förhållande till revolutionen hos detta författarens möjliga alter ego. Men är det författarens alter ego och är han så politiskt medveten som detta kan tyckas antyda? Kanske antyds lätt ironiskt snarast en rådande syn på konsten i denna tid, personifierad av den möjligen unge konstnären som upptagen av sina personliga mänskliga problem mitt bland de stora avgörande revolutionära händelserna, vilken därför, som man såg det, var tvungen att söka sig ut till det verkliga livet i provinsen. Eller skildrar det revolutionen som trots allt föga betydande för människors personliga liv? De frågorna besvaras inte. ${ }^{57}$

Det avslutande långa stycket av totalt tretton inleds med Kunsts avgörande beslut såsom formulerat i ett brev till sin tetka i provinsen: "Ja edu" ("Jag åker"). Stycket gestaltar så hans faktiska avsked i denna novell som också som helhet utgör ett avsked, med en utdragenhet och laddning i de sista vardagliga stunderna som konstnärligt fördjupar och förevigar denna tillvaros liv. Kvällen övergår i samma stycke till en hästskjuts ankomst i gryningen till nästa dag. Det regnar (såsom himlen i "Timofeev" förebådade) och Kunst som redan är stadd i rörelse mot järnvägsstationen möter med ett upprepat farväl de tre människor som likt en ställföreträdande familj figurerat kring detta hyreshus i utkanten av den forna huvudstaden:

«Я еду», - написал он тетке и купил билет. В последний раз хозяйка принесла вечерний чайник. - Я сама уехала бы, - села она и потерла ру-

${ }^{157}$ I en bevarad version av novellen under titeln "Tetka" (PSSP, 434-438) arresteras instruktör Baumštejn anklagad för mutbrott och novellen slutar med att Ivan Il'ič därefter, utifrån att han också påstår sig ha fått ett brev från en "tetka", som är sjuk, talar om att han kanske skyndsamt måste ge sig av. Avresan i "Proščanie" hade med detta framstått mer politiskt motiverad. "Tetka" slutar dock varken med någon kvällsstund eller avresa utan med Kunsts plumpa konstaterande (som inte tycks förstå detta tal om en moster som också en omskrivning för behovet av att fly): "- Значит, и у вас есть тетка, - удивился Кунст." ("- Så ni har också en moster, sade Kunst förvånat.") Kunst visar sig i "Tetka" överhuvudtaget mer osympatiskt och märkligt känslokall gentemot andra, med nedlåtande repliker. Han tycks ha svårt att veta hur han ska förhålla sig till vad som händer. Samtidigt som den historiska och politiska verkligheten och särskilt misären med svält och prostitution skildras mer klargörande och ingående i "Tetka" är novellen konstnärligt inte genomkomponerad och levande. Den lyfter inte som "Proščanie" med sina tidsbundna mänskliga detaljer ur historien. 
кавом глаза. - Курляндская губерния, - потряхивая головой, торжественно сказала она, - никогда не позабуду я тебя. - Кунст вышел на крыльцо. Луна без блеска, красная, тяжеловесная, как мармеладный полумесяц, пробиралась над задворками. Закутавшись в большой платок, сиделка, неподвижная, сидела на ступеньке. Кунст сел выше. Красный запад был исчерчен пыльными полосками. Далеко свистнул паровоз. - Фильянка, - прошептала, не пошевелясь, сиделка. - Может быть, приморская, - подумал молча Кунст. С рассветом подкатил извозчик. Капал дождь. - Прощайте, - крикнула с крыльца хозяйка. - Прощайте, - обернулся Кунст. - Прощайте, - высунулась Фрида из окна. - Прощайте. - Поэтическая, в одеяле и чепце, она махала голыми руками. Фея - уличная бабочка, позевывая, шла домой. - Прощайте.

"Jag åker", skrev han till mostern och köpte en biljett. För sista gången kom värdinnan in med tekannan. - Jag skulle själv ha åkt, sade hon och satte sig och torkade ögonen med ärmen. Guvernementet Kurland, sade hon högtidligt och skakade på huvudet: jag kommer aldrig att glömma dig. Kunst gick ut på trappan. En måne utan glans, röd, tung, som en marmeladbåge, tog sig fram över bakgårdarna. Insvept i en stor sjal satt sköterskan orörlig på ett trappsteg. Kunst satte sig ovanför. Den röda västerhimlen var överstreckad med dammiga ränder. I fjärran visslade ett ånglok. - Filjändskan, viskade sköterskan utan att röra sig. - Kanske kustlinjen, tänkte Kunst tyst. I gryningen körde en droska fram. Regnet droppade. - Farväl, ropade värdinnan från trappan. - Farväl, vände sig Kunst om och sade. - Farväl, sade Frida som lutade sig ut genom fönstret. - Farväl. Poetisk, i täcke och hätta, vinkande hon med bara armar. Fen, gatufjärilen, gick gäspande hemåt. - Farväl.

Den utblommande känslosamheten i själva avskedet - som först utvecklas genom hyresvärdinnan, som ger uttryck för gemenskapen med Kunst både i det som varit och i den liknande längtan som hans avresa fyller henne med - blir den upplösning som denna vår ledde fram till. Det är nu sköterskan och inte värdinnan som i "Timofeev" som huvudpersonen delar stunden med. ${ }^{158}$ Beslutet och slutet kommer tillsynes plötsligt, men med en potentiell insikt om den dynamiska processen bakom i denna konkret förankrade slutstund med en betydelsefullhet i alla sina detaljer: den röda månen, den röda himlen västerut mot havet och dammet från staden och tågen som visslar och leder iväg. Stunden som ett samlande intryck av denna redan svunna tillvaro laddas så som en utgångspunkt för det liv som skildras i de följande novellerna. De utspelar sig först efter åren av inbördeskrig och svält och på långt avstånd från centrum, i det nya sovjetiska samhället under sin uppbyggnad i en provinsstad på tjugotalet.

\footnotetext{
${ }^{158}$ Felsägningen får inte samma plats som i förlagan. Kunst tycks inte reagera på feluttalet utan bara tänka att det kanske inte är järnvägslinjen till Finland utan kustlinjen (primorskaja (Sankt-Peterburg-Sestroreckaja) železnaja doroga) som loket hörs ifrån. Men det talar fortsatt om deras delade längtan.
} 


\section{"Kozlova" - i väntan på ett brev från monsieur}

Med titeln "Pis'mo" ("Brevet") ingick "Kozlova" som den sista av de fem novellerna i Večera i staruchi (Kvällar och gamla kvinnor), en samling som Dobyčin våren 1924 översände till den kända Petersburgsförfattaren Michail Kuzmin för, som han uttryckte sig, dennes "översyn" och "omdöme". Föga förvånande besvarade aldrig Kuzmin detta indirekta utgivningsförsök från en för honom helt okänd L. Dobyčin vid guvernementsfackföreningsrådet i Brjansk, såsom brevet som enda upplysning om författaren var undertecknat. Tack vare att Kuzmin ändå sparade försändelsen så bevarades dock de fem novellerna till eftervärlden av vilka annars endast den sista, något omarbetad och omdöpt efter huvudpersonen, kom att publiceras under Dobyčins livstid. ${ }^{59}$

"Kozlova" publicerades för första gången av Michail Slonimskij i tidskriften Leningrad 1925 (nummer 9) efter att den redan året före, tillsammans med novellen "Vstreči s Liz" ("Mötena med Liz"), hade antagits av Kornej Čukovskij för Russkij sovremennik men inte hunnit utkomma innan tidskriften lades ner. "Kozlova" kom sedan att inleda den första novellsamlingen Vstreči s Liz och följa efter "Proščanie" i den andra novellsamlingen Portret.

Med sina fyra numrerade kapitel är "Kozlova" till omfånget, stilen och innehållet den som mest liknar de noveller som Dobyčin därefter skrev. "Kozlova" utspelar sig som de följande novellerna i den sovjetiska samtid som den tillkom i med ett flertal referenser till historiska händelser från

${ }_{159}$ Till M. A. Kuzmin 30 maj 1924 (brev I52), PSSP, 324. Mötesproblematiken kan observeras redan i Večera i staruchi. Efter "Timofeev" med dess mötesliknande upplevelse av något betydelsefullt i kvällsstunden i Petrograd följer "Kukueva" med en olycklig kärlekstriangel i den provinsiella sovjetiska samtiden; den drömmande Šuročka upplever en själslig gemenskap med den revolutionärt käckt handlingkraftiga Žorž som, om än fysiskt närvarande, i sitt inre upptas av ett förestående möte med den mer flärdfulla men borgerliga Kukueva. Efter dessa två "Kvällar" ("Večera") inleder den tredje novellen "Ninon" avdelningen "Gamla kvinnor" ("Staruchi") med att två kvinnor förenas vid en likvaka. Efter fyrtio år kan de äntligen ge uttryck för sin förbjudna kärlek till varandra vilket den avlidna Ninon tidigare stått i vägen för. I Dobyčins längsta novell "Evdokija" som upptar över hälften av samlingen utgör huvudpersonens längtan efter en djupare vänskap än vad hon upplever med sina väninnor i sin vardag grunden för konflikten. Genom sitt aktiva samhällsengagemang ser hon sig som jämbördig med en polsk grevinna i det lilla samhället (med Krāslava utanför Dvinsk som verklig förebild) och föreställer sig en förfinad vänskap med denna. När hon upplever sig bli bryskt avvisad tar sig hennes möteslängtan istället uttryck i att hon enar de ryska kvinnorna i samhället vilket snart utvecklar sig till en del av den allmänna nationalistiska rörelsen i upprinnelsen till första världskriget med vars utbrott novellen slutar. Den sista novellen i samlingen, "Pis'mo" som blev "Kozlova", följde alltså efter detta krigsutbrott med sin skildring av en gammal kvinna i den sovjetiska samtiden. 
I923. Vi befinner oss tydligt i det efter världskriget och inbördeskriget etablerade nya sovjetsamhället i en icke namngiven provinsstad men med en äldre kvinnlig huvudperson som fortsatt försöker hålla kvar vid det gamla.

\section{I (Ett inre motstånd)}

Det är de äldres mötesproblem, nostalgiska minnen samt konfrontationer med det nya samhället som gestaltas. Den sovjetiska samtiden gör sig ständigt påmind och skildras som påträngande. Berättelsen inleds i kyrkan som inte ens den erbjuder en skyddad vrå från moderna inslag:

Электричество горело в трех паникадилах. Сорок восемь советских служащих пели на клиросе. Приезжий проповедник предсказал, что скоро воскреснет бог и расточатся враги его. ${ }^{60}$

Elektriciteten lyste i tre kandelabrar. Fyrtioåtta sovjetiska tjänstemän sjöng i koret. Den tillreste predikanten förutsade att gud snart skulle uppstå och hans fiender skingras.

Även i kyrkan gör sig den nya samhällsordningen påmind - såväl med gudfruktiga sovjettjänstemän som med den moderna elektriciteten (som en konkret manifestation av den ideologiska upplysningen enligt Lenin: "kommunism är sovjetmakt plus elektrifiering av hela landet"). Men fortfarande finns frågan om hur man ska förhålla sig till det nya. Och därmed hur man här tolkar orden ur den psalm av David som predikanten anför som en del av gudstjänstritualen (psaltaren 68:2): "Gud reser sig, hans fiender skingras, / hans motståndare flyr undan."

Är Gud med sovjetmakten, är det dess fiender som snart fullständigt kommer att skingras, är det världsrevolutionen, internationalens förverkligande som förebådas? Eller är det tvärtom det nya bolsjevikiska som är det onda och att den gamla ordningen snart kommer att återställas som förutsägs? För huvudpersonen Kozlova som nu framträder tycks det vara det senare, vilket antyds redan av att hon här avviker och tränger sig ut från mässan, efter att sant gudfruktigt ha kysst en ikon och strukit ut oljan i pannan. Det rent antireligiösa revolutionära kaos som väntar på torget utanför framstår tydligt som hennes fiende:

[...] пускали ракеты, толкались, что-то выкрикивали, жгли картонного

бога-отца с головой в треугольнике, музыка играла Интернационал.

- Мерзавцы, - шептала Козлова, - гонители... [...]

${ }^{160}$ Novellen citeras ur PSSP, 49-53. 
[...] de sköt raketer, trängdes, skrek något och eldade upp en gud fader av

kartong med huvudet i en triangel, musiken spelade Internationalen.

- Odjur, viskade Kozlova, skändare... [...]

Hennes fasthållande vid sina egna övertygelser grundade i den gamla ordningen understryks av att det först är i ensamheten efteråt, när Kozlova tagit sig bort från både kyrkans och torgets trängsel, som miljöangivelserna blir konstnärligt pregnanta. De börjar rymma en kontrasterande lågmäld och personlig känslosamhet: "Снег скрипел под ногами. Примасленные полозьями места жирно блестели." ("Snön knarrade under fötterna. De glatta ytorna efter slädmedarna glänste fett.") Snöns glans ges mer vikt än ikonens i kyrkan som den återkopplar till; åtminstone finns det här, i avskildhet från de andra, utrymme för något kontemplativt, för den egna längtan, för de personliga minnena. Här kan något betydelsefullt äga rum.

Som nästan en regel i novellerna är det just något glänsande som introducerar den sorts lyrisk stund av personligt dagdrömmande i den sovjetiska vardagen som följer. De nya socialistiska namnen på en skola som Kozlova går förbi nämns och en måne, som ännu en återkommande ingrediens i det lyriska tillståndet, dyker upp. Vi rör oss därefter in i vad denna syn framkallar hos huvudpersonen:

[...] Над школой Карла Либкнехта и Розы Люксембург стояла маленькая зеленоватая луна. Козлова вздохнула: здесь мосье Пуэнкарэ учил пофранцузски.

Она пошла тише. В памяти встали приятные картины дружбы с мосье.

[...] Över Karl Liebknecht- och Rosa Luxemburgskolan syntes en liten grönaktig måne. Kozlova suckade: här hade monsieur Poincaré undervisat på franska.

Hon saktade farten. Angenäma bilder av vänskapen med monsieur steg upp ur minnet. ${ }^{16 r}$

Dessa vänskapsbilder följer härefter i två konkreta scener i presens, en tedrickning och ett biobesök. De utgör resten av det första kapitlet. Monsieur Poincaré, hennes vän som gett sig av hem till Frankrike strax efter revolutionen, är utan att det kommenteras namne med den franske högerpolitikern Raymond Poincaré. Eftersom det nya namnet på skolan där han arbetade, efter de mördade tyska kommunisterna, först anges framstår namnvalet som något av ett parodiskt, i stil med den nya ideologins övertydlighet, utpekande av dennes politiska hemvist (liksom av Kozlovas genom hennes

\footnotetext{
16I Den röda månen i slutet av förra novellen följs här av en grönaktig måne som står i kontrast till det röda namnet på skolan. Även i andra noveller, som "Erygin" och "Konopatčikova", används den gröna färgen för att antyda en opposition mot den nya ordningen.
} 
vänskap med honom).162 Även huvudpersonens visserligen fullt existerande efternamn är bildat av det i ett sådant sammanhang, som av mobben på torget, tillämpbara skällsordet "kozël" ("getabock").

Låt oss närmare betrakta Kozlovas två tablåer ur minnet. I den första dricker de te:

Вот - чай. Мосье рассказывает о лурдской богородице. Авдотья отворяет двери и подсматривает. Козлова показывает на нее глазами. - Приветливая женщина, - говорит мосье. Потом он берется за шляпу, Козлова встает, и они отражаются в зеркале: он, аккуратненький, седенький, раскланивается, она - прямая, в длинном платье, пальцы левой руки в пальцах правой, тонкий нос немного наискось, на узких губах - старомодная улыбка. - Приходите, мосье...

Te. Monsieur berättar om Jungfrun i Lourdes. Avdotia står med dörren på glänt och kikar. Kozlova visar med ögonen mot henne. - En älskvärd kvinna, säger monsieur. Sedan griper han hatten, Kozlova reser sig, och de ser sig själva i spegeln: han, reserverad, lite grå, bugar sig, och hon - rak, i lång klänning; vänsterhandens fingrar håller hon i högra handen, den smala näsan

${ }^{162}$ I Majakovskijs senare drama Klop (Vägglusen), från 1928-9, som visar på denna användning av namnet är det bara några Chamberlainare och Poincaréer som står i vägen för världsrevolutionen. "[Баян:] Вам мировая революция нужна, вам выход в Европу требуется, вам только Чемберленов и Пуанкаро́в сломить, и вы Мулен Ружи и Пантеоны красотой телодвижений восхищать будете." ("[Oleg Bajan:] Du behöver en världsrevolution, du måste ut i Europa. När du har krossat Chamberlain och Poincaré, kommer du att glädja Moulin Rouge och Pantheon med skönheten i dina rörelser.") Vladimir Majakovskij, "Klop", Polnoe sobranie sočinenij v I3 tomach, II, Moskva 1958, 215-276, 233; Vägglusen, översättning Sam J. Lundwall, Bromma I986, 27.

Som Frankrikes president 1913-1920 hade Raymond Poincaré bidragit till att kväsa den kommunistiska revolutionen i Tyskland och också stått bakom de fransk-brittiska interventionerna under inbördeskriget. 1923, när novellen skrevs och utspelar sig, var Poincaré, som konseljpresident (premiärminister) och utrikesminister, aktuell i samband med den franska ockupation av Ruhrområdet som tillgripits som svar på Weimarrepublikens uteblivna betalningar av det tyska krigsskadeståndet från första världskriget. Poincaré fick kritik från socialister och kommunister (vilkas sida Sovjetunionen stödde) eftersom ockupationen sades skapa hat mellan folken och hindrade världsrevolutionen. Vid sidan av den brittiske utrikesministern Lord George Curzon, som en manifestation senare i novellen riktas mot, var Poincaré sedan en återkommande måltavla i de orkestrerade demonstrationerna i samtiden. I novellen "Portret" återkommer han i ett banalt slagord om att ge honom på käften ("Пуанка́ре - получи по харе!"). Dobyčin övervägde rentav Puankáre (felbetonat som i slagordet) som namn på hela den andra novellsamlingen innan han istället landade i Portret. Som motivering till Puankáre som namn, i ett brev till Michail Slonimskijs fru Ida Isakovna, nämner han bara slagordets förekomst och inget om den franske läraren i "Kozlova" (I juni 1930). Att förslaget väcker reaktioner antyds av nästa brev ("Не будем подымать шума из-за заглавия" (4juni 1930)), men Dobyčin klargör inte vad han ville uttrycka med namnet. Brev II8 och II9, PSSP, 303-304. 
något från sidan, på de smala läpparna - ett gammalmodigt leende. - Kom förbi igen, monsieur...

Detta presenteras alltså som en minnesbild. Det går att läsa det som att Kozlova i sitt minne av situationen upplever den så här sceniskt utan tankar på vad som upptog hennes medvetande då. I minnet framträder de andras perspektiv och interaktion, genom hennes tjänstekvinnas betraktande av dem som antyder ett liknande intresse för denne belevade fransman och genom hans kommentar om denna. Kozlovas egna exakta rörelser beskrivs också liksom sedda utifrån eller som omedelbara bilder. Medan hans utseende som borde ha upptagit hennes intresse knappt noteras är beskrivningen av henne - inte som hon minns sig utan som hon i en konkret impression ser sig i spegeln i minnet - insisterande detaljrik. Den tycks också distanserad från hennes medvetande med angivelser som hennes "gammalmodiga leende" och hur precis hon stod med fingrarna, näsans vinkel. Hon kan möjligen se sig sådan i efterhand i hög stelnad konkretion, stolt över denna gammalmodighet, men framförallt gestaltas hon här som sådan, rentav lätt ikonlik genom sina epitet: klänningen, fingrarna, den smala näsan halvt i profil (en likhet som ikonen i kyrkan och nu talet om jungfrun $\mathrm{i}$ Lourdes underbygger).

I minnestablån bryter hennes egen röst slutligen in och uttalar genom den vardagliga artigheten hennes längtan som den tycks ha förblivit fram till nuet.

Dessa så kallade vänskapsbilder är påtagliga. De tycks levande för henne i nuet och väcka samma längtan efter beständighet, efter verklighet, som redan de flyktiga faktiska mötena tycks ha gjort. Denna vardagliga stund när hon uppfylls av minnen av deras möten skiljer sig kanske inte substantiellt från deras verkliga möten. De utgör en del av hennes liv. Om det nu är hennes blick i spegeln i minnet så tycks de aldrig riktigt se på varandra, aldrig vända sig emot varandra, aldrig riktigt ha mötts då heller. Det är i spegeln han bockar till avsked.

Och avskedet fortsätter i andra tablån, från biografen, det är nu inte en vana som skildras. Här är allt från början i avskedsstämning. Vi ser dem nu i det moderna och mondäna som en kontrast till den tidigare minnesbilden. Patoset i Kozlovas känsloyttringar i minnet får nu samma melodramatiska klang över sig som i det "lyxiga drama" de beskådar. Och detta börjar redan utanför salongen med blandningen av klassiska romantiska inslag (fiolen) och triviala föremål som hon finner talande för sina känslor. De nya bolsjevikiska inslagen som framträder mitt i minnesskimrets patetik talar för att avskedet, som filmen sedan tematiserar, inte kan ligga så långt bakåt i tiden: 
А вот - в кинематографе. Играют на скрипке. Мосье завтра едет. С тоненького деревца в зеленой кадке медленно падают листья. - Как грустно, мосье... - Девица в красной вязаной кофте отдергивает занавеску и впускает. По сторонам холста висят Ленин и Троцкий... Бьет посуду и ломает мебель комическая теща, красуются швейцарские озера и мелькают шесть частей роскошной драмы: Клотильда отравилась, Жанна выбросилась из окна, а Шарль медленно отплывает на пароходе «Республика», и ему начинает казаться, что все случившееся было только сном.

- Так и вы, мосье, забудьте нас, как сон.

- О, мадмуазель!

Och så biografen. Det spelas fiol. Monsieur ska åka imorgon. Från ett spensligt träd i en grön tunna faller löven långsamt. - Så sorgligt, monsieur... En flicka i röd stickad kofta drar undan draperiet och släpper in. På varsin sida av duken hänger Lenin och Trotskij... En komisk svärmor krossar porslin och slår sönder möbler, sköna schweiziska sjöar breder ut sig och ett flärdfullt drama i sex delar flimrar förbi: Clotilde har tagit gift, Jeanne har kastat sig från ett fönster, och Charles seglar långsamt iväg på ångbåten "Republiken", och han börjar känna det som att allt som skett blott varit en dröm.

- Så kommer också ni, monsieur, att glömma oss, som en dröm.

- Å, mademoiselle!

Är det här Kozlovas minne? I så fall tycks det färgat av hur hon vill minnas det, hur hon i efterhand har gestaltat det för sig själv. Men mot slutet av minnestablån väcks också tvivlet om det överhuvudtaget är minnesbilder vi har att göra med. Är rentav allting här faktiskt bara en dröm?

Обратный путь полон излияний. В прекрасной Франции мосье будет думать о ней. Он будет следить за политикой.

«Кого же и назвать Сивиллой нашего времени, если не мадам де-Тэб», - напишет он, когда можно будет ждать чего-нибудь такого...

Återresan är fylld av känslor. I det vackra Frankrike kommer monsieur att tänka på henne. Han kommer att följa den politiska utvecklingen.

"Vem är väl vår tids Sibylla om inte Madame de Thèbes", kommer han att skriva när man kan vänta sig något sådant...

Med futurumformerna om vad som ska ske när monsieur reser, hans äventyrliga hemfärd till det vackra Frankrike, börjar det snarast likna föreställningar och fantasier inspirerade av stumfilmens berättande och utifrån hennes bild av hur denne monsieur är. Vad har i så fall överhuvudtaget varit sant? I hur stor utsträckning har hon föreställt sig, skapat sina "vänskapsbilder"? Det synopsisartade, filmlikt regisserade i det som presenterats som minnesbilder kan på så sätt läsas inte bara som författarens sätt att framställa huvudpersonens minnesbilder, utan också som huvudpersonens egna kreativa fiktionsskapande i sitt dagdrömmande. 
Det är förvisso fortsatt möjligt att läsa det som Kozlovas inre återgivning av vad som sades mellan dem och vad hon upplevde före monsieurs hemfärd. Hon minns så sett sin romantiska föreställning av den farofyllda hemfärden, och hon minns vad monsieur lovade, att han skulle följa den politiska utvecklingen hemifrån och skriva till henne när en förändring var $\mathrm{i}$ sikte. Det han då kommer att skriva, den formulering som citeras, kan tolkas antingen som en hemlig kod de kommit överens om eller som Kozlovas föreställning om hur monsieur troligen skulle uttrycka sig i stil med sina andliga intressen..$^{163}$

Oavsett om det är faktiska minnen eller inte så vårdar hon dessa bilder. Hon tycks upplivas av dem i denna konkreta stund i ensamhet på väg hem från kyrkan. De framkallar något av ett mänskligt möte inom henne som har betydelse i hennes liv. Det smått komiska i detta möjligen halvgalna fantiserande och det avläsande av tecken i samtiden, i stil med madame de Thèbe, som bara inletts, säger samtidigt något om det som det bottnar i. En stilla förtvivlan och rädsla efter inbördeskrigets kaotiska år som hon nu fortsatt - som uppenbart borgerlig - känner i den pågående kaotiska och fortfarande ovissa förändringen i samhället.

Kozlova är osäker i det nya samhället och håller krampaktigt fast vid det gamla, vid sina föreställningar som sitt verkliga liv, i en väntan och ett sökande efter tecken på att det sovjetiska ska gå över, som en ond dröm. Vare sig det är fantasier eller verkliga minnen så erbjuder minnena av monsieur och väntan på ett brev en meningsgivande tillflykt - som emellertid samtidigt gör henne ensam i sin vardagliga tillvaro.

\section{2 (Tecken på förändring)}

Andra kapitlet inleds inte med någon ny konkret händelse utan tar ett steg tillbaka från huvudpersonens direkta perspektiv och beskriver Kozlovas vanor i nuet, hennes situation. Vi får här en första glimt av vad som tycks vara en central inspirationskälla, vid sidan av det kyrkliga och stumfilmsmelodramerna till hennes drömmande sinnelag, nämligen litteraturbilagan till den populära förrevolutionära tidskriften Niva: "Вечера Козлова просиживала на лежанке, - штопала белье или читала приложения к «Ниве»." ("Kvällarna tillbringade Kozlova på spisbänken - stoppade linne eller läste litteraturbilagan till Niva.") Utgivningen av Niva hade upphört 1918, den

\footnotetext{
${ }^{163}$ Den i samtiden världsberömda politiska sierskan madame de Thèbes ansågs bland annat ha förutspått första världskrigets utbrott. Eftersom hon gick bort redan 1916 måste det, om det nu inte är en övernskommen kod, röra sig om en tidigare förutsägelse, även om den fortsatta utvecklingen, som monsieur ska komma att skriva om.
} 
månatliga litteraturbilagan två år tidigare. Dessa nummer av bilagan är en av de spillror av sitt förrevolutionära liv som Kozlova ömt bevarar och fortsätter att rutinmässigt försjunka i som en tillflykt undan sin samtid. ${ }^{164}$

Den enda som Kozlova i sitt nuvarande liv tycks kunna dela sitt nostalgiska dagdrömmande och sitt obehag inför det nya med är väninnan Suslova som ibland kommer förbi och dricker te. I tedrickningarna ingår att Suslova utifrån motiven på tekopparna, Amiralitetet respektive Vinterpalatset, återger en minnesskärva från den forna, för den förrevolutionära kulturen emblematiska huvudstaden, exempelvis hur hon (kanske) såg en glimt av tsarinnan: "- Не знаю, может быть - саму императрицу: иду мимо дворца, вдруг подъезжает карета, выскакивает дама и - порх в подъезд." ("- Vet inte, men kanske var det tsarinnan själv: jag går förbi palatset och plötsligt kör en täckvagn fram, en dam hoppar ur och vips upp för trappan.") Tillsynes rutinmässigt ifrågasätter och nedvärderar Kozlova upplevelsen: "- Может быть, экономка с покупками, - отвечала Козлова..." ("- Kanske en hushållerska med inköpen, svarade Kozlova...")

I beskrivningen av Kozlovas vardagliga umgänge med Suslova, och mot bakgrund av de bilder av sin vänskap med monsieur, som Suslova återkommande bekräftar istället för att ifrågasätta genom att fråga om han skrivit, har samtidigt fröet till den fortsatta händelseutvecklingen såtts. För även om Suslova tycks likasinnad, tycks vara en god vän, så har skillnaden mellan dem accentuerats. Den tillsynes neutrala yttre beskrivningen har lagt grunden för hur Suslova i Kozlovas ögon inte lever upp till den borgerliga förfining som Kozlova ser hos sig själv och föreställer sig dela med monsieur (liksom möjligen också med de människor hon identifierar sig med i litteraturbilagorna till Niva). Suslova är helt enkelt inte på samma sociala och kulturella nivå som sin värdinna: "хозяйка - чинная, с любезной улыбкой, гостья - растрепанная, толстая, с локтями на столе и шумными вздохами." ("värdinnan - nobel, med ett älskvärt leende, gästen - ovårdad, tjock,

164 Niva med sin litteraturbilaga är också emblematisk för den förrevolutionära borgerliga kultur som många i början av tjugotalet började förhålla sig till på ett liknande sätt som Kozlova, som att den uppblomstrade ryska sekelskifteskulturen med dess drömmande sinnesstämningar lagts i spillror av revolutionen och inbördeskriget och nu var på att väg att gå under eller exproprieras för det nya samhällets kollektiva utopier. För Osip Mandel'štam i Šum vremeni (Tidens larm) från 1924 står litteraturbilagan till Niva dock för en kulturell sentimentalitet kring sekelskiftet som dog ut av sig själv, det nya fanns inte där. Osip Mandel'štam, "Šum vremeni", Sobranie sočinenij v četyrech tomach, 2, Moskva 1993, 347-392, 347349, 354-358. Den lukt av möss som Kozlovas litteraturbilagor senare i novellen tillskrivs antyder en liknande uppfattning som Mandel'štam om tidskriften hos Dobyčin. Om huvudpersonen däremot ens märker lukten så ignorerar hon den nog, för henne är det, liksom dagdrömmarna om monsieur inte en spillra. Det är det som fyller hennes liv med djup och mening. 
med armbågarna på bordet och högljudda suckar.") Det de förenas i är sitt förhållande till det nya samhället: "Говорили о тяжелой жизни и о старом времени." ("De pratade om det svåra livet och den gamla tiden.") Själva tedrickandet frammanar också de mer eller mindre föreställda tedrickningarna med monsieur. På samma sätt som i de inre bilderna står tjänsteflickan Avdot'ja där när Suslova är på besök som en tyst men lyssnande iakttagare från ett socialt skikt som inte ens tycks komma ifråga för vänskap.

Kozlovas behov av att ta ifrån Suslova det att hon skulle ha sett någon $\mathrm{i}$ tsarfamiljen, liksom det lätt enfaldiga i Suslovas sätt att berätta och själva upprepandet av denna historia varje gång de ses, pekar åt samma håll som beskrivningen av dem: på huvudpersonens längtan efter en djupare och sannare vänskap. Som vi kommer att se är det en drivkraft hos så gott som samtliga av novellernas huvudpersoner och grundläggande för novellernas konflikter. Den fråga som indirekt ställs är om denna föreställda sanna vänskap överhuvudtaget finns eller om föreställningarna om den bara ställer sig i vägen för de faktiska relationerna, för det som är möjligt åtminstone i denna tillvaro.

En sådan vänskap har vi sett Kozlova föreställa sig ha haft med monsieur, en sådan tycks hon inte uppleva med sin väninna Suslova. Vantrivseln med denna gamla vänskap utvecklar novellens handling som redan initierats, inser man nu, med den skildrade ensamheten och minnet av monsieur i första kapitlet. När Kozlova i nästa kapitel får hopp om en ny sannare vänskap i sitt nuvarande liv, en som mer är i samklang med det nya samhället, så tas konflikten ytterligare ett steg.

Men berättelsen återknyter först, efter den sedvanliga tedrickningen, till det tidsförlopp som den konkreta vinterdagen i början av berättelsen slog an. Vanorna som beskrivits har varit vinterns vanor. $\mathrm{Nu}$ åter gestaltas en bestämd händelse i tiden. Det är första maj men Kozlova står hemma och stryker och hör bara demonstrationstågen på håll: "Зима прошла. Первого мая Козлова выстирала две кофты и полдюжины платков: пусть выкусят. В открытые окна прилетали звуки оркестров..." ("Vintern förflöt. Första maj tvättade Kozlova två koftor och ett halvdussin sjalar: låt dem hållas. Genom de öppna fönstren kom ljud från orkestrar...")

Istället för den nya tidens manifestationer, går Kozlova och Suslova till kyrkan för en religiös begivenhet. En ikon av det lokala helgonet Kukša har flyttats till kyrkan och ska invigas. Att de återvänder uppjagade och att Kozlova förbannar något med samma ord som om den antireligiösa manifestationen i första kapitlet tyder på att ceremonin på något sätt blivit störd av demonstranter: 
[...] Из монастыря принесли икону святого Кукши. Ходили встречать. Возвращались взволнованные.

- Мерзавцы, гонители...

[...] En ikon av den heliga Kuksja hade hämtats från klostret. De gick och mötte den. Återvände uppjagade.

- Odjur, skändare...

Suslovas följande replik varierar predikantens ord i första kapitlet och anknyter till monsieur som en underrättelsekälla, som något att hoppas och vänta på: "- Господи, когда избавимся?.. Мусью не пишет?" ("- Gode gud, när ska vi bli av med dem?.. Har inte musiö skrivit?”)

Som en ytterligare spegling av första kapitlet dyker månen upp och väcker mildrande känslor: "Потом взошла луна, и души смягчились..." ("Sedan gick månen upp, och det mjuknade i själen...") ${ }^{165}$ Klanger och musik blandas från det kyrkliga och från det nya sovjetiska samhällslivet i en omdöpt park, i vad som nu liknar en kort harmoni med sakernas tillstånd. De möter också Kozlovas kollegor från kansliet, det vill säga nya sovjettjänstemän som hon själv, som liksom mänskliggörande bär på häggkvistar:

[...] В соборе трезвонили. В саду «Красный Октябрь» играли вальс. Встретили Демещенку, Гаращенку и Калегаеву, задумчивых, с черемуховыми ветками.

[...] Klockorna ringde i katedralen. I Röda Oktoberparken spelades en vals. De mötte Demesjtjenka, Garasjtjenka och Kalagaeva, tankfulla, med häggkvistar.

Kozlova och Suslova stannar och ser ut över floden, månskenet är där och de ser en eka med någon som spelar balalajka. Kozlova med sitt klassiskt romantiska drömmande associerar till Venedig: "- Венеция, прошептала Козлова" ("- Venedig, viskade Kozlova"). Suslova hakar på och utbrister, inom citationstecken, "Venezia e Napoli" på italienska. Denna titel på Franz Liszts pianostycken framstår här snarast som ett varumärke, möjligen är det namnet på en parfym, det är i alla fall vad hon med sitt mer triviala vardagligt förankrade lyriska sinnelag därefter associerar till:

- «Венеция э Наполи», - ответила Суслова и, помолчав, сказала тихо и мечтательно:

- Когда горел кооператив, загорелись духи, и так хорошо запахло...

\footnotetext{
${ }^{165}$ Fëdor Fëdorov har behandlat månen som frekvent motiv hos Dobyčin med omväxlande profanerad, romantisk och grotesk karaktär i "Kosmos v Dobyčinskoj kartine mira", DS, 5I2, 9-II.
} 
- "Venezia e Napoli", svarade Suslova, tystnade, och sade stilla och drömmande:

- När kooperativet brann tog parfymerna eld och det luktade så gott...

Suslova framstår möjligen i Kozlovas ögon som banal med sina världsliga associationer istället för Kozlovas bildat romantiska, men det är snarast Suslovas känsla för det lyriska i vardagen som är närmast besläktad med vad berättelsen stannar upp vid och håller sig allvarlig inför. Här skildras denna vardagens poesi med distans, på samma gång lite löjlig och som trots allt en sublim upplevelse i deras värld. Det finns en komisk glädje i det. Kozlovas längtan är mer ensidigt riktad bort från deras tillvaro.

En dröm som Kozlova härefter har på natten tycks innebära något av en vändpunkt i detta avseende. Det är den helige Kukša, vars ikon de bevittnat på dagen, som hon ser framför sig. Kukša ger henne en skrift i drömmen där hon läser de ord om madame de Thèbes som hon antingen föreställt sig eller som monsieur Poincaré faktiskt utlovat som en signal om förändring. Kozlova vaknar sedan orolig och ger sig av tidigare hemifrån för att hinna till kyrkan före kansliet.

Kyrkan är stängd och hon sätter sig på gården utanför och väntar. Här bevittnar och upplever hon nu den sortens vardagligt förankrade förunderlighet som Suslova tidigare gav uttryck för, vilket tidigare för Kozlova mest föranlett inre lyriska utsvävningar. Nu håller hon sig kvar i nuet, den vardagliga rutinen hon bevittnar förankras i det religiösa och blir betydelsepåkallande utan romantiska associationer eller tillrättalägganden. Det hon ser är biskopen som liksom ceremoniellt inväntar slagen i klockstapeln innan han profant tömmer slaskhinken vid en stolpe med en kristusikon:

Столб с преображением и зеленым куполом стоял под кленами. Таяли рыхлые облака телесного цвета, и через них местами сквозило синее. Скрипнула дверь, епископ вышел из сторожки - простоволосый, с ведром помоев. Постоял, считая удары часов на каланче, и опрокинул свое ведро под столб с преображением.

Stolpen med Kristi förklaring och en grön kupol stod under lönnarna. De sladdriga, hudfärgade molnen smälte och det blå skymtade fram på några ställen. En dörr gnisslade, biskopen kom ut ur gårdshuset - barhuvad, med en slaskhink. Han stod ett tag, räknade slagen från klockan i brandtornet, och tömde sin hink vid stolpen med Kristi förklaring.

Ikonen avbildar Kristi förklaring, då Jesus på ett berg inför lärjungarna förvandlas och blir lysande så att lärjungarna förstår att han är gudomlig. Här knyts han till jorden igen, även molnen som illuminerar visionen är 
mänskligt kroppsfärgade. Scenen följs av Kozlovas reaktion, hennes tolkning av den: "- Недолго мучиться, - радостно думала Козлова, смотря ему вслед." ("- Plågan är snart över, tänkte Kozlova glatt när hon såg efter honom.")

Vad åsyftas, varför gläds hon? Hon tycks tolka denna stund på kyrkogården och biskopens handlande som ett förebud om att plågorna snart ska vara över, vilket för hennes del är det samma som att det gamla samhället ska återupprättas. Hon har också gått till kyrkogården på grund av sin dröm om Kukša och den förebådande formuleringen om de Thèbes. Kanske är det drömmen som hon nu utifrån dessa vidare tecken tycker sig kunna tolka: det indirekta budet om en förändring kom inte i ett brev från monsieur som hon föreställt sig det, utan som en hemlig skrift (chartija) från Kukša i drömmen. Kozlova tycks uppleva ett slags befriande lättnad i själva stunden men också anse att hon genom den har fått tecken på en förestående befrielse i någon form. ${ }^{166}$

Efter arbetet på kansliet äter hon middag, släpar sig till sängen och vaknar för trött för att gå till Suslova. Istället skickar hon först iväg Avdot'ja att hämta korna och går sedan själv ut i trädgården för att vattna. Så följer nästa poetiska vardagsstund som kopplas till den tidigare i det att hon vattnar sina växter liksom biskopen hällde slaskvatten på stolpen med Kristus i sin gudomliga gestalt - alltså liksom i väntan på, och liksom som hjälp för hans återkomst. Detta kan hon uppgå i utan att fundera på symboliken (i exempelvis färgerna): "Садилось солнце; и закат был простенький: одна полоска - красноватая и одна - зеленоватая." ("Solen sjönk; och solnedgången var enkel: en rödaktig liten strimma, och en - grönaktig.") Här har hon heller inga tankar längre om den sofistikerade monsieur Poincaré eller en annan tillvaro, hon tycker bara helt enkelt om att vattna: "Козлова была любительница поливать. - Когда поливаешь, - говорила она, - душа отдыхает и погружается в сладостное состояние." ("Kozlova var hängiven sitt vattnande. - När man vattnar, sade hon, vilar själen och försjunker i ett ljuvt tillstånd.") Till sist är månen där igen, och ett blänkande beskrivs, det är klimax av den poetiska och självfullkomliga stunden. "Лила двенадцатую лейку, и луна блестела в быстро исчезавших лужицах." ("Hon hällde den tolfte kannan, och månen glänste i de snabbt försvinnande små pölarna.")

Denna uppnådda ro, denna känsla av liv i vardagen avbryts av en sovjetisk manifestation. En orkester hörs. Nu beskrivs detta demonstrationståg

\footnotetext{
${ }^{166}$ Richard C. Borden föreslår i kommentarerna till sin översättning att hennes reaktion också kan ha att göra med att en full hink är ett tecken på något gott enligt rysk folktro. Leonid Dobychin, Encounters with Lise and Other Stories, Evanston, Illinois, 2005, II6.
} 
med fysiskt påtagliga detaljer, som en reell händelse i vardagen och inte bara något nämnt eller omtalat, med damm som får henne att nysa och blänk i trumpeterna och ljus över ansiktena från facklorna.

Чихнула от пыли. Дымные огни развевались на факелах. Отсвечивались в медных трубах. Керзон болтался на виселице. Свет перебегал по лицам маршировщиков.

- Ать, два! Левой! Да здравствует коммунистическая партия! Ура!

Hon nyste av dammet. Rykande lågor fladdrade på facklorna. Speglades i mässingstrumpeterna. Curzon dinglade i galgen. Ljus löpte över ansiktena på de marscherande.

- Ett, två! Vänster! Länge leve kommunistpartiet! Hurra!'67

Och så, och detta är det avgörande för novellens utveckling, med i denna uppviglade massa dyker hennes väninna Suslova upp, med en slagordsropande eller bara enfaldigt öppen mun, liksom en förrädare i Kozlovas ögon: "Разинув рот, маршировала Суслова." ("Med öppen mun marscherade Suslova.") Detta följs av att tjänsteflickan Avdot'ja kommer springande och återger ett rykte om att England kommer att förklara krig. Vad Kozlova tänker om detta sägs inte. Möjligen antyds, genom vad som föregått, att hon tar emot det som början på just den förändring som hon på kyrkogården tycks ha fått en insikt om att drömmen om Kukša med monsieurs ord förebådade. Det pekar på en känsla av hopp att hon tänder ljusen vid ikonerna och dricker riktigt te, som alltså inte hör till vanligheten, med sin tjänsteflicka. Men det är samtidigt en naturlig del av att de, visar det sig, firar påsk.

Из темноты пробежала Авдотья: - Англия воюет. - Перед киотами зажгли лампадки и при двух лампах пили настоящий чай. Воняло керосином и копотью.

С светлым лицом, Козлова достала из лекарственного шкафа баночку малины. - Пасха, - наслаждалась Авдотья. Ругали дурищу Суслову.

Ur mörkret kom Avdotia springande: - England förklarar krig. De tände lyktorna vid ikonskåpen och i skenet från två lampor drack de äkta te. Det stank av sot och fotogen.

\footnotetext{
${ }^{167}$ Manifestationen med en docka föreställande den engelske utrikesministern George Curzon i en galge knyter också som tydligast denna tillvaro till den historisk tid som novellen skrevs i, till maj 1923 när sådana manifestationer organiserades över hela Sovjetunionen. Manifestationerna var en reaktion på Curzons ultimatum att bryta de diplomatiska förbindelserna med Sovjetunionen om inte Kominterns propaganda och stöd till motståndsrörelser i Östeuropa upphörde. Curzons agerande syftade till att bevara demarkationslinjen mellan Polen och Sovjetunionen från 1919 (Curzonlinjen) som han varit med om att upprätta och genom vilken han gjort sig till en lika emblematisk fiende för Sovjetpropagandan som Poincaré.
} 
Med lysande ansikte tog Kozlova fram en liten burk hallonsylt ur medicinskåpet. - Pascha, sade Avdotia och njöt av färskostkakan. De ondgjorde sig över tokan Suslova.

$\mathrm{Nu}$ när Suslova setts delta i manifestationen tycks tjänsteflickan Avdot’ja vara den enda som Kozlova kan hålla fast vid sina gamla vanor tillsammans med, som här också framträder mer som en like. Med påsken, denna omvälvningens högtid, som också i inledningsnovellen förknippades med föraningar om förändring, fullbordas så den förebådande stämning som genom huvudpersonens teckensökande sinnelag byggts upp. Kozlovas ansikte är så kanske inte bara ljust av lamporna utan också av det hopp om befrielse som hon tyckt sig ha fått förebådat. Påskhögtiden förstärker känslorna. Den eventuella högtidlighet hon upplever förankras samtidigt i den triviala vardagen genom stanken av sot och fotogen. ${ }^{168}$

\section{3 (Den nya vännen)}

I inledningen av tredje kapitlet väcker en ny kollega på Kozlovas arbetsplats hopp om en djupare vänskap med en kulturellt jämbördig också i den nya tillvaron. Av den kyrkohögtid som nämns, Johannes krigarens dag, I2 augusti, framgår att drygt tre månader förflutit sedan förra kapitlet.

Сидели на сверхурочных. Кусались мухи. Гудел большой колокол, дребезжа подпевали стекла.

Демещенко согнулась над столом и выцарапывала: - Товарищ Ленин.

Гаращенко и Калегаева, развалившись на стульях, грызли подсолнухи и глазели на новую.

- Завтра Иоанна-воина, - сказала новая, франтоватая старушка с красными щеками. - Когда вы с кем-нибудь поссоритесь, молитесь Иоаннувоину. Я всегда так делаю, и, знаете, ее забрали и присудили на три года.

- Хорошая женщина, - подумала Козлова, - религиозная... Сутыркина, кажется.

De hade övertidsarbete. Flugorna bet. Den stora kyrkklockan slog, skallrande stämde rutorna in.

Demesjtjenko böjde sig över bordet och ristade: - Kamrat Lenin.

Garasjtjenko och Kalegajeva, nersjunkna på stolarna, knaprade solrosfrön och glodde på den nya.

- Imorgon är det Johannes krigarens dag, sade den nya, en snobbig gammal dam med röda kinder. - När ni grälar med någon, be till Johannes krigaren. Jag gör alltid det, och, vet ni vad, de hämtade henne och dömde henne till tre år.

- En bra kvinna, tänkte Kozlova, religiös... Sutyrkina, tror jag det var.

${ }^{168}$ I92I inföll påsken den första maj vilket inte stämmer historiskt med övriga händelser (från 1923) men dramatiskt understryker konflikten mellan det nya och det gamla. 
Liksom sovjettjänstemän var i kyrkan i början av berättelsen, tränger det religiösa här in i den sovjetiska kanslimiljön. Rutorna skallrar av klockklangen samtidigt som en av Kozlovas mer sovjetiskt sinnade kollegor gör det nya samhällets ikon fysiskt påtaglig.

Deras "folklighet" markeras i kontrast till Kozlova - hur de brer ut sig i stolarna, tuggar solrosfrön och glor på den nya. Den nya talar dock om morgondagens helgonhögtid och råder de andra att be till helgonet. Det verkar vara ungefär allt som Kozlova uppfattar eller väljer att lyssna till att döma av vad hon drar för slutsats: Den nya är en god kvinna eftersom hon är religiös. Vad Kozlova överser med i repliken är i själva verket vad som ska utmärka denna "snobbiga gamla dam" (vilket snarast framstår som de andra kanslikvinnornas epitet för henne). Här tillförs något till vår bild av Kozlova. Varför såg Kozlova ett svek i Suslovas deltagande i manifestationen medan hon bortser från Sutyrkinas instrumentalisering och sovjetanpassning av religionen, hur hon bett till Johannes krigaren så att någon hon bråkat med dömts till tre års fängelse? Anledningen tycks vara att Kozlova känner en social gemenskap påminnande om den hon upplevt eller i alla fall drömt om med monsieur.

Kozlova tar initiativet: "Перенесла свои бумаги и чернильницу к Сутыркиной: - Вы где живете?" ("Hon flyttade med sig sina papper och bläckhornet till Sutyrkina: - Var bor ni någonstans?") Det följs upp av en jämförande beskrivning av dem, av deras grundläggande karaktärsdrag och hur de återspeglas i deras yttre: "Вышли вместе: Козлова - степенная, в синем газовом шарфе с расплывчатыми желтыми кругами, Сутыркина - вертлявая, в старой соломенной шляпе с перьями." ("De gick ut tillsammans: Kozlova - imposant, med en blå tyllscarf med utflutna gula cirklar, Sutyrkina - lättsinnig, i en gammal halmhatt med fjädrar.") Kozlova är sedan liksom förälskat berusad av Sutyrkinas sätt och berättelser. De finner en gemenskap i denna småborgerliga finess samtidigt som Sutyrkinas rörlighet, som först attraherar Kozlova som en kulturell och intellektuell esprit, även rymmer det som kommer att skilja dem åt - nämligen en ideologisk rörlighet, en obrydd anpassningsbarhet till det nya som redan hennes första replik gav en fingervisning om.

Fristående gatubilder bygger ut känslorna i luften men antyder också komplikationer:

У калиток ломались перед девицами кавалеры. Мальчишки горланили «Смело мы в бой пойдем». Оседала поднятая за день пыль. Торчали обломки деревьев, посаженных в «день леса». Тянуло дохлятиной. 
Vid grindarna krumbuktade sig kavaljerer framför unga flickor. Småpojkar skrålade "Tappert går vi ut i strid". Dammet som rörts upp under dagen lade sig. Stumpar av träden som planterats på "skogens dag" stack upp. Det kom en lukt av as.

Dammet, det misslyckade statliga trädplanteringsinitiativet, en ofruktsamhet, en konstgjordhet, en unken lukt: intrycken går emot de positiva känslorna i mötet och deltar så potentiellt i modulerandet av berättelsen. Men de fungerar också som lösa blickar mot den samtida verkligheten, liksom vid sidan av den mening som Kozlova söker i sitt liv. Denna verklighet ger henne inga förebådande tecken. Gatubilderna skapar snarast en kommenterande, desillusionerande distans till hennes romantiska dramatiserande av sitt liv.

I den nya kollegans första berättelse tog Kozlova fasta på att hon var religiös, i den som nu följer tar hon in det som tycks bekräfta att Sutyrkina också har ett poetiskt sinnelag. Kozlova uppfylls av orden "kvällar fulla av poesi" (men den återgivna exklamationen i Kozlovas inre föregås av ett ironiserande yttre intryck av hennes ansikte):

- Свое холщовое пальто, - говорила Сутыркина, - я получила от союза финкотруд. В девятнадцатом году я у них караулила сад, жила в шалаше. Приходили знакомые, и, скажу не хвастаясь, мы проводили вечера, полные поэзии.

Козлова слушала с таким лицом, как будто у нее во рту была конфета: полные поэзии вечера!

- Min yllekappa, sade Sutyrkina, har jag fått från finans- och kontrollarbetarfacket. Nittonhundra nitton vaktade jag deras trädgård, jag bodde i en koja. Vänner kom på besök och, det säger jag utan att skryta, vi hade kvällar fulla av poesi!

Kozlova lyssnade och såg ut som om hon hade en karamell i munnen: kvällar fulla av poesi!

Att Sutyrkinas berättelse också uttrycker revolutionsromantik, att hon tog del, att hon levde enkelt tycks för Kozlova oväsentligt. För henne står poesi evigt för det sköna och då snarast för den kultur och den borgerliga förfining som hon håller fast vid och drömmer sig tillbaka till, vilket hennes minne från det nakna året I9I9 ger uttryck för:

- Вы говорите, в девятнадцатом году, - сказала она любезным и приятным голосом. - Помните, все тогда ахали - того бы я съела, этого бы съела. А у меня была одна мечта: напиться хорошего кофе с куличиком.

- Ni talar om nittonhundra nitton, sade hon med vänlig och behaglig röst, minns ni hur alla stönade då - det skulle jag vilja äta, och det. Men jag hade bara en dröm: att dricka riktigt gott kaffe med påskkaka. 
"Oni podružilis"' ("De blev vänner"), konstateras lakoniskt efter detta utbyte och deras samvaro beskrivs som en redan etablerad vana: "Часто пили друг у друга чай и, когда не было дождя, прохаживались за город. Разговаривали о начальстве, об обновлениях икон, вспоминали прежние моды." ("De drack ofta te hos varandra, och när det inte regnade strosade de ut från staden. De pratade om de överordnade, om förnyelse av ikoner och mindes svunna moden.") En idealisk vänskap för Kozlova tycks det. Dessutom har Sutyrkina den där kittlande moderna kryddan i sitt sätt. Hon tar del i det nya och vågar tala om kroppsliga lustar:

- Вы не были на губернской олимпиаде? - спрашивала иногда Сутыркина: - почти совсем голые! Фу, какое неприличие. - И, улыбаясь, долго молчала и глядела вдаль.

- Var ni inte på guvernementsolympiaden? frågade Sutyrkina stundtals: nästan helt nakna! Fy, så oanständigt. Och hon log och blev tyst en lång stund och blickade mot fjärran.

Den stackars Suslova tycks nu helt avfärdad som vän:

Раз или два встретили Суслову, и она останавливалась и, обернувшись, смотрела на них, пока не исчезнут из вида...

Ett par gånger mötte de Suslova, och hon stannade, vände sig om och såg efter dem tills de försvann ur sikte...

Efter en blankrad följer en vardagligt poetisk stund. Det blänker igen. Det har blivit höst. Vi får både Kozlovas inre konkreta associationer och ett bildlikt intryck av henne utifrån:

В зеркальных крестах горело солнце. Ярко желтелись клены. Рябины с красными кистями напомнили Козловой земляничные букетики. Она остановилась, наклонила набок голову и, держа левую руку в правой, картинно любовалась.

Solen brann i spegelkorsen. Lönnarna lyste skarpt gula. Rönnbärsträdens röda klasar påminde Kozlova om smultronbuketter. Hon stannade, lade huvudet på sned, höll vänstra handen i den högra och log vackert som på en tavla.

Detta uppfyllda tillstånd, den lyriska upplevelsen i ensamhet avbryts av att Sutyrkina dyker upp. Något har hänt, nu tycks hennes prat liksom Suslovas tidigare snarast upplevas plumpt och störande av Kozlova:"- Недурная погода. С удовольствием бы съездила на выставку. Очень хорош, гово- 
рят, Ленин из цветов."'б9 ("- Skapligt väder. Jag skulle gärna åka på utställningen. Väldans ståtlig, säger de, Lenin av blommor.") Sutyrkina punkterar stunden och Kozlovas nätta smultronbuketter med sitt tal om Lenin av blommor: "Козлова поджала губы." ("Kozlova snörpte på munnen.") En spricka har uppstått mellan dem som växer när Sutyrkina, som märker Kozlovas reaktion, försvarar sin politiska lättvindighet:

- Знаете, - с достоинством сказала ей Сутыркина, - я всегда соображаюсь с веянием времени. Теперь такое веяние, чтобы ездить на выставку пополнять свои сельскохозяйственные знания...

- Vet ni, sade Sutyrkina till henne med värdighet, jag håller mig alltid underrättad om vilka vindar som blåser. Nu är vinden sådan att man går på utställning, för att vidga sina jordbrukskunskaper.

En ny blankrad markerar slutet på denna korta men avgörande episod för Kozlovas nya vänskap och berättelsen. Denna peripeti byggs på och bekräftas i de sista raderna i kapitlet där en dystrare stämning sätts med regn, svarta grenar och mörkret när de är tillbaka på kansliet där vänskapen tog sin början. Som av en tillfällighet läser Sutyrkina upp två kungörelser från tidningen. Från konditorn som utlovar ett stort utbud till revolutionsfirandet, men också en från biskopen om att högmässa med tackbön kommer att firas på revolutionsdagen. Detta ger Sutyrkina vatten på sin kvarn. När även kyrkan nu omfamnar revolutionen, varför skulle man avstå från att följa med i vinden? Hennes retoriska och uppfodrande fråga avslutar kapitlet: "Понимаете, какое теперь веяние?" ("- Förstår ni hur vindarna blåser nu?")

Hon har gjort Kozlova mållös och därmed, för Kozlova rubbas inte i sin övertygelse, gjort slut på deras vänskap.

\footnotetext{
${ }^{169} \mathrm{Om}$ man följer den historiska tiden tycks det röra sig om den första allryska lantbruksutställningen som hölls i Moskva i augusti 1923 där det också ska ha funnits ett Leninporträtt av blommor. PSSP, $46 \mathrm{I}$.

${ }^{170}$ Enligt Brjanskforskaren Golubeva innebär inte detta att församlingen tillhör "förnyarna" (obnovlency), den rörelse inom kyrkan som stödde revolutionen, men däremot avspeglar den en schism mellan dessa och de gammalkyrkliga under patriark Tichon som utspelade sig i valet av biskop i den stora katedralen (Novo-pokrovskij sobor) i Brjansk 1923. De senare gick segrande ur striden. Istället, menar Golubeva, att denna episod avspeglar ett 1923 framtvingat påbud från patriark Tichons om att be för Sovjetmakten. "Kozlova" är den enda novell där gudstjänster fortfarande hålls i katedralen. 1924 stängdes den och gjordes om till den biograf som istället dyker upp i senare noveller. Ė. S. Golubeva, Pisatel' Leonid Dobyčin i Brjansk, Brjansk 2005, 75-79.
} 


\section{4 (Tillbaka till det gamla)}

Kozlova återgår till sin tidigare vardag. Sista kapitlet inleds med samma vanor som i början av det andra. Men det är nu ett specifikt tillfälle som skildras. Gestaltningen svarar mot den förändring hon genomgått. Genom konfrontationen med Sutyrkina tycks hon nu uppskatta sina rutiner mer, de har liksom fått betydelse för henne just genom att hon som ett aktivt ställningstagande håller fast vid dem.

Hon läser i litteraturbilagan till Niva vid spisen medan Avdot'ja städar. De sinnliga detaljer som först ger en ny påtaglighet åt hennes tillvaro, nämligen lukten av möss från bilagorna och malört från kvasten, talar inte nödvändigtvis för Kozlovas direkta intryck i situationen eftersom Kozlova är försjunken i läsningen, men bidrar till den nya stämningen i berättelsen. Lukten markerar bilagorna som gamla, som en relik från den förrevolutionära kultur som hon bevarar och håller vid liv. Malörtslukten från sopborsten (som accentueras genom upprepning: "[Пахло] полынью от полынного веника" ("[Det luktade] malört från malörtskvasten")) anspelar möjligtvis på den förebådade stjärnan i Uppenbarelseboken - i stil med tidigare teckenmystik - men bidrar också helt enkelt till den verklighetsskapande konkretionen, den insisterande specificiteten i sinnesintrycken. Lukterna ackompanjerar antydningsvis också det Kozlova läser, för den berättelse som återges luktar förvisso lite mus och malört med sin blänkande skönhet och det avvägt lyckliga och lite vemodiga slut som refereras:

[...] Александра Николаевна вышла за Петра Иваныча - стоя под венцом, они блистали красотой. А Алексей Егорыч приходил к ним каждый праздник и, сидя после сытного обеда в удобном кресле, от времени до времени испускал глубокий вздох.

[...] Alexandra Nikolajevna gifte sig med Pjotr Ivanytj - de stod under bröllopskronan och strålade av skönhet. Men Alexej Jegorytj kom på besök vid varje högtid, och satt efter den mättande måltiden i en bekväm fåtölj och gav med jämna mellanrum ifrån sig en djup suck.

I en sådan romanvärld känner sig Kozlova hemma. Det är nog så, som i sådan litteratur, som hon vill att tillvaron och människor ska vara. Och det är så det blir i hennes minnen och föreställningar, som i dem med monsieur, men annars, i hennes dagliga liv, inte är mer än i korta stunder. Men den sentimentala litteraturen finns kvar och den håller hon fast vid trots att pappret blivit gammalt, och kanske det relikartade rentav bidrar till att göra njutningen som läsningen framkallar djupare och mer vemodsfylld: 
"Козлова закрыла глаза и несколько минут наслаждалась этим приятным концом." ("Kozlova slöt ögonen och njöt några minuter av detta angenäma slut.")

Denna melodramatiska borgliga litteratur kan det nu upplevas som något av en motståndshandling att hålla fast vid, liksom vid sina personliga övertygelser och sitt ursprung. Det rutinmässiga läsandet av de gamla bilagorna ingår för henne $\mathrm{i}$ ett vårdande och bevarande av det gamla och av Kulturen överhuvudtaget.

Hon övergår därefter till en annan syssla hon finner ro i, syarbete, och tar precis fyra knappnålar och fållar upp en kjol. I den nya frid hon tycks ha funnit i sin tillvaro och kanske med blicken för de berättelser som vardagsföremålen bär på förstärkt av läsningen, lägger hon nu märke till detaljer som är förankrade i det gamla livet, som väcker minnen, som ger en känsla av hemmahörighet och att detta hem är hotat. Violerna på träskålen med knappnålar har hon målat själv "när hon var ung" ("когда была молоденькой..."), vilket också framstår som ett lugnt konstaterande att hon inte är det längre. Liksom Aleksej Egorytj i slutet av romanen hon läst tycks Kozlova nu försonad med sin tillvaro trots sin ensamhet.

Hon går ut och går efter läsningen och syarbetet. Det är vinter igen. $\mathrm{Nu}$ dyker Suslova upp, hennes gamla väninna, med sin vardagliga livfullhet: "Подскочила Суслова - красная, в большом платке, с петухом под мышкой." ("Suslova hoppade fram - röd, i en stor sjal, med en tupp under armen.") I några korta spridda satser slätar hon över att Kozlova ignorerat henne. Hon förklarar tuppen under armen och återknyter till deras tidigare umgänge genom konstaterandet att livet är svårt och med frågan om inte monsieur skrivit: "- Ну, как? - бормотала она. - Давно не встречались... тяжело жить. Вот, купила петуха - на два раза. При такой-то семье... Мусью не пишет?" ("- Nå, hur är det? mumlade hon, det var länge sedan vi sågs... livet är svårt. Se här, jag köpte en tupp - räcker till två mål. Med en sådan familj så... Musiö har inte skrivit?")

Kozlova tar Suslova under armen och bjuder hem henne till sig så som förut. Suslova delar hennes världsbild trots allt. Med henne kan hon hålla fast vid det gamla, ceremoniellt påminna sig om det och vänta och hoppas på att det nya samhällets fasor ska gå över. Suslova är kanske något enfaldig, som när hon lät sig ryckas med i demonstrationen, men hon ifrågasätter inte Kozlovas sätt att leva såsom Sutyrkina gjorde. Några klara och kala vinterintryck från promenaden följer med en syntaktisk symmetri som understryker alldagligheten: "По дороге скакали светлоглазые галки. Низко висели тучи. Иногда пролетали снежинки." ("På vägen hoppade ljusögda kajor. Molnen hängde lågt. Ibland flög några snöflingor förbi.") 
Kanske framstår dessa omgivningens detaljer med en skärpa och enkel skönhet för Kozlova. Hon småskrattar åt några angenäma tankar. Friden från det romanslut hon läste har fyllts på av återföreningen med Suslova och fyller också hennes sätt att se världen.

Som en ytterligare, avslutande, försoning med sin tillvaro så går hon till kyrkogården igen där hon ju också före det misslyckade vänskapsförsöket upplevde ett hopp i biskopens vardagliga tömmande av slaskhinken:

Посмеиваясь приятным мыслям, Козлова бродила по улицам. Зашла на кладбище с похожими на умывальники памятниками и, улыбаясь, поклонилась родительским могилам.

Småskrattande åt angenäma tankar gick Kozlova omkring på gatorna. Hon gick in på kyrkogården med sina handfatslika gravstenar och bugade sig leende vid föräldrarnas gravar.

Leende åt den profana likheten eller bara åt den plötsliga oförklarliga upprymdhet som hon tycks känna bugar hon inför sina föräldrars gravar. Hon känner kanske ett sammanhang. Det är i alla fall vad berättelsen skapar genom ytterligare några intryck som återknyter och ger helhet åt hennes tillvaro:

Из ворот был виден монастырь святого Кукши - тоненькие церковки, пузатые башни. Вспомнились: красно-коричневый дворец, желтое Адмиралтейство...

Från porten syntes den helige Kuksjas kloster - tunna små kyrkor med pösiga torn. Hon mindes: det rödbruna palatset, det gula Amiralitetet...

Hon ser den heliga Kukšas kloster på håll från kyrkogården. Det var efter drömmen om Kukša som hon begav sig till kyrkogården förra gången. Klostrets utseende för i sin tur tankarna till Vinterpalatset och Amiralitetet i Petersburg, till motiven av dem på Kozlovas tekoppar och till de minnesskärvor av den förrevolutionära kulturen, med sin dröm om Petersburg, som hon och Suslovas tidigare rituellt utbytte. Kozlova föreställer sig nu den förestående tedrickningen på kvällen och hur Suslova åter ska se på kopparna och dra sig till minnes historien om hur hon en gång kanske såg tsarinnan. Kozlova tänker sig att det ska vara hemtrevligt som i romanen i litteraturbilagan till Niva och att hon ska säga till Suslova att vänskapen med Sutyrkina inte var äkta:

Сегодня вечером чувствительная Суслова заглядится на чашки, притихнет, задумается и расскажет, как видела императрицу. Уютно, как в 
романе из «Приложений», будет шуметь самовар, от лампы будет домовито попахивать керосином. - Вы меня, кажется, встречали с этой женщиной, - скажет Козлова: - Настоящей дружбы у нас с ней не было.

Ikväll skulle den känslosamma Suslova betrakta tekopparna, tystna, falla i tankar och så berätta om hur hon såg tsarinnan. Hemtrevligt, som i romanen i "Bilagan", skulle samovaren låta och lampan avge en huslig lätt fotogenlukt. - Ni råkade mig visst tillsammans med den där kvinnan, skulle Kozlova säga: Det var ingen äkta vänskap mellan mig och henne.

I dessa föreställningar i ensamheten om hur det ska bli är hon försonad med sin vardag. Här finns inget av det som tidigare störde henne eller kändes otillräckligt i vänskapen med Suslova. Hon tillskriver Suslova känslosamhet och deras vänskap, om än av ett annat slag, kan i Kozlovas föreställningar göras lika idealisk som den med monsieur. Detta tycks vara äkta vänskap för henne.

Hur relationen med monsieur verkligen var eller om den ens existerat får vi inte veta. Och hur samvaron med Suslova nu de facto kommer att gestalta sig i fortsättningen ligger utanför berättelsen. Den äkta vänskap Kozlova föreställer sig kommer i verkligheten troligen alltid att störas och på något sätt inte passa med hennes ideal. Men hennes upprymdhet inför omgivningens triviala detaljer här i slutet kan trots allt också antyda en försonande insikt om mötets realism. Hon ser ju faktiskt fram emot just Suslovas banala historia liksom lukten av fotogen som en del av hemtrevligheten.

Intryck i nuet, under Kozlovas väg från kyrkogården, avslutar berättelsen genom att också återknyta till inledningen i kyrkan och monsieur. Möjligen antyds en försoning med att monsieur inte kommer att komma tillbaka.

На столбах зажглось электричество - желтые пятнышки под серыми тучами. Два воза дров въехали в ворота школы Карла Либкнехта и Розы Люксембург... Здесь учил мосье Пуэнкарэ.

Elektriciteten tändes på stolparna - gula fläckar under grå moln. Två lass ved for in igenom porten till Karl Liebknecht- och Rosa Luxemburgskolan... Här undervisade monsieur Poincaré.

\section{De upplevda mötena med Liz}

"Vstreči s Liz" ("Mötena med Liz") debuterade Dobyčin med i det fjärde och sista numret av tidskriften Russkij sovremennik hösten I924. Novellen har en ung manlig huvudperson. Han, Kukin, bor med sin mor som bär vissa likheter med Kozlova i förra novellen i sitt nostalgiska vårdande av förrevolutionära minnen och reliker. Kukin ställs liksom de unga huvudpersonerna i 
kommande noveller inför andra frågor än den äldre generationen. De är inte lika förankrade i den tidigare kulturen även om de, som de också visar prov på, är gamla nog att minnas den. De var, som Roman Jakobson några år senare beskrev denna generation ("som slösade bort sina poeter"), visserligen redan formade av det förrevolutionära samhället men inte stelnade $\mathrm{i}$ det; de kunde följa med det nya i dess framväxt och förvandlas. ${ }^{171}$

Det är i det sovjetiska samhället som Kukin har hela sitt liv framför sig. Han kan inte som den äldre generationen livnära sig enbart av minnen och små stunder i vardagen. På något sätt måste han vara en del av det nya. Och han är också, som han uttrycker det, "gotov sočuvstvovat"' ("beredd att sympatisera") med den sociala förändring som revolutionen fört med sig.

Konflikten handlar om hur Kukin ska vara sig själv och sina känslor trogen bland de krav på ideologisk inordning som det nya samhället ställer. Likt Kozlovas möten med monsieur Poincaré förblir Kukins möten med den borgerliga Liz i stort sett bara inre föreställningar. De verkliga mötena, det umgänge huvudpersonen faktiskt tar del $\mathrm{i}$, har han på samma sätt som Kozlova svårt att värdesätta. Han vill något annat än vad det nya samhället erbjuder, men är ung och inte så säker som Kozlova på vad det är. Slutet av novellen talar för att kompromisser är vad som förestår i hans liv. I längden finns inget alternativ till det nya sovjetiska livet.

\section{I (Liz och Kukin)}

Berättelsen börjar med en utvecklad gestaltning av Liz (eller Lise om man vill understryka det franskklingande och fina i hennes namn i motsats till det folkligt ryska Liza). Hon etableras som någon som åtrås innan huvudpersonen Kukin träder in och liksom tar över och motiverar detta betraktande av henne. Beskrivningen av henne förefaller samtidigt inte ensidigt färgad av huvudpersonens medvetande. Hans beteende ställs också ut som att han "frejdigt" ("molodcevato") går efter henne - och ger en viss ironisk distans till attraktionen:

Шевеля на ходу плечами, высоко подняв голову, с победоносной улыбкой на лиловом от пудры лице, Лиз Курицына свернула из улицы Германской революции в улицу Третьего интернационала.

С каждым шагом поворачивая туловище то направо, то налево, она размахивала, как кадилом, плетеным веревочным мешком, в который был втиснут голубой таз с желтыми цветами.

\footnotetext{
${ }^{171}$ Roman Jakobson, "O pokolenii, rastrativšem svoich poètov" ("Om en generation som slösade bort sina poeter"; I93I), Selected Writings, V, Berlin, New York, I979, 355-38I, 355.
} 
Кукин повернулся через левое плечо и молодцевато шел за ней до бани. Там она остановилась, повертелась, торжествующе взглянула направо и налево и вспорхнула на крыльцо. ${ }^{172}$

Gungande med axlarna i farten, med huvudet högburet och ett segerrikt leende i det pudrade, lila ansiktet vek Liz Kuritsyna av från Tyska revolutionens gata in på Tredje internationalens.

För varje steg vred hon kroppen än till höger, än till vänster och svingade som ett rökelsekar en flätad trådkasse i vilken ett tvättfat var nerstoppat, blått med gula blommor.

Kukin vände sig över vänster axel och gick frejdigt efter henne till bastun. Där stannade hon, vände sig, blickade triumferande åt höger och åt vänster och flög upp för trappen.

Detta uppenbarande av Liz som ett föremål för Kukins attraktion utgör, tillsammans med den fortsättning det får i Kukins medvetande, hela det första mötet med Liz. Vid sidan av attraktionen tecknas samtidigt de grundläggande konflikterna i samhället. Hennes borgerliga yttre kontrasterar mot de nya sovjetiska gatunamnen. Tyska revolutionens gata och Tredje internationalens talar för de storslagna revolutionära visionerna som både Liz och Kukin tycks föga upptagna av. ${ }^{173}$ Dessutom får hennes koketta yttre en kyrklig kontrast genom att hennes svingande med nätkassen liknas vid hur man svänger ett rökelsekar, en detalj som i all sin oskyldiga livfullhet kan föra tankarna till svängandet med rökelse över en avliden och så ses förebåda hennes öde. Till sist påkallar även upprepningen av höger och vänster uppmärksamheten (om hur hon går och hur hon ser sig om, därtill vänder sig Kukin över just vänster axel) som ett möjligt tecken på det politiska vägval som det nya samhället avkräver.

Dörren slår igen efter Liz men attraktionen till henne fortsätter verka inom Kukin. Vardagslivet utanför ser han bort från; möjligen ger vad han eventuellt trots det uppfattar i ögonvrån - inlagda äpplen - associationer som samspelar med fantasierna som följer:

Дверь хлопнула. Торговки, сидя на котелках с горячими углями, предложили Кукину моченых яблок. Не взглянув на них, он, радостный, спустился на реку.

- Пожалуй, - мечтал он, - уже разделась. Ах, черт возьми!

Dörren smällde. Månglerskorna satt på grytor med varma kolbitar i och erbjöd Kukin inlagda äpplen. Utan en blick åt dem gick han glad i hågen ner till floden.

\footnotetext{
${ }_{172}$ Novellen citeras ur PSSP, 54-58.

${ }^{173}$ Endast den senare, Ulica Tret'ego Internacionala (tidigare Moskovskaja ulica (Moskvagatan) som har en central roll i novellen "Portret"), existerade i Brjansk. Namnen utgör här således mer än realia. PSSP, 46 I.
} 
- $\mathrm{Nu}$, tänkte han drömmande, kanske hon redan klätt av sig. $\mathrm{Aj}$, fan anamma!

I den dagdrömmande sinnesstämning som framkallats dras nu även omgivningen in. Som så gott som alltid i dylika lyriska stunder i ensamhet hos Dobyčin registreras som sagt den glänsande lystern hos något föremål. Här är det isskorpan på snön som blänker. Men innan dagdrömmandet fortsätter vidgas först perspektivet och tar in en social verklighet som kontrasterar mot romantiken. De bönder som iakttas framstår här och som vi ska se även i kommande noveller som utomstående till det sociala sammanhang som skildras. Såväl inför Kukins otidsenliga borgerliga förtjusning som för det nya sovjetiska samhället ter de sig främmande och därigenom bidragande med ett slags neutral distans som kan upplevas störande och ifrågasättande:

Ледяная корка на снегу блестела на вечернем солнце. Погоняя лошадей, мужики ехали с базара. Вереницами шли бабы с связками непроданных лаптей и перед прорубью ложились на брюхо и, свесив голову, сосали воду:

- Животные, - злорадствовал Кукин.

Isskorpan på snön glänste i kvällssolen. Bondkarlarna på väg från marknaden drev på sina hästar. Gummor kom gående i led med knippen av osålda bastskor och vid en vak lade de sig på buken, hängde ner med huvudet och sög i sig vattnet.

- Djur, tänkte Kukin skadeglatt.

När Kukin sedan går tillbaka är månen inte bara där som en längtansframkallande detalj utan genomtränger hela scenen med sitt sken. Detta välver in ett föreställt kärleksmöte med Liz i en vithet som potentiellt också är politiskt antydande (vid samma flod, när mötena med Liz når sitt slut, kommer istället det röda i de solbadande kropparna att understrykas):

Когда он шел обратно через сад, луна была высоко, и под перепутанными ветвями яблонь лежали на снегу тоненькие тени.

- Через три месяца здесь будет бело от осыпавшихся лепестков, - подумал Кукин, и ему представились захватывающие сцены между ним и Лиз, расположившимися на белых лепестках.

När han gick tillbaka genom parkträdgården stod månen högt och under äppelträdens hoptrasslade grenar låg tunna skuggor över snön.

- Om tre månader kommer det att vara vitt av fallna kronblad här, tänkte Kukin, och han såg för sig gripande scener mellan sig och Liz utsträckta på de vita kronbladen.

Kapitlet avslutas med att Kukin kommer hem. Där råder ett slags bevarad men tyst förrevolutionär atmosfär i vilken Kukin sjunker ner. Med sin 
mor blir och benämns han "hennes son". Han dricker te, som i väntan, till tickandet från en klocka med franskt (och monarkistiskt) namn. Han beskrivs slutligen helt utifrån som en lydig pojke:

Чайник был уже на самоваре. Мать сидела за евангелием.

- Я исповедовалась.

Кукин сделал благочестивое лицо, и под тиканье часов «ле руа а Пари» стали пить чашку за чашкой - седенькая мать в ситцевом платье и ее сын в парусиновой рубахе с черным галстучком, долговязый, тощий, причесанный ежиком.

Tekannan stod redan på samovaren. Modern satt med evangeliet.

- Jag biktade mig.

Kukin anlade ett fromt ansiktsuttryck, och till tickandet från vägguret "Le roi à Paris" drack de kopp efter kopp - den lite gråhåriga modern i kattunsklänning och hennes son i segelduksskjorta med en svart liten slips, lång och mager och med igelkottsfrisyr.

\section{2 (En gynnsammare förbindelse)}

Liksom sin författare och ett flertal av novellernas huvudpersoner arbetar Kukin på ett kansli. I denna sovjetiska miljö inleds andra kapitlet. Här finns en reell samvaro och alla möjligheter till verkliga möten. Han kommer rentav att uppmanas till att börja träffa en av kvinnorna. En förbindelse med denna förklaras han dessutom ha allt att vinna på för sin framtid i det nya samhället.

Drömmen om Liz och den bevarade borgerliga kulturen i hemmet som presenterats i första kapitlet ger en bakgrund till hans något frånvarande sätt och avvaktande hållning. Snarare än någon utvecklad ideologisk övertygelse, som skulle stå i konflikt med de revolutionära och idealistiska sovjetiska kvinnorna, tycks det vara de alltför reella och rationella perspektiven som får honom att skjuta upp det aktiva handlande som han uppmanas till. Möjligen talar det just "färglösa" håret på hans arm, som hamnar i fokus i mötet med kvinnan på kansliet, för en motsvarande inre karaktärsmässig färglöshet.

En Riva Golubuškina som gör en haltande entré, ideligen skjuter fram brösten och vid sidan av dessa nedsättande markörer också tycks stå lägre i rang, ikläder sig rollen som mäklerska. Hon uppmanar Kukin att ta kontakt med den sovjetiskt idealiska Fiškina:

В канцелярию приковыляла хромоногая Рива Голубушкина и велела идти к Фишкиной - графить бумагу. 
- Читали газету? - спросила она, подняв брови: - есть статья Фишкиной: «Не злоупотребляйте портретами вождей». - И, откинув голову, она выкатила груди.

Den halta Riva Golubusjkina kom instapplande på kansliet och befallde honom att gå till Fisjkina - för att linjera papper.

- Har ni läst tidningen? frågade hon med höjda ögonbryn: det är en artikel av Fisjkina i den: "Missbruka inte ledarnas porträtt". Och hon kastade huvudet bakåt och sköt ut bysten.

Sedan följer mötet med denna Fiškina, med Riva som vittne, under arbetet med att linjera papper. Det är Fiškina som tillsynes oskyldigt närmar sig Kukin så att en fysisk kontakt uppstår. Det är sedan hennes reaktion på kontakten som gestaltas. Kukin framstår som oberörd. Stunden byggs inte upp med någon romantisk måne eller lyriskt blänk, utan omges av en matt alldaglig atmosfär - med kyla, en våt vind och moln:

Было холодно. В открытое окно дул мокрый ветер.

Рива усердно переписывала. Кукин, стоя, разлиновывал.

Фишкина, приблизив темное лицо к его руке, смотрела, и ее черная прическа прикоснулась к его бесцветным волосам. Тогда она встряхнулась и отошла к окну.

Стояла, вглядываясь в тучи, коротенькая, черная, прямая и презрительная. Потом негромко высморкалась и, повернувшись к комнате, сказала:

- Товарищ Кукин.

Det var kallt. En våt vind blåste in genom det öppna fönstret.

Riva renskrev nitiskt. Kukin linjerade stående.

Fisjkina, som närmat sig hans arm med sitt mörka ansikte, granskade, och hennes svarta frisyr råkade snudda hans färglösa hår. Då ruskade hon på sig och gick bort till fönstret.

Hon stod där, stirrande på molnen, liten och svart, rak och föraktfull. Sedan snöt hon sig lågmält och vände sig mot rummet och sade:

- Kamrat Kukin.

Mot fönstret blir Fiškina rent av svart - som kontrast till den med Liz associerade vitheten. Hennes snytning efter att hon stått och sett ut på molnen efter den korta beröringen kontrasterar också mot Liz kvinnliga flärd. Det samtal som tilltalet därefter möjligen är avsett att initiera kommer aldrig till stånd. Mötet störs av att någon tittar in genom dörren varpå Fiškina tar på sig sin bolsjevikiska skinnjacka och lämnar honom: "Приоткрылась дверь, и кто-то заглянул. Она надела желтую телячью куртку и ушла." ("Dörren öppnades på glänt och någon kikade in. Hon tog på sig den gula kalvskinnsjackan och gick.”) 
Om hennes blickande i molnen talar för att hon har känslor för Kukin så bottnar möjligen hennes agerande och föraktfulla uttryck i den aktiva bolsjevikens dilemma. Det vill säga att hon har svårt att förena sitt politiska liv - att i ideologisk övertygelse ha vigt sitt liv åt arbete och ständig kamp för revolutionens sak - med personliga känslor. ${ }^{174}$

Genom atmosfären som byggs upp och reaktionen på den subtila, obetydliga beröringen, liksom den tvetydiga stunden vid fönstret efteråt skildras Fiškina här framförallt som människa. Föraktet mot andras småborgerliga svaghet och passivitet som hon senare kommer att visa uttryck för kan härigenom delvis förstås som ett förakt mot egna vekare sidor.

Trots beskrivningens torrhet ger den sköra kontakten, hennes blickande genom fönstret och det outsagda som hon lämnar honom med, utrymme för ett intresse och känslor att börja växa. Kukin lämnas emellertid inte ifred med detta. När Fiškina är borta griper Riva in igen och hennes påträngande kroppslighet följs nu av hennes krassa hantering av situationen som inte lämnar plats för något outsagt. Hon gratulerar honom till den första kontakten, förklarar vad han har att vinna och erbjuder sig, eftersom hon och Fiškina snart ska byta arbetsplats, att arrangera nya möten. Kukin lyckas svara avvaktande och med glädje på samma gång. På samma sätt avslöjar inte heller hans deklarerade sympati med lägre klasser och upprymda visslande på Internationalen huruvida han faktiskt menar allvar och med det antyder sig ha känslor för Fiškina:

- Вы ей понравились, - выкатывая груди, поздравляла Рива и таинственно оглядывалась. - Старайтесь к ней подъехать: она вас будет продвигать. Жаль только, что нас с ней переводят. Но ничего, я вам буду устраивать встречи.

- Возможно, - радовался Кукин. - В конце концов, я не против низших классов. Я готов сочувствовать. - И, ликуя, он насвистывал «Вставай, проклятьем».

- Ni föll henne i smaken, gratulerade Riva, sköt ut bysten och såg sig hemlighetsfullt omkring. Försök att lägga an på henne: hon kommer att hjälpa er upp. Synd bara att hon och jag blir förflyttade. Men det är inte hela världen, jag ska arrangera möten åt er.

- Det är möjligt, sade Kukin glatt. Jag har när allt kommer omkring inget emot de lägre klasserna. Jag är beredd att sympatisera. Och hänfört började han vissla på "Upp, trälar".

${ }^{174}$ Att övervinna sin kärlek för det högre ändamålet (som kamrat Leningradov idealiserande skildras göra i en berättelse författad av huvudpersonen i nästa novell, "Erygin") är en återkommande lösning på konflikten i såväl samtidens realism som senare i socialistisk realism (exempelvis i Pil'njaks Golyj god (Det nakna året), 1922, Fedins Goroda i gody (Städer och år), I924, och Ostrovskijs Kak zakaljalas' stal' (Hur stålet härdades), 1934). 
Det lättsamma visslandet tas upp i de gatubilder som följer, men sjunker också undan bland dem. För under flygande röda och blå ballonger står först en skäggig gatuförsäljare, sedan jämrar sig "krymplingar", troligen krigsinvalider, och till sist återges en tiggerskas ramsa. Dessa tycks föga befriade av revolutionen:

Красные и синие шары метались по ветру над бородатым разносчиком. На углах голосили калеки. От дома к дому ходила старуха в черной кофте:

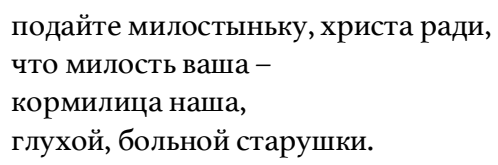

Röda och mörkblå ballonger snodde runt i vinden ovanför en skäggig gatuförsäljare. Krymplingar jämrade sig i gathörnen. Från hus till hus gick en gammal gumma i svart kofta:

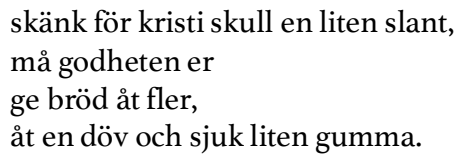

Gatubilderna fungerar ofta i novellerna som ett intermezzo. Det är inte bara samhälleliga koder eller diskurser utanför huvudpersonens direkta sociala sammanhang som framhävs, utan också tysta, fysiska upplevelser av det som inte kommer till tals i berättelsen. Denna ordlösa sfär utanför spelar som bönderna tidigare visade antydningsvis mot något inom de personer som är i centrum. Det som gestaltas är inte en tolkning av denna påträngande verklighet utan själva upplevelsen av den. Dessa upplevelser kan tränga in i och påverka huvudpersonens liv och berättelsen utan att helt medvetandegöras. En tillfällig samstämmighet lyfter ofta fram ett intensivt intryck som aldrig blir helt översättbart som en begriplig insikt.

Det finns möjliga kopplingar framåt, exempelvis kan invaliderna i gathörnen associeras till Liz belägenhet som härefter nämns, men varken de eller tiggerskan eller den skäggiga gatuförsäljaren uttöms med det. De blir kvar och upptar plats i den skildrade verkligheten, de kan varken lindas in i den nya ideologins berättelse eller i huvudpersonens. Om det först finns en rörelse som låter intrycken passera förbi utan att pocka på betydelse, så stannar den upp vid tiggerskans ord när de får ta plats som en dikt i berättelsen. Här skär något igenom. I vädjandet för Kristi skull om hjälp, träder 
ett subjekt fram med rop som från en annan tid. Hon stödjer sig inte på något ideologiskt argument utan vädjar bara till andra människors medkänsla.

Att Liz på något sätt råkat illa ut, vilket härnäst skildras, aktualiserar ideologins domän och för oss tillbaka till berättelsens intrig. Kukins tankar på Liz när han går förbi utanför hennes hus utgör berättelsens andra upplevelse av ett slags möte med henne. De fallna vaserna vid porten talar möjligen för hur revolutionen och inbördeskriget dragit fram där men antyder också hennes nuvarande situation. Kukins hand på hjärtat och redogörelsen som färgas av hans medvetande uttrycker medlidande:

У ворот с четырьмя повалившимися в разные стороны зелеными жестяными вазами Кукин положил руку на сердце: здесь живет и томится в компрессах Лиз. У нее нарывы на спине - в газете было напечатано ее письмо, озаглавленное «Наши бани».

Vid en port med fyra gröna bleckvaser som låg välta åt olika håll lade Kukin handen på hjärtat: här levde och plågades i sina kompresser Liz. Hon hade bölder på ryggen - hennes brev hade publicerats i tidningen rubricerat "Våra badstugor".

Liz tycks alltså ha drabbats av något $\mathrm{i}$ bastun. Troligare än att hon bränt sig eller utsatts för något på grund av sin borgerlighet rör det sig nog om en sjukdom som hon av den bristande hygienen i den allmänna bastun smittats av, något hon så manar till åtgärder mot med sitt brev i tidningen. Tuberkulos i ryggraden (tuberkulös spondylit) stämmer möjligen bäst med beskrivningen; sjukdomar som denna, särskilt tyfus hade fått spridning under svälten i början av tjugotalet och fortsatte att skörda liv.175 Liz öde framstår så också som en avromantiserande beskrivning av vad som egentligen följde för Liz del vid förra mötet, efter att dörren till bastun gick igen och Kukin började fantisera. Även om hennes tillstånd nu delvis tycks skildrat genom hans medvetande, möjligen utifrån vad som framgått i hennes brev i tidningen, bryr det honom inte mer än att han genast härefter när han går till biblioteket visar sig göra det för Fiškinas skull. Är Kukin så lättsamt obekymrad som han ger sken av?

Tuberkulos antyds också genom de revolutionära plakaten på biblioteket. Enligt dessa (genom interpunktionen lätt parodierade) slagord ska sjukdomar behandlas med ideologi, tuberkulos är en proletär sjukdom,

\footnotetext{
${ }^{175}$ Tillståndet i vad som omtalas som "naši bani" ("våra badstugor"), utifrån en samhällsdebatt i början av tjugotalet, skämtar också Michail Zoščenko om i sin tillbakablickande povest' Pered voschodom solnca (Före soluppgången) från 1943. M. M. Zoščenko, Sobranie sočinenij, 7 , Moskva 2009, 358.
} 
hemmens smittohärdar måste bort (men inte den kollektiva bastuns?): "B библиотеке висели плакаты: «Туберкулез! Болезнь трудящихся!» «Долой домашние! Очаги!»" ("På biblioteket hängde plakat: 'Tuberkulos! En arbetarsjukdom!' - 'Ut med hemmens! Härdar!'”)

Kukins ärende visar sig vara att låna några revolutionära böcker för att med dem framstå i god ideologisk dager inför Fiškina. Och han har, som vi får veta efter att allt revolutionärt visat sig utlånat, redan börjat föreställa sig möten med henne (inlett med samma svordom som föreställningarna om Liz):

- Что-нибудь революционное, - попросил Кукин. Девица с желтыми кудряшками заскакала по лесенкам.

- Сейчас нет. Возьмите из другого. «Мерседес де-Кастилья», сочинения Писемского...

Ax, черт возьми, а он уже видел себя с теми книжками - встречается Фишкина: - Что это у вас? Да? - значит, вы сочувствуете!

- Något revolutionärt, bad Kukin. En flicka med gula lockar for upp på stegarna.

- Inget just nu. Ta något av någon annan. Mercedes de Castilla, Pisemskijs samlade...

$\mathrm{Aj}$, fan anamma, och han som redan sett för sig hur han skulle gå med de där böckerna och så träffa på Fisjkina: - Vad är det ni har? Nä? Då sympatiserar ni alltså!

Även detta kapitel slutar i hemmet och dess i förhållande till den nya ordningen ideologiskt smutsiga härd. Hans mor dricker te med en väninna. När denna vänder sig till Kukin med en fråga om den politiska situationen kommer svaret direkt, liksom automatiskt och strängt tillrättavisande. Han uttalar den officiella diskursen:

- Не слышно, скоро переменится режим? - томно спросила Золотухина, протягивая руку.

- Перемены не предвидится, - строго ответил Кукин. - И знаете, многие были против, а теперь, наоборот, сочувствуют.

- Hörs det något om det blir en annan regim snart? frågade Zolotuchina matt och sträckte fram handen.

- Inga förändringar finns i sikte, svarade Kukin strängt. Och ni vet, många var emot men nu, tvärtom, sympatiserar man. ${ }^{176}$

Denna ordning är vad han själv verkar försöka anpassa sig till, vilket möjligen innefattar att ge upp drömmarna om den borgerliga Liz. De två äldre

${ }^{176}$ Apropå tuberkulos och hemmets härd kan namnet Zolotuchina kopplas till "zolotucha" ("skrofler" eller "barntuberkulos"). 
kvinnorna tar föga notis om det han säger utan fortsätter, efter denna artighet mot den unge mannen, att vemodigt minnas det gamla. Liksom i "Kozlova" utgör det förrevolutionära Petersburg kärnan för väninnans nostalgi. Utifrån sina minnen försöker hon också tränga igenom Kukins ideologiska fasad - saknar inte han också sin tid i huvudstaden?

- Где хороша весна, - вздохнула Золотухина, - так это в Петербурге: снег еще не стаял, а на тротуарах уже продают цветы. Я одевалась у деНоткиной. «Моды де-Ноткиной»...

Ну, а вы, молодой человек: вспоминаете столицу? Студенческие годы? Самое ведь это хорошее время, веселое...

Она зажмурилась и покрутила головой.

- Var är väl våren så vacker, suckade Zolotuchina, som i Petersburg: snön har inte smält bort än men på trottoarerna säljer man redan blommor. Jag brukade ekipera mig hos de-Notkina. "de-Notkinas Moden"...

Men ni då, unge man: tänker inte ni på huvudstaden? Studentåren? Det är ju den bästa tiden, den glada...

Hon kisade och vickade lite på huvudet.

Och Zolotuchina lyckas smitta honom med sina minnen. Kapitlet slutar med att Kukin faller ner i ett angenämt vemod över sin tid i staden utifrån liknande trivialiteter:

- Еще бы, - сказал Кукин. - Культурная жизнь... - И ему приятно взгрустнулось, он замечтался над супом: играет музыкальный шкаф, студенты задумались и заедают пиво моченым горохом с солью...

О, Петербург!

- Om jag gör, sade Kukin. Ett kulturellt och civiliserat liv... Och ett behagligt vemod kom över honom, han föll i drömmar över soppan: ett musikskåp spelade, studenterna satt och grubblade och åt gula ärtor med salt till ölen...

$\AA$, Petersburg!

Det är inget överflöd han minns, men det enkla blir bevingat i minnet och det tycks för honom, på samma sätt som för Zolotuchina, rymma en mer allmän längtan efter något annat än det nuvarande livet. För honom som ung som söker ett sätt att leva med en framtid i den nya tillvaron tycks denna längtan komma och gå. Det gör honom till något av en vindflöjel, både politiskt och känslomässigt.

\section{3 (Det faktiska mötet)}

Tredje kapitlet inleds med en politisk manifestation som sammanför $\mathrm{Ku}-$ kins tre tidigare skilda sociala sammanhang: hemmet, kansliet och Liz. 
Först visas skillnaden mellan hans mor och hennes väninna upp i relation till manifestationen. Även om fru Kukina anger sina trasiga sulor som skäl till att inte delta och inte direkt fördömer Zolotuchina så påminner hon i sin självständighet om Kozlova i förra novellen (där väninnan Suslova deltog i första maj-demonstrationen):

- Идемте, идемте, - звала Золотухина. - Долой Румынию.

Кукина отнекивалась, показывала свои дырявые подметки...

Ходили долго. Развевались флаги и, опадая, задевали по носу.

эх, вы, буржуи,

эх, вы, нахалы.

Луна белелась расплывчатым пятнышком. В четырехугольные просветы колоколен сквозило небо. Шевелились верхушки деревьев с набухшими почками.

- Nu går vi, nu går vi, kallade Zolotuchina. Ut med Rumänien.

Fru Kukina avböjde, visade på hålen i sina halvsulor... näsan.

De gick omkring länge. Flaggorna fladdrade och när de föll lade de sig på

oj, vilka borgare,

oj, vilka svin.

Månen lyste vit i en utfluten fläck. I de fyrkantiga öppningarna i klockstapeln syntes himlen. Trädtopparna rörde sig med uppsvällda knoppar. ${ }^{177}$

Inte heller de tidigare kapitlen har inletts med att genast placera huvudpersonen i rummet. Den som står närmast till hands som ett reflekterande och seende subjekt är Kukins mor. Men hon deltar inte i tåget och det sinnligt specifika i hur exempelvis flaggorna faller på näsan påkallar ett upplevande subjekt i demonstrationen. Här framträder den gestaltade världen snarast genom en samling av perceptioner och medvetanden som skapas av bildernas impressionistiska sinnlighet. (Att månen ser ut som utfluten fläck påkallar ett medvetande, att den skiner just igenom ett fyrkantigt mellanrum situationsbestämmer iakttagelsen i den berättade världen. De gick omkring länge, "chodili dolgo", uttrycker en värdering. Och så vidare.) I denna blandning av perspektiv lyfts det samfällda ideologiska skanderandet ut och mot det kommer, från den enda vi vet inte deltar i demonstrationen,

\footnotetext{
${ }_{177}$ De arrangerade manifestationerna mot Rumänien grundade sig i Bessarabiens frigörelse och anslutning till Rumänien, eller Rumäniens ockupation av Bessarabien, I9I8. 1924 erbjöd sig Rumänien att officiellt erkänna Sovjetunionen i utbyte mot att anspråken på Bessarabien gavs upp vilket föranledde en ny våg av antirumänska manifestationer. PSSP, 46I
} 
Kukins mors uttalande som en replik till detta dikterade politiska engagemang för något långt borta:

- Вот, все развалится, - вздыхала Кукина, качая головой на покосившиеся и подпертые бревнами домики: - где тогда жить? ${ }^{178}$

- Se, allt faller samman, suckade Kukina skakande på huvudet åt de lutande små husen som var uppstöttade med stockar: var ska vi bo då?

Kukins mor ser sig omkring och ser det som är nära. Hon bekymrar sig om livet. En omtanke som den framstegs- och framtidsinriktade ideologin skulle förklara som närsynt borgerlighet, en position som nu Fiškina från kansliet också träder in och representerar. Hon blickar långt förbi några trasiga gamla hus och viljan till ett drägligt vardagligt liv. Det hon ser är hur det gamla drönarsamhället biter sig kvar med sina sjukdomar i hemmets härdar, såsom propagandan på biblioteket förklarat:

\footnotetext{
Фишкина презрительно посмотрела направо и налево: - Фу, сколько обывательщины!
}

Fisjkina tittade föraktfullt åt höger och åt vänster: - Fy, så mycket kälkborgerlighet!

Till sist beskrivs så Kukin som till skillnad från sin mor går med i tåget. Om han måhända från början är där för att visa upp sin sympati för Fiškina, så har hans intensiva uppmärksamhet helt kommit att upptas av Liz och hennes liksom i inledningen svängande höfter. ${ }^{179}$ Det är andra gången Liz får gestalt i berättelsen och tredje gången hon upptar Kukins medvetande. Men inte heller denna gång utgör det mycket till möte såsom titeln på novellen utlovat. Allt som händer är att han i en paus i musiken - och i den politiska demonstrationen som framstår som störande och ett hinder för att ta kontakt med henne - uppfattar något hon säger till kvinnan bredvid sig:

\footnotetext{
${ }^{178} \mathrm{Jämför} \mathrm{det} \mathrm{kommande} \mathrm{centrala} \mathrm{problemet} \mathrm{som} \mathrm{det} \mathrm{formuleras} \mathrm{i} \mathrm{Andrej} \mathrm{Platonovs} \mathrm{Kotlovan}$ (Grundgropen) om samhällsutvecklingen i övergången till trettiotalet när uppbyggnaden tagit fart:"Дом человек построит, а сам расстроится. Кто жить тогда будет?" ("Människan bygger upp ett hus och raserar samtidigt sig själv. Vem skall då leva där?") A. A. Platonov, Kotlovan; Juvenil'noe more, Moskva 1987, 2I, respektive Andrej Platonov, Grundgropen, översättning Kajsa Öberg Lindsten, Stockholm 2007, I6.

${ }^{179}$ Den haltande revolutionära Riva och den borgerliga Liz lätta gång - att det inte är så det borde beskrivas för att passa in i samtiden, att personerna i skönlitterära berättelser av de ideologiska kritikerna redan på tjugotalet lästes som generaliserade typer tas upp av Mariètta Čudakova i artikeln "Na poljach knigi M. Okutjur'e 'Le réalisme socialiste"', Catherine Depretto (red.), De la litterature russe: Melanges offerts a Michel Aucouturier, Paris 2005, 315333, 3I9f.
} 
Ковыляя впереди, оглядывалась на Кукина и кивала Рива и, пожимая плечами, отворачивалась: он ее не видел. Перед ним, размахивая под музыку руками, маршировала и вертела поясницей Лиз. Когда переставали трубы, Кукин слышал, как она щебетала со своей соседкой:

- В губсоюз принимают исключительно по протекции...

Stapplande därframme såg sig Riva om på Kukin och vinkade, ryckte på axlarna och vände sig tillbaka: han såg henne inte. Framför honom, slängande med armarna till musiken, marscherade Liz och svängde på midjan. När trumpeterna gjorde uppehåll hörde Kukin hur hon kvittrade med sin granne:

- Guvernementsfacket antar uteslutande med protektion...

Repliken slutar med tre punkter, antingen för att inte mer uppfattas eller som en antydan till reflektion. Men Kukins tankar får vi inte tillgång till. Scenen bryts här.

Denna novell saknar nästan helt inskott av huvudpersonens reflektioner i relation till sin omgivning. Det kan läsas som en del av en gestaltning av att huvudpersonen faktiskt saknar och snarast förvirrat söker efter en egen ståndpunkt. De direkta intrycken och de andras repliker antyder med honom i centrum samtidigt en inre utveckling mot en egen övertygelse som snart börjar hamna i konflikt med omgivningen. Liz replik tycks till att börja med antyda att hon med sin borgerliga bakgrund har svårt att få ett arbete inom den nya byråkratin - det vill säga ett liknande arbete som det Kukin har.

På detta följer ett meddelande från Riva mottaget på kansliet (vilket hon och Fiškina, som Riva förvarnade, tycks ha förflyttats ifrån):

В канцелярию пришел мальчишка:

«Не теряйте времени, - прислала Рива записку и билет в сад Карла Маркса и Фридриха Энгельса: - подъезжайте к Фишкиной. Она вас продвинет. Вы не читали «Сад пыток»? - чудная вещь».

- Лиз, - сказал Кукин, - я вам буду верен...

En pojke kom in på kansliet:

"Ni har ingen tid att förlora", hade Riva skrivit på en lapp och skickat med en biljett till Karl Marx- och Friedrich Engels-trädgården: "Lägg an på Fisjkina. Hon hjälper er att komma er upp. Har ni läst Lidandets lustgård? en förunderlig sak."

- Liz, sade Kukin, jag ska vara dig trogen...

Meddelandet bekräftar Liz tal om protektion. Från att tidigare visat intresse reagerar Kukin nu med att tydligt ta avstånd från någon relation med Fiškina. Den övertygelse som därigenom antyds ha mognat inom honom, 
som distanserar honom från dessa sovjetiska kvinnor, tycks dock framförallt grundad i hans förälskelse i Liz som nu fått nytt liv efter hennes uppenbarelse i demonstrationståget.

Det visade intresset för Fiškina i förra kapitlet följdes dessutom av hans försjunkande i minnen från Petersburg tillsammans med moderns väninna. Möjligen ger det en ledtråd till vad Liz symboliserar för honom. Hon tycks i alla fall tillhöra samma sfär av det han kallat ett kulturellt liv när han som svar på Rivas meddelande tilltalar henne som något upphöjt inom sig som han ska vara trogen. Dessa upphöjda föreställningar om Liz, som får honom att avhålla sig från en relation med Fiškina, är möjligen samtidigt något som ställer sig i vägen för att försöka förverkliga ett möte med Liz. ${ }^{80}$

Efter meddelandet och Kukins trohetsförklaring följer nu det enda faktiska mötet med Liz i berättelsen; det är bara denna enda gång de ser på varandra och utbyter något, om än inte ens nu med ord. Omständigheterna byggs upp likt en saga, medan själva mötet sker av en bevingad tillfällighet.

"- Плохи стали мои ноги" ("- Jag har blivit dålig i benen"), börjar Kukins mor orsakskedjan. Hon ska på grund av sina dåliga ben be gumman Aleksandricha att gå med den aladåb och de ostplättar hon lagat till biskopen. Sin son, som hon kallar vid det franskklingande förnamnet Žorž, Georges, ber hon i sin tur att följa med och se efter Aleksandricha eftersom hon är gammal. Det är under de omständigheterna som Liz plötsligt uppenbarar sig för Kukin i sin ledmotiviska färgprakt:

Лиз, лиловая, с лиловым зонтиком, с желтой лентой в выкрашенных перекисью водорода волосах, смотрела.

Кукин остановился и обдергивал рубашку. Лиз засмеялась, покачнулась, сорвалась с места и отправилась.

За ней бы, - но нельзя было оставить без присмотра Александриху.

Liz, lila, med ett lila parasoll och ett gult band i det väteperoxidfärgade håret, stod och tittade.

\footnotetext{
${ }^{180}$ Snarast över Kukins huvud innehåller lappen från Riva också ett kontrasterande av den sovjetiska Karl Marx och Friedrich Engelsträdgården med en Lidandets lustgård utifrån den franska romanen Le jardin des supplices av Octave Mirbeau från I899. I romanen (som översatts till ryska 1907 och därefter utkommit i flera utgåvor och uppenbarligen vunnit popularitet) suggererar Mirbeau det mörka hjärtat hos sin tids franska borgerlighet - dess begär och dess barbari som släpptes lös i kolonierna. Clara, en elegant och frigjord kvinna som huvudpersonen förälskar sig i, tar med huvudpersonen till Kina för att visa och med honom delta i den kulturens bestialiska njutande av att se andra torteras. Finns det någon möjlig koppling till Kukin som man kan tänka sig att Riva vill antyda? Varnar hon indirekt för att Liz leder honom till en depraverad borgerlig kärlek? Eller är det bara för att på detta aparta sätt locka honom till den sovjetiska trädgården vilken Riva också återkommer till att mystifiera i ett senare meddelande?
} 
Kukin stannade och drog i skjortan. Liz föll i skratt, gungade, rörde sig från stället och gav sig av.

Efter henne - men han kunde inte lämna Alexandricha utan tillsyn.

Det är trivialiteter som hindrar Kukin. Han tycks instängd i sin mors värld som den gode lille pojken Georges, men också i sina tankar om vad han skulle vilja, och han är oförmögen att ens inleda ett vanligt samtal. Scenen har föregåtts av att han när modern bad honom om hjälp först läste klart ett recept på den franska efterrätten blanc-manger ("дочитав «Бланманже»"), lade ihop den gamla kokboken med torkade blommor i och suckande utbrast: "- Ax, [...] не вернется прежнее." ("Aj, [...] det gamla kommer inte tillbaka.") Han tycks så helt ha försjunkit i sin mors värld och i det drömmande bakåtblickande som han tidigare försökte stå emot.

Efter sammanstötningen med Liz beskrivs Kukin och Aleksandricha när de återvänder från kyrkan. Kukin beskrivs utifrån så som i slutet av första kapitlet tillsammans med modern: hans skjorta i segeldukstyg, den svarta lilla slipsen. Ett blänkande inleder och frammanar tillsammans med en poetisk eller dement replik från Aleksandricha (hon talar i alla fall om morgon fast det är kväll) en lyrisk stund. Mötet med Liz fortsätter liksom första gången inom Kukin. Aleksandrichas ord kan läsas som en poetisk kommentar om ungdomens frihetstörst. Lukten av puder (liksom Liz var lilapudrad) tillsammans med ett bröllopsfölje framför kyrkan tar Kukin, trots det nyss oförverkligade mötet, för ett hoppfullt tecken:

Возвращались вместе - Александриха в холщовом жилете и полосатом фартуке и унылый Кукин в парусиновой рубашке с черным галстучком и белесым отражением мелькали в черных окошках.

- Утром дух бывает очень вольный, - рассказывала Александриха...

Бегали мальчишки и девчонки. Хозяйки выходили встречать коров. В лоске скамеек отсвечивалась краснота заката.

Запахло пудрой: на крыльце у святого Евпла толпилась свадьба - какое предзнаменование!

De återvände tillsammans - Alexandricha i ullväst och randigt förkläde och den nedslagne Kukin i segelduksskjortan med den svarta lilla slipsen och som en blekvit spegling flimrade de förbi i de svarta fönstren.

- På morgonen brukar anden vara väldigt fri, berättade Alexandricha...

Små pojkar och flickor sprang. Kvinnorna gick ut för att möta korna. I bänkarnas glans speglades det röda i solnedgången.

Det kom en lukt av puder: på trappan till Helige Euplus trängdes ett bröllop - vilket förebud! 


\section{4 (Slut på drömmarna)}

Sista kapitlet inleds med en spegling i vattnet som liknas - till både innehåll och textur - vid ett motiv på en soffkudde: "В воде расплывчато, как пейзаж на диванной подушке, зеленелась гора с церквами." ("Utflutet i vattnet som landskapet på en soffkudde skimrade berget med kyrkorna i grönt.")'si Bilden ses från badstranden vid floden och drar förutom själva soffkuddens borgerlighet också in det kyrkliga som avtecknar sig med en anknytning till det förebådande bröllopet i slutet av förra kapitlet. Speglingen ligger just över vattnet där det som snart kommer att ske till sist får en ett helt annat slags koppling till kyrkan.

I hur solen steker ryggar och magar på stranden aktualiseras både det tidigare bastumotivet och den röda gemenskap som råder. Det kroppsliga blandas trivialiserande med det politiska. Sammanträffandet med Liz i förra kapitlet föregicks av en gatubild på väg till kyrkan av straffsoldater som utkommenderats till att krypande på knä skriva "Proletärer i alla länder, förenen eder" med tegelstenar runt bataljonen. Denna tråd tas nu upp.

Солнце жарило подставленные ему спины и животы.

- Трудящиеся всех стран, - мечтательно говорил Кукину кассир со станции, - ждут своего освобождения. Посмотрите, пожалуйста, достаточно покраснело у меня между лопатками?

Solen svedde de ryggar och magar som vänts mot den.

- Arbetare i alla länder, sade kassören från stationen drömmande till Kukin, väntar på sin befrielse. Kan ni vara snäll och se efter om det blivit tillräckligt rött mellan skulderbladen?

Efter den bekymmerslöse kassörens uppvisade delaktighet i det kollektiva drömmandet - är han nog röd? - följer så den avgörande händelsen i berättelsen. Det som inträffar skildras inte direkt utan rapporteras genom andras ord och kommentarer. Den enda antydan om allvaret i händelsen ges genom det plötsliga namngivandet, Šurka Gusev, av den som kommer med budet. Eftersom han inte tidigare nämnts framstår händelsen som subjektivt och stundligt upplevd, av Kukin eller av flera av de församlade som ett kollektivt subjekt. En spegling av det inträffade ges vidare genom samma bönder, med sina vagnar och bastskor, som Kukin såg efter att han i inledningen följt efter Liz till bastun. Det är fullt möjligt att vi är på just samma plats där han i vintras fantiserade om hur han och Liz snart skulle ligga

\footnotetext{
${ }^{18 I}$ Denna bild liksom speglingen i lacken på bänkarna i slutet av förra kapitlet har Dobyčin återanvänt från den opublicerade novellen "Kukueva" i Večera i staruchi. Även där heter också den manlige huvudpersonen Žorž, medan den borgerliga Kukueva han är förälskad i påminner om Liz - men till namnet, som för tankarna till en gök ("kukuška"), om Kukin.
} 
bland vita kronblad. Det inträffade reflekteras nu av böndernas och några baderskors rörelser, knappar som knäpps, att man samlas. I de första intrycken står händelsen så liksom utanför det ideologiska och sociala spel som den därefter genast dras in i, inlett av Rivas mor (som Riva tycks ha ärvt sin cynism ifrån):

Шурка Гусев, мокрый, запыхавшись, с блестящими глазами прибежал по берегу и схватил штаны:

- Девка утонула.

Толпились мужики, оставив на дороге свои возы с дровами, бабы в армяках и розовых юбках - с ворохами лаптей за спиной, купальщицы - застегивая пуговицы.

- Вот ее одежа, - таинственно показывала мать Ривы Голубушкиной, кругленькая, в гладком черном парике с пробором:

- Знаете ее обыкновение: повертеть хвостом перед мужчинами. Заплыла́ за поворот, чтобы мужчины видели...

Sjurka Gusev, blöt, flämtande, kom med glänsande ögon springande på stranden och grep sina byxor:

- En flicka har drunknat.

Bondkarlar, som lämnat sina vagnar med ved på vägen, samlades och gummor i vadmalsrockar och rosa kjolar - med bastskoknippen bakom ryggen - och baderskor som stod och knäppte knapparna.

- Här är hennes klär, visade hemlighetsfullt Riva Golubusjkinas mor, lite rundlagd i en slät svart peruk med bena:

- Ni känner hennes vana: svansa framför karlar. Hon simmade bortom flodkröken för att karlarna skulle se...

Kukin som huvudperson framstår som mottagare av dessa intryck. Vad han tänker och känner får vi emellertid inte veta något om. Han varken gör eller säger något som röjer hans inre. Hans tystnad kan tolkas som att han försjunker i sig själv och blir den lydige Georges igen såsom han tidigare porträtterats tillsammans med sin mor.

Till den stumma effekten av händelsen hör att vi inte får veta vem som drunknat. Hon omtalas bara nedlåtande som en som hade för vana att svänga med svansen framför männen, ett svängande som visserligen redan antyder Liz rörelser som de tidigare beskrivits. Denna nedlåtenhet efter någons död följt av bristen på reaktion från Kukin lämnar ett molande obehag. Rivas mor talar om att göra sig till men beskrivs samtidigt med en blänkande peruk. Berättelsen tycks neutral och utan värdering, men i denna lakonism kan man också se ett bågnande innestängt hat mot just denna brist på medkänsla, denna cynism och inskränkthet, under det nya samhällets ideologiskt röda yta. 
Direkt efter händelsen på stranden, utan att det utsagts att det är Liz som drunknat, följer en ny uppmaning från Riva, nu med en konkret strategi för hur han ska imponera på Fiškina:

«Почему вы к ней не подъезжаете? - писала Рива. - Я опять пришлю билет. Будьте обязательно. Есть вокальный номер:

$$
\begin{aligned}
& \text { деньги у кого, } \\
& \text { сад наш посещает, } \\
& \text { а без денег кто - } \\
& \text { в щелки подглядает. }
\end{aligned}
$$

После него сейчас же подойдите: - Что за обывательщина! Я удивляюсь; никакого марксистского подхода!»

"Varför lägger ni inte an på henne?" skrev Riva. "Jag skickar en biljett igen. Se till att komma. Det finns ett vokalnummer som går:

$$
\begin{aligned}
& \text { den som pengar har } \\
& \text { kan trädgården besöka, } \\
& \text { den som är på pengar bar - } \\
& \text { får genom springorna försöka. }
\end{aligned}
$$

Efter den så går ni genast fram: - Vad är det för kälkborgerlighet! Jag blir förvånad; inget marxistiskt förhållningssätt!"

Det Riva instruerar Kukin i är alltså hur han ska göra sig till en ideologisk kritiker av den småborgerligt lättsamma kupletten för att imponera på Fiškina. Vad Kukin tänker eller vem han är spelar ingen roll, huvudsaken är att lägga sig till med rätt ideologisk fernissa. ${ }^{182}$

Inte heller på detta meddelande följer någon reaktion från Kukin. Hemma med sin mor igen framträder han inte längre som ett subjekt. Bara den yttre stämningen ger en antydan om hans inre: dammet, värmen, flugorna och den ryska bärkrämen (istället för den franska efterätten blancmanger som han tidigare drömt om): ${ }^{183}$

\footnotetext{
I82 Möjligen ansåg man i redaktionen på Russkij sovremennik som först publicerade novellen att detta var en alltför krass skildring av ideologisk opportunism; "никакого марксистского подхода!" ("inget marxistiskt förhållningssätt!") hade i alla fall strukits. Med det, klagade Dobyčin efteråt, hade halva Fiškina försvunnit: "Половина Фишкиной с этим отскочила." Till Čukovskij 20 januari I925 (brev 9), PSSP, $25 \mathrm{I}$.

${ }^{183}$ Richard C. Borden ser detta som en betydelsebärande kontrast i noterna till sin översättning. Leonid Dobychin, Encounters with Lise and Other Stories, Evanston, Illinois, 2005, II9. Även utan denna koppling passar ordet med sin etymologi ("kislyj" betyder "sur") väl in i stämningen.
} 
Пыльный луч пролезал между ставнями. Ели кисель и, потные, отмахиваясь, ругали мух. Тихо прилетел звук маленького колокола, звук большого - у святого Евпла зазвонили к похоронам. Бросились к окнам, посрывали на пол цветочные горшки, убрали ставни.

- Курицыну, - объявила Золотухина, по пояс высунувшись наружу.

Кукина перекрестилась и схватилась за нос: - Фу! - Чего же вы хотите в этакое пекло, - заступилась Золотухина. - А мне ее душевно жаль.

En dammig solstråle trängde sig in mellan fönsterluckorna. De åt kräm och viftade svettiga ifrån sig och svor åt flugorna. Stilla svävade ljudet in från den lilla kyrkklockan, ljudet från den stora - i Helige Euplus ringde det till begravning.

De kastade sig fram till fönstren, rev ner blomkrukorna på golvet, tog bort fönsterluckorna.

- Kuritsyna, förkunnade Zolotuchina som lutat sig ut till midjan.

Kukina korsade sig och höll sig om näsan: - Fy! - Vad väntar ni er i den hära hettan, invände Zolotuchina. Ja, jag tycker innerligt synd om henne.

Stämningen - mörkt, instängt, varmt - härbärgerar känslorna som inte uttrycks. Klockringningen når så in, fysiskt konkret beskrivet, och med vad man ringer till som en stegring ur detta tillstånd. Med en anspänd iver öppnar de så helt konkret upp och släpper in de sinnliga intrycken av vad som sker. Det är moderns väninna som först nu krasst uttalar vem den döda är. Kuricyna, konstaterar hon, med Liz lite löjliga och banalt ryska efternamn. Redan med sin etymologi (höna, kyckling) spelar det in i den trivialisering av henne som Rivas mor inledde på stranden. Å andra sidan förmänskligar namnet henne. Hon är inte bara den Liz som hon varit i Kukins drömmar, utan den verkliga människa som så att säga just sammansättningen av Liz och Kuricyna rymmer. ${ }^{184}$ Att hon är en vanlig dödlig - som hennes bölder på ryggen tidigare gav uttryck för - görs nu makabert påträngande genom lukten från liket som Kukins mor reagerar på. På ett annat plan kan man se denna profant konkreta liklukt som en frammaning av detta faktiska människoliv som spillts. Generellt kan det ses tala för en mänsklighet bortom de

${ }^{184}$ Med hennes namn antyds överhuvudtaget en litterär referens till Nikolaj Karamzins klassiska berättelse "Bednaja Liza" ("Stackars Lisa") från I792. Den borgerliga Liz står i den sovjetiska samtiden efter revolutionen utanför samhället likt en spegelvändning av hur Karamzins bondflicka Liza gjorde det i slutet av I700-talet. Karamzins Liza dränker sig efter att ha haft en affär med och sedan blivit avspisad av den adlige Ėrast som efter att ha spelat bort sina pengar sett sig tvungen att gifta sig med en äldre, rik änka (som i det omvända samhälle Dobyčin skildrar kan ses motsvarad av Fiškina). Liksom Ėrast har svårt att släppa sina romantiska föreställningar om en renare kärlek med den enkla bondflickan Liza, har Kukin svårt att släppa sina föreställningar om den på samma gång socialt högre stående (enligt det gamla samhället) och utstötta (i det nya) borgerliga och flärdfulla Liz. Denna parallell utvecklas också av V. N. Toporov i "Rasskaz L. Dobyčina 'Vstreči s Liz' v kontekste bednoj Lizy 'železnogo veka'”, Willem G Weststeijn, Daniela Rizzi \& Tat'jana Vladimirovna Civ'jan (red.), "Vtoraja proza": Russkaja proza 20-ch-30-ch godov XX veka, Trento 1995, 82-90. 
yttre sociala och ideologiska skalen som de dagliga konflikterna i samhället utspelats i och som antydningsvis bidragit till detta slut. Liz död vardagliggörs men den avhumaniseras inte som något ideologiskt motiverat.

Det lilla "a" före "mne", ("men jag" eller som jag översatt det, "ja, jag") kan antyda att den syn som Rivas mor gav uttryck för redan på stranden har blivit vedertagen: att Liz på något sätt fick skylla sig själv eller i alla fall som ett borgerligt element inte är något att sörja. Att Zolotuchina behöver markera att hon trots allt känner djupt med henne kan också, i stil med tidigare antydningar om hennes utsatta situation, tänkas ge uttryck för att drunkningen inte bara uppfattats som vållad av hennes oförsiktighet utan som ett självmord.

Om Liz borgerliga bakgrund på något sätt låg bakom hennes död och om den var självförvållad eller inte utreds aldrig. Kukins enda replik i sista kapitlet och hans enda uttryck för sin reaktion på Liz död talar i stil med Zolotuchina bara om hans sympati med hennes art: "- Конечно, - сказал Кукин, - девушка с образованием..." ("- Visst, sade Kukin, en flicka med utbildning...") Repliken känns torr och kall, helt distanserad från några känslor. De tre punkter som den slutar i antyder möjligen något som han är oförmögen att ge uttryck för, för en sorg han håller hårt inom sig, men det finns ingredienser i berättelsen, exempelvis då han stod utanför hennes hus där hon låg sjuk, som helt enkelt talar för en oförmåga till verkligt medlidande. Den glatt dagdrömmande människa som han skymtade fram som i inledningen är i vilket fall försvunnen - antingen för att den han drömt om är död, eller för att detta drömmandes baksida blottats som en handlingsförlamning och en brist på känslor inför det verkliga. Är det synd att hon är död för att hon hade en god utbildning? Det är i alla fall allt han i denna undertryckthet säger om den hon var för honom.

Härefter fortsätter vardagen. De hör straffbataljonen sjunga Internationalen när de går ut efter att ha druckit te och Zolotuchinas ros i silver blänker till på en krage. Ett miniatyrlikt blänk till den sovjetiska musiken, men det är nog för att framkalla en sista liten stund av drömmande minnen. Den sovjetiska nationalsången får Zolotuchina att associera till den tidigare tsarryska. Hon talar i presens om det, att den och "Fader vår" sjungs så här dags, som om det Petersburg som minnet sannolikt härstammar från fortfarande fanns. Även (den imperiegula) kyrkan dit begravningståget troligen lett påminner henne om "det petersburgska", vilket antydningsvis återigen skriver in Liz i samma sfär som Petersburg och den förrevolutionära kulturen:

- В ротах, - встрепенулась Золотухина, - в этот час солдаты поют «Отче наш» и «Боже, царя». А перед казармой - клумбочки, анютины 
глазки... Я люблю эту церковь, - показала она на желтого Евпла с белыми столбиками, - она напоминает петербургское.

- I kompanierna, ryckte Zolotuchina upp sig, sjunger de "Fader vår" och "Gud, bevare tsaren" så här dags. Och framför kasernerna - rabatter, penséer... Jag älskar den här kyrkan - hon pekade mot den gula Euplus med vita pelare - den påminner om det petersburgska.

Stunden är också ett rekviem över denna kultur. Den finns bara i minnet nu. För Kukin finns inga alternativ kvar i det nya samhället. Liz är borta. Nu står han som en duktig pojke bredvid sin mor när den nya kulturens kvinna kommer gående. Och Fiškina ser sig fortsatt omkring med sitt förakt. Nu finns inget direkt trivialiserande eller förmänskligande i beskrivningen av henne (som hennes blickande genom fönstret tidigare). Kukin uppvisar inte längre någon självsäkerhet inför henne - möjligen hade den tidigare att göra med hans känslor för Liz. Fiškina är kraftfull och modern i sovjetiskt randig kofta och kort kjol. Kukins mor har inte deltagit i Zolotuchinas drömmande. Kanske har hon, för sin sons bästa, insett behovet av anpassning och ser Fiškina som passande för sin son. Och hennes Georges är lyhörd och rättar till slipsen för att nu göra ett gott intryck på Fiškina. Nu ser alla efter Fiškina. Mötena med Liz är över:

Все повернули головы. По улице, презрительно поглядывая, черненькая, крепенькая, в короткой чесучовой юбке и голубой кофте с белыми полосками, шла Фишкина.

- Интересная особа, - сказала Кукина.

Жорж поправил свой галстучек.

Alla vred på huvudena. På gatan, föraktfullt blickande, lite mörk och lite kraftig, i en kort råsidenkjol och blå kofta med vita ränder, gick Fisjkina.

- Intressant person, sade Kukina.

Georges rättade till sin lilla slips.

\section{Den samtide (Dobyčin kontra Erygin)}

"Erygin" är den första nya berättelse Dobyčin skriver efter att fått kontakt med Kornej Čukovskij och genom honom "Kozlova" och "Vstreči s Liz" antagna till tidskriften Russkij sovremennik. ${ }^{185}$ Dobyčin väntar fortfarande på

\footnotetext{
${ }^{185} \mathrm{Jag}$ gör här ett avsteg från ordningen i samlingen Portret - där de två novellerna "Lidija" och "Savkina" som är skrivna efter "Erygin" föregår denna efter "Vstreči s Liz" - eftersom "Erygin" belyser författarskapets utveckling efter debuten. I den första, mer kronologiskt ordnade novellsamlingen, följde "Erygin" efter "Vstreči s Liz".
} 
det fjärde numret som ska innehålla "Vstreči s Liz" när han i slutet av november 1924 börjar skriva på den nya berättelsen.

Med en lekfull ton skriver han till Čukovskij att den nya berättelsen är helt i samklang med samtiden eftersom den utspelar sig i den omedelbara samtiden: "«Повесть» писать я начал, и очень модную (то есть действие в I924 году)" ("Jag har börjat skriva en 'povest", och en mycket modern sådan (vilket vill säga att handlingen utspelar sig 1924)"). ${ }^{186}$ Tonen förklaras troligen av att Dobyčin tidigare i brevet beklagat att Čukovskij inte funnit novellen "Evdokija" från Večera $i$ staruchi publicerbar, antagligen främst för att den utspelar sig före första världskriget. ${ }^{187}$ Det är mot bakgrund av ratandet av denna novell, vilken Dobyčin tidigare förklarat vara den som han tycker mest om vad han dittills skrivit, som han med lätt sårad ironi understryker det mycket moderna i den nya men samtidigt förklarar det enbart vara liktydigt med att handlingen utspelar sig i den omedelbara samtiden. Så anpassar han sig till samtidens ensidiga krav på aktualitet som Čukovskij förmedlat genom sitt urval och också tidskriften Russkij sovremennik (Den ryske samtide) ger uttryck för redan i sitt namn.

Det fjärde och sista numret av Russkij sovremennik med hans "Vstreči s Liz" som det sista av de skönlitterära bidragen nådde Dobyčin den 20 januari 1925. På Čukovskijs inrådan vänder han sig därefter till Michail Slonimskij med sina alster - först med dem som befunnit sig hos Russkij sovremennik, men därefter, med "Erygin" som den första, också med nya. Medan Slonimskij under året 1925 ser till att både "Kozlova" som varit antagen för Russkij sovremennik och den nya novellen "Savkina" som tillkommit

\footnotetext{
${ }^{186}$ Han skriver povest' inom citationstecken för att Čukovskij efterfrågat något längre än en novell (rasskaz). Snart meddelar dock Dobyčin beklagande att det återigen bara blir en novell med fyra kapitel, av samma längd som de föregående två, som om han var dömd till denna form: "Должно быть, мне не уйти от «четырех глав»." ("Jag kan nog inte ta mig bort från 'fyra kapitel'") Möjligen innehåller detta en ironisk anspelning på författaren Lidija Sejfullinas povest' "Četyre glavy" från 1922 - en författare han återkommande driver med på grund av hennes ideologiskt inställsamma, gulliga realism. Se vidare om detta i samband med novellen "Lidija" i nästa kapitel.

${ }^{187}$ Troligen har Čukovskij åtminstone tyckt om detaljerna för Dobyčin lovar, tillsynes citerande ett omdöme, att "stoppa in dess 'friska' detaljer i andra alster": "Ее «свежие» детали я буду рассовывать по другим изделиям". Det ska vi se att han gör redan i "Erygin". Dobyčin skickar även novellen "Ninon" från den första provisoriska samlingen till både Čukovskij och Slonimskij med samma resultat; det framgår ur Dobyčins brev att Čukovskij funnit den "torr" (brev 7, PSSP, 250). Arkivforskning har nyligen visat att Russkij sovremennik hade den förkortade fyra kapitel långa versionen av "Evdokija", benämnd "Staruchi v mestečke" ("Gamla kvinnor i en köping") i sitt förvar och till och med, i motsats till vad som framgår av Dobyčins brev till Čukovskij, avsåg att ge ut den i ett senare nummer som aldrig kom till stånd. V.N. Sažin, "L. Dobyčin. Novye materialy k biografii i tvorčestvu", Kul’tura i tekst, I (19), 2015, 9-33, I3-I5, http://www.ct.uni-altai.ru/kultura-i-tekst-2015-II9, 20I9-03-I5.
} 
efter "Erygin" blir utgivna i tidskriften Leningrad där han ingår i redaktionen, verkar censuren först helt sätta stopp för "Erygin".

Dobyčin är från början högst medveten om att "Erygin" kan bli svår att publicera. När han fått det fjärde numret av Russkij sovremennik i sin hand ber han Čukovskij att hålla honom underrättad om eventuell kritik av hans debutnovell: "Если Начальники обратят внимание на «Встречи» и найдут их нахальными, очень прошу сообщить мне, по возможности подробно". ("Om De Överordnade lägger märke till 'Mötena' och finner dem fräcka, får jag verkligen be er att upplysa mig om det, om möjligt - utförligt.") I slutet av brevet använder han åter ordet "nachal'nyj" ("fräck" eller "grov") när han frågar om Čukovskij finner "Erygin" alltför "nachalen" underförstått för "Načal'niki" ("De Överordnade") - med andra ord för den redan hårdnande litteraturkritik och censur som Dobyčin genom Russkij sovremenniks öde fått en första erfarenhet av.

Denna "Erygins" fräckhet betyder å ena sidan att han från början tvivlar på möjligheten att få den utgiven, "Ерыгин, должно быть, так и пропадает" ("Erygin går nog troligen förlorad"), men å andra sidan gör det den särskilt angelägen för honom: "В особенности портит мне настроение неизвестность о Ерыгине" ("Det som i synnerhet förstör mitt humör är ovissheten om Erygin"). ${ }^{88}$

I breven till Michail Slonimskij återkommer han ständigt till frågan om "Erygin". Publiceringen ser han rentav som avgörande för sin framtid som författare: "Если Начальники не пропустят Ерыгина, мне, увы, по-видимому, больше ничего не придется печатать: то, что я буду писать впредь, будет тоже недостойно одобрения." ("Om De Överordnade inte släpper igenom Erygin, o ve, verkar det som att det inte kommer att bli aktuellt för mig att publicera något mer: det som jag kommer att skriva framöver, kommer inte heller att bevärdigas ett godkännande.")|'89 När Slonimskij två månader senare meddelar att "Erygin" knappast kommer att kunna publiceras, skickar Dobyčin redan nästa dag en lång lista med ändringar för att på så sätt trots allt försöka få den att passera. Han kallar det "en lista på reformer [...] för att blidka De Överordnade" ("список реформ [...] для смягчения Начальников"). ${ }^{90}$ Att Slonimskij publicerat "Kozlova" och både kan och vill publicera en annan ny novell, "Savkina", skriven efter "Erygin", tycks inte väcka någon större glädje. "Savkina" omtalar han nedlåtande när han

\footnotetext{
${ }_{188}$ Till Čukovskij 3 mars respektive Io mars 1925 (brev 12 och I4), PSSP, 252-253.

${ }^{189}$ Till Slonimskij Io februari 1925 (brev 43), PSSP, 268.

${ }^{190}$ Listan skickar han 5 april och omtalar den som citerat 7 april 1925 (brev 45 och 46), PSSP, 268-269. (Slonimskijs besked den 4 april framgår av Dobyčins brev till Čukovskij samma dag (brev I7), PSSP, 255.)
} 
skickar den som att "den blev lite tom" ("вышла какая-то пустопорожняя"). Och den anledning som han ser till denna tomhet förklarar indirekt varför den och inte "Erygin" går att publicera: "Это потому, что - без политики." ("Det är för att det är utan politik.")'19

Men "Erygin" blir ändå till sist, trots sin politik, kanske tack vare Dobyčins enträgenhet och Slonimskijs tålamod, publicerad i sin samtid. Den blir det i Serapionbrödernas litterära almanacka Kovš som Slonimskij också sitter i redaktionen för, dock först ett år senare, 1926 (fjärde numret), tillsammans med novellerna "Lidija" (också från våren 1925) och "Sorokina" (färdig hösten 1925). "Erygin" publiceras där helt i sin ursprungliga form, helt utan några politiska reformer.

\section{I (Författaren Erygin)}

Den samtid som "Erygin" utspelar sig i och förhåller sig till är alltså år I924, som han befinner sig i slutet av när han börjar skriva. De politiska händelser som beskrivs bekräftar detta. Handlingen sträcker sig från sommar till sen höst och äger rum i samma icke namngivna provinsstad (men med igenkännbara miljöer och motiv från Dobyčins egen verklighet i Brjansk) som nu - liksom ett svar på kravet på samtidighet - permanentas som hans berättelsers värld.

Berättelsen börjar med ett stycke som Čukovskij ansåg borde strykas, och man kan delvis förstå honom, för scenen med sin närbildsliknande uppmärksamma observation tycks inte ha något med det som sedan följer att göra:

Ерыгин, лежа на боку, сгибал и вытягивал ногу. Ее волоса чертили песок. ${ }^{192}$

Jerygin låg på sidan och böjde och sträckte på benet. Dess hårstrån gjorde streck i sanden.

Något effektfullare, kan man hålla med Čukovskij om, hade det varit att starta direkt med andra styckets trumvirvel och den tydligare rörelse som därmed sätts igång:193

\footnotetext{
${ }^{191}$ Till Slonimskij II maj 1925 (brev 52), PSSP, 27 I.

${ }_{192}$ Novellen citeras ur PSSP, 66-70.

${ }^{193}$ Dobyčin benämner visserligen Čukovskij sin ende läsare (före kontakten med Slonimskij) men tvivlar inte på sitt eget omdöme: "Многоуважаемый Корней Иванович, Вы не правы. Первый абзац нужен: там следы от волос на песке, а в четвертой главе - следы сена на снегу." ("Bäste Kornej Ivanovič, Ni har fel. Första stycket är nödvändigt: där finns spår av hår
} 
Затрещал барабан. Пионеры с пятью флагами возвращались из леса. Ерыгин поленился снова идти в воду и стер с себя песчинки ладонями.

En trumma smattrade. Pionjärerna med fem flaggor kom tillbaka från skogen. Jerygin orkade inte gå ner i vattnet igen utan strök av sig sandkornen med händerna.

Vem är denna Erygin som är berättelsens huvudperson? Vi följer honom nu, i första kapitlet av fyra, på hans väg från stranden in till marknaden i staden, och sedan hem. Det tycks vara söndag, veckans lediga dag.

Vi ska få se att han liksom Dobyčin själv vid den här tiden bor tillsammans med sin mor men däremot inte har några syskon (även i den mer öppet självbiografiskt baserade romanen Gorod Én saknar huvudpersonen syskon). ${ }^{194}$ Han är anställd vid arbetsförmedlingen liksom Dobyčin och framförallt: han skriver och får snart en berättelse publicerad.

Dobyčins berättarsätt har som nämndes i inledningen liknats vid filmens montageteknik, med sekvenser av närbilder och panoraman och därtill, som i den samtida stumfilmen, med repliker eller kommentarer inskjutna som textskyltar emellanåt. För detta har "Erygin" tagits som ett särskilt utmärkande exempel. ${ }^{195}$ Det man lätt förbiser med ett fokus på den generella tekniken är en mer väsentlig typ av "montage" för förståelsen av just denna berättelse; nämligen ett montage av texter med olika berättarsätt, och i förlängningen rentav olika förhållningssätt till världen, olika ideologier. Det är i kontrasten mellan de olika sätten att berätta om samtiden som berättelsens centrala konflikt manifesteras, mellan ett sökande i samtiden efter möten och porträtt å ena sidan och ett sökande efter dolda intriger och resoluta handlingar å den andra.

Denna konflikt utspelar sig huvudsakligen inom huvudpersonen, mellan vad han möter, hur vi får den värld förmedlad i vilken han utgör ett upplevande subjekt, och vad han - när han visat sig vara en ung sovjetförfattare - skriver med denna gestaltade verklighet som material. Kontrasten mellan Erygins egna försök till ett med den nya politiska ordningen ideologiskt och tematiskt lojalt skrivande och det sätt på vilket den berättelse som han utgör huvudperson i förmedlas, går även igen i en diskrepans mellan beskrivningen av den omgivande verkligheten och de infogade yttrandena om den. Huvudpersonen försöker vara modern, han försöker förhålla sig till det nya

\footnotetext{
i sanden och i fjärde kapitlet spår av hö i snön.”) 26 januari 1925 (brev II), PSSP, 252. (Att Čukovskij fann det bättre att inleda berättelsen med andra stycket framgår av brev $4 \mathrm{I}$ till Slonimskij, 27 januari I925, PSSP, 267.)

194 På samma sätt som Proust för övrigt uteslöt sin bror ur À la recherche du temps perdu.

195 Fëdor Fëdorov, "Dobyčin i kinematograf", $P L D, 69-76$, och "O kompozicionnom montaže v russkoj proze I920-x godov (Ju. Tynjanov, L. Dobyčin, M. Zoščenko)", DS-7, I62-175.
} 
sovjetiska samhället på ett ideologiskt riktigt sätt. Konflikten handlar om att verkligheten, som det gestaltas att han upplever den, är svår att passa in i det nya ideologiska mönstret. Samtiden är uppenbarligen inte lika modern som idén om den.

Konflikten finns redan mellan etymologin i huvudpersonens namn, från "eryga", ungefär "dagdrivare", vilket han inledningsvis gestaltas som ("leža", "polenilsja" ("låg", "orkade inte")), och de sovjetiska ideal han omedelbart därefter börjar uttrycka. Det vardagliga i hans drönande på stranden har följts av det nya sovjetiska i de tågande pionjärerna; nu uppträder denna kontrast också mellan det vardagliga i vad han ser, "По лу́гу бегали мальчишки без курток и швыряли ногами мяч" ("På ängen sprang små pojkar utan jacka och sparkade omkring en boll med fötterna"), och det politiska slagord som det kommenteras med i hans återgivna tankar: "- Физкультура, - подумал Ерыгин, - залог здоровья трудящихся." ("- Fysisk kultur, tänkte Jerygin, borgar för arbetarnas hälsa.") Och på det viset fortsätter det.

På marknaden reagerar Erygin inte nämnvärt på att någon tigger, däremot spanar han efter om några arbetslösa olovligen står och säljer något. Den ideologiska otydligheten fortsätter när Erygin nu möter sin överordnade, kamrat Generalov. Denne sovjettjänsteman, möjligen veteran från inbördeskriget om man ska lyssna till vad familjenamnet låter konnotera, framställs med en yttre beskrivning som å ena sidan markerat kommunistisk - han har till och med döpt sin dotter till Krasnaja Presnja (efter 1905-års revolt i detta arbetarkvarter i Moskva) - och å andra sidan som välmående och med lätt borgerliga vanor. Erygins reaktion avslutar stycket.

Перед лимонадной будкой толпились: товарищ Генералов, мордастый, в новеньком синем костюме с четырьмя значками на лацкане, его жена Фаня Яковлевна и маленькая дочь Красная Пресня. Наслаждались погодой и пили лимонад. Ерыгин поклонился.

Framför lemonadståndet trängdes kamrat Generalov, plufsig i ansiktet, i ny mörkblå kostym med fyra märken på slaget, hans fru Fanja Jakovlena och den lilla dottern Krasnaja Presnja. De njöt av vädret och drack lemonad. Jerygin bugade.

Erygin upprepar sovjetiska paroller för sig själv, utför sina plikter även på sin lediga dag samt bugar inför sin överordnade. Han framstår som en god sovjetmedborgare.

Så följer en episod som rentav än mindre än inledningsscenen tycks väsentlig för berättelsen: 
По заросшей ромашками улице медленно брели епископ в парусиновом халате и бархатной шапочке и Кукуиха с парчовой кофтой на руке: Клеопатра - русское имя? - говорили они. - Да. - А Виктория?

På gatan som var igenväxt med kamomill strosade biskopen i segelduksrock och sammetsmössa och Kukuicha med en broderad kofta över armen. - Kleopatra, är det ett ryskt namn? sade de. - Ja. - Och Viktoria?

Att det är Erygin som finner en laddning i den tillsynes helt triviala scenen och därför registrerar den, kommer att framgå först långt senare när den ideologiskt uttolkad och omstöpt kommer till användning i hans skrivande.

Att Erygin är författare, eller i alla fall drömmer om att bli en, framställs i slutet av första kapitlet. Han kommer hem till sin mor. Hon vill att han ska läsa några bokhållarkurser för att få bättre betalt, detta framställs som något hon brukar tjata om. Senare, på kvällen, får vi veta vad som håller honom tillbaka: medan modern stoppar kläder skriver han rent en berättelse.

Stämningen som omger skrivstunden byggs upp genom två kontrasterande grannkvinnor när han går ut och hämtar vatten i brunnen. Den ena, Ljubov Ivanovna, framställs där hon står i sitt fönster som en kvinna med intellektuella intressen. Hon är borgerligt elegant av sig: "В кисейной кофте, она одной рукой ощупывала закрученный над лбом волосяной окоп, другою с грацией вертела пион." ("Hon stod i muslinkofta och fingrade med ena handen på den rullade hårvalken ovanför pannan, med den andra snurrade hon elegant en pion.") Den andra kvinnan tycks sovjetiskt sinnad. Namnet, härlett från "korova" ("ko"), och attributen framställer henne mer kroppslig och mer banal: "Против колодца, прищурившись, глядела крохотными глазками белогрудая кассирша Коровина в голубом капоте." ("Mitt emot brunnen spejade kisande med pyttesmå ögon den vitbröstade kassörskan Korovina i en ljusblå kapott.") Och hon förknippas också vidare med det sovjetiska genom den musik som hörs och som hon frågar om:

[...] - Не знаете, откуда эта музыка? - Возвращаются со смычки с Красной Армией, - ответил Ерыгин и пошел улыбаясь: вот, если бы поставить ведра, а самому - шасть к ней в окно!

[...] Ni vet inte var musiken kommer ifrån? - De återvänder från en sammankomst med Röda armén, svarade Jerygin och gick leende därifrån: om han ställde ner hinkarna och så bara - vips upp till henne i fönstret!

På samma sätt som Kukin med Liz i förra novellen föreställer sig han ett aktivt närmande som han inte utför. Eftersom Korovina inte anges stå i sitt fönster (utan bara "mitt emot brunnen") tycks det vara den borgerliga Ljubov' Ivanovna som han har i tankarna och föreställer sig detta närmande 
till. Det underbyggs av vad denna senare på kvällen väcker hos honom med sin musik och sitt sätt: "Вечером Любовь Ивановна играла на рояле. Наигравшись, стала у окошка, смотрела в темноту, вздыхала и потрагивала голову - не развился ли окоп." ("På kvällen spelade Ljubov Ivanovna på flygeln. När hon spelat färdigt ställde hon sig i det lilla fönstret och såg ut i mörkret, suckade och kände på huvudet - valken hade väl inte löst upp sig.”) I denna längtande nostalgiska stämning får vardagliga småborgerliga föremål som omger Erygin en lyster över sig, liksom en mening, som den noggranna återgivningen insisterar på: "На комодике поблескивали вазы: розовый рог изобилия в золотой руке, голубой - в серебряной." ("På byrån stod vaserna och blänkte; ett rosa ymnighetshorn i en guldhand, ett ljusblått i en silverhand.")

Det är denna stämning som omger hans renskrivande (som likställs med moderns stoppande). Men med vad han skapat, som vi får ett utdrag av, framträder med ens det väsensskilda i Erygins skrivande från den berättelse han ingår i och den människa som där skymtat fram. Trots de yttre likheterna med sin författare och de lyriskt nostalgiska inslagen i den samtida sovjetiska verkligheten som tycks inspirera honom, så försöker Erygin uppenbarligen att följa med i tiden och vara en ideologiskt rättrogen sovjetförfattare. Han har valt ett av den samtida litteraturens mest omhuldade ämnen, Röda armén och inbördeskriget. I sin politiskt oklanderliga tappning, tillsynes influerad av samtidens proletärförfattare, skulle fragmentet rentav kunna tas som en förebild för trettiotalets socialistiska realism:

Белые бандиты заперли начдива Виноградова в сарай. Настя Голубцова, не теряя времени, сбегала за Красной армией. Бандитов расстреляли. Начдив уехал, а Настя выкинула из избы иконы и записалась в РКП(б).

Vita banditer låste in divisionschef Vinogradov i ett uthus. Nastia Golubtsova ödslade ingen tid utan sprang iväg efter Röda armén. Banditerna blev skjutna. Divisionschefen reste sin väg, och Nastia slängde ut ikonerna ur stugan och skrev in sig i RKP(b).

\section{2 (Samhället)}

Andra kapitlet börjar vid järnvägsstationen där Erygin närvarar vid ett högtidligt mottagande av utlänningar som är på rundresa för att beskåda det sovjetiska miraklet. Kvinnan som översätter deras tal framstår varken med sitt namn, mademoiselle Wunsch (önskan), eller attribut "med en sliten vit filthatt på sned" ("в истасканном белом фетре набекрень") som särskilt föredömlig för det nya samhället. Dessutom talar hon "med svag liten röst" 
("слабеньким голоском"). På så sätt skapas en mild, ironisk kontrast till anförandena som sammanfattas i en mening: "Они проезжали через разные страны и нигде не видели такой свободы." ("De hade rest genom olika länder och ingenstans sett en sådan frihet.") Och på det svarar folkmassan: "Ура! - Играла музыка, торжествовали и, гордясь отечеством, смотрели друг на друга." ("- Hurra! Musiken spelade, man jublade och såg stolt över fosterlandet på varandra.") Något som liknar engelska återges (i bearbetningen av novellen till samlingen Materjal har Dobyčin förtydligande infogat "[п]овторяли иностранные слова", att åhörarna på detta sätt "upprepade de utländska orden" ur talen). Återigen förmedlas en ironisk distans till det fullt igenkännliga språkbruket:

- Со́вьет репёблик!

- Реакшьон фашишт!

- Soviet repoblik.

- Reaksjon fasjisjt.

Men det är inte uppenbart satiriskt. Dobyčin visar upp, han framställer den politiska händelsen som den ter sig i en vardag, i ett pågående nu. Det ger det en mänsklighet som potentiellt blir kritiskt avslöjande eller förlöjligande. Det minimala i gestaltningen, de få sinnliga detaljerna, de talande namnen och lösryckta citaten, lyfter upp olika röster och perspektiv i samtiden. Enskildheterna är talande i sig, men utgör samtidigt, genom de kontraster de förmedlar i den helhet de ingår i, ett sätt att berätta.

Upprymda återvänder man till sina arbeten, sina kanslier. Kamrat Generalov, Erygins överordnade, förses med nya inte helt kommunistiska attribut; hans kontor har en schäslong och han läser något som handlar om tolv världsberömda konstverk. ${ }^{196}$ Erygin sätter sig på sin plats, bakom ett galler, en avbalkning, till kontoret, eller "bakom galler" som det syntaktiskt framhävs ("Ерыгин - за решетку"). Två käcka och gladlynta arbetskollegor beskrivs som kontrast till Erygin: "Захаров и Вахрамеев подскочили расспрашивать. Здоровенные, коротконогие, в полосатых нитяных фуфайках. Они, черт побери, проспали." ("Zacharov och Vachramejev skuttade fram för att höra sig för. Kraftigt byggda, kortbenta, i randiga trådiga undertröjor. De hade, fan i mig, försovit sig.") Sedan släpps de arbetslösa in. Detta är Erygins arbete.

\footnotetext{
196 I den senare versionen, i Mater’jal, har det tillfogats att det är en bilaga till Izvestija. I kommentarerna till den första version av berättelsen förklaras dock "Dvenadcat' Proizvedenij Mirovoj Živopisi" vara ett premiealbum till Krasnaja Niva från I923. PSSP, 464.
} 
På kvällen återkommer grannen Ljubov' Ivanovna, hon lägger sitt hår, sin "valk", "okop" som också betyder skyttegrav, och sätter fast en reseda i koftan. Och även Erygin visar ett visst făfängt intresse för sitt utseende, han speglar sig och verkar nöjd: "белая рубашка с открытым воротом была к лицу" ("den vita skjortan med öppen krage klädde honom"). Känslosamheten byggs ut med en bild av flickor som går ut genom grindar och skyndar någonstans med sina kavaljerer. Det har emellertid också nämnts att musik börjat dundra och de privata känslorna i luften blandas snart med ännu en politisk tillställning. För det de skyndar sig till är ett arrangemang på torget till förmån för det översvämningsdrabbade Leningrad. ${ }^{197}$ En paroll återges: "- Под руководством коммунистической партии поможем трудящимся Красного Ленинграда!" ("- Under kommunistpartiets ledning hjälper vi Röda Leningrads arbetare!") Därefter följer vad som förefaller vara antingen Erygins inre föreställning eller hans anteckningar:

Ленинград! Ревет сирена, завоняло дымом, с парохода спускаются пузатые промышленники и идут в музей. Их обгоняют дюжие матросы - бегут на митинги. В окно каюты выглянула дама в голубом...198

Leningrad! En siren tjuter, det stank av rök, från ångbåten går rundmagade industrimän ner och beger sig till museerna. De blir omsprungna av kraftiga matroser - på väg till massmöten. I fönstret på en kajuta tittade en dam i ljusblått ut...

En ny paroll utropas: "- Да здравствуют вожди ленинградского пролетариата!" ("- Leve ledarna för Leningrads proletariat!") Det blåses i trumpeter, skjuts raketer, bengaliska eldar tänds. Och ur det tumultartade politiska sammanhanget kommer plötsligt en ny syn av kassörskan Korovina. Hon lyses upp av eldarna och beskrivs som rundaxlad, fnissande, pudrad och med grisögon. Och hon tycks nu ha hittat en annan, mer passande partner i kassören Edrenkin ("edrënyj" eller "jadrënyj" betyder kraftfull, frisk, stark). Bakom den svartsjuka eller bara krassa blicken förnimmer vi Erygins närvaro fast han fortfarande inte nämnts under tillställningen. Efter en blankrad följer tre fristående sinnliga intryck som slår an en lyrisk stämning som liknar den i slutet av första kapitlet: "Из дворов несло кислятиной. За лугами, где станция, толпились огни и разбредались. Без грохота обогнала́ телега, блестя шинами." ("Det luktade surt inifrån gårdarna. Bortom

197 Översvämningen är en verklig händelse från september I924. Hjälpkampanjer ordnades över hela landet. PSSP, 464 .

${ }^{198}$ I versionen i Mater'jal är detta stycke liksom fragmentet av det han renskrev tidigare indraget på samma sätt som hans eget skrivande markeras längre fram även i denna version av novellen. 
ängarna där stationen låg samlades och skingrades eldar. Ljudlöst körde en vagn om, däcken glänste.”)

Vi får nu säkert veta vems hemväg vi följt: "Ерыгин отворил калитку." ("Jerygin öppnade grinden.") Erygin tycks på samma sätt som i första kapitlet långt från det politiska som han visat prov på i sitt skrivande. Han ser på månen och bilden av damen i ett båtfönster återkommer: "Над сараями выплыла луна, наполовину светлая, наполовину черная, как пароходное окно, полузадернутое черной занавеской." ("Ovanför uthusen gled månen fram till hälften ljus, till hälften svart, som fönstret på en ångbåt, halvt fördraget med en svart gardin.") Den klassiskt romantiska bilden, och det lätt poetiska i meningens rytm och klang, framställer en vackert vemodig ensamhet och personlig längtan. ${ }^{199}$

Han avbryts i sitt sentimentala drömmande av modern. Hon hade uppenbarligen (i linje med att han borde vidareutbilda sig) önskat att han stannat ute längre, att han träffat någon: "- Ты? - удивилась мать. - Скоро!" ("Är det du? frågade modern förvånat. Redan!")

Så slutar andra kapitlet.

\section{3 (För vem talar detaljerna?)}

"«Настя» будет напечатана. Пишите..." ("'Nastia' kommer att publiceras. Skriv..."), börjar plötsligt, i ett självständigt stycke, det tredje kapitlet. Av titeln att döma är det berättelsen som Erygin renskrev som han fått antagen. Han blir som Dobyčin genast uppmanad att skriva något nytt.

$\mathrm{Nu}$ följer en tid i berättelsen där Erygin, liksom sin författare tycks ha gjort, söker efter uppslag till en ny berättelse och slutligen finner det i ett sätt att förhålla sig till, och bruka, den ideologiskt otydliga samtida verkligheten i sitt skrivande. Dobyčins resultat blev denna novell "Erygin" som skildrar just denna tillvaros idémässiga otydlighet genom de olika rösterna och perspektiven, genom mönster och kontraster av yttringar och sinnliga detaljer. Huvudpersonen Erygin däremot söker i sitt skrivande snarast ett sätt att ideologiskt avslöja samma tillvaros detaljer, att ideologiskt förklara dem.

\footnotetext{
${ }^{199}$ Den melodramatiska bilden har Dobyčin återanvänt från novellen "Evdokija”. Där är det vänskapen med den polska grevinnan som denna bild, med dess trots allt halvöppna fönster, ger huvudpersonen hopp om. Den ljudlösa och glänsande vagnen tidigare är i sin tur en återanvänd detalj från den likaledes outgivna "Kukueva" i Večera i staruchi. (I romanen Gorod $\dot{E} n$ skildrar en ljudlös vagn, på grund av nya gummidäck, en del av den historiska utvecklingen före första världskriget.)
} 
När Dobyčins första noveller blev antagna hade Russkij sovremennik redan börjat väcka skarp kritik. Kritiken skulle snart tillta. Den nya ekonomiska politiken hade i början av året möjliggjort en litterär tidskrift som Russkij sovremennik, den första, sedan avskaffandet av fri press efter revolutionen, som inte var bunden till partiet. Det första numret utkom i den tid av ovisshet som rådde efter Lenins död 2I januari 1924 och två nummer till av de sex som var planerade för året hann se ljuset innan en ny stramare kulturpolitik började göra sig gällande. Under hösten följde en omfattande nedskrivning av tidskriften i den officiella pressen, vilket ledde till att det fjärde numret, med Dobyčins första novell, det som skulle bli det sista, hölls av censuren och blev kraftigt fördröjt.

I Pravda den 5 november gjordes politiken tydlig: "В «Русском современнике» нэпманская литература показала свое подлинное лицо." "I Russkij sovremennik har NEP-litteraturen visat sitt rätta ansikte." Vad detta rätta ansikte innebar klargjorde tidskriften Zvezda sedan redan i rubriken till sin recension av de tre första numren: "Единый фронт буржуазной реакции" ("Den borgerliga reaktionens enade front"). Och i partiorganet Bol'ševik följde en vink om tidskriftens öde i rubrikens ordlek: "Несовременный Современник" ("Den osamtidige samtide"). ${ }^{200}$

Russkij sovremennik med sin i namnet deklarerade inriktning på det samtida ansågs alltså redan otidsenlig. Den egentliga frågan rörde sig dock snarast om vilken slags ny litteratur som samtiden behövde, och därmed, genom de vidare inskränkningar av yttrandefriheten som indirekt påbjöds av kritiken, om den fortsatta kulturpolitiken.

Med Maksim Gor'kij, Aleksandr Tichonov, Čukovskij och Evgenij Zamjatin i redaktionen, som alla i någon form tagit del i den revolutionära rörelsen, kunde det inte vara tal om tidskriften som någon i egentlig mening borgerlig och reaktionär bastion. Debatten, om man betraktar det som en sådan, mellan tidskriften och den mer eller mindre officiella kritiken, stod istället mellan olika socialistiska uppfattningar om hur litteraturen skulle ta del i utvecklingen av det nya samhället. Abram Ėfros, den femte redaktionsmedlemmen, uttryckte i en artikel i första numret av Russkij sovremennik en syn på konstens förhållande till samhället som är talande för tidskriften i stort: "Konstens sociala värde är direkt proportionellt mot dess koncentration av liv - dess sociala verkan direkt proportionell mot dess formella fulländning." Det samtiden i första hand behövde var därför inte per se arbetares

\footnotetext{
${ }^{200}$ Dobyčin håller sig ajour med detta tack vare att fackföreningen för folkhushållning (Narpit), vars servering dyker upp i början av nästa kapitel, trots kritiken prenumererade på Russkij sovremennik. Till Čukovskij december 1924 (brev 6 samt kommentarer), PSSP, 249, 505.
} 
amatörmässiga hantverk, utan att ett konstnärligt mästerskap återupprättades, vilket var vad Russkij sovremennik ville bereda plats för, diskutera och utveckla. ${ }^{201}$

Talet om hantverkare kontra mästare för tankarna till trettiotalet, den till Stalin tillskrivna parollen om författare som "själens ingenjörer" kontra Bulgakovs skildring av en mästare. Den sovjetiska litteraturpolitiken syntes under tjugotalet dock fortfarande öppen för en utveckling av det litterära mästerskapet oavsett klassbakgrund, med en tolerans för så kallade medlöparförfattare som borgerlig expertis på samma sätt som inom andra områden. Samtidigt prioriteras redan 1924 tydligt ideologisk lojalitet framför konstnärlig kvalitet av samtidens kritiker. Och snarare än att stimulera några fria mästare inom konsten kom man, för att tala i Ėfros termer, att å ena sidan försöka skola hantverkarna till mästerskap och å andra sidan ideologiskt tämja eller tysta de frispråkiga mästarna. Kanske är det en sådan ideologiskt lojal hantverkare, som också tycks vara det slags författare som kritiken av Russkij sovremennik påbjuder, som Dobyčin porträtterar med Erygin, och problematiserar genom de sidor av honom som inte visar sig i det han författar.

Kritiken mot Russkij sovremennik kom inte i form av någon egentlig polemik mot den litteratursyn som tidskriften gav uttryck för. Istället inriktade man sig på enstaka detaljer i texterna som man menade avslöjade att en borgerlig och reaktionär ideologi dolde sig bakom dem, och därmed bakom tidskriften som helhet - det "rätta ansiktet", som Pravda skrev, hos den litteratur som NEP gett utrymme för. I fjärde numret, där Dobyčin debuterade, lät redaktionen publicera ett svar på kritiken med titeln "Peregudam" ("Till Pereguderna"). Det är inte så mycket ett svar som en satir, omisskännligt författad av Evgenij Zamjatin, över kritikernas tillvägagångssätt, över just deras användande av lösryckta detaljer som komprometterande bevis. Zamjatin jämför kritikerna med Onoprij Opanasovič Peregud i Leskovs povest’ Zajačij remiz (Harsnåret) som för att avslöja en misstänkt samhällsomstörtare i I80o-talets Ryssland lägger beslag på en av dennes anteckningar och framlägger det för överheten i hopp om att därmed vinna uppskattning. Anteckningarna visar sig då vara från evangelierna. På samma sätt och med

\footnotetext{
201 "Социальная ценность искусства прямо пропорциональна его жизненной насыщенности - социальная активность искусства прямо пропорциональна его формальному совершенству. Это значит, что восстановление мастерства есть первейшая задача сегодняшнего дня. Современность должна быть мастером, а не ремесленником. Пусть у нее будут точные и тонкие руки, - иначе она лишь испортит материал и инструмент - и поранит себя." Abram Ėfros, "Vosstanie zritelja", Russkij sovremennik, I, I924, 272-279, 279.
} 
samma resultat, menar Zamjatin, är det som de unga kritikerna nu söker ovedersägliga bevis för att Russkij sovremennik är samhällsomstörtande. ${ }^{202}$

Kritikerna tycker sig med sina exempel avslöja det borgerligt reaktionära som döljer sig bakom texterna i tidskriften, Zamjatin visar upp det absurda i deras ideologiska tolkningar av de textställen de för fram som bevis och försvarar så indirekt verkens konstnärliga integritet och behovet av en fri litteratur. Det är den konspiratoriskt sinnade, ideologiskt avslöjande strategin som kommer att bli tongivande för litteraturkritiken och censuren framöver, men delvis också för själva den nya lojala hantverksmässiga realismen och dess förhållande till verkligheten. Detta demonstreras i "Erygin".

"«Настя» будет напечатана. Пишите..." ("'Nastia' kommer att publiceras. Skriv...") Så börjar alltså det tredje kapitlet i "Erygin". Vad ska då Erygin skriva om härnäst?

Genom fönstret ser han och hans mor hur en ryttare anländer till den kultiverade grannen Ljubov' Ivanovna vilken strålande kommer utspringande. Inget mer följer på händelsen, men det får Erygin att dagdrömma: "Ерыгин приятно задумался. Вспомнил строку из баллады." ("Jerygin blev behagligt tankfull. Han mindes en rad ur en ballad.") Modern liknar antydande detta skådespel och Erygins iakttagande av det genom fönstret med en film på bio och är åter den som kallar Erygin tillbaka till verkligheten: "- Кинематограф, - посмеялась мать и засучила рукава - мыть тарелки." ("- En biograf, skrattade modern och vek upp ärmarna - för att diska tallrikarna.")

Några lösa detaljerade miljöbilder följer: "Золотой шарик на зеленом куполе клуба «Октябрь» блестел." ("Guldklotet på den gröna kupolen på Oktoberklubben glänste.") Klubben tycks vara inhyst i en tidigare kyrka (som man fjärnat korset från). .20 "Низ штанов облепили колючие травяные семена." ("I byxornas nederkant fastnade stickiga frön från gräset.") Vad har dessa gräsfrön med något att göra? Och slutligen en bild av en polisman i en situation långt ifrån allt politiskt och samtida (eller betyder just den genomgående gröna färgen i intrycken något?): "Милиционер с зелеными

\footnotetext{
${ }^{202}$ Att läsa evangelierna på ryska kunde förvisso uppfattas som något av en revolutionär handling på I8oo-talet. Det man läste i hemmet var en andaktsbok medan bibeln lästes på kyrkoslaviska och av präster och munkar och eventuellt nunnor. Läsandet av evangelierna eller bibeln som något nytt, som Kukins mor i förra novellen visade prov på, antyder ett deltagande i en förnyande rörelse inom kyrkan (obnovlency) vilket vidare kommer att tematiseras i novellen "Portret" som jag tar upp i fjärde kapitlet.

${ }^{203}$ Som verklig förebild tjänar enligt Brjanskforskaren Golubeva den stora katedralen i Brjansk (Novo-Pokrovskij sobor) som 1924 stängdes och gjordes om till ett Folkets hus med biograf med namn efter Oktoberrevolutionen. Ė. S. Golubeva, Pisatel' Leonid Dobyčin i Brjansk, Brjansk 2005, 75-82.
} 
петлицами стоял у парикмахерской. Ему в глаза томно смотрела восковая дама." ("En milisman med gröna kragspeglar stod vid frisersalongen. En dam i vax såg smäktande in i hans ögon.") Det här är Erygins vardagliga samtid. Vad ska han skriva om?

Efter bilderna följer ett möte mellan Erygin och hans käcka kollegor från arbetet på en bro som de badar ifrån. Deras bara kroppar beskrivs, Erygin känner på deras muskler, de röker. Och kollegorna berättar att de antagits till bokföringskurserna. Frågan ligger i luften, ska Erygin trots allt följa deras exempel (såsom modern tidigare föreslagit)? "- Нет, - сказал Ерыгин, у меня в голове другое. / Он пошел. Они взобра́лись на перила и бултыхнулись." ("- Nej, sade Jerygin. Jag har annat i huvudet. / Han gick. De tog sig upp på räcket och plumsade i.") Nej, allfartsvägen är inte hans, tycks detta uttrycka, han har sitt skrivande; han går sin väg och de hoppar i vattnet.

Mademoiselle Wunsch, tolken, är nästa person han stöter på. Hon sitter under ett pilträd med sin hatt på sned med vilket hon sägs likna en rövare. Erygin hälsar sovjetiskt med en honnör. Hon ser honom inte; hon blickar, "med halvblinda ögon" ("подслеповатыми глазами"), mot den ljusa himlen i väster, och drömmer. Beskrivningen som färgas av Erygins perspektiv, likheten med en rövare, det närsynta blickandet mot väst, visar att detta inte heller är hans väg, eller en väg överhuvudtaget.

Det skymmer, blir fuktigare, ett tåg syns passera som det yr gnistor kring - och i denna melankoliska stämning skrivs det så ut vad som plågar Erygin: "ничего из жизни Красной Армии или ответственных работников не приходило в голову" ("han kunde inte komma på något om livet i Röda armén eller om ansvarsfulla arbetare"). Han hittar inget av det ideologiskt önskvärda att skriva om. Det som följer, med indragen marginal, liknar anteckningar, skisser till berättelser, som framställs som det som rör sig genom hans huvud i stunden. Först: "Шагает рота, красная, с узелками и вениками, хочет квасу..." ("Ett kompani marscherar, de röda, med knyten och ruskor, vill ha kvass...") Idén tycks stranda, kanske i det alltför profana, mänskliga behovet hos de röda. Istället följer något ur hans samtid. Men porträttet av hans överordnade blir inte heller vidare politiskt rätlinjigt:

Расскандалился безработный, лезет к товарищу Генералову. А у него на кушетке Фаня Яковлевна с Красной Пресней - принесли котлету. - Товарищ, прошу оставить этот кабинет!..

En arbetslös har tappat fattningen, tränger sig in till kamrat Generalov. Och hos honom på schäslongen är Fanja Jakovlevna och 
Krasnaja Presnja - de kom förbi med en kotlett. - Kamrat, jag ber er lämna det här kontoret!204

Sedan börjar tankarna bli alltmer politiskt otydliga och för samtiden ovidkommande, vilket också först konstateras i en vanlig mening mellan de indragna styckena: "А постороннее, чего не нужно, вертелось:" ("Bara ovidkommande, sådant som inte behövdes, snurrade:") Det som följer är en föreställning av Mademoiselle Wunsch som ung, ett bakåtblickande till nationalistiska manifestationer i början av första kriget. I sin ideologiska otydlighet, sin vardaglighet, är det långt från vad vid sett Erygin skriva och vad samtiden efterfrågar:

Мадмазель Вунш, еще молоденькая, слабеньким голоском диктует: «Немцы - звери». - На столе клеенка «Трехсотлетие»: толстенькие императорши, в медалях, с голыми плечами и с улыбками... - До свиданья. - Бродит лошадь. Бородатые солдаты молча плетутся на войну. У дороги стоит барыня - сует солдатам мармелад. Последние три штучки отдает Ерыгину...

Mademoiselle Wunsch, fortfarande en ung flicka, dikterar med svag liten röst: - "Tyskar är odjur". - Vaxduken "Trehundraårsjubileum" ligger på bordet: de små tjocka tsardöttrarna med medaljer, bara axlar och leenden... - På återseende. En häst stryker omkring. Skäggiga soldater släpar sig iväg mot kriget. Vid vägen står en ung dam - sticker till soldaterna marmelad. De sista tre bitarna ger hon till Jerygin...

"Eryginu" ("till Jerygin")? Att hans namn dyker upp i slutet tycks bekräfta att fragmentet inte ska läsas som Erygins egen antecknade skiss. Snarare en föreställning då som återges i denna form, i presens och med en syntax som liknar anteckningens, en föreställning som i slutet börjar likna ett barndomsminne där Erygin ser sig själv. Men egennamnet påkallar också berättelsens författare, Dobyčin, och dennes skrivsätt som kan förefalla utgå från liknande anteckningar - predikatlöst ibland, en ordföljd som liksom följer tanken, knappheten. Man kan därmed också läsa det som Dobyčins eget skissande, sina utkast och sökanden efter en ny berättelse under denna tid, som han indirekt gestaltar genom dessa Erygins föreställningar. Till innehållet bär detta sista mest omfattande fragment - som rubriceras som ovidkommande och onödigt - dessutom likheter med den under hösten av Čukovskij avfärdade (och av Dobyčin särskilt avhållna) novellen "Evdokija"

\footnotetext{
204 Dessa två första utkast strök Dobyčin som en av sina politiskt mildrande reformer (som
} alltså till sist inte visade sig nödvändiga för att få novellen publicerad). PSSP, 43 I. 
(Wunsch påminner om den också nationalistiskt aktiva huvudpersonen Katerina Aleksandrovna i den novellen där även den rojalistiska vaxduken förekommer, och det är tiden före första världskrigets utbrott som skildras). Detta var just vad Dobyčin av Čukovskij hade fått veta var ovidkommande och onödigt för samtiden.

Klockan i brandtornet slår elva och tredje kapitlet slutar som det andra, med en bild av månen (här "красная, тусклая, кривая", "röd, matt och sned") och att Erygin återvänder hem i en dyster sinnesstämning. När han knackar för att bli insläppt lutar sig grannen Ljubov' Ivanovna, som också står för denna längtande, nostalgiska sida, ut genom fönstret och får åter sitt yttre beskrivet: "в ночной кофте, с бумажками в волосах" ("i nattkoftan och med pappersbitar i håret"). Hon undrar vem det är till. Vi vet nu, i och med synen av ryttaren, att det inte är Erygin hon väntar på.

Fantasin om en dam i blått i förra kapitlet (efter att han sett kassörskan med en annan) som upprepades vid hemkomsten i månens likhet med dennas halvt fördragna båtfönster, framstår nu tydligare som också ett uttryck för hans känslor för Ljubov' Ivanovna, vilket även första kapitlet slutade med.

\section{4 (Lösningen)}

Tiden går nu. Medan de första tre kapitlen har skildrat tre sommardagar (den tredje möjligen i september) passerar hela hösten i det fjärde. Ett nytt tillstånd beskrivs efter att Erygin inledningsvis står utanför en servering "Перед столовой «Нарпит» воняло капустой" (Det stank av kål framför serveringen Folkhushållet") -, blickar in, skymtar en slumrande kassörska, blir störd av en panoramaförevisare som (helt ovidkommande) erbjuder honom att titta på den belgiska staden Liège, ruskar av sig denne och slutligen skyndar iväg till bokföringskurserna för att - som han motiverar det för sig själv med det argument modern använde i början av novellen - tjäna mycket pengar och kunna gå till serveringen och dricka öl.205 Ger Erygin därmed upp sitt skrivande?

\footnotetext{
${ }^{205}$ Möjligen spanar han också efter sin granne kassörskan Korovina när nu Ljubov’ Ivanovna är ute ur bilden. Detta inre resonemang, där också moderns ord ekar, framställs för övrigt genom fri indirekt diskurs (erlebte Rede): "Будет много получать, придет пить пиво." ("Наn skulle tjäna mycket, komma och dricka öl...") Det vill säga på ett sätt, med en språklig interferens, som, vilket jag tog upp i inledningen att forskaren Boris Maslov menat, knappt förekommer hos Dobyčin. I själva verket kan man finna ett flertal exempel, där inte bara intrycken, som Maslov uteslöt, utan även inre tal framställs på ett liknande dialogiserande sätt, vilket inte bara ifrågsätter Maslovs retoriska karaktärisering av Dobyčin utan också Fedorovs beskrivning av det som filmiskt montage.
} 
Erygin umgås härefter med sina käcka kollegor på arbetet utan att något tycks skilja dem åt. De skrattar tillsammans åt en skämtteckning över Tyskland under den femte Dawesplanen som en av dem ritar när de inte har några arbetslösa att ta emot: "дождь, плавают утки, рабочие с бритыми головами таскают камни, надсмотрщики щелкают коровьими кнутами, из-под зонтика выглядывают социал-предатели, потирают руки и хихикают" ("regn, simmande ankor, arbetare med rakade huvuden släpar stenar, tillsynsmän snärtar med oxpiskor och ut under paraplyet tittar socialförrädare, gnuggar händerna och fnittrar"). En ideologisk karikatyr som helt stämmer in i den officiella sovjetiska kritiken av planen (som innebar reducerade krigsskadestånd för Sovjet) utifrån att de tyska socialdemokraterna, dessa "social-förrädare", hjälpt till att kväsa revolutionen och nu skodde sig på arbetarnas bekostnad. I sin ideologiska rätlinjighet påminner teckningen om det sätt att skriva om samtiden som Erygin eftersträvar.

Sedan är det redan november och första snön har kommit. Beskrivningen av revolutionsfirandet begränsar sig till ett konstaterande: "Седьмого и восьмого веселились" ("Sjunde och åttonde roade man sig"). Det nämns att även Erygins mor varit på klubben "Oktober", men att hon spottar åt det ("plevalas'") på vägen hem, troligen för att klubben är inhyst $\mathrm{i}$ en kyrka. (Att stryka att hon spottar är ännu en av de reformer Dobyčin föreslår när han försöker att politiskt mildra berättelsen.) Uppenbarligen är Erygins mor trots sin uppvisade pragmatism inte så sovjetisk som Erygin försöker vara.

De korta inledningsmeningarna till de tre föregående styckena har (på liknande sätt som i "Proščanie") angett stämningsförändrande tillstånd i naturen: "Глина раскисла.", "К праздникам подмерзло.", "Висели тучи." ("Leran blev lös.", "Det frös på fram mot helgerna.", "Molnen hängde.") Tiden har gått och stämningen har byggts upp till en avslutande episod i vilken Erygin har återvänt till platsen där novellen inleddes.

Landskapet bortom floden är nu snötäckt: "За рекой было бело - с черными кустиками." ("Det var vitt bortom floden - med svarta buskar.") En klockringning bakom honom och en bro av hästben över en bäck bygger på den ödesmättade svartvita stämningen. Det har nämnts att några bönder som driver sina kor kommer emot honom, nu lägger han märke till att höet som de fraktar hänger ner och gör spår i snön: "Тоненькие стебельки свисали и чертили снег..." ("De tunna små stråna hängde ner och gjorde spår i snön...") Och det får honom att minnas något: "Что-то припомнилось." ("Något kom till minnes.") Det förklaras att det är just den där stunden på stranden på sommaren, den som inledde novellen, vilken följdes av att pionjärernas trumma hördes, som han minns: "Барабанный треск, песок 
тонко исчерченный..." ("Trumsmatter, sanden täckt av tunna streck...") Det är en upplevelse av något betydelsefullt. Streck i snön liksom streck i sand kan därtill specifikt leda tankarna till skrivande.

Inget mer berättas om Erygin, det ovanstående är det sista. Det som följer som avslutning på novellen är en ny längre text författad av Erygin. Den plötsliga hågkomsten med den känsla den tycks ge honom av ett subtilt sammanhang, en helhet, i symmetrin av detaljer, ger inte bara form åt Dobyčins berättelse om den svårgripbara samtiden. Det plötsliga sammanhang som framkallas i Erygins tillvaro går nämligen igen i det utkast som Erygin som en berättelse i berättelsen kan författa i sin otvetydiga ideologiska stil. Erygin tycks nu till slut ha funnit ett sätt att göra bruk av sin samtida tillvaro för sitt skrivande. På ett likartat sätt som de ideologiska kritikerna i samtiden avslöjar han vad som döljer sig bakom detaljer som förefallit oskyldigt vardagliga; det vill säga såsom Dobyčins uppvisande framställning antytt att han själv tidigare varseblivit dem. Nu kan Erygin forma en berättelse genom att som en ideologisk teckentydare uttolka de reaktionära konspirationer detaljerna vittnat om, och så visa vad det "rätta ansiktet" är bakom sin samtida tillvaros ideologiska otydlighet. Det blir Erygins berättelse om samtiden. Den sluter också än tydligare den större berättelsen genom att tidigare tillsynes lösa scener nu återkommer i hans ideologiskt avkodade form.

Det börjar med kvinnan och biskopen som han såg på en övervuxen gata i första kapitlet, hon betecknas nu "nepmanša", NEP-kvinna. Dessa blir sedan sammankopplade med hans kulturella granne (möjligen i ett slags undermedveten hämnd för de känslor för henne som han tvingats övervinna) och hennes ryttare. De får också, som ett blottande av Dobyčins eget grepp att använda karaktärstecknande egennamn, plumpt övertydliga talande namn. "Intelligentka Gadova" säger allt om vad för ett äckligt odjur ("gad") som döljer sig bakom Ljubov' Ivanovnas borgerliga yttre. "Kamrat Leningradov", som presenteras som en ansvarsfull arbetare och oklanderlig revolutionär, får ersätta den berättade verklighetens tvetydiga "Generalov". Erygin använder sig också liksom sin författare av färger. Samtidigt fortsätter med denna Erygins text också Dobyčins visande berättarsätt. Dobyčin gestaltar detta konspiratoriska ideologiska skrivande, liksom Zamjatin försökte göra med kritikernas recensioner, för att utifrån den ram hans tidigare skildring gett skratta åt dess absurditet in till sista meningens bitande ironi:

По зеленой улице с серыми тропинками разгуливают архиерей и нэпманша - затевают контрреволюцию. Интеллигентка Гадова играет на рояле. Товарищ Ленинградов, ответственный 
работник, влюбляется. Ездит к Гадовой на вороном коне, слушает трели и пьет чай. Зовет ее в РКП(б), она - ни да, ни нет. В чем дело? Вот Гадова выходит кормить кур. Товарищ Ленинградов заглядывает в ящики и открывает заговор. Мужественно преодолевает он свою любовь. Губернская курортная комиссия посылает его в Крым. Суд приговаривает заговорщиков к высшей мере наказания и ходатайствует о ее замене строгой изоляцией: Советская власть не мстит.

På den gröna gatan med grå stigar strövar en biskop och en NEPkvinna - de förbereder en kontrarevolution. Den intellektuella Gadova spelar på flygeln. Kamrat Leningradov, en ansvarsfull arbetare, blir förälskad. Han kommer ridande till Gadova på en svart hingst, lyssnar på drillarna och dricker te. Han kallar henne till RKP(b), hon - varken ja eller nej. Vad är det frågan om? Så går Gadova ut och matar hönsen. Kamrat Leningradov tittar lite i lådorna och uppdagar en sammansvärjning. Tappert övervinner han sin kärlek. Guvernementets kurortskommission skickar honom till Krim. Domstolen dömer de sammansvurna till lagens strängaste straff och förordar att det omvandlas till strikt isolering: Sovjetmakten hämnas inte.

\section{Ett samtidsporträtt och en mötesproblematik}

En ytterligare effekt som avslutningen av "Erygin" har är att det tidigare skildrade framstår som en verklighet som Erygin ideologiska text är uppdiktad utifrån. Det bidrar, för att tala med Barthes, till verklighetseffekten i Dobyčins berättarsätt. Detta belyser också det verklighetsskapande i att berätta genom en sammansättning av små händelser, sinnliga detaljer, namn och citat såsom Dobyčin gör. Den osäkerhet i tolkningen som de kontrasterande minimala enskildheterna ofta leder till utgör en viktig del av denna prosas upplevda realism. Att de tvetydiga och ibland otydliga skeendena ständigt behöver vår tolkning för att göras begripliga och sammanhängande förmedlar en känsla av en mångfald av samtidiga kontrasterande perspektiv och värderingar som liknar vår upplevelse av verkligheten. Och när denna komplexitet reduceras genom en entydig ideologisk tolkning, som Erygin här förser oss med, framstår den som falsk.

Dobyčins berättarsätt har inte bara liknats vid filmens montage, utan också vid Gustave Flauberts i vissa avseenden montagelika prosa, en författare som Dobyčin uttryckligen såg som en förebild. ${ }^{206}$ Förutom att Dobyčin

\footnotetext{
${ }^{206}$ Fëdorov beskriver Dobyčins filmiska montage som härstammande från Flauberts objektiva metod i "Dobyčin i kinematograf", $P L D, 69-76,70-71$. Fedorov jämför också Dobyčins och Flauberts (i Madame Bovary) användande av provinsen som mytskapande i förhållande till centrum i "Flober i Dobyčin (k tipologii provincial'nogo soznanija)", DS-2, I2-23. Dobyčin själv beskriver i ett brev till Slonimskij (8 augusti 1925 (brev 57), PSSP, 272) hur han ska komma
} 
visar likheter med Flauberts användning av sinnliga detaljer och klichéer ur samtiden i berättandet, så finner vi exempelvis i en känd scen i Madame Bovary också en konkret överensstämmelse med de olika textlagren i "Erygin". I kapitel åtta i andra delen av sin roman låter Flaubert en skildring av en lantbruksmässa åtföljas av en journalistisk redogörelse för samma händelser författad av apotekaren Homais i berättelsen. Med Homais sätt att skriva parodierar Flaubert retoriken och de ideologiska klichéerna i I80otalets idealistiska journalistik. På samma sätt tycks Dobyčin med Erygin driva med sin samtids ideologiskt lojala, hantverksmässiga författare. Förutom att de infogade texterna genom kontrasten förstärker känslan av den övriga gestaltningen som en verklighet, blir själva detta ideologiserande också en utmärkande del av den samtid som skildras. ${ }^{207}$

Till skillnad mot Flauberts Homais är Erygin dock huvudperson i sin berättelse. Det är i mycket ur hans perspektiv vi upplevt det som hans skrivande sedan kontrasterar mot. Konflikten mellan olika förhållningssätt till verkligheten finns därmed även inom honom. Medan Erygin som författare så gestaltar den förljugenhet Dobyčin upplever att den samtida officiella kritiken kräver, blir "Erygin" som berättelse - som skildring av en provinsiell vardaglig verklighet som inte låter sig stöpas i en sådan form utan att förvanskas - Dobyčins svar på det allmänna kravet att vara samtida. Att Erygin i slutet av hösten i berättelsen slutligen finner ett sätt att ideologiskt avslöja sin samtid, och därmed hittar tillbaka till skrivandet, tycks spegla hur Dobyčin i november 1924 finner detta sätt att porträttera den.

Det Erygin upplever, det som gestaltar berättelsen om honom, ger också, genom kontrasterna och överensstämmelserna i detaljerna och klichéerna, en laddning och känsla av sammanhang i den vardagliga och mångtydiga verklighet som skildras. För detta, och för upptäckten eller skapandet av en berättelse med ett samlande uttryck för samtiden i sig, med en "densitet av liv" ("žiznennaja nasyščennost") som Ėfros uttryckte det, tycks den typ av tillfälligt uppenbarad symmetri i tillvaron som berättelsen leder fram till vara utlösande. Det väcker minnet och minnets strukturer kan så användas också på den direkta samtiden, för att ge den, eller upptäcka, dess form och sammanhang.

till Leningrad med sin nya berättelse ("Dorian Grej") "som en Flaubert till Paris med 'Madame [Bovary]'” ("как некоторый Флобер в Париж с «Мадамой»"). Författarkollegan Leonid Rachmanov minns som nämnt att Flaubert var den enda klassiker Dobyčin uttryckte uppskattning för. L. N. Rachmanov, Ljudi-narod interesnyj, Leningrad I98I, 330-33I.

${ }^{207}$ Flauberts kontrasterande och därigenom realismskapande återgivningar av lantbruksmässan exemplifierar Sara Danius i Den blå tvålen: Romanen och konsten att göra saker och ting synliga, Stockholm 2013, 284-300. 
Den triviala uppenbarelsen, epifanin, upplevelsen av något betydelsefullt, påminner också om ett möte. ${ }^{208}$ Erygin har berättelsen igenom träffat andra människor men inte riktigt mött dem. Han har tyckts längta efter något annat eller någon annan. Denna längtan, och att han inte finner sig tillrätta i tillvaron som den är, inte känner gemenskap, har framstått som anledningen till eller möjligen följden av hans form av handlande, hans skrivande. Hans svartmålning av den granne som han uppenbart attraheras av visar särskilt tydligt prov på hur detta skrivande, likt en aktiv handling utifrån en ouppfylld längtan efter vänskap eller kärlek, framställs som något negativt, som destruktivt. På liknande sätt som Katerina Aleksandrovna i den refuserade novellen "Evdokija", som när hon känner sig försmådd av den polska grevinna hon längtat efter en vänskap med ordnar en nationalistisk sammanslutning och manifestation riktad mot densamma, skriver Erygin om den kultiverade grannen Ljubov' som ett kontrarevolutionärt odjur i ett utkast till en dogmatisk berättelse. Novellens existentiella realistiska skildring av hur huvudpersonens handlingsproblematik grundar sig $\mathrm{i}$ en banalt mänsklig mötesproblematik, blir politisk och utmanande i Dobyčins samtid. Där och i dess idealistiska realism var handling, att aktivt ta del i den fortsatta klasskampen och uppbyggnaden av ett socialistiskt samhälle, lösningen på alla problem.

\footnotetext{
${ }^{208}$ Den engelska översättaren Richard C. Borden betecknar denna Erygins förlösande déjà vu-upplevelse som en epifani enbart för huvudpersonen. En epifani för läsaren, menar Borden, framkallas istället av den text av Erygin som hans upplevelse resulterar i då den gör oss varse vad för slags författare han är, vilket enligt min mening redan framgått. Richard C. Borden, "Introduction", Leonid Dobychin, Encounters with Lise and Other Stories, Evanston, Illinois, 2005, vii-xxvii, xv-xvi.
} 


\section{Småstadens rum och längtan}

Den provinsiella småstadens kronotop börjar etableras i takt med att konkreta platser och motiv upprepas i Dobyčins samtidsnoveller. Ett återkommande mönster i handlingen börjar också framträda. Dobyčin frågar oroat i ett brev om han inte fallit in i en schablon. ${ }^{209}$ För att belysa detta behandlar jag i detta kapitel de sex noveller som Dobyčin skrev efter "Kozlova", "Vstreči s Liz" och "Erygin" i den ordning de tillkom. Dessa nio noveller sammantagna och i denna ordning utgjorde också den första novellsamlingen Vstreči s Liz som utkom 1927.

Först följer tre noveller om kvinnors kärleksträngtan och längtan bort: "Savkina", "Lidija" och "Sorokina" eller "Dorian Grej" ("Dorian Gray") som "Sorokina" döptes om till i andra samlingen. Längtan efter något annat, ett annat slags möte, varieras därefter i två kortnoveller (av samma längd som ett kapitel i de föregående) med en ung man respektive en liten pojke som huvudpersoner: "Sidelka" ("Sköterskan") och "Lëška" (som döptes om till "Matros" ("Matrosen") i andra samlingen). I den åter fyra kapitel långa "Konopatčikova", som alltså avslutade den första publicerade novellsamlingen, tas frågan om litteratur och konst i samtiden tydligare upp som en aspekt av denna möteslängtan. ${ }^{210}$

\section{Kvinnor som drömmer om möten}

De tre novellerna med kvinnliga huvudpersoner som följde efter "Erygin" i första samlingen är alla uppbyggda kring ett oinfriat möte påminnande om Kukins "möten" med Liz i titelnovellen "Vstreči s Liz". En attraktion till någon antyds inledningsvis varefter huvudpersonerna gör sig föreställningar om och längtar efter ett möte som sedan aldrig i vanlig mening förverkligas. Men något äger rum. Likt den allra första kvällsstunden i författarskapet $\mathrm{i}$ "Timofeev" framstår de stunder av sinnlig närvaro som huvudpersonerna

\footnotetext{
${ }^{209}$ Till Čukovskij I2 november 1925 (brev 23), PSSP, 257.

210 I den andra samlingen Portret har "Lidija" och "Savkina" (i den ordningen) placerats före "Erygin" som följs av "Konopatčikova", "Dorian Grej" och "Sidelka". Därefter följer den nytillkomna "Otec" ("Fadern") och först därefter "Matros" före ytterligare fyra nya noveller.
} 
genom sin längtan istället upplever rentav som något mer betydelsefullt än vad de faktiska mötena troligen hade inneburit. Med denna dragning till en viss person som drivkraft målas också deras sociala liv och livssituationer upp. Dessa tre noveller är inte lika starkt kopplade till händelser i samtiden, inte lika politiska, vilket Dobyčin som sagt också anmärkte om "Savkina".21 ("Savkina" blir den första nytillkomna novell efter debuten som Dobyčin får publicerad, i tidskriften Leningrad, nummer 23, 1925. De andra två publicerades tillsammans med Erygin i Kovš.) Det liv som gestaltas i novellerna kommenterar visserligen ofrånkomligt indirekt det nya sovjetiska samhället och dess fortsatta framväxt, men konflikten är inte lika direkt förbunden med samtiden utan har den mer som en bakgrund, om än en klaustrofobiskt påträngande sådan. En ny sovjetisk vardag har i dessa noveller börjat infinna sig. De människor som skildras frågar sig inte längre om det gamla ska komma tillbaka men försöker fortfarande komma underfund med hur de ska leva i det nya.

Platserna som novellerna utspelar sig på går igen. Huvudpersonerna är hemma, på sitt arbete på kansliet, utomhus på gatan eller på något sätt i naturen, ofta med utsikt över floden. I övrigt finns kyrkor och kyrkogårdar, biografen, parken och ibland någon servering eller möteslokal.

De möten som faktiskt sker i novellerna istället för det efterlängtade är vardagliga. I jämförelse med de föregående novellerna är huvudpersonerna i mindre grad socialt isolerade. De är del av en familj och har bekanta. Samtidigt är de liksom tidigare ensamma med sin längtan, och tvingas hålla den för sig själva. Huvudpersonernas belägenhet avspeglar också att den nya vardag som de ingår i blivit mindre oviss, mer rutinartad. Framtiden står inte längre på spel och är inte lika mycket i fokus. Det handlar mer om att leva i den nya vana som infunnit sig. Det finns nu en viss hoppfullhet $i$ denna vardag som den är, i dess små luftiga, vardagliga detaljer som ingen längre försöker uttolka samhällets fortsatta utveckling ur. Detaljerna är nu en del av vanan, något som ger den laddning och betydelse som den är, och när de tolkas som förebådande tecken gäller de det personliga, de håller liv i drömmen om ett möte med den efterlängtade i denna vardag. Det dagdrömmande och den längtan som små händelser och detaljer ständigt ger näring åt erbjuder, liksom överhuvudtaget huvudpersonernas vardagliga bestyr, en tillflykt undan det mörker och den smärta som inte har upphört utan bara blivit mer av en vardag i den nya tillvaron.

\footnotetext{
2II "Savkina" "blev lite tom" eftersom den var "utan politik" ("bez politiki"). Till Slonimskij II maj 1925 (brev 52), PSSP, 271. Han hade i det föregående brevet (2 maj, brev 5I, PSSP, 270) också varnat för att "Savkina" i än mindre grad än "Vstreči s Liz" och "Erygin" hade en "Fängslande Historia" ("а Захватывающей Фабулы еще меньше, чем в Ерыгине и в истории о Кукине").
} 
Begravningstågen fortsätter att dyka upp, med marscher och svarta flaggor liksom de orkestrerade politiska manifestationerna mot olika fiender. Religionen fortsätter att vara omdebatterad, men med personliga snarare än samhälleliga konsekvenser. Tron och kärlekslängtan har begränsats till det privatas sfär och manifesteras endast med få undantag utanför huvudpersonernas inre, medan dessa uppträder som sociala varelser i det nya samhället.

\section{"Savkina" (Kavaljeren och den döda grannkvinnan)}

(I) Kansliet. Huvudpersonen Savkina introduceras i första kapitlet av fyra som en bland andra kanslister, hon renskriver något på maskin. Brottet mot vanan och början på handlingen, Savkinas längtan efter ett möte, kommer med ett luftdrag. Någon öppnar dörren in till denna vardag:

Дунуло воздухом. - Двери! Двери! - закричали конторщики. Вошел кавалер - щупленький, кудрявый, беленький...212

Det kom ett luftdrag. - Dörren! Dörren! skrek kanslisterna. En kavaljer kom in - spinkig, med lockigt hår, så vit...

Den som kommer in betecknas som en kavaljer och de ömsint diminutiva och expressivt uppradade epiteten beskriver hans utseende på samma gång som de subjektifierar den som betraktar honom. Uppenbarelsen avslutas med tre punkter. Perspektivet är Savkinas. Det är i hennes inre som denna uppenbarelse av en ny person, denna attraktion är av vikt och sätter igång en längtan efter ett verkligt möte. Denna längtan blir en underliggande rörelse i den vardag som skildras och kommer succesivt, i huvudpersonens inre, att forma en upplevelse av ett sammanhang och en helhet i den. Tillsammans med det yttre porträttet, detta utsnitt av Savkinas liv blir det den berättelse vi får ta del av.

Gatan. Kavaljeren framställs som någon ny för Savkina ("[v]ošel kavaler" och inte "kavaler vošel" ("en kavaljer" och inte "kavaljeren")). Dem man får glimtar av i staden utanför är alla bekanta. De tillhör den nya ekonomiska politikens vardag såsom den börjat infinna sig. Två "čvannye bogački" ("högfärdiga förmögna damer") noteras med också komiskt nedlåtande namn, Frumkina och Fradkina, i stil med tidens satirer och den allmänna mening som byggdes upp om denna nya småborgerlighet. Ett begravningståg som Savkina nu visar sig delta i beskrivs inte som ett brott $i$ hennes var-

\footnotetext{
${ }^{212}$ Novellen citeras ur PSSP, 62-65.
} 
dag trots att hon var bekant med den avlidna. Det beskrivs bara: begravningsmarsch, svarta flaggor, granris, en röd kista på en vagn med förhängen. Men Savkinas uppträdande är vardagligt och oemotionellt - eller möjligen känslomässigt undertryckt. De specificerande detaljerna skildrar händelsens, och dödens, trivialitet. Hon stryker handflatorna mot sidorna, hon marscherar med några kvarter ("promarširovala neskol'ko kvartalov") och hon suckar lite ("[p]ovzdychala"). Hon minns hur den döda, någon av de sista gångerna de träffades, talade längtande om sitt hemland (troligen Polen), om att alla var ordentligt klädda där. Även detta minne av den döda profaneras, och placeras i en vardag, av några störande konkreta knott - "[t]olklis' moški" ("[k]notten svärmade") - samt genom denna Olimpija Kukel's överemotionella sätt såsom det lätt ironiskt återges: "таращила глаза. - У некоторых приколоты розы... Ах, родина, родина!" ("[Olimpija] hade spärrat upp ögonen. - En del har rosor instuckna... Ack, mitt hemland, mitt hemland!")

Hemmet. Savkina bor med sin mor och lillebror. Efter de längtande äldre damerna och de dagdrömmande unga männen skildras nu en ung kvinna med liknande karaktärsdrag i det nya samhället. Savkinas melankoli kontrasterar mot broderns ysterhet och entusiastiska omfamnande av det nya, men också mot modern som beskrivs som handfast och enkel, med ett naturligt vördnadsfullt förhållande till religion och det gamla samhällets värden, utan sin dotters melankoliska längtan och drömmande. Modern beklagar Olimpija, som nu visar sig vara en granne, för att hon inte fick en kyrklig begravning.

Efter middagen går Savkina ut bakom ladorna och läser dikter som hon har i ett skrivhäfte. Herr Kukel', Olimpijas man, mjölkar korna och ger förklaringen till att han inte kunde ge henne en kristen begravning. "- Обиждаются, что без ксендза, - пожаловался он. - А когда я - партейный." ("- De tager illa upp för det var utan pater, klagade han. Men när jag är med i partiet.").

Med det triviala i mjölkningen, hans brutna ryska och att det uppenbart inte är av politisk övertygelse eller brist på religiös tro utan bara för att det inte ser bra ut som partimedlem, som han tvingats ge frun en borgerlig begravning, trivialiseras och förmänskligas denna företrädare för det nya sovjetiska samhället och framvisar den NEP-tidens pragmatism som infunnit sig. Någon sorg över Olimpijas död ger ingen öppet uttryck för, på ytan finns bara vardagslivet och den ideologiska samhällsdebatten.

Savkina upplever sedan en lyrisk stund för sig själv utomhus med sina dikter. Ingen dikt citeras, istället beskrivs själva omslaget till häftet. Det 
pryds av en bild av Gogol' "med en liten svart mustasch" ("s černymi usikami"). Tillägget antyder den längtande Savkinas blick. Möjligen antyder det också att hon aldrig kommer till att läsa några dikter utan förlorar sig bland de tankar och känslor som attraktionen till kavaljeren på kansliet satt igång i henne. Den tillvarons tyngd som skildrats genom Olimpijas begravning fördjupar också detta som en existentiell längtan. "«Чуден Днепр при тихой погоде»" ("'Dnjepr är skönast vid stilla väder."'), ett citat från en lyrisk utvikning (liksom här) i Gogol's povest' Strašnaja mest' (Den förfärliga hämnden), står under bilden på omslaget. En kort naturbeskrivning framkallar stunden och anger tiden: "Появилась маленькая белая звезда." ("En liten vit stjärna framträdde." ${ }^{213}$ Det hela uttrycker en stillsamhet som Savkina tycks bruka uppleva här bakom uthusen, där också stunden med Olimpija som hon drog sig till minnes utspelade sig, som ett andrum från det sociala livets tyngd samtidigt som det göder den inre längtan i henne som gör henne melankolisk och frånvarande i det sociala.

Savkina fåri den banala lyriska stunden tillsynes smälta det som inte kan visas och uttryckas i samhället. I en drömmande sinnesstämning ("mečtatel'naja") reser hon sig, går till porten och tar på håll in intrycken från sitt sociala sammanhang: från gravölet över Olimpija och från en trumpet någonstans, som möjligen spelar något revolutionärt. Den lyriska stunden flyter över i vardag. Savkinas bror kommer tillbaka från badet och en direkt namngiven Kolja Evreinov, någon för Savkina välbekant som ska visa sig vara en vän till brodern, kommer gående. Beskrivningen av honom, med uppknäppt skjorta i halsen och kjolvida byxor, gestaltar en liknande kroppslig attraktion i perspektivet som epiteten om den okände kavaljeren i inledningen. Något nytt tycks ha väckts hos Savkina. Är det en förälskad blick som nu också gör de välbekanta personerna och intrycken mer fysiskt påträngande, liksom betydelsefulla?

(2) Olimpijas begravning i första kapitlet har igångsatt en trivial händelseutveckling på ytan, genom vilken den rådande samhälleliga diskursen framträder. Kavaljerens uppdykande tycks i sin tur ha givit impulsen till en stegrad känslosamhet och inre utveckling hos huvudpersonen som en laddad fond eller underström. I andra kapitlet ges ytterligare tillskott.

\footnotetext{
${ }^{213}$ Denna mening utgör ett bra exempel på hur Dobyčin undviker en påtaglig berättarinstans. I ett brev från samma dag som han översänder novellen tillför han meningen som en rättning. Tidigare inledde bara en tidsangivelse Savkinas uppbrott direkt efter Gogol'citatet: "Когда стемнело, Савкина [...] встала" ("När det blev mörkt reste sig Savkina"). Med den hela meningen och den konkreta bilden innan Savkina går anges tiden samtidigt som stunden byggs ut. Till Slonimskij II maj 1925 (brev 53), PSSP, 27 I.
} 
Hemmet. Savkina kokar te medan brodern rakar sig och modern kammar sig. En sinnlig närvaro etableras, med solrutor och blad- och gardinskuggor, bara för att avbrytas av att modern föreslår att Savkina, smeksamt kallad Njušen'ka, ska gå till den katolska kyrkan ("ichnij kastël") och tända ett ljus för Olimpija (vilket utvecklar ytberättelsen om att Olimpija inte fick någon riktig begravning).

Kyrkan. I den mörka och kalla timmerkyrkan finner Savkina ingen låda att tända ett ljus för den döda i (såsom i en ortodox kyrka). Istället blir hon här vittne till hur den katolske prästen iakttas av en Mar'ja Ivanovna Babkina som betecknas som fransyska och vars flärdfulla kläder drar till sig Savkinas uppmärksamhet.

Gatan och kansliet. Samhället skisseras med dess förfall och motsägelsefulla nyordning. Det osar bränt och ligger skräp på gatan. På kansliet luktar det tobak och surt och på väggarna hänger å ena sidan ett porträtt av någon som vunnit pengar (på lotteri troligen, det återkommer i andra noveller) och å andra sidan väggtidningen Krasnyj luč (Röda strålen) med ett drev mot en kamrat (med det talande namnet Samochvalova ("självskryt")) vars farfar eller morfar visat sig ha en butik (och alltså inte är någon riktig proletär).

Biografen. En leende och i lila bubbelblus uppklädd Savkina möter den Kolja Evreinov som introducerades i slutet av första kapitlet. Genom dennes vidöppna krage ser hon när han bugar sitt (sovjetiskt) rakade huvud hans svarta brösthår nedanför nyckelbenen. Han far ut över någons borgerliga klädsel vilket tycks syfta på filmen som börjat. Men Savkina berörs. Hon tycker sig se sitt öde i filmen (på liknande sätt som Kozlova såg sitt i minnet av biobesöket med monsieur). Referatet av filmen ger strukturen till hennes inre känsloutveckling, en berättelse som hon drömmer fram i sitt liv. Miss Maj i filmen är hon och kavaljeren på kansliet motsvaras av "klobmèn Bajbl" (clubman Bible) vilka i inledningen står på varsitt däck när två ångbåtar möter varandra. Miss Maj är olycklig efteråt, livet är tomt och i sina drömmar sträcker hon ut armarna mot en förbiseglande ångbåt. Men plötsligt stiger Bible ut ur en bil, i jaktkostym och tyrolerhatt. ${ }^{214}$ Det är ett sådant möte Savkina väntar sig, som hon drömmer om, och som hon nu tycks se förebådat genom filmen. Kolja Evreinov som hon är bekant med, som redan finns i hennes närhet skänker hon inte en tanke. Hennes dröm är om någon annan.

\footnotetext{
${ }^{214}$ Den tyske översättaren Peter Urban gissar sig till att filmen det rör sig om, om än inte exakt överenstämmande, är Der Fremde Vogel: Eine Liebestragödie im Spreewald från I9II av Urban Gad med Asta Nielsen i rollen som Miss May. Leonid Dobyčin, Die Erzählungen, Berlin 2013, 192.
} 
Gatan. Kapitlet slutar med att vardagen framträder i all sin tristess efter filmen med skällande hundar, dagg, och en kvinna i en kiosk som också nämndes i första kapitlet. Hon skuggades av flaskor och satt och tittade då, nu slumrar hon vid ett ljus.

(3) Hemma. Först i tredje kapitlet blir Savkinas hittills bara antydda förälskelseutbrott uttryckt i det att Savkina, efter middagen, drömmer om kavaljeren. Drömmen är motsägelsefull, hon ser honom strosande bland gravar med en liten hatt $\mathrm{i}$ handen, och han får ingen närmare beskrivning: "Лица было не разобрать, но Савкина его узнала." ("Hans ansikte gick inte att urskilja, men Savkina kände igen honom.") Handlingslinjen om Olimpija, som drömmens kyrkogård redan antytt, får en fortsättning med kopplingar till kärlekstemat. Grannflygelns öppna fönster och nykalkade väggar kommenteras med att herr Kukel' flyttat till en ny fru i en annan stad.

Gatan. Floden. Kyrkan. Som en variation på Frumkina och Fradkina i första kapitlet beskrivs med samma plumpa komik ett liknande par borgerliga kvinnor: "Фрида Белосток и Берта Виноград щеголяли модами и грацией." ("Frida Belostok och Berta Vinograd visade upp sina moden och gracer.") Sedan följer några närvaroskapande intryck vid floden liksom utanför det ideologiska nätet (något floden ofta utgör en gräns för): "На мосту сидели рыболовы. В темной воде отражались зеленоватые задворки. Купались два верзилы - и не горланили." ("På bron satt några fiskare. I det mörka vattnet speglades de gröna bakgårdarna. Två smala pojkar badade utan att skrika.")

Först när Savkina beskrivs gå in på en kyrkogård framgår det att de lösa bilderna har beskrivit hennes vandring dit. Lukten av barr sätter samma stämning som tidigare vid den katolska timmerkyrkan. Bronsikoner på korsen och påskrifterna i diktform kopplar till hennes skrivbok liksom till drömmen om kavaljeren på en kyrkogård. Genom buskarna skymtar hon nu dem hon såg i kyrkan när hon skulle tända ett ljus för Olimpija. Nu ser hon bara det gula hattbandet hos "fransyskan" och en rodnad hos prästen. Så antyds ytterligare en berättelse som liksom filmreferatet kan tänkas spegla Savkinas inre längtan men som också ger tillskott till händelseutvecklingen på ytan.

Hemma. En diskussion mellan lillebrodern och en kvinnlig gäst om guds existens anknyter till handlingslinjen om Olimpija. Den ystre lillebrodern förklarar att vetenskapen bevisat att gud inte finns. Gästen ber honom då förklara uttrycket guds värld, "mir božij". Och så lämnas diskussionen med båda sidornas argument lika ironiskt svaga, eller mänskligt vardagliga, i denna i samtiden högst allvarliga debatt som vi får se fler glimtar av längre 
fram. ${ }^{215}$ Samtalet får istället en annan utveckling genom att Savkina, efter att ha rättat till kjolen, sätter sig och berättar om vad hon nyss sett i kyrkan: "- Опять я их встретила." ("- Jag mötte dem igen.") Även sitt första bevittnande av prästen och fransyskan tycks hon alltså ha berättat om. Av de repliker som följer framgår att det redan har tolkats som en förbjuden relation. Gästen föreslår att umgänget med prästen kanske bara handlar om att hon, fransyskan, funderar på att bli katolik, vilket brodern avfärdar med en brysk kommentar och gest som i sin tur moderns kärleksfulla förmanande antyder betydelsen $\mathrm{i}$ :

- Не собирается ли в католичество? - мечтательно предположила гостья улыбаясь.

- Проще, - сказал Павлушенька и махнул рукой. Мать, улыбаясь, погрозила ему пальцем. Посмеялись.

- Hon är inte på väg att bli katolik? framkastade gästen drömmande.

- Det är enklare än så, sade Pavlusjenka och viftade med armen åt det. Modern hytte leende med fingret åt honom. De skrattade.

Broderns krassa syn på fransyskans umgänge med prästen kan möjligen av den melankoliska systern med sina kärleksproblem dessutom uppfattas som en indirekt pik, att det så att säga finns enklare sätt också för henne. Modern som båda barnen har något av sin karaktär ifrån bjuder dem i alla fall som slut på denna episod käckt att äta av munkarna bakade av amerikanskt (nödhjälps-)mjöl och drömma att de är i Amerika ("вообразите, что вы - в Америке!").

Efteråt sitter Savkina tungsint över sina dikter bakom uthusen och brodern kommer från badet, precis som i slutet av första kapitlet. Brodern visar sig upptagen av något $\mathrm{i}$ tankarna och sätter sig, som en uppföljning på det tidigare samtalet, vid köksbordet och skriver ett öppet brev till tidningen om "fransyskan" Babkinas osedlighet.

(4) Sista kapitlet börjar också i hemmet, Savkina ligger på gräset utanför huset efter att ha arbetat över på kansliet. De yttre detaljerna talar för hennes fortsatt längtande själstillstånd: hon är rufsig, slår myggor, bryter en ros och luktar. Hon ser en ny granne, de som flyttat in efter Kukel', och en (ortodox) präst. Denna stund för sig själv med sin längtan bryter brodern av med att apart ropa "Roza, Roza" och springa in i huset efter tidningen där hans artikel om fransyskan nu publicerats. Han lutar sig ut genom fönstret och frågar om Savkina sett den och börjar berätta om någon han blivit be-

\footnotetext{
${ }^{215}$ Mest utvecklat blir det i novellen "Portret", där det också framgår att debatten med delvis liknande argument fördes på högsta nivå, med metropolit Vvedenskijs deltagande.
} 
kant med. Roza betyder ros, och ger en koppling till den romantiskt drömmande ros hon luktat på, men skrivet med stor begynnelsebokstav och med tanke på broderns politiska intresse är det möjligen Rosa Luxemburgs förnamn han utropar (som fonetiskt riktigt transkriberas så på ryska). Brodern är uppspelt och imponerad av den han blivit bekant med. Denne framställs som livserfaren och manlig, dennes handlingskraft är broderns poesi:

[...] Нюшка, где газета? Мы с ним подружились. Как я рад. Он разведенный. Платит десять рублей на ребенка... - Этот, - говорит, - пень, давайте, выкопаем и расколем на дрова.

[...] - Njusjka, var är tidningen? Jag har blivit vän med honom. Jag är så glad. Han är skild. Han betalar tio rubel för barnet... Den här, säger han, stubben, kan vi gräva upp och hugga ved av.

Ingen introduktion ges, inget flikas in om vem han talar om, men att han talar så ger både en känsla av verklighet - vi får närvara just denna stund $\mathrm{i}$ deras vardag, det är inte riktat till oss som en berättelse med en berättare och suspension: vi väntar på förklaring vem det är han talar om och vad det har för betydelse, för det är trots allt en berättelse. Slutet kopplar nu samman Savkinas och broderns längtan genom den som brodern lärt känna.

Kolja Evreinov, den gamla vännen (som tidigare beskrivits med byxor feminint vida som kjolar) och som Savkina var på bio med utan att visa honom något större intresse, kommer först för att träffa Savkinas bror. Det blir av modern som vi får förklaringen till vem brodern talat om: "- Идите за сараи", säger hon till Kolja Evreinov: "- Он там с сыном новой жилицы: подружились." ("- Gå bakom uthusen, [...]: Han är där med sonen till den nya hyresgästen: de har blivit vänner.")

Ett mellanspel på gården föregår slutscenen. Några barn springer runt och leker med en hund hoppande efter sig. Modern hasar runt med tofflorna i huset. Samovaren hörs. Det är helt i vardagen, det är dags för te, men samtidigt väntar, i det att modern nu ber Savkina att gå hämta brodern och hans vänner, upplösningen på den handlingslinje som Savkina bär inom sig. När hon närmar sig (bakom uthusen är den plats där hon brukar läsa dikter) hör hon dem sjunga en revolutionssång om hur ett uppror $\mathrm{i}$ Kronstadt 1906, en del i 1905 års revolution, bestraffades (hur kommunarderna dömdes "till grymma och gruvliga straff" ("к жестокой, мучительной казни")). Sedan ser hon dem sitta där tillsammans, hålla om varandra och vagga till sången. Och Savkina känner igen den nya vän som brodern talat om: "третий был тот, щупленький." ("den tredje var han, den spinkiga.") 
Så slutar sista meningen. Det är allt. För att förstå vem hon kallar "tot" ("han" eller egentligen "den där") måste vi ha följt med i Savkinas inre känslor, eller få vårt minne väckt av det specifika adjektivet som denne i inledningen beskrevs med.

För det är förstås kavaljeren som är återfunnen. Han är nu till och med vän med brodern. Alla chanser finns så för att hon också, med början vid teet, faktiskt ska möta och lära känna honom. Det tycks faktiskt ha skett precis så som i filmen, att den som hon bara sett och förälskat sig i plötsligt dyker upp. Brodern har dessutom redogjort för att han åtminstone inte är gift längre. Inget tycks hindra ett förhållande. Samtidigt har Savkina genom att hon inte vetat att det var kavaljeren som var broderns nya vän fått en annan person beskriven för sig, med den revolutionära sången som tillägg. Han har visat sig som en den nya tidens röde kavaljer. Den Savkina drömt om, med en förfining, en själsfrändes sinnelag utifrån dennes yttre spädhet har visat sig innehålla en man som är precis som alla andra, åtminstone som alla andra försöker vara i det nya sovjetiska samhälle som hon vantrivs i och vars obehagliga hyckleri den triviala händelseutvecklingen visat upp med broderns angivelse som kulmen. Sångens slutord om straff klingar också i igenkännandet.

\section{Geten "Lidija" och den röda bocken}

Novellen "Lidija" som Dobyčin kallar för "koza" ("geten") i breven - Lidija i berättelsen är namnet på huvudpersonens get - skickar han en månad efter "Savkina", den I3 juni 1925, till Slonimskij. Redan i mars har han nämnt den i sina brev till Čukovskij och där omtalat den som en berättelse för barn. Čukovskij, själv barnboksförfattare, verkar ha föreslagit honom att skriva något sådant. När Dobyčin snart tvivlar på att den kommer att lämpa sig för barn undslipper han sig ett av sina mest tydliga kritiska uttalanden om den nya ordningen: "Пригодится ли она [коза] для детей, не знаю. Впрочем, теперь и нет детей, а Детские коммунистические отряды Имени Товарища Ленина." ("Om hon [geten] kommer att passa för barn vet jag inte. Förresten så finns det inga barn numera utan bara Kommunistiska barntrupper i Kamrat Lenins Namn") Med Lidija, namnet på geten, förklarar han ironiskt för Slonimskij att han vill ära "madame Sejfullina som prisas så" ("в честь мадам Сейфуллиной, которую так хвалят"). Dobyčin ser up- 
penbarligen den samtida proletärrealisten Lidija Sejfullina som emblematisk för den värsta sortens duktigt ideologiska litteratur som hyllas av samtidens kritiker. ${ }^{216}$

Till sin uppbyggnad liknar novellen "Savkina"; en person, här en ledare för partiets ungdomsorganisation Komsomol, skymtar förbi i inledningen och väcker attraktion och längtan efter ett möte. Emellertid medvetandegör inte huvudpersonen på samma sätt sin längtan. Eftersom hon är gift är den också mer förbjuden. Komsomolledarens rättrogna bolsjevism kontrasterar mot hennes nostalgiskt lagda man, tillsynes en före detta anhängare av Socialistrevolutionärerna. Huvudpersonens intresse för "ledaren", som han omtalas, får istället utlopp i ett öppet diskuterat behov att hitta en bock som hennes get, Lidija, kan para sig med. Historierna knyts ihop när hon slutligen i ett slag återser komsomolledaren och finner en lämplig bock, nämligen den som han kommer gående med.

Hur man ska förstå driften med Lidija Sejfullina är inte helt uppenbart. Möjligen är det inte mer raffinerat än att hon är som en vanlig gammal get som betäckts av en kommunistisk bock. Den i sin kroppsbehåring getlika huvudpersonen Zajceva, som inte framstår särskilt politiskt upplyst i själva verket, är också tänkbar som en del av nidporträttet av Sejfullina.

Novellen är liksom den följande "Sorokina"/"Dorian Grej" tre istället för fyra kapitel lång.

(I) Gatan. Zajcevas karaktär tecknas inledande genom de flärdfulla varor hon inhandlat. Eau de colognen heter Voyage och etiketten avbildar förtydligande resenärer i slädar på omslaget. Drömmen om att resa, längtan till det flärdfullt franska och lyxiga antyds genom hennes betraktande av och luktande på det substitut för detta som hon konsumerat. Hon har vita (getlika) små mustascher och äter på en glass med prisangivelse. Mot denna intresseinriktning bryter så en komsomolsång in som kontrast, men snarare

\footnotetext{
${ }^{216}$ Till Slonimskij 20 juni 1925 (brev 56), PSSP, 272. Fler ironiska kommentarerna om Lidija Sejfullina ska följa. Om nästa novell "Sorokina" skriver han 8 augusti 1925 (brev 57, PSSP, 272): "все будет очень комильфо, хотя, конечно, не так, как у Сейфуллиной: она недосягаема." ("allt kommer att bli väldigt comme il faut, om än inte som hos Sejfullina förstås: hon är ouppnåelig"). 3I augusti skriver han att en högt uppsatt person undervisat honom om "perspektiv", med vilket denna avsåg att "'inte allt är dåligt, det finns också det som är bra'" ("«не одно же плохое, есть хорошее»"). Efter detta skriver han i samma ironiska anda som tidigare om Sejfullina och hennes perspektiv: "Вы угадали: я ее очень люблю. В особенности - за перспективы." ("Ni gissar rätt: jag älskar henne mycket. Särskilt för perpspektiven." I ett tidigare brev till Čukovskij framgår tydligare vad han har emot Sejfullina som författare: "Сейфуллина [...] все же не пишет, а сюсюкает." ("Sejfullina [...] skriver i vilket fall inte, utan gullar." (Verbet "sjusjukat" kan också betyda att läspa eller att överbruka diminutiv.) (I4 april I925, brev I9, PSSP, 256) Han förklarar sig senare ha fattat tycke för Tynjanov redan på grund av hans starkt kritiska recension av Sejfullina i Russkij sovremennik. Till Čukovskij 8 mars 1926 (brev 32), 263.
} 
än politiken upptas Zajceva av fysiken hos den undersätsige man som går sist, med uppkavlade ärmar, fjuniga kinder och kraftig stämma:"-Vänster!" ropar han till de marscherande pionjärerna. Zajceva hör sig för om vem han är och får svaret "vožatyj" ("ledaren").217

Hemma. En ointroducerad Pet'ka väntar vid grinden när Zajceva kommer hem och sätter igång en parallell berättelse genom att rapportera att en soldat drunknat. Sedan vidtar vad som liknar en vana. De sitter under päronträdet där Pet'ka gör läxan med hjälp av Zajceva, som tydligen är lärare; de övar rättskrivning, men det som skildras är hennes tankspridda blickande utanför staketet. De drömmar och den sorts längtan som anslogs med eau de colognen i början vecklas nu ut som i en känslomättad eftertanke om komsomolledarens plötsliga uppenbarelse i hennes vardag. Hennes inre lyrik som antyds genom miljöbeskrivningarna tycks också parodiskt ta prägel av denna NEP-tidens blandning av gamla och nya storheter. En grå låg kyrka, uppkallad efter högtiden Guds moders avsomnande, Uspen'e, liknas vid en pansarbil. ${ }^{218}$ En mening, som hon dikterar för Pet'ka att skriva, om att paradiset var en underbar trädgård i öster, där hon upprepar just orden "underbar trädgård", antyder vidare både väckta drömmar och det avsomnande som hennes levnadssätt utmärks av i kontrast till pionjärledarens.

Vi får först härefter veta att Zajceva har en man; han läser tidningen efter middagen och uttrycker beundran för kineserna utifrån en nyhetsartikel där innan han går och lägger sig. ${ }^{219}$ En väninna, Dudkina, kommer förbi. De sätter sig också under päronträdet, i skymningen, och Zajcevas get gör nu bräkande sin entré i berättelsen. Geten njuter när de kliar henne och har (naturligt nog men specificerat) vita ögonfransar som liksom speglar sin ägarinnas vita små mustascher. Dudkina frågar om hon tagit geten till en bock.

Avsomnandekyrkan blir svart under en färglös himmel och en måne dyker upp och ger stämning till kvällstunden. Dudkina berättar tankfullt och allvarligt något helt banalt, att hon provat alla likörer på en lärarmiddag.

(2) Utomhus, gator och natur. Nu påbörjas en mer ihållande rörelse i den vardag som skisserats fram. Zajceva lyfter armbågarna för att det ska fläkta, lilla Dukina hinner knappt med och Zajcevas man kommer flåsande

\footnotetext{
${ }^{217}$ Novellen citeras ur PSSP, 59-6I.

${ }^{218}$ Brjanskforskaren Golubeva menar att liknelsen möjligen kan förstås som en kommentar till att denna församling var den enda som tillhörde förnyarna, obnovlency, inom kyrkan vilka aktivt stödde revolutionen och den nya makten - med Lenin på en pansarbil som en klassisk revolutionsbild. Ė. S. Golubeva, Pisatel' Leonid Dobyčin i Brjansk, Brjansk 2005, 83-84.

${ }^{219}$ Enligt kommentarerna i PSSP (sidan 462) rör det sig om en arbetar- och studentdemonstration i Shanghai som sköts ner av engelsk polis 30 maj 1925 (alltså under samma tid som novellen tillkom) och lade grunden för den kinesiska revolutionen 1925-I927.
} 
efter. Vi får veta att de, något kryptiskt, ska "till den drunknade": "- A мы к утопленнику". Bilder av det samtida samhället ges under vägen. Bioaffischer visar med samtidskulturens propagandistiska tydlighet på de vitas bestialitet under inbördeskriget medan verkligheten omkring inte är lika entydig. Funktionsnedsatta barn sitter utanför en mottagning och spelar kort där det tidigare var en krocketplan (vilket Dudkina suckande berättar om). Röda soldater vid kasernerna beskrivs inte marscherande eller på annat sätt respektingivande: "Взявшись за руки, прогуливались по двое и трое солдаты." ("Soldaterna strosade omkring två eller tre tillsammans och höll varandra i handen.")

Vad som sedan egentligen äger rum på den plats som de når fram till, vid en strömvirvel där fler åskådare trängs, klargörs inte men troligen är det där som soldaten sägs ha drunknat. Det spelas gitarr, en vakt står och gäspar. Zajceva, väninnan och mannen har picknick och betraktar några unga män som klär av sig för att bada och hör deras ekivoka skämtande:

- Нырни, - веселились они, - и скажи: под лавкой.

Смеялись: - Пока ты нырял, мы спросили, где тебя сделали.

- Dyk, roade de sig, och säg: under en bänk.

De skrattade: - Medan du dök frågade vi var du blev gjord någonstans.

Medan Dudkina kisar och mannen muntert ojar sig över ungdomen får det Zajceva att återknyta till inledningens komsomolledare: "- «Левой!» - замечталась Зайцева." ("- 'Vänster!', drömde sig Zajtseva bort.") Skämtet liksom hela den parallella berättelsen med betäckandet av geten talar potentiellt också om deras tillsynes barnlösa äktenskap som en del av konflikten, som en förklaring till hennes dragning till komsomolledaren som representant för det fruktsamma nya.

På vägen hem sägs de "småprata om politik" ("поболтали о политике") men endast mannen och väninnan tycks delta i samtalet.

(3) Hemma. I inledningen till sista kapitlet avslutas episoden med den drunknade soldaten som en bagatell - han hade inte drunknat. Zajcevas man skiner upp och berättar nyheten som står i tidningen: "- Утопленник, - рассказал он новость, - выплыл." ("- Den drunknade, berättade han nyheten, har dykt upp.") Troligen roas mannen av dubbeltydigheten i verbet "vyplyt"" ("dyka upp"). Detta sker efter att mannen inledningsvis, på väg för att bada efter arbetet, har skildrats se rester av Socialistrevolutionärernas valaffischer, "mints forna tider och blivit sentimental" ("[v]spomnil staroe, rastrogalsja"). Den lättsamma gladlynthet som nyheten om soldaten för honom tillbaka till tycks vara hans sätt att hantera livet i det nya samhället. 
Till skillnad från de allra första novellerna i sovjetmiljö finns nu en vardag som personerna i berättelserna i viss mån kan finna små glädjeämnen i. De kan sucka över det gamla, som Dudkina över minnet av krocketplanen, eller som mannens nedstämdhet här, men det är övergående. Det finns nu en vardag med NEP-tidens olika förströelser. Samtidigt tycks de instängda i denna förströelse och liksom tystade i sin personlighet.

Gatan. Zajceva är ute och handlar igen, nu är det knappar. En fontän, blommor och en staty beskrivs. Frånsett vem statyn avbildar - kamrat Figatner, en bolsjevik som vid denna tid satt i fackföreningarnas centralråd tycks samhällslivet inte skilja sig så mycket från förrevolutionär tid. ${ }^{220}$

En servering. Zajceva går till "«Закусочная всех холодных закусок»" (ungefär "'Delikatesservering med alla slags kalla delikatesser"'), blir serverad kvass av värdinnan som just tvättat håret och får höra om hennes vardagliga missöde i bakningen, att det på grund av ugnen blev ogräddat i mitten. Två närbilder från interiören följer som bygger på känslan av en betydelsefull närvaro: (en askkopp i form av) en hand med fimpar, två rosor utan stjälk som simmar i vatten på ett fat. In i denna stillsamhet kommer nu en blöt flicka infarande med nyheten om en regnbåge som Zajceva och värdinnan måste komma ut och titta på.

Natur. Som förebådat av de fysiska detaljerna (även flickans våta kofta som hon beskrivs dra ut från brösten har påkallat en sensualitet) uppenbarar sig så komsomolledaren igen. Nu kommer han i en vardaglig skepnad, utan livrem, barfota och så ledande en getabock med hjälp av en kvist. Zajceva skiner upp med en enkel fråga som ett nöjt konstaterande: "Ихний?" ("Deras?"). Ja, bocken är deras, komsomolernas, och den kan hon nu föra samman sin get med så som diskuterades i första kapitlet. Förutom en lösning på det triviala problemet innebär just denna bock möjligen ett glädjande substitut till ett förverkligande av hennes egen omöjliga attraktion till komsomolledaren. Allting lättar efter regnet:

Туча убегала. Кричали воробьи. Мальчишки высыпали на дорогу, маршировали:

- красная армия
всех сильней.

Molnet drog bort. Sparvar skrek. Pojkarna vällde ut på gatan, marscherade:

\footnotetext{
${ }^{220}$ PSSP , 462. Dobyčin arbetade vid denna tid vid guvernementets fackföreningsråd. Någon sådan staty existerade inte i Brjansk enligt Ė. S. Golubeva, Pisatel' Leonid Dobyčin i Brjansk, Brjansk 2005, 93-94.
} 
- röda armén

är starkast av alla.

Nu dyker också Zajcevas get upp. Först nu, när hon kallar på den, får vi veta att den heter som novellen: "Lidija, Lidija!" ropar hon. "Lidija, Lidija", härmar de funktionsnedsatta henne. Sedan, till ljudet av en vals, belyses en skylt med fyra hattar av solnedgången och en ränsel hänger i ett skyltfönster. Kanske är den gjord av getskinn. Kanske antyds en insikt hos huvudpersonen om hennes eget liv, eller brist på liv, efter denna lösning för geten. Gestaltningen lämnar i slutet hennes perspektiv:

Закат светил на вывеску с четырьмя шапками. Играли вальс. В окне лавчонки висел ранец.

- Жоржик! - закричала Свистуниха и остановилась с ведрами в руках.

Это Лидию прежде звали Жоржиком: Зайцева переименовала. - Не женское имя, - объясняла она.

Den nedgående solen sken på en skylt med fyra hattar. En vals spelades. I fönstret till den lilla boden hängde en ränsel.

- Georgis! ropade Svistunicha och stannade med hinkarna i händerna.

Det var för att Lidija hette Georgis förut: Zajtseva hade döpt om. - Det är inte ett kvinnonamn, förklarade hon.

Svistunicha är en bekant för vilken de förklarade att de var på väg till den drunknade i förra kapitlet. Hon sade då att hon skulle ta emot en ikon. Hon tycktes så vara en som höll fast vid det gamla (om än inte mer än att hon efter att ha tagit emot ikonen också skyndade iväg "till den drunknade"). Hon kallar här på geten Lidija med manligt namn, det franska Georges (såsom Kukin kallades av sin mor i "Vstreči s Liz") men med ryskt diminutiv: Žoržik (som möjligen Georgis kan vara en svensk ekvivalent för). Novellen slutar med den nyktra utredande förklaringen av namnbytet och hur Zajceva tidigare förklarat det, vilket liksom avbryter den gestaltade scenen och hela novellen.

Vad "Lidija" uttrycker är ovanligt svårfångat. Bakgrundsinformationen att Dobyčin med Lidija syftade på Lidija Sejfullina tillför inte heller mycket till förståelsen, snarare tvärtom, då det leder en till att läsa berättelsen som en rebus. Kan namnbytet anspela på Sejfullinas icke-proletära ursprung (hon var prästdotter) eller möjligen hennes användning av den manliga pseudonymen "bibliotekar" ("bibliotekarien")? Som rebus förblir novellen olöst. Det väsentliga är återigen den vardagliga levande närvaro som fångas. Skillnaderna mot tidigare noveller är att de vardagliga detaljerna där tydligare avtäcker en genomgående mänsklig konflikt som fördjupar denna tillvaro. Det gåtfullt outsagda tenderar i denna novell, istället för att utveckla 
och levandegöra de inre personliga perspektiven, enbart att bli störande. Händelser och detaljer framstår just kryptiska och som antydningar över de gestaltade personernas huvuden. Berättelsen blir överhuvudtaget inklusive det centrala mötet med komsomolledaren mer plumpt ironisk än både tidigare och senare noveller.

Dobyčin tycks också själv osäker i efterhand. Det är utifrån denna och nästa novell som han ett halvår senare frågar om Čukovskij tycker att han "fallit in i en Dobyčinsk schablon" i sitt skrivande ("нет ли там впадения в Добычинский шаблон?").221

\section{"Sorokina"/"Dorian Grej" - den inte längre avresande}

Skrivandet av nästa novell, som han i förväg säger ska handla om en ung kvinna som ger sig av från staden, sammanfaller med Dobyčins egna planer på en definitiv avresa till Leningrad. ${ }^{222}$ I brist på pengar - för sina publiceringar har han ännu inte fått betalt - och på grund av att han hålls kvar på sin arbetsplats av sina "Goda Överordnade" ("Dobrye Načal'niki") skjuts resan dock ständigt upp och resulterar till slut inte i mer än en längre men tidsbegränsad vistelse under vintern 1925-26.

Även huvudpersonen i den nya novellen visar sig när han färdigställer den under hösten ha rönt samma öde: "она уже не отъезжающая, ибо никуда не едет и не собирается" ("hon är inte längre avresande, ty hon åker ingenstans och planerar inte heller att göra det”). Dobyčin är ovanligt osäker på den nya berättelsen som nu fått namnet "Sorokina": "сам я в ней ничего не могу понять и не знаю, может ли быть такой рассказ" ("själv kan jag inte förstå någonting i den och vet inte om en sådan berättelse är möjlig"). Han understryker dock med samma ironiska ton som om "Savkina" att

221 Till Čukovskij I2 november 1925 (brev 23), PSSP, 257. Dobyčin fortsätter brevet med att tala om en ny novell till vilken han som titel föreslår antingen "Blauė berge" eller "Blinova i Voblina". I denna novell som inte bevarats (som han i andra brev också benämner "Kazanskij") säger han sig uppleva denna schablon om än, tillägger han (vilket man också skulle kunna säga om "Lidija"), den inte är helt utan liv: "Но все-таки рассказ не без живости". ${ }^{222}$ Han avreseplaner utvecklas efter några dagars vistelse i Leningrad sommaren 1925 då han för första gången träffade Čukovskij (medan Slonimskij var bortrest). Det är med denna novell, denna "avresande flicka", som han fantiserar om att komma till Leningrad som Flaubert till Paris med "Madame". (Till Slonimskij 8 augusti 1925 (brev 57).) Allt tycks bestämt: "в конце сентября - начале октября или немножко позже адрес (постоянный) будет не «Брянск», а «Ленинград»" ("i slutet av september - början av oktober eller lite senare kommer [min] (fasta) adress inte att vara 'Brjansk' utan 'Leningrad'”). (Till Slonimskij Io augusti I925 (brev 59).) Men han oroar sig redan för att han inte kommer att lyckas stanna i Leningrad: "Если ничего не выйдет, то это будет ОЧЕНЬ ПЛОХО." ("Om det inte blir något av med det blir det MYCKET ILLA") (Till Slonimskij 3I augusti 1925 (brev 6I).) PSSP, 272-274. 
den åtminstone inte innehåller en gnutta politik - utan bara handlar om amour. ${ }^{223}$

När han översänder den oroar han sig för att alla "utsmyckningar" ("ukrašenija") kanske gör det överlastat ("konditorskoe" ("konditoriskt") är ordet han använder). ${ }^{224}$ Utan att ens invänta Slonimskijs omdöme ber han honom därefter att slänga den för att han nu själv insett att den är "motbjudande" ("gadost"). ${ }^{225}$ En månad senare skickar han en ny version. Han menar nu att den visserligen fortfarande är hemsk men kan tänka sig att låta trycka den för, som han säger, "värre saker publiceras ju". ${ }^{226}$

Möjligen påverkad av sin oförverkligade avresa har Dobyčin uppenbarligen börjat tvivla på sitt berättande. De två kortnoveller som följer under våren I926, särskilt "Sidelka", kan ses som ett försök till förnyelse, men redan "Sorokina" präglas stilmässigt av en större uppbrutenhet med kortare meningar och stycken än tidigare.

(I) Mötet. "Sorokina" eller "Dorian Grej" (det vill säga "Dorian Gray" vilket novellen i samlingen Portret döpts om till) liknar till handlingen på flera sätt de föregående två novellerna. Uppenbarelsen av, eller det första mötet med en tidigare okänd, sker här i slutet av första kapitlet:

Светился погребок. Пошатываясь, вылезли конторщики:

- Ваня, не падай...

- Кто это?

- Не знаю. Вылитая копия Дориана Грея - как вы полагаете?

Ваня. Плескались в вставленных в вертушку бутылках кагор и мадера, освещенные лампочками. Ваня. 227

En källarkrog lyste. Vinglande klättrade några kontorister ut.

- Vanja, ramla inte...

- Vem är det?

- Vet inte. Rena kopian av Dorian Gray - vad tycker ni?

Vanja. Cahors och Madeira skvalpade i flaskorna som ställts på en snurra i fönstret belysta med lampor. Vanja.

Huvudpersonen, som precis som i Lidija hör sig för (hos sin väninna Mil'onščikova) om vem denne Vanja som gör intryck på henne är, har vid

\footnotetext{
223"Политики в нем ни на грош [...]. Там все - про амуры"." I en not (till "amour") tillägger han: "Это потому, что люблю Сейфуллину." ("Det är för att jag älskar Sejfullina.") Till Slonimskij 9 september 1925 (brev 62), PSSP, 274.

${ }^{224}$ Till Slonimskij I6 september 1925 (brev 63), PSSP, 275.

225 Till Slonimskij I8 september 1925 (brev 65), PSSP, 275.

226 "[Sorokina] подправлена, но все-таки какая-то мерзкая. Но если можно напечатать, то пусть идет, потому что печатаются штучки и похуже.” Till Slonimskij 2 oktober 1925 (brev 68), PSSP, 276.

${ }^{227}$ Novellen citeras ur PSSP, $76-79$.
} 
det laget hunnit gestaltas som en ung dagdrömmande kvinna med visst religiöst intresse.

Inomhus, möteslokal. Novellen har inletts med att en jurist framträtt vid vad som liknar en nyandlig sammankomst (men med en inramad Engels i lokalen) och berättat om mystiska händelser i sitt liv. Huvudpersonen Sorokina introduceras som slött lyssnande på detta. Inget sägs om vad för slags händelser det berättas om, men möjligen sås ett frö till att betrakta den senare uppenbarelsen av den stupfulle Vanja som något av motsvarande betydelse i huvudpersonens liv.

Gatan. Lösa gatubilder, utan att Sorokina nämns, följer men med ett närvarande medvetande som kan tala om hur berget på andra sidan floden både ser ut nu och på vintern (då det är "smutsvitt och streckat av tunna träd, likt strilande regn" ("грязно-белая, исчерченная тонкими деревьями, будто струями дождя") likt sanden och snön i "Erygin").228 Att det luktar fastemat från bodarna och att råkor har kvistar i näbbarna talar om att det är tidig vår. Soldater marscherar sjungande.

Hemma. Sorokina står framför spegeln och ser att hon börjar få rynkor under ögonen. Hennes far är käck och levnadsglad. Han har ett stetoskop som visar att han är läkare (i likhet med såväl Dobyčins egen far som de senare fäderna i novellen "Portret" och i den mer uppenbart självbiografiska romanen Gorod Én). Både modern och fadern framställs genom att liknas vid bilder:

И, поправив черную наколку, осанисто, словно дама на портрете в губернском музее, посмотрела на отца.

Он, бравый, с висячим носом, как у тапира в «Географии», стоял перед зеркалом и протирал стетоскоп.

Och, efter att ha rättat till sin svarta spetsmössa, tittade modern, ståtlig, lik damen på porträttet på guvernementsmuseet, på fadern.

Han, kraftfull, med hängande näsa som tapiren i Geografiboken stod framför spegeln och torkade av stetoskopet.

Den senare titeln "Dorian Grej" i Portret antyder tydligare en associativ betydelse i dessa levande porträtt liksom i Sorokinas inte längre helt unga ansikte i spegeln.

Utomhus. Kyrkan. Moln skingras, en gamling talar om vinden, kyrkljus, kyrkklockor, en tiggare beskrivs. Sorokina tvekar om hon ska gå in i kyrkan, men gör det och ser hakor upplysta av tunna ljus, andliga personer i svart

\footnotetext{
${ }^{228}$ Enligt Golubeva beskriver detta Brjansks sluttningar ner mot floden sedda från andra sidan, den sida Dobyčin var bosatt på fram till 1927. Ė. S. Golubeva, Pisatel' Leonid Dobyčin $i$ Brjansk, Brjansk 2005, 73.
} 
sammet, det lackerade korset och hör orden "sade Pilatus till honom" på kyrkoslaviska, "Глагола ему Пилат!". Det är en text som läses på skärtorsdagen. Utanför kyrkan igen omges det kyrkliga med profanare detaljer. Vi känner igen Dobyčins vardagliggörande från biskopen med slaskhinken i "Kozlova". Antalet klockslag anger vilket textavsnitt i liturgin som läses:

Моргали звезды. Сторож, задрав бороду, стоял под колокольней:

- Нюрка, шесть раз бей.

Stjärnor tindrade. Vaktmästaren stod och drog sig i skägget under klockstapeln.

- Njurka, slå sex gånger.

I bevittnandet av detta blir Sorokina upptäckt av en väninna av mer anpassat sovjetiskt slag som indirekt ifrågasätter Sorokinas kyrkobesök: "- Я полагала, вы неверующая" ("- Jag trodde inte att ni var troende").

Utomhus. Gatan. Sorokina slår följe med sin väninna och moderna sovjetiska festligheter som konkurrerar med kyrkohögtiden beskrivs. En karusell snurrar med glänsande lyktor och spelar en krakowiak som väninnan sjunger till så att det rimmar på namnet på dansen: "русский, немец и поляк" ("en ryss, en tysk och en polack"). Efter blänket och sången följer så den redan citerade scenen utanför källarkrogen med den uttumlande kontoristen Vanja. Vi förstår nu bättre varför Sorokina trots hans föga tilltalande framträdande börjar göra sig drömmande föreställningar om ett möte med denna Vanja. Hon längtar så efter något annat.

(2) Stadion, gatan. Det har blivit sommar. Det nya sovjetiska livet beskrivs. Barnflickor sitter och tittar på en löpare endast iförd kortbyxor på idrottsstadion. Sorokina beskrivs gå därifrån och en serie minimala händelser följer, en blandning av intryck som är ovanligt löst kopplade till varandra, som liksom upplöser berättelsen i det vardagliga livet ett tag. Det är kanske dessa pregnanta men tämligen disparata detaljer som Dobyčin kallar utsmyckningar och befarar att det blir för mycket av. Kan man läsa det som en skildring av Sorokinas sinnestillstånd, av hur hennes personlighet flyter ut, suddas ut i denna vardag?

Сорокина встала и, оглядываясь, медленно пошла.

- Вы не Василий Логгинович? - прислонясь к воротам, тихо спросил пьяный.

Грудастая девица сунула записку и отпрянула:

«Придите, послушайте слово „За что умер Христос“».

Цвела картошка. На оконцах красовались занавесочки, были расставлены бутылки с вишнями и сахарным песком. Побулькивали граммофоны.

Поздоровалась дебелая старуха в красной кофте - уборщица Осипиха. 
- Товарищ Сорокина, - сказала она, - я извиняюсь: какая чудная погода.

Голубые и зеленые пространства между облаками бледнели.

Sorokina reste sig och gick långsamt iväg medan hon såg sig om.

- Det är inte ni som är Vasilij Logginovitj? frågade tyst en berusad man som stod lutad mot porten.

En storbröstad flicka stack fram en lapp och skyndade iväg:

"Kom och lyssna till predikan 'För vad dog Kristus'".

Potatisen blommade. Små gardiner prydde fönstren och flaskor med körsbär och strösocker var utställda. Grammofoner kluckade.

En mullig gumma i röd kofta hälsade - städerskan Osipicha.

- Kamrat Sorokina, sade hon, jag ber om ursäkt: vilket underbart väder.

De blå och gröna ytorna mellan molnen bleknade. ${ }^{29}$

Hemma. Var det detta liv som Kristus dog för? Frågan på lappen, levererad av en storbröstad flicka som bidrar till den sinnligt profana inramningen, står ut och dröjer sig kvar bland det andra. Den jurist som talade om mystiska händelser i inledningen visar sig nu vara på besök hos Sorokinas föräldrar när hon kommer hem. En trivial händelseutveckling sätter igång igen efter de undertryckta uttrycken i gatubilderna. Modern och faderns ideologiska ståndpunkter tecknas nu när först modern liksom övriga mödrar och äldre kvinnor i novellerna förklarar sig hålla fast vid religionen trots allt:

- Религия - единственное, что нам осталось, - задушевно говорила мать: - Пахомова - кривляка, но она - религиозная, и ей прощаешь.

И, держа на полдороге к губам чашку, значительно глядела на отца.

Он дунул носом.

- Religionen - är det enda som återstår för oss, sade modern innerligt. Pachomova apar sig, men hon är religiös, och då förlåter man henne.

Och med koppen halvvägs till läpparna såg hon menande på fadern.

Han blåste genom näsan.

Fadern, läkaren, har liksom övriga äkta män en mer jordnära, och här också sekulärt bildad hållning som på detta sätt kommer till uttryck utan

${ }^{229}$ Flaskorna med körsbär och socker nämner Dobyčin uttryckligen som exempel på en utsmyckning i novellen som han då inte börjat skriva än: "В числе украшений - бутыли на окнах, с вишнями и сахарным песком [...]." Han utlovar också "vid mån av plats", även det som utsmyckning, "en sammankomst med några troende i kyrkoärenden": "и, если, вместится, - собрание верующих по церковным делам." Möjligen är den inbjudan som citeras det enda av detta som "fick plats". Dobyčin skriver också på förhand om novellen som "osammanhängande, men trevlig" och att den ska innehålla såväl "kontoristen Vanja, en fyllbult samt den Lokala Intelligentsian": "Это будет бестолковая вещь, но приятная, с конторщиком Ваней, пьяницей и Местной Интеллигенцией." Möjligen är juristen Petrov enda resten av det sistnämnda och Vanja och fyllbulten tycks ha slagits ihop till en person (om nu inte ett komma har fallit bort). Till Slonimskij 8 augusti 1925 (brev 57), PSSP, 272. 
ord. Scenen avslutas med att juristen börjar berätta om sina mystiska händelser igen. Innehållet återges inte heller denna gång. Som vanligt hos Dobyčin ligger fokus istället på sättet och på de omgivande detaljerna där olika perspektiv och medvetanden kan mötas. Men ointresset för innehållet antyder också liksom i inledningen Sorokinas dagdrömmande karaktär. Det som noteras är vad som troligen är faderns, en läkares, dödskalle på skrivbordet som på samma gång som det skänker en mystisk atmosfär till berättandet kan antyda ett vetenskapligt och jordiskt avfärdande av denna "mystik": "В тени на письменном столе показывал зубы череп." ("I skuggan på skrivbordet visade en dödskalle tänderna.")

Parken. I nästa stycke, utan övergång, utan att huvudpersonen anges närvara, beskrivs lampor lysa under träden och musikanter på en scen. De beskrivs lite vid sidan av, inte när de spelar utan när de står och röker, som människor: "Музыканты на эстраде подбоченивались, покуривали и глазели." ("Musikanterna på estraden stod med händerna i sidorna, rökte och såg sig om.") De börjar spela en vals och det saknas uppenbarligen damer för dansen: "Притопывая, кавалеры чинно танцевали с кавалерами. Расходясь, раскланивались и жали руки." ("Stampande dansade kavaljerer stelt med kavaljerer. När de skiljdes åt bugade de och skakade hand.") Först därefter, i ett nytt stycke, får vi bekräftat att det är Sorokina som betraktar detta där hon står i mörkret och väntar på någon. Och hennes någon vet vi är Vanja. Tydligen är han en av kavaljererna som hon nu ser gå sin väg fast de har avtalat ett möte. Av stelheten att döma övar bara dessa kavaljerer med varandra, men det manliga samkvämet kan också ge homoerotiska associationer och antyda en förklaring till att Vanja inte dyker upp i linje med hans påstådda likhet med Dorian Gray.

Сорокина ждала в потемках за скамейками.

Вот он. Шапка на затылке, тоненький...

Если бы она его остановила:

- Ваня, -

может быть, все объяснилось бы: он перепутал, думал, что не в пять, а в шесть.

- Не забираться же с пяти, раз - в шесть.

Она взяла бы его за руку, и он ее повел бы:

- Мы поедем в лодке. У меня есть лодка «Сун-Ят-Сен».

Sorokina väntade i mörkret bakom bänkarna.

Där var han. Mössan i nacken, så smal...

Om hon hejdade honom:

- Vanja,

kanske allt skulle förklaras: han hade tagit fel, trott att det var vid sex och inte vid fem.

- Man träffas väl inte vid fem redan när det börjar först vid sex. 
Hon skulle ta honom i handen, och han skulle leda henne:

- Vi tar en båttur. Jag har en båt, "Sun Yat-sen".

Liksom tidigare huvudpersoner skrider Sorokina inte till handling, hon springer inte efter Vanja för att ändå förverkliga mötet utan upplever själv hur hon låter det gå sig ur händerna. Istället fylls hon av en levande föreställning av ett möte inom sig med exakta repliker och detaljer. Inom henne kan mötet bli så som hon vill ha det, det leder iväg mot en romantisk båttur i Vanjas båt uppkallad efter den samma år avlidne grundaren av Kuomintang. Inom henne kan Vanja uppfylla rollen som den hon längtar efter samtidigt som händelsen återigen, liksom redan Vanjas första stupfulla framträdande, låter antyda att det aldrig skulle ha blivit så och aldrig kommer att bli något mellan dem i verkligheten.

(3) Utanför hemmet. Lösa intryck inleder det sista kapitlet. En gumma som i första kapitlet utanför kyrkan talade om att vinden skulle vara till Kristi himmelsfärds återkommer och ser nya tecken. Nu är det löv som landat med den sträva sidan upp som talar för en god skörd. Dobyčin tycks både fascinerad av och ironisera över detta triviala teckentydande. Sorokina ser sedan i ett öppet fönster gummans barnbarn sitta vid en flygel och spela valsen "Diana". Valsen skulle kunna tänkas väcka minnet av valsen i parken i förra kapitlet men det som följer är att juristen återkommer och nu stödd mot fönstret utanför sjunger en juridisk grundsats på latin till melodin: "de in jus vocando, / de actionae danda", det betyder att handla enligt lagen. Hans värdiga drömmande ansikte får Sorokina att tänka på Italien och minnas universitetet. Troligen har hon likt Kukin i "Vstreči s Liz" haft en studenttid i (det Italieninspirerade) Petersburg.

Gatan, biblioteket, gatan. Utan att något mer sägs om vad Sorokina tänker på fortsätter en längtan att utveckla sig lyriskt och associativt genom nya intryck med allt otydligare kopplingar. Det är som om valsen ännu pågår bland det vardagliga när intrycken gestaltar Sorokinas rörelse till biblioteket och sedan vidare till ett möte med sin väninna. Det hela avslutas med att väninnan påkallar minnet av Vanja den allra första gången efter kyrkan. Antydningsvis har allting, alla sinnligt preciserande intryck och det intensivt betydelseupplevande medvetande det gestaltar, fortsatt att tala om honom för Sorokina, trots eller just tack vare det försummade verkliga mötet:

Развевались паутины. Под бурыми деревьями белелась церковь с синими углами.

- Мама, - кляузничала девчонка за забором: - Манька поросенка то розгами, то - пугает.

Библиотекарша смотрела на входящих и угадывала:

- «Джимми Хиггинс»? 
По улице Вождей слонялись кавалеры в наглаженных штанах и девицы в кожаных шляпах:

- В Америке рекламы пишутся на облаках... - Мечтали.

В сквере подкатилась Осипиха с георгиной на груди и старалась разжалобить:

- Говорят, я гуляка, - горевала она, - а я и дорог не знаю.

- В первую декаду - иссушающие ядра, - предложил газету зеленоватый старичок, - во вторую - обложные дожди.

Подсела Мильонщикова:

- Пройдемтесь в поле.

Голубенькое небо блекло. Тоненькие птички пролетали над землей.

- Помните, - оглянулась и понизила голос Мильонщикова: - однажды весной мы обратили внимание...

Молчали. В городе светлелись под непогасшим небом фонари. Расстались не скоро.

- Эти звезды, - показала Сорокина, - называются Сэптэнтрионэс...

Spindelnäten vajade. Under de bruna träden lyste en vit kyrka med mörkblå knutar.

- Mamma, skvallrade en liten flicka bakom staketet, Manka slår griskultingen med riset och skrämmer den.

Bibliotekarien såg på dem som kom in och gissade:

- Jimmie Higgins?

På Ledarnas gata strosade kavaljer i strukna byxor och flickor i skinnhattar:

- I Amerika skriver de reklamen på molnen... De drömde sig bort.

I parken kom Osipicha med en dahlia på bröstet och passade på att försöka få medlidande:

- De säger att jag stryker omkring, sade hon bedrövat, jag som inte ens kan gatorna.

- Den första dekaden - värmebölja, sade en grönaktig gamling och erbjöd tidningen, den andra - ihållande regn.

Miljonsjtjikova satte sig intill:

- Vi går ut och går på fältet.

Den ljusblå himlen bleknade. Smala små fåglar flög förbi över jorden.

- Minns ni, sade Miljonsjtjikova och såg sig omkring och sänkte rösten: en gång i våras uppmärksammade vi...

De tystnade. I staden sken lyktor under den osläckta himlen. De dröjde med att skiljas åt.

- De där stjärnorna, visade Sorokina, heter Septentriones...

I tystnaden delar de på något sätt minnet bortom orden. Sorokina tar till ord igen när de skiljs åt genom att kommentera stjärnorna med namnet på stjärnbilden, det antyder både längtan och att föreställa sig helheter utifrån 
enstaka lysande detaljer.230 Stjärnor syntes dessutom såväl den första kväll de drar sig till minnes som den andra gången hon såg Vanja i parken.

Hemma. Nu avslutas berättelsen. Fadern lägger patiens. Modern syr om en regnkappa (väderprognosen har ju varnat för regn). Och Sorokina öppnar boken från biblioteket - som inte är den socialistiska Jimmie Higgins av Upton Sinclair som bibliotekarien nämnde - och hon läser, försöker läsa, men nu är Vanja överallt för henne. Klockan tickar och slår, en hund skäller vintrigt. Och boken hon visar sig ha valt, Dorian Grays porträtt, kommer troligen bara att väcka fler ljuva föreställningar om den i hennes inre evigt unge och idealiske Vanja. Slutet återknyter också till det porträtt som Sorokinas väninna gav honom den allra första gången när hon just kallade honom "Rena kopian av Dorian Gray". Att Sorokina nu lånat den bok som väninnan anspelade på sluter också på ett ytligt plan händelseutvecklingen i novellen som ett möte bortom orden.

Vanja har liknats vid en litterär person vars porträtt blir mer levande än den verkliga människan. Vanja är också lik porträttet av Dorian Gray i det att han evigt är mer ung och levande för Sorokina än han troligen hade varit vid ett verkligt möte eller i ett liv tillsammans att döma av vad som samtidigt skymtat fram utanför hennes bild av honom. Möjligen antyder väninnan med liknelsen mest en förfining, en ovanlig skönhet precis som i Oscar Wildes bok. I detta finns också ett drag som kontrasterar mot det maskulint sovjetiska och som det anknöts till med det oskyldiga men trots allt antytt homoerotiska umgänget i parken som Sorokina bevittnade - kavaljererna som dansade med kavaljerer. Men tydligare än så blir det inte. Novellen slutar med Sorokina som uppfylld av sin längtan ser namnet Dorian i boken som vi vet leder hennes tankar till Vanja. (Namnet är också upprepat och utställt på liknande sätt som Vanja i det första mötet.) Litteraturen fyller ut verkligheten och verkligheten litteraturen. Sorokina ("soroka" betyder för övrigt "skata") är inte längre på väg någonstans:

Отец, приподняв брови, думал над пасьянсом. Мать порола ватерпруф. Сорокина раскрыла книгу из библиотеки.

Тикали часы. Били. Тикали.

За окном собака лаяла по-зимнему.

«Дориан, Дориан», - там и сям было напечатано в книге:

- «Дориан, Дориан».

\footnotetext{
${ }^{230}$ Så som jag i inledningen tog upp också sker i "Evdokija” och Gorod Én med möjliga metapoetiska konnotationer. Sorokina kan dessutom Karlavagnens namn på latin. Det självbiografiska jaget i romanen Gorod Én studerar både latin och har, trots sin närsynthet, ett astronomiintresse.
} 
Fadern satt med höjda ögonbryn över patiensen och tänkte. Modern sprättade upp en regnkappa. Sorokina öppnade boken från biblioteket.

Klockan tickade. Slog. Tickade.

Utanför fönstret skällde en hund som på vintern.

"Dorian, Dorian", stod det tryckt här och var i boken:

- "Dorian, Dorian".

\section{Flugan och björnen, pojken och matrosen}

I sina brev till Slonimskij och hans fru Ida berättar Dobyčin i en skämtsam ton men ändå öppet om sin kärlek till en viss Zajcev i Brjansk. Den vänskapliga relation de tycks ha kan möjligen ha gett drag åt porträttet av Muchin och Miška i "Sidelka" ("Sköterskan" eller "Vårdbiträdet"). Dobyčin beskriver (efter publiceringen av denna novell) bland annat hur en sensuell konnotation i Zajcevs i själva verket helt triviala ord tycks göra Dobyčin lika förlägen och handlingsförlamad som sina huvudpersoner:

На улице подкараулил Зайцева. Он был очень мил. - Подожди минутку, - сказал он, - я пойду помою руки: трогал кожу. - Оказывается, что он просто-напросто был в лавке и приценивался к сапогам.

В кинематографе идут «Нибелунги». Если бы я попросил Зайцева, он, может быть, со мной пошел бы, но я был страшно горд, и про кинематограф - ни слова.

På gatan väntade jag ut Zajceva. Han var väldigt vänlig. - Vänta en minut, sade han, jag går och tvättar händerna: jag rörde vid skinnet. Det visade sig att han helt enkelt var i en bod och frågade om priserna på stövlar.

På biografen går Nibelungarna. Om jag hade frågat Zajcev så hade han kanske gått med mig, men jag var förfärligt stolt och sade inte ett ord om biografen. ${ }^{231}$

En vänskap utvecklar sig men tycks inte leda till något mer. Man anar en smärta bakom orden när Dobyčin efter ytterligare några skämtsamma omnämnanden skriver: "Если Вы вывели, что Зайцев несимпатичный, из моих каких-нибудь слов, то я о них очень жалею. Я его очень люблю.” ("Om ni utifrån några av mina ord dragit slutsatsen att Zajcev är osympatisk så ångrar jag dem. Jag älskar honom väldigt mycket.")232 Sista gången Dobyčin nämner Zajcev är i samband med novellen "Lëška" (som i Portret döpts om till "Matros" ("Matrosen")) när han önskar införa en tillägnan till Zajcev under titeln - "för det är i själva verket också till Zajcev" ("потому

\footnotetext{
${ }^{231}$ Till Slonimskij I8 mars 1926 (brev 77), PSSP, 283-284.

${ }^{232}$ Till Ida Slonimskaja (Michail Slonimskijs fru) I7 juni 1926 (brev 83), PSSP, 288-289.
} 
что это и на самом деле - Зайцеву"). 233 Möjligen är novellen ett slags avsked till deras relation.

\section{"Sidelka" - sköterskan och det som inte finns}

"Sidelka" är kanske den formmässigt mest extrema av samtliga av Dobyčins noveller. Majoriteten av de totalt 48 styckena i den två sidor långa novellen är bara en mening långa. 22 meningar av totalt 82 består av bara ett eller två ord.

I förstone kan den tyckas utgöra ett koncentrat av den vanliga historien om en väckt längtan efter ett möte som inte infrias. Men det är något med den vardagliga vänskapen i denna berättelse. Tidigare har de existerande relationerna oftast framställts som grå och alldagliga i jämförelse med dem som huvudpersonerna längtar efter. Något med vänskapen är här annorlunda. Ett mått av detta vänskapens djup som gränsar till kärlek fanns möjligen redan i förra novellen, "Dorian Gray", i det möte bortom orden med väninnan som föregick slutet.

Något andra miljöer skildras nu, varken någon arbetsplats, någon familj eller några äldre kvinnor figurerar. Huvudperson är en ung men vuxen man, han studerar, bor ensam och dricker öl på en servering. Beskrivningarna är inte lika ingående, detaljerna mer strängt utvalda och bärande. Bruket av talande namn har blivit mer iögonfallande då flera av dem är enhetligt zoologiska. Huvudpersonens namn Muchin kommer av "mucha" ("fluga").

Att meningarna och styckena är kortare bidrar till att perspektivet kan upplevas mer distanserat från huvudpersonen. Novellen inleds med en naturbeskrivning, med ett lyriskt blänk, som inte förankras i ett medvetande innan en rörelse av människor, med flaggor på väg ner mot huvudgatan, beskrivs i vilken huvudpersonen dyker upp med en käck hälsning till någon:

Под деревьями лежали листья.

Таяла луна.

Маленькие толпы с флагами спускались к главной улице. На лугах за речкой блестел лед, шныряли черные фигурки на коньках.

- Здоро́во, - трогал шапку Мухин. Улыбаясь бежал вниз. Выше колен болело от футбола. 234

Det låg löv under träden.

Månen tynade.

233 Till Slonimskij 20 juli 1926 (brev 85), PSSP, 289.

${ }^{234}$ Novellen citeras ur PSSP, 80-8I. 
Små skaror med flaggor var på väg ner mot huvudgatan. Is glänste på ängarna bortom floden, mörka små figurer snodde omkring på skridskor.

- Hejsan, sade Muchin och rörde vid mössan. Han sprang leende neråt. Ovanför knäna gjorde det ont efter fotbollen.

Intrycken har individualiserande drag, vad som ses och hur det ses framkallar en närvaro i världen men etablerar inte tydligt huvudpersonens perspektiv. Med smärtan efter fotbollsspelandet får vi plötsligt tillgång till hans inre men med Muchin fortsatt mer som ett objekt än subjekt. Med sitt käcka hälsande, idrottsintresse och fart framstår han också mindre som en med författaren besläktad dagdrömmare. Förhållandet till huvudpersonen liknar det till pojken Lëška i nästa novell.

Vid den uppställning framför arbetarpalatset som rörelsen leder fram till presenteras några andra personer liksom för en utomstående och utan rumsligt perspektivskapande, deiktiska detaljer: "Товарищ Окунь, культработница, стояла на балконе со своим секретарем Володькой Граковым." ("Kamrat Okun, kulturarbeterska, stod på balkongen med sin sekreterare Volodka Grakov.") En kvinna talar till Muchin om sekreteraren som hon högtidligt romantiskt benämner med det finare, lite borgerliga Vol'demar: "- Вольдемар - мое неравнодушие, - говорила Катя Башмакова и смотрела Мухину в глаза." ("- Voldemar gör mig svag, sade Katja Basjmakova och såg Muchin i ögonen.") Möjligen har kamrat "abborre" ("okun") lagt beslag på den nu sovjetiskt sinnade Volod'ka och kanske provar denna Katja, som senare ska visa sig vara Muchins granne, med detta indirekt Muchins känslor för henne. ${ }^{235}$

Det är troligen revolutionsdagen som firas. Det stämmer med årstiden och förklarar flaggorna och ceremonin. Det stämmer också med en verklig historisk händelse som kan ha tjänat som material: avtäckandet av en staty över den lokale revolutionshjälten Ignat Fokin (I889-I8I9) på revolutionsdagen 7 november 1922.236

\footnotetext{
235 Att denne Grakov, vars namn skulle kunna associeras till "grač" ("råka"), var en faktisk person i Brjansk som arbetade som just sekreterare (vid kommunistpartiets regionskommitté) enligt Golubeva, medan såväl Okun’ som Muchin troligast är påhittade namn utifrån olika djur, är betecknande för Dobyčins användning av talande namn. Detta verkliga namns möjliga djuretymologi framhävs så genom sammanhanget som sällan är så påtagligt och enhetligt i sin tematik som i denna novell. Det som är utpräglande för Dobyčins namnanvändning är annars att namnen, som med Grakov och snart Gusev, samtidigt som de potentiellt är talande inte känns konstruerade och ofta är verkligt existerande namn som Dobyčin har dragits till att använda på samma sätt som till andra dolda underfundigheter i sin vardag. (E். S. Golubeva, Pisatel' Leonid Dobyčin i Brjansk, Brjansk 2005, 97.)

${ }^{236}$ PSSP, 468.
} 
Under musik och rött kattun med guldskrift ger man sig nu av till Offrens torg. Den sovjetiska pompan profaneras av (det påhittade) namnet på torget, att någons babusjka nämns i samma mening som den avskilt begravda kamrat Gusev (från "gus'", "gås") som man kommit för att hylla samt av det triviala småskämtandet om monumentet:

На площади Жертв выстроились. Здесь были похоронены капустинская бабушка и, отдельно, товарищ Гусев.

Закрытое холстом, торчало что-то тощее.

- Вдруг там скелет, - хихикала товарищ Окунь.

Сдернули холстину. Приспустились флаги. Заиграл оркестр. У памятника егозили, подсаживали взлезавших на трибуну.

- Товарищ Гусев подошел вплотную к разрешению стоявших перед партией задач!

Вертелись. Сзади было кладбище, справа - исправдом, впереди - казармы.

De ställde upp sig på Offrens torg. Här var Kapustins mormor begraven och, avskilt, kamrat Gusev.

Något spinkigt stod övertäckt med ett skynke.

- Det kanske är ett skelett, fnittrade kamrat Okun.

Skynket drogs av. Flaggorna sänktes på halv stång. Orkestern började spela.

Det vimlade framför statyn, de som trängt sig fram gavs plats på läktaren.

- Kamrat Gusev tog sig helhjärtat an att lösa de uppgifter som partiet stod inför!

De vred på sig. Bakom låg kyrkogården, till höger uppfostringsanstalten, framför - kasernerna.

Det militäriskt officiella i talet fångas upp av den återhållna beskrivningen av vad som omger dem. Bakom dem på Offrens torg ligger en kyrkogård, till höger ett "ispravdom" (uppfostringsanstalt eller helt enkelt det nya namnet för fängelse) och framför dem kaserner. Det som utpekas visar så fram den mörka verkligheten bakom lösningarna av de uppgifter partiet ställdes inför.

När nu ett kärleksobjekt uppenbaras för huvudpersonen, helt enligt den vanliga strukturen, sker det utan att perspektivet förankras i några känslor; inte mycket tilltalande, inget drömskt skimmer, ingen anspänning finns i hur hon presenteras, inget som talar för en attraktion, snarast tvärtom: "Щекастая в косынке - сиделка, - высунув язык, лизала губы и прищуривалась." ("Rundkindad med sjalett satt en sköterska - stack ut tungan, slickade sig om läpparna och kisade.")

Muchin intresse framvisas: "Мухин присмотрелся, вышел из рядов и караулил." ("Muchin höll ögonen på henne, bröt ledet och vaktade.") Men 
istället för hans känslor eller tankar om sköterskan följer en utvecklad beskrivning av honom såsom han iakttas av andra och med en mer attraherande prägel än i synen av sköterskan: "На него заглядывались: тоненький, штанишки с отворотами, над туфлями - зеленые носки." ("Man betraktade honom intresserat: smal och fin, byxor med slag, gröna strumpor som stack upp ur lågskorna.") Så har snarare huvudpersonen med detta uppenbarats som ett objekt innan berättelsen går vidare.

Folksamlingen skingras och Muchin hindras från att närma sig sköterskan genom att kamrat Gusevs far kommer fram och vill berömma statyn över sin son (vilket skildras med samma operspektiverade ironi som tidigare):

- Каково произведение! - протянул он руку к обелиску с головой товарища Гусева на острие.

Сиделка уходила.

- Мне необходимо, - устремился Мухин. - Пардон.

- Vilket konstverk! sade han och sträckte ut handen mot obelisken med kamrat Gusevs huvud på spetsen.

Sjuksköterskan gick iväg.

- Jag måste, sade Muchin och rusade iväg. Pardon. ${ }^{237}$

Muchin sliter sig loss för att följa efter sköterskan men hindras nu av ett begravningståg. Efter det direkta intrycket följer förklarande bakgrundsinformation som låter som något av ett referat av den officiella diskursen om dödsfallet, medan upplevelsen av begravningen i stunden i den vardagliga tillvaron framträder som ett mänskligt motspråk:

Дорогу перере́зали. Трубя, маршировали - хоронили исключенную за неустойчивость самоубийцу Семкину:

- вы жертвою пали.

237 "Gusevs huvud på spetsen", menar Golubeva är en talande förvrängning (likt ett spetsat huvud på detta Offrens torg) av den verkliga gravobelisken över Fokin där hans byst avbildades i relief i stenen med en minnesplakett i brons under. Ė. S. Golubeva, Pisatel' Leonid Dobyčin i Brjansk, Brjansk 2005, 97-98. Att Dobyčins satir över dylika monumentalkonstverk inte är ensidigt riktad mot det sovjetiska kan exemplifieras med att han här återanvänt en episod från den förrevolutionära novellen "Evdokija" där en nationalistiskt kitchig staty avtäcks: "стояло что-то тощее, закрытое холстиной. - Я боюсь, - кокетничала одна дачница, - вдруг там скелет! [...] Сдернули холстину, и памятник открылся и заблестел: на цементном кубике стояла, дулом вверх, пушка, и на ней - золоченый орел в короне. Как мило, - щебетали дамы [...]. ("det stod något spinkigt övertäckt av ett skynke. - Jag är rädd, koketterade en sommargäst, det kanske är ett skelett! [...] Skynket drogs av och statyn visade sig och blänkte: på en cementkub stod med mynningen uppåt en kanon och på den en förgylld örn med krona. - Så fint, kvittrade damerna.") PSSP, 348. 
Ее приятельница, кандидатка Грушина, ревя, смотрела из ворот.

Vägen var spärrad. Det blåstes i trumpeter och marscherades, de begravde självmörderskan Siomkina som uteslutits på grund av otillräknelighet:

- ni föll offer.

Hennes väninna, kandidat Grusjina, stod och grät och såg på från porten.

Självmörderskan Semkina blir besjungen med den revolutionära begravningssången som ännu ett offer. Men ett offer för vem? Vi får veta att hon på grund av "neustojčivost" ("obeständighet" eller "otillräknelighet") blivit utesluten (ur partiet) vilket så framstår som anledningen till självmordet.

Hennes gråtande väninna som står och ser på men utan att delta föranleder en replik vars anföring ytterst komprimerat introducerar en Miška som nu plötsligt dyker upp och visar sig vara en vän till huvudpersonen:

- Дисциплинированная, - похвалил растратчик Мишка-Доброхим: - в процессии не участвует.

- Disciplinerad, berömde förskingraren Misjka från Kemvapenskyddsföreningen: deltar inte i processionen.

Väninnan sägs alltså vara disciplinerad för att hon inte deltar i begravningståget (kanske skulle hon då själv riskera att bli utesluten). Det säger denne Miška lakoniskt medan han själv med epitetet "rastratčik" ("förskingrare") presenteras som allt annat än disciplinerad; tillägget "Dobrochim" ("Obščestvo druzej chimičeskoj oborony i promyšlennosti", "Vänsällskapet för kemiskt försvar och industri") till hans namn lär vara vad man specificerat denne Miška med tidigare efter hans arbetsplats där han sedan troligen anklagats för förskingring. Hans kommentar om att vara disciplinerad kan därmed tolkas som på samma gång cyniskt distanserat och medkännande.

Det konstateras att sköterskan försvunnit och en miljöbeskrivning - röken från ett tåg som rör sig bortom floden - ger rum åt kontemplation och en stunds närvaro i en längtan efter något annat vilket det ska framgå att Muchin och Miška delar. Först därefter blir Miška iakttagen och Muchin reagerar: antagligen är det från sitt straff för förskingringen som Miška nu har blivit frisläppt:

Сиделка скрылась...

За лугами бежал дым и делил полоску леса на две - ближнюю и дальнюю. 
Запихнув руки в карманы, Мишка, сытенький, посвистывал.

- Выпустили? - встрепенулся и поздравил его Мухин.

Sköterskan hade slunkit undan...

Bortanför ängarna drog en rök fram och delade skogsstrimman i två - en närmre och en bortre.

Misjka körde ner händerna i fickorna, såg välnärd ut och visslade lite.

- Har de släppt dig? spratt Muchin till och gratulerade honom.

Det finns något spefullt och lockande med Miška. Hans uppdykande sammanfaller med att sköterskan försvinner ur bilden. Novellen börjar liksom om med denna blick över ängarna på andra sidan floden som beskrivs i inledningen. Det som nu följer, resten av den dag som skildras, är utvecklingen av Muchins relation med Miška - "flugan" och "(nalle-)björnen" om man ser till betydelsen i deras namn.

De går neråt, liksom Muchin i inledningen skyndade neråt, och liksom han hälsade då sägs de hälsa på dem de möter. De stannar vid några affischer som inte beskrivs och Miška tar avsked för att gå hem till sig och äta.

Det är först nu, efter detta möte med Miška, som Muchin verkligen börjar framträda som längtansfylld i stil med tidigare huvudpersoner. Efter att han blivit lämnad ensam tar beskrivningen av varorna i ett skyltfönster vid och formar en romantisk miniatyrberättelse i glamorös NEP-stil:

На крае зеркальца в окне «Тэжэ» блестела радуга. Кругом была разложена «Москвичка» - мыло, пудра и одеколон: пробирается к кому-то, кутается в горностай, ночь синяя, снежинки...

Захотелось небывалого - куда-нибудь уехать, быть кинематографическим актером или летчиком.

I kanten av en handspegel i skyltfönstret till "Teeff", Trusten för fett- och benprodukter, glänste en regnbåge. Runt omkring var en "Moskvafröken" utlagd - tvål, puder och eau-de-cologne: hon är på väg till någon, sveper sig i hermelinpälsen, natten är mörkblå, snöflingor...

Man fick lust till något enastående - åka iväg någonstans, vara filmskådespelare eller pilot.

Det uttrycks som en existentiell längtan, från en vardaglig tristess, efter något annat, något betydelsefullt. Men möjligen talar "nebyvaloe" ("något enastående") också för något som faktiskt finns men bara inte kan få utlopp inom detta sociala sammanhangs ramar, nämligen en kärlek som vännen Miška snarare än sköterskan har väckt.

Intrycken under vad som ska framgå är en väntan på Miška är laddade; det invigda nyss ironiskt trivialiserade monumentet presenteras i tidningen som ett mönsterexempel på monumentalkonst. Denna officiella konst kan 
här ses kontrasterad mot novellens subtila konstnärlighet i de vardagliga impressionerna som fångas som ett uttryck för Muchins sinnesstämning:

В столовой Мухин засиделся за газетой. Открывающийся памятник образец монументального искусства...

Спускалось солнце. Церкви розовелись.

Шаги стучали по замерзшей глине.

В комнатке темнело. Над столом белелось расписание: физкультура, политграмота...

В гостиной у хозяйки томно пела Катя Башмакова и позванивала на гитаре.

På serveringen blev Muchin sittande med tidningen. Den invigda statyn var ett mönsterexempel på monumentalkonst.

Solen sjönk. Kyrkorna blev rosa.

Stegen klapprade mot den frusna leran.

Det blev mörkare i det lilla rummet. Över bordet lyste schemat vitt: fysisk kultur, elementär politikkunskap...

I vardagsrummet hos värdinnan sjöng Katja Basjmakova vemodigt och klinkade på gitarren.

På Muchins schema - han är alltså student - syns bara "fysisk kultur" (eller frisksport, idrott (vilket möjligen förklarar den i inledningen nämnda värken efter fotbollen)) och politisk fostran. De tre punkterna andas uppgivenhet, och de rodnande kyrkorna, stegen på frusen lera, skymningen och grannen Katjas sång (hon med sina drömmar om Vol'demar) talar för drömmen om något annat.

I denna stämning återkommer så Miška med sitt rättframma sätt. Han gör antydningar om att Muchin skulle vara intresserad av grannen, vilka Muchin inte behöver ord för att tolka. Istället uppstår åter en samvaro mellan dem liksom bortom orden genom dessa allmänna antydningar på ytan:

Пришел Мишка. Прислушался. Состроил хитрое лицо.

- Нет, - покачал Мухин головой печально: - кому я нравлюсь, мне не нравятся. А чего хотел бы, того нет.

- Это верно, - согласился Мишка.

Misjka kom. Lyssnade. Såg finurlig ut.

- Nej, sade Muchin och skakade dystert på huvudet: den som tycker om mig tycker inte jag om. Och det jag skulle vilja, det finns inte.

- Det är sant, höll Misjka med.

Det är inte så att den han tycker om vill ha någon annan, inte heller förklarar han sig sakna känslor - men det han skulle vilja finns inte. Det är vad han säger till Miška efter hans frågande finurlighet. Miškas bekräftande kan 
tolkas som att han helt enkelt delar denna upplevelse av att det man egentligen längtar efter aldrig kan infrias. Men med anknytning till Miškas första replik om självmörderskans väninna som disciplinerad kan man också tolka det som ett fastslående, att det måste vara så, som svar på det Muchin sade förstått som en indirekt fråga: Det är sant, det andra som du antyder får inte finnas. Denna fråga står inte uppenbart på spel mellan dem i deras umgänge härefter. Men en spänning dröjer sig kvar, skildrat genom sinnliga detaljer och deras samfällda tankfullhet och sång. De umgås som de kan, som man gör, utan att mer beröra ämnet eller överskrida några gränser, disciplinerat, med en renhet som den mångtydiga sången också kan ge uttryck för (det i sången upprepade "čistim" ("vi gör rent" eller "vi rensar"), som är en verklig skomakarsång ger i den sovjetiska kontexten ofrånkomligen associationer till politisk "čistka" ("utrensning")): ${ }^{238}$

Светились звезды. У ворот шептался кто-то. Шелестели листья под ногами.

Шли под руку. Задумчивые, напевали:

$$
\begin{aligned}
& \text { - чистим, чистим, } \\
& \text { чистим, чистим, } \\
& \text { чистим, гражданин. }
\end{aligned}
$$

Stjärnor lyste. Någon viskade vid porten. Löven prasslade under fötterna. De gick armkrok. Tankfulla småsjöng de:

- vi gör rent,

\begin{abstract}
${ }^{238}$ Se Boris Sergeevič Markus, "Moskovskie kartinki I920-ch - I930-ch gg. (vospominanija)", Litmir: Ėlektronnaja biblioteka, https://www.litmir.me/br/?b=24I9I8\&p=3I, 20I9-03-22. Där citeras sången bland minnen från I920- och 30-talet som en oskyldig skomakarsång. Besynnerligt nog tycks Dobyčin, som om han var lika omedveten som sin huvudperson, ännu inte känna till den nya sovjetiska betydelsen hos ordet som vi i samband med de nya novellerna i Portret i nästa kapitel ska se att han blivit varse. I ett brev skrivet efter att "Sidelka" publicerats (tre dagar senare skriver han att han köpt numret av tidskriften Novaja Rossija där "Sidelka" först kom i tryck (nummer 2 1926)) förstår han i alla fall inte den liknande innebörden i det prefigerade "načistit" som i denna kontext snarast betyder "arrestera" (Poperečnjuk är en kollega): "Поперечнюк сказал мне: «Сегодня ночью начистили многих ребят». Я подумал, что это значит обокрали, и спросил: «На вашей улице?» - «На разных, - сказал он, к дяде на поруки». - «К какому дяде?» - пришлось мне унизиться до вопросов. - «Разве вы не знаете этого выражения? - поторжествовал он. - В исправдом, по делу Свешникова». Свешников - это проворовавшийся бухгалтер." ("Poperečnjuk sade till mig: 'I natt rensade de många killar'. Jag tänkte att det betydde rånade och frågade: 'På er gata?' - 'På olika', sade han, 'till farbror som borgen.' - 'Till vilken farbror?', var jag tvungen att nedlåta mig till frågor. -'Känner ni verkligen inte till det uttrycket?' sade han triumferande. 'Till uppfostringsanstalten, för Svešnikovfallet.' Svešnikov är en bokhållare som ertappats med att stjäla.") Till Slonimskij I8 mars I926 (brev 77), PSSP, 284-285.
\end{abstract}


rent, rent, rent,

rent, medborgare.

Sedan skiftar stämningen. Det som stått ut från det vanliga börjar sjunka ner i vardagen. Något som tycktes uppfyllt i deras ordlösa samvaro och i sången försvinner efter den, som om innebörden, "rena" eller "rensa ut", framträtt och gjort dem - likt Kunst och Ivan Il'ič i "Proščanie" - förlägna. Något saknas ändå, något hindrar dem från att finna ro att bara vara med varandra. Först är det solrosfrön som de ångrar att de inte har med sig: "3aшли в купальню и жалели, что не захватили семечек, а то бы здесь можно посидеть." ("De gick in i badhuset och beklagade att de inte tagit med sig några solrosfrön, annars hade man kunnat sitta här ett tag.") De går till bion istället och skyndar sig att köpa biljett till vad som antagligen utifrån affischen beskrivs: "граф разговаривает с дамой" ("en greve samtalar med en dam"). Och sedan är de slutligen på en servering där det sköra mellan dem försvinner i det allmänna stimmet. De omges nu av en trivial lätt forcerad godmodighet när de sköljer glasen med ölet (troligen för att få bort baciller, i samma associationssfär som det disciplinerade och renandet) och slutligen skålar, varpå Muchin till sist tar till orda:

За прилавком дремала хохлушка в коричневом галстуке. Подбодрили ее: - Веселей!

Стаканы, чтобы чего-нибудь не подцепить, ополоснули пивом. Чокнулись.

- Я чуть не познакомился с сиделкой, - сказал Мухин.

Bakom disken dåsade en ukrainska med brun slips. Man muntrade upp henne: - Gladare!

De sköljde glasen med ölet för att inte dra på sig något. Skålade.

- Det var på vippen att jag blev bekant med en sköterska, sade Muchin.

Den avslutande repliken är det första i direkt tal återgivna som sägs mellan dem efter sången. Med återknytandet till sköterskan knyts berättelsen ihop som en icke-händelse, som om det var det väsentliga denna dag. Det slags samtal som repliken kan tänkas inleda ger samtidigt en avrundning av det speciella mellan dem som inte kunnat få utlopp. Det här är vad som får finnas. En sköterska han bara sett på håll men talar om som om han nästan lärt känna henne, men kanske egentligen inte är intresserad av, det är något han kan berätta om, något en man kan prata med en man om över en öl. Det är som det ska vara. Det blir den berättelse om sin dag som Muchin kan uttala medan vi i berättelsen om Muchin anat att det väsentliga egentligen var att han umgicks med och "var på vippen" att lära känna Miška. 


\section{"Lëška"|"Matros" - ett barns längtan}

Om huvudpersonens namn i förra novellen gav uttryck för något av känslan av att vara en fluga i relation till en björn, så är huvudpersonen här en liten pojke som dras till en kraftfull men ömsint sjungande vuxen matros (vilken novellen istället är uppkallad efter i samlingen Portret).

Novellen var ursprungligen (liksom "Lidija") tänkt som en berättelse för barn, något Dobyčin troligen på grund av gynnsamma utgivningsmöjligheter uppmuntrats till att skriva. Både Kornej Čukovskij och Michail Slonimskij kom att lovorda berättelsen men ansåg samtidigt inte heller denna lämplig för ett barnlitteraturförlag. ${ }^{239}$ Dobyčin beskriver den själv nedlåtande som något "en gymnasist skrivit enligt Klassiska Förebilder" (men att det "därmed förvisso inte finns någon politik") och reagerar rentav misstänksamt på Slonimskijs ovanligt berömmande ord: är det för att "det inte ser ut som att jag skrivit den" som Slonimskij tycker om den? Uppskattar de honom mer när han inte är originell?240

Det finns en mer utpräglad sinnlighet i denna novell. Om än den möjligen grundar sig i en verklig åtrå och en förälskads förhöjda detaljförnimmelse motiveras den i berättelsen av den unga huvudpersonens, för att tala med formalisterna, ännu inte automatiserade upplevelse av världen. Det affektiva drag som formalisternas recept att se världen som främmande, ny, som för första gången, lätt för med sig, är möjligen vad som på samma gång får denna novell att falla sina två samtida läsare mer på läppen och vad som gör Dobyčin obekväm. Han själv tycks ha problem med det affektiva, såväl hos Lidija Sejfullina - med henne "sjusjukan'e" ("gullande") istället för skrivande - som hos Isaak Babel' som han lär ha kallat "parfjumernyj" ("parfymerad").24r

\footnotetext{
239 Detta är en av de få gånger Čukovskij nämner Dobyčin i sin dagbok: "Новый рассказ «Лешка» - отличный, но едва ли пригодный печати. (Он прочит его для детей.)" ("Den nya berättelsen "Lëška" är utomordentlig, men knappast lämplig för publicering. (Han avser den för barn.)") K. Čukovskij, Dnevnik. I9OI-I929, Moskva 199I, 367, citerad i PSSP, 469. Efter att den också ratats av barnlitteraturförlaget Raduga arbetar Dobyčin om den för publicering i tidskriften Novaja Rossija som dock endast antog "Sidelka". Istället kommer den första gången i tryck i samlingen Vstreči s Liz, 1927.

240 "Интересного в нем ничего нет, он похож - как будто ученик старших классов сочинял по Классическим Образцам, - но зато нет и «политики»." Till Slonimskij 20 juni 1926 (brev 84), PSSP, 289. "Я очень рад, что Вам понравилось, а то Вы всё ругались." Men: "Чем вам понравилось? Тем, что не похоже, что это я писал?" Till Slonimskij 20 juli 1926 (brev 85), PSSP, 289-290.

${ }^{241}$ Till Čukovskij I4 april 1925 (brev I9, PSSP, 256) respektive enligt Leonid Rachmanov, "Staryj ljubitel'skij snimok", V. A. Kaverin (red.), Vospominanija o Ju. Tynjanove: Portrety $i$ vstreči, Moskva I983, 294-30I, 298. I samma anda redogör Dobyčin tillsynes stolt för ett läsarbrev där en madame menar att Babel' är som gipyrspets eller krämfärgad gipyr och han själv
} 
Vi följer pojken Lëška genom hans dag. Det börjar tidig morgon: "Лешка соскочил с кровати. Мать дежурила." ("Losjka hoppade ur sängen. Modern hade jour.") Den ensamma pojkens medvetande framträder i beskrivningen av gården; det är "liksom" över brunnen som månen lutar och lyser vit och en björk beskrivs som med medkänsla där den står utan att röra sig:

Склонившись, словно над колодцем, чуть белелась полукруглая луна. Не шевелилась жидкая береза с темными ветвями. На траве блестели капельки. Поклевывая, курицы с цыплятами бродили по двору. ${ }^{242}$

Liksom lutad över brunnen syntes en vit halvrund måne. Den klena björken stod orörlig med mörka grenar. Droppar lyste i gräset. Nickande gick hönorna med kycklingarna på gården.

En grannfru kommer och i iakttagelsen av henne, där en nyckel och särskilt (markerat av ett tankstreck) en tiger på väskan är väldigt intressanta $\mathrm{i}$ sig, finns fullt ut barnets uppmärksamhet: "У нее в руке был ключ, а на руке висела вышитая сумка - с тигром." ("Hon hade en nyckel i handen och över armen hängde en broderad väska - med en tiger".) Efter att ha beskyllt honom för att vara en lortgris förklaras hon ge sig av för att köpa bullar. Dessa bullar ska visa sig vara ett centralt sammanfogande kitt mellan episoderna. "Sitnyj" ("siktbröd" eller "vetebröd") är nämligen vad huvudpersonen i första hand längtar efter liksom en ersättning för den romantiskt färgade längtan efter ett möte som håller samman övriga berättelser.

Siktbröd är vad en vattenkörare som härnäst dyker upp sitter och äter på efter att grannkvinnan gått iväg efter bullar:

Усатый водовоз, кусая от фунта ситного, гремел колесами. Пыль сонно поднималась и опять укладывалась.

Vattenköraren med mustasch satt och bet på ett pund siktbröd och dundrade med hjulen. Dammet lyfte sömnigt och lade sig igen.

Det trötta dammet och vattnet som fraktas spelar in i samma längtanssfär hos pojken. Lëška får åka med. Sittande på vattentunnan på vagnen beskrivs, som pojken föreställer sig det, hur andra är avundsjuka på honom. Dessa räknas upp, och samhället målas upp med dem, men utan dagsaktuella eller kritiskt kontrasterande motiv. Föremålen och människorna är underliga och spännande i sig så som de fokuseras:

som rimfrost i månljus. ("Какая-то мадам прислала мне письмо, что Бабель - это кружевной гипюр (не то кремовый гипюр, я забыл), а я - лес в инее при луне и должен обязательно познакомиться с Бабелем [...].”) Till Slonimskij I6 maj 1929 (brev II2), PSSP, 300. ${ }^{242}$ Novellen citeras ur PSSP, 85-87. 
[...] Завидовали бабы, несшие на коромыслах связки глиняных горшков с топленым молоком, кондукторша в очках, которая гнала́ корову и замахивалась на нее веревкой, и четыре жулика, сидевшие под горкой и разбиравшие мешок с бельем.

[...] Gummorna var avundsjuka där de gick och bar knyten med lerkrukor med varm mjölk hängande från oken, och även en konduktörska med glasögon som jagade en ko och viftade med ett rep efter henne liksom fyra skurkar som satt nedanför en kulle och gick igenom en säck med linne.

Efter att han blivit avsatt följer nästa episod utan annan koppling till det tidigare än siktbrödet. Nu är det solen som subjekt som lyser in i en viss för pojken känd teservering: "Солнце поднялось и припекало. Освещало ситный в чайной у Силебиной." ("Solen gick upp och gassade. Den lyste på siktbrödet i tehuset hos Silebina.") Här, på gatan, ser Lëška också en pojke som sätter upp bioaffischer. Med dessa sås ett frö till den senare avgörande vändpunkten; affischerna gör reklam för en gratisföreställning, "men Lëška", griper berättaren in över huvudet på honom, "kunde inte läsa": "Там было напечатано: «Бесплатное», но Лешка не умел читать."

Denna exposé avslutas med att en tillsynes tidigare okänd matros introduceras på liknande sätt som kärleksobjekten i tidigare noveller. Han är solbelyst och de specifika detaljerna - just ett brunt staket, på en bänk under körsbärsträd - insisterar på hans betydelse och framkallar en intensitet $\mathrm{i}$ själva stunden (ackompanjerad av sången om ett fjärran Transvaal):

В палисаднике с коричневым забором, сидя на скамье под вишнями, нежился на солнышке матрос и играл на балалайке.

- Трансваль, Трансваль...

Было хорошо у палисадника. Забор уже нагрелся и был теплый, сзади пригревало плечи, пахло клевером.

Матрос...

I trädgården framför ett hus med ett brunt staket mot vägen satt en matros njutande i solen på en bänk under körsbärsträden och spelade balalajka.

- Transvaal, Transvaal...

Det var skönt utanför trädgården. Staketet hade redan värmts upp och var ljummet, bakifrån värmde det lite på axlarna, det luktade klöver.

En matros... ${ }^{243}$

${ }^{243}$ Det afrikanska Transvaal är det enda som citeras ur denna vid sekelskiftet populära ryska sången om boerkriget (som hyllar kolonisatörernas självständighetskamp mot engelsmännen). PSSP, 469. 
Med samma tvära kast som tidigare är Lëška sedan tillbaka där han började: "А мать уже вернулась и перед осколком зеркала чесала волосы." ("Men modern hade redan kommit tillbaka och kammade håret framför spegelskärvan.") Som ett fattigt substitut för te och siktbröd dricker de hett vatten med socker och äter mörkt bröd. Deras tillvaro och samvaro beskrivs utan att de växlar ett ord. Deras i en enordsmening lakoniskt konstaterade pustande - "Otduvalis'." - behöver inte, åtminstone inte ur pojkens obekymrade perspektiv uttrycka bedrövelse över deras materiella situation, vilken framstår som mer prekär än i tidigare noveller, det kan läsas som deras konkreta blåsande på det heta vattnet.

Därefter förmanar modern Lëška att inte gå ner till floden och lägger sig att sova efter sitt nattarbete. Moderns förbud gör förstås bara floden till ett än mer frestande äventyr. Det är dit berättelsen leder nu. Plötsligt och med tumultartad rörelse bland musik och marscherande pionjärer och hundar, är Lëška ute på gatan igen medan modern sover. Han dras för ett kort tag med i denna samfällda rörelse, den enda påtagliga manifestationen av det sovjetiska i novellen:

Вдруг загремела музыка. Все бросились.

Блестели наконечники знамен. Трещали барабаны.

Пионеры в галстуках маршировали в лес. Телега с квасом громыхала сзади.

Вслед! с мальчишками, с собачонками, размахивая руками, приплясывая, прискакивая:

- В лес!

Plötsligt dånade musik. Alla störtade iväg.

Flaggknopparna glänste. Trummorna smattrade.

Pionjärerna i halsdukar marscherade till skogs. En vagn med kvass skramlade bakom.

Efter! med pojkarna, med hundarna, hoppande, dansande, viftande med armarna:

- Till skogs!

Likt tidigare huvudpersoner föreställer han sig följa efter men gör det inte. Det som avbryter honom är matrosen som åter uppenbarar sig. Tre gånger upprepas "en matros" med utropstecken som uttryck för Lëškas upprymdhet. Tvättlappen, kragen, mössbanden - allt rör sig sinnligt och talar för den dragningskraft matrosen utövar. Pionjärernas musik avlägsnar sig, Lëška står med bultande hjärta och kan förstås inte annat än följa efter till den förbjudna floden:

Вдоль палисадников, вертя мочалкой, шел матрос. Его голубой воротник развевался, за затылком порхали две узкие ленточки. 
Матрос! Стихала, удаляясь, музыка, и оседала пыль. У Лешки колотилось сердце. Он бежал на речку - за матросом.

Матрос! Со всех сторон сбежались. Плававшие вылезли. Валявшиеся на песке - вскочили.

Матрос!

Längs staketen till trädgårdarna, svängande med en tvättlapp, gick matrosen. Hans ljusblå krage fladdrade, bakom nacken slängde två smala band.

En matros! Musiken avlägsnade sig och tystnade, dammet sjönk. Ljosjkas hjärta bankade. Han sprang mot floden - efter matrosen.

En matros! Man kom springande från alla håll. De som badade kom upp på stranden. De som låg utsträckta på sanden - hoppade upp.

En matros!

Matrosen är världens centrum och badstranden vid floden är det yttersta äventyret i Lëškas värld. När han ser matrosen dyka i och simma uppnås ett slags klimax. Matrosens kropp är dessutom brun som en lerkruka, vilket återkopplar till de lerkrukor med varm mjölk som Lëška såg gummor bära på morgonen, och musklerna liknar för Lëška till sist också det siktbröd som han suktar efter:

Коричневый, как глиняный горшок, он прыгнул, вынырнул и поплыл. На его руке был синий якорь, мускулы вздувались - как крученый ситный у Силебиной на полке.

Brun som en lerkruka hoppade han i och dök upp och simmade. Det var ett blått ankare på hans arm, musklerna svällde - som det tvinnade siktbrödet på hyllan hos Silebina.

Här knyts allt Lëška längtar efter samman och som ett uttryck för att matrosen är hans, i detta inre möte med honom, utbrister han högt (fast det snarare var tvärtom): "- Это я его привел, - хвалился Лешка." ("- Det var jag som ledde honom hit, skröt Ljosjka.") I denna uppfylldhet men förankrat i det högst prosaiska, i en för ett barn naturlig uppfattning av världen, förblir berättelsen i beskrivningen av strandlivet och hur dagen snabbt förflyter:

Было жарко. Воздух над рекой струился. Всплескивались рыбы. Проплывали лодки, женщины в цветных повязках нагибались над бортом и опускали в воду пальцы.

Купальщики боролись, кувыркались и ходили на руках.

А солнце подвигалось. Было сзади, стало спереди - пора обедать.

Det var hett. Det rörde sig i luften över floden. Fiskar slog. Båtar kom förbi, kvinnor med färgade sjaletter böjde sig över relingen och släppte ner fingrarna i vattnet.

Badarna brottades, gjorde kullerbyttor och gick på händerna. 
Och solen rörde på sig. Först var den bakom, sedan framför - det var dags för middag.

Därhemma väntar en torftig middag som samtidigt tycks upplevd som en stor njutning:

Мать ждала́. Картошка была сварена, хлеб и бутылка с маслом - на столе.

Наелись. Мать похваливала масло. Облизали ложки. Вышли на крыльцо.

Во дворе, разостлав одеяла, сидели соседки. Качали маленьких детей, тихонько напевали и кухонными ножами искали друг у друга в голове.

- И мы устроимся, - обрадовалась мать и сбегала за одеялом.

Modern väntade. Potatisen var klar, bröd och en flaska olja stod på bordet.

De åt sig mätta. Modern berömde oljan. De slickade av skedarna. Gick ut på trappen.

På gården satt grannkvinnorna på utbredda filtar. De vaggade småbarnen, sjöng lite stillsamt och letade igenom varandras huvuden med köksknivar.

- Vi ska också ordna det för oss, sade modern glatt och sprang och hämtade en filt.

"I my ustroimsja" ("Vi ska också ordna det för oss"). Med en ny potentiell dubbeltydighet i det triviala (som pustandet tidigare) blir detta också ett allmänt uttalande om deras situation, att de nog ska reda sig (efter det associativt effektfulla letandet med knivar i varandras huvuden (efter löss)). Med sitt huvud i moderns knä och hennes fingrar i hans lockiga hår ser Lëška upp i molnen och återser i deras former matrosen, som kopplas till siktbröd och ännu ett spännande intryck från dagen (stöldgodset): "По небу пролетали маленькие облачка в матросских куртках, облачка, похожие на ситный и на вороха белья." ("På himlen flög små moln förbi i matrosjackor, moln som liknade siktbröd och högar med linne.")

Men detta är ännu inte allt. Nu rycker modern till och har en dubbel överraskning för Lëška: först gå och bada och sedan en gratis bioföreställning (den Lëška sett affischen till på morgonen men inte kunnat läsa). Allting sätter åter fart. Han och modern springer ikapp och skrattar på vägen till floden. När de närmar sig lugnar de sig och sjunger på en romans tillsammans om en flicka som dränkte sig i en flod av kärlekssorg ("Bednaja devica, gorem ubitaja”):

платье бедняги за корни цепляется, ветви вплелись в волоса.

flickstackarns klänning har fastnat i rötterna, grenarna flätats i håret. 
Varken Lëškas fascination för matrosen eller vad modern tidigare gett uttryck för motiverar egentligen sången. Han är inte olyckligt kär. I berättelsen blir den en del i skildringen av dagens lopp genom olika stämningar; den smärtsamhet i sommarkvällen som uttrycks, tas upp av en påträngande sinnlighet i beskrivningen av deras vana att riva gräs att lägga under fötterna på stranden: "Срывали жесткую высокую траву - класть под ноги, когда выходишь на́ берег. Тек горький белый сок и засыхал на пальцах." ("De rev åt sig av det sträva höga gräset - för att lägga under fötterna när de gick upp på stranden. En bitter vit saft rann ut och torkade på fingrarna.") I den kroppsliga attraktionen till matrosen, i sången och i dessa rentav erotiskt anstrukna fysiska intryck kan man samtidigt, över huvudet på personerna i berättelsen, uppleva ett centrallyriskt uttryck för författarens kärlekssorg. (Någon tillägnan infördes aldrig och Dobyčin nämner inte om Zajcev ens läste berättelsen, men den var ju, som han skrev, "i själva verket till Zajcev".)

Det skymmer med en enkel intensiv närvaro i stunden: "Садилось солнце. Начали кусаться комары. Заквакали лягушки. Небо выцвело." ("Solen gick ner. Myggor började stickas. Grodor kväkte. Himlen falnade.") Vägen tillbaka skildras med ett par noggrant utvalda detaljer som vidare gestaltar den förhöjda sinnliga närvaron och stämningsförändringen (och också avrundande återknyter till inledningen och dagen med dammet som nu har lagt sig): "Трава похолодела. Пыль в колеях лежала теплая и грела ноги." ("Gräset blev kallare. Dammet låg ljummet i hjulspåren och värmde fötterna.")

Berättelsens avgörande vändpunkt byggs upp av att förmiddagens figurer med sina mikrohistorier återkommer. Vattenköraren kikar neråt även när han går, konduktörskan viftar på armen som om det var ett snöre i den och de fyra skurkarna som tagit linne från en vind kommer glatt springande. Alla är på väg till den gratisföreställning som Lëška tidigare sett affischen till men inte kunnat läsa. Men nu visar det sig plötsligt med trivial tragik att barn inte släpps in och i tumultet utanför biografen försvinner dessutom modern (som märkligt nog tycks välja att ändå gå på föreställningen):

Был гвалт. Стояли очереди к мороженщикам. Шуршала подсолнечная шелуха. В саду горели фонари, играла музыка и бил фонтан. Мать потерялась. Маленьких в кинематограф не пускали. Лешка заревел.

Det var oväsen. Det var köer till glassförsäljarna. Solrosfröskal frasade. I parken brann lyktor, det spelades musik och en fontän sprutade. Modern var försvunnen. Barn släpptes inte in på biografen. Ljosjka började tjuta. 
Upplösningen, det återseende av matrosen som följer på denna förtvivlan, speglar den första uppenbarelsen av matrosen och knyter samman ytterligare trådar i cirkelkompositionen:

Темнело. Музыка кружилась невысоко, прибитая росой. Силебина сидела на крылечке - тихо, тихо, задумчивая, не замахивалась полотенцем, не орала. В палисаднике, впотьмах, матрос тихонечко наигрывал на балалайке:

Трансваль, Трансваль.

Det skymde. Musiken virvlade inte så högt utan hölls fast av daggen. Silebina satt på trappan - stilla, stilla, tankfull, inte viftande med en handduk, inte rytande. Inne i trädgården, i mörkret, spelade matrosen stilla och försiktigt på balalajkan:

Transvaal, Transvaal.

Stämningen hålls nere, förankrad som musiken, stilla som ägaren till teserveringen vars lugn nu framhävs av hur hon brukar vara när någon pojke försöker få lite av hennes siktbröd. Denna tillbakahållenhet laddar matrosens framträdande som med samma sång som tidigare är mer stillsamt i det lugna mörkret.

Lëška finner något utanför den allmänna högljudda trängseln. Konstaterandet att matrosen inte heller är på gratisföreställningen, också är utanför, följs av ett ömhetsord från pojkens medvetande. Hans känslor inför matrosen har utvecklats till en känsla av samhörighet: "Он, как и Лешка, не был на бесплатном - миленький..." ("Han var liksom Ljosjka inte heller på gratisföreställningen - käre vän...")

Mötet med matrosen är över och novellen rundas av hemma på gården där det började. Grannkvinnan med tigerväska, som skällde på honom för att vara smutsig när hon gav sig ut efter bullar på morgonen, beskrivs nu tillsynes försänkt i en trivialt lyrisk stund som hon vaknar upp ur för att till slut med en liten pirog uppfylla Lëškas genomgående längtan efter siktbröd. I denna uppfylldhet fullbordas novellen med den sista sammansmältning av dagens intryck som den salta smutsen och bittra växtsaften på hans otvättade händer (en orenhet som grankvinnan i inledningen också beskyllde honom för) tillför den söta pirogen. Varje detalj har haft betydelse:

Вздыхая, по двору прохаживалась Трифониха и, любуясь звездочкой, жевала. Из сумки с тигром вынула пирог и протянула Лешке.

Сидя на ступеньке, он стал есть, пихая в рот обеими руками: пирог был сладкий, а руки - соленые от грязи и горькие от той травы, которую он рвал, когда шел с матерью на берег. 
Suckande gick Trifonicha omkring på gården, såg beundrade mot en liten stjärna och tuggade. Ur väskan med tigern tog hon upp en pirog och räckte den åt Ljosjka.

Sittande på trappsteget började han äta och tryckte in den i munnen med båda händerna: pirogen var söt men händerna salta av smuts och bittra av gräset som han rivit när han gick till stranden med modern.

Stunden är inte olik den i Dobyčins allra första novell "Timofeev". Timofeev tuggar också just siktbröd till teet där i sin kvällsstund på trappen i vilken han tyckte sig ha upplevt något betydelsefullt.

\section{"Konopatčikova" - om en konst bortom orden}

Novellen "Konopatčikova" är återigen fyra kapitel lång. Den avslutade den första samlingen Vstreči s Liz där den liksom "Lëška" för första gången publicerades. I samlingen Portret följer den efter "Erygin". På samma sätt som med "Erygin" omtalar Dobyčin den flera gånger i sina brev som något särskilt, som en bra novell men som han nästan inte klarar av att skriva. ${ }^{244} \mathrm{Han}$ ger en glimt av sin arbetsprocess när han i början av 1926 beskriver förberedelserna för själva skrivandet som ett sammanfogande av skärvor, inte helt olikt det sökande efter ett sammanhang för de vardagliga intrycken som speglades i författaren Erygins mödor. ${ }^{245}$ Det tar ovanligt lång tid. I slutet av sommaren skriver han att han inte lagt till en enda rad till berättelsen som han kallar "Begravningen" ("Pochorony"). Först i början av 1927 översänder han den. ${ }^{246}$

Novellens huvudperson Konopatčikova är nu åter en äldre kvinna. Liksom de tidigare är hon förankrad i den förrevolutionära kulturen men försöker också att aktivt delta i de nya kulturyttringarna. Längtan efter ett möte ger även denna novell dess nerv och den inleds med att en attraktion väcks till en viss person. Här handlar det dock mer om en själslig gemenskap som

244 "Я все собираюсь начать хороший рассказ, о котором столько времени трублю, но никак не могу - он очень трудный." ("Jag försöker börja på den bra berättelsen som jag så länge utbasunerat, men jag kan bara inte - den är väldigt svår.") Till Čukovskij 4 februari I926 (brev 27), PSSP, 259.

245 "[C]егодня утром все обломки, из которых должна была составиться трубная история (так называемая «протрубленная»), соединились не без ловкости, и возможно, что к весне эта история будет написана." ("I morse förenades, inte utan finess, alla skärvor som den slitsamma historien (den så kallat "utbasunerade") ska bestå av, och det är möjligt att denna historia kommer att bli skriven till våren.") Till Čukovskij 25 februari 1926 (brev 30), PSSP, 262.

${ }^{246}$ Till Slonimskij 20 juli 1926 (brev 85) respektive I7 januari 1927 (brev 89), PSSP, 290-29I. Det är åtminstone troligen "Konopatčikova" som han översänder med det senare brevet som en av de "två noveller" som han nämner. 
hon inledningsvis upplever. Ett umgänge med denna person realiseras här i novellen. Den slutar också med att de faktiskt finner varandra som likasinnade, att de avslutningsvis tycks mötas bortom orden, i en diskussion om konst som äger rum på ett gravöl efter den begravning som novellen utspelar sig kring.

\section{I (Den kulturelle mannen)}

Huvudpersonen avviker från en politisk sammankomst; det rör sig troligen om undervisning i "politgramota", grundkunskaper i politik. Adol'f Adol'fovič som håller en föreläsning om Lenin och specialisterna beskrivs trivialiserande kasta mänskligt ömma blickar från scenen. Dobronravova, näst på tur med historiematerialism och kvinnans frigörelse, går som en ironisk kontrast till ämnet nervöst och lär in talet från en broschyr. Huvudpersonen Konopatčikova introduceras med få attribut, till karaktär och värderingar endast genom det sätt hon avviker på:

Конопатчикова, низенькая, скромно посмотрела направо и налево, незаметно поднялась и улизнула. - Боль в висках, - пробормотала она на всякий случай, поднося к своей седеющей прическе руку, будто отдавая честь. 247

Konopattjikova, som var kort, såg sig försiktigt om till höger och till vänster, reste sig obemärkt och smet ut. - Ont i tinningarna, mumlade hon för säkerhets skull och lyfte handen till sin grånande frisyr som om hon gjorde honnör.

Detta "för säkerhets skull" kan hennes medvetande tänkas färga men knappast liknelsen av hennes värkmarkerande gest med en honnör - det påkallar en samtidig yttre blick på henne och en tolkning präglad av det politiska sammanhanget. ${ }^{248}$

Hennes sorti gör att vi uppfattar de beskrivningar som följer som det hon möter på gatan utanför och som i sin stämning därför reflekterar hennes inre:

\footnotetext{
247 Novellen citeras ur PSSP, 7I-75.

${ }^{248}$ Boris Maslov tar beskrivningen av Konopatčikovas gest som exempel på en "dubbel metapragmatisk bearbetning" av det direkta talet med två ömsesidigt uteslutande sociala innebörder som här krockar: den tolkning som Konopatčikova föreslår som förklaring till sitt avvikande är att visa på huvudvärken medan berättaren föreslår den i sammanhanget absurda liknelsen med en militärisk honnör. (I min läsning faller det sig naturligare att betrakta liknelsen som en association, hur gesten kan framstå, som kan tillskrivas de andra närvarandes yttre perspektiv på henne.) Boris Maslov, "Oratio recta kak modernističeskij priem (Poètika povestvovanija L. Dobyčina s pozicii metapragmatiki)", DS-4, IOI-I25, II6.
} 
Плелись старухи с вениками, подпоясанные полотенцами. Хрустел обледенелый снег. Темнело. Не блестя горели фонари.

Några gummor med bastukvastar lunkade fram med handdukar kring midjan. Den istäckta snön knastrade. Det mörknade. Lyktorna lyste utan glans.

Vintereftermiddagen och de äldre kvinnornas samvaro ger kontrast till den politiska sammankomst som hon lämnat. Ett plingande bryter in i denna vardagliga stillhet och en viss Malkina dyker upp, i rollen som en avresande privilegierad sovjetkvinna: "Звенел бубенчик: женотделка Малкина, поглядывая на прохожих, ехала в командировку." ("En bjällra klingade: kvinnosektionsdelegaten Malkina åkte iväg på tjänsteresa och spanade på de förbipasserande.") Efter detta återknytande till den politiska inledningen skapar triviala men potentiellt antydande sinnliga detaljer och koordinerade fysiska rörelser en allt intensivare spänning i luften. Det mynnar ut $\mathrm{i}$ det möte som sätter igång handlingen på allvar:

[...] Стрелочник трубил в рожок. Въезд на мост уходил в потемки, и оттуда, вспыхнув, приближалась искра. Обдало махоркой, с песней прошагали кавалеры:

ветер воет, дождь идет,

Пушкин бабу в лес ведет.

Гудели паровозы. Дым подымался наискось и, освещенный снизу, желтелся. Из ворот, переговариваясь, выходили Вдовкин и Березынькина: поклонились праху Капитанникова и были важны и торжественны.

Конопатчикова с ними кое-где встречалась. Она остановилась и приветливо сказала: - Здравствуйте.

[...] Växlaren blåste i hornet. Uppfarten på bron försvann i mörkret och därifrån blixtrade och närmade sig en gnista. En dust av grovtobak drev in, med en sång tågade några kavaljerer förbi:

vinden viner, regnet slår, till skogs med gumman Pusjkin går.

Loken tjöt. Röken steg snett och gulnade av ljuset underifrån. Ur porten kom Vdovkin och Berjozynkina och växlade några ord med varandra: de hade varit och besökt den avlidne Kapitannikov och var märkvärdiga och högtidliga.

Konopattjikova hade träffat dem någonstans. Hon stannade till och sade vänligt: - Goddag. ${ }^{249}$

\footnotetext{
249 Arkadij Neminuščij tar denna sång, användningen av Pusjkin i en skabrös folklig visa, tjastusjka, som exempel på hur kulturen förlorar sin status i den sociala världen i Dobyčins noveller. Kulturen blir så en del av en tidslighet präglad av orörlighet och negativ rundgång vilken korrigeras av en annan tidslighet i naturens värld - en hälsosam cykliskhet med löfte
} 
Konopatčikovas granne Kapitannikovs begravning och gravöl kommer att utgöra den triviala händelseutveckling genom vilken en relation succesivt växer fram mellan Konopatčikova och Vdovkin (som har den antydande betydelsen "änkling" ("vdovec") i namnet samtidigt som han tycks gift med Berëzyn'kina). Konopatčikova hälsar på dem, och hälsningen skrivs ut som kulmen av den stämning som de tidigare sinnesintrycken och rörelserna byggt upp.

Orden i sig är oviktiga. Efter den tomma hälsningsfrasen återges efter en blankrad, ett brott, bara hur de samtalar, inte vad de säger. Det är också fortsättningsvis väsentligen i deras sätt och inte i själva orden som deras karaktärer framträder och en känsla av samhörighet uppstår mellan huvudpersonen och denne Vdovkin som alltid har Berëzyn'kina vid sin sida. Konopatčikova vet vilka de är men detta möte inleder något nytt:

Негромко разговаривали и печально улыбались: Конопатчикова в шерстяном берете с кисточкой, Вдовкин, плечистый и сморкающийся, и Березынькина, кроткая, с маленькой головкой. Раздался первый удар в колокол. Примолкли и, задумавшиеся, подняли глаза. Вверху светились звезды.

De samtalade lågmält och log sorgset: Konopattjikova i en ullbasker med tofs, Vdovkin bredaxlad och snörvlande och Berjozynkina saktmodig med litet huvud. Första slaget ljöd i kyrkklockan. De tystnade och höjde tankfullt blicken. Däruppe sken stjärnorna.

Intrycket av att samtalet fortlöper under denna beskrivning anges av kolonet och bekräftas av att de tystnar när de hör ett första slag i en kyrkklocka. Den tankfullhet och blick mot stjärnorna som följer talar för upplevelsen av något betydelsefullt.

Den manligt bredaxlade men samtidigt lite löjligt snörvlande Vdovkin fyller nu denna tysta stund genom att citera en känslosam romans. Samtidigt som det lätt patetiska i denna deklamation liksom i Vdovkins fortsatta trivialt nobla sätt ironiskt banaliserar honom framgår det att han med detta

om outplånlighet. Arkadij Neminuščij, "Formula vremeni v sbornike L. Dobyčina 'Vstreči s Liz"', PLD, 255-26o, 257. Just tjastusjkan som en form av folklig kreativitet med livgivande profanering och förankring i det kroppsligas natur, tas inte upp i artikeln, men det är något Dobyčin återvänder till. I novellen "Sad" (som behandlas i nästa kapitel) fungerar en tjastusjkans levande konst som kontrast till ideologisk sovjetisk poesi. I "Portret" (som behandlas i nästa kapitel) dyker Puškin upp i en skabrös anekdot med betydelse för helhetens kulturdiskussion. 
gör intryck på Konopatčikova; för henne talar det för den kulturella förfining som hon söker i sitt liv. En avslutande konklusion pekar fram mot deras gemensamma kvällsaktivitet som skildras i nästa kapitel:

- Жизнь проходит, - вздохнул Вдовкин и прочел стишок:

так жизнь молодая

проходит бесследно.

Дамы были тронуты. Он чиркнул зажигалкой. Осветился круглый нос, и в темноте затлел кончик папиросы.

Сговорились вечером пойти на стружечный.

- Livet går, suckade Vdovkin och läste en vers:

så går livet det unga

spårlöst förbi

Damerna var berörda. Han knäppte med tändaren. Den runda näsan belystes och i mörkret började papyrossens ände glöda.

De kom överens om att gå till spånfabriken på kvällen..$^{250}$

\section{2 (Den sörjande och spånfabrikens konstnärliga teater)}

Ett citat ur tidningen återknyter till den ideologiska diskurs som inledde första kapitlet:

«Машинистка Колотовкина», - поглядывая на часы, сидела Конопатчикова за губернской газетой, - «пассивна и материально обеспечена.

зачем писать ей на машине?

может играть на пианине».

"Maskinskriverskan Kolotovkina", satt Konopattjikova och läste i guvernementstidningen och tittade på klockan, "är passiv och materiellt bemedlad.

varför ska hon skriva på maskin då?

hon kan ju spela pianino".

Konopatčikova väntar på Vdovkin och Berëzyn'kina för att bege sig till vad som ännu bara omtalats som "spånfabriken". Konopatčikovas egna "passivitet" och relativt materiellt bemedlade tillvaro som snart framträder skulle kunna tala för en sympati med den niddikten riktats mot. Men inget sådant

${ }^{250}$ Romansen, som Vdovkin citerar inledningen tillika titeln på, är skriven och komponerad av L. D. Malaškina. 
uttrycks, hon tycks förströdd, upptagen av det hon väntar på. När hennes nya bekanta så anländer visar de sig likasinnade i sin uppskattning för hennes förrevolutionärt och europeiskt borgerliga interiör:

Похвалили комнату и осмотрели абажур «Швейцария» и карты с золотым обрезом. Тузы были с картинками «Ль эглиз дэз Энвалид», «Статю дэ Анри Катр».

- Парижская вещица, - любовался Вдовкин. - Я и сам люблю пасьянсы, - говорил он. - «Дама», например, «в плену», «Всевидящее око»...

- «Деревенская дорога», - подсказала Конопатчикова.

De berömde rummet och studerade lampskärmen "Schweiz" och spelkorten med guldsnitt. Essen var med bilder av "L'église des Invalides" och "Statue d'Henri Quatre".

- En parisisk liten sak, sade Vdovkin uppskattande. Jag tycker själv också om patienser. "Damen", till exempel, "i fångenskap", "Det allseende ögat"...

- "Byvägen", hjälpte Konopattjikova honom.

I det ömsesidiga intresset för patiens utvecklas känslan av samhörighet mellan Vdovkin och Konopatčikova. Det är med en på samma gång löjlig och belevad nonchalans som han betecknar kortleken som "en parisisk liten sak" och räknar upp de två namnen på patienser som antydningsvis är talande för något annat - för hennes situation, för det nya samhällets allseende öga? Konopatčikova lägger till ett tredje, trivialt, som neutraliserar symboliken. Ett upplevt samförstånd bortom orden framträder redan i utbytet av dessa namn. Spänningen dröjer sedan kvar i luften under kvällen i hur Vdovkins rörelser och uppenbarelse beskrivs och genom Konopatčikovas reaktioner.

Denna föremålens och patiensernas borgerligt passiva värld är dock inget de rituellt beskrivs hålla fast vid som i tidigare noveller. Det evenemang på spånfabrikens teater, som det ska visa sig att de är på väg till, är helt och hållet det nya samhällets kultur som de försöker ta del i. Det gamla, som kyrkklanger, dikter och föremål aktualiserar, undviker de att öppet diskutera. De framstår som mer lämnade åt sig själva med sina tankar om det och sin eventuella nostalgi. Det speglar på sätt och vis samhällsutvecklingen under de få åren från den första till den sista novellen i den första samlingen. Nu råder inte längre något tvivel om att den sovjetiska ordningen är där för att stanna.

På väg ut använder Vdovkin sin cigarettändare igen, nu för att gentilt lysa för damerna i trappan. Därmed återknyts det associativt till hans förfinade vers om livets förgänglighet, som han tände sin papyross efter i första kapitlet, innan grannfrun, hustrun till den avlidne som de då hade besökt, 
kommer utspringande och utvecklar den parallella handlingen om begravningen genom ett förtvivlat och oinlindat gråtkväde, pričitanie:

Наверху захлопали дверьми: Капитанничиха выбежала в сени убиваться по покойнике.

и зачем ты себе все это шил, -

причитала она, -

если ты носить не хотел? -

и притопывала.

и зачем ты пол в погребе

цементом заливал,

если ты жить не хотел?

Остановились и, послушав, медленно пошли по темным улицам, оглядываясь на собак.

Ovanför slogs det i dörrar. Kapitannikovskan sprang ut i farstun för att sörja den döde.

och varför lät du dig allt detta sy,

klagosjöng hon,

om du inte ville bära det?

och stampade takten.

och varför lade du cement

på golvet i källaren

om du inte ville leva mer?

De stannade till och lyssnade och gick sedan långsamt på de mörka gatorna och såg sig om på hundarna.

Rör det sig alltså om ett självmord? Inget mer sägs varken här eller senare om det. Stämningen på gatorna efteråt som möjligen antyder en molande tystnad och inre reflektion jagas snabbt bort när Konopatčikova tillsammans med Vdovkin och Berëzyn'kina kastas rakt in i det nya samhällets stojiga kulturevenemang på spånfabrikens teater.

Uppfordrande och undervisande slagord framförs som lättsmält underhållning. Budskapet är påfallande tomt: slut upp kring den nya ordningen. Det gör man genom samhällsnyttigt arbete samt med kultiverande, tillika ideologiskt disciplinerande konst. Resten är ett förevisande av regler: 
«Жизнь без труда», - было написано над сценой в театре стружечного, - «воровство, а без искусства - варварство». Оркестр играл кадриль.

Рвал, рявкая, железные цепи и становился в античные позы чемпион Швеции Жан Орлеан. Скакали и плясали мадмазели Тамара, Клеопатра, Руфина и Клара и, тряся юбчонками, вскрикивали под балалайки:

$$
\begin{aligned}
& \text { чтоб на службу } \\
& \text { поступить, } \\
& \text { так в союзе } \\
& \text { надо быть. }
\end{aligned}
$$

- Эх, - сияя, передергивал плечами Вдовкин. Конопатчикова улыбалась и кивала головой...

"Ett liv utan arbete", stod det skrivet över scenen på spånfabrikens teater, "är tjuveri, och utan konst - barbari". Orkestern spelade en kadrilj.

Rytande rev den svenske mästaren Jean Orléans i järnkedjor och ställde sig i antika poser. Hoppande och dansande kom mademoisellerna Tamara, Kleopatra, Rufina och Klara in och svängde med sina små kjolar och skrek gällt till balalajkorna:

$$
\begin{aligned}
& \text { för att man } \\
& \text { en tjänst ska få, } \\
& \text { må man med } \\
& \text { i facket gå. }
\end{aligned}
$$

- Oj, sade Vdovkin strålande och ryckte med axlarna upp och ner. Konopattjikova log och nickade...

Det Vdovkin och Konopatčikova visar sig förnöjda med tycks vara den ungdomliga energin och aktiviteten. Hellre detta i alla fall än de tråkiga föredragen som novellen började med. Konopatčikovas leende och nickande kan också tolkas som ett milt överseende med det banala i underhållningen. Huruvida detta är vad de menar med konst utan vilket livet skulle vara barbari ställer gestaltningen ut som en fråga utan att vi får huvudpersonens tankar om det.

Det är först utanför i kylan efteråt, under stjärnorna, med ljudet av ett hamrande piano (som återkallar versen om maskinskriverskan i tidningen som inte ansågs behöva någon tjänst) och till åsynen genom fönstren av dem som dansar vals i lokalen de lämnat - det är först i denna atmosfär som Konopatčikova yppar något om sin längtan efter kultur. I sitt sätt att tala om en bok som läses i vad som troligen är något av en läsecirkel som arrangeras av spånfabrikens klubb framstår hon som hoppfull om kulturen i det nya samhället:

- Они, - проникновенным голосом сказала Конопатчикова, - читают книгу, очень интересную. Заглавие выскочило у меня из головы. 
Поговорили о литературе...

Улыбающаяся, полная приятных мыслей, Конопатчикова ощупью нашла край лампы: загорелись звезды над швейцарскими горами и цветные огоньки в окошках хижин и лодочных фонариках.

- De, sade Konopattjikova med innerlig röst, läser en bok, väldigt intressant. Titeln har fallit mig ur minnet.

De talade lite om litteratur...

Leende och full av behagliga tankar trevade sig Konopattjikova fram till kanten på lampan: så tändes stjärnorna över de schweiziska bergen och de kulörta eldarna i stugornas fönster och roddbåtarnas lanternor.

Eftertrycket i rösten tillsammans med att hon glömt namnet på boken understryker samtidigt ironin (som helt ska framgå när vi i slutet av novellen också får veta titeln). Vad de sedan talar om när de talar om litteratur tycks heller inte viktigt för henne. Bara det faktum att de talar om litteratur tycks räcka för henne, det är en del av den fina kultur som ger henne en känsla av mening på samma sätt som den sirliga lampskärmen hon tänder när hon kommit hem. Kanske spelar känslorna för Vdovkin också en roll för denna upprymdhet.

Hon avbryts i sina behagliga tankar av den nyblivna änkan Kapitannikova, som folkligt benämns Kapitanničicha, en folklighet som också hennes åtbörder understryker i kontrast till huvudpersonens förfining.

В дверь поскреблись. В большом платке, жеманная, вскользнула Капитанничиха. С скромными ужимками, перебирая бахрому платка, она просила, чтобы завтра Конопатчикова помогла в приготовлениях к поминкам.

- Не откажите, - двигала она боками, егозливая, и прижимала голову к плечу. - Я загоню его костюмчики, и пусть все будет хорошо, прилично.

Det krafsade på dörren. I en stor sjal, tillgjord, smet Kapitannikovskan in. Med blygsamma små grimaser frågade hon, plockande med fransarna på sjalen, om Konopattjikova kunde hjälpa till med förberedelserna till gravölet nästa dag.

- Snälla säg inte nej, sade hon och rörde rastlöst på kroppen och tryckte huvudet mot axeln. Jag ska sälja av hans kostymer, så kan allt bli bra, anständigt.

Den på ytan sammanhållande händelseutvecklingen kring den döde tar så ett steg vidare. Huvudpersonen återbördas till den deprimerande verklighet som hon för en stund såväl i det sovjetiska kvällsnöjet som det efterföljande samtalet drömt sig bort från genom känslorna av en begynnande vänskap som något nytt och betydelsefullt i sitt liv. 
Den första dagen har nått sitt slut, i de kommande två kapitlen skildras den nästföljande. Novellen utspelar sig under en betydligt mer begränsad tid än de andra flerkapitelsnovellerna.

\section{3 (Begravningen)}

Det är dagen för begravningen. På vägen ut luktar Konopatčikova på en nypa av röken från ett rökelsekar som det ordnas med för ceremonin över den döde hos grannen. Väl ute i staden - om man läser gatubilderna som upplevda av henne - upptas hon vidare, estetiskt, av sköna, på något sätt kittlande sinnesintryck. Hon tycks inte ägna mycket tanke åt den begravning som hon trots allt är indragen i. När begravningståget med svarta fanor dyker upp, som hon alltså inte heller deltar i, skildras bara det intryck det gör på andra:

Стал слышен похоронный марш, и показались черные знамена. Сбежались. Мужики смотрели, опустив кнуты. Вздыхали бабы в кружевных воротничках на зипунах и в елочных бусах.

En begravningsmarsch började höras och svarta fanor dök upp. Man rusade dit. Bondkarlarna såg på med piskorna sänkta. Fruarna med små spetskragar på bondrockarna och granpärlhalsband suckade.

Om själva tåget och den avlidnes hustru ges endast ett konkretiserande verb: "Народу было много. Капитанничиха вскрикивала." ("Det var mycket folk. Kapitannikovskan gav upp små skrik.") Istället riktas intresset mot Vdovkin och hans fru. Att perspektivet är huvudpersonens blir explicit: "Вдовкин, подпевая, шел с склонившей набок голову Березынькиной. Конопатчикова проводила их глазами." ("Vdovkin gick och sjöng med bredvid Berjozyn'kina som lade huvudet på sned. Konopattjikova följde dem med blicken.") Mer plats än så ges inte döden. Och livet går vidare bland de små bestyren.

En väninna till änkan som fått uppdraget att sälja den avlidnes kostymer, för att finansiera ett anständigt gravöl, kommer till Konopatčikova och berättar att hon fått dem sålda. De kan nu tillsammans börja göra de nödvändiga inköpen. Men istället för att upptas av detta riktas åter intresset, som speglar huvudpersonens, mot nya impressioner. En liten ovidkommande miniatyrberättelse träder fram ur det speciella glidande perspektivet när de färdas hemåt sittande baklänges på en släde:

Возвращались на дровнях, спиною к лошади. Блестела на дороге жижа. Воробьи кричали. Убегал базар. Беседовали, выйдя постоять на солнце, оба в фартуках, кондитер Франц и парикмахер Антуан... 
De tog sig tillbaka på en vedsläde sittande med ryggen mot hästen. Lervällingen glänste på vägarna. Sparvarna skrek. Marknaden avlägsnade sig. Samtalande efter att ha gått ut i solen stod, båda i förkläden, konditor Franz och barberare Antoine...

Hemma i köket hos grannen där gravölet förbereds är berättelsens och huvudpersonens uppmärksamhet fortsatt riktad ut från den händelse hon är där för. Vardagliga sinnesintryck där ute - droppar från taket, rök från ångloken - ackompanjeras av ljudet från spisen därinne och en sovjetiskt betitlad person, rabkor (arbetarkorrespondent) Petrov, sjunger dystra romanser till balalajka nedanför fönstret. Stämningen som de triviala intrycken tillsammans bygger upp är det centrala för uttrycket. Den blir en ersättning för ett samtal om den döde eller om denna tillvaro. Väninnan som sålt kostymerna bryter in. Hon gråter inte över den döda utan för att hon river pepparrot. Hon skryter om sin son som målat en tavla av "Lenin" (eller åtminstone en tavla med den titeln). Denna sovjetiska konst som hennes Nikiška också vid gravölet i sista kapitlet kommer att representera ställs redan här antydningsvis först mot ett rojalistiskt porträtt och sedan mot huvudpersonens inre konstupplevelse, en plötsligt minnesframkallande samstämmighet i de triviala intrycken:

На кофейной мельнице был выпуклый овал с голландской королевой Вильгельминой. Конопатчикова медленно молола, стоя у окна. Задумавшись, она глядела вслед начальнику милиции, скакавшему, красуясь, в сторону моста и инвалидки Кац. Воспоминания набегали.

Det var en utbuktande oval på kaffekvarnen med den holländska drottningen Wilhelmina. Konopattjikova stod vid fönstret och malde långsamt. Hon hade fallit i tankar och såg nu efter milischefen som ståtande red i riktning mot bron och invaliden Kats. Minnen kom strömmande.

Den underliggande, väsentliga berättelsen framträder så i samspelet mellan de ytliga detaljer, intryck och miniatyrhistorier som lagts i huvudpersonens synkrets och lagrats i hennes inre. Upplevelsen av en enhet - hos huvudpersonen liksom hos läsaren - kommer sig av återknytningen till platsen där handlingen i novellen tog sin början, där det första mötet med Vdovkin ägde rum. Milischefen har ersatt den då avresande Malkina (i samband med vilken också denna Kats beskrevs sälja bullar). Vilka minnen som väcks sägs det inget mer om, kapitlet slutar så här. Att denne ryttare och just i kombination med ovalen på kaffekvarnen också kan tala för ett djupare, konstnärligt minne hos huvudpersonen kommer man först kunna ana sig till när hon i diskussion om konst vid gravölet i nästa kapitel försiktigt tar 
till orda. Denna konstnärliga upplevelse pekar så också framåt mot novellens upplösning.

Det outsagda, att det aldrig framgår vad som är betydelsefullt i det dödsfall som är i centrum för händelserna på ytan, vad det har att berätta, vilka omständigheterna kring det egentligen var, visar sig här tydligt inte utgöra en brist i Dobyčins berättande. Tvärtom har det bidragit till den stadiga framåtrörelse med vilken succesivt tillsynes tillfälliga intryck och stämningar, bibetydelser och åtbörder, bortom de uttalade orden, som ett pågående samtal i det tysta, har samlats till ett uttryck för vad huvudpersonen upplever i sitt inre, för den meningsgivande samhörighet hon känner med en annan människa. Detta kommer till slut också till ytan i ett meningsutbyte mellan henne och den även i sina upplevelser av något betydelsefullt $\mathrm{i}$ tillvaron likasinnade Vdovkin.

\section{4 (Gravölet och konsten)}

\section{Allt är nu tillrett för gravölet:}

Поблескивали рюмки, и бутылки, толстобрюхие и тоненькие, мерцали. Капитанничиха, в черном платье, прилизанная, постная, стояла у стола и, горестная, любовалась.

Конопатчикова, скромно улыбаясь, завитая и припудренная, сидела на диване и сворачивала в трубку листик от календаря: рисунок «Нищета в Германии» и две статьи - «О пользе витаминов» и «Теория относительности».

- Благодари, Марусенька, - учила Полушальчиха и, разводя руками, низко кланялась, как в «Ниве» на картинке «Пляска свах».

Входили гости. Конопатчикова выпрямлялась и в ожидании смотрела на отворявшуюся дверь...

Snapsglasen glänste till och flaskorna, rundmagade och smala, glimrade. Kapitannikovskan stod i svart klänning framför bordet, slätkammad, tärd av fastan, och beundrade det sorgtyngd.

Konopattjikova satt blygsamt leende, lockad och lite pudrad, på soffan och vred en strut av ett kalenderblad: teckningen "Fattigdomen i Tyskland" och två artiklar - "Om nyttan med vitaminer" och "Relativitetsteorin".

- Tacka, Maruska, lärde henne Polusjaltjicha och bredde ut armarna och bugade djupt, som på bilden "Äktenskapsmäklerskornas dans" i Niva.

Gästerna var på ingång. Konopattjikova rätade på sig och såg förväntansfullt på dörren som öppnades...251

\footnotetext{
${ }^{251}$ I teckningen "Fattigdomen i Tyskland", dvs. under Dawesplanen, kan man se en sammankoppling, om än det är ett vanligt motiv i samtiden, med den teckning som en arbetskollega i den i Portret föregående novellen "Erygin" ritade. För att tillsynes utspela sig i samma småstad, med återkommande miljöer, är det annars påtagligt hur strängt åtskilda novellerna är
} 
Flaskornas former ger en associativ föraning om gästerna de väntar på. Den moderna samtiden gör sig påmind konkret men högst indirekt och utanför damernas fokus. För dem utgör som i flera tidigare noveller den förrevolutionära tidskriften Niva deras självklara referensram. Liknelsen med "Äktenskapsmäklerskornas dans", hur Konopatčikova ordnat sig och blygsamt ler till det förströdda pysslandet, hur hon rätar på sig och ser med förväntan på dörren - vi förstår nu att det är Vdovkin hon väntar på med dessa symptom på sina känslor.

Härefter skildras bara de anlända gästerna som ett anonymt kollektiv. De beskrivs förtingligande med sina skedar och näsor som subjekt. Och de glänser impressionistiskt:252

Стучали ложки, и носы, распарившись над супом, блестели. Полушальчиха, одетая кухаркой, в фартуке, прислуживала. Кланялись Маруське, подымая рюмочки. Она откланивалась, скорбная, и выпивала. [...]

Skedar knackade och näsorna, som mjuknade över soppan, glänste. Polusjaltjicha, klädd som en köksa, i förkläde, passade upp. Man bugade åt Maruska och höjde snapsglasen. Hon bugade sorgset till tack och drack ur. $[\ldots]$

De uppvärmda näsorna fångar att tiden förflyter. Det allmänna, kollektiva sättet hos gästerna etableras. Inga tal över den döde hålls och inte ens några ord yttras om vad som trots allt är föremålet för tillställningen. Fortsatt anonymt och som en del i den pågående middagen uttrycks i tysta gester deltagandet med värdinnans sorg. Liksom väninnan är klädd som en köksa svarar värdinnan möjligen med den värdiga borgerliga bugning hon övat på.253

Med en fläkt inträder så på denna gamla scen en leende företrädare för den nya sovjetiska kulturen. Hon framstår som högre stående, respekterad, samtidigt som hon bär det trivialiserande namnet Kuroedova (ungefär "hönsäterska"). Hon företräder uppenbarligen kulturaktiviteterna på spånfabriken och Konopatčikova tar därför tillfället i akt att fråga om den bok hon inte mindes titeln på i det litterära samtalet med Vdovkin:

sett till persongalleri och händelser. De utgör var och en en egen isolerad värld om än tillvaron är densamma.

${ }^{252}$ Denna typ av förtingligande av människor respektive besjälande av ting (som flaskornas former i början av kapitel kan ses som) är troligen vad som ligger till grund för den i forskningen återkommande generaliseringen av Dobyčin poetik som ett likställande av människor och ting som jag nämnde i inledningen.

${ }^{253}$ Här är väninnan bara utklädd. En faktisk köksa i den sovjetiska samtiden, vars låga samhällsstatus trots vad som utlovats med revolutionen tycks oförändrad, kommer att dyka upp i novellen "Portret". I den förrevolutionära Gorod Én (kapitel 2) uttrycks som en dröm om det hinsides livet det till Lenin tillskrivna framtidslöftet om att köksorna då kommer att styra. 
[...] Повеяло акацией. Любезно улыбаясь, прибыла внушительная Куроедова. - Как ваши, - с уважением справлялись у нее, - на стружечном? Они, - засуетилась Конопатчикова, - еще читают эту книгу, интересную? - «Тарзан»? - спросила Куроедова, глотая...

[...] Det kom en fläkt av akacia. Älskvärt leende anlände den respektingivande Kurojedova. - Hur står det till med era, hörde man sig artigt för hos henne, på spånfabriken? - Säg, sade Konopattjikova ivrigt, läser de fortfarande den där boken, som lät så intressant? - Tarzan? frågade Kurojedova och svalde...254

Kort och oengagerat, samtidigt som hon sväljer, svarar Kuroedova "Tarzan”. De tre punkterna kan i novellens inre värld inte antyda annat än att samtalet rinner ut i sanden. För Konopatčikova kommer nämligen svaret knappast som en besvikelse över att de inte läser något mer högtstående; hennes omtalande av boken som intressant tidigare grundades sig tillsynes inte i att hon läst den utan i själva titeln och möjligen vad hon hört om den. För henne kan den fortfarande verka lockande och fin som en del av den spännande nya litteratur man ägnar sig åt inom ramen för spånfabrikens kulturaktiviteter. Här följer inget konkret mer om en debatt i samtiden om Tarzans problematiska popularitet framför uppbyggligt socialistisk eller överhuvudtaget sovjetisk samtidsskildrande litteratur. Det inleder dock en indirekt diskussion om den samtida konsten.

Edgar Burroughs romanserie om Tarzan, en människa uppvuxen bland apor, var i själva verket de utan jämförelse mest lästa böckerna i Sovjet början av tjugotalet. Det är inte utan en viss förtret som de som ivrade för en god ny samtida litteratur tvingades konstatera detta fenomen. Det skedde bland annat i tidskriften som Dobyčin debuterade i, Russkij sovremennik, där formalisterna Viktor Šklovskij och Jurij Tynjanov på olika sätt försökte förklara Tarzans popularitet. Šklovskij menade att de många nya ovana läsare som den ökade läskunnigheten fört med sig inte insåg att Tarzanböckerna bara utgjorde estetiskt förlegade kopior av I8oo-talets vaudeviller med samma billiga moral. Anledningen till att de nya läsarna lockades av dem var att de erbjöd en helt igenom främmande tillvaro att fly iväg från den egna till. Denna främmande tillvaro kan i sig (enligt Šklovskijs teori om främmandegöring) bara ge något som påminner om en konstnärlig upplevelse. Det är inte konst, tycks han mena. 255 Tynjanov skriver i samma anda -

\footnotetext{
${ }^{254}$ Möjligen påkallar just akacialukten samtidigt den dödes tidigare närvaro i rummet; i den opublicerade novellen "Ninon" omges den dödas kropp när hon ligger i hemmet före begravning av doftande växter.

255 "Вероятно, здесь сказываются усталость от своего быта; чужой быт, резко отличающийся от нашего, дает впечатление, напоминающее художественное." Viktor Šklovskij, "Tarzan", Russkij sovremennik, 3, 1924, 253-254.
} 
i den artikel där han söker efter något berörande i den nya sovjetiska litteraturen som jag tog upp i inledningen - uppgivet om att dagens läsare utmärker sig genom att de inte läser. Präglade av böcker som just de om Tarzan frågar läsaren bara vad som händer sedan - "och när man ger honom detta 'sedan' hävdar han att det redan varit", som Tynjanov uttrycker det. Tynjanov menar vidare att den samtida sovjetiska litteraturen dras med samma problem som Tarzanböckerna i det att den nya tillvaron där framställs som fantastisk och främmande, konstlad och inte verklig och berörande, eftersom nya litterära ting ännu saknas. ${ }^{256}$

Det är med en möjlig koppling till denna debatt om Tarzan som avsaknad av genuinitet i den kultur som framförs under röd flagg i samtiden nu utvecklas:

Красные, блаженно похохатывая и роняя вилки, громко говорили. Есть смысл, - доказывала Куроедова, - покупать билеты в лотерею. Наши, например, недавно выиграли игрушечную кошку, херес и копилку «окорок».

Röda och saligt gapskrattande tappade de gafflar och pratade högljutt. Det finns en viss mening, intygade Kurojedova, med att köpa lotter till lotteriet. Våra vann till exempel nyss en leksakskatt, sherry och en "skinkan"sparbössa.

Först markeras de närvarande som röda men av helt opolitisk anledning. Kuroedova, företräderskan för den sovjetiska kulturen, gör därefter reklam för ett lotteri av lika politiskt ovidkommande art som deras läsande av Tarzan. "Est' smysl" ("Det finns en mening"), kan ironiskt ses understryka meningslösheten i de aktiviteter som man kräver en allmän uppslutning kring.

Efter att vi först påmints om värdinnan, med i alla fall en liten antydan om allvaret under denna sociala yta, där hon sitter som en försynt flicka inför denna prominenta samling människor med Kuroedova i centrum, tar väninnan Polušal'čichas son Nikiška, vars Lenintavla modern i slutet av förra kapitlet skröt om, ordet i församlingen med ett allmänt uttalande om konstens hemlighet:

\footnotetext{
256 "Читатель сейчас отличается именно тем, что он не читает. Он злорадно подходит к каждой новой книге и спрашивает: а что же дальше? А когда ему дают это «дальше», он утверждает, что это уже было." Jurij Tynjanov, "Literaturnoe segodnja", Russkij sovremennik, I, 1924, 292-306, 292. Det nya och därför berörande ting i litteraturen som Tynjanov menar att Pasternak, som ett undantag, i Detstvo Ljuvers faktiskt lyckats skapa, beskrivs, som citerat i inledningen, i termer av ett ihoplimmande av "oblomki" ("skärvor") av först, genom uppväxtålderns mikroskopiska perspektiv, sönderslagna verkliga ting som gör tingen till levande abstraktioner. Att Dobyčin har läst artikeln och har denna debatt i åtanke i novellen kan möjligen hans tal (i det ovan citerade brevet till Čukovskij) om just de "oblomki" han lyckats förena tyda på.
} 
Маруська слушала, зажав в колени руки и состроив круглые глаза, как тихенькая девочка, умильная, и приговаривала: - Выпейте.

Никишка встряхивал свисавшими на бархатную куртку волосами. Искусство, - восклицал он. Полушальчиха пришла из кухни и, гордясь, стояла. - Тайна красок!

Maruska satt och lyssnade med stora runda ögon och händerna tryckta i knät, som en tyst liten flicka, rörd, och uppmanade dem ibland: - Drick.

Nikisjka skakade till med håret som hängde ner på sammetsjackan: Konst, utropade han. Polusjaltjicha kom ut från köket och stod och yvdes. Hemligheten ligger i färgerna!

Nikisjka visar sig duktig. Den klichéartade förklaringen förefaller snarare vara ett citat ryckt ur sin kontext än någon egen tanke. Samtidigt är det en möjlig självironi eftersom Dobyčin som författare använder sig flitigt av just färger, vilket vi får ytterligare prov på redan i nästa stycke när arbetarkorrespondenten Petrov som en passande återknytande kommentar i det anslagna samtalet om konst citerar en del av slagordet på banderollen på spånfabriken:257

- Жизнь без искусства - варварство, - цитировал рабкор Петров... Зеленое кашне висело у него на шее.

- Ett liv utan konst är barbari, citerade arbetarkorrespondenten Petrov... En grön näsduk hängde runt hans hals.

Den gröna färgen kan möjligen antyda att han inte är så politiskt röd som han inställsamt ger sken av. Före gravölet var det samme Petrov som hördes sjunga dystra romanser vilket inte stämmer in i den uppsluppna ideologiserade underhållning som banderollen på spånfabriken rubricerat. Att inte delta i den nya lättsamma masskulturen tycks - så som berättelsen nu tematiserat spånfabrikens så kallade konst - bli det som citatet förklarar vara barbari.

Ungefär så knyts novellens samtidsporträtt samman innan Vdovkin och Konopatčikova tar plats i samtalet. Han tar till orda med en tillsynes helt ovidkommande replik, men vars inledning - genom den inskjutna anföringssatsen - i förstone framstår som en frustrerad invändning mot det som Nikiška sagt eller det Petrov citerat, dessa olika uttryck för den tomma samtida konsten. "- Ja ne mogu" ("- Jag kan inte"), börjar han:

\footnotetext{
257 Dobyčins färganvändning i gestaltning av personer och relationer tas upp i Marina Novi-
} kova, "Tekstoformirujuščaja funkcija cvetovoj leksiki v rasskazach Dobyčina", $P L D, 243-248$. 
- Я не могу, - заговорил задумавшийся Вдовкин, - забыть: в Калуге мы стояли у евреев; в самовар они чего-то подсыпа́ли, и тогда распространялось несказанное благоухание.

- Jag kan inte, tog Vdovkin tankfullt till orda, glömma: i Kaluga var vi förlagda hos judar; de strödde något i samovaren, och då spred sig en sådan obeskrivlig väldoft.

Till det minne han berättar istället för ett genmäle ansluter nu Konopatčikova genast med ett eget av samma art. Hennes triviala men för henne laddade och bevarade minne bär likheter med vad som vid den minnesframkallande upplevelsen i slutet av förra kapitlet tycktes vara ovidkommande detaljer. Nu framkommer att de minnen som kom strömmande troligen inte bara var av det första mötet med Vdovkin och Berëzyn'kina. Såväl den ridande polisen som den utbuktande ovalen på kaffekvarnen, med dess material och imperialistiska motiv, visar sig nu nämligen också samstämma med ett djupare lagrat minne hos Konopatčikova. Det är ett minne av samma art som det Vdovkin just berättat om:

- В Витебске, - нагнувшись, заглянула Конопатчикова ему в лицо, - к вокзалу приколочен герб: рыцарь на коне. Нигде, нигде не видела я ничего подобного.

- I Vitebsk, sade Konopatčikova framåtlutad och såg honom i ansiktet, är stadsvapnet uppsatt på stationshuset: en riddare till häst. Ingenstans, ingenstans har jag sett något liknande..$^{258}$

Hur banala dessa minnen än kan framstå för andra är de djupt personligt betydelsefulla. Till skillnad från den konst det talats med stora ord om tidigare utgör de levande och mänskligt berörande konstnärliga upplevelser. De är en del av livet. Konopatčikova liksom instämmer med Vdovkin om värdet i sådana upplevelser genom att berätta om sitt minne - av stadsvapnet på stationshuset i Vitebsk - om än dess betydelsefullhet är lika obeskrivlig för andra som väldoften i Kaluga.

Det är både estetiskt och existentiellt: något betydelsefullt i en detalj eller händelse i en vardaglig tillvaro som blir något som fastnar, som man bär

\footnotetext{
258 Även det tidigare självständiga Belarus statsvapen föreställde en riddare på en häst. Möjligen skulle man i detta och utifrån det tidigare uttalandet om att konstens hemlighet ligger i färgerna kunna se en anspelning på Marc Chagall. Anspelande på samma stadsvapen avbildade han bland annat sig själv som en röd ryttare på en grön häst spelande på ett horn (vilket ersatt svärdet) svävande ovanför sin hemstad Vitebsk ("Trubjaščij vsadnik"/ "Rider Blowing a Horn" 1918, en tavla som bland annat Abram Éfros, en av redaktörerna för Russkij sovremennik, skrev om). Se Angela Lampe, "Chagall in the service of the revolution", Angela Lampe (red.), Chagall, Lissitzky, Malevich: The Russian Avant-Garde in Vitebsk, 19I8-1922, München, London, New York 2018, 19-28, 20.
} 
med sig. Detta slags outgrundliga och personliga upplevelse av mening, som från och med den allra första novellen "Timofeev" varit centralt för författarskapet, framhålls här tydligare som en motvikt mot det nya samhällets konst med dess ideologiska förklarande av verkligheten. Det sker samtidigt långt ifrån triumfatoriskt; både Vdovkins och Konopatčikovas upplevelser framstår i relation till den vikt de lägger vid dem som lätt löjliga och banala. De är bara vad de är, det betyder något för dem, men utgör inget svar vare sig på vad konsten ska vara eller hur man ska leva.

Detta utbytande av minnen av betydelsefulla sinnesintryck sker, som sista stycket visar, tillsynes över huvudet på Berëzyn'kina vid Vdovkins sida. En sista gång, nu med en blick på hans ansikte, tycks Konopatčikova i detta uppleva ett själsligt samförstånd med Vdovkin som hans hustru står utanför. Likt ett uttryck för hustruns obekymrat oengagerade position framställs hon till sist behagligt berusad och till skillnad från Vdovkin och Konopatčikova, med deras uttryck för en längtan efter något annat, som nöjd och njutande i stunden:

Березынькина, запрокинув голову, с закрытыми глазами, счастливая, макала в рюмку кончик языка и, шевеля губами и облизываясь, наслаждалась.

Berjozynkina med huvudet bakåtlutat och slutna ögon, lycklig, stack tungspetsen i snapsglaset och rörde på läpparna, slickade av dem och njöt.

\section{Det mänskliga}

Dobyčins huvudpersoner är inga hjältar eller föredömen, de är människor bland andra, ofta självupptagna genom sitt drömmande, ofta lite egoistiska i sitt handlande. Den milda ironin består även i skildringen av Vdovkins och Konopatčikovas utväxlande av betydelsefulla upplevelser, dels genom själva minnenas banalitet och dels genom det klichéartade i deras återgivning av dem: Vdovkins "neskazannoe blagouchanie" ("obeskrivlig väldoft") och Konopatčikovas upprepade "nigde, nigde" ("ingenstans, ingenstans") med ett sentimentalt tonfall som hämtat ur något i Nivas litteraturbilaga.

Konopatčikovas minne som återknyter till den plats där handlingen tog sin början bidrar också till novellens konstnärliga helhet. På samma sätt som Erygin i novellen om honom (men inte i det han själv skrev) är huvudpersonerna även i övriga noveller medskapare av novellernas helhet genom sitt sökande efter något betydelsefullt i sin tillvaro. Det är en del av hemligheten bakom denna novellkonst. Så framkallar novellerna också sina por- 
trätt av samtiden. Huvudpersonerna berättar inte om sig själva och sin tillvaro, men deras kreativa sökande efter något betydelsefullt blir en del av frammanandet av ett sammanhang i denna tillvaro som ett samtidens mänskliga självuttryck. För detta uttryck är inte den formella tekniken det avgörande, inte hur några tingliga skärvor har sammanfogats, inte färgen, utan det mänskliga samspel som dessa skärvor och färger skildrar, den mänsklighet som kommer fram i de olika formerna av meningssökande, de mänskliga möten som anas bortom orden. Därför blir Dobyčins konst berörande. Den ger inga svar men - för att återknyta till Richard Rortys litteratursyn som jag tog upp i inledningen - förlöser oss potentiellt från något av vår självupptagenhet och våra förutfattade meningar genom problematiserandet av sin tids ideologiska tvärsäkerhet. Vad är egentligen betydelsefullt? frågar oss Dobyčin och med detta samtidigt: Vad är konst?

Berëzyn'kina som novellen "Konopatčikova" slutar med tycks visserligen befinna sig långt från denna konstdiskussion och sin makes utbyte av berörande minnen med en annan - berörande genom det svunna mänskliga liv som de sinnliga detaljerna bär på. Med sitt triviala njutande visar hon emellertid på en försoning med tillvaron som den är. Detta slags uppgående i vardagen, som i viss mån också Konopatčikova och Vdovkin på sitt kulturella sätt ger prov på, kommer den rad kortnoveller som följde på den första samlingen att vidare utveckla och problematisera.

Det låga, lätt nedlåtande i beskrivningen av Berëzyn'kina antyder också - såsom fortsatt förankrat i den vardagliga dramatiken - huvudpersonens perspektiv, hennes medvetande och känslor. För minnet av en riddare kan också tala för Konopatčikovas längtan efter något mer än bara detta upplevda själsliga möte med denne kulturelle man. Och för att han verkligen skulle kunna bli hennes riddare står denna enfaldiga men livsnjutande fru i vägen.

Mötet mellan Konopatčikova och Vdovkin under gravölet framställs i all sin ofrånkomliga vardagliga ofullkomlighet. Därför färgas det av en mild ironi. Deras möte framställs alltså som en kontrast, något av en replik till den kulturellt förpackade färdigstöpta ideologi som det nya samhället har att erbjuda. Men det utgör knappast en politisk vision.

Om detta är samhällskritik så är kritiken i sig inte ideologisk. Hos Dobyčin är det istället tomheten eller hyckleriet i proklamerandet av en sann ideologi oavsett slag som avslöjas snarare än idéerna, snarare än socialistiska, borgerliga eller religiösa övertygelser i sig. Det är ett porträtterande av och därigenom ett sökande efter betydelsefulla berättelser i den pågående samtiden som upptar Dobyčin. 
Den röda tråden genom novellerna börjar nu framträda. Den framstår inte ensidigt som en kritik av den nya sovjetiska ideologin, utan mer som ett problematiserande sökande efter mening, efter något betydelsefullt, efter ett sätt att leva i denna nya tillvaro i provinsen med dess enfald och trivialiteter - men också mänsklighet och vardagliga skönhet.

De stundliga ensamma upplevelserna av något betydelsefullt i tillvaron tycks ligga till grund för det som huvudpersonerna får hopp om att mer varaktigt kunna dela med en annan människa - om bara ett möte med denna förverkligades. Deras längtan ger i sig en rörelse åt tillvaron som framkallar flyktiga känslor av sammanhang och mening. Det är vad novellerna främst utgörs av. Huvudpersonernas längtan efter ett förverkligande möte med en viss person kan indirekt ses spegla författarens sökande efter berättelser, berättelser som sedan tar gestalt som mänskliga samtidsporträtt just med hjälp av huvudpersonernas kreativa dagdrömmande och förhöjda uppmärksamhet för betydelsefulla detaljer.

Den mänskliga längtan som skildras nöjer sig inte med ideologiernas färdiga svar på hur man ska leva. Detta accentueras i det nya sovjetiska samhället så som det utvecklas. Den samstämmighet mellan Konopatčikova och Vdovkin i något som man kan ana bortom orden är inte bara ett subtilt sätt att skildra deras själsliga möte och den livets konst de tycks förespråka, det är möjligen också det enda politiskt gångbara sätt som de i sitt sammanhang och Dobyčin i sin samtid kan uttrycka dessa tankar på. Det är kanske också ett skäl till att novellen var mycket svår att skriva. 


\section{En dag, en stund och något slags möte - samtidens sista berättelser}

De sju nya noveller (av totalt sexton) som Dobyčins andra samling Portret innehåller är troligen alla skrivna I929 och I930. Uppehållet i produktionen efter den första samlingen - som utkom 1927 men i princip var klar året före - förklaras bara till viss del av att han redan 1926 hade börjat försöka skriva en roman; att döma av de få detaljer han nämner i sina brev rörde det sig redan om Gorod Én, den roman han efter novellerna till den andra samlingen återupptog och till sist, I935, fick utgiven.

Men I927 är också året för en fruktansvärd händelse i Dobyčins familj. Dobyčins yngsta bror Nikolaj som då börjat arbeta som kemist i Moskva grips av säkerhetstjänsten anklagad för att tillhöra en kontrarevolutionär terroristgrupp och döms till döden. Det mått av osäkerhet som fortfarande rådde om den fortsatta politiska utvecklingen efter Lenins död - och som präglar den samtid som skildras i novellerna i den första samlingen - fick Dobyčin på detta sätt personligen erfara slutet på. Det hårdnande samhällsklimatet mot slutet av tjugotalet, med krav på allmän uppslutning kring byggandet av socialismen, inleder Stalins epok.

Dobyčins korrespondens sinar under denna tid. Med Čukovskij upphör den kontinuerliga brevväxlingen redan I926. Till Slonimskij skriver han betydligt färre och mer affärsmässiga brev I927-I928. Dobyčin uttrycker ingen glädje över debutboken och påstår att den överhuvudtaget inte ens blev recenserad - Nikolaj Stepanovs recension i Zvezda som var den enda har tydligen undgått honom. Det Dobyčin upptas av är främst att få ut sin ersättning för boken. Han ger på olika sätt uttryck för en uppgivenhet. ${ }^{259}$

\footnotetext{
259 "[Р]омана не написал, но теперь (недавно начал) пишу. Но если будет хорошая погода, - брошу. Ничего нет, что побуждало бы писать, а время (даже уже́ Средний Возраст) уходит. Деньги это дает совершенно ничтожные, а шуму - больше бывает, когда лягушка в воду прыгнет. / Скоро год, как вышла Сметаничева книжка [«Встречи с Лиз»], а о ней нигде ни разу не упомянули, даже к новобуржуазной литературе не причислили." ("[R]omanen har jag inte skrivit, men nu (jag började nyss) skriver jag. Men om det blir bra väder, lägger jag ner det. Det finns inget som ger mig lust att skriva och tiden (jag är ju redan Medelålders) går. Pengarna det ger är helt försumbara och en groda som hoppar i vattnet gör mer väsen av sig. / Det är snart ett år sedan Smetanič lilla bok kom ut [Mötena med Liz]
} 
Romanskrivandet tycks länge mest vara något han planerar och trots att Slonimskij ber honom om det skickar han aldrig den romanbörjan han till sist fått till stånd. Anledningen är att han vänt sig med den till "en annan expertis som ratat den". ${ }^{260}$

Fem av de nya noveller Dobyčin skriver efter sitt uppgivna romanförsök är av samma slag som "Sidelka" och "Lëška" från första samlingen och har placerats i en följd med dessa (med den senare omdöpt till "Matros"). Dessa kortnoveller föregår den avslutande, åter fyra kapitel långa, nya titelnovellen "Portret" ("Porträttet") som skiljer sig från samtliga andra genom att vara berättad i första person. Den sjunde nya novellen var inledningsnovellen "Proščanie" ("Avskedet"). (De två sent tillkomna kortnovellerna från hösten 1930 som inte medtogs i samlingen var avsedda att infogas bland de övriga före "Portret".)

Kortnovellerna är av ungefär samma längd som varje enskilt kapitel i de längre novellerna (liksom i de två längre verken från trettiotalet). Medan handlingen i de längre novellerna sträcker sig över flera dagar, ofta flera månader och upp till ett år, så är tidsförloppet i kortnovellerna begränsat till mindre än ett dygn. Oftast avrundas de naturligt med mörkrets inbrott. (Den efterlämnande novellen "Mater'jal" ("Materialet") är enda undantaget vars tidsförlopp, trots att novellen bara är på två sidor, påminner om flerkapitelnovellernas.) Tiden i kortnovellerna löper typiskt från dag till kväll och skildrar på så sätt en dag i huvudpersonens liv. Generellt sett är gestaltningen i de nya kortnovellerna mindre uppbruten i olikartade intryck och mer koncentrerad till ett fåtal scener, ett förlopp, en situation - en upplevelse av något betydelsefullt. De är snarare uppbyggda kring ett möte i någon form än drivna av en längtan efter möten med någon.

och den har inte en enda gång omnämnts någonstans, man har inte ens räknat den till den nyborgerliga litteraturen." Till Slonimskij 9 april 1928 (brev IOI), PSSP, 295.

260 "[Я] подверг это сочинение другой экспертизе, которая его забраковала [...]". Till Slonimskij, I november 1928 (brev I06), PSSP, 297. När han väl började med själva romanskrivandet 1928 gav han först uttryck för en entusiasm över den även om det gick förtvivlat långsamt: "Роман, который Вы велели, пишется. Готово 700 слов." ("Romanen som Ni anbefallde håller på att skrivas. 700 ord är klara.") "Роман это будет аховский и, возможно, к моей смерти будет кончен (потому что я пишу по воскресеньям - и не каждое воскресенье)." ("Den här romanen kommer att bli förbannat bra och möjligen avslutad före min död (för jag skriver på söndagarna - och inte varje söndag)" Till Slonimskij I2 juni respektive I2 september 1928 (brev I04, I05), PSSP, 296-297. Slonimskij tycks också ha insisterat på att ändå få inledningen skickad till sig för Dobyčin försvarar den icke namngivna expertisens omdöme, det som fått honom att "kasta allt åt svinen" ("я поскореe отправил все это к свиньям"). Omdömet belyser ironiskt Dobyčins berättarsätt i romanen: "Экспертиза была вполне права. «Было, было, - писала она, - а видно, что ничего не было»." ("Expertisen hade helt rätt. 'det var, det var,' skrev hon, 'men det syns ju att det inte var någonting'.") Till Slonimskij 2I november 1928 (brev I07), PSSP, 297. 
De fyra första av de nya kortnovellerna - "Lekpom" ("Läkarassistenten"), "Otec" ("Fadern"), "Chiromantija" ("Kiromanti") samt "Požalujsta" ("För all del") gestaltar på olika sätt en stark närvaro i den vardagliga tillvaron, med små stunder och möten i mer socialt avgränsade situationer än i både de föregående och följande novellerna. Konflikterna är på olika sätt uppbyggda kring ett kärleksmöte.

"Sad" ("Trädgården"), "Portret" och de efterlämnade två novellerna "Čaj" ("Teet"; som skulle ha föregått "Požalujsta") och "Mater'jal" ("Materialet"; som skulle ha föregått "Sad") tematiserar, som de sista noveller som Dobyčin överhuvudtaget skrev, också en tilltagande svårighet med att överhuvudtaget hitta fler betydelsefulla berättelser i samtiden, vilket delvis framställs som en följd av striktare krav på inordning och förbud mot alternativa yttringar. Novellerna beskriver en tystnande och mörknande tillvaro där inte mycket finns kvar av mänskligt betydelsefulla yttringar eller möten bortom samtidens politiska och populärkulturella ideologiska skval.

Den avslutande titelnovellen som kortnovellerna bygger upp för tycks också präglad av det första romanförsöket. Trots att huvudpersonen är en ung kvinna i den sovjetiska samtiden anslår dess jagberättelse något av en förtäckt självbiografi med en mor och far som till stor del överensstämmer med hur de beskrivs i Gorod Én. Novellen kan också ses tematisera novellernas porträtterande av andra människor liksom av själva samtiden som en del av mötesproblematiken. Jaget observerar snarare än lever i sin samtid. Men det är hon i viss mån också förvisad till som ett politiskt "främmande element" så som hon med sin borgerliga bakgrund uttryckligen utpekas. Detta samtidsporträtt vid övergången till trettiotalet, av denna slutligen helt sovjetiserade provinsiella miljö som samlingen skildrat framväxten av, avslutas, likt inledningsnovellen, också med ett slags avsked. Det till sist helt ensamma jaget har dock ingen annanstans att ta vägen med sin längtan efter något betydelsefullt.

\section{Vardagens stunder som något betydelsefullt}

"Lekpom", "Chiromantija" och "Požalujsta" publicerades även i tidskriften Leningrad våren 1930 (nummer 3). Att novellerna var mindre politiska än tidigare innebar inte att de undgick ideologisk kritik. Redan i tidskriften anmärkte redaktionen att novellerna publicerades som ett typexempel på en småborgerlig författare som helt saknade samtidsförankring. ${ }^{261}$

\footnotetext{
${ }^{261}$ Jag citerade denna redaktionella kommentar i inledningen. Tidskriften Leningrad var inte densamma som den Dobyčin tidigare publicerat sig i. Den tidigare, med endast Slonimskij i
} 


\section{"Lekpom" ("Läkarassistenten") - ett oförverkligande möte}

"Lekpom" är endast en sida lång i den samlade utgåvan av Dobyčins verk och den kortaste av novellerna i Portret. Den är något av ett kammarspel och skiljer sig i denna begränsning från övriga noveller. De båda agerande huvudpersonerna har inga namn utan enbart yrkestitlar: "telegrafistka" (en kvinnlig telegrafist) och en "lekpom" ("läkarassistent" eller "läkass" enligt en karaktäristisk sovjetisk omdöpning av "feld'šer" ("fältskär") till "lekarskij pomoščnik" följt av en nyordsskapande förkortning). Att de framträder i egenskap av sina yrken, sin samhälleliga plats, och inte med sina namn spelar in i deras problem med att mötas, men mer än så är inte den samtida politiska diskursen närvarande. Den tredje personen är telegrafistens mor som läkarassistenten kommit för att undersöka. När telegrafisten hämtat läkarassistenten från stationen låter de modern sova ett tag - han förklarar sig ha tid - och får så utrymme för en stunds tedrickning och konversation. När modern till slut väcks är också novellen över. Då har allting redan ägt rum.

Redan den första kontakten mellan huvudpersonerna, vid stationen, bygger genom deras konventionella manér upp romantiska förväntningar inför fortsättningen samtidigt som detaljerna trivialiserar och mänskliggör dem:

Человек сошел с поезда, вытащил зеркальце и огляделся. К нему подбежала дожидавшаяся возле звонка телеграфистка.

- Фельдшер? - спросила она и стояла, как маленькая, смотря на него.

Он поднял брови, соединявшиеся на переносице, и взглянул снисходительно.

- Лекпом, - поклонился он. ${ }^{262}$

En person klev ner från tåget, drog fram en liten spegel och mönstrade sig. En telegrafist som stått och väntat vid ringklockan sprang fram mot honom.

- Fältskären? frågade hon och stod som ett barn och såg på honom. Han höjde ögonbrynen som var sammanvuxna vid näsroten och gav henne en nedlåtande blick.

- Läkarassistent, sa han och bockade.

redaktionen, utgavs endast $1924-25$ av Leningradskaja Pravda (med det första numret under namnet Petrograd och sedan den fullständiga titeln Leningrad: Dvuchnedel'nyj chudožestvennoilljustrirovannyj i literaturnyj žurnal). Den nya, Leningrad: Literaturno-chodožestvennyj i obščestvenno-političeskij ežemesjčnik, som började utges I930 utgjorde istället ett organ för LAPP (Leningrads proletärförfattare) med bland annat Dobin och Ėrlich i redaktionen vilka senare, åtminstone med säkerhet den förstnämnde, blev betydande för Dobyčins öde. K. D. Muratova, S. D. Baluchatyj, Periodika po literature i iskusstvu za gody revoljucii 19I7-I932, Leningrad I933, I4I, I93, http://lib2.pushkinskijdom.ru/Media/Default/PDF/Person/Muratova-I933.pdf, 2019-04-26.

${ }^{262}$ Novellen citeras ur PSSP, 82. 
Han speglar sig fåfängt med en fickspegel. Hon ser på honom som ett barn (eller "som en liten"). Beskrivningen rymmer både en yttre bild av situationen, hur den ter sig för någon som betraktar deras möte, och en inre - en antydan om hur hon känner sig inför honom. Det är också snarast med hennes blick på honom som han, med sina ögonbryn och sin nedlåtande blick som understryker hennes litenhet, därefter beskrivs. Hans sammanvuxna ögonbryn framstår inte uppenbart som attraherande (i stil med hårdetaljer i andra noveller och även senare i denna), men det individualiserar och levandegör honom som människa, det stämmer på något sätt ihop med hans lite löjligt galanta sätt som hans tillrättavisning och bockande också ger exempel på. Hennes användande av "fel'dšer" ("fältskär") istället för den nya sovjetakronymen "lekpom", markerar henne som borgerlig, åtminstone som någon som inte hänger med i det nya, som han på sitt galanta sätt tycks försöka göra:

Идти было скользко. Он взял ее под руку.

- Ах, - удивилась она.

Фонтанчик у станции был полон, и брызги летели по ветру за цементный бассейнчик.

- Сюда. - С трех сторон темнелись сараи, рябь пробегала по лужам. Через лед сквозила трава. Взбежали по лестнице, в кухне сняли пальто и повесили их на дверь.

Det var halt att gå. Han tog henne under armen.

- Åh, sade hon förvånat.

Fontänen framför stationen var full, och stänken flög med vinden utanför cementbassängen.

- Åt det här hållet. På tre sidor stod uthusen mörka, en krusning drog över pölarna. Genom isen syntes gräs. De sprang upp för trappan, i köket tog de av sig ytterkläderna och hängde dem på dörren.

Halkan ger en förevändning för fysisk kontakt. Det utrop och den förvåning hon reagerar med låter antyda att hon kanske också uppfattar det som ett närmande. De följande yttre intrycken kan också antyda känslor: en bräddfullhet, stänk som hamnar utanför. Det prosaiskt vardagliga blir genom sin avgränsning och utvaldhet lyriskt talande. Och snarast för henne fastän hennes medvetande inte tydligare än med hennes litenhet och blick på honom har etablerats.

Samtidigt finns inget i själva intrycken som knyter dem specifikt till någon av personerna. Skjulen som beskrivs kan avspegla upplevelsen hos någon som ser platsen för första gången samtidigt som det ger känslan av ett trängande obehag. Den tillsynes tidiga vinterskymningen, krusningen och 
gräset (återigen instängt) under isen bygger i alla fall upp en orolig och laddad stämning som på samma gång är objektivt omgivande och talande för en inre anspänning. Springandet uppför trappan är på samma gång konkret motiverat som det med konventionell, freudiansk symbolik bygger upp förväntningar inför fortsättningen. De hänger av sig.

Men så begränsas situationen, förutsättningarna för ett möte slås fast:

В комнатке было тепло. Мать дышала за ширмой.

- Разбудить? - заглянув туда, вышла на цыпочках телеграфистка.

- Нет, - помахал он галантно руками. - До поезда долго, пусть спит. Оборачиваясь, она выкралась в кухню и стала греметь самоваром.

Det var varmt i rummet. Modern andades bakom en skärm.

- Ska jag väcka henne? kom telegrafisten ut på tå och frågade efter att ha kikat in dit.

- Nej, sade han och viftade galant med armarna, det är långt kvar till tåget, låt henne sova. Hon vände smygande ut i köket och började slamra med samovaren.

Det är ett litet varmt rum. Modern konstateras inte bara ligga utan hörs andas bakom skärmen. Nu är perspektivet inte telegrafistens. Om det är någon av de närvarandes så är det läkarassistentens perspektiv. Han ser lägenheten för första gången och i förhållande till honom har "telegrafisten" (inte "hon" även om det förstås skulle ha riskerat att misstas som pronomen för modern) kikat in "dit" ("tuda"). Hon kommer ut igen från bakom skärmen och med sin fråga, oskyldigt eller medvetet, lägger hon upp för honom att avgöra om deras umgänge ska få någon fortsättning.

Det är ett upplägg som han - åter sedd utifrån som lite löjlig i sitt galanta sätt - ivrigt tar vara på. Och som en reaktion på hans initiativ, drar hon sig tillbaka för att tillreda te. En tickande klocka har satts igång för deras umgänge, redan smygandet och sedan slamret med samovaren påkallar risken att modern när som helst kan vakna.

Gestaltningen dröjer vid läkarassistenten i rummet med modern bakom skärmen i fonden. Först tycks han med sitt löjliga luktande på en så gott som luktlös blomma iakttagen, sedan följer intryck genom fönstret för vilka han framstår som den varseblivande:

Цикламен цвел в горшке. Лекпом нюхал. Под окном шла дорога, валялась солома. За плетнем лежал снег, и из снега торчала ботва. [...]

Cyklamen blommade i en kruka. Läkarassistenten luktade. Under fönstret gick vägen, halm låg och skräpade. Bortanför gärdsgården låg snö, och ur snön stack blast upp. [...] 
Vittnar luktandet på blomman om en nervositet eller är det bara hans sätt - att uppträda som om han var betraktad, som på en scen, som tillgjort romantisk? De av handlingen opåkallade prosaiska intrycken genom fönstret, ger en liksom neutral yttre blick eller antyder en stund av försjunkenhet $\mathrm{i}$ denna tillvaros realitet, dess gråkalla alldaglighet. Tänker han möjligen på hennes situation? Här bor hon med sin mor. Det här är vad hon har utanför fönstret. Är blasten i snön från fjolåret, något oskördat? Halmen skräpar, gärdsgården stänger in. Betyder det något eller ger dessa detaljer bara ett slags verklighetens nyktra, dämpande motspråk till den antydda romantiken och deras roller, en ny ton i stämningen som inte behöver översättas till ord. Till skillnad från i exempelvis "Vstreči s Liz", när Kukin går ner till floden fylld av föreställningar efter att Liz gått in i bastun, utvecklas här varken några inre föreställningar eller reaktioner på den kontrasterande verkligheten.

Efter denna närvaro i stunden återges det, som sista mening i samma stycke, summerande om dem båda att de drack te och talade om staden (med bara adverbet "tichon'ko", "lite tyst och försiktigt" som återknyter till situationens skörhet). Vad som därefter återges är emellertid enbart mannens galanta, liksom världsvana repliker om livet i staden. Det görs inte tydligt men den stad han kommer ifrån och talar om är här troligen inte det Petersburg eller Leningrad som det i tidigare noveller talats hänfört om utan samma provinsstad med Brjansk som förlaga som skildras i övriga noveller. Denna novell utspelar sig då i ett samhälle vid en järnvägsstation i utkanten av småstaden. (Det synes märkligt att en läkarassistent skulle skickas efter längre ifrån och det gör det rimligt att han kan komma med tåget på eftermiddagen och resa tillbaka samma kväll):263

[...] Пили чай и тихонько говорили про город.

- Интересная жизнь, - восхищался лекпом, - Мери Пикфорд играет прекрасно.

Он смотрел на огонь и, чуть-чуть улыбаясь, задумывался. Брови были приподняты. Волосок, не захваченный бритвой, блестел под губой.

[...] De drack te och pratade tyst och försiktigt om staden.

- Ett intressant liv, sade läkarassistenten hänfört, Mary Pickford spelar förtjusande.

Han tittade på elden och föll i tankar med ett litet leende. Ögonbrynen var höjda. Ett hår som missats med hyveln blänkte under läppen.

\footnotetext{
263 Det får också miljön att likna den kring den enrumslägenhet i ett litet samhälle vid järnvägsstationen på linjen mellan Riga och Orjol cirka fem kilometer utanför Brjansk där Dobyčin och hans två systrar trängdes tillsammans med sin mor fram till 1927. Den kvinnliga huvudpersonen har också antagits vara systern Ol'ga som i början av tjugotalet ingick ett ytterst kortvarigt äktenskap. Ė. S. Golubeva, Pisatel’ Leonid Dobyčin i Brjansk, Brjansk 2005, 40.
} 
Läkarassistentens filmskvaller bidrar till att själva situationen framträder som stumfilmslik. Såväl hans lite tillgjort galanta sätt som själva gestaltningen och novellens dramatik har faktiskt något av stumfilmsmelodram över sig. Det berättas att de talade om staden: vi ser deras munnar röra sig men hör inte vad de säger, vi ser hans hänfördhet över något (liksom tidigare hans galant viftande armar) och får som texten i en stumfilm en stiliserad replik, liksom ett exempel, en talande detalj för ett mer omfattande samtal: "Ett intressant liv. Mary Pickford spelar förtjusande." Efter denna kontenta av samtalet gestaltas så, liksom i närbild, hur han försjunker i denna filmens värld i tankarna. Men vi erfar också att hon möjligen betraktar honom på detta sätt, med intresse för det svaga leendet i belysningen från elden och de höjda ögonbrynen igen som inte längre uttrycker nedlåtenhet. Så fokuseras ett litet - liksom kittlande litet - hårstrå under läppen som både är närvaroskapande och visar på en brist i hans ordnade och galanta yta. Och håret blänker som något betydelsefullt.

Känner hon för honom, förförs hon, väcker det han säger drömmar om ett annat liv, något han indirekt kan uppfattas erbjuda henne genom sitt tal om livet i staden? Om detaljerna i gestaltningen av hans yttre banaliserande öppnar honom som människa - eventuellt såsom sedd av henne - så antyder samtidigt hans försjunkenhet i sin filmvärld, som även den följande repliken visar på efter att de flyttat över till soffan, att han själv tycks uppleva den verkliga situation han ingår i halvt som en film. Han agerar åtminstone liksom enligt melodramernas konventioner. Istället för att tala till henne som en människa - exempelvis genom att fråga något om hennes situation, hennes liv, eller vem hon är - förefaller han försöka närma sig henne genom att som en komplimang föra in henne i den filmens värld som uppfyller honom.

Перешли на диван и сидели в тени. Печка грела. Самовар умолкал и опять начинал пищать.

- Женни Юго брюнетка, - заливался лекпом и сам же заслушивался. Она - ваш портрет.

De flyttade över till soffan och satt i skuggan. Spisen värmde. Samovaren blev tyst och började gny igen.

- Jenny Jugo är brunett, brast läkarassistenten ut och lyssnade liksom till sig själv. Hon är ett porträtt av er.

Soffan och skuggan och värmen lägger upp för ett fysiskt närmande. Ljuden från samovaren skapar på samma gång en anspänning som den potentiellt ger en förminskande parallell till hans på samma sätt återupptagna prat. Men hans försök att få henne att passa in i filmens värld, genom att plötsligt 
förklara henne porträttlik den berömda skådespelerskan, inleder, med denna "igenkänning" som ett slags peripeti, på samma gång upplösningen av novellen.

Närmandet, komplimangen, blir på samma gång ett avståndstagande till henne som person. Den människa han sitter nära talar han inte till utan om genom likheten med en annan, som i relation till ett Det och inte ett $\mathrm{Du}$ enligt Martin Bubers uppdelning.

Värt att notera är dock att han faktiskt säger att Jenny Jugo är hennes porträtt och inte tvärtom, vilket så trots allt gör henne, telegrafisten, till den verkliga människan. Om man läser repliken så, som klumpig men trots allt ett erkännande av henne som levande och vacker, kan hennes påföljande reaktion tolkas som att hon faktiskt känt sig sedd, som att det är väckta innestängda känslor och inte en uppgivenhet med denne man som till en början tar sig uttryck i den tystnad under vilken hon nu först också utseendemässigt porträtteras. I så fall förstör läkarassistenten slutligen alla möjligheter till något annat när han åter, och nu iklädande sig sin yrkesroll, bryter den talande tystnaden:

Поджав ноги и съежившись, телеграфистка молчала. Глаза ее были полузакрыты и темны от расширившихся, как под атропином, зрачков.

- Вас знобит, - присмотрелся лекпом. - Вы простудились. Весна подкузьмила вас. - Нет, я здорова, - сказала она и застучала зубами, - может быть, форточка.

Hopkurad och med benen uppdragna under sig satt telegrafisten tyst. Hennes ögon var halvslutna och mörka av de, som av atropin, vidgade pupillerna.

- Ni har frossa. Läkarassistenten såg närmare. Ni har förkylt er. Våren har spelat sitt spratt med er. - Nej, jag är frisk, sade hon och hackade med tänderna, kanske vädringsfönstret.

"Som av atropin" och det anatomiskt sakliga antyder hans närvaro i varseblivandet redan innan det sägs att han ser närmare på henne som den läkarassistent han är. Beskrivningen av henne rymmer möjligen något av en ironiskt distanserad bekräftelse på hans tidigare replik, en förevändning för den. Med just de av mörkret, och kanske faktiskt också en förkylning, här naturligt vidgade pupillerna uppvisar telegrafisten nämligen ett av just Jenny Jugos utmärkande drag som skådespelerska. ${ }^{264}$

\footnotetext{
${ }^{264}$ Antropin eller så kallade Belladonnadroppar från örten Atropa bella-donna var också just vad som användes inom stumfilmen för att i brist på röst på detta sätt förstärka uttrycksfullheten, gärna liksom telegrafisten här i kombination med liksom lidelsefullt halvslutna ögon. Hos Jenny Jugo, exempelvis som Theresa i den stora ryska emigrantproduktionen Casanova
} 
Denna telegrafarbeterskas naturligt förstorade pupiller skildrar på detta sätt indirekt den levande verkligheten bakom de samtida stumfilmernas skimrande lidelse och melodramatiska ideal. Snarare än att gestaltningen som helhet, exempelvis med sitt användande av ljus och skugga, konsekvent efterliknar en stumfilmsestetik kan dessa inslag ses skildra de av stumfilmen präglade romantiska föreställningar som läkarassistenten som en del av denna verklighet upptas av.

Genom hela det möte novellen beskrivit har de melodramatiska dragen hållits tillbaka och kontrasterats av prosaiska detaljer som inte riktigt kunnat inpassas i de romantiska föreställningarna. Med uppvaknandet ur deras korta samvaro i och med läkarassistentens nu helt opersonligt distanserade diagnos och förmaningar blir det tydligt att även denna novell syftar till att skildra den mycket mer oberäkneliga, osäkra och dramatiskt otydliga verkligheten utanför eller under detta kammarspel. Är det bara förkylningssymptom, är det en förälskelses feber eller, kanske snarast, en innestängd dröm om ett helt annat liv som hans prat, likt den förrädiska tidiga våren, väckt tankarna om? Spänningen förtas i vilket fall. Telegrafisten bryter upp som svar på hans förmaningar. Möjligen med en antydd irritation i skramlandet med disken drar hon sig också tillbaka till sin sociala roll och den situation som deras nu avslutade möte utgick ifrån.

Он оглянулся и повертел головой: - Закрыта. Наденьте пальто. Я вам дам потогонное. Надо беречь себя, одеваться, как следует, перед выходом из дому - есть. - Она встала и начала мыть посуду, стукая о полоскательницу. Лекпом поднялся, прошелся на цыпочках, взял со столика ноты, посмотрел на название и замурлыкал романс. Мать проснулась.

Han såg sig om och skakade på huvudet: - Det är stängt. Ta på er kappan. Jag ger er vätskedrivande. Man måste ta hand om sig, klä sig ordentligt, äta innan man går ut ur huset. Hon reste sig och började diska kopparna knackande mot sköljfatet. Läkarassistenten reste sig, gick omkring lite på tå och tog några noter från bordet, tittade på titeln och började humma på romansen. Modern vaknade.

Läkarassistentens präktiga ton, dessa instruktioner och hans sista handling tyder inte på att han är medveten om någon möjlig annan innebörd än den medicinska i sina ord om frossa och våren som lurat henne tidigare. Han uppfylls av sin yrkesmässiga bedömning. Myndigt och liksom godhjärtat ger han henne sina råd. Om hon visar tecken på irritation så märker han det inte. Om han nu någonsin faktiskt erfarit något betydelsefullt mellan dem

från 1927 (i regi av Aleksandr Volkov), låg antropin säkerligen bakom hennes karaktäristiskt hypnotiserande, men också liksom sjukliga ansikte. 
så tycks han åtminstone inte inse att det nu är över. Han fortsätter i samma stil.

Som den företrädare för den sovjetiska samtiden han är till både titel och sätt, präglad av både dess ideologi och underhållningskultur, tycks han okänslig för några möten bortom orden, för det utbyte mellan dem som ändå ägt rum i denna vardagliga situation och som skulle ha kunnat få en fortsättning. I vad som skulle kunna uppfattas som en sista trevare, ett sista romantiskt försök, men som vi och troligen också hon nu tydligare inser bara är en del av hans tillgjorda filminspirerade sätt, börjar han humma på en faktisk romans som hon, talande för hennes sinnelag, har noterna till liggande på bordet. Både med sitt smygande och sitt hummande anknyter han tillsynes omedvetet till det som nyss utspelat sig mellan dem, till den förtäckta romans vi med telegrafisten upplevt men som han möjligen rakt igenom liksom omedvetet ingått i. För honom har inget hänt. Och i samma andetag som han åter råkar antyda något med romansen, upphäver han slutgiltigt möjligheten för en vidare utveckling av mötet genom att väcka modern. ${ }^{265}$

\section{"Otec" ("Fadern") - en i alla fall närvarande far}

Novellen "Otec" ("Fadern") är nästan lika kort som "Lekpom". I läsningens möte, i det liv som förverkligas, är novellen väldigt enkel, kanske den enklaste av Dobyčins samtidsnoveller. Den genomsyras av det slags omedelbara relation till världen som något levande som Martin Buber beskriver i termer av barnets ännu av Det-världen oskadade Jag-Du-relation. Jag tog i inledningen upp detta i samband med att barnperspektivet hos Dobyčin, vilket han använder i båda de längre verken från trettiotalet, mer naturligt kan ses motivera hans slags gestaltande av förkategoriella, associativa tillstånd av igenkänning av något betydelsefullt i den vardagliga tillvaron, av möten bortom orden. Denna novell är samtidigt inte lika begränsad av barnets föreställningsvärld som den från början för barn avsedda berättelsen om Lëška ("Matros"). Här utgör faderns mötesproblematik den egentliga konflikten.

I all sin enkelhet blir den närvaro i tillvaron som novellen skapar emellertid komplex om man försöker se till hur den faktiskt framkallas genom

\footnotetext{
${ }^{265}$ Arkadij Neminuščij poängterar att något själlöst nästan djuriskt understryks i läkarassistentens existens (vilket Neminuščij ser som en följd av dennes provinsialism så som den förstärkts av det sovjetiska samhället) i det verb, "zamurlykat", som beskriver honom ta ton. Att han började "brumma" eller "spinna" romansen kunde vara översättningar som underbyggde en sådan, i min mening alltför entydig, tolkning. "O poètike rasskaza L. Dobyčina 'Lekpom'", PLD, 275-279, 277-278.
} 
denna vardagliga tillvaros beståndsdelar. Endast genom en förverkligande läsning av denna enkla närvaro, i vilken man upplever en samhörighet och samvaro med de medvetanden som ingår i den, blir gestaltningens formella särdrag naturligt förståeliga - och därmed samtidigt ovidkommande.

Vem berättar? Vem ser? Vad spelar de frågorna för roll? Vi är genom inledningsmeningen redan i en levande, pågående tillvaro, och också i skapandets mitt. Världen är välbekant för de som upplever den men upplevelsen så som den förmedlas tyder inte därför på ett enbart automatiskt, vanemässigt noterande. Istället präglas gestaltningen av en lustfylld och insisterande betydelsefullhet i de vardagliga detaljerna - inte för att den vardagliga tillvaron egentligen görs främmande utan för att den i sina levande, mänskliga beståndsdelar igenkänns. Den kyrkogård som en fader går med sina två pojkar över är genom sina vardagliga föremål full med liv eller vittnesbörder om liv:

На могиле летчика был крест - пропеллер. Интересные бумажные венки лежали кое-где. Пузатенькая церковь с выбитыми стеклами смотрела из-за кленов. Липу огибала круглая скамья.

Отец шел с мальчиками через кладбище на речку. За кустами, там где хмель, была зарыта мать. - Мы к ней потом, - сказал отец, - а то мы опоздаем к во́лнам. ${ }^{266}$

På pilotens grav var korset en propeller. Här och var låg intressanta papperskransar. Den bulliga kyrkan med utslagna rutor tittade fram bakom lönnarna. Runt linden böjde sig en rund bänk.

Fadern gick med pojkarna till floden över kyrkogården. Bakom buskarna, där humlen stod, var modern nergrävd. - Vi går till henne sedan, sade fadern, annars kommer vi för sent till vågorna.

Barnperspektivet etableras genom den lekfulla jämförelsen av korset med en propeller utifrån vetskapen om att det är en pilots grav samt av beskrivningen av papperskransarna som intressanta.267 Även det diminutiva och

\footnotetext{
${ }^{266}$ Novellen citeras ur PSSP, 83-84.

${ }^{267}$ En möjlighet som gestaltningen håller öppen är att en faktisk spännande sekulär propeller ersatt ett kors såsom mer passande för en sovjetisk pilot. I en efterlämnad kortare version av novellen (PSSP, 433) står kors och propeller ihopskrivna som ett koncept "krest-propeller" (ungefär "propellerkors") vilket är ett existerande begrepp för ett slags (tämligen likformigt) kors med ett avbildat krucifix.

I denna pilots grav som inte har någon vidare funktion i novellen kan man möjligen se ett förebådande sammanknytande med en pilot i den sista, men troligen tidigare tillkomna novellen "Portret". Den pilot som med sitt flygplan där återkommande väcker både romantiska drömmar och en frihetslängtan störtar till slut och novellsamlingen slutar med dennes begravningståg i bakgrunden.
} 
lätt besjälande attributet för kyrkan ("puzaten'kaja" ("bullig" eller "lite rundmagad")) gör den till något av ett levande väsen. ${ }^{268}$ Så följer nästa stycke med ett plötsligt distanserat berättande i den mening som klargör situationen, där de barn som framträtt genom varseblivandet bara nämns som tillhöriga fadern, för att sedan åter perspektiviskt, deiktiskt, och med lätt barnfärgat språk peka ut moderns grav. ${ }^{269}$ Faderns ord följer också likt en replik på beskrivningen, kanske på barnens tysta blickande ditåt, mot humlen. Så introduceras också den döda modern, med både faderns och barnens antydda okänslighet eller liksom fortfarande levande relation till henne - de ska till henne (och inte bara till graven) sedan.

Denna gestaltning gör det svårt att tala om någon renodlad form av berättande eller ett renodlat perspektiv. Tillvaron med dess människors medvetanden flyter fram för oss i ett levande nu. I denna upplevda närvaro har samtidigt novellens dramatiska exposition, handlingens förutsättningar effektivt avklarats samt en konflikt och vardaglig tragik antytts. Berättelsen har också getts en riktning framåt: de måste skynda sig för att hinna till vågorna, med vilket vi ännu inte vet vad som avses.

Till den levande rörelsen, det syntesskapande och den samtidiga närvaron av flera medvetanden bidrar också den jämna, om man så vill metriskt avkodbara, språkliga rytmen. Efter att ha flutit stillsamt genom denna exposition blir den mer påtaglig - som en del i gestaltandet av den språngmarsch som nu utlöses av en plötslig signal. Taktfast ackompanjeras deras utlösta handlingsiver. Sett till innehållet framstår rytmen som en naturlig del i de stämningar och rörelser som gestaltas, som, utifrån Meschonnics syn på rytm som jag tog upp i inledningen, oskiljbar från subjektens aktivitet och det innehåll och uttryck som förmedlas. Men den upplevda rytmen följer här ett för prosa ovanligt utpräglat jämnt mönster av betonade och obetonade stavelser som kan beskrivas som en tvåstavig meter (understruket markerar rytmisk betoning, kursiv den utifrån detta abstraherbara meterns tomma slag):

Заревел гудок. - Скореeе, - закричалии малльчики. - Скореeе, - заспешил отец. Все побежали. [...]

\footnotetext{
${ }^{268}$ Den samtida sovjetiska kontextens närvaro även i denna vardag skulle möjligen detta epitet om kyrkan (vars utslagna rutor redan antyder samtidens vandaliseringar och att den är stängd) också ses som ett uttryck för. Präster på antireligiösa bolsjevikiska affischer avbildades ofta markerat rundmagade. Men beskrivningen lär också överensstämma med den kyrka i Brjansk som troligen tjänat som förebild. Den kyrkan stängdes I927. E். S. Golubeva, Pisatel' Leonid Dobyčin i Brjansk, Brjansk 2005, 82-83.

${ }^{269}$ För att förstärka barnens perspektiv skulle man här kunna tänka sig "mor" istället för "modern" medan "far" istället för "fadern" i föregående mening skulle bli märkligt.
} 
Visslan tjöt. - Snabbare, skrek pojkarna. - Snabbare, sade fadern och skyndade sig. Alla sprang. [... $]^{270}$

En visslas tjut kan i den sovjetiska kontexten ge associationer till en fabriksvissla - en klassisk schablon i den samtida litteraturen. Men det är varken till arbete eller uppror som visslan ljuder här. Deras rörelse, deras glädjefyllda handlingskraft står snarast fram i lätt ironisk kontrast till denna antydda kontext när vi får veta vad de med sådan iver skyndar till. ${ }^{27}$ Till rytmens påtaglighet $\mathrm{i}$ deras aktiva handlande bidrar de tre verbens alliteration - zarevél, zakričáli, zaspešíl - liksom i det upprepade, instämmande och påhejande "skoree". Detta "vse pobežali" ("alla sprang") istället för "oni" ("de") bär prägel av ett barns sätt att berätta vilket gör att pojkarna upplevs som något av ett subjekt för den betraktelse som därefter följer i stycket (inget nytt pronomen för dem införs, det subjektslösa verbet i plural ("zabyli") är därmed också liksom öppet för ett tänkt "vi”).

270 Även i tidigare noveller har det i vissa passager funnits drag av en sådan abstraherbar främst tvåstavig meter. I de nya novellerna i Portret (som också inledningsnovellen "Proščanie" tillhör) och än mer i de längre verken från trettiotalet blir denna om man så vill "metriska rytm" mer utpräglad och genomgående. I de längre verken växlar det tvåstaviga mellan kapitlen också över till en trestavighet, vilket ibland tycks avsett att ackompanjera det som gestaltas med en stämningsmässigt mer elegisk ton. Av de skäl jag redogjorde för i inledningen, utifrån Henri Meschonnics kritik av metriskt inriktade studier av språklig rytm, har jag här inte utvecklat dessa metriska aspekter utan försökt att se till den i alla noveller befintliga rytmen (enligt Meschonnics syn), oavsett metrisk regelbundenhet, som en del i gestaltningen och uttrycket. Generellt kan det metriska draget ses som en konsekvens av en särpräglande intensiv laddning i Dobyčins prosa som rytmen har en (dock icke analytiskt isolerbar) del i att skapa.

${ }^{271}$ I novellen "Sad" ("Trädgården") återkommer ordet "gudók" (då i betydelsen fabriksvissla) just i en pastisch på proletär poesi. Den där citerade samtidspoesin menar forskaren Ėduard Mekš är en parafras på just Aleksandr Gastevs dikt "Gudki" (se not 286). Men visslans tjut, och just formuleringen "zarevel gudok" är förvisso något av ett stående inslag i den proletära och senare socialistiska sovjetiska realismen. Redan i Maksim Gor'kijs roman Mat' (En moder) från 1906 (som 1934 presenterades som förebildlig för den socialistiska realismen) tjuter fabriksvisslan som inledning på en avgörande händelse (visslan kallar till arbete men inleder samtidigt huvudpersonens första maj-tal): "Заревел гудок, поглотив своим черным звуком людской говор." ("Visslan tjöt och slukade människornas tal med sitt svarta ljud.") "Mat", Sobranie sočinenij $v$ I6 tomach, 4, Moskva 1979, 4-320, I39. I Nikolaj Ostrovskijs roman Roždennye burej (Födda av stormen) (1936) signalerar huvudpersonen själv med fabriksvisslan för att mana folk ut på gatorna under inbördeskriget: "Вновь, потрясая воздух, заревел гудок, прерывистый, страшный вестник несчастья." ("På nytt tjöt visslan och skakade luften med ojämna avbrott som ett skrämmande olycksbud.") "Roždennye burej", Sobranie sočinenij $v$ trech tomach, 2, Moskva 1956, 7-209, IOI. Il'ja Il'f och Evgenij Petrov använder för övrigt med ett ironiskt-komiskt drag samma uttryck om just en ångbåtsvissla som det här visar sig vara tal om i den nästan helt samtida romanen Dvenadcat' stul'ev (Tolv stolar) från 1928: "Снова заревел гудок, и снова солнце в испуге убежало. [...] Пароход был готов к отходу." ("Åter tjöt visslan och åter sprang solen skrämt iväg [...] Ångbåten var klar för avresa.") Dvenadcat' stul'ev; Zolotoj telenok, Moskva 1956, 259. 
[...] Над калиткой стоял ангел, нарисованный на жести и вырезанный. Второпях забыли постоять и, подняв головы, полюбоваться на него.

[...] Över grinden stod en ängel ritad på bleck och utskuren. I brådskan glömde de att stå ett tag med lyfta huvuden och beundra den.

Beskrivningen av vanan att betrakta ängeln som bryter in (och upplöser taktfastheten för ett tag) tycks präglad av pojkarnas medvetande samtidigt som de nu förefaller alltför upptagna av sitt springande för en reflektion över vad de inte gör. Detta upplevande av en bleckplåtsängel som inte äger rum står snarare ut som något betydelsefullt som försummas i den sovjetiskt anslagna handlingsivern.

Сбега́ли по тропинке, и гудок опять раздался. - Опоздаем, - подгонял отец. Сердца стучали, в головах отстукивалось.

De sprang på stigen neråt och visslan ljöd igen. - Vi kommer för sent, jagade fadern på. Hjärtana bultade och $\mathrm{i}$ huvudena bultade det tillbaka.

Fadern driver på och rytmens taktfasthet tas upp i de inre men kollektiva pulslagen (som med allitteration och assonans fonetiskt intensifieras). Rytmen samverkar så såväl med syntaxen som med semantiken i att göra det skildrade fysiskt kännbart och närvarande. Så fortsätter det i den uppskruvade stämningen på stranden när de stressat trasslar av sig kläderna och slutligen, markerat med ett kolon efter rörelsen som del av en sammanhängande inre upplevelse, kan konstatera att de faktiskt hann, varefter det de hunnit till så med skarpa ljud- och synintryck gradvis framträder och framkallar ett förtjust klimax:

Сбрасывая куртки, добежали и, вытаскивая ноги из штанов, упали на землю: успели. Справа тарахтело, приближался дым, нос парохода, белый, показался из-за кустиков. Вскочили, заплясали, замахали шапками. Величественный капитан командовал. Шумело колесо, шипела пена, след в воде кипел. Присели, потому что с палубы смотрели женщины, и, глядя на них боком, сжали себе руки коленями.

De sprang fram medan de kastade jackorna och ramlade på marken när de drog ut benen ur byxorna: de hann. Det tuffade från höger, en rök närmade sig, ångbåtens vita för dök upp bakom buskarna. De hoppade upp och började dansa och vifta med mössorna. Den majestätiska kaptenen kommenderade. Vattenhjulet brusade, skummet fräste, spåret i vattnet kokade. De satte sig på huk, för det var kvinnor som tittade från däck, och klämde händerna med knäna och såg på dem från sidan.

I sista meningen sker ett intrång i den hittills av andra människor ostörda samvaron mellan pojkarna och fadern. De blir nu objekt för andras blickar 
- för kvinnor. Och i att de blir varse sin nakenhet framträder de med denna sexuella medvetenhet också själva som subjekt, som en del av det sociala, en värld av lagar, orsak och verkan. Liksom fortsatt präglat av barnens medvetande, som om detta är något de lärt sig av fadern men inte riktigt förstår vitsen med ännu, förklaras förnumstigt hur de skyler sig och ser tillbaka på kvinnorna. ${ }^{272}$

Men när så svallvågorna från båten börjar slå mot stranden som den fullständiga måluppfyllan - det var dessa vågor som fadern först nämnde på kyrkogården - släpper de åter på hämningarna. För de andra människorna på stranden, som också kastar sig i det vilda vattnet nu efter att ångbåten med sina kvinnor passerat, tycks de inte behöva skämmas:

- Шлеп, - набежала первая волна. - Скорей! - все бросились.

Река была как море. - Ух, - кричали люди и подскакивали. - Ух, - кричал отец, держа мальчишек на руках и прыгая. - Ух, ух, - кричали они, обхватив его за шею, и визжали.

- Klatsch, kom den första vågen. - Snabbt! Och alla kastade sig i.

Floden var som ett hav. - Oj, ropade folk och studsade upp och ner. - Oj, ropade fadern och höll sina pojkar i famnen och hoppade. - Oj, oj, ropade de och grep honom om halsen och tjöt.

Detta är den fysiska upplevelse de skyndat till. Den första vågens slag mot stranden, som en replik, initierar deras aktivitet som ett svar på samma sätt som ångbåtsvisslan inledde språngmarschen. Deras interjektioner och rörelser gestaltar sedan vågornas ostyrighet och tumult, det havslika. Det tycks omtumlande, rentav lite skrämmande för pojkarna som nu åter beskrivs mer distanserat, som tillhöriga fadern som det handlande subjektet. Alla tre tycks liksom sedda utifrån (ett perspektiv som kan knytas till de andra på stranden). ${ }^{273}$

\footnotetext{
${ }^{272}$ Med Martin Buber skulle man i denna scen kunna se det som att pojkarna är på väg att träda ut ur en oreflekterad förbundenhet i världen, en omedelbar Jag-Du-relation som intrycken på kyrkogården talade för, till ett mer socialt och relaterande Jag-Det-förhållande.

${ }^{273}$ I en tidigare mer språkmaterialistisk version av novellen ingår dessa interjektioner tydligare i en kedja med tidigare ljud. Det börjar i spelet mellan ångbåtens där som repliker utskrivna och stegrade ljud och deras utrop - mellan maskinen och människan - på väg ner: "- У, - заревел гудок" ("- U, tjöt visslan"), "гудок раздался два раза: - У! У! - Мы опоздаем [...]" ("visslan ljöd två gånger: - U! U! - Vi kommer för sent [...]") och till sist i ett eget stycke efter hjärtslagen bara visslingarna: "- У! У! Y!" ("U! U! U!"). Sedan kommer ångbåten: "- Tyxтух-тух" ("Tuff-tuff-tuff") och efter ett i indirekt tal uttryckt hurra över att ha hunnit i tid svarar de på ångbåtens ljud med ett direkt utrop i ett eget stycke: "- Ypa!" ("Hurra!)". På den första vågens ljud följer så ett "- O!" i ett eget stycke före deras ojande under badandet som behållits. PSSP, 433. I den slutgiltiga versionen är ljuden mer integrerade och indirekt framträdande genom det gestaltande språkets fonetiska rytmväxlingar - i allitererationer $(/ \mathrm{k} /$ $/ \mathrm{ch} /-|\check{c} /-| \check{s} /-\mid \check{z} /)$ och assonanser $(/ \mathrm{a} /$ och $/ \mathrm{u} /)$.
} 
Sedan lugnar sig vågorna och stämningen. Likt en metapoetisk exemplifiering av den språkliga rytmens performativa följsamhet med det som skildras, härmar fadern ångbåten när han först leker med barnen. Sedan får de också göra nytta, som stora, genom att hjälpa till när han tvättar sig. Efter att först kroppsligen ha framträtt i sin manlighet framträder fadern nu som subjekt i det att vi ur hans medvetande blir informerade om att denna tvagning för honom (vilket barnen troligen är ovetande om) denna dag har ett särskilt syfte, samt att den kvinna han ska träffa, att döma av samvetskvalen, troligen är den första efter hustruns bortgång. Så igångsätts en ny händelseutveckling och konflikt, en i princip helt ny berättelse kommer till ytan efter den första som nu med badet har fullbordats. Denna dramatiska vändpunkt sammanfaller med den vardagligt konkreta - att de efter badet beger sig tillbaka igen:

Волны кончились. Отец, гудя по-пароходному, ходил в воде на четвереньках. Мальчуганы ездили на нем. Потом он мылся, и они по очереди терли ему спину, как большие. Выпрямляясь, он осматривал себя и двигал мускулами: вечером он должен был отправиться к Любовь Ивановне. Он думал: - Но зато я не плохой отец.

Vågorna tog slut. Fadern gick tutande som en ångbåt på alla fyra i vattnet. Pojkarna red på honom. Sedan tvättade han sig med tvål och de turades om att skrubba honom på ryggen som stora. Han såg granskande på sig när han rest sig och rörde på musklerna: ikväll skulle han ge sig iväg till Ljubov Ivanovna. Han tänkte: - Men jag är i alla fall ingen dålig far.

Den nu fullbordade berättelsen om badet som framförallt präglats av pojkarnas perspektiv avrundas med deras väg tillbaka med en förhöjd närvarokänsla efter badet. Efter några skrämmande känslor på kyrkogården kommer pojkarnas dag att krönas av att de av fadern får varsin pepparkaka som de njuter av medan fadern röker en cigarr.

Den andra berättelsen som informationen om faderns förestående kärleksmöte igångsatt - och som sammanknutits med den första genom att badet för honom samtidigt utgjort en förberedelse för detta möte - utvecklas, med få yttre antydningar, inom fadern liksom över huvudena på hans barn som är närvarande och uppfyllda av sina upplevelser för stunden.

Sammanknytningen av dessa två berättelser antyder samtidigt tematiskt en problematik förknippad med detta möte. Också fadern uppvisar en glädjefylld närvaro i det som är. En del av faderns kval inför mötet på kvällen kan så ses bottna i det begär det är förknippat med, de föreställningar som rycker honom ut ur sin lyckliga rena närvaro med pojkarna.

Den Ljubov' Ivanovna han ska till är också, med "kärlek" ("ljubov") som sitt förnamn, namne med (eller möjligen samma person som) den flärdfulla 
granne som störde den unge författarens lugn i "Erygin". Inom berättelsens ramar blir denna Ljubov' bara ett hägrande objekt för fadern. Hon utstakar en gräns för den samvaro mellan honom och barnen som skildras vilken i sig, nu i kvällsstundens mättnad, framhävs som något betydelsefullt:

Назад шли медленно. - А то купанье, - говорил отец, - сойдет на нет. Взбирались по тропинке долго. Обдували одуванчики и обрывали лепестки ромашек. Оборачивались и смотрели вниз. Коровы шли по берегу, отсвечиваясь в речке. Иногда они мычали. Огоньки зажглись у станции и переливались. [...]

De gick långsamt tillbaka. - Annars var ju badet, sade fadern, meningslöst. Det tog lång tid för dem att ta sig upp för stigen. De blåste på maskrosbollar och plockade kronbladen från prästkragar. De vände sig och tittade neråt. Korna gick på stranden och speglades i floden. Ibland så råmade de. Lamporna tändes vid stationen och skimrade. [...]

Faderns förklaring följer som ett svar på den situation som presenteras som i dialog med pojkarnas medvetande. Hans replik återknyter samtidigt, bortom barnens förståelse, till badets särskilda syfte för honom. Den långsamhet som fordras för att han inte ska komma svettig till mötet bidrar samtidigt till att de vardagliga intrycken framträder som en upplevelse i sig.

Denna stund, med kvällens mättnad och i friskheten efter badet som en uppfylld närvaro (med ett blänk i speglingen av korna i vattnet och slutligen med stationen som framträder med en riktning bort), avrundas av det stämningsskifte som solnedgången och återinträdet på kyrkogården för med sig: "[...] Солнце село. Звезд еще не видно было. Ангел над калиткой потемнел." ("[...] Solen hade gått ned. Stjärnorna syntes inte än. Ängeln över grinden hade mörknat.")

Ängeln som de glömde i brådskan på vägen ner är nu för mörk för att stå och titta på. Stunden har slocknat och nu lämnar fadern pojkarna ensamma vid den i inledningen utplacerade bänken runt en lind för att själv gå till graven. Den stämning som solens nedgång naturligt initierat griper nu in med oro, obehag och dödens realitet på kyrkogården:

- Вы подождите здесь, - сказал отец у липы. - Я приду. - Они уселись, сняв картузики, и взялись за руки. Пищал комар.

Кусты сливались, черные. Верхи крестов высовывались из них. Хмель светлелся. Здесь отец остановился и стоял без шапки. Он зашел по поводу Любовь Ивановны и мялся: как и что сказать? А мальчуганам было страшно. Мертвые лежали под землей. В разбитое окошко церкви кто-нибудь мог выглянуть, рука могла оттуда протянуться. Стало хорошо, когда пришел отец. 
- Vänta ni här, sade fadern vid linden. Jag kommer. De tog av sig skärmmössorna, satte sig och höll varandra i händerna. En mygga gnydde.

Buskarna flöt ihop och var svarta. Topparna på korsen stack upp ur dem. Humlen syntes ljus. Här hade fadern stannat och stod utan mössa. Han kom med anledning av Ljubov Ivanovna och tvekade: hur säger man det, vad säger man? Och pojkarna tyckte att det var otäckt. Det låg döda under jorden. Genom det sönderslagna lilla fönstret på kyrkan kunde någon titta ut, en hand kunde sträckas ut därifrån. Det blev bra när fadern kom.

På faderns upplevelse och inre monolog vid sin hustrus grav (vilken humlen i inledningen utpekat) följer gestaltningen av pojkarnas känslor och föreställningar som ett svar. Han vänder sig till hustrun som en fortfarande levande motpart i tankarna med sina fortsatta samvetskval inför kvällens möte. Kvalen förknippas med problemet att han måste lämna pojkarna ensamma (det som på stranden bara antyddes med att han "zato" ("i alla fall") inte var en dålig far. Med beteckningen av pojkarna med det smeksamma "mal'čugany" som på stranden användes om dem när de åkte på honom som en ångbåt tycks övergången till pojkarnas belägenhet ske i faderns tanke - vilket dock genast följs av pojkarnas egna upplevelser fram tills han med sin återkomst återupprättar den för dem uppfyllande samvaron.

Med detta har också inledningen knutits in i helheten. Upplevelsen av kyrkogården i mörkret är mindre lättsam men fortsatt präglad av barnens medvetande i tankarna på de döda och eventuella vålnader. De sörjer inte uttryckligen sin mor men upplever ett obehag. Liksom de för ett tag skrämmande havslika vågorna från ångbåten följdes av deras glada lekar med fadern och njutande av intrycken på vägen upp från floden, för nu faderns återkomst och inträdet i staden med sig en ny lättnad som präglar deras samvaro i slutet. Det uppfyllda njutande som novellen slutar i förebådar samtidigt den vardagliga tragiken i att denna samvaro måste upplösas, att pojkarna snart troligen lämnas ensamma hemma när fadern beger sig till sitt kärleksmöte:

Приятно было идти улицами, мягкими от пыли. Фонари горели коегде. Ларьки светились. Во дворах хозяйки разговаривали с чинными коровами, пришедшими из стада. В городском саду пожарные отхватывали вальс. Отец купил сигару и два пряника. Молчали, наслаждаясь.

Det var trevligt att gå på gatorna som var mjuka av dammet. Lyktor brann här och var. Salustånden var upplysta. På gårdarna samtalade kvinnorna med sina kor som värdiga kommit hem från flocken. I stadsträdgården rev brandmännen av en vals. Fadern köpte en cigarr och två pepparkakor. De var tysta och njöt. 
Den enkla lättnaden i intrycken kan ses präglad av barnens naiva fascination inför det vardagliga (lyktorna brinner nu "här och var" ("koe-gde") såsom de intressanta kransarna låg på kyrkogården i inledningen). Men även fadern kan tänkas lättad efter bekännelsen vid graven. Kanske är han mer förnöjd med sin situation nu. De förkänslor inför kärleksmötet som hans rökande av en cigarr kan antyda liksom kompenserar han pojkarna för med varsin pepparkaka (dessa två pepparkakor är i själva verket det i berättelsen som tydligast visar på att rör sig om just två pojkar).

Den musikaliskt komponerade stämningen genom intrycken tas upp i den faktiska valsen från stadsträdgården, inte olikt hur "Lekpom" mynnade ut i en romans. Med denna vals i bakgrunden njuter de så tysta av cigarren respektive pepparkakorna, av sin närvaro och samvaro i världen, som inför ett ofrånkomligt slut.

Den sociala verkligheten hinner knappt framträda. Det omtalade förestående kärleksmötet nämns inte med ett ord. Det mötet framstår i denna novell mer som ett hot än ett löfte om förändring av huvudpersonernas tillvaro. Denna fars närvaro och njutande tillsammans med sina barn gestaltar så samtidigt livets och det betydelsefullas skörhet.

\section{"Chiromantija" ("Kiromanti") - konsten att läsa i samtiden}

"Chiromantija", "Kiromanti", det vill säga konsten att spå i handen var en titel som Dobyčin också övervägde för hela den andra novellsamlingen. ${ }^{74}$ Även om så inte blev fallet så antyder det att det förhållande till tecken i tillvaron som gestaltas i denna novell också kan ses som ett uttryck såväl för den egna poetiken som för en problematik som novellsamlingen som helhet skildrar.

Förhåller sig Dobyčin till den samtida tillvaron såsom en kiromantiker till en handflata, det vill säga med en tro på att i dess subtila detaljer kunna utläsa något om framtiden?275 I så fall problematiserar han här samtidigt detta förhållningssätt. Det kiromantiintresse som präglar huvudpersonen skildras å ena sidan med en lätt förlöjligande distans som något som leder till hans vardagliga tillkortakommanden när det gäller att möta andra människor i nuet. Tillvarons för honom betydelsefulla tecken visar sig som

\footnotetext{
274 "Puėnkarė" och "Požalujsta" ("För all del"; namnet på nästa novell) var andra alternativ innan valet till slut föll på Portret. Till Ida Slonimskaja I juni och 4 juni 1930 (brev II8, II9) och till Michail Slonimskij II juni, 8 juli och 19 juli 1930 (brev I20, I24, I25), PSSP, 303-309.

${ }^{275}$ Dvs. ungefär som Pasternak i Ochrannaja gramota (Lejdebrev) från 1930 beskriver att nuets detaljer redan bär framtiden i sig: "уже одна заметность настоящего есть будущее". Boris Pasternak, "Ochrannaja gramota", Sobranie sočinenij v pjati tomach, 4, Moskva I99I, I49-239, I78.
} 
också i tidigare noveller högst otillförlitliga. Å andra sidan leder hans allvarliga sökande efter mening i tillvarons detaljer, att försöka läsa dem likt linjerna i en hand, till att en känsla av något betydelsefullt i denna triviala vardag uppenbaras. Liksom tidigare huvudpersoners föreställningar tjänar detta i viss grad som en ersättning för de mänskliga relationer som går om intet. Möjligen kan man i den på detta sätt med ett konstnärligt sinnelag förbundna mötesproblematiken också utläsa ett uttryck för ett tvivel över de egna litterära försöken att uttrycka något väsentligt om samtiden.

Det börjar med en inandning: "Петров с наслаждением вздохнул продушенный воздух" ("Petrov andades njutande in den parfymtunga luften"). Succesivt framträder att vi befinner oss hos frisören. Petrov räknar "de väntande" och en viss Ladislas avlägsnar sig från en som "rakas" för att låsa dörren. Vi får en första inblick i Petrovs karaktär genom att han tolkar det att han hann in som sista kund för dagen som ett gott tecken. ${ }^{27}$

Sedan gestaltas den tryckta stämningen i en frisersalong i slutet av dagen samtidigt som yttre intryck når in som både klargör situationen - tiden på året och vad som hörs och inte i detta samhälle - och indirekt potentiellt utvecklar huvudpersonen som den som upplever detta:

Парикмахеры брили в молчании - устали, спешили и не отпускали учтивостей. Звякнули ножницы. Рождество наступало. Колокола были сняты и не гудели за окнами. - Пи, - басом пищал иногда и, тряся улицу, пробегал грузовик. ${ }^{277}$

Frisörerna rakade under tystnad - de var trötta, skyndade sig och gav inte ifrån sig några artigheter. Saxar skramlade. Det närmade sig jul. Kyrkklockorna var nertagna och ljöd inte utanför fönstren. - Pi, pep en lastbil med basröst ibland och for förbi och skakade gatan.

"Petrov läste inte", börjar nästa stycke när han troligen sitter framför spegeln hos frisören. Boken som han inte läser men bläddrar igenom presenterar källan till novellens titel och utvecklar ämnet i hans inre; den och spegeln får honom att tänka på gårdagskvällen och det betydelsefulla barndomsminne som den då framkallade:

Петров не читал. Он — просматривал. Он уже изучил эту книгу с изображенными на каждой странице ладонями. Он кончил ее вчера вечером и, закрыв, присел к зеркальцу и вспомнил стишки, которые когда-то разучивал в школе:

\footnotetext{
${ }^{276}$ Liksom i förra novellen återkommer ett namn från tidigare i samlingen utan att det på något ytterligare sätt framgår att det skulle röra sig om samma person - Petrov är här namne med den sjungande arbetarkorrespondenten i "Konopatčikova".

277 Novellen citeras ur PSSP, 88-89.
} 
исполнен долг, завещанный от бога

мне, грешному.

Petrov läste inte. Han - bläddrade igenom. Han hade redan studerat den här boken med illustrationer av handflator på varje sida. Han blev klar med den igår kväll och när han slutit den satte han sig framför spegeln och mindes några verser som han en gång fått lära sig utantill i skolan:

den plikt som Gud beskärt mig syndige är utförd.

I denna vardagliga situation där ingenting egentligen är märkligt finns redan ett nät av möjliga associationer. Men snarare än att utgöra en rebus som ska lösas gestaltar de antydda kopplingarna, lästa som en del av den vardagliga tillvaron, huvudpersonens kiromantipräglade medvetande. Den vers från skolan han drog sig till minnes är biskop Pimens ord ur Puškins drama Boris Godunov..$^{28}$ Dennes religiösa plikt i den stora oredans tid kontrasterar så mot det lätt ockulta studium av teckentydande som Petrov ersatt bibeln med och, vilket det väckta minnet antyder, i sin samtid upplever en liknande förpliktande mening i. Detta anknyter till kyrkklockorna tidigare som inte längre hörs. I denna associationssfär kan också det dova pipande som lastbilarna ger ifrån sig föra tankarna till ett matematiskt $\pi$ som ett uttryck för den vetenskap som ska ersätta religionen. Kanske bidrar lastbilarnas "pi" på samma gång, genom att också utgöra början på Pi-mens namn, rentav till att återkalla gårdagens minne. ${ }^{279}$ Den sanningssägande krönika över sin tid som Pimen i Puškins drama som en plikt säger sig ha utfört ger

\footnotetext{
${ }_{278}$ Еще одно, последнее сказанье -

И летопись окончена моя,

Исполнен долг, завещанный от бога

Мне, грешному. Недаром многих лет

Свидетелем господь меня поставил

И книжному искусству вразумил;

Когда-нибудь монах трудолюбивый

Найдет мой труд усердный, безымянный, [...]
}

Blott ännu en berättelse, en sista så är den slut, den krönika jag skriver, det uppdrag jag förlänats av Vår Herre är fullgjort då. Med goda skäl har Gud gjort mig, en stackars syndare, till vittne och lärt mig skrivarkonstens hemlighet; en gång skall någon strävsam klosterbroder få fatt i det jag ägnat namnlös möda.

Inledningen av Scen V i Puškins Boris Godunov med min kursivering av det som citeras i novellen. A. S. Puškin, "Boris Godunov", Polnoe sobranie sočinenij v I6 tomach, 7, Moskva I948, I98, I7. Svensk översättning av Lars Erik Blomqvist: Aleksandr Pusjkin, Boris Godunov, Umeå 20IO, $3 \mathrm{I}$.

279 I början av 1930, vilket möjligen kan datera novellen, togs kyrklockorna ner från flera av Brjansks kyrkor för att gjutas om till annat. Samtliga kyrkor stängdes. "Пусть смолкнут колокола, пусть громче гудят гудки!" ("Låt kyrkklockorna tystna, låt fabriksvisslorna ljuda högre!"), som det motiverades i tidningarna. Ė. S. Golubeva, Pisatel' Leonid Dobyčin i Brjansk, Brjansk 2005, 80. 
inte bara ett ironiskt skimmer åt Petrovs högtidliga förhållande till sin kiromanti. Med en blandning av självironi och allvar speglar det möjligen också det samtidsskrivande Dobyčin själv sysslar med.

Efter besöket hos frisören och med det teckentydande sinnelag som där etablerats ger sig huvudpersonen ut i staden:

Подбритый и подстриженный, он вышел. Он благоухал. Усы, бородка и завитушки меха на углах воротника покрылись инеем. Высокая луна плыла в зеленом круге. Жесткий снег переливался блестками. Как днем, отчетливы были афиши на стенах. Петров уже читал их: показательный музей «Наука» с отделениями гинекологии, минералогии и Сакко и Ванцетти снизил цены.

Nyklippt och ansad gick han ut. Han doftade gott. Mustaschen, skägget och pälslockarna på kraghörnen täcktes av rimfrost. Den höga månen svävade i en grön ring. Den sträva snön skimrade av glitter. Affischerna på väggarna var skarpa som på dagen. Petrov hade redan läst dem: utställningsmuseet "Vetenskapen" med avdelningarna gynekologi, mineralogi och Sacco och Vanzetti hade sänkt priserna.

Efter friseringen (som i sammanhanget kan ge konnotationer till en kyrklig tonsur, póstrig) flyter den höga månen likt ett väsen i det magiskt gröna ljusfenomenet. Den illuminerar det till innehållet inte entydigt röda men dock sekulära vetenskapliga museets affischer (det sovjetiska museet profaneras också med prissänkningen som själva budskapet). ${ }^{280}$

$\mathrm{Nu}$ är det affischerna som Petrov redan läst - liksom han inte läste utan bara bläddrade i handboken tidigare - och antytt av kolonet själv återger budskapet på. Det av honom i stunden upplevda är hur de står fram i månljuset, tydliga som på dagen, och bidrar till en känsla av betydelse i den vardagliga kontext de ingår i. I berättelsen förebådar de museets senare uppdykande. För Petrov är de bara något med en oklar känsla av betydelse på hans väg till, som vi nu får veta, ett möte med en kvinna. Det tycks vara främst för hennes skull han varit hos frisören - och med henne i åtanke som det bådade gott att han hann innan de stängde. Då det dock visar sig att denna kvinna inte som förväntat är hemma utan har begett sig till just detta museum, kan de månskensbelysta affischerna tas för ett uppenbart omen om detta även av Petrov - sett i efterhand. Petrov är uppenbart bara en nybörjare i spådomskonsten.

\footnotetext{
${ }^{280}$ Sacco och Vanzetti var två italienska anarkister som invandrat till USA. Dödsdomen emot dem för ett väpnat rån och mord I92I väckte omfattande protester världen över. Åtalet ansågs politiskt motiverat. Trots att nya uppgifter framkom som pekade mot andra gärningsmän vägrade domaren öppna fallet på nytt. Dödsstraffen verkställdes 1927. Femtio år senare blev de officiellt oskyldigförklarade.
} 
Tingens betydelsemättade lyster hittills har också indirekt antytt hans sinnesskärpande förkänslor inför det förestående mötet. Hans förväntningar blommar nu ut i en inre både realistisk och drömmande föreställning om hur det kommer att te sig. Han tycks tolka det ointresse hon vanligen visar som koketteri:

Маргарита Титовна жила недалеко. Петров смеялся. Как всегда, она шмыгнет в другую комнату, мать будет ее звать, она придет, зевая и раскачиваясь, и состроит кислую гримасу. Не смущаясь, он задержит ее руку, повернет ладонью вверх, прочтет, что было и что будет, кого надо избегать. Она заслушается... - Маргарита Титовна, - пел мысленно Петров, ликуя и покачивая станом.

Margarita Titovna bodde i närheten. Petrov skrattade. Som vanligt skulle hon slinka ut i det andra rummet, hennes mor skulle kalla på henne och så skulle hon komma ut, vaggande och gäspande, och göra en sur grimas. Utan att bli förlägen skulle han ta hennes arm, vända handflatan uppåt och läsa vad som varit och vad som väntade, och vem som borde undvikas. Hon skulle börja lyssna uppmärksamt... - Margarita Titovna, sjöng Petrov jublande i tanken och gungade lite med kroppen.

Namnet Margarita - den ryska formen av Margarete, Gretchen, i Goethes Faust - spelar i samma ockulta register som Petrovs studier i kiromanti med vilka han tycks tro sig kunna vinna hennes hjärta. Margaritas undvikande av honom, som hans tanke på hur det brukar vara trots allt inte slätar över, hamnar i bakgrunden för den berusande föreställningen om hur han ska imponera på henne med sina kiromantiska färdigheter. Denna hybrisartade hoppfullhet inför mötet störs nu av en ny tillfällighet som han försöker läsa som ett tecken - två unga män och deras förlupna ord springer likt en svart katt över vägen:

Громко разговаривая, пробежали под руку два друга в финских шапках. - Я ей сделал оскорбительное предложение, - услыхал Петров, - она не согласилась. - Он задумался: она не согласилась - предзнаменование, пожалуй, неблагоприятное.

Högljutt samtalande sprang i armkrok två vänner i finnmössor förbi. - Jag gav henne ett oanständigt erbjudande, hörde Petrov, hon avböjde. Han blev tankfull: hon avböjde - det var nog inget gynnsamt omen.

Liksom i hans föreställning om samvaron med Margarita tycks han genom sin upptagenhet vid att tyda detaljer som tecken för något annat, något dolt, något kommande, fast i sin pseudovetenskapliga logik och frånvarande från verkligheten. Då blir det också svårt att möta någon som ett du i Bubers mening. Margarita är där i hans föreställningar med sitt sätt och sin hand att 
tyda - men inte som en människa han försöker lära känna. Han blir ensam genom dessa föreställningar. Att männen betecknas som vänner markerar också deras gemenskap som något Petrov tycks fjärran från i sitt liv upptagen som han är av att söka dolda betydelser i det snarare än att leva det.

"I pravda" ("Och sannerligen"), tar nästa stycke vid i ett inre bekräftande av att hans tolkning av männens ord som ett illavarslande förebud var riktigt. Den demonstrativa tonen, det obetydliga i vad som förutsågs samt trivialiteterna i det följande mötet med Margaritas mor drar ett ironiskt löje över honom som siare på samma gång som det öppnar honom lite som människa. Det är den enda i nuet gestaltade relation, det enda möte i novellen som han faktiskt upplever:

И правда: Маргариты Титовны не оказалось дома. - У музей ушодчи, посочувствовала мать. - Ко всенощной теперь не мода, - посмеялась она. - Да, - вздохнул Петров. - Мышь одолела, - занимала его мать беседой: Я на крюк в ловушке насадила сало: уж теперь поймается. - Поймается, похохотал Петров.

Och sannerligen: Margarita Titovna befann sig inte hemma. - Slank till museet, sade hennes mor medkännande. Kvällsmässan är int på modet mer, skrattade hon. - Nej, suckade Petrov. - Musen överlistade mig, uppehöll modern honom med ett samtal: Jag har agnat kroken i fällan med ister: nu ska hon väl fastna. - Hon kommer att fastna, skrockade Petrov.

Skildringen av Petrov ironiserar över hans tro på att kunna läsa och förutspå något $\mathrm{i}$ verklighetens tillfälligheter. I det från det pågående varat avskilda verket har däremot varje detalj såväl som Petrovs uppmärksamhet för möjliga förebud inför mötet byggt upp den vardagliga dramatiken. Moderns i själva verket troligen helt triviala kallprat blir även det, inom den konstnärligt avgränsade helheten, betydande som en antydande och framåtpekande parallell till Petrovs jakt efter hans dotter. Om Petrov också läser in en dold innebörd i denna ordväxling får vi inte veta - vi får överhuvudtaget inte veta något mer om hans tankar efter detta.

Moderns kärleksfulla sarkasm över att dottern gått till det sekulära museet av bara den anledningen att det inte "längre är på modet" att gå till kyrkan, fortsätter gestaltningen av den ytliga nyckfullhet hos dottern som vi tidigare upplevde genom Petrovs inre föreställning om deras möte. Något av ett flyktigt men ändå själsligt samförstånd med Petrov kommer till uttryck som hans möten med dottern aldrig tycks kunna komma att ge. Noteringen av de inte längre ljudande kyrkklockorna och den närmast religiösa högtidligheten i hans kiromantiska studier antyder också ett samförstånd i att andliga värden hotas av sådant som det "vetenskapliga" museets sekulära kompott, något Petrovs suckande ja här antyder. Samtidigt har Petrov 
också övergett kyrkan för en andlighet som är mer på modet, och modern säger detta med ett skratt. Här ges inget svar om vad som är rätt. Den allvarliga pliktkänsla som kiromantin uppfyllt Petrov med tycks skingras i detta mänskliga möte. Han skrattar åt den helt triviala berättelsen om musen.

Dubbelheten i att det som huvudpersonen försöker utläsa en bestämd betydelse ur framställs som obetydligt och tillfälligt i den skildrade verkligheten samtidigt som det som material i det avgränsade och formade konstverket ofrånkomligt får betydelse, den dubbelheten kan här ses speglad $\mathrm{i}$ huvudpersonens mötesproblematik. Präglad av sitt kiromantiska intresse har han visat sig försöka uttyda verkligheten som ett format verk. Det som dröjer sig kvar i berättelsen, i de få okommenterade intryck som följer, kan uppfattas som helt enkelt hans fortsatta försök i den riktningen. Eller har detta triviala, liksom avväpnande möte med modern fört med sig en förändring? Han kan nu för en stund tyckas ha gett upp sina försök att utläsa förebud och bara uppleva en närvaro, en känsla av något betydelsefullt i själva tillstånden i den vardagliga tillvaron. Detta kan fortsatt ses som något hans konstnärligt färgade sökande bidrar till att frambringa, men med den väsentliga skillnaden att han nu inte längre - mer i likhet med sin författare söker efter en viss bestämd betydelse, att han inte längre försöker lösa verkligheten som en gåta.

De skarpa intrycken med de öde kyrkornas blickande mot månen när han ger sig ut i vintermörkret igen tar i vilket fall vid med en allmän längtan efter något annat, något mer betydelsefullt, innan han slutligen når det samtida sovjetiska museet med sin rödbelysta populärkultur. Efter några filmaffischers möjliga antydningar om det förestående mötet (en dotter tas om hand, en gorilla närmar sig en flicka) återknyter han med en ordnande handrörelse till både besöket hos frisören och handboken i kiromanti. Om inte annat kan kanske illusionen av honom som en siare fortsatt tjäna som ett lockbete när han nu ger sig in för att fånga sin sovjetiska Margarita:

Шаги визжали. Провода и ветви были белы.

Церкви с тусклыми окошками смотрели на луну.

Музей сиял. Прелестные картины, красные от красных фонарей, висели возле входа. Умерла болгарка, лежа на снегу, и полк солдат усыновляет ее дочь. Горилла, раздвигая лозы, подбирается к купающейся деве: «Похищение женщины». Петров шагнул за занавеску и протер очки. - Билет, - потребовал он, посучил усы и тронул бороду и хиромантию, выглядывавшую из кармана.

Stegen gnisslade. Ledningarna och grenarna var vita.

Kyrkorna tittade med sina dunkla små fönster mot månen.

Museet strålade. Lockande bilder, röda av röda lyktor, hängde vid ingången. En bulgariska låg död i snön och ett regemente soldater adopterade 
hennes dotter. En gorilla trängde undan vidjorna och smög fram mot en badande jungfru: "Kvinnorov". Petrov steg in bakom draperiet och torkade glasögonen. - En biljett, begärde han, tvinnade mustaschen och rörde vid skägget och vid kiromantin som kikade upp ur fickan. ${ }^{28 r}$

Till museets märkliga collage av gynekologi, mineralogi och politiska aktivister lägger så de två affischerna vid ingången (den senare troligen för den amerikanska stumfilmen Gorilla från 1927) krigsmotiv och skräckromantiska vilddjursscener i samma populärkulturella anda som spånfabrikens läsning av Tarzan och andra aktiviteter i "Konopatčikova". Liksom Petrovs kiromanti har visat sig komma till korta med att förklara sammanhangen $i$ hans liv tycks detta utställningsmuseum ha misslyckats med att åstadkomma ett på något sätt koherent montage utifrån den officiella ideologin som en konst att läsa samtiden. Det finns en komisk lättnad i detta misslyckande.

\section{"Požalujsta" ("För all del") - livets salt}

"Požalujsta" var som nämnt också en titel (föreslagen av Jurij Tynjanov) som Dobyčin övervägde för hela den andra novellsamlingen. ${ }^{282}$ För det sammanhang som ordet här avslutningsvis uttalas i passar översättningen "För all del" bäst, som ett uttryck för huvudpersonens resignation inför (snarare än försoning med) sin livssituation och vad som står till buds. Som namn på hela samlingen hade andra innebörder (som ett banalt "Varsågod", ett vädjande "Snälla" eller medgivande "Ja, tack") också aktualiserats.

Första tredjedelen av novellen upptas av att den kvinnliga huvudpersonen söker efter botemedel till ett sjukt djur: "Ветеринар взял два рубля" ("Veterinären tog två rubel"), lyder inledningsmeningen. ${ }^{283}$ När den medicin hon köper av veterinären inte hjälper följer hon ett råd hon får om att istället gå till en alternativmedicinsk gumma, en babka. På vägen till denna gumma och i ritualerna kring det salt hon får med sig därifrån framträder hon som person. Först ges en yttre beskrivning av henne när hon går ut genom grinden som också (i att hon går lite böjd) antyder något betryckt: "в платке, засунув руки в обшлага, согнувшись, низенькая, в длинной юбке, в валенках" ("i en sjal, med händerna instoppade i ärmarna, böjd, liten och kort i lång kjol och filtstövlar"). De yttre konstaterande beskrivningarna av omgivning som följer framställer samtidigt hennes intryck och medvetande. En väderangivelse ger en antydan om hennes känsloliv:

\footnotetext{
28I Troligen står den stora katedralen i Brjansk som hade gjorts om till biograf men också inhyste ett antireligiöst museum som förebild. E். S. Golubeva, Pisatel' Leonid Dobyčin i Brjansk, Brjansk 2005, 80-8I.

${ }^{282}$ Till Ida Slonimskaja I juni 1930 (brev II8), PSSP, 303.

${ }^{283}$ Novellen citeras ur PSSP, 90-91.
} 
"Предчувствовалась оттепель." ("Det kändes att ett töväder var på väg.") Efter en beskrivning av det framväxande sovjetiska samhället med fabriker och nya hus och stolta promenerande ingenjörer görs det också explicit att huvudpersonen, Seleznëva, upplever och tolkar detta:

Дымили трубы фабрик. Новые дома стояли - с круглыми углами. Инженеры с острыми бородками и в шапках со значками, гордые, прогуливались. Селезнева сторонилась и, остановясь, смотрела на них: ей платили сорок рублей в месяц, им - рассказывали, что шестьсот.

Fabrikernas skorstenar rykte. De nya husen stod där med rundade hörn. Ingenjörer med spetsiga skägg och mössor med märken, stolta, promenerade. Seleznjova drog sig undan och stannade och tittade på dem: henne betalade man fyrtio rubel i månaden, dem - sex hundra, sades det.

I anmärkningen som uttrycker förtret över hur lite hon tjänar i förhållande till ingenjörerna finns också en återkoppling till inledningens angivna priser för veterinären (två rubel) och medicinen (sju grivna, dvs. o,7 rubel).

När hon nu framträtt som ett reflekterande subjekt och därmed medskapare i gestaltningen blir miljöbeskrivningens detaljer mer uppenbart talande för hennes tankar och känslor:

Репейники торчали из-под снега. Серые заборы нависали. - Тетка, эй, - кричали мальчуганы и катились на салазках по́д ноги. $[\ldots]$

Дворы внизу, с тропинками и яблонями, и луга и лес вдали видны были.

Kardborrarna stack upp ur snön. De grå staketen hängde. - Tanten, hoj, skrek några ungar och for förbi på kälkar framför fötterna.

Gårdarna därnere syntes, med stigar och äppelträd, och ängarna och skogen i fjärran. [...]

Det finns något dystert, oordnat och förfallet här i utkanten av staden. Hon kallas tant av barnen, fast hon troligen inte är så gammal, och hon är i vägen för dem, vilket samstämmer med den känsla av att inte passa in i det nya som fortsättningsvis gestaltas. Det finns samtidigt en närvaro i vad som ses, i utsikten, vad som är synligt. Det finns något i sig betydelsefullt i intrycken på vägen till gumman. Hon är här upplevande i stunden utanför ideologiska betydelseladdningar.

Den gumma hon gått till och hennes ockulta attribut trivialiseras genom den vardagliga inramningen och konkreta beskrivningen:

[...] У бабкиных ворот валялись головешки. Селезнева позвонила. Бабка, с темными кудряшками на лбу, пришитыми к платочку, и в шинели, отворила ей. 
[...] Utanför gummans port låg några förkolnade vedträn. Seleznjova ringde på. Gumman, med mörka lockar i pannan som var fastsydda i sjalen och med kappa på sig, öppnade åt henne.

Gummans ritualer härefter framstår snarast komiska. Ett liknande ironiskt förhållningssätt som till spådomskonsten i "Kiromanti" kan anas. Samtidigt finns på samma sätt som där något i proceduren och orden omkring det som möjligen, som nämnt $\mathrm{i}$ inledningen, kan läsas metapoetiskt, som en ironisk spegel för Dobyčins egen konst:

- Смотрите на ту сосенку, - сказала бабка, - и не думайте. - Сосна синелась, высунувшись над полоской леса. Бабка бормотала. Музыка играла на катке. - Вот соль, - толкнула Селезневу бабка[...]

- Titta på den där tallen, sade gumman, och tänk inte. Tallen stack upp över skogsranden och blånade. Gumman muttrade. Musiken spelade vid skridskobanan. Det här är saltet, sade gumman och knuffade till Seleznjova[...]

Titta och tänk inte, då framträder livet och en musik hörs. När gumman efter sitt muttrande åter börjar tala låter uppskjutandet av fortsättningen på repliken först antyda en överförd bemärkelse i orden, likt en slutsats om det föregående: "Vot sol"' ("Det här är saltet") i betydelsen "det är vad det handlar om, poängen, kärnan, det väsentliga". Den existentiella och metapoetiska antydningen förflyktigas dock genast av fortsättningen: "- Вот соль, толкнула Селезневу бабка: - вы подсыпьте ей..." ("Det här är saltet, sade gumman och knuffade till Seleznjova: strö i lite åt henne...") Samtidigt kan just denna konkretisering, detta upplösande av det symboliska, "prosaiseringen" av detta salt ses som en vidare demonstration, ett praktiserande av en i den konkreta vardagliga tillvaron förankrad konst och livssyn: titta och tänk inte.

Det betydelsefulla är inget avskilt, inget bestämbart som en etisk sanning om livet. Något betydelsefullt genomsyrar den vardagliga verkligheten i sin fysiska påtaglighet och levande konkretion. Det kan bara gestaltas genom denna tillvaros specifika enskildheter - ord, gester och yttre detaljer såsom upplevda i den här världen, i de liv och skeden som skildras, som en tillvarons förunderlighet bortom andliga, existentiella eller ideologiska anspråk.

De tre punkterna leder utan förklarande övergång över till att saltet får sin tillämpning. Det är Seleznëvas get som är sjuk. Denna punkterar nu den berättelse som hittills byggts upp, sökandet efter ett botemedel åt henne, genom att helt rata den dryck som saltet, får man anta, lösts ut i. Hon får 
inte ens i sig medicinen: "Коза нагнулась над питьем и отвернулась от него. Понурясь, Селезнева вышла." ("Geten böjde sig över drycken och vände sig bort från den. Seleznjova gick ut med tungt huvud.")

Nästa tredjedel av berättelsen lämnar geten därhän. Istället skildras Seleznëva. Hennes betryckta uppsyn och upplevelser av en omgivande gråhet har framställt en stark medkänsla med getens öde. När hon nu kommer ut med hängande huvud från den sjuka geten framstår det rentav som att hon identifierar sig med denna. Även Seleznëva tycks i behov av något slags botemedel. Det är också just vad hennes nu uppdykande väninna verkar tycka sig komma med - i form av en ledig man som dessutom skulle kunna lösa hennes antydda ekonomiska bekymmer:

[...] - Вот вы где, - сказала гостья в самодельной шляпе, низенькая. Селезнева поздоровалась с ней. - Он придет смотреть вас, - объявила гостья. Я - советовала бы. Покойница была франтиха, у него все цело - полон дом вещей. - Подняв с земли фонарь, они пошли, обнявшись, медленно.

[...] - Där är ni ju, sade en kvinnlig gäst, liten och kort, i en egentillverkad hatt. Seleznjova hälsade på henne. - Han kommer och tittar på er, tillkännagav gästen. Jag - skulle råda er. Hon var en snobb den avlidna, allt är helt hos honom, huset är fullt med saker. De lyfte lyktan från marken, höll om varandra och gick långsamt iväg.

Mannen kommer så på visit. Han förhåller sig till huvudpersonen som ett objekt som han bemödar sig om att framstå i god dager inför, men inte om att lära känna. Han talar om våren i överförd bemärkelse och utför hela sitt frieri på ett indirekt, uppenbart enligt hans egen uppfattning delikat sätt:

Гость прибыл - в котиковой шапке и в коричневом пальто с барашковым воротником. - Я извиняюсь, - говорил он и, блестя глазами, ухмылялся в сивые усы. - Напротив, - отвечала Селезнева. Гостья наслаждалась, глядя.

- Время мчится, - удивился гость. - Весна не за горами. Мы уже разучиваем майский гимн.

- Сестры,

- посмотрев на Селезневу, неожиданно запел он, взмахивая ложкой. Гостья подтолкнула Селезневу, просияв.

- наденьте венчальные платья, путь свой усыпьте гирляндами роз.

- Братья,

- раскачнувшись, присоединилась гостья и мигнула Селезневой, чтобы и она не отставала: 
- раскройте друг другу объятья:

пройдены годы страданья и слез.

- Прекрасно, - ликовала гостья. - Чудные, правдивые слова. И вы поете превосходно. - Да, - кивала Селезнева. Гость не нравился ей. Песня ей казалась глупой. - До свиданья, - распростились наконец.

Den manliga gästen anlände - i sälskinnsmössa och brun rock med fårpälskrage. - Jag ber om ursäkt, sade han, glänste med ögonen och log förnöjt i de grå mustascherna. - Tvärtom, svarade Seleznjova. Den kvinnliga gästen tittade på henne och njöt.

- Tiden rusar iväg, sade den manliga gästen förundrat. Våren är inte långt borta. Vi övar redan på majhymnen.

- Systrar,

började han oväntat sjunga viftande med skeden efter att ha tittat på Seleznjova. Den kvinnliga gästen sken upp och knuffade på Seleznjova.

i klänning till bröllopet kläd er, strö eder väg så med rosengirland.

- Bröder,

anslöt vaggande den kvinnliga gästen och blinkade åt Seleznjova så att hon också skulle stämma in:

bred famnarna ut för varandra:

förbi är nu åren av tårar och nöd.

- Så vackert, jublade den kvinnliga gästen. Underbara och sanna ord. Och ni sjunger fantastiskt. - Ja, nickade Seleznjova. Hon tyckte inte om den manliga gästen. Sången fann hon fånig. - På återseende, sade de till avsked till slut.

Det ska visa sig att djurdetaljerna i hans kläder - mössan av sälskinn och fårpälskragen - inte är tillfälliga, utan är hämtade, åtminstone mössan, från den avlidna hustruns kläder (hennes muffar). Därigenom understryks vad pälsen och kanske också mustascherna möjligen kan påminna huvudpersonen om: nämligen geten som hon i sin tur obekymrat övergett och som medan detta har utspelat sig ska visa sig ha legat för döden. ${ }^{284}$

Efter denna tillgjorda romantik som Seleznëva inte visar sig mottaglig för, som hon vänder sig bort ifrån såsom hennes get vänt sig bort från gummans salt, följer morgonen, med ett helt annat slags intensitet i stämningen, med ett annat slags lyrik och musik än den sentimentala sångens. Känslan

284 Även i huvudpersonens namn döljer sig en djurreferens: "selezen”" betyder "andhane". 
inför getens öde framstår så som djupare och mer väsentlig än det som denna mänskliga samvaro gav henne:

Набросив кацавейку, Селезнева выбежала. Мокрым пахло. Музыка неслась издалека. Коза не заблеяла, когда загремел замок. Она, не шевелясь, лежала на соломе.

Рассвело. С крыш капало. Не нужно было нести пить. [...]

Seleznjova kastade på sig en vadderad väst och sprang ut. Det luktade vått. Det kom musik långt bortifrån. Geten bräkte inte när låset skramlade till. Hon låg orörlig på halmen. $[\ldots]$

Det grydde. Det droppade från taken. Man behövde inte gå och ge vatten.

I den sista delen av berättelsen ordnar Seleznëva med begravningen av geten innan hon går till kontoret. Hon lejer en man från marknaden för att forsla bort geten. Återigen antyds likheten mellan henne och geten när några pojkar ropar "dochlaja koza" ("död get" som också kan tolkas som "svag eller sjuklig get") efter vagnen (vilket återkopplar till hur hon i början blev kallade tant av några andra pojkar). Hon är nu ensam och åter böjd när hon hemma igen börjar räfsa ut ströet efter geten.

I denna belägenhet dyker gästen från gårdagen plötsligt upp igen. $\mathrm{Nu}$ presenteras informationen om att hans mössa, möjligen som något Seleznëva nu inser eller minns sig ha hört, är från hans fru. Hans sätt att gå vidare i livet, liksom att låta sy om den avlidnas kläder, stämmer överens med det obekymrade och okänsligt överspelade i hans försök till medkänsla med den döda geten:

- Здравствуйте, - внезапно оказался сзади вчерашний гость. Он ухмылялся, в котиковой шапке из покойницыной муфты, и блестел глазами. Его щеки лоснились. - Ворота у вас настежь, - говорил он, - в школу рановато, дай-ка, думаю. - Поставив грабли, Селезнева показала на пустую загородку. Он вздохнул учтиво. - Плачу и рыдаю, - начал напевать он, едва вижу смерть. - [...]

- Goddag, sade plötsligt gästen från igår som dykt upp bakom henne. Han log förnöjt, i sälskinnsmössan av den avlidnas muff, och glänste med ögonen. Hans kinder blänkte. Porten stod på vid gavel hos er, sade han, och det var lite tidigt till skolan så varför inte, tänkte jag. När hon ställt ifrån sig krattan pekade Seleznjova på den tomma inhägnaden. Han suckade artigt. - Jag gråter och förtvivlar, började han sjunga begravningsversen, när jag blir varse döden. [...]

Hans självupptagna frånvaro i mötet med henne (möjligen som en yrkesmässig åkomma - efter det nämnda inlärandet av majhymnen får vi nu tydligt besked om att han är lärare) kontrasteras av hennes sinnliga närvaro 
som de fysiska detaljerna talar för efter att hon visat mot den tomma inhägnaden som enda svar. Hon vidrör, ser, känner, hör - väggen, dropparna, kråkans kraxande. Det är ett slags tystnad som inte han förstår sig på eller vet hur han ska hantera. Så han fortsätter obekymrat på samma resultatinriktade sätt varpå Seleznëvas enda ord i detta möte följer:

[...] Потупясь, Селезнева прикасалась пальцами к стене сарая и смотрела на них. Капли падали на рукава. Ворона каркнула. - Ну, что же, - оттопырил гость усы: - Не буду вас задерживать. Я, вот, хочу прислать к вам женщину: поговорить. - Пожалуйста, - сказала Селезнева.

[...] Seleznjova sänkte huvudet och rörde vid uthusväggen med fingrarna och såg på dem. Det föll droppar på ärmarna. En kråka kraxade. - Men men, sade gästen och putade med mustaschen: Jag ska inte uppehålla er. Jag, så här är det, jag vill skicka en kvinna till er, för att prata lite. - För all del, sade Seleznjova.

"För all del", för att denne man, som hon inte tycker om, är vad som bjuds? För att hon nu med getens död är än mer ensam och inser att hon måste försöka leva med det som ges, svälja den medicin som hennes väninna bjudit henne, för att inte själv också gå under? Samtidigt lovar hon ingenting med sitt "požalujsta". Hennes sinnliga närvaro, hur hon rör vid väggen och ser på sina fingrar, har visat på en känslosam skörhet men också en motståndskraft.

\section{Samtidens mörknande trädgård, en ostädad sång}

Novellen "Sad" ("Trädgården"), som är ungefär dubbelt som lång som de föregående kortnovellerna (av liknande längd som den vid samma tid tillkomna inledningsnovellen "Proščanie") men fortfarande koncentrerad till en dag och en mötesliknande upplevelse av något betydelsefullt, föregår och bygger upp för den avslutande längre titelnovellen i samlingen Portret.

Huvudpersonen i "Sad" är städerska. Denna i berättelsen också markerade låga sociala status skiljer henne från huvudpersonerna i övriga noveller. Men hon framställs inte som enfaldig i sin enkelhet. Med en folklig otvungenhet framstår hon snarast mer självständig i förhållande till det sociala spelet, som orädd och oförvägen trots att politiskt färgade anklagelser riktats mot hennes sätt att vara. Genom att hon inte låter sig hämmas blir varken mötesproblematiken eller den med denna sammanhängande frågan om att bevara sig själv, sina drömmar och sin personliga frihet i det nya samhället direkt grundläggande för intrigen. 
I sin ofta narraktigt och förnöjsamt observerande roll och genom det spontana konstnärliga uttryck som detta observerande leder fram till kommer huvudpersonen att påminna om sin författare. Novellens samlade trädgård av vardagliga händelsekedjor som ett uttryck för denna samtid speglas på så sätt, lätt självironiskt, i det kondensat som huvudpersonen i sin tur når fram till i sitt eget konstutövande. Det som utvecklar mötesproblematiken är att den livsförankrade konst hon ger prov på och det frihetliga, mänskliga sammanhang som hon är en del av, här utgör något bestående, något betydelsefullt som faktiskt ännu kan äga rum i denna sovjetiska tillvaro i det sena tjugotalet. Huvudpersonen upptas inte av en längtan efter en annan tillvaro. Däremot framställs genom hennes liv de mänskliga mötena och de fria uttrycken i samtiden som hotade av en ögontjänande politisk rödhet med nya titlar, strikta hierarkier och angivelser mot oliktänkande som ett sätt att vinna förmåner. Denna tilltagande korrekthet är något det framställs som att man allmänt anpassar sig till med de mänskliga mötena som pris.

I de inledande två styckena beskrivs hur delegaterna från en kongress kopplar av i den stadsträdgård som utgör centrum för novellen. De manliga och kvinnliga delegaterna beskrivs i tur och ordning. Ord som "blaženstvovali" ("fröjdades") om männen och "rastrogannye" ("rörda") om kvinnorna bidrar till att milt ironiskt framställa dem som borgerligt konventionella trots den "rödhet" som det politiska sammanhang de ingår i talar för:

Делегаты окружного съезда союза медсантруд сидели на скамейке и беседовали о политике. Дорожные корзиночки стояли между ними. Утреннее солнце грело. Развалясь, они вытягивали ноги и блаженствовали.

Улыбаясь, делегатки медленно ходили вокруг клумб. Они смотрели на цветы, склоняя набок головы. - А в будущем году еще прекрасней будет, - говорил садовник Чау-Дин-Ши. Растроганные делегатки окружили его. - Можете пустить фонтан? - просили они. ${ }^{285}$

Delegater från regionkongressen för medicin- och sanitetsarbetarförbundet satt på en bänk och samtalade om politik. Små resekorgar stod emellan dem. Morgonsolen värmde. De lutade sig bakåt, sträckte på benen och fröjdades.

Leende gick några kvinnodelegater långsamt runt rabatterna. De tittade på blommorna och lade huvudena på sned. - Och nästa år blir det ännu vackrare, sade trädgårdsmästaren Chao-Din-Shi. Kvinnodelagaterna blev rörda och samlades runt honom. - Kan ni slå på fontänen? frågade de.

\footnotetext{
${ }^{285}$ Novellen citeras ur PSSP, 92-94. En kinesisk trädgårdsmästare med detta efternamn (med Evgenij Pavlovič som ryskt för- och fadersnamn) existerade verkligen i Brjansk. Ė. S. Golubeva, Pisatel' Leonid Dobyčin i Brjansk, Brjansk 2005, 92-93.
} 
Denna gestaltningens småleende blick på dem antyds så ha varit huvudpersonens när hon framträder i tredje stycket. Hennes kommentar - interjektionen "iš'” ("ajaj") - bekräftar också den erotiska anstrykningen i deras svärmande kring trädgårdsmästaren och vilja att han ska slå på fontänen:

\footnotetext{
Чернякова посмеялась, глядя на них. - Ишь, - сказала она. В красном галстуке, в кудряшках над морщинами, она сидела под акацией. - Господин китаец, что я вам скажу, - подозвала она. - Сегодня будем хоронить Таисию, уборщицыю: вы пожалуйте уже. - С огромным удовольствием, ответил Чау-Динши, и она встала и пожала ему руку. - Мы надеемся, простилась она и, сорвав травинку, повернулась и пошла, мурлыча.
}

Tjernjakova tittade på dem och skrattade. - Ajaj, sade hon. Hon satt under en akacia med en röd slips och lockar ovanför rynkorna. - Herr kines, jag ska säga er något, kallade hon honom till sig: Idag ska vi begrava vår Taisija, städerskan, det vore vackert om ni kom. - Med ofantligt nöje, svarade Chao Dinshi, och hon reste sig och tog hans hand. - Det hoppas vi, sade hon till avsked, slet loss ett grässtrå och vände sig om och gick hummande iväg.

Den kongress som delegaterna tar rast ifrån kommer att förlöpa i sina yttre manifestationer i bakgrunden som en sammanhållande händelseutveckling i takt med dagens gång. In i den, också anknutet till trädgården, flätar sig två händelsekedjor som huvudpersonen initierar.

Den första är denna begravning av en annan städerska, Taisija, som Černjakova nu har bjudit in den kinesiska trädgårdsmästaren till. Hon framträder med en folklig livfullhet i sitt sätt att tala. Böjningsformen "uborščicyju" istället för "uborščicu" är bara hennes första kreativt normbrytande i novellen (med den extra stavelsen bibehåller hon en tvåstavighet $\mathrm{i}$ rytmen som även utanför hennes repliker präglar gestaltningen; detta musikaliska språkbruk kommer hon snart också tydligare att demonstrera sin känsla för). Kinesen är mer karikerad med sin överdrivna artighet. Hennes vänskap med denna trädgårdsmästare - som hon förhåller sig till som en like - tycks ge henne en blick för hur han uppvaktas av andra.

Den andra händelsekedjan, som introduceras på hennes väg ut ur parken, är av mer tematisk art. Huvudpersonen har utan att vara medveten om det en av de två rollerna i denna; det är författaren som kontrasterar henne mot en ideologiskt renlärig men helt ooriginell poet. Förutom i det levande språkbruket har vi fått ett första yttre tecken på huvudpersonens konstnärliga ådra när hon rev av ett grässtrå och hummade. Med en obesvarad hälsning och fråga (och en egensinnig ändelse på poetens efternamn) flyttas så fokuset till den som författaren låter framträda som hennes rival, hennes motsats i både konstnärligt och politiskt avseende: 
Поэтесса Липец встретилась ей, и она остановилась и любезно поздоровалась: - Мое почтение, товарищ Липецковая, куда спешите?

Обмахнув скамейку, поэтесса Липец села и откинулась. В сегодняшней газете были напечатаны ее стихи:

гудками встречен день. Трудящиеся. ${ }^{286}$

- и она, под плеск фонтана, декламировала их. Чернякову ждали неприятности. Ей объявили, что ее уволят, если она будет принимать гостей. Она заголосила. - Это кучер доказал, - сказала она.

Hon mötte poetissan Lipets och stannade och hälsade älskvärt: - En sådan ära, kamrat Lipetskovaja, vart har ni så bråttom?

Poetissan Lipets borstade av bänken, satte sig och lutade sig bakåt. I dagens tidning var hennes dikter tryckta:

med visslors tjut är dagen hälsad. Arbetare.

- och hon deklamerade dem till plasket från fontänen. Obehagligheter väntade Tjernjakova. Man hade meddelat att hon skulle bli uppsagd om hon fortsatte att ta emot gäster. Hon hade jämrat sig. - Det är kusken som har anmält, sade hon.

Exemplet på poetissan Lipec duktiga diktning och deklamerande i stadsträdgården kontrasteras i samma stycke av den infogade informationen (som utvecklas sceniskt men inte äger rum i nuet) om anklagelser mot Černjakovas, hennes motparts, tillsynes friare livsföring. Kanske är dessa anklagelser (som Lipec kan ha reda på genom sin far som, ska det visa sig, arbetar på kansliet där Černjakova städar) anledningen till att hon inte besvarar hennes hälsning och fråga. En annan möjlig förklaring är att Lipec, trots den ideologi hon deklamerar, helt enkelt ser städerskan Černjakova som lägre stående och oviktig; en sådan borgerligt anstruken överlägsenhet hos poetissan kommer i vilket fall att göras tydlig längre fram.

Efter en blankrad - men med kuskens angivelser som övergång då just denne nu anländer med kistan - gestaltas begravningståget som Černjakova bjudit in trädgårdsmästaren till. I ett ovanligt långt stycke vävs en mängd olika saker - titlar och namn, precisa rörelser och intryck - samman till en enhetlig bild av en levande mångfald där själva företeelsen impressionistiskt framvisas. Den kinesiske trädgårdsmästaren ansluter också efter

\footnotetext{
${ }^{286}$ Som nämnt i samband med ångbåtsvisslan i "Otec" var fabriksvisslan ett frekvent motiv i proletärlitteraturen. Forskaren Eduard Mekš menar att Lipec dikt är en parafras på just dikten "Gudki" av proletkul'tideologen och -poeten Aleksandr Gastev som förvisso inleds likartat: "Когда гудят утренние гудки на рабочих окраинах, это вовсе не призыв к неволе. Это песня будущего." ("När fabriksvisslan ljuder på morgonen i arbetarförortena är det alls inte en kallelse till ofrihet. Det är framtidens sång.") Ėduard Mekš, "Chudožestvennyj mir rasskaza L. Dobyčina 'Sad'”, $P L D, 267-272$, 271.
} 
att först ha kört ut besökarna ur sin trädgård med en liten klocka. Den samfällda rörelsen och livet i begravningstågets vardagliga manifestation är vad den döda ges av vördnad och åminnelse. Inga tankar om vare sig den avlidna Taisija eller om döden i allmänhet uttrycks. Alla visar sig upptagna av det direkt förestående när nu jordfästningen, i kontrast till en ändå närvaroskapande utförlighet i begravningstågets rörelse, snabbt avklaras och samlingen upplöses för den gratismåltid som utlovats:

Таисию засыпали. Вскочив на дроги, кучер укатил. Девицы побежали. Секретарь союза медсантруд дал им по делегатскому талону на обед в столовой - надо было захватить места, пока не набрались сезонники. Пенсионерка Закс, попрыгивая, шла с китайцем. Чернякова возвращалась с профуполномоченным.

- Товарищ профуполномоченный, - учтиво говорила она, - на меня доказывают, но подумайте, какая моя ставка: двадцать семь рублей.

De strödde över Taisija. Kusken hoppade upp på likvagnen och rullade iväg. Flickorna sprang. Sekreteraren för medicin- och sanitetsarbetarförbundet hade gett dem varsin delegatskupong för lunch på serveringen - det gällde att ta en plats innan säsongsarbetarna anstormade. Pensionären Zaks gick skuttande bredvid kinesen. Tjernjakova återvände med fackföreningsombudet.

- Kamrat fackföreningsombud, sade hon artigt, man kommer med anklagelser mot mig, men tänk på vad jag har för lön: tjugosju rubel.

Denna abrupthet, och de krassa motiven för skyndsamheten, uttrycker möjligen en smärta i den bortgångnas obetydlighet för de efterlevande, i livets flyktighet. Men det är inget som det talas om i berättelsen. Alla upptas av något annat: flickorna av att hinna få en plats på serveringen, den kvinnliga pensionären av att umgås med den intressante kinesen och Černjakova tar tillfället i akt att ta upp anklagelserna som riktats mot henne med den överordnade som hon gått tillsammans med i tåget.

Men vad är det hon har gjort sig skyldig till? Den tyske översättaren Peter Urban anför utan tvekan i sina kommentarer till novellen att Černjakova prostituerar sig. Till intäkt för detta tar han hennes utseende, med slips och troligen lösa lockar, samt att hon uppmanats att sluta ta emot gäster. Hennes ursäkt här kan då betraktas som ett indirekt erkännande - hon är tvungen att på något sätt dryga ut sin låga lön som städerska. Det samkväm på kvällen som novellen leder fram till, under vilket hon framträder med en typiskt rysk folklig visa, en så kallad tjastusjka, som hon själv diktat utifrån en upplevelse under dagen, antyder dock inget i den riktningen. De vänner hon umgås med framstår däremot som likasinnade i en glad och frihetlig otvungenhet. Kanske är det dessa som hon mottagit som gäster och som 
kusken med viss rätt fattat misstankar om som en mot den sovjetiska ordningen oppositionell samling. Denna tolkning styrks av den efterlämnade novellen "Mater'jal" där huvudpersonen avser att ange sin granne för ett liknande samkväm med gäster utifrån deras tillsynes oskyldiga lättsamma skämtande om den sovjetiska ordningen. Hennes låga lön kan i vilket fall ses som en anledning att ha förbarmande med henne. ${ }^{287}$ Den ställer henne härefter också, utan att vi får veta vad fackföreningsombudet anser om detta, åter indirekt i opposition mot poetissan Lipec, vars far som är ingenjör dröjer sig kvar på kontoret $\mathrm{i}$ hopp om att få löneökning; det vill säga med ett liknande ögontjänande ideologiskt hyckleri som i dotterns dikt. Den återkommer nu när han i sken av att arbeta fördriver tiden med att njuta av publiceringen av dikten i tidningen invid ett porträtt och en artikel av honom själv. När den redan i sig styltiga diktraden nu åter hörs i texten är det så med ironisk dissonans till den sköna nya verklighet som den ger sig ut för att gestalta:

В окрэспеэс уже никого не было. Один отсекр окрэмбеит, товарищ Липец, инженер-электротехник, еще сидел. Он подал заявление о прибавке и начал каждый день задерживаться. Он держал газету: был его портрет, его статейка и стихотворение его дочери:

гудками встречен день. Трудящиеся.

På regionrådet var det ingen kvar längre. Endast ansvarig sekreterare för regionala sektionssamordningsbyrån för ingenjörer och tekniker, kamrat Lipets, elektroingenjör, satt på sin plats. Han hade lämnat in en ansökan om löneförhöjning och börjat dröja sig kvar varje dag. Han höll i tidningen: hans porträtt var där, hans lilla artikel och dikten av hans dotter:

med visslors tjut är dagen hälsad. Arbetare.

Černjakova väntar med städningen till senare, men stänger till och ber, respektfullt men inte underdånigt, liksom inför dottern tidigare, ingenjör Lipec att hänga in nyckeln när han går. Nu skyndar hon efter de andra till serveringen för att hinna få sin gratismåltid innan de säsongsarbetande bönderna kommer stormande.

Hon möter de tidigare med sina titlar presenterade deltagarna i begravningståget på vägen. De framträder nu som människor, sjavigt kroppsliga i mättnaden efter gratismåltiden. På serveringen torkar Černjakova av läpparna med slipsen, liksom i en markerande opposition till de andras fina

\footnotetext{
${ }^{287} 27$ rubel kan jämföras med att Seleznëva i "Požalujsta" beklagade sig över sin lön på 40 rubel medan hon påstod att ingenjörer (som poeten Lipec far) tjänade 600 rubel. Inte konstigt att den nya ekonomiska politiken ifrågasattes som en väg till socialism.
} 
sätt att äta - en finess som samtidigt också förtas av omständigheterna, av flugorna de måste jaga undan. Oavsett sin samhällsstatus enligt den nya hierarkin skymtar alla fram som banala människor. Till denna profanerande prosaiska poesi bidrar också några helt alldagliga verklighetsförankrade detaljer. Det finns speglar på väggarna men inget yttre perspektiv, ingen utsaga om den här världen annat än vad gestaltningen frambringar genom paralleller och speglingar i en stadig rytm som laddar denna vardagliga tillvaro som något betydelsefullt. Namnet på en ort, Novozybkov, som ligger i närheten av Brjansk, står "inpräntat" ("vyvedeno") på några träbyttor med palmer. I slutet av novellen återkommer ordet när Černjakova sjungande "präntar in" sitt uttryck för denna tillvaro med en fras hämtad från det kärleksmöte hon här blir vittne till:

Было жарко. Тротуар размяк. Телеги, подвозившие кирпич к постройкам, громыхали. Регистраторша, курьерша, машинистки Закушняк и Полуектова уже поели и плелись распаренные, ковыряя языком в зубах. Они перемигнулись с Черняковой. - Хорошо? - спросила она и заторопилась. Образованные люди чинно ели, отставляя пальцы и гоняя мух. На кадках пальм было выведено «Новозыбков». На стенах висели зеркала. Напротив Черняковой интересный кавалер любезничал с девицей. - Вы и сами лимонады, - наливая ей стаканчик, говорил он, - только красненькие. Неужели я такая красненькая? - удивлялась она. - Ишь ты, - посмеялась Чернякова и, доев, утерла губы галстуком и вышла, повторяя этот разговор.

Det var hett. Trottoaren hade mjuknat. Kärrorna som fraktade tegelsten till byggena bullrade. Registratorn, kuriren och maskinskriverskorna Zakusjnjak och Polujektova hade redan ätit och släpade sig svettiga därifrån pillande med tungan mellan tänderna. De utväxlade blinkningar med Tjernjakova. Bra? frågade hon och skyndade på. Bildat folk åt med värdighet, höll undan fingrarna och jagade bort flugorna. På byttorna till palmerna var "Novozybkov" inpräntat. På väggarna hängde speglar. Mitt emot Tjernjakova satt en tilldragande kavaljer och var älskvärd med en flicka. - Ni är själv som lemonader, sade han när han hällde i hennes glas, fast som röda sådana. - Är jag verkligen så röd? sade hon häpet. - Ajaj du, skrattade Tjernjakova och torkade sig om läpparna med slipsen när hon ätit upp och gick ut medan hon upprepade samtalet för sig själv.

Den lekfulla mångtydigheten i kavaljerens ord och hur flickan fångar upp det som en komplimang utan att beröva det röda sin antydan om både något politiskt och kroppsligt närgånget, vilket de söta safterna bidrar till, - det tycks vara något som fascinerar Černjakova. Hon bär med sig detta brottstycke av ett flörtande pars möte bortom orden efter att ha kommenterat det med en variant av samma interjektion som hon använde om kvinnodelegaternas svärmande antydningar till Chao Din-shi i inledningen. 
Och tillbaka på kontoret för att städa öppnar hon först fönstren för en inspirerande vind och landskapsvy med frigjort nakna pojkar vid floden. Liksom fortsatt oviss om innebörden, liksom lekfullt kännande på den öppna betydelsen, smakande på orden, så uttalar hon för sig själv ett kondensat av kavaljerens ord och ler och skrattar åt det liv det uppväcker: "Чернякова подоткнула юбку, засучила рукава и начала уборку. - Вы такие красненькие, - говорила она, делала приятную улыбку и смеялась." ("Tjernjakova fäste upp kjolen, kavlade upp ärmarna och började med städningen. - Sådana där röda ni är, sade hon, log ett vänligt leende och skrattade.") Så har huvudpersonen egentligen redan funnit något betydelsefullt i den vardagliga tillvaron som ett uttryck för sin situation och sin samtid, samt därmed indirekt demonstrerat en konstnärlig metod som tycks ligga författaren av novellen nära.

Hon yttrar detta i den nu tomma röda kontorsmiljön - efter den av poetissan Lipec hyllade arbetsdagen - vars dikt hennes far där tidigare med sin lemonadaktigt, inställsamt klibbiga rödhet anknöt till. De uppsnappade vardagliga orden som Černjakova bringar till vidare betydelse, i ett vardagligt skapande som tycks skänka en stundlig lättnad, ställs så också antydningsvis mot Lipec i denna miljö upprepade ideologiska schablon som gav exempel på den konst som premieras i denna samtid. Černjakovas leende och skratt kan så uppfattas som riktat mot den sovjetiska tillvarons och den pågående samhällsomvandlingens förunderliga enfald. "Vy takie krasnen'kie" ("Sådana där röda ni är") kan också tänkas anspela på alla dessa så kallat röda ingenjörer, maskinskriverskor, fackombud, kurirer och registratorer - som hon städar efter för sina futtiga tjugosju rubel.

Den sista tredjedelen av novellen utvecklar sig härefter i fyra längre stycken. Den mångtydigt citerade frasen under städningen framstår som ett slags lyrisk och tematisk peripeti för novellen. Det som följer är först med skymningen och sedan med månskenet som stämningsskapare mest upprepningar och variationer av det föregående. Det mättar intrycken och samlar händelsekedjorna till en avslutning där de två poetiska nyckelfraserna, Černjakovas respektive poetissan Lipec, tydligt ställs mot varandra som en livets poesi kontra den officiella ideologins. I detta manifesterar novellen den konst som Černjakova exemplifierat. Den mänskliga kontexten profanerar den ideologiska diktningen. Den politiska kontexten får det oskyldigt vardagliga att framstå som själva tillvarons levande motspråk:

Перестали грохотать телеги. Конартдив, резерв милиции и ассенобоз по очереди проскакали к речке: подымалась пыль и затемняла солнце. Тусклое, оно спускалось к кепке памятника. Сад был полон. Женщины 
стояли у фонтана и бродили вокруг клумб. Мужчины, развалясь, в рубашках из «туаль-дю-нор», сидели. Волейбольщики скакали, отбивая головами мяч. Пенсионерка Закс ходила за китайцем.

Kärrorna slutade dundra. Ridande artilleridivisionen, reservmilisen och renhållningsvagnen skumpade förbi efter varandra mot floden: dammet rördes upp och fördunklade solen. Matt sänkte den sig ner mot kepsen på statyn. Trädgården var full. Kvinnorna stod invid fontänen och promenerade runt rabatterna. Männen satt tillbakalutade i skjortor av grovt toile du nord. Volleybollspelarna hoppade och nickade tillbaka bollen. Pensionären Zaks gick bakom kinesen.

Det skramlande samhällsbyggnadsarbetet tystnar för kvällen. De olika samhällsfunktionerna beger sig mot floden - kanske för att klä av sig och bada efter dagen som de människor de är. Det damm de rör upp leder associativt musikaliskt vidare, via den fördunklade solens sinnliggörande av en konkret detalj och därmed profanerande av vad som troligen är en staty av Lenin med kepsen i näven, ${ }^{288}$ till en avrundande gestaltning av den nu fulla trädgården där novellen tog sin början. Uppdelningen mellan männens och kvinnornas sysslor är densamma. Volleybollspelarna ger en ny rörelse åt folkvimlet. Det är kväll, man kopplar av, och det sociala liv som redan skildrats rörs åter upp till ett samspel som för berättelsen vidare. Zaks hörs nu tala med kinesen:

- Я воображаю, как вам скучно с нами, - говорила она. Чернякова подошла и слушала с участием. - Умерла́ Таисия, - сказала она, кашлянув. Побагровели облака и побледнели. Съезд союза медсантруд закрылся и запел «Вставай». Цветы запахли. Громкоговоритель закричал «Алло». Темно стало, присматривать за посетителями стало трудно. Чау-Дин-Ши прошелся с колокольчиком. Он запер на замок калитку и пошел к Прокопчику. Пенсионерка Закс и Чернякова провожали его. [...]

- Jag inser hur tråkigt ni måste ha det med oss, sade hon. Tjernjakova kom fram och lyssnade deltagande. - Taisija är död, sade hon med en hostning. Molnen purpurfärgades och bleknade. Medicin- och sanitetsförbundets regionkongress avslutades och stämde upp i "Upp trälar". Blommorna doftade. Högtalaren skrek "Hallå". Det blev mörkt, och svårt att hålla koll på besökarna. Chao-Din-Chi gick runt med klockan. Han stängde och låste grinden och gick iväg till Prokoptjik. Pensionären Zaks och Tjernjakova följde honom. [...]

Pensionären Zaks dras till kinesen vilket också beskrevs vid begravningen tidigare. Det liksom föranleder Černjakova att påminna dem om sin avlidna kollega och om än bara med sitt konstaterande uttrycka något av en sorg.

${ }^{288}$ Ė. S. Golubeva, Pisatel' Leonid Dobyčin i Brjansk, Brjansk 2005, 94. 
Det tas upp i himlens skiftning och i ljuden från den politiska kongress som nu som en inramning når sitt slut med sjungandet av "Internationalen" profanerat genom samspelet med den nu påtagligare blomdoften och ett förvirrat hallå ur en högtalare. Trädgården stängs för dagen på samma sätt som för begravningen. Det hade kunnat sluta här. Men så sätts en ny kurs ut med det plötsligt introducerade namnet Prokopčik. För dem i berättelsen tycks det ha en given innebörd. Präglad av deras inre perspektiv, gestaltad utifrån deras medvetanden snarare än berättad flyter novellen så vidare $\mathrm{i}$ en händelsekedja av intryck och korta repliker:
[...] Фонари покачивались тихо. Запах сена прилетал с лугов. В окне у оп- тика стояли гипсовые головы в очках, и в их глазах то загоралось электри- чество, то гасло. - Господин китаец, это красота, - сказала Чернякова. - Замечательные вещи, - согласился Чау-Дин-Ши. Пенсионерка Закс, насу- пившаяся, простилась. - Не подумайте, что я устала, - предостерегла она.
[...] Gatlyktorna vajade tyst. Det kom hölukt från ängarna. I fönstret hos opti- kern stod gipshuvuden med glasögon, och i deras ögon tändes och slocknade elektriciteten. - Herr kines, det är så vackert, sade Tjernjakova. - Fantastiska saker, höll Chao Din-shi med. Pensionären Zaks hade rynkat pannan och tog avsked. - Tro inte att jag är trött, varnade hon.

Hölukten kommer i kvällsbrisen från samma håll som den inspirerande vinden när Černjakova städade på kontoret, från ängarna längs floden som det även i tidigare noveller har blickats ut mot. Det är ditåt de är på väg när nu pensionären Zaks inte längre vill följa dem. Med sin rynkade panna tycks hon svartsjuk på Černjakovas och kinesens möte i denna rentav komiskt triviala skönhetsupplevelse. Möjligen antyder Zaks varnande intygande, att det inte är för att hon är för trött, samtidigt att det är något förbjudet de är på väg till. Černjakovas förundran inför den triviala kitschens konkreta skönhet stämmer in med hur hon fascinerades av de förlupna orden från paret på serveringen. Detta slags konstnärssinne är möjligen något en trädgårdsmästare kan känna sig befryndad med.

Antydningarna om en viss dold betydelse fortsätter men gäckar en samtidigt: Om dessa gipshuvuden med elektriska ögon symboliskt talar för en robotartad mänsklighet, exempelvis, skulle det då sägas vara vackert (eller mer ordagrant, likt en estetisk utsaga, att "det här är skönhet")? Ska man se dem, i stil med Černjakovas ordvrängande och skapande som ett metapoetiskt uttryck för författarens konst, som ett uppenbarande av något betydelsefullt i det banala? Även den trädgård som allt har kretsat kring kan på liknande sätt möjligen tolkas som en bild för novellens gestaltande av en upplevd mening genom konkreta sinnliga intryck; att detta skapande med samtidens material liknar ett trädgårdsmästeri. Dobyčins antydningar lösgör 
sig inte som symboler. Det är denna tillvaro det handlar om, dess möten bortom orden som framkallas.

Så framträder nu resten av novellen som något betydelsefullt i månskenet. Först är det Černjakova som med denna oklara samling vänner hos Prokopčikov framför den kvädeslika sång som vi sett henne utarbeta inom sig under dagen. Den stiger liksom upp ur de omgivande intrycken - med den sovjetiska akronymen för Černjakovas arbetsplats nu lyriskt blänkande på dess friluftsanläggning, med de fria, nakna badandet som den sovjetiska kulturen vill sätta stopp för, med eldar, skratt och brusande vatten. ${ }^{289}$ Sången, de förlupna orden som ett uttryck för denna tillvaro, är nu innehållsligt, sinnligt och rytmiskt framkallad. Den inleds med ett befriande svärande över kusken som angivit henne (troligen för att hon tagit emot just dessa fria andar hemma hos sig) och ackompanjeras av en profan vild klumpighet som Černjakovas tidigare utpekande attribut (läpparna och slipsen) tar del i (kanske är deras högljuddhet den enkla förklaring till varför kusken angivit henne):

Костры плотовщиков горели у реки. Луна всходила. Золотые буквы водной станции окрэспеэс блестели. Поздние купальщики плескались в темноте. Прокопчик сосал трубку. Он был рад гостям. - Мое почтение, приветливо здоровались они, - как поживаете? - и жали ему руку. - Прилетела культотдельша, - рассказал он, - требовала, чтобы все были в трусах. - Качали головами и смеялись. В городе горели огоньки. Вода журчала. - Кучер на меня доказывает, сукин сын, - пожаловалась Чернякова. - Эx, - сказала она, заиграла на губах и завертелась, грохоча. Мужчины ей подтопывали. Галстук разлетался.

вы такии

красненькии

- выводила она и трясла боками, топоча, и вскрикивала.

Flottarnas eldar brann vid floden. Månen gick upp. Guldbokstäverna på regionrådets båthus och bryggor glänste. Några sena badare plaskade i mörkret. Prokoptjik sög på sin pipa. Han gladde sig åt gästerna. - En sådan ära, hälsade de vänskapligt, hur står det till? och skakade hans hand. - En dam från kulturavdelningen kom farande, berättade han, och krävde att alla skulle ha underbyxor. De skakade på huvudet och skrattade. I staden brann små eldar. Vattnet porlade. - Kusken anger mig, den horungen, klagade

\footnotetext{
${ }^{289}$ Det är åtminstone troligt att det just är akronymen "Okrèspeès" ("Okružnoj sovet professional'nych sojuzov" ("Fackföreningarnas regionsråd") som står skriven med guldbokstäver. I översättningen har jag sett mig tvungen att utveckla dessa nyordsbildande förkortningar. I sin anhopning i denna novell framstår de nonsensartade, liksom talande för det politiskt nonsensartade, den ytliga rödhet som skildras. Samtidigt lär åtminstone de flesta av dem ha varit begripliga i samtiden och då inte givet ha framkallat en sådan reflektion.
} 
Tjernjakova. Oj, sade hon och började spela på läpparna och vrida sig runt, dundrande. Männen stampade åt henne. Slipsen flög.

sådana dä

röda ni ä,

präntade hon in, skakade stampande på höfterna och gav till små skrik.

Till skillnad från tidigare novellers alternativ till det sovjetiska samhällslivet tycks inte denna samvaro utgå från någon form av gemensam konkurrerande ideologi - kyrklig, mystisk, borgerlig, västlig, romantisk - eller präglad av nostalgi. Mänskliga möten är inget som denna huvudperson bara längtar efter i ensamhet eller upplever i korta stunder bortom orden i den sociala tillvaro hon ingår i. Här är hon bland likasinnade, här blir hon förstådd och stöttad i sitt uttryck för kritik av samhällets ytliga rödhet och nya hierarkier.

Den som i "Sad" bär störst likhet med tidigare huvudpersoners mötesproblematik är intressant nog istället den främsta representanten för det nya samhällets kultur, poetissan Lipec. Fast hon i sin diktning så väl passar in i det nya framstår hon (inte olikt hur Erygin som person kontrasterar mot det han skriver), i den spegelscen till Černjakovas skapande som avslutar novellen, som ensam och med en längtan efter något annat. Får hon utlopp för detta i sin diktning?

Поэтесса Липец, обратив лицо к луне, прогуливалась, и ее отец, отсекр окрэмбеит, прогуливался вместе с ней. Они прогуливались, отсмотрев спектакль, делегатские билеты на который получили от секретаря союза медсантруд. Шарф поэтессы Липец развевался. Глядя вверх, она покачивала головой и декламировала тихо:

- гудками встречен день. Трудящиеся.

Poetissan Lipets promenerade med ansiktet vänt mot månen, och hennes far, ansvarig sekreterare för regionala sektionssamordningsbyrån för ingenjörer och tekniker, promenerade tillsammans med henne. De promenerade efter att ha sett klart en föreställning till vilken de fått delegatbiljetter av sekreteraren för medicin- och sanitetsförbundet. Poetissan Lipets scarf fladdrade. Hon tittade uppåt, svängde med huvudet och deklamerade stillsamt:

- med visslors tjut är dagen hälsad. Arbetare. ${ }^{290}$

\footnotetext{
${ }^{290}$ Parallellen mellan Černjakovas framförande av sin tjastusjka och Lipec deklamerande av sin dikt understryks också av att slipsens flygande rimmar med scarfens fladdrande på ryska: "razletalsja" - "razvevalsja".
} 
Den ideologiska rättrogenhet som far och dotter Lipec ger uttryck för - de är "sådana där röda" som Černjakova i sin sång fått de förlupna orden att ironisera över - framställs här till sist inte som någon garant för att känna sig som en del av en gemenskap, så som det ibland framstått i tidigare noveller utifrån de "borgerligt" sinnade huvudpersonernas perspektiv.

Far och dotter promenerar tysta tillsammans. Likt en plikt har de "sett klart" ("otsmotrev") den föreställning som de som en sista avrundande återkoppling till kongressen förärats med biljetter till. De sovjetiska titlarna framstår också som ytliga ordnar, som ett kapital; upprepningen av dem även i denna kontext understryker faderns ställning och fina kontaktnät i samhället. Denna röda ytlighet framställs också genom det borgerligt sentimentala skimret kring dem i denna stund: i den genomgående titeln poetissa, i deras genom upprepningen understrukna promenerande, i scarfen, blickandet mot månen och det stillsamma deklamerandet. Och i denna stämning, under samma måne som Černjakova nyss, kommer den proletära diktraden ut en tredje och sista gång - likt ett fullbordat självförräderi innan fabriksvisslan ljuder igen.

\section{"Porträttet" - ett avsked till samtiden}

Den avslutande novellen "Portret" ("Porträttet") är den enda förstapersonsberättelsen i samlingen. Det är för den skull inget uppenbart självporträtt. Jaget är en ung kvinna och ingen författare. Distansen till huvudpersonen upprätthålls också, om än hennes medvetande färgar gestaltningen, på samma sätt som i tidigare noveller. Det finns ansatser till en berättelse, jagets berättelse om sig själv och sin tillvaro, men först och främst gestaltas hon som nersänkt i en vardags omedelbara nu där saker händer av sig själva och först succesivt framträder som en berättelse. Yttre sinnesintryck istället för inre reflektioner är vad som i första hand ger tillgång till det hon upplever och känner. Novellen framstår på så sätt inte som väsentligt annorlunda än de föregående berättelserna i tredje person. Jaget blir snarare något av ett anonymt namn.

Vi kastas in i hennes värld. Tillvaron pågår. Den är känd för henne och det man vet förklarar man inte för sig själv. Ändå klargörs en hel del liksom för en utomstående. Liksom i tidigare noveller är det å ena sidan ingen medvetandeström vi har att göra med och å andra sidan saknas en tydlig berättarinstans.

Novellen börjar visserligen med en ansats till en jagets "berättelse om sig själv" genom den upprepade berättarmarkören "kak vsegda" ("som alltid"), och trots att denna skildring av en vana sedan flyter ut i en gestaltning av en 
alldeles konkret dag, en dag som fortlöper liksom utom jagets kontroll och utan en känsla av tillbakablickande, återkommer i novellen vissa drag av en både vädjande och stolt självbekännelse. Detta kommer som mest tydligt till uttryck i ett inskjutet konstaterande, som alltså är jagets men som framställs med ett symptomatiskt opersonligt uttryck - som om det gällde för fler än henne själv -, som ett allmänt uttryck för en känsla i denna samtid: "Откровенности и дружбы захотелось." ("Man längtade efter öppenhet och vänskap.") Detta ensamma, anonyma mänskliga jag och hennes triviala öde blir så talande för en allmän mötesproblematik i samtiden. Den hänger samman med att den sovjetiska verkligheten och dess ideologi nu alltmer kommit att utgöra den enda existerande världen utan utrymme för alternativa uppfattningar.

Dobyčin nämner knappt den andra samlingens nya noveller i sina brev. Undantaget är "Portret" som han genast efter att ha gett upp romanförsöket tycks ha påbörjat.

I november 1928 frågar Dobyčin Slonimskij vad det "skojarmode" innebär som han läst att dennes nya roman Srednij prospekt "ger tribut åt" ${ }^{291} \mathrm{Fem}$ månader senare, i april 1929, efter att ha nämnt att han kommer att skicka ett manuskript innan han kommer till Leningrad nästa gång (han hör sig under denna tid också för om möjligheten att i sin egenskap av ung skriftställare få något annat än ett kansliarbete i Leningrad), skriver han att den nya berättelsen, trots att Slonimskij aldrig svarade på hans fråga, bland annat kommer att handla om "skojare" ("žuliki").292 En glimt av vad han möjligen bland annat inkluderar i detta tema ger han i förbifarten i nästa brev från mitten av maj efter att ha berättat att sommaren redan kommit och att han börjat bada: "Сады с оркестрами и эстрадами открылись (состоялось открытие), одного гуляющего зарезали впотьмах, а в Бежице (девять верст от нас) двоих повесили: интеллигентские течения среди молодежи." ("Stadsträdgårdarna med sina orkestrar och estrader har öppnat (invigning har hållits), en flanör knivskars i mörkret och i Bežica (nio verst från oss) var det två som blev hängda: intellektuella strömningar bland ungdomen.") ${ }^{293}$ I november 1929 har han översänt berättelsen till Slonimskij. Han

\footnotetext{
291 "Где-то я читал, что Вы платите в нем дань моде на жуликов. Что это за мода? Если бы я знал, то принял бы и себе к руководству." Till Slonimskij 2I november 1928 (brev IO7), PSSP, 297-298.

292 "Кстати, Вы мне не ответили о жуликах. Я все же решил не отставать, и в составляемом мною сочинении будет о них." Till Slonimskij I3 april 1929 (brev IIо), PSSP, 299. Tidigare omnämnande av ett påbörjat manuskript och frågan om arbete: 8 mars respektive I april 1929 (brev I08, I09), PSSP, 298.

${ }^{293}$ Till Slonimskij I6 maj 1929 (brev II2), PSSP, 299.
} 
tackar då Slonimskij för dennes berömmande ord eftersom novellen, menar han, är det mest noggrant genomarbetade han skrivit och att han före Slonimskij har fått ytterst obehaglig kritik för den. ${ }^{294}$ Han översänder också novellen till Čukovskij med ett kort följebrev där han benämner den "en provinsiell souvenir" ("provincial'nyj souvenir").295 På dessa olika sätt förhåller sig Dobyčin till sin provinsiella samtid som något han nu både som författare och människa står i färd att lämna. Detta ger också novellen uttryck för.

"Portret" publicerades första gången i tidskriften Strojka (nummer 3) 3I mars 1930.296 Som citerat i inledningen förseddes även denna publicering med en varningstext från redaktion: Dobyčins "analytiska" sätt att varsebli världen - genom dess enskilda, ännu sammanhangslösa föremålsliga detaljer - sades bära på faran för ett typiskt borgerligt förfall i världsåskådningen. Detta förfall som en aspekt av skojarmodet är samtidigt något som novellen tematiserar och problematiserar.

Med sina fyra kapitel liknar "Portret" de längre novellerna från första samlingen. Även grunden till intrigen är uppbyggd på liknande sätt kring ett initialt sammanträffande med någon som huvudpersonen därefter söker och längtar efter ett möte med.

\section{I (Allt var som vanligt men någonting hände)}

En insisterande specifik beskrivning av ett rörelseförlopp inleder det första kapitlet. Samtidigt presenteras det som bara den vanliga rutinen. Det som

\footnotetext{
294 "Спасибо за то, что Вы меня похвалили. Теперь я больше не думаю об этом рассказе (потому что он самый выверенный из всего, что я делал, а мне его до Вас чрезвычайно неприятным образом ругали), и у меня голова свободна.” Till Slonimskij I7 november 1929 (brev II4), PSSP, 30I. I detta brev skriver Dobyčin också att han "av olika skäl borde" införa en tillägnan under titeln på novellen till en viss G. L. Rysjukov. Det görs inte, men möjligen talar det för att en egen olycklig kärlekshistoria ligger till grund.

295 Brevet till Čukovskij är det första efter att Dobyčin översände sin första novellsamling och följs enbart av två brev från I93I där han bland annat översänder de två noveller som inte medtogs i den andra samlingen. Årtalet är inte angivet i brevet och i PSSP har man antagit att det är från 1930 samtidigt som man i kommentarerna slår fast att det är just "Portret" som åsyftas med "provinsiell souvenir". 1929 förefaller mig mer troligt eftersom han då samtidigt översänder novellen till Slonimskij och att den 1930 redan publicerats i tidskriften Strojka. Till Čukovskij 19 oktober [1929?] (brev 38), PSSP, 266.

${ }^{296}$ Dobyčin avsåg först novellen för den av OBĖRIU planerade, men aldrig förverkligade, antologin för nyskapande författare med titeln Vanna Archimeda (Archimedes badkar) som han av Kaverin fått erbjudande om att ingå i. Detta framgår av brev II2 och II4 (PSSP, 299-30I) samt av Daniil Charms anteckningsbok där Dobyčin ingår i prosasektionen tillsammans med Charms själv, Kaverin, Vvedenskij, Tynjanov, Šklovskij och Oleša. Se D. I. Charms, A. I. Vvedenskij, N. A. Zabolockij, N. M. Olejnikov, I. V. Bachterev, K. K. Vaginov \& A. I Aleksandrov (red.), Vanna Archimeda, Leningrad I99I, 486.
} 
händer nu, konkret och momentant, är på samma gång precis som alltid. Det är en vana som redan är känd, men som därför kan framställas som betydelsefull i hur den är, som något man redan distanserat sig från, som en vana man redan lämnat. Samlingen inleddes med minnet av den forna huvudstaden, nu börjar denna "provinsiella souvenir" att forma sitt avsked från samtiden: ${ }^{297}$

Как всегда, придя с колодца, я застала во дворе хозяина.

Он тряс над тазом самовар и, как всегда, любезно пошутил, кивнув на мои ведра: - Фызькультура.

Как всегда, раскланявшись с маман, мы вышли, и в воротах, распахнув калитку, отец, галантный, пропустил меня. По тени я увидела, что горблюсь, и выпрямилась.

Стояли церкви. Улицы спускались и взбирались. Старики сидели на завалинках. Сверкали капельки и, шлепаясь о плечи, разбрызгивались. Как всегда, на повороте, тронув козырек, отец откланялся. 298

Som alltid när jag kom från brunnen stötte jag på husvärden på gården.

Han skakade samovaren över ett fat och skämtade som alltid älskvärt med en nick mot mina hinkar: - Fisisk kultur.

Som alltid efter att vi tagit avsked av maman gick vi ut, och i porten slog far galant upp grinden och lät mig gå före. På skuggan såg jag att jag kutade med ryggen, och sträckte på mig.

Kyrkorna var där. Gatorna löpte ner och tog sig upp. Det satt gamlingar på vallarna längs husväggarna. Droppar gnistrade, daskade mot axlarna och skvätte. Som alltid vid korsningen rörde far vid mössan och bockade till avsked.

Det var som vanligt men det var av betydelse för något särskilt hände denna dag. Så hade jaget - om det varit medvetet om sig självt som berättare - kunnat sammanfatta denna inledande beskrivning av en livssituation genom vilken handlingen som det ska visa sig redan påbörjats. Då hade ett jag som reflekterande blickar tillbaka på sig självt uppstått som en berättarinstans. Det undviker Dobyčin genom att bara ge detta antydande anslag. Vi är i denna tillvaros pågående nu, ett nu som jaget $\mathrm{i}$ berättelsen kan uppleva vara som alltid, som en vana hon är trött på.

Utan att framstå som utvalda exempel ger oss detaljerna ett begrepp om jaget. Husvärden är där och anspelar på hennes kropp med sin älskvärda skämtsamhet: att hon bär vatten som ett slags frisksport, fysisk kultur, som han antingen feluttalar för att det är en nymodighet eller medvetet, som en

\footnotetext{
297 Upprepningen av "kak vsegda" ("som alltid") liknar också användningen av "uže" ("redan") i inledningsnovellen "Proščanie".

${ }^{298}$ Novellen citeras ur PSSP, 95-IO2.
} 
del av sin skämtsamhet, för att liksom ironisera över företeelsen. Även i faderns sätt finns något av ett älskvärt uppassande. Och i hur hon sedan ser sin egen krumhet och genast rätar på sig antyds hur hon internaliserat männens älskvärdhet och blickar på sig, på sin kropp, som ung kvinna.

Att modern kallas maman och faderns galanta sätt tillsammans med hyresvärdens älskvärdhet framställer också jagets sociala hemvist som borgerlig. Än så länge är det bara begreppet fysisk kultur som kopplar berättelsen till den sovjetiska samtiden. Kyrkorna pekas ut och en liksom verklighetens Brjansk kuperad stad. Med gamlingarna vid husväggarna anslås så något av ett utomstående, utomsocialt perspektiv, liksom bönder har gjort i tidigare noveller. Den fysiskt följsamma gestaltningen av droppandet på deras axlar bidrar till den omedelbara närvaron i nuet i det som presenteras som en vana. Att detta noteras i jagets värld bidrar till karaktärsteckningen av henne som sensibel även om det inte uppenbart ger känslan av att vara jagets iakttagelse. Det bara händer. Den beskrivning av en stadsmiljö som följer, vilken ska visa sig vara den där hennes arbetsplats ligger, framställer inte heller, frånsett att den gestaltas som något redan känt, vare sig jaget som berättare eller hennes medvetande i stunden:

Четыре четырехэтажных дома показались, площадь с фонарями и громкоговорителями. Подоткнув шинели, бегали солдаты с ружьями, бросались на землю и вскакивали. Стоя на крыльце и переглядываясь, канцелярские девицы их рассматривали. Шляпы отражались в полированных столбах.

De fyra fyravåningshusen dök upp, och torget med lyktor och högtalare. Några soldater hade fäst upp rockarna och sprang med gevär, kastade sig på marken och hoppade upp. Kansliflickorna stod på trappan, utbytte blickar och bedömde dem. Hattarna speglades i de polerade stolparna.

Vad som noteras och hur det noteras berättar något specifikt om jaget. Men samtidigt finns samma slags neutralitet, och konstaterande, nominativa anslag som i tredjepersonsberättelserna, som gör att saker till en början framträder som självständiga och inte direkt motiverade av huvudpersonens medvetande. 299

\footnotetext{
299 Att nominativ generellt hos Dobyčin dominerar som kasus menar Ol'ga Abankina och ser det som en del av hur tingen i sig framhävs i ett "montage av fakta" istället för "följd av akter". O. I. Abankina, "Vnutrennjaja individual'naja model' mira v romane L. Dobyčina 'Gorod Ėn'”, PLD, 235-240, 237. Det nominativa draget är för Abankina ett utslag av den "likhetslag" ("zakon toždestva") som Viola Ėjdinova lyft fram (först i "O stile Leonida Dobyčina", PLD, IOI-II6) som kännetecknande för författarskapet och en grund till det konstaterande tonfallet och, som hon menar, antidialogiska i berättandet, i den mening att hjältens ord inte tillåts utvecklas på egen hand i dialog med författarens, utan strikt avgränsas. "Slovo Leonida
} 
Beskrivningen av soldaterna kan tyckas vittna om ett intresserat betraktande. Men snarare än att antyda jagets fascination så förevisar det bara krasst vad de kansliflickor som därefter presenteras betraktar. Och det är i betraktandet av de senare som perspektivet, genom speglingen, impressionistiskt framhävs som personligt.

Utan förklarande övergång uttrycks sedan ett nytt vi (det förra utgjorde jaget och fadern). Gradvis framgår det att det är kansliflickornas kollektiv som jaget nu anonymt blivit del av:

Хваля погоду, мы уселись. Счеты стали щелкать. В кофте «сольферин» прошла товарищ Шацкина и осмотрела нас. Передвигалось солнце. Тень аэроплана пробежала по столам, и мы поговорили, сколько получают летчики. ${ }^{300}$

Vi lovordade vädret och satte oss ner. Kulramarna började knäppa. I koftan "solferino" gick kamrat Sjatskina förbi och inspekterade oss. Solen rörde sig. Skuggan från ett aeroplan drev över bordet, och vi började prata om hur mycket piloter tjänar.

Lovordandet av vädret tillsammans med droppandet från taken tidigare antyder att det är sen vinter eller tidig vår. De arbetar. Deras överordnade i en troligen färgstark och moderiktig kofta inspekterar dem. Hela arbetsdagens gång tecknas genom solens rörelse. Det monotona understryks. Den infallande solen låter också ett flygplan framträda. Samtal om hur mycket piloter tjänar vittnar om kontorsflickornas känslor och längtan - men också krassa kalkylerande.

Med det är arbetsdagen över. I nästa stycke, tillbaka i hemmet, framträder jaget igen, i tidsangivelsen och tilltalet maman, vilket dock genast övergår i en ny ren händelsekedja utan jagets reflektioner. De på morgonen noterade kyrkorna och den antydda borgerliga förfiningen i familjen utvecklas nu tematiskt. Ett nytt vi som modern tillhör introduceras som avseende det religiösa uttrycker en opposition till det vi som jaget med fadern åter utgör:

После обеда, кончив мыть, маман переоделась и, в перчатках, чинная, отправилась.

- Мы выбираем дьякона, - остановилась она и взглянула на меня и на отца внушительно.

Dobyčina (Antidialogičeskaja tendencija v proze 20-x godov)”, PLD, II7-I29. I min läsning finns som sagt och som synes huvudpersonens medvetande (ord) potentiellt med även i de konstaterande beskrivningarna men de kräver läsarens tolkande aktivitet för att framträda. ${ }^{300}$ Namnet på koftan har troligen med färgen att göra; solferino är en lilaröd anilinfärg, lik magenta. Båda har fått sina namn från blodiga slag, i Magenta och Solferino, I859. 
- Прекрасно, - похвалили мы.

Отец, прищурившись, шелестел газетой. Ветви перекрещивались за окном. В конюшне за забором переступала лошадь.

Efter middagen när hon var klar med disken bytte maman kläder och med handskar, värdig, var hon på väg att gå.

- Vi ska välja diakon, stannade hon till och sade och tittade med eftertryck på mig och på far.

- Fantastiskt, berömde vi.

Far satt kisande och prasslade med tidningen. Grenarna korsades utanför fönstret. I stallet bakom staketet trampade hästen.

Rollfördelningen liknar den i tidigare noveller; modern med sitt religiösa engagemang, sitt fasthållande vid förrevolutionära värden och fadern med en mindre definierad, mer obekymrad position. Som vi snart ska se försöker han intressera sig för det nya men utan att aktivt engagera sig. Han läser tidningen som tidigare äkta män och fäder och hans upptagenhet vid det och de följande intrycken framhäver den tysta närvaron tillsammans med dottern. Inget sägs om vad hon tänker. Antyder intrycken något specifikt korsade grenar, en otålig, instängd häst? Eller talar bara själva sinnligheten för något undertryckt och anspänt? Vilken är jagets position?

Stämningen avbryts av ett knackande. Det är några väninnor till modern. De beskrivs som tillhörande samma ideologiska sfär som modern, fasthållandet vid det gamla, en högtidlig kyrklig och borgerlig kultur. Det tecknas med en boa, "расстегивая выхухоль на шее" ("knäppte upp boan av desmanråtta i halsen"), och blänkande broscher: "Брошь-цветок и брошькинжал блестели." ("En blombrosch och en dolkbrosch glänste.")

Efter en replik i direkt tal ger sig jaget iväg för att hämta modern vilket genast följs av en beskrivning av denna på sammankomsten. Bara i sina iakttagelser och liknelser talar den för jagets närvarande medvetande. I förbifarten skildras denna kyrkliga sammankomst i en skolsal för den förnyande riktning inom kyrkan, obnovlency, som följer med i tiden genom att i demokratisk anda välja sin nya diakon, vilket var det som jaget och fadern berömde:

[...] - Я иду сказать маман, - сбежала я.

Она, торжественная, как в фотографии, сидела в школе. Старушенции шептались. Кандидат на дьяконскую должность, в галифе, ораторствовал.

- Я из пролетарского происхождения, - восклицал он.

Разноцветные, с готическими буквами, висели диаграммы: мостовых две тысячи квадратных метров, фонарей двенадцать, каланча одна.

- А вы учились в семинарии? - поднялась маман.

Я позвала ее.

[...] - Jag går och säger till maman, sade jag och sprang ner. 
Högtidlig som på ett fotografi satt hon i skolan. Gummorna viskade till varandra. Kandidaten till diakontjänsten klädd i ridbyxor orerade.

- Jag är av proletär härkomst, utropade han.

Olikfärgade och med texten i frakturstil hängde diagrammen: tvåtusen kvadratmeter stenlagd yta, tolv lyktor, ett brandtorn.

- Men har ni studerat vid ett prästseminarium, reste sig maman och frågade.

Jag ropade på henne.30r

Som på ett fotografi, sitter modern stelnad i en gammal högtidlighet, vilket både skolmiljön med sina diagram och kandidaten - som framhåller sin proletära härkomst som skäl till att välja honom till diakon - kontrasterar mot. Liksom många tidigare äldre kvinnor har modern svårt att bara följa med i de nya vindarna. Jaget tycks medvetet ingripa mot att moderns protest ska utvecklas genom att just då kalla henne hem till de väntande gästerna.

Utan förklaring följer gatubilder: vattenpölar som täcks med is mot kvällen, folk som stänger sina fönsterluckor, pojkar som sitter och klirrar med sina skridskor och så en bullrande gata med rytande bussar som ett nytt inslag i stadsmiljön jämfört med tidigare noveller - och likt en kommentar till denna nya konkurrent kastar några kuskar av sig sina förkläden. Denna gata som återkommer i berättelsen namnges: "Улица Москвы, по-старому - Московская" ("Moskvas gata, tidigare Moskvagatan") Här kikar snarast författaren fram med en liten parodi på samtidens många omdöpningar. ${ }^{302}$ Först därefter dyker uttryckligen jaget upp:

[...] Взойдя на паперть, я взяла билет. Стояли пальмы. Рыбки разевали рты. Топтались кавалеры, задирая подбородки и выпячивая бантики. Я терлась между ними.

\footnotetext{
301 I hur diagrammen lyfts fram som intressanta och mystiska - olikfärgade, med gotiska bokstäver (frakturstil) - samt i uppräkningens rytm och efterställda siffror finns möjligen en ironiskt antydd kristen symbolik: lyktorna är tolv som apostlarna och brandtornet är ett som Kristus.

302 Denna omdöpning tycks nämligen inte ha någon motsvarighet i verkligheten. Den verkliga Moskovskaja ulica (Moskvagatan) i Brjansk döptes om till Ulica Tret'ego Internacionala (Tredje internationalens gata) efter revolutionen (som figurerar under det nya namnet $\mathrm{i}$ "Vstreči s Liz"). Sedan 1956 är gatan istället uppkallad efter Michail Kalinin: "Ulica Kalinina (Brjansk)", Wikipedia, https://ru.wikipedia.org/wiki/Улица_Калинина_(Брянск), 2019-о4-І6.

Slonimskij undrade uppenbart över meningen med detta: Dobyčins förklaring understryker att det är en parodi och säger också något om hans berättarsätt (att det inte finns plats för något förtydligande, som Slonimskij tycks ha efterfrågat, är här förståeligt då det redan i denna knapphet känns avlägset från huvudpersonens medvetande): "Идея этой улица та, что она была просто Московская, но ее переименовали по случаю революции. Никакие объяснения в текст не умещаются, и я решил оставить так." ("Idén med denna gata är den att den bara vara Moskvagatan förut men att man döpte om den med anledning av revolutionen. Inga förklaringar får plats i texten och jag bestämde mig för att låta det vara så.”)
} 
[...] Uppe på kyrktrappan köpte jag biljett. Palmerna var där. Fiskarna gapade med munnarna. Några kavaljerer vankade omkring, drog upp hakorna och spände flugorna. Jag strök bland dem.

Så framgår till slut att det föregående har beskrivit hennes väg till något slags föreställning efter att hon kallat hem modern. Jaget (och även fadern ska det visa sig) håller sig borta från moderns religiöst anstrukna samkväm med sina väninnor. Kyrktrappan ("papert"), som ger en ironisk spegel till den underhållning som sedan äger rum, utpekar att det är en faktisk kyrkobyggnad som gjorts om till biograf med palmer och akvarium i foajén. ${ }^{303}$ Bland dessa intryck, det som från början beskrivits vara som alltid, framträder så de som snart ska bli avgörande för novellens handling och mötestemat: kavaljererna. Tillsynes inte helt ofrivilligt tycks jaget fysiskt snudda vid dem.

Detta ska utvecklas efter den film som visar sig vara det hon köpt biljett till. Filmens huvudperson framställer först också något av ett romantiskt ideal. Jaget har nu inträtt i ett nytt vi - den sovjetiska och allmänt moderna populärkulturens. Den utländska filmen avrundas med musikalisk satir med ideologiska inslag (vad som ska hånas pekas tydligt ut; den andra internationalen som enade socialistiska partier I889 hade efter revolutionen förkastats genom upprättandet av den rent kommunistiska Tredje internationalen (Komintern)):

Ричард Толмедж был показан в безрукавке и коротеньких штанишках. Он лечился от любви, и врач его осматривал.

- Милашка Ричард, - улыбались мы и взглядывали друг на друга, сияя.

Сверх программы - музыкальные сатирики Фис-Дис трубили в веники. - Осел, осел, - кричали они, - где ты? - и отвечали: - Я в президиуме Второго Интернационала.

Richard Talmadge visades i slipover och kortbyxor. Han vårdades för sin kärlek och läkaren undersökte honom.

- Stackars lille Richard, log vi och såg på varandra och strålade.

Utanför programmet trumpetade musiksatirikerna Fiss-Diss på bastukvastar. - Åsna, åsna, ropade de, var är du? Och svarade: - Jag sitter i presidiet för Andra internationalen.

Men vad händer sedan? Det överrumplande i händelsen framhävs genom en lucka i beskrivningen av den, som om även jaget först $i$ efterhand kan göra det klart för sig:

303 Den stora katedralen i Brjansk (Novo-Pokrovskij sobor) vilken som nämnt stängdes 1924 och gjordes om till ett Folkets hus med biograf låg just vid den tidigare Moskvagatan. Ė. S. Golubeva, Pisatel' Leonid Dobyčin i Brjansk, Brjansk 2005, 75-82. 
Наскакивая на прохожих, я гналась за ним. - Послушайте, - хотела крикнуть я. Он шел, раскачиваясь, невысокий, с поднятым воротником и в кепке с клапаном.

Отец остановил меня. Он тоже убежал от го́стий. - Ричард мил? - спросил он, и по голосу я видела, как он приподнял брови: - И идеология приемлемая?

Узкая луна блестела за ветвями. На тенях светлелись дырки. Дикие собаки спали на снегу.

- Да, да, - кивала я, не слушая... Тот, в кепке, - в толкотне у двери он ощупывал меня.

Jag sprang in i förbipasserande när jag skyndade efter honom. - Lyssna, ville jag ropa. Han gick svängigt, ganska kort, med kragen uppfälld och i en keps med nedfällbart bakstycke.

Far stoppade mig. Han hade också flytt från gästerna. - Var Richard söt, frågade han och på rösten såg jag hur han höjde ögonbrynen lite: Och ideologin acceptabel?

Den smala månen sken mellan grenarna. I skuggorna syntes ljusa hål. Vilda hundar sov på snön.

- Ja, ja, sade jag och nickade utan att lyssna... Han med kepsen, i trängseln vid dörren, han tog på mig.

"Ja, ja", är det enda, efter några kontemplativa sinnesintryck, som hon säger högt till fadern som plötsligt dykt upp. Hon blir hindrad i sin jakt på den okände som hon tillsynes har avsett att skälla ut. Hon lämnas här med bara några väl allmänna signalement: går svängigt, är ganska kort och bär en keps med nerfällbart bakstycke (eller ordagrant "klaff" ("klapan")). Om Richard var söt och om ideologin var acceptabel är de frågor som huvudpersonen svarar på med sitt halvt frånvarande "ja, ja". Konstaterandet av det inträffade gör hon inom sig. Denne med filmens huvudperson vagt associerade kavaljer antastade alltså henne i trängseln. Det tycks ändå ha väckt något mer än en ilska.

Enligt samma mönster som många tidigare noveller blir denna triviala uppenbarelse av en ny okänd person början på en tillväxt av känslor och ett sökande efter att återse denne, som i ett sökande efter mening överhuvudtaget för huvudpersonen. Det här mer intima och ekivoka i sammanstötningen kommer att tematiseras som en del av samhällsandan; den okände kavaljeren framstår som en "skojare" ("žulik") enligt det mode som Dobyčin sagt sig vilja skildra i novellen. Huvudpersonens fördröjda uppfattande av händelsen, hur hon tillsynes inte lyssnar på faderns prat och hur de skarpa alldagliga sinnesintrycken tränger in, gestaltar också ett obehag i känsloomtumlingen.

Första kapitlet har upprepat rörelsen ut från hemmet - först till arbetet, sedan till kvällens kulturaktivitet. Jaget och fadern tycks ensamma ute i 
samhället. Under tiden har moderns religiösa och borgerligt färgade samkväm med sina väninnor pågått. Kapitlet avslutas med den kvardröjande atmosfären efter detta. Modern diskar. Nedlåtande och viktigt återger hon några daterade händelser som gästerna berättat om som dagsaktuella nyheter. Lukten av skokräm dröjer sig kvar. Här återknyter berättelsen också till inledningens melankoliska vana som jaget är nersjunken i. Det är åter "som alltid" och det särskilda som inträffat denna dag framstår lika mycket ha varit en överraskning för jaget självt med ännu oklar innebörd. I en instängdhet med maman och far läser hon annonserna, bland annat för ett hårförbättringsmedel, i en veckotidningsartad bok som gästerna haft med:

Как всегда, мы сели. Кошка, тряся стул, лизала у себя под хвостиком. Отец шуршал страницами. Маман, посмеиваясь, пришивала кружево к штанам. Я перелистывала книгу. - Анна Чилляг, волосастая, шагала и несла перед собой цветок. Поль Крюгер улыбался. Это - гостьи принесли. ${ }^{304}$

Som alltid satte vi oss. Katten skakade stolen när hon slickade sig under svansen. Far prasslade med sidorna. Maman sydde fast spets på ett par byxor och skrattade lite för sig själv. Jag bläddrade i en bok. - Anna Csillag med sitt långa hår gick och bar en blomma framför sig. Paul Krüger log. Det var något gästerna haft med.

\section{2 (Sökande efter Honom)}

De tre första kapitlen följer samma årstidsutveckling, med medföljande känslor, som inledningsnovellen "Proščanie". Om vintern led mot sitt slut i första kapitlet (på samma sätt som novellsamlingen tog sin början med beskrivningen av Kunsts vana) så bryter våren nu ut och i tredje kapitlet firas påsk. Inget sägs längre vara "som alltid", men motiv och teman från första kapitlet återkommer som en del i skildringen av vårens och känslornas fortskridande.

Jaget och fadern ger sig liksom i första kapitlet av på morgonen. Husvärden är där och återger nu nyheten om en politisk konflikt: att folkkommissarien för upplysning Lunačarskij kritiserat Rykov, ordförande för folkkommissariernas råd och del av den högerfraktion i partiet som Stalin, efter att först ha använt sig av deras stöd i utmanövrerandet av Trotskij, nu mot slutet av tjugotalet i samband med den radikala övergången till planekonomi, slog ner på. I den annars ovidkommande nyheten bär nämnandet av

\footnotetext{
304 Även hos den samtida polskspråkiga författaren Bruno Schulz dyker denna Anna Csillag upp i ett liknande sammanhang - novellen som inleder samlingen Sanatoriet timglaset har just "Boken" som titel. Bruno Schulz, Kanelbutikerna; Sanatoriet timglaset, översättning Johan Malm, Stockholm 1987.
} 
Lunačarskij på en innebörd som först utvecklas i några affischer om att metropolit Vvedenskij, företrädare för den förnyande, revolutionssympatiserande riktningen inom kyrkan, skall komma till staden och debattera guds existens: "Есть ли бог?" ("Finns gud?") citeras affischerna. Det brukade han annars resa runt och göra med ateisten Lunačarskij (vilken här vid denna föreställning som följer samma kväll emellertid är ersatt av en lokal förmåga). Därigenom kommer indirekt moderns kyrkliga aktivitet i opposition till jaget och fadern att tematiskt vidareutvecklas.

Bland intryck som går igen från första kapitlet - vattenpölarna som mörknat, ett flygplan på den nu blå himlen - springer några visslande kavaljerer förbi med hår som sticker ut under kepsarna. Det återknyter till den okände med keps även om jaget inte igenkänner honom bland dessa (och med hårväxten till Anna Csillag). Det är på deras axlar istället för gamlingarnas som vattendroppar nu glänser.

Tankarna på den oförskämde kavaljeren har inte släppt henne. Detta framgår tydligare efter att hon som vanligt skiljts från fadern. Flygplanet på himlen leder över till något på samma höjd. Hon följer en montör på taket till en teater med blicken. Han är ganska kort, ett av signalementen för den okände. Det räcker för att få henne att tro att det är den okände kavaljeren. I den tanken framträder hon för första gången i kapitlet som ett jag:

К надписи над театром проводили электричество. Монтер, приставив к глазам руку, шел по крыше и раскачивался, невысокий. «Это он», - подумала я. - Что там? - спрашивали у меня, остановясь. Меня толкнули. Лаком для ногтей запахло. Выгнув бок, кокетливая Иванова в красной шляпе поздоровалась со мной. Я сделала приятное лицо, и мы отправились. - Весна, - поговорили мы.

De drog elektricitet till skylten ovanför teatern. En montör gick på taket med handen ovanför ögonen och svängde lite, och han var ganska kort. - Det är han, tänkte jag. - Vad tittar du på? frågade man mig och stannade. Man stötte till mig. Det kom en lukt av nagellack. Koketta Ivanova i röd hatt sköt ut höften och hälsade på mig. Jag anlade en trevlig uppsyn, och vi gav oss av. - Det är vår, pratade vi lite.

Situationen, hur hon uppslukas och blir knuffad påminner om den initierande upplevelsen i trängseln på väg ut från biografen. Och återigen blir hon avbruten. Med lukten av nagellack introduceras arbetskollegan Ivanova; med kokett som epitet, attribut och pose karikeras hon som förfaren $\mathrm{i}$ den flärdfulla NEP-kulturen. Det samtal om vädret som i första kapitlet inledde arbetet varieras nu med deras kollektiva konstaterande av vårens verkliga inträde. Den nakna årstidsangivelsen blir också potentiellt en kommentar till hennes känslor och betraktandet av montören på taket. 
Själva arbetet sveper obemärkt förbi som i första kapitlet. Huvudpersonen har annat i tankarna. På lunchrasten närmar hon sig Ivanova som på sitt fortsatt koketta sätt - hon sitter och ser sig i en spegel medan hon äter också ger uttryck för en längtan efter något annat. I förbifarten - innan jaget försiktigt frågar om kollegan ska gå på ett kvällsevenemang på kontoret samma dag - interfolieras brottstycket av en nyhet som utvecklar Moskvas gata som motiv. Den tidning som förmedlar nyheten förankras högst konkret av en korv vilken ger möjliga obscena associationer som spelar in i tematiken:

[...] Колбаса лежала на газете. - «И избил», - прочла я, - «проходившую гражданку по улице Москвы». Я кашлянула скромна.

- Вы будете на вечере? - спросила я.

[...] En korv låg på tidningen. - "Och misshandlade", läste jag, "en förbipasserande kvinnlig medborgare på Moskvas gata". Jag hostade försiktigt.

- Ska ni på festen ikväll? frågade jag.

Utan inre reaktion på nyheten och utan svar på frågan är de därefter redan på kvällevenemanget. Raderna ur tidningen har anslagit en med mötestematiken förknippad anspänning. Att den glättigt romantiska fysiska kultur som nu framträder under ordnade former för kansliflickorna också har en fysiskt våldsam baksida i denna tillvaro gav redan den okände kavaljerens antastande en föraning om.

Выступали физкультурники в лиловых безрукавках, подымали руки, волоса под мышками показывались. Хор пел.

Frisksportarna framträdde i lila slipovers, lyfte på armarna, håret i armhålorna syntes. Kören sjöng.

Modulerandet av vad som introducerades i första kapitlet fortsätter. Här är den fysiska kultur, frisksport, som värden skämtade om. De framträder i slipover liksom Richard Talmadge i filmen. Deras hår under armarna ger en erotisk kittling som fortsätter hårtemat. En kör sjunger likt i en kyrka och ger ännu en antydan om denna sovjetiska fysiska kultur som ett sekulärt alternativ. Sedan tar balalajkaspelare vid och publiken av kansliflickor som jaget ingår i faller in med ett samfällt vaggande. De bevakas även nu av sin överordnade som tycks nöjd med detta uttryck för kollektiv om än lätt tvångsartad entusiasm: "Товарищ Шацкина, довольная, оглядывала нас: Хорошо, - зажмуривались мы и хлопали ладошками." ("Kamrat Sjatskina betraktade oss nöjd: - Bra, ropade vi kisande och klappade med händerna.") Därefter brister de tillsammans ut i den patriotiska, förrevolutionära valsen 
"Na sopkach Man'čžurii" ("På Manchuriets kullar") tillägnad de stupade i rysk-japanska kriget. Denna sång tycks rymma något betydelsefullt för jaget. Den får henne att minnas sin barndom. Sångstunden avbryts av den koketta väninnan Ivanova som fortsatt rastlöst söker efter något mer i hennes smak:

- тихо,

- как когда я была маленькая, завертелся вальс, -

- кругом,

и ветер на сопках рыдает.

- Я пойду на лекцию, - перестав смотреть на дверь, сказала Иванова, нет ли там чего, - и вытащила пудру: озеро с кувшинками и лебедь.

- stilla,

som när jag var liten började valsen virvla,

runtom,

och vinden på kullarna tjuter.

- Jag går till föreläsningen, sade Ivanova och slutade titta på dörren: det kanske är något, och drog fram pudret: en sjö med näckrosor och en svan.

Därefter är jaget och Ivanova redan på väg. Föreläsningen är den debatt med Vvedenskij som affischerna i inledningen utlovade. Puderdosan antyder dock att det inte är av intresse för själva föreläsningen som Ivanova vill gå dit. Även jaget antyds på deras väg till teatern, på vars tak hon sett en montör som liknat den okände kavaljeren, vara uppfylld av romantisk längtan. Hon ser sig omkring efter honom och till och med stjärnorna tycks ge bilder av vad som möjligen är hans försvinnande rygg. Deras ointresse för själva debatten framställs också genom att den kvarlämnade, melodramatiskt romantiska dekoren på scenen beskrivs medan hela debatten begränsas till ett konstaterande:

Подмерзло. Две больших звезды, как пуговицы на спине пальто, блестели. Над театром, красные, окрашивая снег на площади и воздух, горели буквы. Люди в кепках проходили.

Я - приглядывалась к ним.

Сад цвел на сцене. Нимфа за кустом белелась, прикрывая грудь. Митрополит Введенский возражал безбожнику губернского значения Петрову. Мы рассматривали зрителей. Отец сидел, зевая. Он кивнул мне. Гостьи, — объяснил он. 
Det frös på. Två stora stjärnor, som knapparna på ryggen på en rock, glänste. Över teatern lyste bokstäverna röda och färgade snön på torget och luften. Människor i kepsar gick förbi.

Jag - iakttog dem.

Trädgården blommade på scenen. En vit nymf som skylde bröstet syntes bakom buskarna. Metropolit Vvedenskij argumenterade emot den i guvernementet kände gudsförnekaren Petrov. Vi såg oss omkring bland publiken. Far satt där och gäspade. Han nickade till mig. - Gästerna, förklarade han.

Medan jagets sökande precis som i första kapitlet avbryts av faderns plötsliga uppdykande - vilken återigen flytt moderns religiösa gäster - finner Ivanova faktiskt den som hon har spanat efter: "- Вот он, засияла Иванова и толкнула меня: Жоржик с электрической увидел нас." ("- Där är han, sken Ivanova upp och knuffade på mig: Georgis från elverket hade upptäckt oss.")

Denne Georgis eller Žoržik, med ett ryskt diminutiv av Žorž, det franska Georges, presenterar sig för jaget med sin yrkestitel, elektriker, och uppvisar en tillgjordhet i stil med sitt lite borgerliga namn (han är namne både med Kukin i "Vstreči s Liz" och geten i "Lidija"). De går ut i foajén. Ivanova börjar där att förebrå honom för ett avtalat möte han inte dykt upp till. Det framgår gradvis att han inte är den kavaljer som jaget söker, den som hon senast trott sig vagt igenkänna i en elektrisk montör och som hon också just på väg ut från en föreställning först blev antastad av. Detta icke-igenkännande återknyter till ursprungshändelsen. Innan huvudpersonen liksom i första kapitlet återvänder till hemmet med fadern följer hon med på en promenad med Ivanova och denne elektriker ner till Moskvas gata.

Jaget iakttar och lyssnar. Jaget håller sig i bakgrunden. Den längtan vi anar hos henne tycks handla om något mer än romantik. Liksom valsen väckte ett barndomsminne framkallar nu bensinlukten på Moskvas gata ett minne av ett tidigare liv i Sankt Petersburg, Petrograd eller Leningrad: "Бензином завоняло. Невский вспомнился - с автомобильными лучами и кружащимися в них снежинками." ("Det började stinka av bensin. Jag mindes Nevskij prospekt - med bilarnas strålkastare och snöflingorna som virvlade i ljuset från dem.”) På vilket sätt jaget har vistats i den stora staden förklaras aldrig, men det bidrar till att framställa henne som annorlunda, som "ett främmande element" vilket hon utifrån sin borgerliga bakgrund kommer att utpekas som i nästa kapitel. Trafiken i minnet kontrasteras, liksom bussarna tidigare här på Moskvas gata i denna provinsstad, av ljudet från en bjällra när en häst ruskar på sig. De vänder vid apoteket och går 
tillbaka.305 En ensam poliskvinna påminner om de faror på Moskvas gata som tidningen rapporterade om, men det enda som elektrikern Žoržik behöver försöka beskydda damerna mot är några skojares ekivoka $\mathrm{Pu}$ sjkinskämt:

- Пушкин, где ты? - говорили впереди. Конфузясь, Иванова прыскала. - Товарищи, - солидно сказал Жоржик: - Неудобно. - На́ плешь, - оглянулись на него.

Снимая шапку, он раскланивался. - Доброго здоровья, - восклицал он. Я - присматривалась.

- Pusjkin, var är du? sade de framför. Ivanova blev förlägen och fnyste. Kamrater, sade Georgis myndigt, det är inte passande. - Du flinten, såg de sig om på honom och sade.

Han tog av mössan och bugade. - God hälsa, ropade han. Jag - tittade uppmärksamt. ${ }^{306}$

Som svar på förolämpningen tar Žoržik galant av sig mössan och är överdrivet artig. Möjligen uppvisar han därmed en faktisk tunnhårighet (i nästa kapitel luktar det i vilket fall hårförbättringsmedel från honom). Kanske iakttar jaget detta, med en anknytning till den reklam med Anna Csillags hårsvall som hon läste i första kapitlet, men troligare, eftersom detta iakttagande utställs på samma sätt som när hon spejade mot montören på taket, så försöker hon utröna om någon av skojarna kan vara den okände kavaljeren. Både skämtets uppbyggnad och scenen lägger grunden för en parallell till novellens slutscen.

Men annars har inget egentligen hänt. Kapitlets triviala händelsekedja mynnar ut i en tomhet. Jagets antydda längtan ut ur sin vardagliga rutin har nu etablerats som en upptagenhet vid, en fix idé om att tvunget återse den man som tog på henne i trängseln på biografen. Hennes brist på en verklig relation med någon har vidare framträtt mot bakgrund av hennes koketta

\footnotetext{
305 Tillsammans med minnet ekar här möjligen Aleksandr Bloks dikt från 1912 om Petersburgs tristess, dess meningslöshet och oföränderlighet, i bakgrunden: "Ночь, улица, фонар, аптека" ("Natt, gata, lykta, apotek") och så vidare.

${ }^{306}$ Anekdoten finns i olika varianter men till grund ligger svaret på den fråga som här uttalas. Frågan är några damers rop efter Pusjkin när de kommit ifrån honom under en svampplockning. Till slut hör de honom svara: "Vo mchu ja!" (eller fullständigare "Vo mchu ja po koleno!") vilket ordagrant betyder "Jag är i mossan" (respektive "Jag är/står till knät i mossan!") men samtidigt är homofont med det synnerligen grova "Vam chuja", ungefär "Kuken (åt er)!" (där fortsättningen med "koleno", "knä" då också kommer att anspela på något intimare). När Pusjkin blir utskälld av damerna efteråt förebrår han dem och säger att de hörde det de hörde bara för att de går runt och tänker på sådant. "Vo mchu ja po koleno" i V. P. Beljanin, I. A. Butenko, Živaja reč': Slovar' razgovornych vyraženij, Moskva 1992.
} 
kollegas visserligen problematiska men ändå reella förhållande med Žoržik. Härefter har jaget lämnat dem. Hon stöter åter ihop med sin far och är på samma sätt som i första kapitlet efter den omtumlande händelsen för upptagen av något inom sig för att lyssna på hans prat när de går hemåt. En ny associativt antydd oanständighet hörs sjungas i den lätt kusliga stämningen på vägen innan de som alltid kommer hem till modern. Som kontrast till oanständigheterna har hon upprymd efter gästerna ett annat och färdigt svar att ge på jagets sökande efter något betydelsefullt, det som också den i bakgrunden debatterade frågan om gud i kapitlet har antytt:

- в магазине Кнопа,

- пели за углом.

Маман была оживлена. Сапожной мазью и помадой пахло. Библия лежала на столе.

- Bсе, все предсказано здесь, - радостно сказала нам маман и посмотрела значительно.

- i butiken Knopp,

sjöng de bakom hörnet.

Maman var upplivad. Det luktade skokräm och pomada. Bibeln låg på bordet.

- Allt, allt är förutsagt här, sade maman glatt till oss med en menande blick. ${ }^{307}$

\section{3 (Påsklig dekadens)}

I kapitel tre bryts den vardagliga rutinen. En särskild händelse inleder. Detta påskfirande, som det visar sig vara, sker emellertid även det enligt en

\footnotetext{
${ }^{307}$ Likt Pusjkinanekdoten låter detta oskyldiga citat en i samtiden populär kuplett framträda som använder sig av den oanständighet som butiksnamnet rimmar på ("žopa" ("rumpa")) men utan att "egentligen" innehålla den mer än som läsarens suggererade association. Så här lyder en version av kupletten (ur Pavel Zal'cmans roman Ščenki från 1952 (del V kapitel 3) med mitt försök till översättning) varav alltså bara första raden citeras i novellen (verbet "vystavlena" ("ställt ut") bidrar möjligen till associationen):

В магазине Кнопа I butiken Knopp

Выставлена жо... Har de ställt ut en sno...

Не подумайте худого, Tänk nu inte på nåt fult,

Желтые ботинки! En snobbig liten känga!

Pavel Zal'cman, Ščenki. Proza 1930-50-ch godov, Moskva 2017.

Med att modern läser bibeln understryks att hon tillhör obnovlency, förnyarna inom den ortodoxa kyrkan där annars traditionen bjöd att enbart en andaktsbok ("molitvoslov") skulle läsas i hemmet. Det förklarar kanske också hennes upprymdhet - här står ju allt!
} 
fastställd ordning; det är "som alltid" som jaget och fadern drar sig undan från moderns religiösa högtidlighållande:

Маман прислушалась. - Идут, - вскочила она и концами пальцев обмахнула грудь - как стряхивают крошки.

Как всегда, мы вышли переждать под грушами. Кулич был виден. Цинерария стояла на окне.

- Христос,

- задребезжали в доме. Запах церкви прилетел. Кругом звонили. Кошка, глядя вверх, следила за аэропланами. Затопотали по ступенькам. Духовенство, надевая шляпы и качая талиями, спускалось, и маман, величественная, с крыльца кивала ему.

Maman lyssnade. - De kommer, sade hon och for upp och viftade över bröstet med fingerspetsarna som när man borstar bort smulor.

Som alltid gick vi ut för att vänta under päronträden. Påskkakan syntes. Cinerarian stod i fönstret.

- Kristus,

skallrade det i huset. Kyrkolukten kom drivande. Det ringde i klockorna runtom. Katten tittade uppåt och följde aeroplanen. Det klampade på trappstegen. Prästerskapet tog på sig hattarna och gick neråt med vaggande midjor, och maman, majestätisk, nickade åt dem från trappan.

Även i detta finns betydelseskapande överensstämmelser med vad som tidigare skildrats: Prästerskapet "kommer" ("idut") liksom affischerna utlovade att metropolit Vvedenskij "var på väg" ("edet"). Den från affischerna citerade och i texten utställda frågan "Finns gud?" blir nu ett utropat, skallrande "Kristus" beledsagat av kyrklig lukt och klockringning. Denna variant på eller brottstycke av påskens lyckliga utrop att "Kristus är uppstånden" ("Christos voskrese") profaneras eller vardagliggörs sedan av kattens blickande i skyn efter flygplan (som redan tidigare figurerat som den nya tidens föremål för existentiell längtan) samt av prästernas klampande och vaggande. Även moderns inledande viftande över bröstet, som bara liknas vid att borsta bort smulor kan tolkas som en profan, främmandegörande beskrivning av hur hon korsar sig. Liksom biskopen med slaskhinken i "Kozlova" skänker detta trivialiserande av det kyrkliga samtidigt en vardaglig och mänsklig betydelsefullhet åt ritualerna. Detta rymmer också ett slags högtidlighållande.

Husvärden dyker även i denna kapitelinledning upp, nu med sin fru för att delta i moderns religiösa firande medan jaget och fadern sin morgonrutin ändå trogna smiter ut i samhället; fadern till sina patienter, med vilket 
det framgår att han är läkare, och jaget för att ensamt ströva omkring denna lediga dag. Att fadern är läkare ger bakgrunden till varför jaget förklaras vara ett främmande element, det vill säga borgerlig, senare i kapitlet. Förutom till yrket påminner denne liksom tidigare fäder i novellerna om Dobyčins egen såsom han skildras i romanen Gorod Enn. I romanen drar sig fadern på liknande sätt undan den religiösa och borgerligt högtidliga modern, som också kallas maman, för att gå till sina patienter.

Att det är en vanlig söndags ledighet denna påskdag som man dock är rädd ska sväva ut i ytterligare firande på grund av påsken antyds av några varnande, tidstypiska affischer: ${ }^{308}$

Гуляли семьи. Маленькие дети спали на руках. Колокола звонили. «Праздники, - расклеены были афиши, - дни есенинщины».

Familjer var ute och gick. Småbarn sov i famnen. Klockorna ringde. "Högtider", stod det på uppsatta affischer, "är esenintider".

Det i samtiden etablerade begreppet "eseninščina", efter poeten Sergej Esenin med suffixet -ščina som uttrycker en skadlig omåttlighet ("är dagar av esenineri” är en mer ordagrann översättning), fordrar viss förklaring. Det är troligen partiets ungdomsorganisation Komsomol som ligger bakom dessa affischer som en uppfordran mot fylleri, våld och skadegörelse i samband med högtiden.

Landsbygdspoeten Sergej Esenin hade efter sitt självmord I925, vilket sågs som en konsekvens av hans dekadenta rumlande leverne sedan han flyttat till Moskva och sedan Petrograd, kommit att ge namn åt vad som betecknades som en under tjugotalet tilltagande pessimism eller undergångsstämning hos ungdomen. Detta samhällsproblem behandlade den i förra kapitlet nämnda folkkommissarien för upplysning Anatolij Lunačarskij I927 i ett långt anförande vid Kommunistiska akademien under rubriken "Upadočnoe nastroenie sredi molodeži: Eseninščina" ("Undergångsstämningen [eller Känslan av förfall] bland ungdomen: Esenineriet"). Han beskriver där det han kallar huliganism och pessimism i samtiden som två symptom på samma sjukdom, samma "esenineri". Denna stämning utgjorde ett stort samhällsproblem då den tog sig uttryck i en reell ökning såväl av antalet våldsbrott (det vill säga "huliganism" av den sort som tidningstexten i förra kapitlet rapporterade om, vilket gjort städerna mer osäkra)

\footnotetext{
${ }^{308}$ Den två dagars påskledighet som gavs i början av tjugotalet i Brjansk utfärdades i en skrivelse I919 om årets lediga dagar utöver söndagarna som kuriöst nog Dobyčin själv, som tillfällig föreståndare för arbetsförmedlingen, står som undertecknad till. Den extra ledigheten var troligen avskaffad när novellen skrevs. Skrivelsen citeras i Ė. S. Golubeva, Pisatel' Leonid Dobyčin i Brjansk, Brjansk 2005, 34-35.
} 
som av självmordsfrekvensen (vilket Lunačarskij i sin tur ser som ett utslag av "pessimismen").

Lunačarskijs utläggning om esenineriet går ut på att förklara att det är ett fullständigt onödigt samhällsfenomen som enbart kommer sig av en brist på politisk förståelse för den lagbundna, nödvändiga utvecklingen mot ett socialistiskt idealsamhälle efter revolutionen som bara inte är färdigbyggt än. Att borgerliga specialister, vilka Lunačarskij också betecknar som farliga "främmande element" (vilket jaget på grund av sin familjebakgrund snart blir kallat i kapitlet) har höga löner och vältrar sig i NEP-tidens lyx, vilket förstås svider i proletariatets ögon och bidrar till en känsla av återgång till det gamla, är en nödvändig del av denna utveckling. (I både "Požalujsta" och "Sad" gavs uttryck för en sådan förbittring över ingenjörernas höga löner.) Att dessa löner och denna småborgerliga lyxkonsumtion är något nödvändigt medan många proletärer går arbetslösa, förklarar Lunačarskij med att bara en skyndsam industrialisering kan ge den ekonomiska utveckling som krävs för att finansiera kvalificerad utbildning av proletariatet, så att på sikt de främmande borgerliga elementen kan ersättas. Den allmänna förståelsen för detta menar Lunačarskij dock försvåras av det område som han som folkkommissarie för upplysning har ansvar för: av dekadenta och pessimistiska istället för pedagogiska och uppbyggliga tendenser inom den samtida kulturen. Roten till det onda ser han i den gamla "ruttnande och döende" intelligentian. Storstädernas borgerliga intelligentia ger Lunačarskij även skulden för Esenins förfall och självmord. Esenins självmord tolkar Lunačarskij som i själva verket grundat i en sista heroisk självinsikt hos Esenin om hans del i spridandet av pessimism och sedefördärv, vilket han på detta sätt tog konsekvensen av.309

309 "Esenin bestämde: synderna är starkare än jag, de dödar poeten i mig, vill göra mig till en kälkborgare som sotar ned himlen [...] Nej. Jag dödar [synderna], för i mig lever ännu stark poeten. [...] / Esenin ville leva som en riktig människa eller inte alls. / Det är därför som jag säger att Esenins porträtt gör honom till en kämpe mot esenineriet.” A. V. Lunačarskij, "Doklad A. V. Lunačarskogo", Upadočnoe nastroenie sredi molodeži: Eseninščina, Moskva 1927, 5-44, 37. Detta är vad Lunačarskij menar att Esenin själv vänt sig till honom för att förklara. Lunačarskijs bild av Esenin är att alltså den av en oskyldig och lovande men sedan fördärvad, aldrig helt förverkligad poet som vill skona samhället från sin egen "entartete Kunst" som han kommit till ideologisk insikt om. Den tolkningen förebådar den form av bikt, botgöring och anpassning som med tilltagande skoningslöshet skulle komma att avkrävas författare vid övergången till trettiotalet. Med ett omvänt perspektiv skulle åtminstone Majakovskijs självmord 1930 kunna ses som resultatet av denna kulturpolitik - att han genom döden bevarade sig själv som poet - och att denna generation, som Jakobson uttryckte det, genom kravet på politisk inställsamhet och skönmålning "förslösade sina poeter" ("O pokolenii, rastrativšem svoich poètov" (193I), Selected Writings, V, Berlin, New York, 1979, 355-38I). Till Lunačarskijs retoriska vrängningar med Esenins död bör tilläggas att många, trots eller 
Förutom mer av politisk fostran, mer propaganda för att göra samhällsutvecklingens förutsättningar förståeliga samt att främja konst som inte är fördärvande som intelligentsians, utan gör ungdomarnas liv kulturellt rikare, framhåller Lunačarskij i sitt tal fysisk kultur (frisksport) som en särskilt effektiv medicin mot esenineriet. Denna fysiska kultur, som han förklarar kan omfatta allt från "hygienisk gymnastik" och sport till expeditioner och exkursioner med klara målbilder, ser Lunačarskij som en metod att på ett godartat sätt ge utlopp för ungdomens bubblande krafter. ${ }^{310}$

Så, det citerade slagordet mot esenineriet på affischerna följs nu av att huvudpersonen - efter att ha mött moderns väninnor som uppklädda skyndar till påskfirandet hemma hos henne - $\mathrm{i}$ en tillsynes just ungdomligt pessimistisk sinnesstämning går och sätter sig i en park för att fördriva tiden:

[...] Я свернула в садик, нелюбезная.

Шуршали листья - прошлогодние. Травинки пробивались.

- В Пензе, - разговаривали на скамье, - все женщины безнравственны.

[...] Jag gick in i parken, nedstämd.

Löv prasslade, fjolårets. Grässtråna tog sig upp.

- I Penza, sade några som satt på en bänk och pratade, är alla kvinnor omoraliska. ${ }^{\text {II }}$

Det uppsnappade samtalet ansluter till debatten om sedefördärvet i samtiden. Indirekt anspelar både rörelsen i naturen och samtalet på jagets innestängda vårkänslor, hennes dragning till en man som antastat henne, vilka möjligen hennes nedstämdhet kommer sig av. Så dras esenineriet försiktigt in i hennes personliga mötesproblematik, en sammankoppling som kommer att fullbordas i skildringen av fysisk kultur i sista kapitlet som avgörande för jagets och novellens konflikt.

kanske just på grund av dess så dramatiska gestaltning (med en sista dikt skriven i blod), betvivlade att det ens rörde sig om ett självmord.

310 Varken i Lunačarskijs tal om esineriet eller i Dobyčins lekfulla betecknande av det som ett "skojarmode" framgår riktigt den brutala verkligheten bakom denna "stämning bland ungdomen" som upplevdes i samtiden. Ett exempel på den verkliga bestialiteten är fallet bakom det alternativa begreppet "čubarovščina" som Lunačarskij också använder för detta samhällsfenomen. Begreppet går tillbaka på en gruppvåldtäkt i Čubarovgränden i Leningrad 1926 där en kvinna, uppenbarligen enligt en utifrån tidigare gånger etablerad ordning, infångades och ropande utbjöds mot betalning till en mängd tillströmmande män. Att såväl komsomoler som partimedlemmar fanns bland dem som deltagit i våldtäkten bidrog till uppmärksamheten och att en bred kampanj mot så kallad huliganism lanserades. E. A. Ignatova, Zapiski o Peterburge: Žizneopisanie goroda so vremeni ego osnovanija do 4 o godov XX veka, Sankt Petersburg 2003, 65I-654.

3II Denna grästrånas profana, cykliska återuppståndelse skildrades även i "Proščanie", då efter påsken, med en bara något annan formulering:"Раздвигая прошлогодний лист, полезли из земли травинки." ("Grässtrån sköt ett fjolårslöv åt sidan och kröp upp ur jorden.") 
I denna situation dyker den koketta kollegan Ivanova upp, smyckad med violer av kalikå och på glatt humör. Hon säger att hon tror sig veta var "han", det vill säga hennes Žoržik, befinner sig och drar åter med sig jaget som en passiv åskådare. De går genom staden, förbi torget vid arbetsplatsen, med en glimt av finklädda kavaljerer som håller varandra runt axlarna och knackar i ägg i något slags profant påskfirande, och går in på biblioteket: "Засаленными книжками воняло." ("Det stank av flottiga böcker.") Och där är mycket riktigt Žoržik men tillsammans med en annan kvinna som de enda två deltagarna i ett sammanträde för Sällskapet bibliotekets vänner. Deras ironiskt beskrivna förfärdigande av ett andefattigt, politiskt aktuellt slagord som duktigt ansluter sig till den officiella diskursen framställer samtidigt denna fettglänsande kvinna som överlägsen Ivanova. I sin ögontjänande politiska verksamhet, sin uppvisade rödhet, besitter hon det nya samhällets kapital, medan Ivanova som tillsynes svartsjukt nedslås av synen av dem inte ens kan uttala ordet "lózungi" ("slagord" eller "paroller") rätt:

[...] Общество друзей библиотеки заседало - Жоржик и стеклографистка Прохорова. В голубом, она жевала что-то масляное, и ее лицо блестело.

Жоржик был рассеян. Вдохновенный, он ерошил волосы. - «Проклятие тебе», - раскрашивал он надпись, - «мистер Троцкий». - Вежеталем «Виолетт де Парм» пахло.

- Лозгуны́!? - приблизившись, спросила Иванова мрачно. [...]

[...] Sällskapet bibliotekets vänner sammanträdde - Georgis och glasskriverskan Prochorova. Klädd i ljusblått, tuggade hon på något fett, och hennes ansikte glänste.

Georgis var disträ. Inspirerad rufsade han om sitt hår. - "Förbannade", färglade han texten, "mister Trotskij". Det luktade av hårvattnet "Violette de Parme".

- Är det palorrer? frågade Ivanova dystert när hon närmat sig. [...].312

Žoržik som tillsynes försöker lägga an på denna Prochorova framställs samtidigt med en avslöjande småborgerligt fåfäng hårvattenlukt. Det framstår också parodiskt hur han liksom i konstnärlig inspiration rufsar om sitt hår fast han bara färglägger de dessutom allt annat än egensinniga parollerna. Hårvattnet och rufsandet kan också, med anknytning till annonsen med Anna Csillag och tilltalet flintis tidigare, antyda en generande, banalt mänsklig tunnhårighet. Med den viollukt som det flärdfulla namnet anger förbinds han också trots allt med den koketta Ivanova prydd med just violer

312 Titeln "mister" syftar på att Trotskij skrev artiklar i utländska medier efter sin utvisning i februari 1929. I sovjetisk press förklarades han därmed ha trätt i tjänst hos bourgeoisien. Enligt kommentarerna i PSSP härör stämpeln "mister Trotskij" från en rad artiklar i Pravda i mars 1929 av Emel'jan Jaroslavskij (M. I. Gubel'man). PSSP, 472. 
i tyg. Redan i förra kapitlet antyddes han vara föga trogen mot henne, hon som vill ha honom. Nu framgår att han siktar högre enligt det nya samhällets normer.

Dessa normer upplever jaget under tiden då hon, som dragit sig undan $\mathrm{i}$ biblioteket från deras kärlekstriangel, ser sin överordnade på ett fotografi i tidningen med ett uppfordrande plakat: "В газете я нашла товарищ Шацкину: она идет в рядах, - «Прочь пессимизм и неверие», - несет она плакатик" ("Jag fann kamrat Sjatskina i tidningen: hon gick i leden, 'Bort med pessimism och tvivel', stod det på plakatet hon bar"). Demonstrationen exemplifierar hur det nödvändiga arbetet med att stävja det reella våldet och känslan av förfall i samtiden också utnyttjades i politiska kampanjer där all form av pessimism och allt tvivel på den nya ordningen framställdes som en sjukdom som måste botas. ${ }^{13}$ Så upplever kanske jaget detta plakat, det vill säga som riktat även mot hennes kärlekskranka nedstämdhet, hennes tvivel på sig själv och problem med att finna något betydelsefullt i sitt liv.

Likt ett svar störtar regnet ner utanför, dörren öppnas och någon uppenbarar sig som har liknande signalement som den okände kavaljer som jaget fixerat sig vid likt en frälsare, någon som kan skingra hennes pessimism:

Дождь хлынул. Отворилась дверь. Все посмотрели. - Гришка с огородов, - объявила Прохорова.

Невысокий, он стоял, отряхивая кепку с клапаном...

Regnet vräkte ner. En dörr öppnades. Alla tittade. - Grisjka från trädgårdarna, förklarade Prochorova.

Han var ganska liten och stod och skakade av en keps med bakstycke...

Inte så lång och med en keps med klaff - allas blick och de tre punkterna antyder betydelsen i detta samtidigt som det banala smeknamnet Griška och vardagligheten $\mathrm{i}$ att han kommer in från trädgårdslanden (där han kanske arbetar) trivialiserar honom. Är han den jaget söker? I vilket fall tar hon inte tillfället i akt att prata med honom och inget mer om honom nämns i kapitlet.

Jaget har härefter följt med de andra tre till en servering. Istället för en stund av trivsam mänsklig samvaro med dessa, istället för vänskap, pekas

\footnotetext{
313 I början av trettiotalet, efter den första femårsplanen, efter alla offer som kollektiviseringen av jordburket skördat i våld och massvälter, skulle det i samma anda från högsta ort komma att formuleras som ett krav på allmän optimism. Mest kännettecknande är kanske Stalin påbudsliknande konstaterande 1935: "Жить стало лучше, товарищи. Жить стало веселее." ("Livet har blivit bättre, kamrater. Livet har blivit roligare.") Även i Gor'kijs utformande av en socialistisk realism utgör behovet av optimism i kulturen en grundval.
} 
hon nu tydligt ut som en fiende som bara på nåder accepteras i detta samhälle. Som ett svar på detta uttrycks i klara ord om än i en allmän formulering något av vad huvudpersonen faktiskt tänker, känner och längtar efter. Detta följer efter att ett förbud mot att sjunga på serveringen först påtalas av Žoržik, möjligen som en del av en allmän förbudsiver mot alla former av "esenineri", något de i alla fall tycks ense om enfalden i (en enfald som också understryks av feluttalet hos den som påminner om förbudet).314 De tycks egentligen lika i sin längtan efter något betydelsefullt; men de andra tre, som saknar en stämpel som främmande borgerliga element, inställer sig $\mathrm{i}$ den nya ordningen samtidigt som en skenhelighet i detta lyser igenom. Ivanova sviker här jaget som vän för den politiskt korrekta Prochorova trots att hon tycks utgöra en kärleksrival:

[...] - Жаль, - горевал он, заедая, - что здесь не разрешают петь: как дивно было бы. - Да, - соглашались мы, а подавальщица вздыхала в другой комнате и говорила: - Запрещёно.

- Вы чуждая, - сказала Прохорова, - элементка, но вы мне нравитесь. - Я рада, - благодарила я. Тускнели понемногу лампы. Голоса сливались. Откровенности и дружбы захотелось. Иванова встала и пожала Прохоровой руку. - Я иду, - бежала я тогда.

[...] - Synd, sade han beklagande och svalde, att de inte tillåter sång här: så underbart det hade varit. - Ja, instämde vi och servitrisen suckade i andra rummet och sade: - Förbjutt.

- Ni är ett främmande, sade Prochorova, element, men jag tycker om er. - Det gläder mig, tackade jag. Lamporna mörknade lite. Rösterna flöt ihop. Man längtade efter öppenhet och vänskap. Ivanova reste sig och skakade hand med Prochorova. - Jag går, sade jag då och skyndade iväg.

Underdånigt sväljer jaget den inlindade anklagelsen. Det hon uttalar som glädjande får lamporna att mörkna och rösterna att flyta ihop. Den hårt återhållna smärtan, som detta utpekande av hennes ensamhet åsamkar henne, kommer till uttryck i hennes inre, i en enkel längtan efter öppenhet och vänskap. Det finner hon inte i sin samtid som framstår som präglad av

${ }^{14}$ Dobyčin har tidigare beklagat sig för Slonimskij över den nya förbudsivern och nostalgiskt jämfört med det förrevolutionära samhället i Dvinsk (2I mars I926 (brev 78), PSSP, 286): "При входе в Сквер написано, чего там нельзя делать. Заканчивается так: / «За неисполнение - штраф или принудительных работ». / Я вспомнил Двинск, где на вывесках было: «Табак, сигар и папирос» и «Сыр, сметана и яиц»." ("Vid ingången till Kvartersparken står det skriver vad man inte får göra dära. Det avslutas så här: / "Vid överträdelse - böter eller straffarbete." / Jag kom att tänka på Dvinsk och vad som där stod på skyltarna: "Tobak, papyross, cigarr" och "Ost, smetana, ägg". (Skylttexterna i Dvinsk följer dessutom den tvåstavighet Dobyčin själv dras till att bevinga vardagen med; i Gorod Én kommer detta till uttryck i huvudpersonen glada sjungande och skanderande av dylika texter och företagsnamn som något i sig meningsgivande.) 
förljugenhet och rädsla under ordens glättiga yta. Hon har bara valet att dra sig undan. Så blir hennes personliga mötesproblematik, hennes längtan efter något mer betydelsefullt $\mathrm{i}$ sitt liv, politisk. Hon blir ett ensamt främmande element med endast en inre, instängd frihet. Och så kommer denna dag tillika skildringen av denna vår att sluta för huvudpersonen. Den bar ingenting med sig.

Trots helgdagen följer kapitlet samma mönster som de föregående två. Hon återvänder nu hem, som tidigare efter arbetet, bara för att åter ge sig ut i samhället för ett kulturellt kvällsnöje innan dagen är all. Som en fortsättning på vad jaget med sin bakgrund just blivit utpekad som beskrivs husvärdparet stå och tjuvlyssna utanför fönstret på vad hennes mor utbreder sig om inför sin beundrande och instämmande gäster. Att jaget snubblar till när hon går iväg igen behäftas även det med en ideologisk suspekthet av omgivningen: "Я уходила, спотыкаясь. - Набралась, - оглядывались на меня. Хихикнув, совторгслужащие говорили шепотом: - Кабу́ки." ("Jag gick snubblande iväg. - Hon har tagit sig något, såg man sig om efter mig och sade. Några sovjethandelsarbetare fnissade och talade viskande med varandra: - Kabúki.") Den berusning hon tillskrivs inordnas med viskningen om "kabuki" i samhällsdiskursen om ungdomens förfall. Inspirerade av ett japanskt gästspel i Moskva 1928 med den japanska traditionella teaterformen kabuki organiserade en grupp arbetare i byggnadsfackföreningen ett hemligt sällskap under samma namn som det 1929 (samma år som "Portret" skrevs) hölls rättegång emot för deras eseninartade dekadens. Detta är alltså vad man associerar till när man ser en ensam, snubblande ung kvinna som ger sig ut i kvällen. ${ }^{315}$

Viskningen kan samtidigt tolkas som en metapoetisk antydan om det kabukiartade såväl i den ideologiskt burleska föreställning som jaget beger sig till som i själva novellens gestaltning av denna samtids ideologiska masker genom sinnliga, musikaliskt sammanvävda kontrasterande intryck - det

\footnotetext{
315 Men vems association är det egentligen? En möjlighet är också att jaget hört fel för att hon är upptagen av sådana tankar och denna kulturella samhällsdiskurs (ett felhörande som liknar det som Puškinanekdoten i förra kapitlet byggde på). Kanske säger de i själva verket "kablukí" ("klackar") som är en betydligt naturligare orsak och kommentar till hennes snubblande - klackar kommer hon i vilket fall i nästa kapitel beskrivas ha vid utgången från hemmet.) Detta sovjetiska kabuki-sällskap beskrev i vilket fall sin verksamhet som "культивация «красивой жизни», «афинских ночей» с женщинами и вином" ("kultivering av 'det vackra livet', 'Atenska aftnar' med vin och kvinnor"). Ė. B. Mekš, "Istoriko-kul'turnyj areal rasskaza L. Dobyčina 'Portret'", PLD, 273-274.
} 
som kritiskt betecknades som en "analytisk metod" vid den första publiceringen av novellen i tidskriften Strojka. ${ }^{116}$

В театре, как всегда, стреляли. Чистильщик сапог укладывал свой шкаф. Мороженщики, разъезжаясь, грохотали.

Шум стоял на улице Москвы. На паперти толпились кавалеры, покупая семечки.

В фойе чернелись пальмы. Рыбки разевали рты. Гремел оркестр. Зрители приваливались к дамам. Али-Вали́ отре́зал себе голову. Он положил ее на блюдо и, звеня браслетами, пронес ее между рядами, улыбающуюся.

- Не чудо, а наука, - пояснил он. - Чудес нет.

Мы переглядывались в изумлении. У дверей толкались. Зашипев, взвилась ракета. Звезды над аптекой вздрагивали.

Я одна осталась. В темноте отзванивали. Щелкали по башмакам шнурки.

- Укра́инская ${ }^{17}$ труппа топотала, вскрикивая: - Гоп. Губернский резерв милиции раздевался, сидя на кроватях.

Сонные собаки подымали головы. В разливе отражались какие-то огни.

На огородах было тихо. Ничего не видно было. Сыростью прохватывало.

Det sköts som alltid inne på teatern. Skoputsaren packade ihop sitt skåp. Glassförsäljarna åkte dundrande iväg.

Bullret steg från Moskvas gata. Kavaljererna flockades på kyrktrappan för att köpa solrosfrön.

Palmerna stod mörka i foajén. Fiskarna gapade med munnarna. En orkester dånade. Männen i publiken lutade sig mot damerna. Ali-Valí skar av sig huvudet. Han lade det på ett fat och bar det mellan raderna, rasslande med armbanden och leende.

- Det är inget under utan vetenskap, förklarade han: Det finns inga under. Vi blickade häpna mot varandra. Det knuffades vid dörrarna. En raket väste till och flög upp. Stjärnorna ovanför apoteket darrade.

Jag blev ensam. Kyrkklockorna ringde ut i mörkret. Snörena knäppte mot kängorna.

Den ukrainska truppen stampade och skrek: - Hopp. Guvernementets reservmilis satt på sängarna och klädde av sig.

${ }^{316}$ Mekš menar att såväl Dobyčins egen gestaltning som den sovjetiska samtiden i sig kan likna teaterformen Kabuki och nämner dess maskeradlika ideologisering och skarpa kontraster. Också teaterformens samtidighet av händelser på olika platser på scenen och syntes av sång, dans och drama, med en kroppslighet och könsöverskridanden som vetter mot det burleska, liksom dess stiliserade uttryck väcker associationer till Dobyčins prosa. Ė. B. Mekš, "Teatr Kabuki v russkom variante (rasskaz Dobyčina 'Portret')", DS, 22-33, 26; "Kabuki", Wikipedia, https://sv.wikipedia.org/wiki/Kabuki, 2019-o6-oI.

317 Den angivna okonventionella betoningen av "ukráinskaja" (istället för "ukraínskaja") överensstämmer med moderns uttal i första kapitlet när hon återgav en nyhet som gästerna berättat. Förutom att möjligen antyda hur jaget ändå bär med sig något av moderns diskurs ute i staden gör betoningen att ordet faller in i en taktfast tvåstavighet som framhäver deras stampande och rop. 
De slumrande hundarna lyfte på huvudena. I översvämningen speglades några eldar.

Det var tyst inne i trädgårdarna. Man såg ingenting. Fukten kom krypande.

De återkommande vardagliga intrycken väcks till en avklingande sång om denna samtida tillvaro. Det skjuts som alltid i de nya sovjetiska dramerna på teatern. På den avsakraliserade förgården till den före detta kyrkan är kavaljererna igen och föreställningen där visar med lekfull magi med bibliska referenser (Johannes döparens huvud på ett fat) på att tro på under är vidskepelse. Efter en stunds samvaro och i ett upplevt vi i denna larmande samtid är jaget sedan åter - efter en trängsel vid utgången som återknyter till det första mötet men som nu inget sker $\mathrm{i}$ - ensam igen. Denna gång finns inte heller hennes far med vid hemgången. Hennes köttsliga men omöjliga längtan antyds genom de dansande militärerna och poliserna som klär av sig. Till ljudet av kyrkklockorna som ringer ut påsken (kyrkklockor som i Brjansk snart efter att novellen skrevs inte skulle ringa längre) liksom avstannar allt för henne i en rå, jordisk kyla.

Magikerns förklaring av sitt trick återknyter också till debatten om guds existens i förra kapitlet. Att detta slags "vetenskapliga" förklarande hörde till ordningen driver Michail Bulgakov senare med i sin föreställning på Varietéteatern i Mästaren och Margarita där publiken förväntar sig att Woland och hans anhang avslutningsvis ska avslöja att det inte är magi. ${ }^{318}$ Frånvaron av under i denna samtid går så antydningsvis igen i frånvaron av något mer betydelsefullt i huvudpersonens liv. Här sker inte längre några möten bortom orden. Hon tycks inte längre göra sig några föreställningar om det. Möjligen återknyter slutligen de tysta trädgårdarna till den Griška som vi aldrig fick veta om han var den hon söker. Men nu syns inget mer i mörkret.

\section{4 (Det frånstötande porträttet)}

Novellen och därmed novellsamlingen hade kunnat sluta så. Allt har redan hänt; inget har hänt. Det var som alltid den våren. Det fjärde kapitlet förflyttar oss med ens till hösten och ger med dess inträde en naturlig, stämningsmässig avrundning. Med distansen till vårens händelser framträder

\footnotetext{
318 Erofeev gör också kopplingen till Bulgakov i "O Kukine i mirovoj garmonii", PLD, 5I-56, 53. Liksom hos Bulgakov med sin mästare rymmer detta potentiellt en kritik mot samtidens vilja att reducera konstens magi till vetenskap och hantverk som jag varit inne på både i samband med hur debatten i Russkij sovremennik om mästare respektive primitiva hantverkare tematiserades i "Erygin" och hur konstens hemlighet förklarades i "Konopatčikova" av den duktigt sovjetiska unge konstnären som enbart en fråga om färg. Så uppstår inga under och inte heller några mänskliga möten $\mathrm{i}$ konsten.
} 
också ett sammanfattande perspektiv ur gestaltningen trots att huvudpersonen som förut är försänkt i en konkret dag. Hon gör inga konklusioner, hon reflekterar inte mer än tidigare över sin tillvaro. Men hon upplever något som hon i slutet ännu inte tycks klar över innebörden i. Hon upplever ett slags slut.

Med bristen på sammanfattande reflektion, med avgränsningen till hennes stundliga upplevelser följer också att en mycket avgörande händelse som troligen har skett sedan påsken i förra kapitlet endast blir vagt antydd.

Förflyttningen till hösten slås an med att päron i inledningsmeningen nu faller dunsande från det träd som fadern och jaget på påskdagen gick ut och ställde sig under: "Груши падали, стуча." ("Päronen föll dunsande.") Händelsen görs stundlig och vardaglig genom att fungera som en signal för husvärdparet att genast kasta sig ut efter fallfrukten som de tycks anse att den som hinner först har rätt att ta (en regel som även omfattar grannens äpplen), en rätt som uttrycks på latin (kanske av författaren snarare än jaget): "jus tollendi". Jaget får en tidning med posten och läser det sovjetiska nöjesskvallret - där den amerikanska filmen The General ideologiskt ifrågasätts i stil med faderns tidigare undran om ideologin i filmen med Richard Talmadge -319 när modern kommer in: "- С праздником, - пришла маман. Демонстративно посмотрела и, вздыхая, сунула свой поминальник за горчичницу." ("- Trevlig helg, kom maman in och sade. Hon gav mig en demonstrativ blick och stack suckande in sin minnesbok över avlidna bakom senapsburken.") Den demonstrativa blicken och minnesboken över de avlidna som hon varit och bett för medan dottern läser nöjessidorna denna troligen vanliga söndag - det är hela den vardagligt förankrade antydningen. Men faktum är att efter det att fadern gav sig av till sina patienter på påskdagens morgon i förra kapitlet är han försvunnen från berättelsen. Jagets hemväg utan fadern, med mörkret och fukten i slutet av förra ka-

\footnotetext{
319 Kritiken i den sovjetiska pressen som här påtalas är att huvudrollsinnehavaren Buster Keaton spelar en ideologiskt sett förkastlig tågingenjör som försöker ta värvning hos och på ett avgörande sätt hjälper sydstaterna: "почему не северянина изображает Бестер Китон?" ("varför spelade inte Buster Keaton en nordstatare?") är den fråga som återges i novellen. Detta förbiseende av den konstnärliga genialiteten i Buster Keatons film präglade också det amerikanska mottagandet. Keatons förmåga att genom oväntade associationer utveckla det komiska ur tillsynes triviala, alldagliga situationer, som i denna film var försänkt i ett historiskt drama, en skildring av allvarliga historiska händelser (vilket gjorde även samtidens amerikanska kritiker osäkra på hur de ideologiskt skulle förhålla sig till filmen), kan Dobyčin ha känt sig befryndad med.
} 
pitlet, kan nu ses ha förebådat något. Har alltså fadern gått bort? Är det honom som modern bett för med sin minnesbok medan jaget inte ägnar honom en tanke? Det får vi inte veta bestämt.320

Härefter har jaget gett sig ut - förstår vi nu av de gatubilder som följer. Och möjligen som en ersättning för jagets åminnelse av sin far, eller ett uttryck för hennes undertryckta sorg, framträder tillvaron med lyrisk resonans genom den mer påtagligt taktfasta rytm som de vardagliga intryckens små rörelser dras in i. Det tidsbundna dras likt i inledningsnovellen "Proščanie" in i något av en tidlös, konstnärlig avskedssång. Även den här samtida vardagen får därmed något minneslikt över sig - som om tillvaron redan i sig isolerats från det pågående varat, som om utvecklingen avstannat.

Variationen av tidigare motiv dras in i de banala begivenheter som äger rum med fokus på dem som impressioner, intryck av ett tillstånd, i den stadsträdgård med utblommade rabatter som nu talande benämns "Kulturens". I inledningsnovellen stod antydningsvis Konsten inför att ge sig av till provinsen för att där söka sig ett annat liv, inför att vända sig ut mot den vardagliga tillvaron och där söka de mänskliga mötena bortom orden som något konstnärligt betydelsefullt. Det sökandet tar sig nu detta slutliga uttryck som ett slags Kulturens höst. Ingenting händer mer. Det finns inget mer att säga. Ingenting står längre på spel. Det är bara denna sovjetiska lediga dag med en lång rad av indirekta farväl. Och det inleds med en melankolisk kärlekssång från en redan tidigare figurerande skoputsare vars kroppsliga detaljer också anknyter till huvudpersonens längtan efter ett möte (här nämns så också hennes klackar som hon möjligen feltolkade kommentaren om (som "kabúki" och inte "kablukí") i förra kapitlet):

Деревья были желты. Листья приставали к каблукам.

- Рахиля,

\footnotetext{
${ }^{320}$ Detta faderns plötsliga försvinnande från berättelsen har flera likheter med hur faderns tidiga bortgång skildras i den autofiktiva romanen Gorod Én som Dobyčin som sagt gjort ett första försök med innan han skrev "Portret": även där ger han sig i väg till en patient den sista gången han är vid liv. Han tar då med sig det unga jaget och återvänder i mörkret. Det sista de gör tillsammans är att de hör en vagn som inte skramlar på grund av de nya gummidäcken. I början av det följande kapitlet (9) konstateras lakoniskt hans död den hösten av blodförgiftning vid en obduktion vilket följs av en påtaglig brist på känslor och reflektion kring det hos jaget. PSSP, 125. Att denna brist på reflektion är ett utdrag för undertryckt sorg är inte en given tolkning. Jaget är också försjunken i nuet, i vardagen, och det är en del av Dobyčins sätt att gestalta att inte avlägsna sig från denna närvaro för en sådan förklaring; det man vet förklarar man inte för sig själv.
} 
- напевал меланхолично чистильщик. Его фуфайку распирали мускулы. В разрезе ворота чернелись волоса. Шнурки для башмаков, повешенные за один конец, качались.

- вы мне даны.

В саду Культуры клумбы отцвели. «Желающие граждане купить цветы, - не сняты были доски, - можно у садовника». Фонтанчик «гусь» поплескивал.

Борцы сидели, подбоченясь. В модных шляпах, они напоминали иностранцев из захватывающих драм. Гражданки, распалясь, вставали и подрагивали мякотями.

В цирке щелкал хлыст. Мелькали за открытой дверью лошади. Наездница подскакивала.

Träden var gula. Löven fastnade på klackarna.

- Rachilja,

sjöng skoputsaren melankoliskt för sig själv. Hans undertröja spändes ut av musklerna. I öppningen vid halsen syntes svarta hår. Kängskosnören som var upphängda i ena änden vajade.

- ni har blivit min.

I Kulturträdgården var rabatterna utblommade. - "Medborgare som önskar köpa blommor", stod på skyltarna som inte tagits ner, "kan göra så hos trädgårdsmästaren". Fontänen "gåsen" plaskade.

Brottarna satt, med händerna i sidorna. I sina moderna hattar påminde de om utlänningar i gripande dramer. Några kvinnliga medborgare som blev uppeldade reste sig och skakade lite på mjukdelarna.

På cirkusen smällde en piska. Innanför den öppna dörren flimrade hästarna förbi. Ryttarinnan for upp och ned. 321

32I Rytmen följer en tvåstavig meter. Den citerade sången bidrar till att göra den mer manifest, mer taktfast och påtaglig, men både före och efter sången kan en så gott som obruten meter avkodas. Även i citaten av de parodiskt enfaldiga skyltarna i trädgården bibehålls exempelvis en diskret tvåstavighet (understrykning markerar sammanfall av metrisk och syntaktisk betoning, kursiv en syntaktiskt obetonad stavelse): "В саду Культұры клұмбы отцвели. «Желающие граждане купить цветы, - не сняты были доски, - можно у садовника». Фонтанчик «гұсь» поплескивал." (Som jag försökt bevara i översättningen: "I Kulturträdgạ̊rden vạr rabattterna utblommade. - 'Medborgare som önskar köpa blommor', stọd på skyltarna som inte tạgits nẹr, 'kan göra såa hos trädgårdsmästaren'. Fontänen 'gạasen' pla laskade." Den lätt tvingade betoningen av "utblommade" och "medborgare" som krävs vid skandering exemplifierar samtidigt problemet med att strikt se till metern vid översättning; den markerade metern som där kan beskrivas som obruten säger inget om den faktiska rytmen vid en

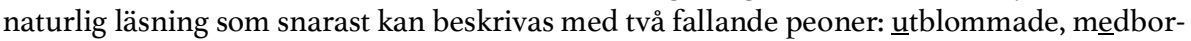
gare.) Denna metriska regelmässighet i rytmen infinner sig inte först nu i fjärde kapitlet som en del av den melankoliska höststämningen, men möjligen är brotten i metern färre än tidigare, och framförallt bidrar andra aspekter än det metriskt schematiserbara till att rytmen nu upplevs som en förenande, lyriska rörelse - från att tidigare ha funnits närvarande som 
De slutställda imperfektiva verbkonstruktionerna i slutet av varje stycke "kačalis", "popleskival", "podragivali mjakotjami", "podskakivala" ("vajade", "plaskade", "skakade lite på mjukdelarna", "studsade") - framhäver tillsammans med rytmen och de detaljer som fixeras, präglade av jagets flärdfulla associationer, själva de sinnligt kittlande rörelserna som det viktiga. Härefter återknyter berättelsen också dramatiskt till sin intrig genom det sociala sammanhang som jaget, liksom utstött, övergav i förra kapitlet:

Прохорова вышла из буфета с чемпионом мира Слуцкером. Они дожевывали что-то, и ее лицо блестело.

Ивановой не было. Общественница, она работала в комиссии по проводам товарищ Шацкиной.

Кружок военных знаний занимался за акациями. - Самый, - хмурил брови лектор, - смертоносный газ - забыл его название - начинается на хве. - Карандаши скрипели.

Жоржик спрятал свой блокнот. В костюмчике «юнгштурм», он обдернулся и подошел ко мне, учтивый. - Теплый день, - поговорили мы и помолчали. Прохорова, вероломная, была видна ему. - А подмораживало уж, - сказала я. - Действительно, - ответил он, - температура превышала.

en bakomliggande faktor till dynamik i gestaltningens intryck. Det Henri Meschonnics syn på rytm som verkets levande kropp och rörelse, som jag tog upp i inledningen, belyser är att de två- eller trestaviga i metern inte är avgörande för om rytmen uppfattas som affektivt böljande eller torrt lakonisk. För rytmen avgörs av så mycket mer än betonad eller obetonad stavelse. Det är hur rytmen med alla sina varierande figurer och rörelser tar del i formandet av ett specifikt innehåll och ett mänskligt uttryck som avgör dess karaktär, vilket gör rytmen oskiljbar från vad texten handlar om. (Henri Meschonnic, Critique du rythme: Anthropologie historique du langage, Lagrasse 1982.) Den metriska aspekten av Dobyčins prosa, som är mer utmärkande för hans längre verk på trettiotalet men redan präglar de nya novellerna i Portret, kan möjligen förstås som något av en sammanhållande form som skapar lyrisk resonans. Denna resonansbotten i rytmen som är tydligare i de nytillkomna novellerna i den andra samlingen kan så ses som en aspekt av en generellt vemodigare, mer lyrisk, resignerad eller försonad grundton i de nya novellerna. Den känsla av ett slut som så framhävs är samtidigt oskiljbar från den förändring av samhällsandan som skildras, den som Dobyčin personligen måste ha drabbats av utan att han nämner det genom sin yngre broders död. Kanske eftersträvar Dobyčin en meter. Med Andrej Belyj som en av mästarna i samtiden som flitigt och affektivt stöpte nästan all sin prosa i en obruten trestavighet, tycks det otänkbart att han skulle vara omedveten om dessa aspekter av sin prosas rytm. På ett medvetet bruk (han berör aldrig ämnet i sina brev) tyder också de systematiska växlingarna mellan två- och trestavighet mellan kapitlen men aldrig inom dem i Dobyčins sista verk Šurkina rodnja. Hans många utsatta betoningstecken - som ibland används för ett betydelsefullt felaktigt uttal, ibland genom att överflödigt påvisa den rätta betoningen som framgår av sammanhanget tillsynes för att påvisa det absurda alternativet, men ofta bara förefaller överflödiga - visar också på en upptagenhet vid textens akustik. Aleksandr Belousov menar som nämnt att Dobyčins texter på detta sätt påbjuder en ljudande läsning: "Ozvučenie teksta v proze L. Dobyčina", Russian Literature, 46, I, 1999, 19-22. 
- Осень, - попрощались мы.

Prochorova kom ut från kafeterian med världsmästaren Slutsker. De tuggade på något och hennes ansikte glänste.

Ivanova var inte där. Hon tog samhällsansvar och arbetade i kamrat Sjatskinas elledningskommission.

En studiecirkel i militärkunskap hölls bakom akaciorna. - Den mest, sade föreläsaren och rynkade ögonbrynen, dödsbringande gasen - jag har glömt vad den heter, det börjar på eff. Pennorna raspade.

Georgis stack undan sitt anteckningsblock. Han var klädd i "Jungsturm"kostym, drog lite i den och kom fram till mig och var artig. - Det är varmt idag, sade vi och blev tysta. Prochorova, den trolösa, var i hans blickfång. Annars har det börjat frysa på redan, sade jag. - Verkligen, svarade han: temperaturen har överskridit normen.

- Det är höst, sade vi till avsked..$^{322}$

Prochorova tycks fortsatt välmående fettglänsande ha hittat någon mer imponerande än lille Georges. Och Ivanova har som handskakningen med Provhorova redan förebådade lämnat sitt koketta borgerliga jag bakom sig och blivit aktiv i det nya samhället. Den enda som jaget träffar - när hon nu slutligen träder fram som ett jag bland intrycken - är den fortsatt duktigt samhällsengagerade Žoržik, Georgis, som jaget inte heller tidigare visat intresse för. Han är under deras möte upptagen av att kasta svartsjuka blickar efter Prochorova och det enda de kan förenas i, innan de tar avsked, är ett konstaterande av årstiden som, liksom andra kapitlets konstaterande av vårens inträde tillsammans med Ivanova, även talar för deras känslor som nu trots denna sista varma dag på olika sätt oåterkalleligt har falnat.

Avskedsstämningen tas vidare upp på den som vanligt myllrande Moskvas gata. Nu är det begravningen av en pilot man samlats för - den pilot och de flygplan som genomgående antytt drömmar om något annat. En flaska i fönstret på apoteket anknyter återigen på denna plats till en längtan till Petersburg och därefter hörs en av de tidigare figurerande bussarna tuta och i en markerad kontrast till jaget ge sig av från staden med sina passagerare. Allt detta dras på så sätt också in i mötestemat. En sista gång ser jaget också sin duktigt röda överordnade som nu som en antydan om hennes hyckleri tillsynes obekymrad, som tillhörande ett nytt herrefolk, håller sig med en köksa som också i sin utstyrsel tycks oförändrad av revolutionen:

322 Žoržik är klädd som en komsomol med sin "jungšturmovka”, en lång ytterskjorta med stora fickor som bärs med livrem, som återges likt ett chict mode. "Kostymen" var influerad av klädseln i den tyska ungdomsorganisationen Jungsturm som under trettiotalet kom att förenas med Hitlerjugend. Hans tal om temperaturens överskridande tycks präglat av den samtida politiska diskursen om att överskrida de mål som satts upp i första femårsplanen. 
На улице Москвы толпились - ожидались похороны летчика. Зеленый шар мерцал в аптеке. На окне стоял флакон с Невой и Крепостью.

Автобус загудел. Сквозь стекла пассажиры посторонними глазами посмотрели на нас. Они - ехали.

Обоз с картошкой прибыл. «Наш ответ китайским генералам», - пояснял плакат. Товарищ Шацкина остановилась, улыбаясь, и ее кухарка в синей кике, нагруженная корзинами, остановилась позади нее.

På Moskvas gata var människor samlade - de väntade på pilotens begravning. Det gröna klotet skimrade inne på apoteket. I fönstret stod en flakong med Neva och Fästningen.

Bussen började tuta. Genom rutorna såg passagerarna på oss med utomstående ögon. De - åkte.

Vagnarna med potatis anlände. - "Vårt svar till de kinesiska generalerna", upplyste ett plakat. Kamrat Sjatskina stannade till och log, och hennes köksa i en mörkblå gammaldags huvudbonad med hornliknande spetsar stannade, överlastad med korgar, bakom henne. ${ }^{23}$

Jagets vidare väg, hennes utträde ur detta sitt sociala sammanhang för en ensam stund nere vid floden där novellens slutscen ska äga rum, markeras av ett sista möte med husvärden. Liksom i en spegelvändning av novellens inledning är det nu han, nervöst skämtande "som alltid", som bär på något, det vill säga som en motsvarighet till jagets vattenbärande som han då benämnde fysisk kultur - något som novellen avslutningsvis också kommer att återknyta till. Han "skämt" denna gång är att jämföra floden hon är på väg till med den symbolladdade Jordanfloden. Floden antyds så liksom i tidigare noveller som den yttre gränsen för denna värld: "Хозяин, отставляя руку, нес в жестянке керосин. - За Иордан? - осклабясь, как всегда, полебезил он." ("Husvärden höll ut armen och bar fotogen i en kanna. - Ska ni över Jordanfloden? frågade han och flinade som alltid inställsamt.")324

323 Detta "svar till de kinesiska generalerna" avser troligen att potatisvagnarna är en del i den militära mobiliseringen och slutligen interventionen i Manchuriet 1929 efter att Kina under Chiang Kai-sheks ledning tagit kontroll över järnvägen. Guomindangpartiets generaler under Chiang Kai-sheks ledning hade 1927 brutit med och angripit kommunisterna under Mao Zedong vilket utlöste det kinesiska inbördeskriget som generalerna gick segrande ur. I Lunačarskijs tal om eseninščina - hållet ett halvår före brottet med "generalerna" - talade han, som exempel på en anledning till optimism, om att Sovjetunionens utveckling redan inspirerat till uppror i Kina.

Ėduard Mekš ser det dolda Lenincitat om köksorna som skulle upphöjas genom revolutionen bakom denna beskrivning, vilket jag tidigare refererat till i "Konopatčikova". Enligt Mekš är hushållerskans huvudbonad ett stående attribut för den gamla tidens tjänstefolk. Ė. B. Mekš, "Istoriko-kul'turnyj areal rasskaza L. Dobyčina 'Portret'", PLD, 273-274, 274.

324 Att gå till andra sidan Jordan är i den ryska kontexten mindre apart som referens till Jesu dop i Jordanfloden och därigenom till flodens genomgående betydelse i Gamla testamentet som gräns för det heliga landet. Jordan kallas nämligen i åminnelse av detta alla floder som man rituellt vinterbadar i på trettondagen, således även floden Desna i verklighetens Brjansk 
Intrycken på hennes väg över till andra sidan floden bygger sedan upp en laddad stämning inför slutet med olika förebådanden om fara. Det inleds med skrikande vilddjur från cirkusen i parken hon lämnat och en musikant som spelar på vodkaflaskor på samma sätt (med samma verb) som klockringningen i mörkret vid påsken:

[...] Звери в балагане вскрикивали. Музыкант с букетом на груди отзванивал на водочных бутылках. "- «Мост опасен», - предостерегала надпись. Рыболовы, молчаливые, вертели ручки удочек с накручиваньем. Прачки с красными ногами наклонялись над водой. Ракиты осыпа́лись.

Паутина облепила кочки на лугу. Бродили гуси. Черепа и кости были нарисованы на электрических столбах.

[...] Djuren i cirkustältet skrek. En musikant med en bukett på bröstet ringde ut på vodkaflaskor. - "Farlig bro", varnade en text. Fiskare snurrade tystlåtna på vevarna till rullarna på spöna. Tvätterskor med röda ben stod böjda över vattnet. Pilarna tappade löv.

Tuvorna på ängen var täckta med spindelnät. Gäss gick omkring. Dödskallar och ben var målade på de elektriska stolparna.

Rytmen löper tvåstavig och samlar musikaliskt en rörelse från skriken som tas upp av ringandet via de tigande fiskarna med sitt snurrande och ner till tvätterskornas kroppar som är fjärran från det politiska i sin rödhet. Och pilarna tappar sina löv. Sedan är huvudpersonen på andra sidan, rörelsen stannar av, gässen går omkring på strandängarna; dödskallarna på de elektriska stolparna kan slutligen associeras till hennes sociala sammanhang som en fara och till hennes utestängdhet - både Ivanova och Žoržik arbetar nu med den elektrifiering som tillsammans med sovjetmakt av Lenin en gång förklarades vara lika med kommunism.

Här framträder hon som ett jag igen, här sätter hon sig ner vid en sten och betraktar poetiskt staden på andra sidan. Allting lägger sig till ro i en stund med blänk av något betydelsefullt som föregår den dramatiskt avgörande händelsen:

Я села у большого камня, про который знала из газеты, что его желательно использовать при установке памятника. Узенькие листья плыли. Новые дома, белеясь на горе, блестели стеклами. На огородах кочаны круглелись, как зелененькие розы.

som är den miljö som novellen använder. Denna skämtsamma mytiska antydning om floden som en yttersta gräns för samhället och att en dopliknande händelse väntar är så samtidigt trivialt och vardagligt förankrad. Floden med sina ängar som en särskild plats har också byggts upp genom att den så många gånger i novellsamlingen utgjort en gräns för det sociala som det blickats ut över i uttryck för längtan efter något annat och upplevelser av något betydelsefullt. 
Jag satte mig vid den stora stenen om vilken jag läst i tidningen att den borde tas i bruk för uppförandet av ett monument. De smala bladen flöt. De nya husen som lyste vita på berget glänste med rutorna. I trädgårdslanden stod kålhuvudena runda som små gröna rosor.

Jaget bär visserligen med sig den nya ideologin - tidningsläsandet i inledningen av kapitlet gör att tidningen som kunskapskälla känns naturlig för henne - och hon ser de nya husen som exempel på samhällsuppbyggnaden. Samtidigt är det något annat hon är intresserad av. Hon sitter vid den stora stenen innan den gjorts till ett politiskt monument. Hon ser husens lysande färg och blänkande rutor och de prosaiska kålhuvudena liknar för henne rosor.

Likt kvällsstunden i "Proščanie", som urupplevelsen av något betydelsefullt i författarskapet, den Kunsts avresa följde på, har novellen först med jagets vardagliga avskedstaganden på sin väg genom staden och nu i hennes vandring bortom floden liksom brutit sig ut ur berättelsen om denna samtids sociala dramatik. Det uttryck som denna stund fullbordar liknar mer poesi men en förtäckt sådan, fortsatt ständigt prosaiskt förankrad, stundligt motiverad, utgående från huvudpersons medvetande. Uttrycket lämnar inte det sociala spel som är prosans väsen men riktar sig samtidigt i det mot något högre, mot något betydelsefullt av existentiellt och djupt mänskligt slag, mot en skönhet oavsett samtid.

Denna sten som ännu inte formats till en fånig staty i stil med den över kamrat Gusev i "Sidelka" och och denna vy som huvudpersonen ser med sitt trivialt poetiska sinnelag är vad Dobyčin ger oss som en sista upplevelse i samlingen av något betydelsefullt även i denna samtid. Det är det porträtt av samtiden som ett slags möte bortom orden som framträder om man ser och inte tänker (och om man som berättarteknik nästan bara ger tillgång till huvudpersonens tankar genom intrycken). De betydelsefulla uttryck som poetiskt igenkänns finns inom oss mitt i den triviala vardagen, som här denna lediga söndag i denna kvinnas liv i slutet av tjugotalet.

Så tar det slut. Stunden avbryts av en avgörande händelse som slungar oss tillbaka ur denna förtäckta poesi till novellen som en berättelse med intrig: huvudpersonens sökande efter den okände kavaljeren. Novellen fullbordas så dramatiskt genom att detta möte fysiskt kommer till stånd, men bara alltför bokstavligt fysiskt, för samtidigt innebär det slutet såväl för huvudpersonens meningsgivande längtan efter något annat, som detta sökande varit en del av, som för gestaltandet av något betydelsefullt i denna samtid. Här anländer den nya oförtäckta fysiska kulturen: 
Физкультурники причалили, разделись и, благовоспитанные, кувыркались в трусиках. Потом посбрасывали их и бегали, гоняясь друг за другом и скача друг другу через голову.

Я поднялась бледнея. Это он был - не монтер, не Гришка, а тот самый, с клапаном.

- Послушайте, - хотела крикнуть я.

- Сфотографировать? - спросил он расторопно, повернулся, наклонился и дотронулся до сгиба. - Вот портрет, - сказал он, показав ладонь.

Frisksportarna lade till, klädde av sig och gjorde uppfostrat kullerbyttor i kalsonger. Sedan drog de av sig dem och sprang och jagade och hoppade över huvudena på varandra.

Jag reste mig blek. Det var han - inte montören, inte Grisjka, utan verkligen han, med bakstycket.

- Lyssna, ville jag ropa.

- Ett fotografi? frågade han hastigt, vände sig om, bockade och tog sig vid vecket. - Här är porträttet, sade han och visade handflatan.

Den väluppfostrade fysiska kultur som frisksportarna först ger prov på, med sin båttur och dessa konster, var alltså vad Lunačarskij framhöll som ett effektivt botemedel mot det moraliska förfallet, mot esenineriet i samtiden. Men tydligen räcker det inte riktigt för att ge fullt utlopp åt ungdomens bubblande krafter. De som utövar det som ska stävja osedligheten trotsar själva ett av förbuden som införts i samma syfte. Detta förbud mot nakenbad gjordes tydligt i den föregående novellen "Sad" - i dess osovjetiska frihetliga sammanslutning vid floden skrattade man åt det.325 Jaget däremot, som de inte verkar ha upptäckt, chockas av nakenheten och deras allt vildare övningar. En chock som är förståelig då hon samtidigt bland dessa spritt språngande nakna män nu igenkänner den kavaljer som antastade henne i trängseln på väg ut från biografen och som hon därefter resultatlöst sökte efter under våren. Det råder nu inget tvivel, montören på taket i kapitel två och Griška från trädgårdarna i kapitel tre var falska spår: här är han, han med kepsen med nedfällbart bakstycke (ett attribut som han inte nödvändigtvis bär på sig nu). Hennes replik är en exakt upprepning av vad hon den första gången också ville, men aldrig ropade, då hon jagade efter honom men blev avbruten av sin far. Nu har hon så möjlighet att skälla ut denne oförskämde skojare, om det nu var det hon ville. Men hon är tyst och tittar bara. Och det är troligen just som ett svar på hennes tysta iakttagande som han, som antagligen inte känner igen henne från den gången för ett

325 I "Sad" var nakenheten också synlig från staden tidigare på dagen. Även om naturismen internationellt kunde vara en del av frisksportens utvecklande av kroppslighet, hade man i Sovjet på partikongressen 1925 som en del i kampen mot ungdomens fördärv slagit ner på den revolutionära naturismrörelsen Doloj styd (Bort med skammen). "Doloj styd (obščestvo)", Wikipedia, https://ru.wikipedia.org/wiki/Долой_стыд_(общество), 20I9-о6-oI. 
halvår sedan, istället visar ännu ett prov på sin fysiska skälmaktighet. Han är naken och hon står där tyst och glor: vill ni ha ett fotografi också så var så god, här har ni porträttet.

Vad han faktiskt gör med sin kropp när han låtsas framställa detta fotografiska porträtt är däremot tvetydigt. Är vecket hans armveck, som antyder att han tar sig där när han gör en gäckande och avvisande fallosgest med armen, innan han visar fram handflatan istället för ett fotografi? Eller är vecket vad som uppstår när han böjer sig vid midjan, likt en klaff (i stil med sitt huvudsignalement), likt en kamera? Det är faktiskt möjligt att denna oklarhet är helt avsiktlig. ${ }^{326}$ Den gäckar i så fall läsaren på samma sätt som den påtalade Puškinanekdoten i andra kapitlet ("Puškin, gde ty?" ("Pusjkin, var är du?")) med sitt homonyma svar skjuter över ansvaret för det ekivoka på åhöraren (vilket även sången om butiken Knop där senare gör med sitt antydda rimord). Med denna liksom kroppsliga grimas, som man själv får föreställa sig, avvisas inte bara jaget - för henne kan det förvisso inte vara tvetydigt vad hon ser - utan potentiellt såväl den misstänksamma, osedlighetsstävjande samtida censuren och kritiken, som läsare oavsett tid. Du är vad du läser in - allt det som skildrats har också skapat ett porträtt av dig. Du har deltagit i dessa möten bortom orden. Ser du något förbjudet i denna realism så är du medskyldig. 327

Jaget tycks uppleva konfrontationen som en ren fräckhet, en form av våld, ett bryskt avfärdande av henne med sina romantiska drömmar om att

\footnotetext{
326 Talande för tvetydigheten i stycket är oenigheten mellan de engelska, tyska och franska översättarna: i den engelska översättningen rör han sitt knäveck ("knee joint"), den tyska följer originalets obestämdhet ("Beuge", med i princip samma betydelseomfång som "sgib", "in der Beuge") och i den franska är det en handled ("repli de son poignet"). (Richard C. Borden och Natalia Belova i Leonid Dobychin, Encounters with Lise and Other Stories, Evanston, Illinois, 2005, 86; Peter Urban i Leonid Dobyčin, Die Erzählungen, Berlin 2013, I60; André Cabaret i Léonide Dobytchine, Rencontres avec Lise, Saulxures I994, 93.) Radiščeva ser i sin avhandling en bakdel, med vilken han, menar hon, fotograferar det väluppfostrade jagets reaktion, hennes grimas: "Если учесть, что герой во время купания снял даже трусы, то показал он не что иное, как свой голый зад. Сделав этот оскорбительный жест, он «сфотографировал» реакцию благовоспитанного зрителя - гримасу отвращения и презрения." E. S. Radiščeva, Chudožestvennyj mir prozy L. I. Dobyčina, Moskvas pedagogiska universitet, 2004, 77. Stroganov är inne på något liknande "erotiskt" och associerar scenen till när fadern och pojkarna täcker könet i "Otec". M. B. Stroganov, "Čelovek kupajuščijsja", DS-7, I42-I6I, I46, I53. 327 Möjligen skulle man i denne skälmaktige frisksportare som gäckar det romantiska jaget med sin fysiska beröring och sin fysiska kultur, kunna se ännu ett ironiskt metapoetiskt porträtt av författaren själv. Här kikar till slut, så sett, bara en naken människa fram istället för en konstnär; här blottas denna konsts nakenhet i sitt porträtterande av livet, dess oidealiserade realism, dess sätt att fotografera, som både fängslar och skrämmer genom att dess porträtt helt enkelt blir levande människor. I det skulle man då vidare kunna se en anspelning på Gogol's novell med samma titel om ett målat porträtt som får liv. Den problematiserade i sin tid frågan om naturtrogenhet och vad för slags konst vi egentligen vill ha.
} 
ändå kunna finna kärlek i denna tillvaro. Hon lämnar inte denna tillvaro så som inledningsnovellen upplöstes och så som Dobyčin kom att avsluta båda sina längre verk på trettiotalet. Men hon går sin väg. Nu är hon på ett sätt, som efter ett dopliknande uppvaknande, befriad från den fixa idén om att kunna finna ett själsligt samförstånd med någon. Hon är fri men hon är också helt ensam. Och hon har ingen annanstans att ta vägen. När hon avlägsnar sig påminner hon till sitt sätt om sin stolta moder (den enda närstående hon tycks ha kvar) med dennas fasthållande vid sina värderingar och sin värdighet. Ett lejons rytande från cirkusen ger ett uttryck för denna tämjda längtan. Musiken som hörs från pilotens begravningståg kan både tänkas påminna henne om den troligen avlidne fadern och ge en parallell till hennes störtade drömmar om något annat, något betydelsefullt i denna tillvaro, något som även det sista intrycket i en sinnlig rörelse i vardagen framkallar en förnimmelse av:

Я удалялась величаво. Лев рычал. Пронзительно играя, похороны двигались, невидимые, за рекой.

Jag avlägsnade mig majestätiskt. Lejonet röt. Genomträngande spelade begravningståget som rörde sig, osynligt, på andra sidan floden. 


\section{Slutet på samtidsberättandet, slutdiskussion}

\section{Trettiotalets första år}

I930 sammanställer Dobyčin sina samtidsnoveller till samlingen Portret som en avslutad konstnärlig helhet. Därefter har han tänkt sig att återgå till arbetet med sin uppväxtskildrande historiska roman som han två år tidigare övergav sitt första försök med. Men 1930 är ett speciellt år.

Han har varit i Leningrad i början av året. Det har varit en längre vistelse. Han har lämnat efter sig ett möblerat rum tillsynes i föresatsen att bara göra ett kort besök i Brjansk, men blir snart tvungen att säga upp det och tvivlar på att någonsin kunna återvända. Han är arbetslös. Novellsamlingen är hos förlaget men han har ännu inte bestämt titel och har också idéer om framsidan. När han inte får kontakt med förlaget vänder han sig till Slonimskijs, till Michails hustru Ida då Michail är bortrest, i första hand för att be henne förmedla sina förslag eftersom hon, som han förklarar, är den enda som svarar honom. Av det ymniga och mer öppenhjärtiga brevskrivandet under sommaren I930 till båda makarna Slonimskij, mer än han skrivit de tre senaste åren sammanlagt, märks också att han blivit närmare bekant med dessa under sin vistelse.

Det framgår att han vid sidan av arbetet med novellsamlingen även har umgåtts med andra i Leningrads litterära kretsar, men inte utan svårigheter vad det verkar. ${ }^{228}$ I ett brev till Ida Slonimskaja markerar han exempelvis sin distans till formalisternas konstnärliga smak utifrån hur han av dessa hånades för sin uppskattning av författaren Elena Tager:

\footnotetext{
${ }^{328}$ Rimligen skrevs några av de nya novellerna under vistelsen i Leningrad ("Portret" som troligtvis var klar tidigare är som sagt den enda han nämner i sina brev). Den enda daterade novellen, till just 1930, är "Tëtka", den mer dokumentära versionen av inledningsnovellen "Proščanie". Även om båda dessa versioner utgår från den allra första novellskissen "Timofeev" från 1923 förefaller det plausibelt att även den nya vistelsen i staden, med en mer eller mindre framtvingad avresa i slutet av våren tillbaka till provinsen, finns i bakgrunden till det som skildras förlagt till I9I8. Möjligen utgör några av de personer som huvudpersonen umgås med på sin arbetsplats indirekta porträtt av några av de nya litterära bekantskaperna i Leningrad. Den lille föreståndaren Glan med sin lilla kostym är inte helt olik Zoščenko. Den flitige Ivan Il'ič som ordnar sin bena skulle kunna ha Slonimskij som förlaga.
} 
Немудрено, что формалисты восторгаются той пьесой, про которую Вы говорили: я похвалил при них Тагерию, так они подняли такое тявканье, какого я никогда еще не слышал. [...] Отсюда видно, что у них - мозги набекрень.

Det är inte underligt att formalisterna hänförs av pjäsen som Ni talade om: när jag lovordade Tager i deras närvaro stämde de upp i ett gläfsande som jag aldrig hört maken till. [...] Därför är det uppenbart att de är vrickade. ${ }^{29}$

Dobyčin har likt många av sina huvudpersoner svårt att bara följa med i de nya vindarna. Han rekommenderar Ida Slonimskaja en roman av den lätt daterade Anatole France (Les Désirs de Jean Servien, I882, på ryska I9I6), som han menar beskriver hans egen situation, medan han säger sig bli nedstämd av alla vackra epitet i Manhattan Transfer av John Dos Passos (I925, på ryska I927) som är vad som nu är på tapeten. (Han förstår efteråt inte varför boken väcker sådan uppståndelse och säger sig ha läst den bara för att litteratören Lidija Varkovickaja sagt att om han skrev en roman så skulle det bli något i den stilen.) Att Dobyčin inte är modern på det sätt man ska vara tycks vara en orsak till att han blir obekväm i stadens kulturliv. Ändå hade han troligen stannat om han bara funnit ett sätt att försörja sig. 330

Snart ser han sig tvungen att åter söka ett kansliarbete: för att bli respekterad som människa, som han skriver. Men dessförinnan har han gjort ett misslyckat försök med vad han ironiskt benämner en "litterär karriär" i Brjansk, nämligen som reporter för lokaltidningen Brjanskij rabočij (Brjanskarbetaren). Hans första och enda uppdrag blir ett besök på tre kolchoser. Med ett något märkligt ordval omnämner han resan för Ida Slonimskaja som mycket "roande" (trots att den "roande text" han skrev om det, tillfogar han, inte blev antagen av tidningen utan istället gjorde honom

329 Det framgår inte vilken pjäs det rör sig om. Vad gäller Tager är det troligen hennes nyutkomna novellsamling Zimnij bereg (Vinterstrand) I929 som han lovordat. Till Ida Slonimskaja I juni 1930 (brev II8), PSSP, 303. Han skriver senare att han skulle önska sig en likadan vit framsida som Tager till sin egen bok, med samma storlek och typsnitt, men med "ett oansenligt vardagsrum (utan människor)" ("жалкая гостиная (без людей)") i ovalen (vilket man delvis försökt förverkliga med framsidan till Dobyčins samlade verk, PSSP 1999 och 2013). Till Ida Slonimskaja 4 juni 1930 (brev II9), PSSP, 304. Denna Elena Tager räknar han för övrigt upp, som ett svar på en fråga från Slonimskijs, som en av de fyra personer som han förutom dem har ett gott förhållande till i staden. De andra tre är Evgenij Švarc, Nikolaj Čukovskij (Kornejs son) och Vol'f Ėrlich. Av nästa brev framgår att Michail Slonimskij på något sätt har förebrått eller varnat honom för de två sistnämnda: Ėrlich misstänks som sagt vara den NKVD-agent som rapporterade om Dobyčin under hans sista tid 1936. Till Ida Slonimskaja respektive Michail Slonimskij, 25 juni och I juli 1930 (brev I2I, I22), PSSP, 306-307.

330 Till Ida Slonimskaja (brev II7 och II8), PSSP, 302-303. Den ryska översättningen av Dos Passos, Manchèttèn, utgavs inte bara samma år utan av samma förlag (Mysl') som Dobyčins första novellsamling. Redaktören V. I. Smetanič stod dessutom bakom översättningen. 
återbetalningsskyldig för förskottet).33I För Michail Slonimskij beskriver han utförligt besöket. Han skriver om kulaker (relativt välbärgade bönder) som undrar om de kan få tillbaka något av sin boskap. Han skriver om en kolchosföreståndare som vill överta ett hus som gjorts till barnkrubba - vilket dock förklaras vara i strid med partiets generallinje. Han beskriver de smutsiga barnen och gamlingarna på jordgolvet hos föreståndaren och ett sammanträde med förhör om pengar som förskingrats. Han skriver om "befolkningen" ("naselenie") som knappt tvättar sig överhuvudtaget eftersom de ändå blir smutsiga igen och om unga som sitter på jordvallarna framför husen och högläser Lermontov. Han skriver som kontrast till detta, men utan någon kommentar, om besöket på en kolchos med kulaker som lyckats hålla sig kvar. Där har föreståndaren trägolv och talar belevat om deras "kultur" ("Vot naša kul'tura"). Allt är städat och ordnat inför Kristihimmelsfärdsdagen som fortsatt högtidlighålls och de talar om att de inte vill utjämnas till samma nivå som de andra "vildarna". Föreståndaren frågar Dobyčin om han tror att det kommer att bli fler kolchoser och Dobyčin svarar att han tror det. Det viftar föreståndaren avvärjande åt och vill inte höra mer. Föreståndaren berättar att de nätt och jämnt lyckats avvärja åtta stycken som kommit dit för att avkulakisera dem men att de valt att stanna.

Dobyčin berättar fascinerat, det han kallar roat, utan slutsatser och åsikter, om denna radikala utveckling i samtiden som han blivit vittne till. Denna erfarenhet som det inte är svårt att förstå att tidningen inte ville publicera skymtar dock försiktigt i bakgrunden i de två nya kortnoveller som tillkommer under sommaren och hösten 1930 - två ytterligare noveller han tillsynes inte kan låta bli att skriva trots att novellsamlingen redan är färdigställd. .32 $^{2}$

\footnotetext{
$33 \mathrm{I}$ "Там я очень позабавился и написал забавную вещицу [...]". Till Ida Slonimskaja 3I maj I930 (brev II7), PSSP, 302. Brjanskforskaren Golubeva har sökt men inte återfunnit den refuserade artikeln. Hon anför en bild från inledningen av Dobyčins redogörelse i brevet som skäl nog, om den nu också ingick i reportaget, för att artikeln inte lämpade sig för publicering i den samtida pressen: mitt i ett fält med ärtor ligger 500 (vita) Denikinsoldater och 2000 rödarmister begravda intill varandra under ett kors respektive en stör med en röd stjärna. (Förutom att sifforna borde vara de omvända menar Golubeva troligen att vardagligheten och avsaknaden av patos i den sakliga beskrivningen framställer de döda - i inbördeskriget men indirekt också i den pågående kollektiviseringen - med en banal mänsklighet bakom sifforna istället för som nödvändiga offer för revolutionens sak.), Ė. S. Golubeva, Pisatel' Leonid Dobyčin i Brjansk, Brjansk 2005, 54.

${ }^{332}$ Landsbygden som miljö och dess människor, mer naket mänskliga och enkelt folkliga än i den provinsiella småstadens sociala sammanhang, kommer han också att återvända till i de två efterlämnade verken efter Gorod Ėn. Möjligen finns denna egna erfarenhet i bakgrunden till titeln "Dikie" ("Vilda") på det första av dessa verk. Där förklarar som nämnts jag-berättaren att berättelsen utspelar sig före kollektiviseringen då folket fortfarande var vilda; här räds kulak-bonden att genom kollektiviseringen utjämnas till samma nivå som "vildarna".
} 
Ser man lite närmare på dessa två noveller finner man i dem också uttryck för ett slut på berättandet om samtiden, en möjlig indirekt förklaring till varför Dobyčin övergav det för historiskt förlagda berättelser. Den första av de två kan man följa framväxten av i breven under sommaren. Då börjar det dyka upp opåkallade och lösryckta uppgifter om en bibliotekarie i Brjansk och hennes aktiva samhällsengagemang. Dobyčin har tidigare nämnt henne i sina brev och hon har även figurerat $\mathrm{i}$ bakgrunden i några av novellerna i samlingen. Omdöpt från Cukerman till Godulevič blir hon nu huvudperson i novellen "Mater'jal". ${ }^{333}$ Material inte i betydelsen "manufaktur" utan "material för att rensa apparaten" ("материал для чистки аппарата"), förklarar Dobyčin i förväg titeln med ironisk övertydlighet. Även till den politiska utrensningen bland kommunanställda i novellen finner man en bakgrund i breven, nämligen i Dobyčins redogörelse för den utrensning som en av hans systrar genomgår.

I breven till Slonimskij tycks inte Dobyčin behöva förklara något. Liksom i skildringen av kolchosbesöken redogör han för den utrensning hans syster genomgår utan kommentarer om det absurda i tillställningen - det framgår av sig självt. Frågan som inställer sig, när han fortsatt också skriver sina sista noveller på detta sätt, genom ett talande framvisande, är om det ännu gör det för alla läsare i samtiden. Detta att den potentiella kritiken i skildrandet av verkligheten i sin triviala vardaglighet kanske inte längre förstås av alla kan samtidigt ses tematiserat i de sista novellerna. På sätt och vis exemplifierar de varför det knappt går att berätta om samtiden längre på Dobyčins vis. Om inte de slags möten bortom orden med läsaren som ligger till grund för novellerna längre uppstår framträder inte heller de olika mänskliga perspektivens samspel i tillvaron som en motröst mot den påbjudna entydiga ideologiska uppfattningen av den. Det Dobyčin skildrar i sina sista noveller är en tillvaro där människorna lämnas ensamma med sina personliga berättelser.

\section{"Mater'jal" ("Materialet")}

Den första lösryckta uppgiften om bibliotekarien i breven kommer så gott som ordagrant att utgöra inledningsstycket i novellen: "Годулевич получила вызов на соревнованье и обдумала его. Два пункта приняла,

\footnotetext{
333 Dobyčin benämner alltid bibliotekarien med en smeksam ändelse, Cukermanša. Golubeva som forskat i denna judiska bibliotekaries livshistoria, vars fullständiga namn var Evgenija Iosifovna Cukerman, har funnit ytterligare överensstämmer med novellens huvudperson utöver vad som framkommer om henne i Dobyčins brev. Novellen tycks ovanligt dokumentär. Ė. S. Golubeva, "'Bibliotekarša' (po motivam rasskaza Dobyčina 'Mater'jal')", DS$7,32-48$.
} 
два отклонила и в один внесла поправку." ("Godulevitj hade fått en inbjudan till en tävling och begrundade den. Två punkter godkände hon, två förkastade hon och i en införde hon en rättelse.") 334 Det denna tävling går ut på förklaras vidare vara att "utföra arbete utomhus bland massorna" ("вести работу среди масс на воздухе") en utmaning som den flitiga bibliotekarien genast antar genom att ordna med ett utomhusbibliotek i stadsträdgården där hon varje dag efter det vanliga bibliotekets öppettider, föga lyckosamt, försöker konkurrera med filmvisningar och dans i parken om massornas uppmärksamhet. Likt ett ironiskt självporträtt av samma art som vi såg i den ideologiskt inställsamme författaren Erygin framhärdar Godulevič i denna självpåtagna plikt trots samtidens ointresse. Hon står ut med att förnedras av småpojkar som gör erotiska gester åt henne. På hemvägen flyr hon skrämt när patienterna på en klinik för veneriska sjukdomar frågar efter en cigarett. Det är mot detta moraliska förfall, och dessa sinnliga distraktioner, som hon för både en yttre och inre kamp.

Intrigen tar sin början efter att Godulevičs helgrutiner först skildrats. På lediga dagar sitter hon i ensamhet och läser uppe på iskällaren på gården (det förklaras hon göra när det är komedier och inte drama som visas på biografen, tvärtemot sin författare som i breven från denna sommar uppskattande nämner nya komedier han sett). Från sin upphöjda plats hör hon också sina grannar: en ingenjör och dennes återkommande gäster och en annan granne som spelar fiol. Och så, en gång, när gästerna ger sig av i mörkret från ingenjören och hans hustru vänder en av dem, ingenjör Smirnov, tillbaka och frågar värdparet om de hört de nya kupletterna om Lenin, vilka han därefter halvhögt börjar sjunga (bara titeln "Lenin ljubit detok" ("Lenin älskar de små barnen") återges). Godulevič närmar sig och hostar. Det är nog för att de genast ska tystna, stänga dörren och skingras.

Godulevičs uppbyggliga men tröttande dubbelarbete med både det vanliga biblioteket och utomhusbiblioteket på kvällarna finner hon så slitsamt att hon ansöker om en plats på ett semesterhem för att lugna nerverna. Detta framställs genom hennes språkligt byråkratiska ansökan vilken föregås av något av ett allmänt uttryck för utvecklingen i samtiden: "Дни были до́лги, а недели коротки. Прошли кампании о кооперации и антивоенная." ("Dagarna var långa och veckorna korta. Kampanjerna om kooperation och mot krig var över.") Som ett bekräftande av sanningshalten i hennes

\footnotetext{
334 Novellen citeras ur PSSP, I03-IO4. Meningen i brevet, helt apropå, är det enda han skriver om bibliotekarien där. De enda ändringarna till novellen är antalet punkter samt att det har strukits att inbjudan kommer från Smolensk, den nya regionshuvudstaden. Till Slonimskij I juli 1930 (brev I922), PSSP, 307.
} 
ansökan framförs, distanserat från hennes medvetande, ett ironiserande banalt exempel: "- И правда, она стала раздражительной и чуть не поругалась с абоненткой Рекс, которая спросила песенник." ("Och sannerligen, hon hade blivit lättretlig och skällde nästan ut låntagaren Reks som frågade efter en sångbok.") En sångbok! När det finns så mycket viktigt politiskt fostrande att läsa. Sång, dans, komedier, skämt och nöjen - sådant stör den allvarligt sinnade bibliotekarien $i$ hennes kamp, hennes aktiva engagemang $\mathrm{i}$ det sovjetiska uppbyggnadsarbetet.

I "Portret" föregick förbudet mot att sjunga på en servering huvudpersonens uttryckta längtan efter öppenhet och vänskap, i "Sad" kontrasterade städerskans kreativt fria och personliga sång mot poetissan Lipec högstämda ideologiska diktning. Nu skildras detta från andra sidan: Godulevič är en som faktiskt tar del i det nya. Novellen är ovanligt distanserad från huvudpersonens perspektiv. När det med samma formulering, "i pravda" ("och sannerligen"), i novellen "Chiromantija" konstaterades att Margarita, såsom tecknen på vägen förebådat, inte var hemma - var det också huvudpersonens konstaterande. Här är det tydligt någon annan som berättar om den lättretliga bibliotekarien. Men snarare än av en för författaren ställföreträdande berättare framstår det som uttalat utifrån en allmän diskurs, något som allmänt konstaterades just av andra, av alla de som till skillnad från henne försöker leva på och roa sig i detta samhälle med vad som bjuds. Här finns antydningar till ett skaz-berättande, en berättande folklig röst som liksom en motröst mot Godulevič - framför detta. Hela novellen om henne formar sig på så sätt också succesivt till inte bara ett porträtt utan också något av ett "material" om henne. Novellen "Mater'jal" vittnar som en motvikt - liksom för en högre, evigt mänsklig och evigt förlåtande instans - mot det material hon själv nu sammanställer om den gäst hos grannen som hon hörde sjunga en kuplett om Lenin.

Det är när Godulevič läser i tidningen om en förestående utrensning inom kommunen som hon duktigt och nitiskt sammanställer sin rapport, sitt material om grannens skämtsjungande gäst, ingenjören Smirnov. På vägen till utrensningen möter hon respektfullt hälsande låntagare. Nu ska hon uträtta sin plikt, framföra sitt material, sina politiska anklagelser mot denne borgerlige ingenjör som behöver rensas ut. Men under utrensningen händer något med henne, hon tycks plötsligt berörd som människa av vad hon bevittnar. Hon ser rädslan hos den anklagade (som kanske starkast framhävs av den tidning han skyler sig med). Och hon avstår från att framlägga sitt material: 
На чистке было людно. Председатель был шутник, и зрители покатывались. Коммунальщики сидели серые. Смирнов держал перед собой газету. Он дул на́ руки, подсовывал их под себя, вставал и выходил, позеленевший. Годулевич пожалела его. - Ну его, - подумала она.

Det var fullt med folk på utrensningen. Ordföranden var en skämtare, och åskådarna gapskrattade. Kommunalarbetarna satt gråa. Smirnov höll en tidning framför sig. Han blåste på händerna, stack in dem under sig, reste sig och gick ut, grön i ansiktet. Godulevitj tyckte synd om honom. - Låt honom vara, tänkte hon.

Detta avslutar berättelsen om hennes vardag. I nästa stycke är hon redan nyss hemkommen från det semesterhem som hon alltså beviljats en plats på. Hennes utbrott av medkänsla på utrensningen innebär inte att Godulevič övergivit sin politiska övertygelse. Snarast tycks hon ha stärkts i den under sin resa och känner nu rentav ånger för att hon inte lade fram sitt material. Hon ser det som en klandervärd mänsklig svaghet ("Она раскаивалась в этом малодушии"), men det är nu för sent att göra något åt. Under hennes frånvaro har hennes ingenjörsgranne med fru tillsammans med ingenjör Smirnov skyndsamt gett sig av till Tadzjikistan. De förklaras ha blivit upplysta om att det där fanns platser med högavlönade arbeten och tillgång till bristvaror. Med andra ord fortsätter de alltså att sko sig.

Efter grannarnas avresa är det tyst på gården. Novellen tar nu slut där en kväll med att en gumma, en av de tidigare gästerna, kommer och sätter sig med Godulevič och nu inställsamt skrattar åt de avresta grannarna och hur folk tittade på dem när de lastade bagaget och satte sig på tåget. Den tidigare fiolspelande grannen smyger sig också tyst fram. Nu är det den röda Godulevič som står i centrum. Hon förklarar kort att hon inte var hemma vid grannarnas avresa och börjar istället, liksom ohejdbar nu när hon äntligen blir sedd och respekterad även hemma på gården, att skrytande berätta för dessa tigande åhörare om sin vistelse på semesterhemmet. Hennes pladdriga reseberättelse är vad novellen slutar med:

Она рассказывала, сколько там давали масла и какой приятный собеседник был товарищ Шацкий из Клинцов. Она рассказывала, как придумала заметку для живой газеты, и как с Эльгой Но́химовной Рог пошла смотреть деревню: хлеб уже был убран, и кругом просторно было; ящерица побежала из-под ног; покрытые соломой, показались избы - сани и ходы́ валялись возле них.

Hon berättade om hur mycket smör man fick och vilken trevlig samtalspartner kamrat Sjatskij från Klintsov var. Hon berättade om hur hon kom på ett inslag till en levande tidning, sådana där iscensatta nyheter, och hur hon och Elga Nochimovna Rog gick och tittade på en by: säden var redan bärgad, och åt alla håll bredde vidderna ut sig; en ödla sprang ut under fötterna; 
täckta med halm dök stugorna upp - slädar och vagnsunderreden låg lämnade vid dem.

Godulevič har fått äta upp sig (hon har beskrivits som åtta pund tyngre, solbränd och livlig vid återkomsten). Och framförallt har hon fått uppleva vänskap med en likasinnad kamrat, hon har haft en samtalspartner, något hon i sin provinsiella småstad annars tycks sakna. I framhållandet av denna vänskap, av inspirationen till ytterligare politisk aktivitet och deras gemensamma utflykt framskymtar hennes personliga mötesproblematik som en grund till konflikten även i denna novell. Godulevičs sociala ensamhet hennes upplevelse av att vara utestängd från både samhällets allmänna och mer specifikt sina grannars glada samvaro - kan så tolkas som den egentliga anledningen till att hon irriterar sig på sina låntagare och vänder sig mot sina grannar och deras gäster fast hon kanske just med dessa hade kunnat finna en gemenskap i sin vardagliga tillvaro. En längtan efter något väsentligare, något idealt tycks ha ställt sig i vägen för möten med andra i omgivningen även för denna huvudperson.

Hennes samhällsengagemang har visserligen gjort henne respekterad och lett till en kortvarig bekantskap under resan men väl hemma igen kvarstår problematiken. Hon talar inför sina kvarvarande lydigt lyssnande grannar utan att tyckas ta notis om dem, som om de var ovärdiga att ens försöka samtala med efter den politiskt upplysta vänskap hon upplevt.

Godulevič framställs nu som ostört förlorad i sig själv med sin rättroende självbelåtenhet och stolta principer. Men trots det, i den reseberättelse hon svävar ut i med sina överflödande detaljer, framkommer i slutet, i deras besök på landsbygden, plötsligt något av en tigande verklighet bakom hennes pladdriga idealism som kanske talar för något. Om de stora vidderna beskriver det nu kollektivt ordnade kolchosjordbruket så som det ska skildras, så undslipper hon sig i det sista faktiskt något som möjligen gjort ett mänskligt intryck på henne (i stil med synen av Smirnov vid utrensningen): För var är egentligen människorna? De tillsynes övergivna bondstugorna kan, med en ytterst försiktig och okommenterad antydning, vittna om det mänskliga lidandet och vad som går förlorat i den radikala samhällsomvandling, den allmänna kollektivisering, som Godulevič, som funnit sin hemvist i den nu allenarådande röda gemenskapen, aktivt tar del i. 


\section{"Čaj" ("Teet")}

Den andra berättelsen från hösten 1930 är också den sista Dobyčin skriver som utspelar sig i den sovjetiska samtiden. Den mynnar också ut i en berättelse liksom i tomma luften men som snarast är av motsatt slag, en sista hopplös och förbjuden längtan efter något annat.

Det är avslutning på en barnträdgård, ett dagis. Barnen som helt vuxit upp och fostrats i det sovjetiska samhället står nu inför att gå vidare till skolan. Det hålls högtidliga tal till dem från ett podium. Man förhåller sig till dem med respekt, de står för den ljusnande kommunistiska framtiden och utgör också ett slags vittnen för de vuxnas politiska korrekthet. Därtill finns det högt uppsatta personer bland föräldrarna, åtminstone en ledamot $\mathrm{i}$ kommunfullmäktige. Tillställningen präglas av ängslighet. En kolchosarbeterska konstateras vägra låta sig övertalas att också hålla tal. En kokerska frågar vädjande barnen om de har något att invända mot henne:

$$
\begin{aligned}
& \text { [...] - Детки, - жалостно сказала она, - вы довольны мной? - Довольны, - } \\
& \text { отвечали они. - Я вас обижала? - продолжала она спрашивать. - Ругала } \\
& \text { вас? Бесчестила вас? - Нет, - разжалобясь, пищали они хором, - нет! - Все́ } \\
& \text { были тронуты.335 }
\end{aligned}
$$

[... - Kära barn, sade hon ömkande, är ni nöjda med mig? - Ja, det är vi, svarade de. - Har jag behandlat er illa? fortsatte hon att fråga. Skällt på er? Förnedrat er? - Nej, gnydde de medlidsamt i kör, nej! Alla var rörda.

Så serveras det te för barnen och berättelsen vrider sig vidare med en dramaturgi byggd på banala överraskningar. Först avslöjas det till allas stora förundran att även föräldrarna kommer att bjudas på te på kvällen. Medan förberedelserna för detta kvällsevenemang pågår utvecklas frispråkigare än i tidigare noveller en homosexuell kärlekshistoria med samtidens tekniska framsteg skymtande i bakgrunden. Radioapparater som ett nytt inslag i stadsbilden erbjuder nya möjligheter till att göra den politiska diskursen ständigt närvarande. Med drastiska liknelser, kontraster och mänskliga trivialiteter uttrycks samtidigt en potentiell kritik:

Закат был красный, и антенны над домами напоминали «колья для насаживания черепов» из книжки с путешествиями. Белый исправдом казался синим. Арестанты, привалясь к решеткам, длинно пели: - А!

Красноармеец Миша поднял яблоко и по́дал Коле. - Ка́к, брат? - взяв его за плечи, спросил он, и Коля полюбил его. Они разговорились. Неза-

335 Novellen citeras ur PSSP, I05-I06. 
метно летело время. Из открытых окон радиодоклады раздавались. Расходясь со стадиона, распаленные футбольщики, невидимые за забором, переругивались.

Solnedgången var röd och antennerna över husen påminde om "pålar för att spetsa skallar på" från boken med upptäcktsresor. Den vita uppfostringsanstalten tycktes mörkblå. Arrestanterna tryckte sig mot gallren och sjöng utdraget: - A!

Rödarmisten Misja lyfte upp ett äpple och räckte det till Kolja. - Hur är det, bror? höll han honom om axlarna och frågade, och Kolja blev kär i honom. De började prata. Tiden flög omärkligt. Från de öppna fönstren spreds radiorapporter. Iväg från stadion gick, osynliga bakom ett plank, upphetsade fotbollsspelare och skällde på varandra.

Under tedrickningen där föräldrarna hänfört gläds åt de piroger och kakor som man bakat respektive lyckats utverka från kooperativet råkar den tigande kolchosarbeterskan också undslippa sig något om sin verklighet (den Dobyčin alltså bevittnade under vårens reportageresa) som ett störande inslag i feststämningen: "Агафьюшка развеселилась и рассказывала, как выходит на работу, а сама боится, чтобы не спалили двор." ("Agafjusjka blev uppsluppen och berättade att hon själv var rädd när hon gick till arbetet för att någon skulle bränna ner gården.") Detta sköljs dock snabbt bort av nästa överraskning: en av föräldrarna har med sig harmonikan och stämmer upp i en vals som man börjar dansa till.

Från valsen leder berättelsen i en sista vridning ut igen till en slutscen ute på trappen framför en mörknande gårdsplan. Pionjären Kolja som rusat fram för att bjuda upp rödarmisten Miša bara för att få se honom bjuda upp en kvinnlig tekniker är den första som går ut för att stå där ensam på trappen i mörkret. Två kvinnor smiter dansande ut för att leta efter fallfrukt men blir också stående på trappan inför kvällshimlen. Därute sitter även barnträdgårdens kvinnliga läkare som var en av dem som höll tal vid avslutningen. Dessa samlas där liksom inför något betydelsefullt, så som i Dobyčin allra första novell och i den vidareutvecklade inledningsnovellen "Proščanie". Men nu är det en annan samtid med en ny tids associationer som kommer till uttryck och formar en upplevelse av ett slut, ett avsked: "Сорвала́сь звезда и покатилась, словно сбросилась на парашюте. Было тихо впереди, оттопывали сзади." ("En stjärna lossade och föll som om den kastat sig ut i fallskärm. Det var tyst framöver, det stampades därbakom.”)

Denna stund avbryts av ledamoten i kommunfullmäktige. Han kommer ut, kliar sig i nacken och fäller en misstänksam kommentar, "Целое собрание" ("En hel samling"), vilket får en av kvinnorna som tänkt leta efter äpplen att genast förklara att de bara är där för att ta lite luft. Ledamoten 
inleder ett samtal (det vill säga en liten föreläsning) om den pågående moderniseringen: att vattenbodarna ska ersättas av automater med myntinkast. Beledsagat av ett betydelseframkallande blänk i hans pincené får det den hittills orörliga läkaren att vakna till. Med en politiskt olämplig lösmynthet börjar hon nu plötsligt utbreda sig om hur fantastiskt allt är i Amerika: "- В Америке, - засуетилась она, - всюду автоматы: опускаете монету, и выскакивает шоколад. - Скажите, - отвечали ей. ("- I Amerika, sade hon ivrigt, finns det automater överallt: man stoppar i ett mynt, och ut hoppar choklad. - Det säger ni, svarade man henne.") Tillsynes obekväma, pinsamt berörda låter de henne sedan prata på. Och hon talar och talar och tycks liksom inte kunna hindra sina annars återhållna drömmar om ett annat liv när de väller fram till stampandet till musiken i bakgrunden och med mörkret framöver. Hon inser själv att hon borde sluta, borde vara tyst. Det är den sista berättelsen om samtiden. Det är så här det slutar:

Никто не расходился. Все хотели переждать друг друга. Докторша тянула канитель, рассказывая об Америке. Там, говоря по телефону, можно видеть собеседника. Там тротуары двигаются, там ступени лестниц подымаются с идущими по ним. Она рассказывала и рассказывала, под гармонику и топот, и не знала, как ей замолчать, хотя и чувствовала, что никто не верит ей.

Ingen bröt upp. Alla ville vänta ut någon annan. Doktorskan spann vidare och berättade om Amerika. Där kunde man se den man pratade i telefon med. Där rörde sig trottoarerna, där lyfte stegen i trapporna med dem som gick på dem. Hon berättade och berättade, till harmonikan och stampandet, och visste inte hur hon skulle få slut på det och bli tyst, fast hon kände att ingen trodde på henne.

Det hade inte varit Dobyčin om hon faktiskt hade sagt något viktigt, om hon hade varit en sanningssägare. Det som är väsentligt med hennes berättelse, det som hennes återgivande av dessa snarast tidskriftsskvallerartade uppgifter om en annan verklighet (den även för Sovjet moderna förebilden Amerika) ger uttryck för, är framförallt en ensam människas längtan. ${ }^{336} \mathrm{Här}$

336 Även om USA ännu inte var den huvudfiende som det blev efter andra världskriget, utan bland annat med sina skyskrapor och moderna fabriker rentav utgjorde en förebild för samhällsplaneringen i Sovjetunionen, sågs detta slags lovordande dock troligen som politiskt olämpligt, inte minst för att det indirekt uttrycker ett klagomål över de sovjetiska förhållandena. Känsligheten för all slags kritik av den rådande materiella situationen framgår av Dobyčins redogörelse för utrensningsförhöret mot en av hans systrar som arbetade i en livsmedelsbutik. När en kvinna i publiken begär att man ska fråga henne hur hon förhåller sig till de ekonomiska problemen protesteras det först eftersom frågan anses politisk. När ordföranden ändå ser sig tvungen att ställa frågan svarar Dobyčins syster undvikande att 
finns ingen huvudperson. Här finns bara detta utbrott av vad som hos andra skildrats i deras tystnad. En längtan efter öppenhet, efter att tala fritt, efter möten och något betydelsefullt, efter en mänskligare tillvaro. Det är vad det som ursprungligen var en avslutning på en barnträdgård och nyss ett samtal om teknikutvecklingen så mynnar ut i.

\section{"Jag kan inte tiga" - författarskapets fortsättning}

Dobyčin hade redan tidigare gett uttryck för en ensamhet i sin provinsiella tillvaro. Hösten 1928 skrev han till Slonimskij i samband med att han redan då såg för sig att han snart skulle bli tvungen att resa till Leningrad eftersom man ämnade ersätta tjänstemän med borgerlig bakgrund med nyutbildade från sovjetiska partiskolor ("sovpartškoly"): "А мне очень наскучило ни с кем не разговаривать. «Не могу молчать», как выразился наш с Вами кумир Лев Николаевич. - Простите." ("Och jag har blivit så less på att inte ha någon att prata med. 'Jag kan inte tiga', som vår idol Lev Nikolaevič [Tolstoj] uttryckte det. - Förlåt.") 337

Det är delvis denna samhällsomvandling, denna politiska utrensning även inom stadsadministrationen i Brjansk för att avskaffa den gamla ordningen, för att "rensa apparaten", som när den följande år, 1929, tar sin början ligger bakom att Dobyčin söker sig till Leningrad för att försöka bli kvar där.338 Tillbaka från Leningrad igen, sommaren 1930, har han också trots sin utbildning och arbetslivserfarenhet stora svårigheter att få ett nytt arbete.

Denna prekära situation förklarar också hans oro över att novellsamlingen Portret inte ska komma till stånd och den enträgenhet med vilken han försöker få de sista två novellerna medtagna i den. Att han tvivlar på att han överhuvudtaget kommer att få något mera utgivet, och att de två novellerna om de inte tas med, som han rätteligen förutspår, inte kommer att gå att

problemen är tillfälliga och klarar sig så genom utrensningen utan anmärkningar. Till Slonimskij I3 augusti 1930 (brev I26), PSSP, 3IO-3II.

337 "Ne mogu molčat"' ("Jag kan inte tiga") är titeln på Tolstojs berömda stridsskrift mot dödsstraff från 1908 skriven som en reaktion på hängningar av bönder och revolutionärer. Till Slonimskij 2I november 1928 (brev IO7), PSSP, 298. Om förestående förändringar I2 juni (brev I04) samma år, PSSP, 296.

338 Även om den omedelbara anledningen är att statistikbyrån där han arbetar upplöses då Brjansk genom en ny regionsindelning mister sin ställning som administativ centralort till Smolensk så är det troligen på grund av sin borgerliga bakgrund som han inte omplaceras, trots sin uppsatta position och trots att han klarat sig genom ett utrensningsförhör året före, till det nya lokala statistikkontoret. Ė. S. Golubeva, Pisatel' Leonid Dobyčin i Brjansk, Brjansk $2005,38-39,5 \mathrm{I}-53,65$. 
publicera någon annanstans, har troligen också att göra med de två tidskriftpubliceringarna av hans nya noveller i början av 1930 - att de i båda fallen försågs med varnande ord från redaktionen för författarens småborgerlighet och brist på kontakt med samtiden (om "Lekpom", "Chiromantija" och "Požalujsta" i Leningrad) respektive borgerliga förfall i världsåskådningen (om "Portret" i Strojka).339 En vecka efter att han översänder den första novellen ("Mater'jal") till Slonimskij får han korrektur på novellsamlingen utan den. Han tycks inte få svar vare sig på sitt brev som följer med novellen eller med nästa där han skriver om korrekturet men också att han tänkt ut "en novell om 'en barnträdgård'" som han tänkt skriva innan han återgår till romanen. Med detta upphör korrespondensen med Slonimskijs i över två år. ${ }^{30}$ Troligen gjordes aldrig något försök att få förlaget att medta de sista novellerna och frågan är om samlingen Portret hade blivit utgiven om dessa ingått - den politiska udden mot samtiden hade i alla fall skärpts med dem.

Att Dobyčin till slut hittar ett arbete under hösten och också skriver"Čaj" då framgår av att han för första gången på fyra år, i början av I93I, hör av sig till Čukovskij igen och översänder den nyutkomna novellsamlingen samt de två novellerna. Liksom i början av sitt författarskap ber han om dennes omdöme då han själv som vanligt säger sig ha svårt att förstå sig på sina berättelser. Den anställning som Dobyčin fått, som han bara omnämner som något slags mindre industri ("promzavedenie"), förklarar han vara mer krävande än tidigare arbeten, även på kvällarna är han upptagen där, vilket inte ger någon tid över till skrivande. ${ }^{34}$ Något om hans materiella situation framgår av att han, om än med sin vardagsförundrade ironi bevarad, omtalar det som ett litet glädjeämne att han just denna dag fått en kupong för att reparera sina stövlar. Inte heller från Čukovskij tycks Dobyčin emellertid ha fătt något svar. ${ }^{342}$

\footnotetext{
339 Möjligen befarar han också att deras brev läses. Åtminstone noterar han en ovanlig fördröjning av ett brev från Slonimskij och ber honom att iaktta vilken dag han mottar svarsbrevet. Om så verkligen var fallet skulle det kunna ligga bakom att något brev verkligen förkommit såsom Slonimskij tycks mena när Dobyčin 1932 återupptar den av oklara skäl avbrutna korrespondensen. Till Slonimskij I9 juli 1930 respektive Io december 1932 (brev I25, 134), PSSP, 309, 315.

340 Till Slonimskij 8 och I4 september 1930 (brev I30 och I3I), PSSP, 313-315.

${ }^{34}$ Det försiktiga omnämnandet av arbetsplatsen har troligen att göra med att det är en vapenfabrik, närmare bestämt Brjansks mekaniska [artilleri-]fabrik nr. 13 där han tjänstgjorde som statistiker och ekonom från I oktober 1930 till 6 juni 1934. Ė. S. Golubeva, Pisatel' Leonid Dobyčin i Brjansk, Brjansk 2005, 55-56.

${ }_{342}$ Till Čukovskij 7 och 12 februari I93I (brev 39, 40), PSSP, 266.
} 
Dobyčin uthärdar inte bara i Brjansk. Han överlever också som författare. När han i december 1932 prövar att vända sig till Slonimskij igen - vilket genast leder till att korrespondensen återupptas om än med färre och mer affärsmässiga brev under de två åren som följer innan hans flytt till Leningrad kommer till stånd - är det enda nya han har att översända visserligen novellen "Čaj", som var klar redan två år tidigare, men han har också gått igenom och bearbetat samtliga noveller i Portret (så att de blivit "trevligare" ("prijatnej")) och av dessa sammanställt den nya, med de två sista novellerna utökade, samlingen Mater'jal i hopp om att kunna ge ut den i Moskva. (Då det framgår att han felaktigt antagit att Portret - vars eventuellt uteblivna utgivning han så våndats över - aldrig släpptes för försäljning måste även de nedgörande recensionerna av den uppenbarligen ha undgått honom.) Dobyčin översänder den nya samlingen och får Slonimskij att göra ett som denne förutsett fruktlöst försök att få den utgiven.

Förutom detta sista arbete med novellerna är romanen det skrivande som har upptagit och nu fortsätter att uppta Dobyčin. Han planerar den. Att arbetet med att skriva den går så oerhört långsamt förklarar han, med sin sedvanliga allvarliga humor, med att han bara hinner vara författare på en halv procent och att de dessutom inte haft elektricitet under vintern och därtill lidit brist på fotogen. ${ }^{343}$ Därför kan skrivandet ta fart igen först fram på våren 1933 när det är ljust på kvällarna (men troligen också för att den återupptagna kontakten med Slonimskij ger förnyat hopp). I slutet av maj översänder han för första gången en första del av romanen till Slonimskij. Dobyčin hör sig genast för om möjligheten att publicera enbart denna inledning i någon tidskrift; det skulle nämligen vara "utomordentligt önskvärt" för honom med betalning. ${ }^{344}$ I nästa brev ber han Slonimiskij att även försöka i Moskva och menar att det skulle vara "på tok för filantropiskt" ("čeresčur filantropično") av honom att fortsätta skriva om han inte får denna inledning publicerad.345

Men det får han, som nämnt, i majnumret 1934 av den prestigefulla tidskriften Krasnaja nov' i Moskva under titeln "Načalo romana" ("Början på en roman"). Det är samma år som Dobyčin så definitivt slutligen flyttar till Leningrad och där får möjlighet att verka som författare på heltid för första gången i sitt liv. Han färdigställer sin delvis självbiografiska uppväxtroman och får den utgiven. Och han skriver ytterligare två verk som inte heller de längre försöker skildra den omedelbara sovjetiska samtiden.

\footnotetext{
343 Till Slonimskij 6, Io och 30 december 1932 samt 3I januari och 15 mars 1933 (brev I33-I37), PSSP, 315-317.

344 Till Slonimskij 23 maj 1933 (brev I39), PSSP, 317.

345 Till Slonimskij I9 juli 1933 (brev I4I), PSSP, 318.
} 
Upptäckt och uppmuntrad av Čukovskij hade Dobyčin som tidsandan bjöd under tjugotalet koncentrerat sitt skrivande till berättelser som skildrade och utspelades sig i den nya sovjetiska samtiden. Troligen delvis påverkad av Čukovskijs och Slonimskijs omdömen och besvären med att få vissa noveller publicerade hade han utvecklat ett sätt att skriva om samtiden antingen "utan politik", som han uttryckte sig, eller åtminstone i tillräcklig grad mildra novellernas uppenbara uttryck för en kritik av den nya ordningen. Han hade fått lära sig att tiga. Vad han inte kunde undvika var att detta slags tigande ändå blev talande. Det var själva poängen. Denna "outsagdhet", som Stepanov betecknade det i sin recension av första novellsamlingen, är själva grunden för att novellernas möten bortom orden ska framträda.

För den misstänksamma kritiken i samtiden innebar, som vi sett, inte bara bristen på en uttalad ideologi utan även överhuvudtaget frånvaron av en uppenbar samhällskritik ett problem: Dobyčins mindre politiska kortnoveller visade sig inte mer gångbara utan gjorde honom i kritikernas ögon genast till en dekadent småborgerlig författare som saknade förbindelse med sin samtid. Och att han sedan skildrade en mötesproblematik även historiskt i sin roman, i det förrevolutionära borgerliga samhället, innebar till sist, 1936, för de som ville se honom som antisovjetisk inte annat än ett kärleksfullt tillbakablickande. Det gick då inte längre att tala öppet, men inte heller att inte tala och samtidigt fortsätta skriva. Då talade de ideologiska kritikerna i ens ställe.

\section{Resultat}

\section{Mötena bortom orden och det mänskliga}

Det jag har visat på i denna avhandling är att Dobyčin ända från första början i sina noveller försökte skildra något bortom den politiska diskursen och de laddade orden i sin samtid. Novellerna talar genom upplevelser av något odefinierat betydelsefullt i tillvaron. Genom sina sinnliga intryck och avskalade repliker utan utvecklade tankar, genom den vardagliga tillvarons kontraster som så framträtt och problematiserat den nya ordningen och dess ideal, erbjuder novellerna ett slags möten mellan människor tillika möten med något grundläggande mänskligt bortom orden. Dessa möten gestaltas genom en insisterande exakthet och konkretion i återgivningen såväl av triviala gester, fraser och klichéer, förlupna ord och felsägningar som av omgivande detaljer - impressionistiskt glänsande, månskensbelysta, vindar, 
lukter och smaker, vardagslyriska naturintryck, ljud och musik som framkallar de inblandade personernas medvetanden. Både genom vad som varseblivs, med vilka ord det beskrivs och hur det rytmiskt accentueras och bringas i samspel framställs indirekt både huvudpersonernas tankar och en interaktion med andra bortom vad de direkt uttalade orden rymmer.

Dessa möten bortom orden är inte generaliserbara som ett koncept. De har framträtt genom en läsning av novellerna som helhetliga konstverk som inte försökt att kritiskt avslöja, inte sökt en hemlig rebusartad kod eller en teoretisk formell nyckel, utan sett till den vardagliga tillvaro som skildras och de banala men betydelsefulla möten, den mänskliga samvaro som där ändå äger rum. Novellerna visar så lästa på ett möjligt själsligt samförstånd, en dialog om denna verklighet och förundran över den för den som vill delta. Det kräver att man lyssnar, försöker förstå novellerna in i sina minsta beståndsdelar, hänger sig och igenkänner det liv som skildras, möter denna vardagliga tillvaro, dess människor och deras berättelser och upplevelser. Den mänskliga mötesproblematik som jag visat på en genomgående gestaltning av som författarskapets centrala tema och grunden till novellernas konflikter kan så, i förhållande till novellsamlingen som en helhet, ses som ett slags försvar av det mänskliga i den sovjetiska samtiden. Det är inget högstämt försvar av det mänskliga som princip utan av denna tillvaros verkliga människor i all sin trivialitet och låghet: med deras naiva tro på tecken, deras omodernitet i sitt fasthållande vid religiösa och borgerliga ritualer och föremål som framkallar nostalgiska minnen, och framförallt med deras romantiska längtan och banala, melodramatiska föreställningar om ideala möten och vänskaper som både ger dem mening och ställer sig i vägen för att leva med världen som den är. Även den nya sovjetiska verklighetens företrädare skildras med en profanerande vardaglighet och banalitet. De tampas ofta med att på rätt sätt efterfölja den nya ideologin eller att inpassa den i sina lätt småborgerliga syften. I förhållande till socialistisk realism råder en klandervärd brist på hjältar och riktig ideologi.

Dobyčin ger oss inte någon lösning, något idealt sätt att leva. Finns det ett ideal så är det det mänskliga i all sin banalitet. Det naiva och oförsiktiga i detta ligger samtidigt till grund för vardagliga möten.

De människor som skildras är överhuvudtaget vanliga. De är inte intressanta för sitt djupa själsliv, inte genom spännande händelser som de upplever, inte genom sitt förflutna. Den stora världen är någon annanstans, liksom Dobyčin själv är personerna provinsiella och längtar och drömmer sig ofta bort därifrån. Men kanske präglat av Dobyčins uppväxt i en annan typ av provinsstad (med en större blandning av människor där ryssar inte ens 
utgjorde majoriteten), av hans studenttid i Petersburg och av den större litterära värld han riktade sig mot, gestaltas denna småstadstillvaro med en distans som får en allmänmänsklig problematik att framträda i den.

Dobyčins noveller har som jag diskuterade i inledningen ofta blivit lästa som ett rent ironiserande över denna provinsiella tillvaro, ett skildrande av dess låghet. Och förhåller man sig i läsningen med en sådan förutfattad mening till dem, som enbart ett nedlåtande ironiserande över dess människor, så blir som sagt novellerna verkligen meningslösa. De kan då endast förstås som och blir inget mer än en meningslös konst som skildring och kritik av en meningslös tillvaro. Dobyčin är ironisk i sina brev, han är ironisk i själva berättelserna, i gestaltningen av tillvaron, men hans ironi är inte hånfullt riktad mot dess människor och deras vardag. Det är inte vad som framträder om man ger sig hän i läsningen. För i novellernas vardagliga upplevelser av vackra stunder, av ett anat samförstånd med någon, av en närvaro i världen som något betydelsefullt, får man, som jag visat på, uppleva en möjlighet för det mänskliga även i denna tillvaro. Det innebär indirekt en kritik mot misstänkliggörandet och inskränkandet av friheten för människors längtan och personlighet. Mötesproblematiken talar så, på sitt tigande sätt, om ett hot mot människan i det nya sovjetiska samhället, i dess krav på inordning i ett ideologiskt system med redan givna svar på hur man ska leva, vad som är betydelsefullt, hur människor skall mötas och samhället organiseras.

Novellernas tigande och avstående från tankar som låter den vardagliga tillvarons sköra mänskliga möten framträda kan så kanske ändå läsas som en stridsskrift i samma anda som Tolstojs som Dobyčin nämnde i sitt brev. Tolstojs artikel "Ne mogu molčat"' ("Jag kan inte tiga") var riktad mot den förrevolutionära bristen på respekt för människoliv, mot den tidens systematiska, obrydda tillämpningar av dödsstraff, den tidens blinda omänskliga system, vilket han inte längre kunde tiga om. Han såg sig tvungen att tala klarspråk om det på ett sätt som man då försökte censurera och bestraffa. I Dobyčins sovjetiska samtid hade författarens liv svävat i fara genom en sådan frispråkighet om den ens lyckats komma i tryck. Hos Dobyčin görs istället läsaren till medskapare till en sådan skrift genom den talande tystnad ur vilken mänskliga möten framträder bortom orden.

\section{Filosofi - att tala utan ord}

Behöver något mera sägas? I inledningen till denna avhandling citerade jag en scen ur det efterlämnande verket Šurkina rodnja där huvudpersonens farfar läser en bok som vist nog enligt honom visar att saker kan vara på både det ena och andra och tredje sättet. Scenen slutar på följande sätt: 
Стало припекать. Полынью стало пахнуть. Философствующих начало морить. 346

Solen började steka. Det började lukta malört. De filosoferande plågades.

Man kan kanske filosofera om betydelsen av Dobyčins verk och om deras verkan på ett liknande sätt. Det jag demonstrerat är att även om Dobyčins verk kan tillskrivas en filosofi i sitt uttryck så är inte filosofin det väsentliga, utan den levande verklighet med dess människor som sedan väller in, som här - med stekande sol och lukten av malört på deras väg över stäppen en konkret dag i livet.

Ett metapoetiskt uttryck för detta kan man möjligen också se i detta Dobyčins sista verk i samband med att Tolstoj (som alltså Dobyčin omtalar som en idol) kommer på tal under ett samtal om religion. Efter att den filosoferande farfadern (som är skrivare) talat om att Tolstoj påstås ha sagt att de heliga böckerna skrivits av så många gånger att fel smugit sig in nämner huvudpersonens gammelmorfar kryptiskt en bok om kyrkor där de beskrivs som "en hög med sten, en förening av guld och silver" ("свалка каменья, слитие золота и серебра").347 Denna omskrivning kan tas som ett indirekt exempel på Tolstojs karaktäristiska sanningssökande, hans sätt att ingående och konkret beskriva det tillsynes välkända och självklara. Detta omskrivande eller omdöpande (perenazyvanie ${ }^{38}$ ) - det formalisterna ser som Tolstojs främmandegöring - för att få läsaren att uppleva ting och företeelser bortom våra invanda uppfattningar om dem är något som också kan sägas vara grundläggande för Dobyčins sätt att få den vardagliga tillvaron att tala. Det omvända perspektiv som jag tog upp i inledningen, det Gasparov presenterar i samband med Pasternak, förefaller dock mer träffande även för Dobyčin: att det handlar om att försöka känna igen något betydelsefullt i själva den bekanta, vardagliga tillvaron. ${ }^{349}$

\footnotetext{
346 PSSP, 214.

347 PSSP, 208-209.

348 A. P. Čudakov, Slovo - vešč - mir: Ot Puškina do Tolstogo: Očerki poètiki russkich klassikov, Moskva 1992, 134-I36.

349 Tolstojs eget ordval "sceplenie" ("sammanlänkning"), när han i ett brev beskriver hur han inte med ord kan sammanfatta vad han ville uttrycka med Anna Karenina eftersom tankarnas innebörd just ligger i hur de sammanlänkats i verket - sammanlänkningar som inte kan uttryckas på annat sätt än just genom att som i romanen med ord beskriva bilder, händelser och tillstånd -, brukar användas för att beskriva Tolstojs berättarteknik (eller, av Lotman, som något av en grund för litterär gestaltning överhuvudtaget). Lev Tolstoj, brev till N. N. Strachov I876, L. N. Tolstoj, Polnoe sobranie sočinenij, 62, Moskva 1953, 268-269; Ju. M. Lotman, Analiz poètičeskogo teksta: Struktura sticha, Leningrad 1972, 36-37. Fëdor Fëdorov betecknar också det han kallar montageteknik hos Dobyčin som ett helhetsträvande i Tolstojs efterföljd, som ett visuellt istället för verbalt sammanlänkande. Fëdorov "O kompozicionnom
} 
Med detta inte sagt att Dobyčin egentligen liknar vare sig Tolstoj, med dennes ständigt framåtdrivande, didaktiska och allomfattande tänkande genom den tillvaro som gestaltas, eller Pasternak med dennes känslostormande elektrifierande av den vardagliga tillvaron till en högspänd betydelsefullhet in i dess minsta beståndsdel. Stämningarna i tillvaron hos Dobyčin är helt andra. Där finns också tristess, långsamhet, monotoni. Det betydelsefulla i denna tillvaro är inte något ständigt påtagligt, det är något som uppstår trots allt, i stunder, i rörelser och intryck i tillvaron som succesivt eller först i efterhand ger en känsla av mening, en upplevelse av ett mänskligt liv och sammanhang. Att Gasparovs ingång till Pasternak har varit viktig även för detta arbete har enbart handlat om inriktningen i läsningen på att förstå berättelserna utifrån den vardagliga tillvaro som skildras. Att en sådan läsning är nödvändig även för att Dobyčins verk ska framträda handlar om att de liknar Pasternaks enbart i det att de tycks söka fånga tillvarons egna konstnärliga uttryck. Det är en konst som inte så mycket skapar sin egen värld med tillvaron som råmaterial utan söker sitt språk och sin form just i denna tillvaros levande, förkategoriella omedelbarhet.

Så kan de många ställföreträdande konstnärerna i Dobyčins noveller förstås: den realistiske författaren Erygin, Konopatčikova och Vdovkin med sina sinnligt konkreta minnen, kiromantikern Petrov, tjastusjkasångerskan Černjakova - så gott som samtliga huvudpersoner tar också del i gestaltningen och ett potentiellt metapoetiskt uttryck med sina dagdrömmande föreställningar.

\section{Politik och läsning}

Anspelningen på Tolstojs stridsskrift och att överhuvudtaget tillskriva Dobyčins verk en viss samhällskritisk position leder lätt fel. Detta tal för det mänskliga genom sitt tigande, sitt bortomideologiska uttryck beskrivs kanske bäst som en oundviklig konsekvens av det han som konstnär drevs till att gestalta. Att han därefter sökte sig till historisk tid, till sin egen uppväxts borgerliga samhälle i romanen Gorod $\dot{E} n$, och sedan en fjärran bytillvaro med en huvudperson med ett helt annat temperament och ett samhällsliv av ett annat slag i sitt sista verk var troligen aldrig tänkt som ett sätt att kunna fortsätta att skriva ett förtäckt försvar för människan i en allt vansinnigare samtid. Man bör nog stanna vid att konstatera att de mänskliga möten han upplevde bortom orden, den känslan av något betydelsefullt,

montaže v russkoj proze 1920-x godov (Ju. Tynjanov, L. Dobyčin, M. Zoščenko)", DS-7, I62I75, I62-I63. 
helt enkelt, oavsett tid, var det som han som författare drevs att ge konstnärligt liv åt. Det politiska i det existentiella uttrycket kan ses uppstå som en konsekvens av att denna konstnärliga inriktning stod i motsats till både det rådande ideologiska språket och till samtidens indirekta och den socialistiska realismens senare formulerade krav på litteraturen.

Den mötesproblematik Dobyčin gestaltade behöver så inte tillskrivas en politisk avsikt. Detta uppenbarande av något betydelsefullt i tillvaron, av det mänskliga samspelet i den vardagliga tillvarons detaljer, gav honom mening och det ger också läsaren - om man ger sig hän i att uppleva hans berättelser - en sådan upplevelse av mening.

Så utvecklas ens läsande. Läsandet av Dobyčin lär en succesivt att läsa Dobyčin. Den äldre kvinna vars läsarreaktion han återger i ett tidigt brev talar för denna upplevelse, när hon liksom börjar läsa novellen en andra gång och plötsligt förstår. Vad man sedan förstått, hur man återger den mening man upplevt i det liv och mänskliga sammanhang som framträtt - det är ens ensak. Det är inte säkert att man möts i det. Det är inte säkert att det kan uttryckas på något annat sätt. Det riskerar att förminskas om man försöker filosofera över det - då filosoferandet lätt medför det slags generalisering och abstraktion som leder till en skymmande ideologisering.

Det jag också hoppas har framgått är att Dobyčins berättelser trots sin knapphet egentligen inte är svåra. De är aldrig osammanhängande eller eftersträvat fragmentariska och händelselösa. De är hela tiden ute efter att uppenbara det skört mänskliga, sinnesrörelser och upplevelser av ett betydelsefullt samspel i tillvaron, oavsett vilka ideologier och belastade ord som kväver och inskränker livet i det yttre. Det skildrar den vanliga människans villkor under denna tid - och indirekt litteraturens och författarens vilket jag lyft fram i mina tolkningar.

Jag har inte eftersträvat en slutsats i form av en given nyckel till Dobyčins författarskap. De insikter i vad författaren uttrycker i sina noveller som mina mötande läsningar av dem som både självständiga och ett sammantaget konstnärligt porträtt av den samtida tillvaron givit är på så vis det viktigaste resultatet av detta avhandlingsarbete. Jag har öppnat författarskapet men inte löst dess gåta.

Kritiken mot Dobyčins svårförståelighet, hans brist på klarspråk, att han är "utstuderat fragmentarisk och lakonisk", som redan den första recensionen anklagade honom för, visade egentligen bara på de egenheter som Dobyčin gestaltade det mänskliga genom, det som indirekt utgjorde ett försvar mot just dessa kritikers ideologiska begränsande av livet och konsten. Såväl samtidens ideologiska konst och läsning av verkligheten som kravet på att vara samtida, har jag också, som en aspekt av mötesproblematiken, 
visat på en tematisering av i novellerna: den unge Erygins försök att vara en lojal sovjetförfattare, den indirekta konstdiskussionen i "Konopatčikova" och kontrasteringen av en städerskas personliga och levande uttryck för sin tillvaro med en ideologiskt diktande poetissa i "Sad", för att nämna de tydligaste exemplen.

\section{Kontexter}

I all sin egensinnighet låter sig Dobyčin - en statistiker som var intresserad av den enskilda människan - förvisso skrivas in i modernismens försök att nå en ny och sannare realism, en där språket rör sig ut ur systemet och in i livet som det levs, en realism där människor gestaltas som unika levande individer bortom sina namn och samhällsroller, bortom representerande typer, vilket man kunde komma åt just genom att söka sig till de vardagliga ögonblicken innan meningen skapas, innan tecknen tyds, i det ständigt ännu oförklarade. De människor och deras samspel som framträder bortom det genomideologiserade språket i stunder av upplevelser av något betydelsefullt kan mycket väl jämföras med exempelvis Joyces Ulysses. Joyce kan där sägas framställa hur gränsen mellan jaget och omvärlden försvagas och samtiden och historien sköljer igenom de människor han skildrar men samtidigt fånga detta mänskliga och levande som kultur. Det verket är också ett sätt att låta det mänskliga framträda i det förkategoriella genom att se och inte tänka (så som medicinkvinnan föreskrev huvudpersonen i "Požalujsta" att göra). Joyce är också väldigt enkel på samma gång som han kommit att betraktas som en av de mest svårförståeliga författarna, som emblematisk för modernismens elitism. 350

Dobyčins återhållenhet eller outsagdhet kan i denna modernistiska litterära kontext ses som ett av sätten att komma åt det mänskliga i ett genomideologiserat språk. Därför är det viktiga inte i första hand vad som sägs i novellerna utan hela tiden - genom att berättelserna stannar upp, avbryter, kontrasterar, visar på gesterna omkring, på något vid sidan av tillsynes ovidkommande - det mänskliga som kommer till uttryck eller igenkänns i hur och att det utsägs. Det blir ofrånkomligen svårt och komplext om man försöker skriva fram något bortom våra förutfattade meningar och ideologier. Varje försök till en enkel sammanfattning av budskapet riskerar att antingen ideologisera eller estetisera det och därmed förta dess verkan som

\footnotetext{
350 Ungefär så utlägger sig Karl Ove Knausgård allmänt om modernismen utgående från Knut Hamsun (en författare som också inledningsnovellen "Proščanie" innehöll möjliga allusioner till) och James Joyce. Min kamp 6, Stockholm 2013, 395-406.
} 
levande- och mänskliggörande konst, liksom det unika i uttrycket. Den risken löper man med en litteraturhistorisk kontextualisering.

Dobyčin är inte uppenbart lik någon i sin samtid - varken Oleša, Babel', Platonov, Charms, Zoščenko eller Mandel'štam som är namn som brukar nämnas och som han jämförts med i forskningen. Hans prosa är modernism men framstår aldrig som eftersträvat nyskapande i sin realism. ${ }^{351}$ Att Dobyčins berättande fortsätter en tradition från Flaubert och Čechov (som han själv pekar ut som förebilder), men också från Gogol' och Tolstoj, i viss mån Dostoevskij och Puškin, och kanske mest liknar Anatole France och Joyce i sin samtid, säger mer men ändå inte mycket. Sådana jämförelser och påvisande av intertexter har det också redan gjorts mycket av i forskningen.

Fokuset i denna avhandling har därför inte varit att litteraturhistoriskt jämföra Dobyčin med andra författare. Däremot har jag gett en insikt i författarens villkor i den litterära samtiden eftersom detta bidrar till förståelsen av mötesproblematiken i Dobyčins verk. Jag har därför närgånget följt Dobyčin i hans förhållande till den sovjetiska samtidens kulturella verklighet och gett prov både i novellerna och ur hans brev på hur han navigerar i den. Jag har försökt att genom läsningarna indirekt gestalta ett möte med författaren Dobyčin och så ge förståelse för de samhälleliga omständigheterna kring och den personliga drivkraften i hans skapande, utan att läsa novellerna som direkt självbiografiska. Indirekt har jag så fördjupat förståelsen för tidsandan såväl i det litterära livet som i den provinsiella vardagliga tillvaron i hans samtid men hela tiden utgående från hans eget uttryck och gestaltning av det. Jag har förehållit mig till novellerna som konstverk.

Jag har inte heller haft som syfte att med novellerna som exempel utifrån förefintliga teorier utveckla författarskapets uttryck filosofiskt, estetiskt eller kulturhistoriskt - utan återigen försökt öppna just vad Dobyčins författarskap har att säga oss.

Jag har varit ute efter att få Dobyčins verk att framträda som konstnärliga helheter som både gestaltar ett liv som en mening i sig och som potentiellt i

${ }^{35}$ Detsamma kan förvisso sägas om andra författarskap som inordnas i modernismen. Thomas Seifrid har exempelvis karaktäriserat Platonovs prosa som "de facto modernism" till skillnad från Andrej Belyjs och andras "self-conscious, avant-gardiste assault on linguistic and artistic convention". Ett uttalande av den unge Platonov om den provins han befann sig i - med vilket Seifrid vill understryka att Platonov med sin de facto-modernism rör sig bort från den ryska modernistiska kulturens centrum och anknyter till en satirisk-grotesk tradition från Gogol', Leskov och Saltykov-Ščedrin - kan också ses som en belysande parallell till Dobyčins inriktning på att skildra en provinsiell tillvaro: "It seems to me [...] that genuine art and thought in fact can only appear in such a backwater." Thomas Seifrid, Andrei Platonov: Uncertainties of Spirit, New York 1992, xii, 273, citerad i Mary A. Nicholas, recension av Thomas Seifrid, Andrei Platonov: Uncertainties of Spirit, Slavic Review, 53, 4, 1994, II96-II97. 
all sin tidsbundenhet, just i den subtila skildringen av det mänskliga, har något att säga oss som läsare oavsett samtid.

Jag har med medveten långsamhet utvecklat vad Dobyčins noveller helt enkelt handlar om, var för sig men också var och en med sitt bidrag till novellsamlingens helhet. Så har den mänskliga mötesproblematiken framträtt som ett genomgående tema i hans samlade noveller. Med läsningen har jag velat ge en ingång till att tala om det betydelsefulla i själva verken, vad de uttrycker som konst, vilket såväl ett fokus på formella egenheter som på det dokumentärt historiska lätt ställer sig i vägen för. Att jag valt att begränsa mig till novellerna har att göra med att de så tydligt lägger grunden för och belyser det fortsatta författarskapet då mötesproblematiken ställs på sin spets just i direkt relation till den sovjetiska samtiden.

\section{Resumé}

Jag utgick från inledningsnovellen "Proščanie" ("Avskedet") med dess minnesskimrande skildring av Petrograd efter revolutionen som ett slags ramberättelse då den slutar med att den delvis författarlika huvudpersonen Kunst avreser till en provinsiell tillvaro. Denna skildras därefter i samlingen men då i den sovjetiska samtiden efter inbördeskriget, den tid som novellerna tillkom i, från I923 till I930. I de första provinsnovellerna präglas tillvaron liksom $\mathrm{i}$ inledningsnovellen, trots åren av inbördeskrig, av en fortsatt ovisshet över den politiska utvecklingen. Det finns ett visst utrymme för olika sätt att leva i samtiden under den nya ordningen. Medan de äldre kvinnor som skildras i de första novellerna försöker förhålla sig till det nya men främst finner mening i sina liv genom att hålla fast vid och vårda minnena och relikerna av den förrevolutionära kulturen - om än den nya verkligheten ständigt gör sig påmind med sina störande manifestationer och påbud - så har de unga inte samma valmöjlighet. Hos dem skildras det ofta känslomässigt konfliktfyllda i att anpassa sig och efterleva de nya sovjetiska idealen. Det görs inte lättare av att ett hyckleri ofta skiner igenom hos de främsta företrädarna för den nya ordningen, eller att inte heller de har helt lätt att leva upp till idealen. De unga har emellertid knappast något annat val än att följa med strömmen. Det är i det här samhället de måste leva sina liv. I att ge upp det gamla och en längtan efter något annat finns en lättnad, då försvinner konflikten. Men med det följer samtidigt risken att de ger upp sig själva, sin personlighet, att de tystnar som människor. Att bli en anonym del av kollektivet innebär att de möten bortom orden med en mångfald av olika mänskliga perspektiv och insikter som upplevts som något betydelsefullt måste överges för en entydig syn på verkligheten enligt den påbjudna 
ideologin. I novellen "Erygin" skildras svårigheten i att fortsatt skriva realistiskt om denna brokiga, mångtydiga samtid om man samtidigt vill vara ideologiskt lojal. På olika sätt skildras kontrasten mellan den påbjudna idealismen och den levande samtida tillvaron (med denna ideologiska idealism som en aspekt av verkligheten).

I de noveller som behandlades i tredje kapitlet kan man se en ny fas i mötesproblematiken. Där etableras småstadslivet monotoni genom novellernas återkommande trånga rum och allmänna platser, genom en återkommande banal längtan hos huvudpersonerna efter något mer betydelsefullt. Med denna längtan inom sig räcker det med att se en ny person på håll för att ett hopp om ett möte med denna ska väckas som ett löfte om en omvälvande förändring. Det finns en medkänsla med dessa människors banala längtan, den är inte mindre värd än någon annans, den är vad som ges och den är på något sätt ändå meningsgivande, den fyller vardagen med en rörelse, med förhoppningar och föreställningar om ett möte som något betydelsefullt i sig. Problematiken och konflikten ligger i att denna idealiserande längtan efter ett möte med en viss person samtidigt tycks skymma blicken för de faktiska som ändå sker, liksom på vägen, i vardagliga vänskaper, i stunder av något slags mänsklig kontakt bortom orden, i korta upplevelser av något betydelsefullt i tillvaron. Detta framställs indirekt som något mer betydande och väsentligt än vad ett möte med den efterlängtade troligen hade inneburit om det kommit till stånd. I novellen "Konopatčikova", som avslutar kapitlet och som avslutade Dobyčins första novellsamling, förverkligas dock till slut ett sådant betydelsefullt möte bortom orden med just den som huvudpersonens attraktion väckts till. Det uppstår i ett avslutande samtal om konstnärliga upplevelser. Här gestaltas det skört mänskliga i deras interaktion på samma gång som detta livets sköra konst framhålls mot den ideologiserade masskulturen i samtiden.

I fjärde kapitlet såg vi först i fem kortnoveller prov på något av en tredje fas i mötestemat genom deras försök till försoning med den sovjetiska vardagen. Där gestaltas ett liv med betydelsefulla stunder och möten och närvaro i vardagen trots allt, bortom det politiska i samtiden. Men de rymmer också resignation: den mänskliga skörhet och känslighet som skulle kunna öppna för mänskligt betydelsefulla relationer - i de faktiska möten som här äger rum - tycks det inte finnas plats för i den sovjetiska samhällsdiskurs som präglar tillvarons yta. Man skulle redan i dessa noveller kunna tala om en blandning av uppgivenhet över att längre kunna gestalta något betydelsefullt i samtiden och en känsla av plikt att ändå fortsätta försöka att fånga dessa levande stunder och de sköra mänskliga uttrycken bortom samtidens genomideologiserade ordskval. 
De sista novellerna visar på hur denna längtan efter kanske egentligen bara "öppenhet och vänskap", som huvudpersonen i "Portret" uttryckte det i sitt inre, kan bli tolkad som pessimism och indirekt en kritik mot den samhällsuppbyggnad som alla nu vid övergången till trettiotalet fordras att helhjärtat sluta upp kring. De skildrar därmed också något av ett slut på själva förutsättningarna för ett samtidsberättande av Dobyčins art. Den sovjetiska ideologins verklighet, dess konceptualisering, upplevs tillsynes alltmer som den enda existerande världen. Det finns knappt någon plats längre för alternativa yttringar och personliga uttryck utanför dess språk. I den tillvaro som skildras i novellerna "Požalujsta", "Sad" och "Portret" framställs än tydligare ett hot mot en levande mänsklig samvaro och de i all sin banalitet betydelsefulla individuella uttrycken.

De två efterlämnade novellerna skildrar slutligen på samma gång mer frispråkigt och mer uppgivet denna brist på personlig frihet och öppenhet $\mathrm{i}$ den sovjetiska verkligheten. Snarare än en fjärde fas i mötestemat skildrar de en utveckling mot en frånvaro av möten. Vad det fortfarande finns utrymme för bortom de tillåtna orden är mest bara en hämmad tystnad, ensam längtan och innestängda drömmar som bara stundtals bryter ut i en mänsklig berättelse, i en plötslig medkänsla eller små vardagliga uttryck för en kvardröjande längtan efter något annat. Människorna samlas men framstår som ensamma i detta kollektiv. Det går inte längre att mötas i något bortom ett bekräftande av den ideologiska ordningen. Ingen vill längre lyssna på sådant som ändå inte kan få utlopp. Människor möts inte längre som människor utan är instängda i sina samhällsroller.

\section{Det betydelsefulla och mötesproblematikens fortsättning}

Det betydelsefulla som Dobyčin från allra första början skildrat upplevelser av kan sägas vara en förenande, banal mänsklighet som vi kan mötas i bortom de ord och övertygelser, samhällsroller och erfarenheter som särskiljer oss. Denna mänsklighet framställs som något outtalat och skört som riskerar att gå förlorat i det nya sovjetiska samhället och dess kultur. Dess nakna fysiska kultur erbjuder, som slutet av novellsamlingen Portret visar på, ingen ersättning för den mänskliga frihet och de mänskliga möten som inskränks. Även den fria nakenheten vid flodstranden utgör till sist en del av ideologin.

Utifrån denna samtidsskildring är det inte svårt att förstå den socialistiska realismen som metod som den lanserades senare på trettiotalet. Den realismen speglade denna verklighet så som den blivit. Med just typer istället för människor, med ideologi framför realism, med en idealiserande partitrogenhet framför en idédriven, utvecklande debatt om ideologin och till 
sist en schablonartad kollektiv folklighet som ersättning för människors fria former av liv och konst.

Att Dobyčin vänder sig till sin egen uppväxts förrevolutionära Dvinsk med dess uppdelning av människor utifrån klass, tro och etnicitet, med ett samhällsliv där människor ser varandra men lever var för sig, med sina undertryckanden av det förbjudna, sin tids blindhet för andras lidande, kan möjligen ses som ett sätt att föra upp den mänskliga mötesproblematiken på ett mer evigt, mer existentiellt plan. Jagets blindhet för andra människor, både andras lidande och andras personlighet, delvis på grund av sina litteraturpräglade ideal, framställs som en faktisk närsynthet som han i slutet av romanen blir varse för att med sin nya pincené på näsan inse att allt som han hittills sett har han sett felaktigt. Det enda som återstår för honom, då de vänner han skulle ha kunnat ha redan på olika sätt är borta, är att också själv ge sig av från staden, vilket han också står inför att göra under en stjärnhimmel i slutet. Så blir mötesproblematiken genom denna historiska belysning nu delvis skildrad som något av ett personligt, psykologiskt problem hos författaren; i porträttet av huvudpersonen har också ett drag av att undandra sig kontakt med andra, en oberörbarhet, framträtt. Samtidigt belyses en mer allmänmänsklig uppväxtproblematik i den närsynthet för andra människor och perspektiv på tillvaron som den ideologi man fostras i för med sig.352

Romanen, som Dobyčin gjorde ett första försök att skriva redan före den andra novellsamlingen, fördjupar en tidlös aspekt av mötesproblematiken som är närvarande redan i novellerna. Frånsett det sovjetiska samhällets inskränkningar av det mänskliga och den längtan det väcker kan nämligen själva de stundliga upplevelserna av något betydelsefullt i tillvaron, just som uppfyllda inre möten, ses som inte bara en ersättning för omöjliga verkliga möten i huvudpersonernas vardag utan också som själva orsaken till att sådana uteblir; den idealiserande längtan som dessa upplevelser av möten

352 Dobyčin var långt från den enda författaren i samtiden som efter att under tjugotalet ha försökt skriva om den nya verkligheten sökte sig tillbaka i historien, om än Dobyčin aldrig blir monumentalt episk så passar han till viss del också in i en generell riktning i litteraturen mot längre format. Caroline Schramm har i en artikel velat skriva in Gorod Én i ett biktliknande drag i uppväxtskildringar i socialistisk realism: "Ispoved v socrealizme", H. Günther, E. Dobrenko (red.), Socrealističeskij kanon, Sankt Petersburg 2000, 9I0-925. Jurij Ščeglov menar att Dobyčin med Gorod $\dot{E} n$ anslöt sig till vad som redan etablerats som något av en genre i sovjetlitteraturen av kritiska skildringar av det förrevolutionära samhället. Även stilmässigt ser Ščeglov romanen, jämfört med novellerna, som en del av den allmänna utvecklingen under trettiotalet mot en kompromiss med den klassiska traditionen. Detta borde ha kunnat innebära att romanen skulle ha betraktats som mer acceptabel än samtidsnovellerna. "Zametki o proze Leonida Dobyčina ('Gorod Ėn')", Proza. Poėzija. Poètika: Izbrannye raboty, Moskva 2012, 333-357, 340-34I, 355-356. 
både kan ses framkallade av och ge upphov till är också något som ställer sig i vägen för att förverkliga möten och relationer. Det kan i sin tur ses som ett uttryck för något av själva konstens dilemma; konsten kan framkalla en ouppfyllbar längtan som på samma gång som den berikar våra liv med inre konstnärliga upplevelser gör oss missnöjda med vår sociala tillvaro och relationer till andra. Samtidigt som konsten får oss att se eller känna igen något betydelsefullt kan dess upplevda ideal förmörka vår syn, förblinda oss för andra människor och det vardagliga livets möjligheter. Den konstnärliga ådra - med en av litteratur eller film präglad romantik - som många av huvudpersonerna uppvisar - och med vilken de tar del i gestaltningens framkallande av dessa stunder av något betydelsefullt - är så en del av denna tidlösa aspekt av mötesproblematiken. Mot deras konstnärliga längtan ställs i novellerna det liv som detaljerna och de vardagliga mötena i deras tillvaro samtidigt trots allt rymmer. Möjligen kan man utifrån författarens antagna homosexualitet se denna problematik som förbunden med en kärlek som svårligen kunde levas ut i en provinsiell sovjetisk småstad.

Det sista verket Šurkina rodnja (för vilket Dobyčin först hade tänkt sig titeln Blagopolučnyj konec (Ett lyckligt slut)) skildrar ett annat mänskligt sammanhang än både det förrevolutionära Dvinsk och det sovjetiska Brjansks nya småstadsborgerlighet (med dess framväxt av nya hierarkier, tabun, kapital och hämningar). Här är man jorden närmare med konkreta fysiska umbäranden och handlingskraft. Det kan i förstone framstå som en lösning på mötesproblematiken. Men den unga huvudpersonens oförvägenhet innebär samtidigt inte ett lyckligt slut i den meningen att den i detta visar på ett lyckligt sätt att leva tillsammans med andra. Även i denna verklighet finns något av en glad folklighet och en fri mänsklig samvaro som går förlorad såväl i takt med samhällets utveckling under första världskriget och inbördeskriget som med att huvudpersonen växer upp. Det frihetliga sinnelag som huvudpersonen ändå bevarar tar sig mot slutet uttryck i ett kringstrykande liv som småtjuv. Sedan hans far återvänt från fronten finner inte heller denna huvudperson längre i sin vardagliga tillvaro och dess mänskliga sammanhang utrymme att vara den han är och göra som han vill. Enda möjligheten till att inte kuvas och inordnas ser han så också till slut - liksom huvudpersonen i Gorod Én inför sin förestående avresa - i att avlägsna sig. Det framhålls som en frihetskamp som måste fortgå: "žit', razbojničat" ("leva, röva"), är den förklaring som huvudpersonen ger till vad han ska göra i den stora stad och större värld han står inför att ge sig av till. Det är det enda möjliga lyckliga slutet för honom. Men i det är han liksom tidigare huvudpersoner ensam. 
Det anonyma jaget i "Portret", den avslutande novellen i den samling vi studerat, avlägsnar sig visserligen också i slutet men har i sin sovjetiska samtid inte någon annanstans att ta vägen i hopp om att där kunna leva friare, åtminstone inte inom livets ramar. Den insikten anslår också musiken från pilotens begravningståg i slutscenen. I detta slut på novellsamlingen framställs så indirekt också den mest troliga anledningen till att Dobyčin därefter valde att söka sig bort från samtiden i sitt författarskap. Han ville fortsätta leva. 


\section{Kort biografi}

I894, 5 juni, föds Leonid Ivanovič Dobyčin som det första av fem barn i den lilla orten Ljutsin (nuvarande Ludza i Lettland). Fadern är lantläkare, modern barnmorska.

I896-I9II växer han upp och går realskolan i den då ryska staden Dvinsk (idag Daugavpils, Lettlands näst största stad). Fadern avlider redan I902 av blodförgiftning och lämnar modern ensam med fem barn att försörja. De två äldsta sönerna får läsa vidare vid tekniska institut i Petersburg, de två döttrarna och den yngste sonen placeras på avgiftsfria internatskolor för föräldralösa långt från hemstaden.

I9II-I9I8 lever Dobyčin som student i Sankt Petersburg (från I9I5 Petrograd). Att han endast lyckas fullborda tre årskurser på ekonomiska avdelningen vid Sankt Petersburgs polytekniska institut förklaras delvis av att han från I9I5 istället för krigstjänst blir tvungen att utan studieuppehåll samtidigt tjänstgöra som statistiker - både vid forskningsresor till nuvarande Ukraina och Kazakstan och vid olika administrativa inrättningar i Petrograd.

I9I8-I934 är Dobyčin bosatt i småstaden Brjansk. Till Brjansk hade modern flyttat I9I7 när fronten i första världskriget närmade sig Dvinsk. Troligen föll valet på Brjansk för att hon där kunde fortsätta arbeta som barnmorska och läkarassistent vid samma järnvägslinje (Riga-Orjol) och att det på makens sida fanns släktingar i staden. Barnen anslöt succesivt från sina respektive utbildningsorter för att bo med henne i en enrumslägenhet i ett samhälle vid järnvägsstationen fem kilometer från stadskärnan, på andra sidan floden Desna. Yngsta brodern Nikolaj flyttar till Moskva I92I, Dmitrij flyttar till Brjansk först I924.

Leonid Dobyčin börjar sin tjänstemannakarriär som statistiker I9I8, först vid arbetsbörsen eller arbetsförmedlingen och från 1920 som företrädare för sektionen för industri- och arbetsstatistik vid arbetsförmedlingens nyinrättade statistikbyrå för Brjanskguvernementet (Gubstatbjuro). Där mobiliseras han för att genomföra en folkräkning som kräver omfattande resor och övertidsarbete. Troligen är det först från slutet av I92I när Dobyčin tar ett nytt arbete som företrädare för statistikavdelningen vid guvernementets 
fackföreningsråd, där han blir kvar i fyra år, som han får någon tid över för skrivande.

Han får sin första novell, "Vstreči s Liz" ("Mötena med Liz"), antagen av Kornej Čukovskij och publicerad i fjärde och sista numret av Leningradtidskriften Russkij sovremennik 1924. Fler publiceringar följer sedan genom Michail Slonimskijs bemedlande, först i dennes tidskrift Leningrad 1925. I december 1925 vistas Dobyčin en månad i Leningrad innan pengarna tar slut och han tvingas återvända till Brjansk och nu åter träda i tjänst vid Guvernementets statistikbyrå.

Varken en prestigefull publicering av tre noveller i Serapionsbrödernas antologi Kovš 1926 eller utgivningen av en första novellsamling, Vstreči s Liz I927, tycks skänka honom någon större glädje. Möjligen är en del av förklaringen till detta att hans yngste bror Nikolaj som börjat arbeta som kemist $\mathrm{i}$ Moskva har arresterats av säkerhetstjänsten anklagad för att tillhöra en kontrarevolutionär terroristgrupp (som han som kemist vid en fabrik skulle ha stulit farliga ämnen åt för tillverkning av bomber eller giftgas) för vilket han döms till arkebusering, vilken verkställs 1927 eller 1929 enligt olika källor. Det är ovisst hur mycket familjen i Brjansk fick veta. I slutet av $1927 \mathrm{flyt}-$ tar de till en större lägenhet, i ett hus som tillhört en släkting, i centrum av staden. Året efter uttrycker Dobyčin oro över sin framtid då han med en läkare som far och därför borgerlig snart tror sig komma att bli ersatt av nyutbildade proletärer från partiskolor. Han klarar sig igenom ett utrensningsförhör under hösten om än inte utan anmärkningar och behåller sitt arbete till slutet av 1929 då hela hans arbetsplats upplöses i samband med att Brjansk inlemmas i Zapadnaja oblast' och förlorar sin ställning som regional centralort till Smolensk.

Som arbetslös söker han sig till Leningrad och ägnar sig ett par månader i början av 1930 helt åt litteraturen innan han tvingas återvända. Han har nu svårare att hitta arbete men får det till slut på hösten som statistiker och ekonom vid Brjansks mekaniska [artilleri-]fabrik nr. I3. Hans andra novellsamling Portret (Porträttet) utkommer i slutet av året (med 193I som utgivningsår).

I slutet av 1933 ansöker han hos författarförbundet i Leningrad om en bostad. 6 juni 1934, dagen efter sin fyrtioårsdag, slutar han på fabriken.

1934-1936 är Dobyčin författare på heltid i Leningrad. Han har fått ett rum i en kollektivlägenhet och försörjningsstöd från författarförbundet. Före flytten, i maj 1934, hade den första tredjedelen av romanen Gorod Én publicerats i tidskriften Krasnaja nov'. Den historiska romanen var vad han hade övergått till att skriva efter de samtidskildrande novellerna. Senast $\mathrm{i}$ början av I935 var romanen färdigställd. Troligen är det under detta år och 
början av det följande som han skriver den längre novellen "Dikie" och kortromanen Šurkina rodnja utifrån vad den yngre granne han lärt känna i kollektivlägenheten berättat om sin uppväxt. Under sommaren 1935 tillbringar han två månader i Brjansk där han väntar på korrektur på romanen Gorod En och ett förskott för att ha råd att återvända. Han återvänder. Romanen utkommer i slutet av året. I början av 1936 kommer de första recensionerna som snart övergår i ett av säkerhetstjänsten understött drev mot Dobyčin. Anklagelserna kulminerar under en konferens i Leningrad anordnad som en del i en kampanj mot formalism och naturalism. 28 mars lämnar han sin bostad och syns inte mera till.

Före sitt försvinnande hade Dobyčin lämnat ifrån sig manuskript till Aleksej Grigor'ev och översänt det mesta av sina tillhörigheter inklusive sitt fickur till sin mor i Brjansk (vilket genast får henne att skriva till författarförbundet och till familjen Čukovskij med en vädjan om att upplysa henne om sin "olycklige sons öde"). Moderns inställning till Dobyčins skrivande framgår av Grigor'evs återberättelse av hur Dobyčin från henne fått sig tillsänt ett tidningsurklipp med en av de många utskällningarna i pressen av Gorod Én med kommentaren: "вот какой ты писатель!.." ("se här vilken författare du är!..") Avogheten ter sig emellertid förståelig i ljuset av den yngsta sonen Nikolajs öde och att också Leonids ett år yngre bror Dmitrij suttit häktad i Brjansk 1930 och belagts med ett omfattande arbetsförbud.Bara två år efter Leonids försvinnande kom Dmitrij att arresteras och dömas till arkebusering anklagad både för spionage och medlemskap i en underjordisk kontrarevolutionär fascistisk organisation. 333

Modern och de två döttrarna antas ha avlidit under den tyska ockupationen under andra världskriget. Inget av syskonen fick barn. Frånvaron av nära släktingar bidrog troligen till den, även jämfört med andra oönskade författare, ovanligt långa tystnaden om hans författarskap. ${ }^{354}$

\footnotetext{
353 Som grund till anklagelserna i både Nikolajs och Dmitrijs fall låg också att de under inbördeskriget på olika håll stridit för de vita. Det hade de förhörts av säkerhetstjänsten för I923 utan påföljder. Nikolaj hade som frivillig i Röda armén vid södra frånten tillfångatagits och inordnats i ett kosackregemente under ett par månader 1919. Dmitrij hade en lång odyssé bakom sig. Som utsänd till USA före revolutionen för att se över vapenbeställningar till armén hade han inkallats till amerikanska militären då USA gick in i kriget på samma sida som Ryssland. Efter att istället valt att strida som frivillig för kanadensiska armén i Frankrike hade han efter kriget återvänt till Ryssland från Kanada till Vladivostok I9I9 bara för att där genast bli mobiliserad i vita armén under Kolčak och snart därefter inlemmas Fjärran Östern-republikens väpnade styrkor. Efter ett anfall från Japan demobiliserades han och arbetade vid tullen när Röda armén tog kontrollen I922. Därifrån tog han sig via Nikolaj i Moskva slutligen till Brjansk 1924 där han flyttade in med modern, Leonid och sina två systrar.

354 Denna redogörelse för Dobyčins och familjens liv grundar sig framförallt på Ėl'vira Golubevas sammanställning utifrån ett omfattande arkivarbete, intervjuer, tidigare forskning och Dobyčins brev i Pisatel' Leonid Dobyčin i Brjansk, Brjansk 2005.
} 


\section{Novellernas publikationer}

Samtliga publiceringar under författarens livstid av de analyserade novellerna i den ordning de behandlas. Siffran anger ordningen i Portret. Vstreči s Liz och Portret avser de två novellsamlingarna: Vstreči s Liz, Mysl', Leningrad I927; Portret, Izdatel'stvo pisatelej v Leningrade, Leningrad I93I.

I "Proščanie" ("Avskedet") - Portret.

2 "Kozlova" - Leningrad", 9 (48), 1925, 2-4; Vstreči s Liz; Portret.

3 "Vstreči s Liz" ("Mötena med Liz") - Russkij sovremennik, 4, I924, II7-I2I; Vstreči s Liz; Portret.

6 "Erygin" - "Tri rasskaza", Kovš, 4, 1926, 235-243, 235-238; Vstreči s Liz; Portret. 5 "Savkina" - Leningrad", 23 (62), 1925; Vstreči s Liz; Portret.

4 "Lidija" - "Tri rasskaza", Kov̌s, 4, 1926, 235-243, 238-240; Vstreči s Liz; Portret.

8 "Sorokina"|"Dorian Grej" ("Dorian Gray") - "Sorokina" i "Tri rasskaza", Kov̌s, 4, 1926, 235-243, 240-243; Vstreči s Liz; "Dorian Grej" i Portret.

9 "Sidelka" ("Sköterskan") - Novaja Rossija, 2 (18), 1926, 73; Vstreči s Liz; Portret. I2 "Lëška"/"Matros" ("Matrosen") - "Lëška" i Vstreči s Liz; "Matros" i Portret.

7 "Konopatčikova" - Vstreči s Liz; Portret.

Io "Lekpom" ("Läkarassistenten") - "Rasskazy", Leningrad"**; 3, 1930, 93-96, 95-96; Portret.

II "Otec" ("Fadern") - Portret.

I3 "Chiromantija" ("Kiromanti") - "Rasskazy", Leningrad"**, 3, 1930, 93-96, 94-95; Portret.

I4 "Požalujsta"("För all del") - "Rasskazy", Leningrad"** 3, 1930, 93-96, 93-94; Portret.

I5 "Sad" ("Trädgården") - Portret. I6 "Portret" ("Porträttet") - Strojka, 3, 1930, 7-8; Portret.

("Mater'jal" ("Materialet") - postumt, först i Leningradskaja pravda, 2I aug., 1988.) ("Čaj" ("Teet") - postumt, först i Zvezda, 9, 1989, I90-19I.)

* Leningrad:Dvuchnedel'nyj chudožestvenno-illjustrirovannyj i literaturnyj žurnal utgavs 1924-25 av Leningradskaja Pravda.

** Leningrad: Literaturno-chodožestvennyj i obščestvenno-političeskij ežemesjčnik utgavs från 1930 av LAPP. 


\section{Litteraturförteckning}

\section{Leonid Dobyčins verk, forskningsantologier, bibliografi}

Dobyčin, L., Polnoe sobranie sočinenij i pisem, Sankt Petersburg 1999.

Dobyčin, L., Polnoe sobranie sočinenij i pisem, Sankt Petersburg 2013.

Pervye Dobyčinskie čtenija, Daugavpils I99I.

Vtorye Dobyčinskie čtenija: V 2-ch častjach, Daugavpils 1994.

Bachtin, V.S. (red.), Pisatel' Leonid Dobyčin: Vospominanija, stat'i, pis'ma, Sankt Petersburg 1995.

Weststeijn, Willem G, Rizzi, Daniela \& Civ'jan, Tat'jana Vladimirovna (red.), "Vtoraja proza": Russkaja proza 20-ch-30-ch godov XX veka, Trento 1995.

Dobyčinskij sbornik, Daugavpils 1998.

Dobyčinskij sbornik - 2, Daugavpils 2000.

Dobyčinskij sbornik -3, Daugavpils 200I.

Dobyčinskij sbornik - 4, Daugavpils 2004.

Dobyčinskij sbornik -5, Daugavpils 2007.

Dobyčinskij sbornik - 6, Daugavpils 2008.

Dobyčinskij sbornik - 7, Daugavpils 20II.

Kul'tura i tekst, I (I9), 2015.

Slavjanskie čtenija XI, Daugavpils 2016.

Dobyčinskie čtenija $v$ Brjanske 20I8, Brjansk 2018.

"Leonid Dobyčin: Bibliografičeskij ukazatel", Wordpress, https://dobychin.wordpress.com/press-about-dobychin/, 2019-02-II.

\section{Referenser}

Abankina, O. I., "Vnutrennjaja individual'naja model' mira v romane L. Dobyčina 'Gorod Ėn'", Bachtin, V. S. (red.), Pisatel' Leonid Dobyčin: Vospominanija, stat'i, pis'ma, Sankt Petersburg 1995, 235-240.

Achmatova, A. A., Stichotvorenija i poèmy, Leningrad 1976.

Adamovič, Georgij, "Literaturnye zametki: Mich. Zoščenko. 'Golubaja kniga'. Moskva, 1935; L. Dobyčin. 'Gorod Ėn'. Moskva, I935", Bachtin, V. S. (red.), Pisatel' Leonid Dobyčin: Vospominanija, stat'i, pis'ma, Sankt Petersburg 1995, I85-I86.

Ajchenval'd, Ju. I., "Vstuplenie", Siluety russkich pisatelej, I, Haag, Paris I969[I929], I49.

Aristoteles, Om diktkonsten, Göteborg 1994

Ar'ev, A. Ju., "Dobyčin Leonid Ivanovič", Nikolaev, P. A. (red.), Russkie pisateli 20 veka: Biografičeskij slovar', Moskva 200o, 234-236; "Otplytie", Dobyčin, L., Polnoe sobranie sočinenij i pisem, Sankt Petersburg 2013, 7-42; "Vozvraščenie k ljudjam", Andreev, V., Baršev, N., Dobyčin, L., Raskoldovannyj krug, Leningrad I990, 3-29. 
Auerbach, Erich, "Den bruna strumpan", Mimesis: Verklighetsframställningen i den västerländska litteraturen, Stockholm I999, 552-582.

Bachtin, M. M., "Problema formy, soderžanija i materiala v slovesnom chudožestvennom tvorčestve", Sobranie sočinenij, I, Moskva 2003, 266-325; "Slovo v romane", Sobranie sočinenij, 3, Moskva 2012, 9-I79.

Bachtin, Michail, "Innehållets, materialets och formens problem i det litterära konstverket", Det dialogiska ordet, Gråbo, I997, I98-25I.

Bachtin, V. S., "Pod igom dobrych načal'nikov", Dobyčin, L., Polnoe sobranie sočinenij i pisem, Sankt Petersburg 1999, 7-44.

Barthes, Roland, La chambre claire: Note sur la photographie, Paris I98I; "L'Effet du réel", Communications, II, I968, 84-89.

Beljanin, V. P., Butenko, I. A., Živaja reč': Slovar' razgovornych vyraženij, Moskva 1992.

Belousov, A. F., (kommentarer och noter), Dobyčin, L., Gorod Ėn, Daugavpils 2007; "Dostoevskij i ego geroi v 'Gorode Ėn'", Bachtin, V. S. (red.), Pisatel' Leonid Dobyčin: Vospominanija, stat'i, pis'ma, Sankt Petersburg 1995, 205-207; "Ozvučenie teksta v proze L. Dobyčina", Russian Literature, 46, I, 1999, 19-22; "Vokrug 'Portreta'", Dobyčinskij sbornik - 7, Daugavpils 20II, 20-3I.

Beja, Morris, Epiphany in the Modern Novel, London $197 \mathrm{I}$.

Benveniste, Émile, "La notion de 'rythme' dans son expression linguistique", Problèmes de linguistique générale, I, Paris I966, 327-335.

Borden, Richard C. (översättning tillsammans med Natalia Belova), "Editor's Introduction", "Editor's Notes", Dobychin, Leonid, Encounters with Lise and Other Stories, Evanston, Illinois, 2005; (översättning tillsammans med Natalia Belova), "Leonid Dobychin's The Town of N: Introduction", "Notes", Dobychin, Leonid, The Town of N, Evanston, Illinois, I998; "The Flogging Angel: Toward a Mapping of Leonid Dobychin's Gorod En", The Russian Review, 2, 200I, 259-274.

Brodsky, Joseph, "Catastrophies in the Air", Less Than One, New York 1986.

Buber, Martin, Jag och Du, Ludvika 2006.

Cabaret, André (översättning), Dobytchine, Léonide, Rencontres avec Lise, Saulxures I994.

Charms, D. I., Vvedenskij, A. I., Zabolockij, N. A., Olejnikov, N. M., Bachterev, I. V., Vaginov, K. K. \& Aleksandrov, A. I (red.), Vanna Archimeda, Leningrad I99I.

Čudakov, A. P., Poètika Čechova, Moskva I97I; Slovo - vešč - mir: Ot Puškina do Tolstogo: Očerki poètiki russkich klassikov, Moskva I992.

Čudakova, M.O., "Na poljach knigi M.Okutjur'e'Le réalisme socialiste'", Catherine Depretto (red.), De la litterature russe: Melanges offerts a Michel Aucouturier, Paris 2005, 315-333.

Čukovskaja, M. N., "Odinočestvo", Bachtin, V. S. (red.), Pisatel' Leonid Dobyčin: Vospominanija, stat'i, pis'ma, Sankt Petersburg 1995, 7-I5.

Danilina, N. N., "Ideja zerkala v rasskaze 'Kozlova', Dobyčinskij sbornik-7, Daugavpils 2OII, I5-I9.

Danilov, D. A., Opisanie goroda, Moskva 2012.

Danius, Sara, Den blå tvålen: Romanen och konsten att göra saker och ting synliga, Stockholm 2013.

Depretto-Genty, Catherine, Le formalisme en Russie, Paris 2009.

"Doloj styd (obščestvo)", Wikipedia, https://ru.wikipedia.org/wiki/Долой_стыд_общество), 20I9-06-оI.

Ėfros, A. M., "Vosstanie zritelja", Russkij sovremennik, I, I924, 272-279. 
Ėjdinova, V. V., "L. Dobyčin - A. Platonov", Dobyčinskij sbornik-7, Daugavpils 20II, I89-200; "O stile Leonida Dobyčina", "Slovo Leonida Dobyčina (Antidialogičeskaja tendencija v proze 20-ch godov)", Bachtin, V. S. (red.), Pisatel'Leonid Dobyčin: Vospominanija, stat'i, pis'ma, Sankt Petersburg I995, IOI-II6, II7-I29; "O tajne Dobyčinskogo povestvovanija”, Dobyčinskij sbornik - 2, Daugavpils 2000, 88-I07; "Poètika bezymjannosti: (Rasskazy L. Dobyčina I920-ch godov), Dobyčinskij sbornik-3, Daugavpils 200I, 44-5I.

Ellerström, Jonas, "Genomlysta ögonblick", Joyce, James, Epifanier, Lund 2011.

Erofeev, V. V., "Nastojaščij pisatel”, Dobyčin, L., Gorod Én: Roman; Rasskazy, Moskva I989, 5-I4; "Poètika Dobyčina, ili Analiz zabytogo tvorčestva", Erofeev, V. V., V labirintach prokljatych voprosov, Moskva I990, I39-I60; "O Kukine i mirovoj garmonii", Bachtin, V. S. (red.), Pisatel' Leonid Dobyčin: Vospominanija, stat'i, pis'ma, Sankt Petersburg 1995, 5I-56.

Fëdorov, F. P., "Dobyčin i kinematograf", Bachtin, V. S. (red.), Pisatel' Leonid Dobyčin: Vospominanija, stat'i, pis'ma, Sankt Petersburg 1995, 69-76; "Gorodskoe prostranstvo v sbornike L. Dobyčina 'Vstreči s Liz'", Dobyčinskij sbornik - 3, Daugavpils 200I, 69-83; "Flober i Dobyčin (k tipologii provincial'nogo soznanija", Dobyčinskij sbornik - 2, Daugavpils 2000, I2-23; "Kosmos v Dobyčinskoj kartine mira", Dobyčinskij sbornik, Daugavpils I998, 5-I2; "O kompozicionnom montaže v russkoj proze I920-x godov (Ju. Tynjanov, L. Dobyčin, M. Zoščenko)", Dobyčinskij sbornik - 7, Daugavpils 20II, I62-I75.

Fomenko, I. V., "Ritm i smysl: Opyt interpretacii romana 'Gorod Én'”, Dobyčinskij sbornik-6, Daugavpils 2008, II6-I27

Gasparov, Boris, Boris Pasternak: Po tu storonu poètiki (Filosofija. Muzyka. Byt), Moskva 2013; Beyond Pure Reason: Ferdinand de Saussure's Philosophy of Language and Its Early Romantic Antecedents, New York 2012.

Genette, Gérard, "Discours du récit", Figures III, Paris 1972, 67-282.

Ginzburg, Carlo, "Making Things Strange: The Prehistory of a Literary Device", Representations, 56, 1996, 8-28.

Golubeva, E. S., "'Bibliotekarša' (po motivam rasskaza Dobyčina 'Mater'jal')", Dobyčinskij sbornik - 7, Daugavpils 20II, 32-48; Pisatel' Leonid Dobyčin i Brjansk, Brjansk 2005.

Gor, G. S., "Na kanale Griboedova, 9", Pjat' uglov: Povesti, ésse, Leningrad 1983, 248250; "Zamedlenie vremeni", Zvezda, 4, I968, I74-I9I.

Gor'kij, Maksim, "Mat'", Sobranie sočinenij v I6 tomach, 4, Moskva 1979, 4-320.

Hamburger, Käte, Die Logik der Dichtung, Stuttgart 1957.

Ignatova, E. A., Zapiski o Peterburge: Žizneopisanie goroda so vremeni ego osnovanija do 40 godov XX veka, Sankt Petersburg 2003.

Il'f, I. A., Petrov, E. P., Dvenadcat'stul'ev; Zolotoj telenok, Moskva I956.

Jakobson, Roman, "O pokolenii, rastrativšem svoich poètov" (I93I), Selected Writings, V, Berlin, New York, 1979, 355-38I; "The Dominant", Language in Literature, Cambridge, Massachusetts, I987, 4I-46; "Zametki o proze poèta Pasternaka", Raboty po poètike, Moskva I987, 324-338.

Joyce, James, Stephen Hero, New York 1963.

Jur'ev, O. A., Neizvestnye Pis'ma, Sankt Petersburg 2014.

"Kabuki", Wikipedia, https://sv.wikipedia.org/wiki/Kabuki, 20I9-o6-oI.

Kahn, Andrew, Lipoveckij, M. N., Reyfman, Irina \& Sandler, Stephanie, "Grotesque modernism of the I920s and I930s", A history of Russian literature, Oxford 2018, $66 \mathrm{I}-672$. 
Kaverin, V. A., "Dobyčin", Bachtin, V.S. (red.), Pisatel' Leonid Dobyčin: Vospominanija, stat'i, pis'ma, Sankt Petersburg 1995, I6-20; Épilog: Memuary, Moskva 1989; "Gorod Ėn", Sobesednik, Moskva I973, I9-23; "Leonid Dobyčin", Večernyj den': Pis'ma. Vstreči. Portrety, Moskva I980.

Knausgård, Karl Ove, Min kamp 6, Stockholm 2013.

Kobrin, K. R., "Polka Kirilla Kobrina", Novyj mir, I, 2000.

Korolev, S. I., "'Ja' i 'drugoj' v proze L. Dobyčina: postanovka problemy", Dobyčinskij sbornik - 6, Daugavpils 2008, 83-I02; Problema avtora v proze L. Dobyčina, Saarbrücken 2013.

Kormilov, S. I., "Metrizovannaja proza L. Dobyčina na fone tradicii russkoj metrizovannoj prozy pervoj treti XX veka", Bachtin, V. S. (red.), Pisatel' Leonid Dobyčin: Vospominanija, stat'i, pis'ma, Sankt Petersburg 1995, I42-I54

Košelev, V. A., "Puškinskie motivy u Leonida Dobyčina ('Vstreči s Liz')", Dobyčinskij sbornik-2, Daugavpils 2000, 24-3I.

Lampe, Angela, "Chagall in the service of the revolution", Lampe, Angela (red.), Chagall, Lissitzky, Malevich: The Russian Avant-Garde in Vitebsk, 1918-1922, München, London, New York 20I8, I9-28.

Lebedev, S. V, "Portret chudožnika v topose: Brjanskaja 'odisseja' L. Dobyčina glazami D. Danilova", Novyj mir, II, 20I4, I66-I76.

Lejderman, N. L., Lipoveckij, M. N., Russkaja literatura XX veka: I9I7-I920-e gody, 2, Moskva $20 I I$.

Lotman, Ju. M., Analiz poètičeskogo teksta: Struktura sticha, Leningrad 1972.

Lukács, Georg, "Die weltanschaulichen Grundlagen des Avantgardismus", Wider den Mißverstandenen Realismus, Hamburg 1958, I3-48.

Lunačarskij, A. V., "Doklad A. V. Lunačarskogo", Upadočnoe nastroenie sredi molodeži: Eseninščina, Moskva 1927, 5-44.

Majakovskij, V. V., "Klop", Polnoe sobranie sočinenij v I3 tomach, II, Moskva I958, 2I5276.

Majakovskij, Vladimir, Vägglusen, översättning Sam J. Lundwall, Bromma 1986.

Mandel'štam, O. Ė., "Šum vremeni", Sobranie sočinenij v četyrech tomach, 2, Moskva I993, 347-392.

Markov, Ė. B., "Chudožestvennoe prostranstvo v rasskaze L. Dobyčina 'Otec', Dobyčinskij sbornik - 2, Daugavpils 2000, 47-56.

Markov, G. B., "Sposoby desakralizacii v sbornike L. Dobyčina 'Večera i staruchi'", Dobyčinskij sbornik - 4, Daugavpils 2004, I56-I64.

Markstein, Elisabeth, "Sintaksis absurda. O proze Leonida Dobyčina", Bachtin, V. S. (red.), Pisatel' Leonid Dobyčin: Vospominanija, stat'i, pis'ma, Sankt Petersburg I995, I30-I4I.

Markus, B. S., "Moskovskie kartinki 1920-ch - I930-ch gg. (vospominanija)", Litmir: Élektronnaja biblioteka, https://www.litmir.me/br/?b=24I9I8\&p=31, 2019-03-22.

Maslov, Boris, "O dvuch tipach pis'ma v rasskazach L. Dobyčina", Dobyčinskij sbornik-5, Daugavpils 2007, 5-23; "Oratio recta kak modernističeskij priem (Poètika povestvovanija L. Dobyčina s pozicii metapragmatiki)", Dobyčinskij sbornik - 4, Daugavpils 2004, IOI-I25.

"Max Stirner", Stanford Encyclopedia of Philosophy, https://plato.stanford.edu/entries/max-stirner/, 20I9-03-II.

Meschonnic, Henri, Critique du rythme: Anthropologie historique du langage, Lagrasse I982.

Mekš, Ė. B., "Chudožestvennyj mir rasskaza L. Dobyčina 'Sad”, Bachtin, V. S. (red.), Pisatel' Leonid Dobyčin: Vospominanija, stat'i, pis'ma, Sankt Petersburg 1995, 267- 
272; "Istoriko-kul'turnyj areal rasskaza L. Dobyčina 'Portret", Bachtin, V. S. (red.), Pisatel' Leonid Dobyčin: Vospominanija, stat'i, pis'ma, Sankt Petersburg 1995, 273-274; "Simvoličeskie konnotacii v rasskaze L. Dobyčina 'Kukueva',, Dobyčinskij sbornik - 4, Daugavpils 2004, I65-I7I; "Teatr Kabuki v russkom variante (rasskaz Dobyčina 'Portret')", Dobyčinskij sbornik, Daugavpils I998, 22-33.

Meškov, V. A., Pisatel'-zagadka Leonid Dobyčin: krymskie stranicy, Simferopol 2015.

Muratova, K. D., Baluchatyj, S. D., Periodika po literature $i$ iskusstvu za gody revoljucii I9I7-I932, Leningrad I933, I4I, I93, http://lib2.pushkinskijdom.ru/Media/Default/PDF/Person/Muratova-I933.pdf, 2019-04-26.

Nabokov, Vladimir, "Anton Chekhov", Lectures on Russian Literature, New York 198I, 245-295; Nikolai Gogol, Norfolk, Connecticut, 1944.

Narkevič, A. Ju., "Dobyčin Leonid Ivanovič", Kratkaja Literaturnaja Énciklopedija, 2, Moskva I964, 725.

Neminuščij, A. N., "Formula vremeni v sbornike L. Dobyčina 'Vstreči s Liz", Bachtin, V. S. (red.), Pisatel' Leonid Dobyčin: Vospominanija, stat'i, pis'ma, Sankt Petersburg 1995, 255-260; "Neverbal'nyj tekst' v maloj proze L. Dobyčina", Dobyčinskij sbornik-5, Daugavpils 2007, 59-64; "O poètike rasskaza L. Dobyčina 'Lekpom'”, Bachtin, V. S. (red.), Pisatel' Leonid Dobyčin: Vospominanija, stat'i, pis'ma, Sankt Petersburg 1995, 275-279; V prostranstve vremeni literatury: do Čechova - Čechovposle Čechova, Daugavpils 2009.

Nicholas, Mary A., recension av Thomas Seifrid, Andrei Platonov: Uncertainties of Spirit, Slavic Review, 53, 4, I994, II96-II97.

Novikova, M. Ju., "Tekstoformirujuščaja funkcija cvetovoj leksiki v rasskazach Dobyčina”, Bachtin, V. S. (red.), Pisatel' Leonid Dobyčin: Vospominanija, stat'i, pis'ma, Sankt Petersburg 1995, 243-248.

Novoe literaturnoe obozrenie, II3, 2012.

Orlickij, Ju. B., "Metr v proze Leonida Dobyčina", Bachtin, V. S. (red.), Pisatel' Leonid Dobyčin: Vospominanija, stat'i, pis'ma, Sankt Petersburg I995, I55-I60; "Osobennosti sillabotoničeskoj metrizacii rasskazov Dobyčina", Slavjanskie čtenija XI, Daugavpils 2016, 213-220.

Ostrovskij, N. A., "Roždennye burej", Sobranie sočinenij v trech tomach, 2, Moskva I956, 7-209.

Pasternak, B. L., "Ochrannaja gramota", Sobranie sočinenij v pjati tomach, 4, Moskva I99I, I49-239

Petrov, G. V., "Princip 'antisjužeta' v poètike rasskaza L. Dobyčina 'Vstreči s Liz", Dobyčinskij sbornik -3, Daugavpils 200I, 84-90.

"Pis'ma L. Dobyčina k L. M. Varkovickoj", Zvezda, I, 2019, https://zvezdaspb.ru/index.php?page $=8 \&$ nput $=3439,2019-02-13$.

Platonov, A. A., Kotlovan; Juvenil'noe more, Moskva 1987.

Platonov, Andrej, Grundgropen, Stockholm 2007.

Popkin, Cathy, The Pragmatics of Insignificance: Chekhov, Zoshchenko, Gogol, Stanford I993.

Popova, Z. A., Poètika prozy L. Dobyčina: Narratologičeskij aspekt, kandidatavhandling, Sankt Petersburgs statliga universitet, 2005.

"Poslednie dni Leonida Dobyčina" (publ. Bljum, A. V.), Bachtin, V. S. (red.), Pisatel' Leonid Dobyčin: Vospominanija, stat'i, pis'ma, Sankt Petersburg 1995, 25-32.

Pusjkin, Aleksandr, Boris Godunov, Umeå 2010.

Puškin, A. S., "Boris Godunov", Polnoe sobranie sočinenij v I6 tomach, 7, Moskva I948, I-98, I7.

Rachmanov, L. N., Ljudi-narod interesnyj, Leningrad I98I. 
Radiščeva, E. S., Chudožestvennyj mir prozy L. I. Dobyčina, kandidatavhandling, Moskvas pedagogiska universitet, 2004; "Priem ostranenija v proze L. I. Dobyčina", Filologičeskie tradicii i sovremennoe literaturnoe obrazovanie, Moskva 2002, 57-59.

Reznik, O. S., "Pozornaja kniga", Literaturnaja gazeta, I9 februari, I0, I93I, 3.

Riffaterre, Michael, "The Referential Fallacy", Columbia Review, 57, 2, I978, 2I-35.

Rochlin, Boris, "Po ètu storonu Lety. (O proze L. Dobyčina)", Dobyčinskij sbornik -6, Daugavpils 2008, I03-II5.

Rorty, Richard, "Redemption from Egotism: James and Proust as Spiritual Exercises", Telos (Venezuela), 3, 200I, 243-263.

Rudnev, V. P., "Generativnaja poėtika", Slovar' kul'tury VV veka, Moskva I997, 6768.

Saussure, Ferdinand de, Cours de linguistique générale, Lausanne i9I6.

Sažin, V. N., "L. Dobyčin. Novye materialy k biografii i tvorčestvu", Kul'tura i tekst, I (I9), 20I5, 9-33, http://www.ct.uni-altai.ru/kultura-i-tekst-20I5-II9, 20I9-03-I5.

Ščeglov, Ju. K., "Zametki o proze Leonida Dobyčina ('Gorod Ėn')", Proza. Poėzija. Poètika: Izbrannye raboty, Moskva 2012, 333-357.

Schramm, Caroline, "'Čto za istorija! - poètika nedostatočnosti Leonida Dobyčina ('Staruchi v mestečke')", Dobyčinskij sbornik-2, Daugavpils 2000, I08-I33; "Die Ästhetik der Kurzsichtigkeit: Minimalismus in Leonid Dobyčins Roman 'Gorod Ėn'", Goller, Mirjam, Witte, Georg (red.), Minimalismus: zwischen Leere und Exzess : Tagungsbeiträge des internationalen wissenschaftlichen Symposiums am Institut für Slawistik der Humboldt-Universität zu Berlin vom II. bis I3. November 1999, Wien 200I, 249-277; "Ispoved v socrealizme", Günther, H., Dobrenko, E. (red.), Socrealističeskij kanon, Sankt Petersburg 2000, 910-925; Minimalismus: Die Prosa Leonid Dobyčins im Kontext der totalitären Ästhetik, Frankfurt am Main 1999.

Schulz, Bruno, Kanelbutikerna; Sanatoriet timglaset, Stockholm 1987.

Šechovcova, T. A., "'Gorod Ėn' L. Dobyčina i 'Egipetskaja marka' O. Mandel'štama”, Dobyčinskij sbornik - 7, Daugavpils 20II, I76-I88; Proza L. Dobyčina: Marginalii russkogo modernizma, Charkov 2009.

Serman, I. Z., "Léonide Dobytchine", Histoire de la Littérature Russe. Le XX Siècle. Gels et Dégels, 3, Paris I990, I9I-I96; "Lišnij", Bachtin, V. S. (red.), Pisatel' Leonid Dobyčin: Vospominanija, stat'i, pis'ma, Sankt Petersburg 1995, 33-37; "Propavšij bez vesti", Russkaja mysl', 3494, 8 dec., Paris I983, I2.

Šklovskij, V. B., "Iskusstvo kak priem”, Sborniki po teorii poètičeskogo jazyka, 2, Petrograd I9I7, 3-I4; "Tarzan", Russkij sovremennik, 3, I924, 253-254.

Stepanov, N. L., "Novella Babelja”, Kazanskij, B. V. \& Tynjanov, Ju. N. (red.), Babel': Stat'i i meterialy, Leningrad 1928; recension av L. Dobyčin, Gorod Én, Literaturnyj sovremennik, 2, 1936, 215-216; recension av Leonid Dobyčin, Vstreči s Liz, Zvezda, II, I927, I70.

Stirner, Max, Der Einzige und sein Eigentum, Stuttgart 1986.

Stroganov, M. B., "Čelovek kupajuščijsja", Dobyčinskij sbornik - 7, Daugavpils 20II, I42-I6I.

Suchich, I. N., "Dobyčin i Čechov: dva 'sobytija' i metafizika prozy", Dobyčinskij sbornik - 4, Daugavpils 2004, I40-I47; "Dobyčin i Charms: dva absurda i metafizika prozy", Dobyčinskij sbornik - 2, Daugavpils 2000, 133-137.

"Sumbur vmesto muzyki", Pravda, 28 januari 1936, 3.

Tihanov, Galin, "Why Did Modern Literary Theory Originate in Central and Eastern Europe? (And Why Is It Now Dead?)", Common Knowledge, I0, I, 2004, 6I$8 \mathrm{I}$. 
Toporov, V. N., "Rasskaz L. Dobyčina 'Vstreči s Liz' v kontekste bednoj Lizy 'železnogo veka', Weststeijn, Willem G, Rizzi, Daniela \& Civ'jan, Tat'jana Vladimirovna (red.), "Vtoraja proza": Russkaja proza 20-ch-30-ch godov XXveka, Trento I995, 82-90.

Tolstoj, L. N., Polnoe sobranie sočinenij, 62, Moskva 1953.

Tynjanov, Ju. N., "Literaturnoe segodnja", Russkij sovremennik, I, I924, 292-306.

Ugrešić, Dubravka, "O 'Gorode Ėn' Leonida Dobyčina”, Bachtin, V. S. (red.), Pisatel' Leonid Dobyčin: Vospominanija, stat'i, pis'ma, Sankt Petersburg 1995, 280-288.

Urban, Peter (översättning), "Anmerkungen", "Nachwort", Dobyčin, Leonid, Im Gouvernement S.: Šurkas Verwandtschaft, Berlin 1996; (översättning), "Nachwort", Dobyčin, Leonid, Evdokija, Berlin 2008; (översättning), "Anmerkungen", "Nachwort", Dobyčin, Leonid, Die Stadt N., Berlin 2009; (översättning), "Editorische Notiz", "Anmerkungen", Dobyčin, Leonid, Die Erzählungen, Berlin 20I3.

Volkov, S. M., Dialogi s Iosifom Brodskim, Moskva 2000

Wood, James, How Fiction Works, New York 2008.

Zal'cman, Pavel, Ščenki. Proza 1930-50-ch godov, Moskva 2017.

Zoščenko, M. M., Sobranie sočinenij, 7, Moskva 2009. 


\section{English summary}

This thesis studies the I93I short story collection Portret [The Portrait] by the Russian author Leonid Ivanovich Dobychin (I894-1936?). Dobychin grew up in Dvinsk, now Daugavpils in Latvia, studied economics and statistics in St. Petersburg-Petrograd and from I9I8 worked as a statistician in Bryansk, a small provincial town close to the Ukrainian and Belarusian borders, where he lived together with his mother and siblings until 1934. Dobychin also came to pursue a short and dramatic literary career in these early days of Soviet rule. After publishing his first short story "Vstrechi s Liz" ["Encounters with Liz"] in 1924, his first collection of stories with the same name in 1927 and his second, Portret, in I93I, Dobychin - though not widely read and sparsely and predominantly negatively reviewed - was recognized by the Writers Union in Leningrad and in 1934 granted subsidies and a room in a collective apartment. But his days as a full-time writer in Leningrad were numbered. In the spring of 1936 , as a part of the campaign against formalism and naturalism in the arts, the reviews that followed the publication of his first novel, Gorod En [The Town of N], 1935, began what turned out to be a fatal blow against him as a writer and person. The novel was accused of being formalistic, lacking values, and a simple play with literary tricks, and as such contrary to socialist realism. This escalated at a literary conference in Leningrad where the novel was also accused of nostalgia for a bourgeois past and declared outright anti-Soviet, hostile and harmful. After the first day of the conference, Dobychin disappeared; his fate remains unknown to this day. Largely forgotten, it was only in the end of the I980s that Dobychin's works were published again in the Soviet Union. The Nobel laureate Joseph Brodsky's mention of Dobychin in 1987 as the best Russian prose writer after 1917 probably contributed to the surge of interest in him that followed. Since then, his works have been translated into more than ten languages, not, however, Swedish.

The stories of the collection Portret were written between I923 and I930, and most of them were first published in the already harsh but less fatal cultural climate of the I920s. While Dobychin's novel takes place in prerevolutionary society, with only one exception the stories are set in the time they were written, in a provincial town resembling Bryansk, and deal with 
the everyday conflicts and tensions of the new Soviet society. The collection went largely unnoticed, but the few reviews it received nevertheless laid the ground for later allegations of "formalism." The reason seems to have been that the stories were difficult to understand. In the I920s they were said to be interesting but too fragmentary, lacking plot and sometimes comprehensibility. Their "unoutspokeness" (nedogovorënnost')—i.e. reticence, a deliberate avoidance of explicitness - was seen as a central trait by the formalist critic Nikolai Stepanov in the only and mostly positive review of Dobychin's first collection in 1927. In the beginning of the I930s the two reviews that followed the publication of Portret (a collection of sixteen short stories that added seven new works to the nine from the first collection) concluded that they lacked substance, meaning and ideas, which led to the ideological judgement that they were therefore harmful to both Soviet literature and society.

The main argument of this thesis is that the principal theme and problem in Dobychin's writings centers on the complexities of human encounters.

To explain the special character of Dobychin's prose, earlier scholars have mainly approached his writings in search of a dominant formal feature, a "key" or "code." My approach is based instead on what I call an affirmative, encountering reading of the stories that aims to bring the characters alive as human beings on an individual level together with their personal conflicts and in the context of their everyday life. The value of the stories as works of art is shown to derive from these brief encounters and interactions occurring in a deeper dimension "beyond words," as it were. I argue that this unformalized, anti-theoretical reading is congenial to the both the central theme of the stories and the way in which they convey their meaning through not yet categorized, "precategorial" experiences of everyday life.

My approach reveals two further important and interrelated aspects of Dobychin's writings. First, that in the social and cultural context of the Soviet I920s, the fundamentally existential and psychological theme of the human encounter and its revelation of the plurality of human perspectives could be interpreted as highly political, since it showed a dimension of human life beyond the discourse of the new ideology.

The second aspect concerns reading and interpretation: I argue that by making visible human interactions in everyday life, Dobychin problematizes the kind of ideological reading of reality that was practiced in both literary criticism and tendentious "realist" literature of the time. Such interpretations involved searching for a an already given hidden cause, plot or point of view, and for types rather than individual human beings. 
In the first chapter, I present Dobychin's fate as a writer in his contemporary cultural and political context. His supposed "incomprehensibility," or, more charitably, the "unoutspokenness" of his writings in his own time, serves as a starting point for a critical discussion of theoretical approaches to literature. I also give an overview of Dobychin's literary production. I present posthumous attempts to establish him as a great writer and discuss the field of scholarly studies of his life and works that has taken shape since the end of the 1980s. I also develop and elaborate my own approach to Dobychin's works as a practice of reading.

My study of Dobychin's short stories is based on what I am calling an encountering reading. This approach draws on mainly two critical practices developed by Boris Gasparov and Henry Meschonnic respectively. First, it relies on Gasparov's 2013 study of Pasternak, Boris Pasternak: Po tu storonu poetiki (Filosofiia. Muzyka. Byt) [Boris Pasternak: On the Other Side of Poetics (Philosophy. Music. Byt [Everyday life])]. Gasparov argues that if Pasternak's works are to be understood and appreciated as art, they must be approached not by searching the dominant feature of their linguistic texture, but by examining the momentary states of everyday life that the author captures.

Secondly, the encountering approach is informed by Henri Meschonnic's work on literary rhythm Critique du rythme: Anthropologie historique du langage (1982). Meschonnic distinguishes the actual rhythm of a text from its abstractly decodable meter. Being an intrinsic part of the text and constituting its fluidity and plasticity, the rhythm is an inseparable aspect of what is expressed. Meschonnic's understanding of rhythm further requires the reader to take active part in appreciating the text as a work of art by following the interplay between rhythm, the active subject and what is expressed, which thus discourages theoretical approaches to literature. By theory Meschonnic means attempts to establish a system corresponding to a linguistic view of language as a synchronous system (la langue), in order to abstract and generalize formal aspects of literary texts. His critique, in contrast, is grounded in an anthropological view that focuses on the living historical usage of language (le language) in literary works.

In a general way, this approach places my study in line with a turn away from the linguistically informed theoretical approaches that dominated the academic study of literature in the twentieth century. A 2012 special issue of Novoe literaturnoe obozrenie devoted to this question likewise qualified the new turn as anthropological. It could also, as suggested by Galin Tihanov ("Why Did Modern Literary Theory Originate in Central and Eastern Eu- 
rope? (And Why Is It Now Dead?)" (2004)), be understood as in fact a turning back to the practice of actually reading literary works rather than using them as material for theoretical pursuits.

My approach also differs from that of traditional close reading, at least the kind that tends to read literary text as rebuses (as Gasparov phrases it) in search of the hidden clue in certain details. My encountering reading doesn't search for something that is closed to the normal reader or something between the lines. Rather, by moving slowly it aims to draw attention to (or "recognize", as Gasparov puts it) the meaningful human interactions the stories make us experience. By applying this approach to the collection Portret as a whole, the complex of problems of human encounters emerges as its central theme. This theme appears both in what the stories show to be important in life and in the way in which they reveal it.

An important point in my thesis is that some of the theoretical approaches that have been most prominent in earlier research on Dobychin's works are intertwined with the contemporary reception of his writings as fragmentary and hardly intelligible. Among Dobychin scholars these characterizations no longer serve as grounds for ideological accusations. The albeit persistent view that his writings, especially his short stories, lack plot, inner coherence and meaning is now explained in terms of theories of avantgarde aesthetics as a kind of anti-aesthetic, deliberately constructed to performatively mirror the absurdness and inadequacies, disorientation and loss of meaning in Soviet reality itself.

Much to the contrary, I argue that there is no intended lack of meaning or incoherence in Dobychin's works. The "unoutspokenness" that Stepanov pointed out in 1927 is instead understood as exactly their way of conveying meaning through what is experienced and shared beyond words in a time overburdened with idealistic ideological discourses. At the heart of his stories are moments of fragile human interaction underlying trivial dialogues and actions in banal everyday existence. Read without searching for formal keys and literary devices, Dobychin's stories invite the reader to experience the sudden and unexpected human connections that the characters perceive in their everyday impressions. This reveals the contrasts and plurality of human perspectives in their everyday life as a dimension beyond societal roles. These meaningful moments or brief encounters are presented as something precarious in a Soviet society that embraces a single true ideology. Dobychin is not so much a purposefully enigmatic author as a writer striving to express in words that which is profoundly wordless: the rare encounters and exchange of personal experiences between people outside of the ideological categories and discourses of their language. 
In chapters 2-4 I present my readings of the sixteen short stories in Portret written between 1923 and 1930 . I develop my interpretation by closely following their chains of events and situations and discuss how the conflicts surrounding human encounters, both within the stories and as part of Dobychin's quests as a writer in relation to the contemporary provincial society where the stories are set. As a whole, the collection also has a historical dimension, as it portrays the gradual change of Soviet society during the I920s and its implications for social life.

Chapter two studies four stories. The opening story of Portret is set in a different time and place from all the others. Like them, "Proshchanie" ("Farewell") portrays a trivial everyday life, but as a striking contrast it is set in Petrograd, both the symbolic center of the old culture and the birth of the Soviet order, in the first spring after the revolutionary year of 1917. The difference in time and space contributes to its status as a frame story for the collection. Ordinary life in the middle of an unordinary political state of affairs is made prosaically present. At the same time, the timebound events and impressions are gradually composed into what as a whole preserves this life with a lyrical timelessness, as a memory of an end, a farewell to this life. Thus this is also a story about how it all began. The protagonist finally bids farewell and sets off for the train station to leave the city for a new life in the provinces. To a provincial, everyday life is also where the following stories bring us - but with a significant jump in time to after the Civil War when Soviet rule has already been established. "Kunst," the young protagonist's very telling name, also seems to suggest that in all his banality and narrowmindedness he is a portrait of the artist at the decisive moment of his evolution as a writer. This might appear as an ironic gesture, given his scarcely heroic or even artistic character and the fact that he barely seems to reflect over the consequences of the revolutionary events surrounding him. Another possibility is to read the name as a personalization of Art itself, which ironically expresses a common view in the contemporary context that art, so to say, had to leave the center and find new ground in the authentic lives of people in the provinces. The story itself gives no such certain directions for the future, either for the young protagonist or art or society. The story instead leads up to a moment of silence on the evening before Kunst takes his leave. The dusty redness of the sky and the sound of a train bring out the experience of something important in the presence of the different human perspectives of the protagonist and his neighbors and landlady. What is important is not the great event but these ordinary people and their personal stories, the human longings and quiet encounters of the past. 
The following stories depict everyday life in a small provincial town. Several years of civil war have gone by, but there is still a sense of uncertainty about political developments and what life will be like in the new society. The story "Kozlova" portrays the disorientation of an older woman. After a failed attempt to befriend another woman who constantly tries to adapt to the new, she returns in the end to nursing her prerevolutionary habits and attitudes and what remains of its culture. She is left to find some relief in everyday moments that evoke memories or give a lyrical sense of meaning. For the young, as first portrayed in Dobychin's first published story "Vstrechi s Liz," the situation is different. Since this is the society in which they have to live their lives, they must also find ways to look to the future. But when they try to adapt to the new ideals it leads to inner conflicts. To give up their romantic daydreaming mentality, their longing for someone or something else, something meaningful in life, would make the conflict disappear, but a part of themselves and their personality would be lost. The young people in Dobychin's stories risk silencing themselves as humans when they neglect the plurality of perspectives that they experience in their everyday life. This is underscored by the portraits of those who take active part in the new order. They too seem to have personal longings that are in conflict with ideological ideals. In "Yerygin" this clash is reflected in the portrait of an ideologically loyal young author who struggles to come up with a new idealistic story, since his everyday existence is too irrelevant and politically ambiguous to be suitable. He finally finds a way of disclosing hidden counterrevolutionary plots within his everyday experiences to make them fit the idealistic "realist" demands of his time. This story ironically reflects how Dobychin has found a way of portraying the dissonances between the ambiguities of everyday life (with its interacting human perspectives) and the ideological discourse of his time.

My third chapter follows the theme of the human encounter in the six following stories. Since the small town setting is repeated between the stories, the monotony of the new everyday life soon becomes apparent. The protagonists long for something else, which easily gives rise to romantic hopes. The plots follow a pattern in which an initial appearance of someone awakens the protagonist's fantasies about this person as an answer to their longing for something meaningful in life. No matter the banality of this longing and the fruitlessness of the search for the encounters they envision, the portraits of the protagonists are still compassionate. Their longings still give a sense of meaning and motion to their lives and make objects and events shine forth as significant in and of themselves, and this luster lends suspense to the stories about them. The stories thus convey these moments 
of experienced meaning beyond words as something of value in the time shared by the author and his protagonists.

One story, "Konopatchikova", stands out in that it portrays a meaningful encounter between the protagonist and the object of her longings. This encounter emerges in a conversation about contemporary art during a funeral feast. Though nothing seems to follow from this brief interaction between her and a married man, it suggests a mutual understanding beyond and through the words they speak. Their fragile way of communicating appears in itself as an example of the same kind as the personal memories they share of trivial but somehow lyrically meaningful experiences in life. This, the art they practice and experience in life, appears as the opposite of the new Soviet culture as represented in the story with its mix of ideological lectures and propagandistic mass entertainment.

The fourth chapter of the thesis studies the remaining six short stories in Portret. The five that precede the final title story are all very short - only one to three pages. They have fewer scenes and characters, unfold in a shorter time span - generally a single day - and the conflicts are less intertwined with the contemporary political discourse. There is a sensitive presence in life that reveals human expressions and interactions. As a contrast to these sensed encounters beyond words, the actual romantic rendezvous that take place or are about to happen appear as ruled by social roles and conventions which render true human contact impossible.

These last stories assume a more melancholy tone. The very ground for fragile and sensitive human encounters, the ambiguous presence of a plurality of perspectives, seems menaced by the ever stricter ordering of social life that now, in the late twenties, has begun. More generally, this can also be read as reflecting the creation of the stories themselves as encounters beyond words. On the one hand, the silencing of personal opinions and expressions makes it difficult to reveal anything more of existential importance in this contemporary society. On the other, it is indirectly suggested that the artist is obligated nevertheless to continue to reveal and make present these precious moments of human connection.

In the last longer story "Portret" ("The Portrait"), existential longing is expressed simply in the mind of the protagonist as a desire for "openness and friendship". Dobychin paints this longing as something precarious in the "building of socialism" initiated by the first five-year plan. In official culture, openness has become obsolete and has been replaced by active and wholehearted participation in this societal and cultural transformation. Doubts are interpreted as pessimism, which is either a disease or an indirect 
expression of counterrevolutionary opinions. "The Portrait" is therefore ultimately also an expression of Dobychin's way of portraying his contemporary everyday life. Soviet ideology's conceptualization of reality has now become identical with the existing world.

The fifth concluding chapter starts with readings of Dobychin's last two short stories from the fall of 1930, which originally were not included in the published collection Portret. These are viewed as showing the final step in the complex of problems related to the human encounter in contemporary Soviet society: the development towards an absence of any meaningful human connection. Any possibility of interaction beyond the words of Soviet ideology is now closed. What remains are inhibited silences and solitary longing, locked-up dreams and imagination that only once in a while break out into a human story, a sudden compassion with someone, or trivial everyday expressions of a lingering yearning for something else.

These final two stories also mark the end of Dobychin's literary portrayal of his own time. In his longer works of prose from the I930s he turns to other historical and societal contexts in search of their encounters beyond words. 


\section{STOCKHOLM SLAVIC PAPERS}

Redaktion: Nadezjda Zorikhina Nilsson, Maria Zadencka

1. LARS KLEBERG

2. BORIS ARAPOVIĆ

3. LARS KLEBERG (red.)

4. KERSTIN OLOFSSON

5. MÄRTA BERGSTRAND \& MATS LARSSON

6. BARBRO NILSSON \& EWA TEODOROWICZ-HELLMAN (red.)

7. EWA TEODOROWICZHELLMAN (red.)

8. EWA TEODOROWICZHELLMAN (red.)
Teatern som handling. Sovjetisk avantgardeestetik 1917-1927. $192 \mathrm{~s}$. Stockholm 1977.

Miroslav Krležas Den kroatiske guden Mars. Tillkomsthistoria, stil, genre. 184 s. Stockholm 1984.

Att översätta polsk poesi. Bidrag till en diskussion. 112 s. Stockholm 1986.

Utan minne inget liv. En analys av Valentin Rasputins Avsked från Matiëra och Čingis Ajtmatovs Och dagen varar längre än ett sekel. 152 s. Stockholm 1988.

Från Königinhofer-handskriften till Novemberorkanen. En bibliografi över tjeckisk och slovakisk skönlitteratur i svensk översättning 1862-1991. 183 s. Stockholm 1992.

Nazwy barw i wymiarów. Colour and measure terms. 134 s. Stockholm 1997.

Adam Mickiewicz. En minnesbok till tvåhundraårsdagen av diktarens födelse. 138 s. Stockholm 1998.

Kvinnan i polska språket. Kobieta w języku polskim. 92 s. Stockholm 2001. 
9. EWA TEODOROWICZHELLMAN \& DOROTA TUBIELEWICZ MATTSSON (red.)

10. EWA TEODOROWICZHELLMAN \& JADWIGA WRONICZ (red.)

11. BARBRO NILSSON \& EWA TEODOROWICZ-HELLMAN (red.)

12. EWA TEODOROWICZHELLMAN

13. DOROTA TUBIELEWICZ MATTSSON
Wizerunki mężczyzny w języku i literaturze polskiej. Images of Man in Polish Language and Literature. 136 s. Stockholm 2003.

W świecie sacrum. In the World of Sacrum. 156 s. Stockholm 2005.

Studies in Lexical Semantics.

Colours, Measures, and Mental Predicates. 125 s. Stockholm 2005.

W drodze do „Krabata”. Richtung „Krabat”. 160 s. Stockholm 2006.

Ord och förändring. Den sociala prosan i Sverige och Polen under mellankrigstiden. 260 s. Stockholm 2006.

14. ALINA NOWICKA-JEŻOWA \& Polonica w Archiwum Narodowym EWA TEODOROWICZHELLMAN (red.)

Szwecji. Kolekcja Skokloster i inne zbiory. Polonica in the Swedish National Archives. The Skokloster Collection and Other Materials. 175 s. Stockholm 2007.

15. DOROTA TUBIELEWICZ MATTSSON \& EWA TEODOROWICZ-HELLMAN (red.)

16. MACIEJ EDER

17. MARIA JUDA, EWA TEODOROWICZ-HELLMAN in cooperation with RAGNHILD LUNDGREN
Kultura - Polityka - Tożsamość. Culture - Politics - Identity. 198 s. Stockholm 2007.

The Polonica Collection from Skokloster Castle. 152 s. Stockholm 2008.

Polonika w bibliotece katedralnej w Strängnäs. Polonica in the Library of Strängnäs Cathedral. $130 \mathrm{~s}$. Stockholm 2011. 
18. LUDMILA PÖPPEL

19. GENNADIJ KOVALENKO \& ELISABETH LÖFSTRAND (red.)

20. RENATA INGBRANT

21. DOROTA TUBIELEWICZ MATTSSON (red.)

22. EWA TEODOROWICZHELLMAN \& JANINA GESCHE (red.) przy współpracy MARION BRANDT

23. PER AMBROSIANI, ELISABETH LÖFSTRAND \& EWA TEODOROWICZHELLMAN (red.)

24. MARIA ZADENCKA

25. KIA HEDELL, ALINA NOWICKA-JEŻOWA, BARBARA PRZYBYSZEWSKAJARMIŃSKA \& EWA TEODOROWICZ-HELLMAN
Frazeologija meždu dvuch revoljucij: slovar' idiomatiki gazety "Pravda" 1917 g. 303 s. Stockholm 2012.

Novgorodiana Stockholmiensia. 263 s. Stockholm 2012.

Kvinnligt och manligt i Polen. Två studier om genus, kultur och politik. 131 s. Stockholm 2013.

Representations of the Holocaust in Polish Literature. 130 s. Stockholm 2013.

Między językami, kulturami, literaturami. Polska literatura (e)migracyjna w Berlinie i Sztokholmie po roku 1981. $360 \mathrm{~s}$. Stockholm 2013.

Med blicken österut. Hyllningsskrift till Per-Arne Bodin. $405 \mathrm{~s}$. Stockholm 2014.

Divided Heritages. Culture in a Time of National Differentiations in the Lands of the Old Polish-Lithuanian Commonwealth, the Baltic Provinces and the Kingdom of Sweden. 208 s. Stockholm 2014.

Polonika muzyczne w Szwecji.

Cztery tańce z repertuaru dworskiej kapeli Zygmunta III Wazy. Musical Polonica in Sweden. Four Dances from the Repertoire of Sigismund III Vasa's Musical Ensemble. 134 s. Stockholm 2014. 
26. PER AMBROSIANI, PER- Да веселитсА Новъградъ. Ма̊ ARNE BODIN \& NADEZJDA Novgorod fröjda sig. Hyllningsskrift ZORIKHINA NILSSON (red.) till Elisabeth Löfstrand. $237 \mathrm{~s}$. Stockholm 2016.

27. HANS ANDERSSON

Något betydelsefullt. Leonid Dobyčins möten bortom orden i den sovjetiska samtiden. $338 \mathrm{~s}$. Stockholm 2019. 
Den ryske författaren Leonid Dobycin (1894-1936?) skrev inte många ord, men de rymde mycket. Denna avhandling handlar om hans noveller från 1920-talet. På ett tigande sätt skildrar de ett hot mot människan i det nya sovjetiska samhället, i dess krav på inordning i ett ideologiskt system med redan givna svar på hur samhället ska organiseras, hur man ska leva och vad som är betydelsefullt. Genom sina sinnliga intryck och avskalade repliker utan utvecklade tankar söker novellerna fånga något levande under ytan i människors vardagliga möten. 